UNIVERSIDADE DE SÃO PAULO

FACULDADE DE FILOSOFIA, LETRAS E CIÊNCIAS HUMANAS

DEPARTAMENTO DE HISTÓRIA

PROGRAMA DE PÓS-GRADUAÇÃO EM HISTÓRIA SOCIAL

\title{
DARWINISMO, RAÇA E GÊNERO: CONFERÊNCIAS E CURSOS PÚBLICOS NO RIO DE JANEIRO (1870-1889)
}

\author{
Versão Corrigida \\ O exemplar original encontra-se disponível no CAPH da FFLCH \\ (Centro de Apoio à Pesquisa Histórica)
}

\section{Karoline Carula}


KAROLINE CARULA

Darwinismo, raça e gênero: conferências e cursos públicos no Rio de Janeiro

(1870-1889)

Tese de Doutorado apresentada ao Departamento de História da Faculdade de Filosofia, Letras e Ciências Humanas da Universidade de São Paulo sob a orientação da Prof $^{\mathrm{a}}$ Dr $^{\mathrm{a}}$ Maria Helena Pereira Toledo Machado.

Este exemplar corresponde à versão corrigida da tese, defendida e aprovada pela Comissão Julgadora. O exemplar original encontra-se disponível no CAPH da FFLCH (Centro de Apoio à Pesquisa Histórica).

\section{BANCA}

De acordo

Prof $^{a}$ Dr $^{\mathrm{a}}$ Maria Helena Pereira Toledo

Machado (orientadora)

$\operatorname{Prof}^{a}{ }^{\mathrm{Dr}}{ }^{\mathrm{a}}$ Olivia Maria Gomes da Cunha

$\operatorname{Prof}^{a} \operatorname{Dr}^{\mathrm{a}}$ Luzia Margareth Rago

Prof $^{a}$ Dr $^{a}$ Regina Cândida Ellero Gualtieri

Prof. Dr. Nelson Schapochnik 


\title{
Resumo
}

O presente trabalho pretende delimitar os contornos de um discurso científico/cientificista, presente de modo mais intenso no último quartel do Oitocentos, que fundamentou argumentos de projetos modernizadores da nação, quais sejam, a aplicação da teoria de Darwin à sociedade, a hierarquização racial da sociedade e a criação de uma boa mãe de família burguesa, nos moldes europeus. Estas três propostas modernizadoras foram apresentadas e discutidas nos seguintes espaços públicos de vulgarização científica - as Conferências Populares da Glória, os cursos públicos do Museu Nacional e as que denominei "Avulsas", pois não se encaixavam nas duas categorizações anteriores - todos realizados na capital imperial entre os anos de 1870 e 1889.

Palavras-chave: darwinismo, raça, gênero, ciência.

\begin{abstract}
The current paper intends to delimit the outlines of a scientific/scientificist speech, present in a more intense manner in the last quarter of the nineteenth century, which grounded arguments of the nation's modernizing projects, which are, application of the Darwin theory to society, racial hierarchization of society and the creation of a good mother of a bourgeois family, in the European molds. These three modernizing proposals were presented and discussed in the following public spaces of scientific vulgarization - the Popular Conferences of Glória, the public courses of the National Museum and the ones which I have named "Miscellaneous", for they did not fit into the two prior characterizations - all performed in the imperial capital between the years of 1870 and 1889.
\end{abstract}

Keywords: Darwinism, race, gender, science. 
Aos meus amados pais, Rogerio Carula (in memoriam) e Alaide Campolina Carula 


\section{Agradecimentos}

Findo o trabalho, chega o momento de relembrar o processo e agradecer a todos aqueles que direta ou indiretamente colaboraram para que esta tese fosse concluída. Nesses anos em que ela me acompanhou, muitas pessoas que estiveram ao meu lado, ou apenas cruzaram meu caminho, tornaram a feitura mais amena.

Maria Helena Machado, sua orientação sempre segura e dedicada, seu incentivo constante, bem como seu carinho, já seriam motivos suficientes para imensos agradecimentos. Entretanto, deixo registrada minha gratidão por ter me ensinado muito sobre o ofício de historiador. Levarei seus ensinamentos sempre comigo.

Aos membros da banca, Olivia Maria Gomes da Cunha, Luzia Margareth Rago, Regina Cândida Ellero Gualtieri e Nelson Schapochnik, agradeço as leituras atentas e as preciosas sugestões.

Agradeço ao Conselho Nacional de Desenvolvimento Científico e Tecnológico pela bolsa de doutorado, que possibilitou minha dedicação integral à pesquisa. Sou grata à Red de Macro Universidades de América Latina y el Caribe e ao Banco Santander pela bolsa para realizar estágio doutoral no exterior.

$\mathrm{Na}$ Universidade Autônoma do México contei com a orientação de Ismael Ledesma Mateos, a quem manifesto minha gratidão, suas indicações e conversas foram de muita valia.

Em todos os arquivos nos quais pesquisei fui muito bem recebida e auxiliada, agradeço, desta maneira, a todos os funcionários que cruzaram meu caminho. Na Seção de Memória e Arquivo do Museu Nacional, Maria José Veloso da Costa Santos e, em especial, Silvia Moura, que a despeito de estar na instituição apenas para colaborar na reorganização do arquivo, ajudaram sobremaneira, a vocês, muito obrigada pela atenciosa colaboração. Na Biblioteca do Museu Nacional, a ajuda e colaboração de Antonio Carlos foi muito preciosa. Já no Arquivo Edgard Leuenroth pude novamente contar com o apoio dos sempre solícitos funcionários, obrigada Ema, Isabel, Emerson e Mário.

As discussões realizadas no "Grupo de Estudos e Pesquisas, Intelectuais, Sociedade e Política - GEPISP" foram muito importantes para a reflexão de alguns temas trabalhados nesta tese. Sou grata a todos os membros do grupo, em especial a 
Magali Gouveia Engel, Maria Letícia Corrêa, Débora El-Jaick Andrade, Ricardo Augusto dos Santos e Márcia Regina da Silva Ramos Carneiro. Aproveito para agradecer à Magali Engel pelo apoio, carinho, e amizade.

A Francisca Carla dos Santos Ferrer e a Thais Helena dos Santos Buvalovas muito obrigada pelas conversas, indicações e incentivos.

Agradeço a Moema de Rezende Vergara pelo apoio e trocas intelectuais.

Aos colegas da UFF de Campos, sou grata pelo apoio e por terem facilitado minha vida nesta reta final.

No México, a distância e a saudade do Brasil foram amenizadas pelas queridas amizades de Lara Melo Souza, Bianca Brasil e Soraya Alencar, muchas gracias a las brasileñas. Outras pessoas que lá atravessaram meu caminho fizeram com que a estadia fosse mais alegre, meus agradecimentos a Aaron Alva e Erika Magali Estrada Alvarado, por termos dividido não apenas moradia, mas também experiências e culturas; a Julio Valdiva-Silva, pela amizade e agradáveis conversas; e àqueles com quem passei agradáveis momentos: Amilcar, Gloria Lu Medina, Martin Arenas Garcia, Iracema Ribeiro e Susana Esparza.

Já diz o ditado, "quem tem amigos, tem tudo" e felizmente pude contar com muitos no correr desses anos. Aos que estão mais distantes, porém sempre presentes, agradeço o carinho e incentivo: Glaydson José da Silva, Adilton Luís Martins, Karen Fernanda Rodrigues de Souza, Paula Christina Bin Nomelini, Paulo Miceli, Guilherme Pinheiro Pozzer, Renata, Luciana da Cruz Brito, Kleber dos Santos, Marcela Miwa, Maísa da Cunha Faleiros, Otávio, Mairon Escorsi Valério, Renilson Rosa Ribeiro, Nathália da Costa Amedi, Ana Helena Cobra Fernandes, Joca, Kleber Amancio, Luiza Tombini Wittmann e Marcelo Téo. Cada um de vocês, a sua maneira, contribuiu muito.

Os novos amigos que fiz na cidade maravilhosa ajudaram a percorrer a estrada de modo mais leve e alegre. Muito obrigada a vocês: Edilson Binote, Roberta Renata, William Pereira, Márcia Sueli Amantino, Rogério da Silva Lopes, Jorge Prata de Sousa, Aurora, Érica Sarmiento da Silva, Marieta Pinheiro de Carvalho, Alessandra Schueler, Luiz Fernando Saraiva, Rita Almico. Nossas reuniões, almoços, jantares, noites na Lapa, etc. trouxeram leveza e alegria nos momentos de tensão e cansaço.

Antes de me mudar para o Rio, contei com a ajuda de Edilson Binote e Carlos Eduardo Moreira de Araújo, que me hospedaram mais de uma vez e, em algumas delas, por um tempo relativamente longo. Muito obrigada por terem me aguentado! 
Não podia faltar a "Diretoria": Jonis Freire, Marcelo Mac Cord, Carlos Eduardo Moreira de Araújo e Robério Santos Souza. A vocês que acompanharam este trabalho desde o começo, sempre compartilhando as alegrias e angústias, escutando os problemas, dando força, apoio e incentivo, o meu muito obrigada!

À querida Juliana Gesuelli Meirelles, agradeço a maravilhosa amizade. Seu carinho e apoio nos momentos difíceis, da tese e fora dela, foram importantíssimos! Nossas horas ao telefone foram essenciais nessa jornada. Sou muito agradecida, também, por suas preciosas dicas e leituras.

Sou grata também a Celia Maria dos Santos e Maria do Carmo Pereira dos Santos, pelo carinho e apoio que deram a todos de minha família e, principalmente, a meus pais.

Agradeço, de coração, aos meus familiares, Carula e Campolina, que compartilharam mais esse trabalhado acadêmico. Cintia Campolina de Onofre, Cesar Rafaelli Munhoz e Tales Onofre Munhoz, muito obrigada pelo apoio, força e alegres conversas via internet. Minha irmã Aline Carula, meu sobrinho Ivan Carula Amaral e Fabrício Fontes contribuíram para dar alegria nesta caminhada. Hamilton Campolina e Sonia Binotti Campolina, sempre muito atenciosos e presentes, muito obrigada. O carinho de minha nova família também foi muito importante, obrigada Sebastiana Francisca, Dalila Freire e Flaviana Freire.

A minha mãe Alaide Campolina Carula sou sempre grata, seu amor, força, carinho, dedicação e apoio foram fundamentais. Meu pai, Rogerio Carula, infelizmente não pôde ver este trabalho concluído, mas deixo aqui registrado meu eterno agradecimento, carinho e amor.

Mais um trabalho que concluo, mais uma vez devo meus profundos e sinceros agradecimentos a Jonis Freire. Aguentar um mestrado e um doutorado não é fácil! Mas você sempre esteve ao meu lado dando apoio pleno, como marido e como historiador, nos momentos bons e ruins da tese e da vida. Suas dicas e leituras, seu amor, amizade, paciência, compreensão, carinho e incentivo foram primordiais em mais esta caminhada. A você, todo agradecimento é pouco! 


\section{SUMÁRIO}

Introdução

I - Espaços de ciência na capital imperial

Dinâmica dos cursos e conferências ....................................................................... 9

Temáticas dos cursos e conferências ................................................................. 19

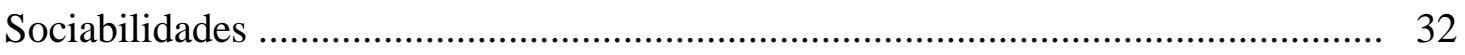

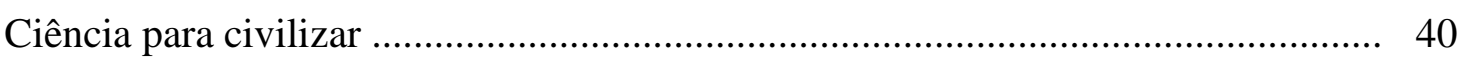

Vulgarização da ciência ............................................................................ 54

II - Concepções sobre o darwinismo

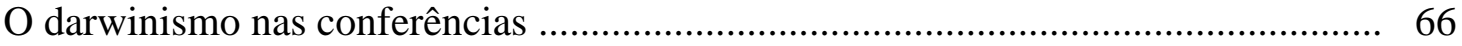

Feliciano Pinheiro de Bittencourt e a luta contra o darwinismo .............................. 74

Miranda Azevedo e as aplicações do darwinismo .................................................... 90

O darwinismo no Museu Nacional ....................................................................... 99

\section{III - A raça em foco}

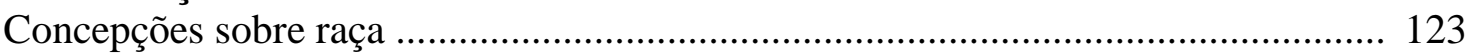

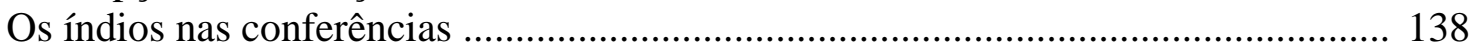

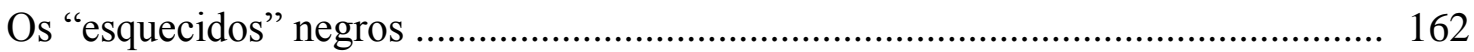

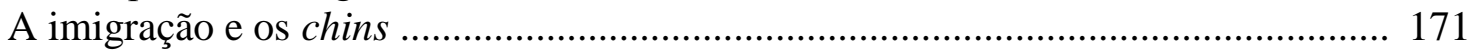

IV - Conferências... um espaço de e para mulheres

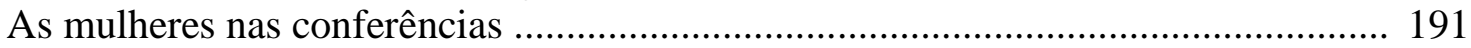

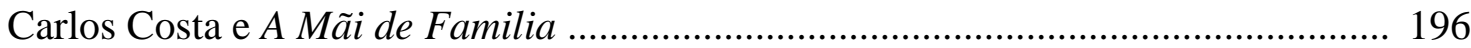

Mães desnaturadas ................................................................................... 213

Aleitamento materno e escravidão .................................................................. 229

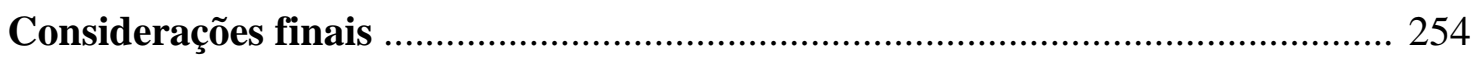

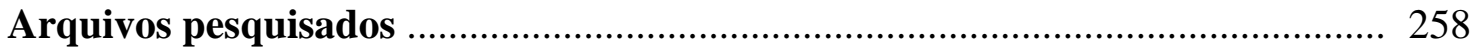

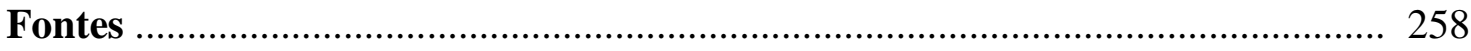

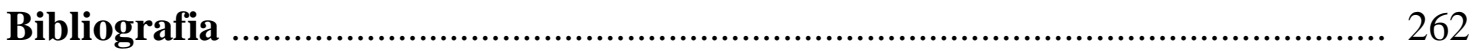

\section{Anexos}

Anexo 1 - Dados biográficos profissionais dos conferencistas até 1889 ................. 275

Anexo 2 - Oradores que se apresentaram nas Conferências Populares da Glória

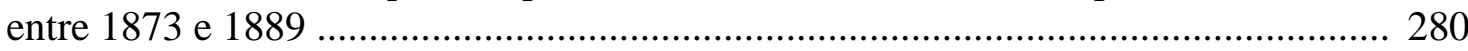

Anexo 3 - Conferências Populares da Glória que abordaram assuntos relativos à

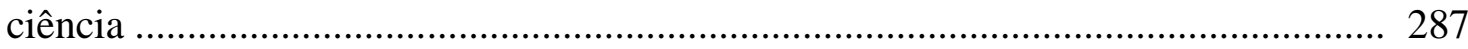

Anexo 4 - Conferências Avulsas que abordaram assuntos relativos à ciência .......... 297 


\section{Índice de Tabelas e Imagens}

\section{CAPÍTULO I}

Tabela I Quantidade de oradores, que mais vezes se apresentaram, e suas preleções realizadas nas Conferências Populares da Glória entre 1873 e 1889

Tabela II Locais de realização das conferências "Avulsas" 17

Tabela III Assuntos relacionados à ciência desenvolvidos nas Conferências 20 Populares da Glória entre 1873 e 1889

Tabela IV Assuntos relacionados à ciência desenvolvidos nas conferências "Avulsas" entre 1873 e 1889

Tabela V Seções e diretores do Museu entre 1876 e 1888

Tabela VI Quantidade de preleções por seção e ano entre 1876 e 1885

Tabela VII Quantidade de conferências oferecidas por cada seção entre 1876 e 29 1885

\section{CAPÍTULO II}

Imagem I Ilustração de fetos presentes na obra The history of creation de 77 Haeckel

\section{CAPÍTULO III}

Imagem I Botocudos da Exposição Antropológica

Imagem II Crânios dos sambaquis

\section{CAPÍTULO IV}

Imagem I Ilustração que se tornou a marca de A Mãi de Familia 199

Imagem II Mãe cuidando de seu filho 200

Imagem III Capa do primeiro número de 1880 com imagem igual à de La Jeune 201 Mère

Imagem IV Página de anúncios de A Mãi de Familia 


\section{Introdução}

Uma das enfermidades que aqui encontrei, revelada muitas vezes por verdadeiros espasmos, é a CONFERENCIOMANIA.

De repente há uma convulsão epileptiforme, os diários escrevem verdadeiras loas, entoam hinos, gritam hosana, os músicos forasteiros esperam ser chamados para robustecer o aplauso, pagando-lhes já se vê, e um conferencista aparece. $^{1}$

O folhetim intitulado "Cartas egípcias" da Gazeta de Noticias, 1878, assinado por Amenophis-Effendi, pseudônimo do médico Ataliba Gomensoro, ${ }^{2}$ em tom sarcástico, criticava a proliferação de conferências públicas pela cidade do Rio de Janeiro. De fato, a irônica observação do autor não era descabida, pois um ano antes, em um único domingo, foram realizadas cinco preleções entre as 11 e 12 horas. ${ }^{3}$ Isto indica que as conferências haviam caído no gosto de uma parcela da população, nomeadamente, a camada letrada, que comparecia para adquirir conhecimentos em determinados assuntos, mostrar para o resto da sociedade que estava em sintonia com as novidades tecnológicas e científicas, e também por considerar aquilo um tipo de entretenimento.

As preleções na capital imperial ocorreram de maneira mais sistemática e em maior quantidade nas décadas de 1870 e 1880 . Os eventos se caracterizaram por serem

\footnotetext{
${ }^{1}$ Gazeta de Noticias, 17/05/1878. Grifos do original. A grafia das fontes primárias foi atualizada, apenas os títulos foram mantidos no original.

${ }^{2}$ As "Cartas egípcias" apresentavam as impressões de um suposto egípcio em viagem ao Brasil, por meio dessas "cartas" Gomensoro polemizou com Machado de Assis acerca do romance O primo Basílio de Eça de Queiros. FRANCHETTI, Paulo. O primo Basílio e a batalha do realismo no Brasil. In: BERRINI, Beatriz (Org.). Eça \& Machado. Conferências e textos das mesas redondas do Simpósio Internacional Eça \& Machado - setembro de 2003. São Paulo: EDUC, Fapesp, Fundação Gulbenkian, 2005, p. 89-113.

${ }^{3}$ Diario do Rio de Janeiro, 15/07/1877.
} 
espaços de sociabilidade letrada e contavam, muitas vezes, com a presença do Imperador na plateia.

A temática abordada pelos oradores era vasta. Política, ciência, cultura e economia estavam no rol dos temas desenvolvidos nas explanações. Dentre essas, as apresentações que trataram de assuntos relativos às ciências foram as que centrei minha análise. No período, havia a concepção de que a difusão do conhecimento científico para um público leigo colaboraria no progresso do Brasil, tornando-se uma via para se alcançar a almejada civilização nos moldes europeus. Dessa forma, o oferecimento de preleções públicas sobre ciência seria uma maneira de colaborar para o progresso nacional; e mesmo quando o foco principal, e explícito, da apresentação não era a ciência, muitas vezes os preletores primavam pela cientificização dos argumentos; a linguagem utilizada para a análise de assuntos variados era cientificizada. Cabe destacar, entretanto, que não se pretende aqui fazer um estudo da produção científica por dentro, mas sim proceder a uma análise da difusão da ciência. ${ }^{4}$

A prática das conferências públicas era um tipo de evento considerado moderno, uma vez que era semelhante às realizadas na Europa e nos Estados Unidos. Além disso, elas tratavam de temas considerados importantes dentro de projetos mais amplos de modernização da nação. Tais projetos refletiam a ânsia pelo moderno que marcou o século XIX. ${ }^{5}$ A modernização no Oitocentos esteve muito vinculada à dinâmica da cidade, locus da modernidade por excelência. ${ }^{6}$ Era no universo urbano que a apreciada novidade irrompia e difundia-se. Neste sentido, as conferências constituíram-se como

\footnotetext{
${ }^{4}$ VERAGARA, Moema de Rezende. Contexto e conceitos: história da ciência e "vulgarização científica" no Brasil do século XIX. Interciencia, vol. 33, n. 5, p. 324-330, may 2008. MOREIRA, Ildeu de Castro; MASSARANI, Luisa. Aspectos históricos da divulgação científica no Brasil. In: MOREIRA, Ildeu de Castro; MASSARANI, Luisa; BRITO, Maria de Fátima (Orgs.). Ciência e público: caminhos da divulgação científica no Brasil. Rio de Janeiro: Casa da Ciência, 2002, p. 43-64. MASSARANI, Luisa; MOREIRA, Ildeu de Castro. Popularisation of Science: historical perspectives and permanente dilemas. Quark, n. 32, p. 75-79, april-june 2004.

${ }^{5}$ Consoante Marshall Berman, "Ao mesmo tempo, o público moderno do século XIX ainda se lembra do que é viver, material e espiritualmente, em um mundo que não chega a ser moderno por inteiro. É dessa profunda dicotomia, dessa sensação de viver em dois mundos simultaneamente, que emerge e se desdobra a idéia de modernismo e modernização." BERMAN, Marshall. Tudo que sólido se desmancha no ar: a aventura da modernidade. Tradução de Carlos Felipe Moisés e Ana Maria L. Ioriatti. São Paulo: Companhia das Letras, 1986, p. 16. As discussões sobre a modernidade no Oitocentos estão situadas nos capítulos III - "Baudelaire: o modernismo nas ruas" e IV - "Petersburgo: o modernismo do subdesenvolvimento".

${ }^{6}$ Walter Benjamin analisa o impacto da modernidade na vida da Paris do século XIX por meio da obra de Charles Baudelaire (1821-1867). Benjamin salienta os paradoxos oriundos da modernidade, que ao mesmo tempo em que era demasiadamente valorizada, com suas inovações que satisfaziam o anseio pelo novo, provocava a melancolia naqueles que a vivenciavam. BENJAMIN, Walter. Charles Baudelaire um lírico no auge do capitalismo. Obras escolhidas. Volume III. Tradução de José Carlos Martins Barbosa e Hemerson Alves Baptista. São Paulo: Brasiliense, 1989.
} 
espaços privilegiados para a exposição pública de novas ideias científicas, reflexões acerca dos locais sociais que as pessoas deviam estar inseridas segundo critérios raciais, propostas para condutas de comportamento, etc.

Assim, este trabalho busca delimitar os contornos de um discurso científico/cientificista, presente de modo mais intenso no último quartel do século XIX, que serviu de argumento para projetos modernizadores da nação, quais sejam, a aplicação da teoria de Darwin à sociedade, a hierarquização racial da sociedade e a criação de uma boa mãe de família burguesa. Estas três propostas modernizadoras foram apresentadas e discutidas nos espaços públicos de vulgarização científica aqui estudados - as Conferências Populares da Glória, os cursos públicos do Museu Nacional e as que denominei "Avulsas", pois não se encaixavam nas duas categorizações anteriores. Os cursos e conferências adotaram uma linguagem científica/cientificista e colocaram para o público um novo projeto europeizante modernizador. Entretanto, esta audiência era extremamente seleta, assistiam a esses eventos apenas a elite letrada da sociedade carioca.

O darwinismo apareceu nas preleções como uma teoria científica moderna e, por meio de uma apropriação ressignificada, foi compreendido como passível de ser empregado para a melhor compreensão e solução dos problemas da sociedade, com a extensão dos conceitos biológicos para a explicação do mundo social. Entretanto, o paradigma de Darwin recebeu críticas, do mesmo modo feitas dentro do protocolo da ciência.

Para tornar a nação moderna, fazendo-a progredir e atingir a civilização, era necessário refletir sobre o local social daqueles que habitavam o vasto território brasileiro. Neste sentido, o discurso científico/cientificista serviu de base para alguns oradores analisarem a população em termos da raça, estabelecendo uma hierarquia racial que serviria de sustentáculo para justificar os lugares nos quais os indivíduos eram inseridos na sociedade.

Para se forjar a imagem de um país moderno também era preciso atuar diretamente na família, educando a mulher na ciência para que ela se tornasse uma boa mãe de família, nos moldes burgueses europeu. Desta maneira, foram proferidas conferências que objetivavam difundir uma concepção de maternidade científica, na qual a mulher, com conhecimentos acerca dos preceitos da ciência, contribuiria para a melhoria da nação ao educar corretamente seus filhos, os futuros cidadãos do país. 
Posto isto, o recorte temporal desta pesquisa inicia-se em 1870, com as primeiras conferências realizadas na cidade do Rio de Janeiro, e acaba em 1889, fim do regime monárquico. O recorte temático dessa pesquisa justifica-se por um prisma político. Embora as conferências e os cursos públicos não possuíssem filiação partidária clara, estavam relacionados com a burocracia do Império, modernizadora, ativa e integracionista. A elite da capital imperial assistia para ser informada sobre quais os projetos de civilização deveria assumir nos espaços públicos e privados. Acerca das Conferências Populares da Glória, José Murilo de Carvalho afirma que: "Embora [o Imperador] não as patrocinasse formalmente, era como se o fizesse pela presença, que podia afastar inimigos políticos, mas era um endosso poderoso não apenas à iniciativa como à própria prática das conferências públicas". 7

A imprensa anunciava as conferências que iriam acontecer, e, muitas vezes, comentava e publicava o resumo das mesmas, em raros casos os discursos foram impressos na íntegra. Neste sentido, utilizei jornais publicados na Corte para mapear os eventos, o acompanhamento diário dos periódicos permitiu que fosse feito um levantamento da quantidade de preleções, oradores que se apresentaram e temáticas que abordaram. Foram analisadas as seguintes folhas diárias: Jornal do Commercio, Diario do Rio de Janeiro, O Globo e Gazeta de Noticias. A sinopse do conteúdo dos discursos era enviada à imprensa pelo próprio orador. Faço tal afirmação porque ao confrontar artigos publicados em jornais diferentes, pude averiguar que tinham muitos trechos idênticos no tocante à síntese do tema discorrido. Isso constatado, utilizei esse material jornalístico para analisar o conteúdo do discurso que era exposto pelos conferencistas.

Entretanto, nem todas as preleções tiveram seus resumos editados na imprensa, muitas foram apenas anunciadas. Alguns oradores publicaram suas falas em pequenos livros. Aqueles que proferiram nas Conferências Populares da Glória, em 1876, tiveram seus discursos transcritos na revista mensal Conferencias Populares, ${ }^{8}$ criada em função do evento, que também levou a público algumas apresentações realizadas nos anos anteriores.

Para compreender as ideias que eram expostas por aqueles preletores, afora esse material, que apresentava o discurso de maneira mais direta, analisei outros textos por

\footnotetext{
${ }^{7}$ CARVALHO, José Murilo. As conferências radicais do Rio de Janeiro: novo espaço de debate. In: (Org.). Nação e cidadania no Império: novos horizontes. Rio de Janeiro: Civilização Brasileira, 2007, p. 33 .

${ }^{8}$ Ao todo foram editados dez volumes, todos em 1876. CARULA, Karoline. A tribuna da ciência: as Conferências Populares da Glória e as discussões do darwinismo na imprensa carioca. São Paulo: Annablume, 2009.
} 
eles produzidos. Artigos e livros científicos, bem como textos publicados em periódicos temáticos também foram utilizados como fontes. Com relação aos temáticos, $A$ Mãi de Familia, jornal direcionado ao público feminino, mereceu atenção especial, uma vez que o seu redator-principal proferiu várias conferências nas quais tratou da mesma temática desenvolvida na folha. Além deste, O Auxiliador da Industria Nacional e a Revista Brazileira também trouxeram artigos assinados por conferencistas. Dentre as revistas científicas, destaco a revista Archivos do Museu Nacional e a Revista da Exposição Anthropologica Brazileira, ambas publicações do Museu Nacional, que apresentavam textos científicos dos diretores de seção da instituição que discursavam nos cursos públicos do Museu Nacional. Também fiz uso de algumas obras de cientistas que fundamentaram as abordagens analíticas dos conferencistas brasileiros.

$\mathrm{Na}$ interpretação e análise das fontes, alguns aportes teóricos foram basilares. A pesquisa teve como objetivo compreender os significados sociais do discurso científico/cientificista, vinculados a projetos modernizadores, apresentados nas conferências e cursos públicos, tendo como base a multiplicidade e a historicidade dos eventos sociais. Para tal me apoiei no trabalho de Maria Odila Silva Dias, que marca a necessidade de se observar a existência da multiplicidade de tempos ao se analisar uma mesma conjuntura histórica. De acordo com a autora, para que o historiador possa recuperar a materialidade da experiência histórica é imprescindível historicizar conceitos amplos e vagos, precisando os significados sociais atribuídos por cada época e por diferentes atores sociais. Com isso, o pesquisador deve, ao analisar as fontes, que são indícios do passado, promover um diálogo com as mesmas, examinando significados implícitos que permaneceram no texto de forma residual ou, em outras palavras, em suas entrelinhas. ${ }^{9}$

Outro autor no qual busquei fundamentação teórico-metodológica foi Reinhart Koselleck, que analisa os planos de correlação entre a história social e a história conceitual, destacando como a metodologia da história conceitual se mostra adequada para a crítica das fontes, na medida em que interpreta analiticamente termos e expressões portadores de conteúdo social ou político. Koselleck sublinha que é indispensável investigar os conceitos políticos e sociais do passado tendo como foco o horizonte conceitual da época; e que por meio da explicação destes conceitos é possível

\footnotetext{
${ }^{9}$ DIAS, Maria Odila Leite da Silva. Hermenêutica do cotidiano na historiografia contemporânea. Projeto História, São Paulo, (17), nov. 1998, p. 223-258.
} 
se concretizar enunciados do passado, colocando de maneira clara, em sua formação linguística, as relações do passado. ${ }^{10}$

Para um embasamento acerca da história e filosofia da ciência, a abordagem de Georges Canguilhem foi de grande valia. Segundo este autor, o objeto analítico da história das ciências é o conceito em sua historicidade. Canguilhem enfatiza que o historiador deve seguir o modelo do julgamento do passado, apoiado na assertiva de que toda verdade é sempre provisória. ${ }^{11}$ Ou seja, uma interpretação que tem como alicerce a historicidade da ciência.

Este trabalho, portanto, se apresenta vinculado à história social das ideias, uma vez que pretende compreender quais ideias eram expostas pelos conferencistas que se apresentavam naqueles espaços sem, contudo, considerá-las como desencarnadas. ${ }^{12}$ Interessam aqui os significados sociais dessas ideias, os usos que foram feitos delas. De que maneira princípios científicos foram lidos, apropriados e ressignificados, com o objetivo de fazer uso social desses preceitos. Busca-se compreender quem eram aqueles sujeitos que expuseram os discursos, quais eram as interpretações que tinham da sociedade, bem como as propostas que sugeriam para uma atuação mais direta.

Desta maneira, a tese está estruturada em quatro capítulos. No primeiro, "Espaços de ciência na capital imperial”, apresento as conferências e os cursos públicos focos desta pesquisa - os seus funcionamentos, os locais onde eram realizados, os oradores que se apresentaram, os temas abordados, nestes frisando os relativos à ciência. Analiso os cursos e conferências em sua característica de espaços de sociabilidade letrada e científica, bem como as redes de sociabilidades nas quais os conferencistas estavam inseridos. Discuto de que maneira os oradores compreendiam a ciência enquanto veículo que poderia colaborar para o progresso e civilização do país. Por fim, investigo as preleções como vulgarizadoras da ciência, evidenciando a importância que a vulgarização tinha para a prática científica no final do século XIX.

\footnotetext{
${ }^{10}$ KOSELLECK, Reinhart. Futuro passado. Para una semántica de los tiempos históricos. Barcelona: Ediciones Paidós Ibérica, 1993.

${ }_{11}$ CANGUILHEM, Georges. Études d'histoire et de philosophie des sciences. Paris: Librairie Philosophique J. Vrin, 1975.

${ }^{12}$ Para discussões acerca da história das ideias, conferir: FALCON, Francisco José Calazans. História das idéias. In: CARDOSO, Ciro Flamarion; VAINFAS, Ronaldo (Orgs.). Domínios da História: ensaios de teoria e metodologia. Rio de Janeiro: Editora Campos, 1997, p. 91-126. DARTON, Robert. História intelectual e cultural. In: ___ O O beijo de Lamourette: mídia, cultura e revolução. Tradução de Denise Bottmann. São Paulo: Companhia das Letras, 2010, p. 204-231. CHARTIER, Roger. História intelectual e história das mentalidades: uma dupla reavaliação. In: __. A história cultural: entre práticas e representações. Tradução de Maria Manuela Galhardo. 2a ed. Lisboa: Diefel, 2002, p. 29-67.
} 
O darwinismo nas conferências é o tema desenvolvido no segundo capítulo, “Concepções sobre o darwinismo". Inicialmente, apresento a teoria de Darwin e o modo como ela foi tratada em algumas preleções. Na sequência, detenho-me em alguns oradores, de modo mais pormenorizado, e suas concepções acerca do darwinismo. Primeiramente examino os discursos de Feliciano Pinheiro de Bittencourt, que se apresentou nas Conferências Populares da Glória mostrando-se contrário ao paradigma do naturalista inglês, defendendo um posicionamento criacionista. Faço uma reflexão sobre as exposições de Augusto Cezar de Miranda Azevedo, que conferenciou no mesmo espaço, porém sustentando a aplicação prática dos preceitos científicos darwinistas na sociedade. Então, analiso como o sistema interpretativo de Darwin esteve presente nos cursos públicos do Museu Nacional, sublinhando as diferentes acepções dos diretores daquela instituição.

"A raça em foco" é o título do terceiro capítulo, no qual discorro sobre a maneira como o discurso racializado esteve presente naqueles espaços de vulgarização científica. Apresento as diversas concepções sobre raça que foram utilizadas pelos conferencistas, ressalto como a racialização da humanidade, em termos científico/cientificistas, marcaram suas falas. Logo após, exponho os discursos classificatórios e racializados feitos sobre o índio e o negro, com destaque ao status hierárquico a eles atribuído. Trato também da imigração chinesa, levantada como uma das possíveis soluções para a falta de braços na lavoura, e as críticas, pautadas em uma interpretação racializada, feitas por um dos diretores do Museu Nacional.

No derradeiro capítulo, "Conferências... um espaço de e para mulheres", mostro como se deu a presença feminina nas conferências - enquanto oradoras, espectadoras e temas das preleções. Então, apresento o médico Carlos Antonio de Paula Costa, que proferiu muitas conferências destinadas às mulheres, e o jornal A Mãi de Familia, no qual publicou artigos com a mesma temática que expôs oralmente. Evidencio como os discursos do médico estavam firmados em argumentos científicos/cientificistas e tinham como intuito educar uma boa mãe de família burguesa. Destaco que para atingir tal objetivo, ele utilizou a estratégia de descrever as mães como desnaturadas, por não exercerem adequadamente sua maternidade. Por fim, analiso como a defesa do aleitamento materno, feita por Carlos Costa, estava relacionada com a escravidão.

Assim, fazendo uso do termo empregado por Ataliba Gomensoro no início desta introdução, naquela "conferenciomania", na qual a cidade estava imbuída, projetos modernizadores eram expostos e polemizados publicamente. Nas suas falas, os 
oradores, por meio de um vocabulário científico/cientificista, tencionavam o progresso e a civilização do país. 


\section{I - Espaços de ciência} na capital imperial

\section{Dinâmica dos cursos e conferências}

O Brasil na segunda metade do século XIX passou por diversos acontecimentos que impactaram o status quo. Em 1850, o fim efetivo do tráfico de escravos africanos acabou com a reprodução da mão de obra oriunda da África, influindo na transição do cativeiro para a liberdade. A Lei do Ventre Livre, de 1871, acentuou as discussões acerca da proximidade do fim da escravidão e da mão de obra a ser utilizada após a abolição. O término da guerra do Paraguai enfraqueceu a opinião pública acerca do poder Imperial. O manifesto republicano de 1870 e a criação do partido republicano, que propunham a mudança de regime político, também colaboraram para a desestabilização monárquica. Os debates que despontaram neste momento eram, muitas vezes, permeados pelas novas teorias científicas/cientificistas europeias - positivismo, evolucionismo, darwinismo, naturalismo, dentre outros ismos - que eram lidas, ressignificadas e apropriadas pela camada letrada brasileira. Muitas dessas ideias foram apresentadas e discutidas em conferências e cursos públicos, que marcaram a capital imperial nas décadas de 1870 e 1880.

Marcus Vinícius de Freitas sugere que tal tipo de evento foi introduzido em terras brasileiras quando da passagem de Louis Agassiz (1807-1873) pelo Rio de Janeiro em 1865. A fim de conseguir simpatizantes ao seu trabalho, o naturalista suíço discorreu suas ideias em conferências no Colégio Pedro II, contando com o apoio do Imperador. ${ }^{1}$ Nos Estados Unidosm, “As conferências públicas de divulgação científica,

\footnotetext{
${ }^{1}$ FREITAS, Marcus Vinícius de. Charles Frederick Hartt, um naturalista no império de Pedro II. Belo Horizonte: Editora UFMG, 2002.
} 
especialidade de Agassiz, eram parte central da estratégia de tornar as ciências naturais uma 'necessidade' social". ${ }^{2}$ Elizabeth Agassiz sinalizou para a novidade que a prática de conferências públicas representava para a sociedade da Corte:

Uma palavra sobre essas conferências; dando crédito às que nos dizem os próprios brasileiros, elas constituem para eles uma novidade desconhecida e, até certo ponto, uma revolução nos seus hábitos. Se algum trabalho científico ou literário é apresentado ao público do Rio, é em condições especiais e diante de um auditório de elite, na presença do Imperador, que o autor faz solenemente leitura. $\mathrm{O}$ ensino popular, que consiste em admitir livremente todos quantos queiram escutar e aprender, tem sido até aqui uma coisa desconhecida. [...] Agassiz realizou, em francês, uma série de lições familiares sobre diversos assuntos científicos. ${ }^{3}$

A prática de conferências na capital imperial se estendeu pelas décadas seguintes do Oitocentos, com grande frequência nos anos de 1870 e 1880. A maioria delas era pública, ${ }^{4}$ e foi justamente nestas que foquei minha atenção. Nos vários locais onde foram desenvolvidas preleções, ${ }^{5}$ versava-se sobre assuntos diversificados, tais como economia, política, ciência e cultura. Dentre estes, dediquei minha análise apenas às conferências que tratavam de temas relacionados à ciência.

Nessa perspectiva, não contemplei as conferências liberais realizadas no Clube da Reforma, ${ }^{6}$ por se tratarem de preleções estritamente de cunho político. As conferências emancipacionistas, da mesma maneira, não foram analisadas, uma vez que apresentavam apenas temas vinculados à abolição, muito embora algumas tenham

\footnotetext{
${ }^{2}$ FREITAS, M. V. de. Charles Frederick Hartt..., p. 56. Entre 1846 e 1847, abordando "as leis da natureza e as maravilhas dos desígnios divinos inscritos no mundo natural", Agassiz proferiu conferências no Lowell Institute, em Boston, que atingiram um público de cinco mil pessoas. MACHADO, Maria Helena Pereira Toledo. Introdução: o adão norte-americano no éden amazônico. In: (Org.). O Brasil no olhar de William James: cartas, diários e desenhos, 1865-1866. São Paulo: Editora da Universidade de São Paulo, 2010, p. 43.

3 AGASSIZ, Elizabeth Cary; AGASSIZ, Louis. Viagem ao Brasil 1865-1867. Tradução de Edgar Süssekind de Mendonça. Brasília: Senado Federal, Conselho Editoria, 2000, p. 113.

${ }^{4} \mathrm{Em}$ oposição às sociedades fechadas, considero como espaços públicos aqueles nos quais qualquer pessoa tem acesso. HABERMAS, Jürgen. Mudança estrutural da esfera pública. Rio de Janeiro: Tempo Brasileiro, 1984.

${ }^{5}$ Os vocábulos conferência e preleção eram utilizados indiscriminadamente como sinônimos. Para uma discussão a respeitos da utilização dos dois termos pela imprensa que noticiava as Conferências Populares da Glória, conferir: CARULA, Karoline. A tribuna da ciência: as Conferências Populares da Glória e as discussões do darwinismo na imprensa carioca (1873-1880). São Paulo: Annablume; Fapesp, 2009.

${ }^{6}$ Clube fundado, em 1868, por liberais que tencionavam uma reforma política e eleitoral. Em 1869, o Clube criou o jornal A Reforma, considerado uma publicação oficial do partido liberal na Corte.
} 
perpassado por temáticas científicas. As desenvolvidas no Clube Politécnico também foram deixadas de lado porque muitas vezes eram franqueadas total ou parcialmente apenas aos sócios, não apresentando o caráter público aqui buscado. A despeito de alguns oradores que discursaram nesses locais terem ocupado outros espaços por mim trabalhados.

Para mapear esses eventos utilizei a imprensa periódica, que anunciava as conferências, e muitas vezes comentava o que lá era exposto. Classifiquei as preleções mapeadas em três grandes grupos: as Conferências Populares da Glória, os cursos públicos do Museu Nacional, e as "Avulsas", que não estavam inseridas em nenhuma das categorias anteriores, via de regra conferências isoladas e realizadas por iniciativa do próprio orador. Embora tenha rotulado estas últimas como "Avulsas", pela análise das mesmas pude verificar que algumas constituíam parte de pequenos cursos, nos quais um tema era exposto em mais de uma conferência, e outras tiveram uma organização mais sistemática.

As Conferências Populares da Glória foram o primeiro espaço onde ocorreram preleções de maneira mais metódica. Receberam esse nome porque eram efetuadas nas escolas públicas da freguesia da Glória, localizada na Praça Duque de Caxias, atual Largo do Machado. Elas foram criadas em 1873 pelo conselheiro Manoel Francisco Correia. ${ }^{7}$ Em seu início, ocorriam duas vezes por semana, depois somente aos domingos às 11 horas. As Conferências eram públicas e gratuitas, sendo apenas necessário adquirir um cartão para a entrada, o que garantia a participação a todos os integrantes de uma mesma família. A entrega do bilhete era feita antecipadamente pelo conselheiro e pelo orador do dia. ${ }^{8}$ Isto mostra que o público frequentador era seleto, vide que para obter os ingressos era necessário pegá-lo com o conselheiro ou com o preletor, ou seja, havia a necessidade de se estar inserido em uma rede de relações sociais de classes altas.

Manoel Correia, além de idealizador, coordenava o evento, selecionando aqueles que iriam ocupar a tribuna da Glória, como ficou conhecido o evento. A partir de 1884, a direção das Conferências Populares passou à Associação Promotora da Instrução Pública, entidade ligada à educação que teve, em janeiro de 1874, Manoel Francisco Correia como um dos fundadores. ${ }^{9}$

\footnotetext{
${ }^{7}$ Alguns dados biográficos profissionais do conselheiro Correia encontram-se no Anexo 1, assim como para os outros conferencistas dos quais foi possível obter essas informações.

${ }^{8}$ CARULA, K. A tribuna da ciência..., p. 37.

${ }^{9}$ A Associação, que funcionava com recurso particular, pretendia expandir a educação na Corte. Centrou sua atuação principalmente no ensino das crianças desvalidas. Em 1881, nas três freguesias onde
} 
Entre 1873 e 1889, ocorreram 596 preleções, proferidas por 145 oradores. No Anexo 2 encontram-se listados os nomes dos oradores e a quantidade de conferências que proferiram neste período. Com relação ao mapeamento das conferências, houve uma preleção, ocorrida em 1874, sobre a qual não tenho registro, mas sei que foi ofertada por um orador que já havia se apresentado naquele ano. Concluo isso ao comparar a minha listagem com a computada por Manoel Francisco Correia, em janeiro de 1875 , pois em ambas a quantidade de conferencistas é a mesma, mas na avaliação do coordenador havia uma conferência a mais. ${ }^{10}$ Em 24 de agosto de 1889, Manoel Francisco Correia teve que subir à tribuna devido a problemas de saúde do orador inscrito, o médico Feliciano Pinheiro de Bittencourt. Neste dia o criador das Conferências fez um balanço da instituição. Esta preleção não foi contabilizada pelo Jornal do Commercio, que ao anunciar a futura conferência, apresentava o tema, o orador e o número da mesma. Apesar disso, adicionei a mesma em meus cálculos. Acrescentei também uma conferência do conselheiro, ocorrida em 17 de março de 1878, que não foi numerada pelo Jornal do Commercio. ${ }^{11}$

A Tabela abaixo mostra quantas conferências ocorreram em cada ano, o orador que mais se apresentou e a quantidade de discursos que enunciou naquele ano. As duas últimas apresentações de 1889 ocorreram já em período republicano.

ocorriam as aulas promovidas pela agremiação chegaram a se inscrever 800 alunos. BASTOS, Maria Helena Camara. Conferências populares da freguesia da Glória (1873-1890). In: Anais do II Congresso Brasileiro de História da Educação: História e Memória da Educação brasileira. Natal: Núcleo de arte e cultura da UFRN, 2002.

${ }^{10}$ CARULA, K. A tribuna da ciência..., p. 39

${ }^{11}$ Cabe ressaltar o papel desta publicação com relação às Conferências da Glória, pois ela, dentre todas as outras utilizadas como fonte, foi a que mais promoveu o evento, anunciando, comentando e editando o resumo das apresentações. 
Tabela I

Quantidade de oradores que mais vezes se apresentaram, e suas preleções realizadas nas Conferências Populares da Glória entre 1873 e 1889

\begin{tabular}{|c|c|c|c|c|}
\hline Ano & $\begin{array}{l}\text { Número de } \\
\text { conferências } \\
\text { no ano }\end{array}$ & $\begin{array}{l}\text { Orador(es) que mais se } \\
\text { apresentou(ram) }\end{array}$ & $\begin{array}{l}\text { Quantidade } \\
\text { de preleções }\end{array}$ & $\begin{array}{c}\text { Percentagem de } \\
\text { preleções com } \\
\text { relação ao ano }\end{array}$ \\
\hline 1873 & 9 & $\begin{array}{l}\text { Luiz Joaquim Duque-Estrada } \\
\text { Teixeira }\end{array}$ & 3 & 33,3 \\
\hline 1874 & 97 & Antonio Ferreira Vianna & 19 & 19,6 \\
\hline 1875 & 50 & Augusto Cezar de Miranda Azevedo & 7 & 14,00 \\
\hline \multirow{2}{*}{1876} & \multirow{2}{*}{70} & João Manoel Pereira da Silva & 9 & \multirow{2}{*}{12,9} \\
\hline & & Joaquim Monteiro Caminhoá & 9 & \\
\hline 1877 & 1 & Francisco Antonio de Carvalho & 1 & 100,0 \\
\hline 1878 & 44 & José Maria Velho da Silva & 8 & 18,2 \\
\hline 1879 & 38 & Feliciano Pinheiro de Bittencourt & 15 & 39,5 \\
\hline 1880 & 47 & Manoel Francisco Correia & 6 & 12,8 \\
\hline 1881 & 50 & Joseph Auguste Aristide Fort & 13 & 26,0 \\
\hline \multirow{2}{*}{1882} & \multirow{2}{*}{30} & Antonio Coelho Rodrigues & 4 & \multirow{2}{*}{13,3} \\
\hline & & Licino Chaves Barcellos & 4 & \\
\hline 1883 & 30 & Feliciano Pinheiro de Bittencourt & 8 & 26,7 \\
\hline 1884 & 35 & Feliciano Pinheiro de Bittencourt & 7 & 20,0 \\
\hline 1885 & 21 & Feliciano Pinheiro de Bittencourt & 6 & 28,6 \\
\hline \multirow{2}{*}{1886} & \multirow{2}{*}{17} & Feliciano Pinheiro de Bittencourt & 4 & \multirow{2}{*}{23,5} \\
\hline & & João Kopke & 4 & \\
\hline 1887 & 25 & Carlos Antonio de Paula Costa & 10 & 40,0 \\
\hline 1888 & 13 & Feliciano Pinheiro de Bittencourt & 8 & 61,5 \\
\hline 1889 & 19 & Feliciano Pinheiro de Bittencourt & 15 & 78,9 \\
\hline Total & 596 & Feliciano Pinheiro de Bittencourt & 90 & 15,1 \\
\hline
\end{tabular}

Fonte: Jornal do Commercio (1873-1889), Conferencias Populares (1876), Gazeta de Noticias (18751880), O Globo (1874-1878), e Diario do Rio de Janeiro (1873-1878).

No período inicial, de 1873 a 1880, foi quando se realizaram mais conferências, ao todo foram $356 .{ }^{12} \mathrm{Em} 1874$ ocorreu o maior número, seguido de 1876 . Houve uma queda após 1881. Essa diminuição no decorrer da década de 1880 pode ser consequência do esgotamento do evento em si - perda da novidade, repetição de temáticas, etc. Muito embora a imprensa continuasse a noticiar as mesmas e a comentar muitas delas. É possível observar também que na primeira fase houve uma variedade maior de oradores. Em 1877, só houve uma preleção porque Manoel Francisco Correia se afastou da coordenação das Conferências, deixando a organização para o deputado

12 Aqui computei uma a mais (a de 28/03/1878) da listagem apresentada em trabalho anterior CARULA, K. A tribuna da ciência... 
Franklin Dória, que não deu continuidade. Com o retorno do conselheiro à direção, elas retomaram a periodicidade. ${ }^{13}$

Nos dois últimos anos, mais da metade das preleções foram proferidas por um mesmo orador, Feliciano Pinheiro de Bittencourt, que foi quem mais se apresentou em todos os anos, com 90 conferências. Médico formado pela Faculdade de Medicina do Rio de Janeiro e professor do colégio Pedro II, na década de 1880, Bittencourt foi figura constante na tribuna. Talvez porque não houvesse pessoas interessadas em se apresentar e, mediante esse problema, a maneira que conseguiu para manter o evento foi ele mesmo conferenciar. Na conferência de número 588, antes de Bittencourt subir à tribuna, Correia felicitou-o "por ter sido agraciado pelo governo imperial, por seus serviços prestados à instituição das preleções populares, durante bom número de anos". ${ }^{14}$ Provavelmente Bittencourt recebera aquela congratulação imperial por ter dado continuidade ao evento e por ter sido o orador que mais se apresentou. Aqui é possível observar a ligação das Conferências da Glória com as esferas do poder. Esta relação já havia sido sublinhada um ano antes, D. Pedro II retornava ao Brasil após uma viagem, então, o conselheiro Correio aproveitou para felicitar o regresso do Imperador, considerado por ele o "augusto protetor das conferências". 15

No outro grupo por mim definido estavam os cursos públicos do Museu Nacional. Inaugurados em 1875, sua realização ratificou uma das funções desenvolvidas pelo Museu: o ensino da ciência. Os oradores eram os diretores e subdiretores das seções da instituição. A promoção de cursos públicos pelo Museu Nacional já estava estabelecida no regulamento 123 de 1842: “Art. $8^{\circ}$ Aos Diretores das secções incumbe: [...] $5^{\circ}$ Dar um curso anual das ciências relativas às suas secções, à vista dos respectivos produtos, segundo as Instruções do Governo". ${ }^{16}$ Frei Custódio Alves Serrão, então diretor do Museu e idealizador do regulamento, se empenhou para instalar os cursos, porém não obteve êxito. ${ }^{17}$ Da criação deste regulamento até a efetivação dos cursos, apenas algumas conferências isoladas foram realizadas. ${ }^{18}$

\footnotetext{
${ }^{13}$ CARULA, K. A tribuna da ciência..., p. 41.

${ }^{14}$ Jornal do Commercio, 24/09/1889.

${ }^{15}$ Jornal do Commercio, 28/08/1888.

${ }^{16}$ Regulamento n. 123 de 3 de fevereiro de 1842. Dá ao Museu Nacional uma organisação accommodada á melhor classificação e conservação dos objectos. Disponível em:

<http://www6.senado.gov.br/legislacao/ListaPublicacoes.action?id=82141>. Acesso: 12 jan. 2010.

17 SÁ, Magali Romero; DOMINGUES, Maria Bertol Domingues. O Museu Nacional e o ensino das ciências naturais no Brasil no século XIX. Revista da SBHC, n. 15, p. 79-88, 1996.

${ }^{18}$ SÁ, M. R.; DOMINGUES, M. B. D. O Museu Nacional e o ensino das ciências...
} 
Foi somente em 1876, com Ladislau de Souza Mello Netto na direção do Museu, que os cursos puderam ser concretizados. Durante a sua administração, 1876 a 1893, o Museu passou por grande reforma, obtendo com isso maior amplitude nacional e internacional. ${ }^{19}$ Ao solicitar verba ao Ministério para reativar o laboratório de química, Ladislau Netto foi cobrado por este órgão da efetivação dos cursos públicos. O decreto n. 6116 de 9 de fevereiro de 1876, que reorganizou o Museu Nacional, normatizou a execução dos cursos. Ficou estabelecido que deveriam ser públicos e gratuitos; feitos por meio de preleções, oferecidas pelos diretores e subdiretores de seção; ministrados à noite, no mínimo uma vez por semana, entre 1 de março e 31 de outubro. ${ }^{20} \mathrm{O}$ Regimento Interno do Museu, de 1876, regulamentou a execução. Estipulou, no art. 31, que eles tinham de ser expostos "[...] de acordo no método de ensino e na essência de cada matéria [...]". ${ }^{21}$ Isto dava aos preletores a liberdade de apresentar o conteúdo segundo os critérios que considerassem convenientes de acordo com a sua área de conhecimento. Determinou também que as aulas, como eram chamadas essas conferências, deveriam começar às 19 horas, e terminar uma no máximo uma hora e meia depois. Os resumos dos cursos eram enviados à imprensa, que os anunciava e às vezes publicava a sua sinopse. ${ }^{22}$

Ladislau Netto, em 16 de julho de 1884, enviou ao Ministério um ofício informando que Orville Adalbert Derby, diretor da seção de "Ciências físicas", havia lhe enviado um comunicado, anexado ao seu, no qual relatava que preparar as conferências para os cursos públicos estava demandando um tempo demasiado grande e isto prejudicava a execução de suas atividades de pesquisa no Museu. Um dos motivos para tal prejuízo era que o geólogo estadunidense tinha que prepará-las e expô-las em língua portuguesa. Após quatro anos de experiência, Derby concluiu que suas preleções não despertavam o interesse do público e não valiam o tempo necessário para planejálas, além da falta do dom da oratória que ele dizia não possuir.

\footnotetext{
19 "Em 1875 assumiu a direção do Museu Ladislau de Souza Mello Netto, que já vinha atuando como Diretor da Seção de Botânica e Agricultura desde 1866, e como diretor interino da instituição desde 1872”. SÁ, M. R.; DOMINGUES, M. B. D. O Museu Nacional e o ensino das ciências..., p. 81.

${ }^{20}$ Decreto n. 6116 de 9 de fevereiro de 1876. Reorganiza o Museu Nacional. Disponível em: <http://www6.senado.gov.br/legislacao/ListaPublicacoes.action?id=69806>. Acesso: 12 jan. 2010.

${ }^{21}$ Regimento interno do Museu Nacional. 1879. Pasta 18, doc. 9A (Seção de Memória e Arquivo do Museu Nacional, doravante SEMEAR).

22 BRASIL. Ministério da Agricultura, Commercio e Obras Publicas. Relatorio do anno de 1881 apresentado á Assembléa Geral Legislativa na $1^{\underline{a}}$ Sessão da $18^{\underline{a}}$ Legislatura. Rio de Janeiro, 1882, pelo ministro José Antonio Saraiva.
} 
Para despertar esse interesse, seriam necessários os recursos oratórios de um Agassiz ou de um Huxley, e isso está muito acima de minhas forças. [...] Penso que o primeiro dever de um empregado do Museu é trabalhar e não discursar [...] Criar e manter por meio de preleções o interesse público pela ciência geológica, está muito acima de minhas forças e não vejo utilidade em continuar a tentativa. ${ }^{23}$

Em seu ofício, Ladislau Netto afirmou que considerava justos e bem fundamentados os argumentos de Derby, que havia contado com o apoio de outros diretores do Museu. Ao término, o diretor da instituição explicitou estar de acordo com as solicitações, todavia, era favorável à continuidade das preleções, mas não sob a forma de cursos e nem de forma obrigatória, "mas aplicadas a certos assuntos de alto interesse para o Museu ou para o país, e à vontade dos preletores". ${ }^{24}$ A solicitação foi bem recebida pelo Ministério, e em 1888, o decreto 9942 estabeleceu que a partir daquela data fossem realizadas apenas conferências públicas, apresentadas sempre que se julgasse "conveniente aos interesses do Museu e da ciência". ${ }^{25}$

Na década de 1870 e 1880 outras preleçõs foram realizadas na cidade do Rio de Janeiro, atingindo o ápice em 1877. Dentre essas que classifiquei como "Avulsas", as primeiras que encontrei registro na imprensa datam de 1874. O levantamento que fiz foi baseado na sua divulgação nos jornais diários. Nesse mapeamento pode ser que algumas não tenham sido contempladas, por não estarem registradas nesses meios de comunicação.

A maioria era de iniciativa particular, de uma pessoa ou de um grupo. Efetuadas, principalmente, ou em torno das 11 horas ou por volta das 19 horas. Diferente das Conferências Populares da Glória, que tinham um salão destinado a este uso, e dos cursos públicos do Museu Nacional, que também possuíam um ambiente específico para tal, as "Avulsas" ocorreram em espaços da cidade utilizados fundamentalmente para outros fins:

\footnotetext{
${ }^{23}$ Registro da Correspondência Oficial do Museu Nacional. Livro $7^{\circ}$. 1881-1885, p. 132 v. (SEMEAR). Grifos do original.

${ }^{24}$ Registro da Correspondência... Livro $7^{\circ} .1881-1885$, p. 132. (SEMEAR).

${ }^{25}$ Decreto n. 9942, de 25 de abril de 1888. Reorganiza o Museu Nacional. Disponível em:

<http://www6.senado.gov.br/legislacao/ListaPublicacoes.action?id=70511>. Acesso: 23 jan. 2010.
} 
Tabela II

Locais de realização das conferências "Avulsas"

\begin{tabular}{|c|c|c|c|}
\hline $\begin{array}{lr}\text { Tipo } & \text { de } \\
\text { estabelecimento }\end{array}$ & Local & Endereço & Freguesia \\
\hline Escolas & $\begin{array}{l}\text { Escola da Glória } \\
\text { Escola S. José } \\
\text { Escola de Santana } \\
\text { Escola de S. Sebastião } \\
\text { Escola noturna de Botafogo } \\
\text { Escola noturna da Lagoa } \\
\text { Escola Industrial da Sociedade } \\
\text { Auxiliadora da Indústria Nacional } \\
\text { Curso noturno gratuito de S. } \\
\text { Cristóvão } \\
\text { Colégio Nossa Senhora da Glória } \\
\text { Externato Aquino }\end{array}$ & $\begin{array}{l}\text { Praça Duque de Caxias } \\
\text { Rua da Ajuda } \\
\text { Praça da Aclamação } \\
\text { Praça } 11 \text { de Junho } \\
\text { Rua S. Clemente, } 39 \\
\text { Rua S. Clemente, } 37 \\
\text { Praça da Aclamação, } 31 \\
\text { Praça de D. Pedro I, } 13 \\
\text { Rua das Laranjeiras, } 41 \\
\text { Rua do Lavradio, } 78 \text { e } 80\end{array}$ & $\begin{array}{l}\text { Glória } \\
\text { S. José } \\
\text { Santana } \\
\text { Santana } \\
\text { S. João Batista da } \\
\text { Lagoa } \\
\text { S. João Batista da } \\
\text { Lagoa } \\
\text { Santana } \\
\\
\text { São Cristóvão } \\
\quad- \\
\quad- \\
\end{array}$ \\
\hline Teatros & $\begin{array}{l}\text { Teatro Cassino } \\
\text { Teatro S. Pedro de Alcântara } \\
\text { Teatro de Pedro II } \\
\text { Teatro S. Luiz } \\
\text { Teatro Fênix Dramática } \\
\text { Teatro Ginásio } \\
\text { Teatro das Variedades }\end{array}$ & $\begin{array}{l}\text { Rua do Espírito-Santo } \\
\text { Praça da Constituição } \\
\text { Rua da Guarda-Velha } \\
\text { Rua de Souza Franco } \\
\text { Rua da Ajuda, } 59 \\
\text { Rua de Souza Franco } \\
\text { - }\end{array}$ & $\begin{array}{rr} & - \\
& - \\
& - \\
& - \\
\text { S. José } & \\
& - \\
& -\end{array}$ \\
\hline Associações & $\begin{array}{l}\text { Ateneu Acadêmico } \\
\text { Grande Oriente Unido do Brasil }\end{array}$ & $\begin{array}{c}- \\
\text { Rua dos Beneditinos, } 22 \\
\end{array}$ & - \\
\hline Instituições & $\begin{array}{l}\text { Faculdade de Medicina } \\
\text { Escola Politécnica } \\
\text { Instituto Farmacêutico } \\
\text { Hospital da Ordem Terceira de S. } \\
\text { Francisco da Penitencia } \\
\text { Policlínica Geral }\end{array}$ & $\begin{array}{r}- \\
- \\
\text { Rua de S. José, } 68 \\
- \\
\text { R. dos Ourives, } 1\end{array}$ & $\begin{array}{l}- \\
- \\
- \\
- \\
-\end{array}$ \\
\hline Outros & $\begin{array}{l}\text { Palácio da Exposição Nacional } \\
\text { Tipografia Nacional }\end{array}$ & $\begin{array}{c}- \\
\text { Rua da Guarda Velha }\end{array}$ & - \\
\hline
\end{tabular}

Fonte: Jornal do Commercio (1870-1889), Diario do Rio de Janeiro (1873-1878), Gazeta de Noticias (1875-1880), O Globo (1874-1878), Almanak Administrativo, Mercantil e Industrial da Corte e do Rio de Janeiro, 1877.

Esses espaços eram cedidos pelos seus proprietários, pelas instituições ou associações que os dirigiam. A diversidade de locais sugere que a prática era bem recebida entre tais sujeitos. Já a quantidade de freguesias indica que os eventos estavam disseminados pela cidade, fazendo parte do cotidiano da vida da elite da sociedade em diferentes regiões.

$\mathrm{Na}$ escola da Glória, em 1877, vários oradores discursaram nos cursos livres de instrução superior. Nesse ano ocorreu apenas uma preleção nas Conferências Populares, 
e alguns oradores que frequentavam esta tribuna criaram esse novo tipo de espaço de exposição. Os cursos eram ministrados por "uma nova associação de literatos", que objetivavam "propagar o conhecimento das ciências e letras e desenvolver o gosto do povo". ${ }^{26}$ Além do conselheiro João Manoel Pereira da Silva, que encabeçava a associação, o grupo contava com Antonio Ferreira Vianna; Affonso Celso de Assis Figueiredo, visconde de Ouro Preto, também conselheiro do Imperador e Francisco Ignacio de Carvalho Rezende, todos se apresentaram nas Conferências Populares da Glória. A temática abordada era muito semelhante àquelas organizadas por Manoel Francisco Correia. O curso deixou de existir no ano seguinte, quando as Conferências Populares da Glória retomaram a sua periodicidade.

Algumas das preleções “Avulsas” foram organizadas a fim de arrecadar fundos para causas beneficentes, como em favor das vítimas da seca da Paraíba e do Ceará ${ }^{27}$ e do Rio Grande do Norte, ${ }^{28}$ e as das enchentes em Campos e em Portugal. ${ }^{29}$ Nos dois casos colocava-se uma caixa de coleta, na qual cada um depositava o quanto desejasse. Com esse mesmo intuito, Octaviano Hudson, tipógrafo da Tipografia Nacional, proferiu uma conferência, em 1877, cujo rendimento seria destinado às órfãs de Fagundes Varella. Lopes Trovão discursou, em 1878, para levantar fundos para a Associação Tipográfica Fluminense; e em 1879 para ajudar a Sociedade Acadêmica da Escola de Medicina.

Entre as conferências beneficentes, encontrei uma proferida por mulher. A condessa Lydia Pasckoff, escritora russa que estava no Brasil, em 1877, apresentou, no Teatro de S. Luiz, a preleção "Estado da mulher na civilização moderna e em seu futuro". Foi cobrada a entrada de $2 \$$ por pessoa, e o valor arrecadado seria doado para as vítimas da seca do Rio Grande do Norte.

Em vista dos grandes número de eventos dispersos pela cidade, conclui-se que em fins do século XIX a sociedade carioca teve a possibilidade de assistir a várias

\footnotetext{
${ }^{26}$ Diario do Rio de Janeiro, 29/06/1877.

${ }^{27}$ As conferências de 03/06/1877, no teatro S. Pedro, e de 17/10/1877, da qual não encontrei referências sobre o local, tiveram a renda revertida para as vítimas cearenses. Já em 08/08/1877, no teatro Ginásio, o rendimento da preleção foi para os atingidos pela seca na Paraíba e no Ceará.

28 Ocorreram nove preleções para angariar fundos para as vítimas das secas no Rio Grande do Norte 25/03/1877 e 01/07/1877, no teatro S. Pedro; 26/05/1877, no Grande Oriente dos Beneditinos; 15/07/1877, 29/07/1877, 12/08/1877 e 19/08/1877, teatro Ginásio; 24/10/1877, no teatro S. Luiz, e 25/05/1878, no teatro das Variedades.

${ }^{29}$ Em 28/01/1877, no teatro Fênix Dramática, a conferência arrecadou verba para as duas localidades e em 11/03/1877, no tetro S. Pedro, o montante recebido foi destinado somente para Campos.
} 
conferências públicas. Promovidas por pessoas e grupos diversos, elas mudaram a dinâmica da cidade e fizeram parte do cotidiano da elite letrada naquele período.

\section{Temáticas dos cursos e conferências}

Os assuntos apresentados nas conferências eram considerados importantes e estavam inseridos dentro de projetos mais amplos de modernização da nação. Ao discorrer sobre essa temática, os preletores faziam uso de um vocabulário científico/cientificista, mesmo quando o foco principal da exposição não era estritamente vinculado à ciência. Ou seja, a linguagem da ciência era a maneira de veicular esta nova agenda de projetos modernizadores que estava se formando.

As Conferências Populares da Glória abarcaram temas variados, destacando-se os culturais (literatura, teatro, história, educação, geografia, letras) e os relativos à ciência (ciências naturais, matemática, medicina, ciências físicas). ${ }^{30}$ Neste trabalho fiz um recorte no qual abordo as que expuseram assuntos relativos à ciência (Anexo 3). Classifiquei, para fins de análise, as preleções segundo o tema central desenvolvido pelo orador. Para algumas conferências, a única informação que encontrei foi o título da mesma, então, a categorização foi feita com base nesta única variável. Para aquelas que obtive mais informações, como o texto integral ou o resumo e/ou comentário publicado(s) na imprensa, analisei o conteúdo exposto para depois catalogá-las.

\footnotetext{
${ }^{30}$ FONSECA, Maria Rachel Fróes da. As "Conferências Populares da Glória": a divulgação do saber científico. História, ciências, saúde - Manguinhos, Rio de Janeiro, Casa de Oswaldo Cruz / Fiocruz, v. 2, n. 3, p. 135-166, nov. 1995/fev. 1996.
} 
Tabela III

Assuntos relacionados à ciência desenvolvidos nas Conferências Populares da Glória entre 1873 e 1889

\begin{tabular}{ccc}
\hline Tema & Número de conferências & \% \\
\hline Medicina & 85 & 36,5 \\
Higiene & 39 & 16,7 \\
Antropologia & 34 & 15,6 \\
Botânica & 24 & 10,3 \\
Evolucionismo & 13 & 5,6 \\
Geologia & 07 & 3,0 \\
Química & 07 & 3,0 \\
Biologia & 04 & 1,7 \\
Matemática & 04 & 1,7 \\
Tecnologias & 03 & 1,3 \\
Meteorologia & 03 & 1,3 \\
Farmácia & 03 & 1,3 \\
Física & 03 & 1,3 \\
História da Ciência & 02 & 0,9 \\
Ciências Naturais & 01 & 0,4 \\
Astronomia & 01 & 0,4 \\
Total & $\mathbf{2 3 3}$ & $\mathbf{1 0 0 , 0}$ \\
\hline
\end{tabular}

Fonte: Jornal do Commercio (1873-1889), Conferencias Populares (1876), Gazeta de Noticias (18751880), O Globo (1874-1878), e Diario do Rio de Janeiro (1873-1878).

Para realizar esta classificação segui, a partir do trabalho de Tania Maria Bessone da Cruz Ferreira, a catalogação de assuntos organizada por Jacques Charles Brunet no século XIX. De acordo com a autora, Brunet escreveu um "manual de orientação para livreiros" utilizando um sistema classificatório que era usual nas bibliotecas. $^{31}$ Em seu sistema, estabeleceu cinco categorias maiores: Teologia, Jurisprudência, Ciências e artes, Belas-letras e História. No item "Ciências e artes" inseriam-se: "filosofia, ciências físicas, ciências naturais, medicina, matemática, artes, música". ${ }^{32}$ Considerei geologia, química, física, astronomia e meteorologia como integrantes de ciências físicas; botânica, evolucionismo, antropologia e farmácia de ciências naturais; e higiene de medicina.

$\mathrm{Na}$ listagem consta o item tecnologias, que abarca as conferências nas quais foram apresentadas novidades tecnológicas, a importância da ciência era evidenciada por meio das inovações por ela produzidas. Para elucidar, cito a conferência de Licinio

\footnotetext{
${ }^{31}$ FERREIRA, Tania Maria Bessone da Cruz. Palácios de destinos cruzados: bibliotecas, homens e livros no Rio de Janeiro, 1870-1920. Rio de Janeiro: Arquivo Nacional, 1999, p. 179. Muito usado na França até fins do século XIX, o sistema Brunet no Brasil serviu de base para a criação do primeiro catálogo da Biblioteca Nacional coordenado por João Saldanha.

Disponível em: <http://www.bn.br/portal/?nu_pagina=14>. Acesso: 10 fev. 2011.

${ }^{32}$ FERREIRA, T. M. B. da C. Palácios de destinos cruzados..., p. 179.
} 
Chaves Barcellos, que em 1882 discorreu sobre a iluminação elétrica, e ao apresentar os diferentes tipos de lâmpada abordou os fenômenos físicos a ela vinculados. ${ }^{33}$

Medicina foi o assunto mais frequente. Nesta categoria inclui as conferências que tratavam de doenças, a profissão e o ensino médicos, discussões sobre determinadas substâncias, fisiologia, anatomia, e aquelas cujas análises e argumentos foram baseados no discurso médico. Moléstias como a tuberculose, a febre amarela e a cólera, que afligiam a população no período, foram analisadas em preleções. As duas últimas doenças, ausentes no Brasil da primeira metade do século XIX, causaram muitas vítimas em sua segunda metade. ${ }^{34}$ Neste período, uma quantidade significativa de teses sobre a febre amarela foi defendida na Faculdade de Medicina do Rio de Janeiro, indicando como a doença era preocupante para os médicos. ${ }^{35}$

A cidade sofreu com duas graves epidemias da enfermidade nas décadas de 1850 e 1870. Sidney Chalhoub assevera que, "ao lidar com o problema da febre amarela num momento histórico particular, as autoridades de saúde pública dos governos do Segundo Reinado inventaram alguns dos fundamentos essenciais do chamado 'ideal do embranquecimento"., ${ }^{36}$ Com relação à tuberculose, Chalhoub ressalta que a letalidade na Corte foi extremamente grande no decorrer de todo o século, chegando a matar mais que do que outras doenças epidêmicas, porém, nenhum plano de combate foi colocado em prática. ${ }^{37}$ Para o autor, esta prioridade em combater a febre amarela ocorreu devido ao fato de ela acometer mais os brancos, atrapalhando o embranquecimento da população via imigração. Diferente do que ocorria com a tuberculose, que atingia indiscriminadamente brancos e negros.

O uso do tabaco foi tema da conferência do médico, especialista em doenças dos olhos, José Cardoso de Moura Brasil, ${ }^{38}$ que associou o uso da substância à cegueira de determinados fumantes. Feliciano de Bittencourt também dedicou sua atenção ao tabaco em 15 preleções, relacionando o seu consumo com a degenerescência física e moral e com o aparecimento de algumas enfermidades, como alienação, cancros e patologias

\footnotetext{
${ }^{33}$ Jornal do Commercio, 17/07/1882.

${ }^{34}$ CHALHOUB, Sidney. Cidade febril: cortiços e epidemias na Corte imperial. São Paulo: Companhia das Letras, 1996, p. 60.

35 Uma lista das teses com caráter social defendidas nesta Faculdade entre 1831 e 1900 pode ser encontrada em: GONDRA, José Gonçalves. Artes de civilizar: medicina, higiene e educação escolar na Corte imperial. Rio de Janeiro: EdUERJ, 2004.

${ }^{36}$ CHALHOUB, S. Cidade febril..., p. 62.

${ }^{37}$ CHALHOUB, S. Cidade febril..., p. 57.

${ }^{38}$ Chefe do serviço de oftalmologia da Policlínica Geral do Rio de Janeiro, da qual era um dos fundadores direto. Disponível em: <http://www.anm.org.br/membros_detalhes.asp?id=470>. Acesso: 11 fev. 2011.
} 
oculares. Bittencourt também desenvolveu uma relação entre o consumo do tabaco e do álcool, enfatizando as causas maléficas para a saúde e para a sociedade da associação de ambos. Salientou como este problema atacava os países do norte europeu, onde o consumo era maior, e citou medidas que a França havia tomado para tentar resolver o problema no país. ${ }^{39}$ É possível verificar, portanto, que os problemas sociais eram analisados e compreendidos por meio do viés da ciência.

$\mathrm{O}$ segundo tema mais recorrente foi o da higiene. Considerei pertencente à categoria as conferências que tinham o termo em seu título ou utilizaram o discurso higienista para sustentar suas ideias. Um exemplo deste último caso foi a intitulada "Ginástica, natação e equitação", proferida pelo médico Feliciano Pinheiro de Bittencourt, em 06 de julho de 1879. Para discorrer sobre a importância para a saúde das três atividades, o orador enfatizou que iria tratá-las como médico por meio da perspectiva da higiene. ${ }^{40}$ Salientou a necessidade das atividades enquanto práticas higiênicas, destacou ainda que a ginástica e a natação deveriam ser realizadas também pelas mulheres.

O médico Antenor Augusto Ribeiro Guimarães, em 1874, ministrou o curso de higiene, composto por sete preleções, tratando em algumas dos problemas que os pântanos causavam para a saúde pública ${ }^{41}$ e do sistema de esgoto da cidade. ${ }^{42}$ Questão semelhante foi discutida por Feliciano de Bittencourt quatro anos depois. Este condenou a edificação de prédios próximos aos pântanos, defendeu a construção de ruas largas e a necessidade do saneamento da Corte. ${ }^{43}$ Segundo Jaime Larry Benchimol, os pântanos eram temidos por serem considerados "focos de exalação de miasmas, os pestíferos gases que veiculavam os agentes causadores das doenças e da morte"; motivo pelo qual muitos médicos defendiam o aterro dos mesmos. ${ }^{44}$ Aqui se pode ver que assuntos do cotidiano da cidade eram discutidos nas Conferências, indicando que elas se constituíram como mais um espaço de debate de tais questões. O discurso higienista

\footnotetext{
39 Jornal do Commercio, 21/10/1885. A associação entre o tabagismo e o alcoolismo foi muito desenvolvida entre os eugenistas do início do século XX, estes acreditavam que tais fatores poderiam causar a degeneração da raça. STEPAN, Nancy Leys. A hora da eugenia: raça, gênero e nação na América Latina. Rio de Janeiro: Editora Fiocruz, 2005.

40 Jornal do Commercio, 09/07/1879.

${ }^{41}$ Diario do Rio de Janeiro, 20/01/1874.

42 Jornal do Commercio, 17/01/1874.

43 Jornal do Commercio, 10/12/1878.

${ }^{44}$ BENCHIMOL, Jaime Larry. Pereira Passos: um Haussmann tropical: A renovação urbana da cidade do Rio de Janeiro no início do século XX. Rio de Janeiro: Secretaria Municipal de Cultura, Turismo e Esportes, Departamento Geral de Documentação e Informação Cultural, Divisão de Editoração, 1992, p. 116.
} 
marcou muitas das discussões; desta maneira, incutia-se nas pessoas que assistiam aos eventos os valores e explicações fundamentados no higienismo.

Com relação às preleções de botânica, a maioria fez parte do curso homônimo desenvolvido, em 1876, pelos médicos Francisco Ribeiro Mendonça e Joaquim Monteiro Caminhoá, também conselheiro, respectivamente, opositor e lente ${ }^{45}$ da cadeira de botânica e zoologia da Faculdade de Medicina do Rio de Janeiro. Provavelmente, em suas apresentações expuseram assuntos que tratavam naquela instituição.

As conferências sobre higiene, antropologia e evolucionismo serão abordadas com maior profundidade nos capítulos seguintes.

Para categorizar as temáticas das conferências "Avulsas" usei o mesmo critério feito com as Conferências da Glória. Ao observar os quadros de temas desenvolvidos nesses dois grupos, encontrei muitas convergências. Selecionei e classifiquei as que estavam relacionadas com assuntos da ciência (Anexo 4). Como fiz o levantamento utilizando os artigos publicados nos jornais, há grupos de conferências que não estão completos.

\section{Tabela IV}

\section{Assuntos relacionados à ciência desenvolvidos nas conferências "Avulsas" entre 1873 e 1889}

\begin{tabular}{ccc}
\hline Temas & Número de conferências & \% \\
\hline Higiene & 70 & 46,1 \\
Medicina & 48 & 31,6 \\
Evolucionismo & 6 & 3,9 \\
Física & 6 & 3,9 \\
Astronomia & 5 & 3,3 \\
Botânica & 4 & 2,6 \\
Química & 4 & 2,6 \\
Farmácia & 3 & 2,0 \\
Antropologia & 2 & 1,3 \\
Geologia & 2 & 1,3 \\
Ciências físicas & 1 & 0,7 \\
Tecnologias & 1 & 0,7 \\
Total & $\mathbf{1 5 2}$ & $\mathbf{1 0 0 , 0}$ \\
\hline
\end{tabular}

Fontes: Jornal do Commercio (1870-1889), Diario do Rio de Janeiro (1873-1878), Gazeta de Noticias (1875-1880), O Globo (1874-1878).

\footnotetext{
${ }^{45}$ Lente era o professor titular da cátedra e opositor o seu substituto. A classe de opositor foi criada com a Reforma Bom Retiro, instituída pelo decreto n. 1.387, de 28/04/1854, que reorganizou as faculdades de medicina do Império. Em 1875, por meio do decreto n. 2.649, de 22 de setembro, os opositores passaram a substitutos e adquiriram o direito à cadeira, na ausência do mesmo um concurso deveria ser realizado. Escola Anatômica, Cirúrgica e Médica do Rio de Janeiro. Dicionário Histórico-Biográfico das Ciências da Saúde no Brasil (1832-1930). Disponível em: 〈http://www.dichistoriasaude.coc.fiocruz.br〉. Acesso: 18 fev. 2010.
} 
Ao comparar a quantidade de preleções apresentadas no Anexo 4 com a exposta na Tabela acima, observa-se que nesta última existem 29 a mais. Isto se explica porque em 1874 encontrei apenas o registro da 4" conferência intitulada "Moléstias do aparelho lacrimal", de Pires Ferreira. No entanto, para fins de cálculo computei as outras três anteriormente realizadas. Neste mesmo ano, o Jornal do Commercio anunciou a $2^{\text {a }}$ conferência do médico Carlos Arthur Moncorvo de Figueiredo sobre "Higiene da infância”, ocorrida no colégio Nossa Senhora da Glória. ${ }^{46}$ Entretanto, não encontrei, nas fontes consultadas, nenhuma referência à primeira, mesmo assim a inseri no cálculo. Igual procedimento foi tomado com as preleções do curso de higiene popular de Carlos Antonio de Paula Costa. No final de 1877 foi noticiada a $19^{\text {a }}$ preleção deste curso, porém eu só havia detectado nas fontes 14 delas, portanto, acrescentei mais cinco. Também, em 1879 , foram anunciadas a $1^{\mathrm{a}}, 2^{-}$e $5^{\frac{a}{a}}$ conferências desse mesmo orador, adicionei à contagem mais duas, referentes às que não achei o registro. Em 1883, encontrei o registro da $2^{\underline{a}}$ conferência acadêmica realizada na Faculdade de Medicina, somei mais uma referente à primeira. Neste mesmo ano, achei nota sobre a $4^{\underline{a}}$ preleção do curso de patologia infantil de Carlos Arthur Moncorvo de Figueiredo, por isso, adicionei mais 3. Não encontrei, em 1884, o registro de sete conferências $\left(5^{\underline{a}}, 7^{\underline{a}}, 9^{\underline{a}}, 11^{\underline{a}}\right.$, $13^{\mathrm{a}}, 14^{\mathrm{a}}$ e $\left.15^{\mathrm{a}}\right)$ do curso de moléstias da pele e sifilíticas, do médico Silva Araujo. Contudo, estas foram computadas. Por fim, em 1885, adicionei cinco preleções ( $1^{\underline{a}}$ a $\left.5^{\underline{a}}\right)$, referentes ao mesmo curso.

Moncorvo de Figueiredo, em 1881, juntamente com outros médicos, fundou a Policlínica Geral do Rio de Janeiro, ficando responsável pela Clínica de Moléstia de Crianças. ${ }^{47}$ Neste local foram realizadas várias conferências, que iniciadas em 1882, perduraram por dezenove anos. As proferidas por Moncorvo de Figueiredo estavam relacionados ao setor clínico de sua responsabilidade. Júnia Sales Pereira afirma que o ensino de uma disciplina específica sobre doenças infantis, separada do ensino da medicina de partos, surgiu nesses cursos livres e não na Faculdade de Medicina. No mesmo ano, Moncorvo de Figueiredo enviou ao Ministro dos Negócios do Império, Rodolfo Epitáfio de Souza Dantas, uma solicitação para a criação de uma cadeira sobre moléstias das crianças nas Faculdades de Medicina do Rio de Janeiro e de Salvador e ofereceu o espaço da Policlínica para sediar a instituição fluminense. Com a Reforma

\footnotetext{
${ }^{46}$ Jornal do Commercio, 12/05/1874.

${ }^{47}$ PEREIRA, Júnia Sales. História, ciência e infância: narrativas profissionais no processo de singularização da pediatria como especialidade. Brasília: CAPES; Belo Horizonte: Argvmentvm, 2008, p. 67.
} 
Sabóia, de 1882, ficou estabelecida a criação da cadeira de Clínica Médica e Cirúrgica de Crianças. ${ }^{48}$

É significativa, ao analisar a Tabela IV, a quantidade de preleções que abordaram a temática da higiene, a maioria oferecida por médicos. Guilherme Belmonte, em 1877, efetuou, na escola de S. Pedro, seu curso de higiene popular. Outro orador que da mesma maneira desenvolveu esse tipo de curso foi o médico Carlos Antonio de Paula Costa, entre 1877 e 1879. Não encontrei nada que vinculasse os dois cursos. Portanto, é possível inferir que aqueles sujeitos estavam preocupados e empenhados em introjetar o discurso higienista, por considerá-lo importante para o desenvolvimento da sociedade.

A iniciativa de executar esses cursos partiu dos próprios médicos, que se julgavam, e de certa maneira eram considerados, detentores de um saber fundamental para a solução dos problemas da sociedade. Carlos Costa elogiou a atitude semelhante de Belmonte:

[...] [Costa] agradece as palavras benévolas que lhe dirigiu o seu ilustre colega, o Dr. Guilherme Belmonte, ao inaugurar um curso idêntico na freguesia de Santana, e faz votos para que outros imitem o seu exemplo, ampliando, porém, o seu programa. ${ }^{49}$

Assuntos como higiene da mulher e da criança também foram discutidos em outros espaços. Um bom exemplo disso foi a questão do aleitamento materno, tema de várias teses nas Faculdades de Medicina do Rio de Janeiro e da Bahia. Nesses trabalhos acadêmicos, o aleitamento materno era incentivado e o mercenário condenado. ${ }^{50} \mathrm{O}$ próprio médico conferencista Carlos Costa esteve envolvido nesses debates.

\footnotetext{
${ }^{48}$ PEREIRA, J. S. História, ciência e infância..., p. 68. A Reforma Sabóia foi implementada pelo decreto n. 9.311, de 25 de outubro de 1884, recebeu este nome em função da atuação do então diretor da Faculdade de Medicina do Rio de Janeiro Vicente Cândido Figueira de Sabóia (Visconde de Sabóia). A Reforma estabelecia mudanças no sistema de ensino médico no Brasil, já propostas no decreto de 1879 , mas ainda implantadas. A nova lei estabelecia que "Cada Faculdade deveria ministrar um curso de Ciências Médicas e Cirúrgicas e mais três cursos anexos, o de Farmácia, ainda em três anos, o de Obstetrícia e Ginecologia, em dois anos e o de Odontologia, em três anos." Escola Anatômica, Cirúrgica e Médica do Rio de Janeiro. Dicionário Histórico-Biográfico das Ciências da Saúde no Brasil (18321930). Disponível em: 〈http://www.dichistoriasaude.coc.fiocruz.br〉. Acesso: 18 fev. 2010.

${ }^{49}$ Gazeta de Noticias, 08/09/1877.

${ }^{50}$ MACHADO, Maria Helena Pereira Toledo. Corpo, gênero e identidade no limiar da abolição: a história de Benedicta Maria Albina da Ilha ou Ovídia, escrava (Sudeste, 1880). Afro-Ásia, Salvador, n. 42, p. $157-$ 193, 2010. CARNEIRO, Maria Elizabeth Ribeiro. Procura-se uma "preta, com muito bom leite, prendada e carinhosa": uma cartografia das amas-de-leite na sociedade carioca (1850-1888). Tese (Doutorado em História) - Instituto de Ciências Humanas, Universidade de Brasília, Brasília, 2006.
} 
Silva Araujo, médico da Policlínica Geral do Rio de Janeiro, promoveu, neste mesmo estabelecimento, em 1884, um curso de moléstias da pele e sífilis. Dissertou sobre variadas doenças fazendo uso de equipamentos de apoio, como, por exemplo, projetores de "lanterna de luz oxídrica" para a exposição de preparações microscópicas. ${ }^{51}$

Com relação aos cursos públicos do Museu Nacional, os oradores que lá se apresentaram eram os diretores e subdiretores das seções. Até 1875, seguindo o estabelecido pelo Regulamento 123 de 03/02/1842, a instituição possuía quatro seções: $1^{\underline{a}}$ ) Anatomia comparada e zoologia; $2^{\underline{a}}$ ) Botânica, agricultura e artes mecânica; $3^{\underline{a}}$ ) Mineralogia, geologia e ciências físicas; e 4ª $)$ Numismática, artes liberais, arqueologia, usos e costumes das nações antigas e modernas.

Em 1876, com o Decreto 6116, o Museu passou a ter três seções, além da anexa de arqueologia, etnografia e numismática, que não oferecia conferências.

\section{Tabela V}

\section{Seções, diretores e subdiretores do Museu entre 1876 e 1888}

\begin{tabular}{|c|c|c|c|}
\hline Seção & Nome da Seção & Diretor & Subdiretor \\
\hline $1^{\underline{a}}$ & $\begin{array}{l}\text { Antropologia, zoologia } \\
\text { geral e aplicada, } \\
\text { anatomia comparada e } \\
\text { paleontologia animal }\end{array}$ & $\begin{array}{l}\text { João Joaquim Pizarro } \\
(1871-83) \\
\text { João Baptista de Lacerda } \\
(1884-91)\end{array}$ & $\begin{array}{l}\text { João Baptista de Lacerda } \\
(1876-83) \\
\text { Emilio Goeldi } \\
(1885-90)\end{array}$ \\
\hline $2^{\underline{a}}$ & $\begin{array}{l}\text { Botânica geral e } \\
\text { aplicada, e paleontologia } \\
\text { vegetal }\end{array}$ & $\begin{array}{l}\text { Ladislau Netto } \\
(1865-93)\end{array}$ & $\begin{array}{l}\text { Nicolau Joaquim Moreira } \\
(1876-83) \\
\text { Collantino Marques de Souza Filho } \\
(1884-86)\end{array}$ \\
\hline $3^{\mathrm{a}}$ & $\begin{array}{l}\text { Ciências físicas: } \\
\text { mineralogia, geologia e } \\
\text { paleontologia geral }\end{array}$ & $\begin{array}{l}\text { Charles Frederick Hartt } \\
(1876-77) \\
\text { Orville Adalbert Derby } \\
(1879-90)\end{array}$ & $\begin{array}{l}\text { Carlos Luiz de Saules Junior } \\
(1876-78) \\
\text { Francisco José de Freitas } \\
(1882-90)\end{array}$ \\
\hline
\end{tabular}

Fonte: Archivos do Museu Nacional, vol. 1-6, 1876-1885. LACERDA, João Baptista de Lacerda. Fastos do Museu Nacional do Rio de Janeiro. Recordações historicas e scientificas fundadas em documentos authenticos e informações veridicas. Rio de Janeiro: Imprensa Nacional, 1905.

Com a reestruturação de 1888, essas seções, assim como os cursos públicos, foram extintos. A partir desta data, passaram a existir quatro seções: a primeira de "zoologia, anatomia e embriologia comparada", a segunda de "botânica", a terceira de

KOUTSOUKOS, Sandra Sofia Machado. Negros no estúdio do fotógrafo: Brasil, segunda metade do século XIX. Campinas, SP: Editora da Unicamp, 2010.

51 Jornal do Commercio, 22/10/1884. 
"mineralogia, geologia e paleontologia", e a última de "antropologia, etnologia e arqueologia". 52

Cada seção deveria desenvolver preleções de suas cadeiras, que após 1876 eram as seguintes: antropologia (João Lacerda) e zoologia (João Pizarro, Emilio Goeldi) para a primeira seção; botânica (Ladislau Netto) e agricultura (Nicolau Moreira, Collantino Souza Filho) para a segunda; e mineralogia (Saules Junior, Francisco Freitas) e geologia (Charles Hartt, Orville Derby) para a terceira. Embora o já referido regulamento n. 6116 não explicitasse que agricultura estava inserida na segunda seção, é possível fazer tal afirmação porque as conferências do conselheiro Nicolau Moreira eram anunciadas pela imprensa como sendo de agricultura, no caso se referindo à botânica aplicada. Isto reforça a inserção do Museu no Ministério da Agricultura, Comércio e Obras Públicas.

Vale ressaltar que em todas as seções a paleontologia estava presente, embora não tivesse sido realizada nenhuma conferência sobre o tema de modo explícito. A presença marcante da paleontologia indica a importância que a área do conhecimento tinha dentro da instituição. Em um momento em que as origens da terra e do homem eram temas de análises e discussões no ambiente científico internacional, não é de se estranhar o interesse do Museu.

Verifiquei quantos cursos foram efetuados em cada ano. Para o ano de 1875, antes da reestruturação do Museu, houve quatro lições (como também eram referenciadas essas conferências) nas primeira e segunda seções, uma na segunda, uma na terceira e duas na quarta. A preleção da terceira seção não foi finalizada devido a problemas de saúde do diretor que a ministrava, João Martins da Silva Coutinho. ${ }^{53}$

Após o primeiro ano de experiência com os cursos públicos, Ladislau Netto enviou um ofício ao Ministério solicitando que o espaçamento entre as apresentações fosse maior, devido à falta de material que considerava essencial para a fácil compreensão das aulas - "estampas murais, quadros explicativos, desenhos". 54 Objetos que ajudariam a tornar mais proveitosos os cursos.

O diretor do Museu também se queixou do tamanho da sala, considerada

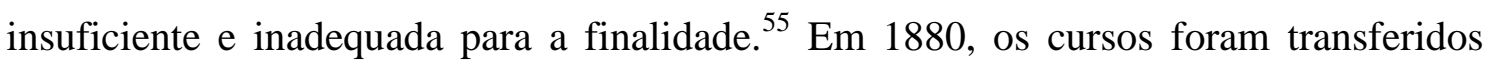
para o pavimento superior do prédio, que acomodaria melhor os ouvintes, uma vez que

\footnotetext{
${ }^{52}$ Decreto n. 9942, de 25 de abril de 1888. Disponível em:

< http://www6.senado.gov.br/legislacao/ListaPublicacoes.action?id=70511 >. Acesso: 23 jan. 2010.

${ }^{53}$ Registro da Correspondência... Livro 6 ${ }^{\circ} .1875-1881$, p. 4 v. (SEMEAR).

${ }^{54}$ Registro da Correspondência... Livro 6 ${ }^{\circ} .1875-1881$, p. 20 v. (SEMEAR).

${ }^{55}$ Registro da Correspondência... Livro 6 ${ }^{\circ} .1875-1881$, p. 134 v. (SEMEAR).
} 
a sala não estaria ao alcance dos transeuntes, além de apresentar "melhores condições de higiene", pois o espaço tinha o dobro da altura. ${ }^{56}$ Três anos antes, Ladislau Netto havia solicitado ao comandante do corpo militar de polícia o envio de dois praças para a manutenção da ordem no salão das conferências. O pedido foi devido à presença de “curiosos que se reúnem nas janelas", fazendo barulho e atrapalhando a realização da preleção. ${ }^{57}$ A mudança para o piso superior foi uma maneira de afugentar o olhar daqueles que passavam pelas ruas, provavelmente não pertencentes à mesma camada social das pessoas que assistiam ao evento. Uma maneira excludente de garantir a seleta composição do público, a elite da sociedade. Ao utilizar o argumento higienista, o diretor conferiu à mudança um ar imparcial e neutro. Tudo isso não excluiu o fato de a nova sala também acomodar melhor as pessoas.

Para quantificar os cursos realizados em 1876 utilizei os dados fornecidos pelo Relatório Ministerial. No entanto, para os anos seguintes não encontrei, nas fontes consultadas, nenhuma referência que indicasse o número de preleções efetuadas. A fim de realizar tal averiguação, fiz uso da imprensa periódica diária (Jornal do Commercio, Diario do Rio de Janeiro, O Globo e Gazeta de Noticias), divulgadora dos cursos que iriam ocorrer, com o intuito de obter dados mais verossímeis. $\mathrm{Na}$ Tabela abaixo as preleções do médico fisiologista francês Louis Couty (diretor do Laboratório de Fisiologia do Museu) estão contabilizadas com as da primeira seção, pois a temática por ele abordada estaria aí inserida. Os membros correspondentes do Museu também poderiam oferecer conferências, desde que não atrapalhassem os cursos regulares. Com base nisto, Couty efetuou preleções entre os anos de 1879 e $1881 .{ }^{58}$ Os cursos foram interrompidos, em 1886, devido a reformas no edifício, ${ }^{59}$ e não foram mais realizados até a sua extinção oficial em 1888. Ao todo ocorreram 337 preleções, distribuídas pelos anos da seguinte maneira de acordo com as seções:

\footnotetext{
${ }^{56}$ Registro da Correspondência... Livro 6º $.1875-1881$, p. 4 v. (SEMEAR).

${ }^{57}$ Registro da Correspondência... Livro 6 ${ }^{\circ}$. 1875-1881, p. 50. (SEMEAR).

${ }^{58}$ Registro da Correspondência... Livro $7^{\circ} .1881-1885$, p. 11 v. (SEMEAR).

${ }^{59}$ Registro da Correspondência... Livro $8^{\circ} .1885-1890$, p. 24 v. (SEMEAR).
} 
Tabela VI

Quantidade de preleções por seção e ano entre 1876 e 1885

\begin{tabular}{ccccccccccc}
\hline Seção & $\mathbf{1 8 7 6}$ & $\mathbf{1 8 7 7}$ & $\mathbf{1 8 7 8}$ & $\mathbf{1 8 7 9}$ & $\mathbf{1 8 8 0}$ & $\mathbf{1 8 8 1}$ & $\mathbf{1 8 8 3}$ & $\mathbf{1 8 8 4}$ & $\mathbf{1 8 8 5}$ & Total \\
\hline $1^{\mathrm{a}}$ & 29 & 22 & 19 & 24 & 21 & 22 & 04 & 04 & 12 & 157 \\
$2^{\mathrm{a}}$ & 15 & 29 & 14 & 20 & 15 & 16 & 01 & 08 & 15 & 133 \\
$3^{\mathrm{a}}$ & 16 & 11 & 04 & 01 & 05 & 01 & 05 & - & 04 & 47 \\
Total & 60 & 62 & 37 & 45 & 41 & 39 & 10 & 12 & 31 & 337 \\
\hline
\end{tabular}

Fonte: BRASIL. Ministério da Agricultura, Commercio e Obras Publicas. Relatorio do anno de 1876 apresentado á Assembléa Geral Legislativa na $2^{\underline{a}}$ Sessão da $16^{\underline{a}}$ Legislatura. Rio de Janeiro, 1877, pelo ministro Thomaz José Coelho de Almeida; Jornal do Commercio (1876-1889); Diario do Rio de Janeiro (1873-1878); O Globo (1874-1878).

Não houve preleções no ano de 1882 devido à realização da Exposição Antropológica no Museu, que utilizou boa parte dos espaços físicos da instituição. A fim de fornecer uma visão mais detalhada, a Tabela seguinte mostra quantas conferências cada cadeira promoveu neste período.

\section{Tabela VII}

Quantidade de conferências oferecidas por cada cadeira entre 1876 e 1885

\begin{tabular}{cccccccccccc}
\hline \multirow{2}{*}{ Seção } & $\begin{array}{c}\text { Cadeira ou } \\
\text { Orador }\end{array}$ & $\mathbf{1 8 7 6}$ & $\mathbf{1 8 7 7}$ & $\mathbf{1 8 7 8}$ & $\mathbf{1 8 7 9}$ & $\mathbf{1 8 8 0}$ & $\mathbf{1 8 8 1}$ & $\mathbf{1 8 8 3}$ & $\mathbf{1 8 8 4}$ & $\mathbf{1 8 8 5}$ & Total \\
\hline \multirow{2}{*}{$1^{\underline{a}}$} & Antropologia & 14 & - & 07 & 13 & 07 & 08 & 02 & 04 & 07 & 62 \\
& Zoologia & 15 & 22 & 12 & 10 & 05 & 02 & 02 & - & 05 & 73 \\
& Couty & - & - & - & 01 & 09 & 12 & - & - & - & 22 \\
\hline \multirow{2}{*}{$2^{-\underline{a}}$} & Botânica & 15 & 18 & 08 & 11 & 07 & 11 & 01 & 05 & 08 & 84 \\
& Agricultura & - & 11 & 06 & 09 & 08 & 05 & - & 03 & 07 & 49 \\
\hline \multirow{2}{*}{$3^{-\mathbf{a}}$} & Mineralogia & 14 & 10 & 04 & - & - & - & 03 & - & - & 31 \\
& Geologia & 02 & 01 & - & 01 & 05 & 01 & 02 & - & 04 & 16 \\
\hline Total & & 60 & 62 & 37 & 45 & 41 & 39 & 10 & 12 & 31 & 337 \\
\hline
\end{tabular}

Fonte: BRASIL. Ministério da Agricultura, Commercio e Obras Publicas. Relatorio do anno de 1876 apresentado á Assembléa Geral Legislativa na $2^{\underline{a}}$ Sessão da $16^{\underline{a}}$ Legislatura. Rio de Janeiro, 1877, pelo ministro Thomaz José Coelho de Almeida; Jornal do Commercio (1876-1889); Diario do Rio de Janeiro (1873-1878); O Globo (1874-1878).

A seção que menos cursos ofertou foi a "Ciências físicas: mineralogia, geologia e paleontologia geral", totalizando 47. A pequena quantidade oferecida pela cadeira de geologia em 1876 foi justificada pelo adoecimento de Charles Hartt ${ }^{60}$ e por ele ter se ausentado da Corte para participar da Comissão Geológica, ${ }^{61}$ organizada pelo Ministério

\footnotetext{
${ }^{60}$ Registro de Atas do Conselho Administrativo do Museu Nacional. Livro N. 3. 1876-1885, p. 7.

${ }^{61}$ Para uma discussão a respeito das comissões geológicas, conferir: FIGUEIRÔA, Silvia. As ciências geológicas no Brasil: uma história social institucional, 1875-1934. São Paulo: Hucitec, 1997.
} 
da Agricultura. ${ }^{62} \mathrm{O}$ geólogo foi exonerado no início 1877 , sendo que a única preleção desta cadeira foi realizada por Saules Junior. O cargo ficou vago até a contratação de Orville Derby, quando reiniciaram os cursos de geologia. A morte de Saules Junior interrompeu a periodicidade do curso de mineralogia. Francisco José de Freitas só assumiu a subdireção no final de $1882 .^{63}$

De acordo com o Relatório Ministerial de 1876, “As doutrinas da cadeira de agricultura não foram professadas, por se achar em Filadélfia o competente professor, na qualidade de comissário do Governo junto à Exposição Internacional”. ${ }^{64} \mathrm{O}$ que explica a ausência de cursos dessa cadeira, uma vez que os diretores e subdiretores eram obrigados a dar tais preleções, e, de acordo com o artigo 35 do regimento interno do Museu, o não cumprimento dessa obrigação, exceto por justificativa de doença, acarretava em "multa equivalente a três dias" do vencimento. ${ }^{65}$

Em 1877, a cadeira de zoologia foi a que mais ofereceu cursos. Dos 21 realizados naquele ano, 11 foram enunciados por Pizarro e os outros 10 por Lacerda. A partir dos anos seguintes os cursos dos dois oradores foram apresentados pelos jornais separadamente, a Pizarro coube a cadeira de zoologia, anatomia e fisiologia comparada, e a Lacerda a de antropologia. Com relação às lições desse ano proferidas por Lacerda, elas faziam parte de um "curso de fisiologia". 66

Optei por colocar as preleções feitas por Couty nessa tabela porque, embora não fizessem parte das regulamentadas nas três seções, eram anunciadas pela imprensa como pertencentes aos cursos públicos do Museu. No ano de 1879 a apresentação realizada teve como tema "veneno de cobras". Das efetuadas em 1880, duas tratavam das "substâncias tóxicas e alimentícias do Brasil" e sete de "biologia experimental". As temáticas de suas exposições estavam vinculadas ao trabalho que ele desenvolvia no Laboratório de Fisiologia Experimental do Museu Nacional.

De acordo com o artigo $9^{\circ}$ do Regimento Interno, os programas dos cursos deveriam ser submetidos à aprovação do Ministro e, tendo parecer favorável, impressos.

\footnotetext{
62 BRASIL. Ministério da Agricultura, Commercio e Obras Publicas. Relatorio do anno de 1876 apresentado á Assembléa Geral Legislativa na $2^{\underline{a}}$ Sessão da $16^{\underline{a}}$ Legislatura. Rio de Janeiro, 1877, pelo ministro Thomaz José Coelho de Almeida, p. 31.

${ }^{63}$ LACERDA, João Baptista de Lacerda. Fastos do Museu Nacional do Rio de Janeiro. Recordações historicas e scientificas fundadas em documentos authenticos e informações veridicas. Rio de Janeiro: Imprensa Nacional, 1905

64 BRASIL. Ministério da Agricultura, Commercio e Obras Publicas. Relatorio do anno de 1876 apresentado á Assembléa Geral Legislativa na $2^{\underline{a}}$ Sessão...

${ }_{65}$ Regimento interno do Museu Nacional. 1879. Pasta 18, doc. 9A (SEMEAR).

${ }^{66}$ Jornal do Commercio, 20/05/1877.
} 
Contudo, só encontrei a programação de alguns dos realizados em 1877 e 1878. Os resumos dos cursos de antropologia, de 1877, e de botânica, de 1878, foram publicados, respectivamente, nos volumes II e III do Archivos do Museu Nacional.

Em 1877, Saules Junior programou dar continuidade ao curso que havia iniciado no ano anterior - "noções preliminares, caracteres para a boa distinção dos minerais, nomenclatura mineralógica e classificação que tem tido aceitação nesta ciência". Para cada espécie mineral estudaria "sua nomenclatura, variedades, caracteres distintivos, importância industrial", indicando as principais jazidas e os mecanismos de exploração. Se sobrasse tempo, trataria da "estrutura das rochas, sua divisão, caracteres, estrutura, arranjamento e principais aplicações industriais". ${ }^{67}$

O curso de zoologia de 1877, estruturado por Pizarro, pretendia enfocar temas desenvolvidos em 1876: história dos animais, o estado das classificações, discussão sobre a mesma, e "caracteres anatômicos e fisiológicos que formam as diferenças nos quadros taxonômicos". ${ }^{68}$ Para o ano seguinte, planejou retomar os pontos centrais já trabalhados; estudar a influência do clima e dos solos nas plantações; examinar as partes que constituem os vegetais, observando os meios de melhorá-los. ${ }^{69}$

Para as aulas de agricultura de 1877, Nicolau Moreira planejou tratar da agricultura de modo amplo, estabelecendo a sua relação com a História Natural e observando sua "influência sobre o progresso e riqueza das nações". Por pertencer à cadeira de botânica aplicada, também estudaria as plantas com aplicações industriais, em especial no tocante à alimentação. ${ }^{70}$ Era indicada aí a relação entre ciência e progresso, e como o avanço agrícola poderia proporcionar o desenvolvimento do país.

A programação para o curso de botânica de Ladislau Netto de 1877 pretendia abordar a anatomia e a fisiologia vegetal, acrescentando as respectivas explicações fisiológicas; e no próximo ano um estudo panorâmico das famílias, finalizando com a geografia botânica, na qual seria salientada a natureza mineralógica do solo e os hábitos dos vegetais existentes. ${ }^{71}$

Lacerda, em 1877, enviou o programa dos próximos dois anos de seu curso de antropologia. O projeto propunha, no primeiro ano, estudar a anatomia e a fisiologia do homem, iniciando com o estudo das funções e terminando com as funções de relação.

\footnotetext{
${ }^{67}$ Pasta 16, Doc. 39, 20/03/1877 (SEMEAR).

${ }^{68}$ Registro da Correspondência... Livro 6 ${ }^{\circ} .1875-1881$, p. 47 v. (SEMEAR).

${ }^{69}$ Pasta 17, Doc. 29, 30/03/1878 (SEMEAR).

${ }^{70}$ Pasta 16, Doc. 35, 15/03/1877 (SEMEAR).

${ }^{71}$ Pasta 16, Doc. 47, 31/03/1877 (SEMEAR).
} 
Para o seguinte, o objetivo era dedicar a atenção ao estudo das raças humanas, com enfoque às da América, "tocando incidentalmente nas questões da herança, mestiçagem e aclimação". Ficariam para o final as "grandes questões gerais de monogenismo, poligenismo, e transformismo". A análise da anatomia e da fisiologia seriam simultâneas, e a descrição anatômica de cada aparelho seria acompanhada de um estudo de sua função. ${ }^{72}$

Vale ressaltar que, pelas fontes consultadas, não houve dissenso entre os oradores sobre quais seriam os reais detentores do saber. Ou seja, em momento algum os cientistas do Museu desqualificaram os preletores não cientistas que se apresentavam nos outros espaços públicos de vulgarização científica.

Assim, ao analisar as temáticas dos cursos e conferências foi possível constatar que havia um grande interesse com temas relacionados à ciência. Assuntos semelhantes foram abordados nas Conferências Populares da Glória e nas "Avulsas", com destaque àqueles vinculados à medicina e à higiene, sinalizando para a importância de sua discussão na sociedade. Os cursos públicos do Museu Nacional, apesar de não possuírem temática tão ampla, também analisaram e debateram assuntos que estavam na ordem do dia.

\section{Sociabilidades}

É difícil descrever ou saber exatamente quem compunha a plateia desses eventos, mas é possível traçar o perfil da mesma. Sobre as Conferências Populares da Glória, os cursos públicos do Museu Nacional e algumas das classificadas como “Avulsas", os jornais da época destacavam a presença de ministros, jornalistas, estudantes, professores, médicos, advogados, engenheiros, e muitas vezes do Imperador e membros da família real. Portanto, não estavam presentes as camadas menos abastadas da sociedade. Esta ausência, com relação às Conferências Populares da Glória, gerou polêmica nos jornais, que esperavam encontrar entre a audiência membros das classes populares. ${ }^{73}$

A presença feminina nos eventos também foi comentada pela imprensa. $\mathrm{O}$ comparecimento de mulheres era visto como sinal de uma nova sociabilidade de tipo

\footnotetext{
${ }^{72}$ Pasta 16, Doc. 36, 16/03/1877 (SEMEAR).

${ }^{73}$ CARULA, K. A tribuna da ciência..., p. 42-28.
} 
moderna/burguesa que se delineava nos países capitalistas do ocidente. A presença feminina nesses eventos no Brasil começou em 1865, nas conferências de Louis Agassiz, que juntamente com sua esposa, insistiu para que elas fossem aceitas no auditório: “A princípio, a presença de senhoras foi julgada impossível, como sendo demasiada inovação nos hábitos nacionais; mas esse preconceito foi logo vencido e as portas se abriram para todos, à moda da nova Inglaterra." 74

Algumas conferências apresentavam assuntos destinados ao público feminino, ou discutiam a importância da educação da mulher. Em 1874, o colégio de Nossa Senhora da Glória, "acompanhando o movimento literário do país, inaugurou em seu colégio uma série de conferências sobre a educação do sexo feminino". ${ }^{75} \mathrm{Em}$ seu segundo discurso realizado no local, o médico Carlos Arthur Moncorvo de Figueiredo abordou a higiene da infância, temática voltada à mulher enquanto mãe, que deveria criar seus filhos dentro dos ditames estabelecidos pela prática higienista.

Um público diferenciado do acima descrito assistiu às preleções do curso de higiene popular criado pelo médico Carlos Antonio de Paula Costa, desenvolvido na escola noturna da Lagoa.

Usando de uma linguagem ao alcance de seu auditório, os alunos da escola que ali se achavam em número maior de quarenta, sendo também [?] hoje honrado com a presença de muitas pessoas distintas da freguesia $[\ldots] .^{76}$

Carlos Costa era presidente da Sociedade Propagadora da Instrução às Classes Operárias, o que já evidencia a sua preocupação com a educação dessa parcela da sociedade. Por meio da associação, instaurou seus cursos populares. Os alunos que assistiram a essa conferência eram os que estudavam na referida escola, "jovens aprendizes de ofícios, menores e adultos, inclusive estrangeiros e africanos livres". 77 Eram, portanto, integrantes das camadas menos favorecidas da sociedade. As preleções

\footnotetext{
${ }^{74}$ AGASSIZ, E. C.; AGASSIZ, L. Viagem ao Brasil..., p. 114.

75 Jornal do Commercio, 12/05/1874.

${ }^{76}$ Gazeta de Noticias, 21/07/1877.

77 GONDRA, José Gonçalves; SCHUELER, Alessandra. Educação, poder e sociedade no Império brasileiro. São Paulo: Cortez, 2008, p. 74. Embora de iniciativa particular, algumas escolas noturnas receberam recursos do governo, foi o caso das promovidas pela Associação Propagadora da Instrução às Classes Operárias da Lagoa, os do Liceu. COSTA, Ana Luiza Jesus da. À luz das lamparinas. As escolas noturnas para trabalhadores no Município da Corte (1860-1889). Dissertação (Mestrado em Educação) Faculdade de Educação, Universidade do Estado do Rio de Janeiro, Rio de Janeiro, 2007.
} 
sobre higiene feitas por Lyra da Silva e Francisco Siqueira Dias Sobrinho podem ter tido o mesmo público, uma vez que foram realizadas na mesma escola noturna. É possível supor que o curso de Guilherme Belmonte, na escola noturna de S. Sebastião, também tenha tido uma assistência parecida, pois Carlos Costa frisou a similitude entre ambos. ${ }^{78}$ Não encontrei, para as outras conferências, descrição de semelhante plateia.

Para analisar as sociabilidades existentes nesses locais, os conceitos de capital social, simbólico e cultural estabelecidos por Pierre Bourdieu foram de grande valia, visto que as conferências e os cursos públicos se constituíram como espaços de sociabilidades letrada e científica. A participação em tais eventos, seja como orador ou espectador, inseria uma determinada parcela da sociedade em redes sociais, e, desta maneira, possibilitava o aumento do capital social e cultural daqueles indivíduos.

Os oradores que se apresentavam possuíam capital simbólico, compreendido como "prestígio, reputação, fama, etc." ${ }^{79}$ Eram pessoas que muitas vezes atraíam o público só por serem elas a discursar, independente do assunto sobre o qual falariam. A presença de um público também detentor de capital simbólico ajudava ainda mais a consagrar e legitimar a conferência. Sempre que o Imperador comparecia aos eventos a imprensa frisava a "augusta presença", já que ele seria uma espécie de encarnação máxima desse capital simbólico.

Ao proferir conferências públicas, os preletores também aumentavam seu capital simbólico. Esse prestígio que se adquiria foi satirizado pelo jornal A Bibliotheca dos Bonds: "Certo de que eu não ia conferir com quem quer que fosse sobre qualquer matéria, mas antes ia fazer uma prática à minha vontade, quis falar e ter nome". ${ }^{80} \mathrm{O}$ fictício conferencista, Dr. Almôndega, não estava interessado em transmitir algo substancial em seu discurso, mas sim acrescer seu capital simbólico, pois ele só queria "ter nome". Para acentuar o caráter da ironia, a preleção intitulava-se "Da patologia social dos seres mancos em relação às exterioridades negativas"; mostrando que não importava o que se ia apresentar. O imaginário orador ainda destacou que "Ninguém a entendeu; porém, quanto mais sábio era apregoado o leitor, tanto mais entendido se

\footnotetext{
${ }^{78}$ Gazeta de Noticias, 08/09/1877. Esta escola era mantida pela Câmara Municipal. COSTA, A. L. J. da. À luz das lamparinas...

${ }^{79}$ BOURDIEU, Pierre. Espaço social e génese das "classes". In: O poder simbólico. Tradução Fernando Tomaz. 8. ed. Rio de Janeiro: Bertrand Brasil, 2003, p. 135. Para uma discussão mais pormenorizada sobre capital simbólico, conferir: BOURDIEU, Pierre. Capital simbólico. In: O senso prático. Tradução Maria Ferreira. Petrópolis, RJ: Vozes, 2009, p. 187-202.

${ }^{80}$ As conferências populares. A Bibliotheca dos Bonds, n. 1, 1876, p. 18. Grifos do original.
} 
presumia". ${ }^{81}$ Aqui ele insinuou que o público presente era sábio, ou pelo menos desejava se passar por, e, devido a isso era possível se falar de qualquer assunto, porque era presumível que a plateia compreenderia.

Os conferencistas também possuíam capital cultural, o qual, segundo Bourdieu, pode ser encontrado em três estados. O incorporado, que está assimilado, faz parte da pessoa. É um capital pessoal que foi acumulado por um longo tempo. O objetivado, que é a apropriação de objetos culturais materiais - livros, esculturas, pinturas, etc. - não basta apenas possuí-los, mas apreender o que eles significam, decodificá-los. Por fim, o institucionalizado, representado na forma do diploma, uma "certidão de competência cultural". ${ }^{82}$ Os três estados do capital cultural estavam presentes na maioria dos oradores que se apresentaram nos cursos e conferências: tinham conhecimento acumulado, conseguiam apropriar-se das leituras que realizavam nos livros e possuíam formação institucional.

Por fim, há também o capital social, que

[...] é o conjunto de recursos atuais ou potenciais que estão ligados à posse de uma rede durável de relações mais ou menos institucionalizadas, de interconhecimento e de inter-reconhecimento ou, em outros termos, à vinculação a um grupo, como conjunto de agentes que não somente são dotados de propriedades comuns [...] mas também são unidos por ligações permanentes e úteis. ${ }^{83}$

O capital social é marcado pela rede de relações sociais que o indivíduo efetivamente possui, e por aquela que pode vir a ter devido aos outros integrantes da rede. Tais pessoas estão ligadas por algo em comum, seja de maneira despretensiosa, seja com um caráter utilitário. O público frequentador, independente do seu perfil, tecia relações sociais nesses espaços. Assistir às preleções seria também uma maneira de ampliar seu capital cultural, pois, de acordo Bourdieu, o capital social pode se transformar em capital econômico ou em capital cultural. ${ }^{84}$

\footnotetext{
${ }^{81}$ As conferências populares. A Bibliotheca dos Bonds..., p. 19.

82 BOURDIEU, Pierre. Os três estados do capital simbólico. Tradução Magali de Castro. In: NOGUEIRA, Maria CATANI, Afrânio (Orgs.). Escritos de educação. Petrópolis, RJ: Vozes, 1998, p. 78.

${ }^{83}$ BOURDIEU, Pierre. O capital social - notas provisórias. Tradução Denice Barbara Catani e Afrânio Mendes Catani. In: NOGUEIRA, Maria Alice; CATANI, Afrânio (Orgs.). Escritos de educação. Petrópolis, RJ: Vozes, 1998, p. 67. Grifos do original.

${ }^{84}$ Neste sentido, merece menção o trabalho de Angela Alonso, que ao analisar a biografia de Joaquim Nabuco apresenta diversos espaços de sociabilidade letrada existentes na Corte nas décadas de 1870 e
} 
Para o público letrado que compunha a audiência era importante comparecer a tais eventos. Primeiro porque o Imperador muitas vezes comparecia. Ir a esses espaços era, portanto, uma maneira de se mostrar em sintonia com o que a casa imperial valorizava e apreciava. Outro motivo era evidenciar para o resto da sociedade que se estava a par das novidades tecnológicas e científicas do momento. Mesmo que a pessoa não entendesse plenamente o que ali foi exposto, comparecer às conferências indicava que ela era moderna, valorizava o conhecimento e compreendia a sua importância para a melhoria da nação. Outra razão, seria o de aproveitar o momento oportuno em encontros sociais, já que boa parte dos sujeitos que iam a tais locais encontravam-se em outros livrarias, associações, rua do Ouvidor. Portanto, ali poderia ser uma boa situação para retomar uma conversa já iniciada, resolver algum assunto pendente, iniciar a discussão de um tema novo, que provavelmente seria retomado quando os mesmos se encontrassem em outros lugares de sociabilidade. Além de ser uma opção de entretenimento, ir de modo desprendido para passar um tempo aprendendo e conhecendo algo novo, ou refletindo sobre um problema da sociedade.

A dimensão das conferências como evento social, também foi satirizada pelo periódico A Bibliotheca dos Bonds:

Nas cenas que servem de acessórios à principal ação da Conferência, busquei [o orador Dr. Almôndega] empregar, como indispensável, a cor local que tanto caracteriza as reuniões aristocráticas, porque um dos merecimentos da Conferência é, sem dúvida, a exatidão com que nela se descrevem as mais notáveis peripécias da vida carioca. $^{85}$

As cenas acessórias às quais o conferencista se refere sinalizam para a importância dos eventos enquanto espaços de sociabilidade da Corte no período em questão. A crítica do jornal é específica às Conferências Populares da Glória, mas pode ser estendida a todas as outras que tinham o mesmo público. ${ }^{86}$ Pois, provavelmente, não só o perfil da plateia era o mesmo, as pessoas que se apresentavam muitas vezes eram as mesmas.

1880, sublinhando como Nabuco fez uso dos mesmos para se promover tanto socialmente quanto como político empenhado na luta abolicionista. ALONSO, Angela. Joaquim Nabuco. São Paulo: Companhia da Letras, 2007.

${ }^{85}$ As conferências populares. A Biblioteca dos Bonds, n. 1, 1876, p. 21. Grifos do original.

${ }^{86}$ VERGARA, Moema de Rezende. Ensaio sobre o termo "vulgarização científica" no Brasil do século XIX. Revista Brasileira de História da Ciência, Rio de Janeiro, v. 1, n. 2, p. 137-145, jul./dez. 2008. 
Os sujeitos que assistiam às preleções e os que proferiam os discursos se encontravam em outros espaços de sociabilidade letrada e científica existentes na cidade. Para compreender um pouco sobre a dinâmica dessa rede de sociabilidade, faço uso das análises empreendidas por Marco Morel, que destacou a multifuncionalidade existente em espaços formais de sociabilidade, ou seja, em uma mesma associação é possível encontrar aspectos econômicos, políticos, culturais, pedagógicos e corporativos. $^{87}$

Com relação às Conferências Populares da Glória, seu funcionamento estava muito vinculado à figura de Manoel Francisco Correia, enquanto esteve na direção era ele quem convidava o orador. ${ }^{88}$ Por exemplo, seu amigo de infância, Antonio Ferreira Vianna, em 1874 subiu à tribuna 19 vezes, sendo 16 para ministrar seu curso de pedagogia. $^{89}$

Feliciano Pinheiro de Bittencourt, que proferiu 27 conferências na tribuna da Glória, era sócio da Sociedade de Geografia do Rio de Janeiro, fundada, dentre outros, pelo conselheiro Correia, em 1883. A escolha de José Lustosa da Cunha Paranaguá para a presidência da Sociedade, em 1884, não foi bem aceita por Correia, que deixou as atividades administrativas da associação e parou de participar de algumas reuniões. Atitude seguida por Bittencourt, sinalizando para uma possível convergência de ideias entre ambos. O mesmo posicionamento teve o sócio Antonio Herculano de Souza Bandeira, conferencista da Glória em $1875 .{ }^{90}$ Outros oradores das Conferências da Glória que fizeram parte da Sociedade foram Tristão de Alencar Araripe e Affonso Celso de Assis Figueiredo Junior. Fernando Pires Ferreira e José de Saldanha da Gama, que realizaram conferências "Avulsas", também integravam a associação. Ladislau Netto, diretor do Museu Nacional, foi um dos sócios-fundadores da Sociedade. Conforme afirma a pesquisadora Luciene Carris Cardoso, o corpo constitutivo era "marcado por fortes ligações com a Coroa", no qual seus membros "compartilhavam da ideia do utilitarismo da ciência e da crença no progresso da nação brasileira", ${ }^{91}$ a posição do grupo também era refletida nas conferências e cursos públicos, conforme será desenvolvido posteriormente.

\footnotetext{
${ }^{87}$ MOREL, Marco. As transformações do espaço público: imprensa, atores políticos e sociabilidades na Corte Imperial, 1820-1840. São Paulo: Hucitec, 2005.

${ }^{88}$ CARULA, K. A tribuna da ciência..., p. 39.

${ }^{89}$ Gazeta de Noticias, 16/07/1877.

${ }^{90}$ CARDOSO, Luciene P. Carris. Novos horizontes para o saber geográfico: a Sociedade de Geografia do Rio de Janeiro (1883-1909). Revista da SBHC, Rio de Janeiro, v. 3, n. 1, p. 80-96, jan./jun. 2005.

${ }^{91}$ CARDOSO, L. P. C. Novos horizontes para o saber geográfico..., p. 88 e 80.
} 
Muitos dos oradores que se apresentaram nos eventos eram médicos. Neste sentido, outro espaço de sociabilidade compartilhado por parte daqueles sujeitos foi a Academia Imperial de Medicina. ${ }^{92}$ Assim que deixou de prestar consultoria à Junta Central de Higiene Pública, em meados do século XIX, a Academia foi perdendo parte do prestígio que possuía. Porém, continuou a congregar grande quantidade dos profissionais da área. Uma significativa parcela dos médicos que discursaram na tribuna da Glória fazia parte da sociedade: José Martins da Cruz Jobim, Antonio José Pereira da Silva Araujo, Hilário Soares de Gouveia, Joaquim Monteiro Caminhoá, José Cardoso de Moura Brazil, Luiz Corrêa de Azevedo, Nuno Ferreira de Andrade, José da Cunha Ferreira, Francisco Marques de Araújo Góes, João Paulo de Carvalho. Com relação aos diretores de seção do Museu Nacional, eram sócios da Academia João Baptista Lacerda, João Joaquim Pizarro, Nicolau Joaquim Moreira. O único integrante das conferências “Avulsas" a participar da Academia foi Carlos Arthur Moncorvo de Figueiredo. ${ }^{93}$ É possível supor que muitos dos temas que apresentaram nas preleções eram discutidos nesse outro local de sociabilidade. Além da Academia, a Faculdade de Medicina, da mesma maneira, tinha como docentes muitos dos conferencistas.

O Instituto Histórico e Geográfico Brasileiro foi outra agremiação que teve como sócios muitos preletores. Entre outros, Manoel Francisco Correia, Feliciano Pinheiro de Bittencourt, os conselheiros João Manoel Pereira da Silva e Nicolau Joaquim Moreira, Carlos Arthur Moncorvo de Figueiredo. A presença deles mostra que, afora outras atividades, se dedicavam à construção da memória nacional.

Associações relacionadas à promoção da instrução pública congregaram vários preletores de cursos e conferências. Estes eventos públicos possuíam um forte caráter educacional, portanto, não é de estranhar que seus oradores estivessem engajados em sociedades dedicadas à promoção da educação. Merece destaque a Sociedade Propagadora da Instrução às Classes Operárias da Lagoa, que tinha como presidente o médico conferencista Carlos Antonio de Paula Costa $^{94}$ e Francisco Siqueira Dias

\footnotetext{
${ }^{92}$ Situada no térreo do Recolhimento do Parto, na rua dos Ourives, n. 1. Sociedade de Medicina do Rio de Janeiro. Dicionário Histórico-Biográfico das Ciências da Saúde no Brasil (1832-1930). Disponível em: $<$ http://www.dichistoriasaude.coc.fiocruz.br>. Acesso: 24 jan. 2010.

${ }^{93}$ Lista completa de acadêmicos. Disponível em: <http://www.anm.org.br/membros.asp〉. Acesso: 24 jan. 2010.

${ }_{94}$ BLAKE, Augusto Victorino Alves Sacramento. Diccionario bibliográfico brasileiro. Rio de Janeiro: Typographia Nacional, 1893.
} 
Sobrinho como alguns dos fundadores. ${ }^{95}$ Ambos abordaram a questão da higiene em suas preleções na escola noturna da Lagoa.

Em 1880, assumiu a presidência da Sociedade Auxiliadora da Indústria Nacional Nicolau Joaquim Moreira, que foi a exceção entre os presidentes da agremiação, por ser o único que não era político. ${ }^{96}$ Ele integrou também a Comissão Industrial de Química da Sociedade. Neste sentido, vale ressaltar que em muitos de seus cursos no Museu Nacional destacou a importância do conhecimento da química para o bom desenvolvimento agrícola. Igualmente fizeram parte da associação João Joaquim Pizarro, outro diretor de seção do Museu; Carlos Antonio de Paula Costa, promotor do curso de higiene popular na freguesia da Lagoa; José de Saldanha da Gama, que proferiu tanto conferências "Avulsas” como na tribuna da Glória.

Além de seu caráter científico, a Sociedade Auxiliadora engajou-se na luta pela instrução, manteve "estabelecimentos de ensino primário, profissional, artístico e técnico, bem como cursos noturnos para adultos". ${ }^{97}$ Embora fosse um órgão particular, era subvencionada pelo Estado. Auxílio financeiro que certamente colaborou na manutenção desses estabelecimentos.

A preocupação com a instrução marcou toda a carreira de Manoel Francisco Correia. Além das Conferências Populares, ele criou, em 1874, a Associação Promotora da Instrução. A entidade atuou principalmente na educação das crianças desvalidas da cidade. Esse órgão contou com a participação de oradores da tribuna da Glória. Dentre eles, Feliciano Pinheiro de Bittencourt, Luiz Joaquim Duque-Estrada Teixeira, e Tristão de Alencar Araripe. ${ }^{98}$

A Sociedade Propagadora da Instrução às Classes Operárias, a Sociedade Auxiliadora da Indústria Nacional e a Associação Promotora da Instrução ao se dedicarem à educação, em especial das classes desvalidas, apresentavam as dimensões pedagógica e filantrópica das multifuncionalidades definidas por Morel para as associações. $^{99}$ Essa multiplicidade faz com que as redes sociais estabelecidas sejam mais complexas, o que, de acordo com Bourdieu, aumenta o capital social dos indivíduos pertencentes a tais grupos.

\footnotetext{
${ }^{95}$ COSTA, A. L. J. da. À luz das lamparinas..., p. 144.

${ }^{96}$ DOMINGUES, Heloisa Maria Bertol. A Sociedade Auxiliadora da Indústria Nacional e as ciências naturais no Brasil Império. In: DANTES, Maria Amélia M. (Org.). Espaços da ciência no Brasil: 18001930. Rio de Janeiro: Editora Fiocruz, 2001, p 83-110

${ }^{97}$ GONDRA, J. G.; SCHUELER, A. Educação, poder e sociedade no Império brasileiro..., p. 70.

${ }^{98}$ CARULA, K. A tribuna da ciência...

${ }^{99}$ MOREL, Marco. As transformações dos espaços públicos...
} 
Os cursos e conferências públicos, portanto, se caracterizaram por serem espaços de sociabilidade, no qual muito do que era exposto ali também era tema de discussão em outros ambientes letrados e científicos, por exemplo, na Faculdades de Medicina, nas agremiações, no parlamento, no Instituto Histórico e Geográfico, nas livrarias, na rua do Ouvidor, etc. Os oradores que se apresentavam transitavam por outros locais, mostrando que a rede de sociabilidade os integrava em outras associações existentes na Corte. Essa interligação sinaliza para o modo como estavam estabelecidas suas relações sociais e como estava constituído seu capital social. Entretanto, se tratava de uma sociabilidade bem limitada e extremamente elitista, as pessoas que integravam tais espaços pertenciam a um estreito grupo da sociedade carioca. O perfil do público era semelhante ao que proferia conferências, então, os espaços eram muito mais reafirmadores de lugares sociais do que de difusão popular de ciência.

\section{Ciência para civilizar}

Civilização e progresso eram palavras recorrentes nas vozes dos letrados brasileiros de fins do século XIX. Em seus discursos inflamados, independente do assunto, justificavam fazer aquilo para o progresso do país, para que este se igualasse às nações civilizadas.

Civilizar e educar a população eram tendências do Império. Marcado por projetos modernizadores, o aparato governamental monárquico empenhou-se para efetivar a civilização, por exemplo, apoiando sociedades particulares que promoviam cursos escolares e exposições nacionais, ${ }^{100}$ enviando representantes brasileiros para as exposições universais, etc. ${ }^{101} \mathrm{O}$ republicanismo, o abolicionismo, o positivismo e a valorização de uma cultura burguesa, presentes de modo cada vez mais crescente na sociedade, sinalizavam para a necessidade de civilizar e educar a população. Com relação à abolição, a percepção de que a escravidão estava com os dias contados ampliava a necessidade de civilizar aqueles bárbaros que em breve sairiam do cativeiro. De modo mais amplo, era preciso civilizar e educar negros, índios, mestiços, brancos

\footnotetext{
${ }^{100}$ A Sociedade Auxiliadora da Indústria Nacional foi uma das agremiações que contou com este apoio, "recebendo subsídio governamental, [ela] colaborou com a organização das Exposições Nacionais realizada no Segundo Reinado". GONDRA, J. G.; SCHUELER, A. Educação, poder e sociedade..., p. 70. 101 Para uma discussão acerca das exposições universais, conferir: PESAVENTO, Sandra Jathay. Exposições universais: espetáculos da modernidade do século XIX. São Paulo: Hucitec, 1997.
} 
pobres e as mulheres para acabar com a barbárie da sociedade brasileira. Neste contexto, a ciência exercia o papel de controle social. No caso dos cursos e conferências, os argumentos dos oradores, com o intuito de civilizar a nação, eram marcados por uma linguagem científica/cientificista.

Cabe aqui, inicialmente, uma discussão sobre o que significava civilizar. Em sua acepção moderna, a palavra civilização surgiu no final do século XVIII significando o ato de civilizar, no sentido de polir os costumes. Jean Starobinski assevera que o vocábulo apareceu para nomear um costume já existente, assim, o significado é anterior ao significante.

A palavra civilização pôde ser adotada tanto mais rapidamente quanto constituía um vocábulo sintético para um conceito preexistente, formulado anteriormente de maneira múltipla e variada: abrandamento dos costumes, educação dos espíritos, desenvolvimento da polidez, cultura das artes e das ciências, crescimento do comércio e da indústria, aquisição das comodidades materiais e do luxo. ${ }^{102}$

Ao analisar como se deu o processo civilizador na sociedade ocidental europeia, com enfoque na França e na Alemanha, Norbert Elias desenvolve sua argumentação mostrando como esse polimento de hábitos e costumes ocorreu principalmente no sentido de uma determinada camada social se diferenciar de outra. No caso francês, por exemplo, a aristocracia nobiliárquica criou normas e regras de comportamento que mostravam que uma pessoa pertencia a essa camada da sociedade, gestos e comportamentos seriam demonstradores do local social no qual o sujeito estava inserido. ${ }^{103}$ De acordo com Roger Chartier, por meio de sua "circulação mais popular", a civilidade conferiu grande valorização das distinções sociais, que deviam ser “decifradas e respeitadas". ${ }^{104}$ Desde inícios do século XVII, era a civilidade que permitia a todos a decodificação das regras comportamentais, que, de maneira desigual, introduzia cada sujeito em determinado lugar social.

\footnotetext{
102 STAROBINSKI, Jean. A palavra "civilização". In: As máscaras da civilização: ensaios. Tradução Maria Lúcia Machado. São Paulo: Companhia das Letras, 2001, p. 14. Grifo do original.

${ }^{103}$ ELIAS, Norbert. O processo civilizador. 2 v. Tradução Ruy Jungmann. Rio de Janeiro: Jorge Zahar, 1994.

${ }^{104}$ CHARTIER, Roger. Distinção e divulgação: a civilidade e seus livros. In: Leituras e leitores na França do Antigo Regime. Tradução Álvaro Lorencini. São Paulo: Editora Unesp, 2004, p. 70
} 
Com relação à polidez, Chartier analisa como, desde o século XVI, com o tratado De civilitate morum puerilium, "de Erasmo e de suas traduções, adaptações ou imitações", o conceito de civilidade, palavra etimologicamente próxima à civilização, esteve recorrentemente associado à normatização dos costumes. ${ }^{105}$ No Oitocentos, civilidade passou, de maneira disciplinarizante, a ser o conjunto das boas maneiras que deviam ser vivenciadas na sociedade; estando, desta maneira, conveniente com os interesses da burguesia.

Segundo Starobinski, civilização é um conceito plural, não existindo a civilização, mas sim civilizações. ${ }^{106}$ Nesta perspectiva, é fundamental compreender o que significava essa palavra para esses homens que vulgarizavam a ciência no Brasil de fins do século XIX.

Em 1881, o Diccionario contemporaneo da lingua portugueza, de Caldas Aulete, estabeleceu civilização como "Grande perfeição do estado social, que se manifesta na sabedoria das leis, na brandura dos costumes, na cultura da inteligência e no apuro das artes e indústria". ${ }^{107}$ Civilização era o ápice que uma determinada sociedade poderia alcançar, e isso era expresso por algumas categorias: grande conhecimento das leis, suavidade nos costumes, e no desenvolvimento intelectual, artístico e industrial do país. Portanto, para se atingir a civilização era essencial cumprir todos esses pré-requisitos.

O Diccionario da lingua portugueza, de Antonio Moraes Silva, oito anos depois, definiu civilização como:

O adiantamento, o progresso, o desenvolvimento do estado social, que se manifesta na perfeição das leis, na brandura dos costumes, nas grandes obras materiais, e na cultura intelectual, representada nas ciências, nas letras e nas artes. ${ }^{108}$

De acordo com a definição, civilização também estava relacionada com o avanço que uma sociedade poderia lograr, porém associando isto ao progresso e ao desenvolvimento. Assim como no dicionário de 1881, para se atingir a civilização era

\footnotetext{
${ }^{105}$ CHARTIER, R. Distinção e divulgação..., p. 51.

${ }^{106}$ STAROBINSKI, J. A palavra “civilização"..., p. 18.

107 AULETE, Caldas. Diccionario contemporaneo da lingua portugueza. Lisboa: Imprensa Nacional, 1881, p. 337.

${ }^{108}$ SILVA, Antonio de Moraes. Diccionario da lingua portugueza. $8^{\mathrm{a}}$ ed. Rio de Janeiro: Empreza Litteraria Fluminense, 1889, p. 471.
} 
preciso cumprir as mesmas exigências das leis, dos costumes e das obras materiais, que seria o desenvolvimento industrial apresentado no dicionário de Aulete. Há, contudo, um novo parâmetro que é o de cultura intelectual, composta por ciências, letras e artes, contemplada isoladamente na acepção de 1881. As novidades foram letras e ciências, que apareceram como condições fundamentais para que uma sociedade atingisse o estado de civilização.

Com isso, além da ideia de avanço, civilização era o estágio máximo que a sociedade poderia alcançar. Ela só chegaria a esse patamar se tivesse leis satisfatórias, abrandamento dos costumes, desenvolvimentos material e cultural (ciências, artes e letras). Cabe destacar a sinonímia de civilização e progresso, dois conceitos que apareciam intimamente imbricados nas falas dos letrados brasileiros do final do século XIX. O pesquisador André Nunes de Azevedo sustenta que no Brasil das últimas décadas do Império a ideia de civilização compreendeu a de progresso, enquanto o inverso ocorreu no período republicano. ${ }^{109}$

Quanto à denominação de progresso, o dicionário de Aulete apresentou a seguinte definição para o vocábulo:

a marcha ou movimento para diante. \| Adiantamento, aperfeiçoamento: O progresso das ciências. \|| aumento progressivo e gradual. \| Movimento progressivo da civilização e das instituições políticas; tendência do gênero humano para a sua perfeição, para a felicidade. \|| Fazer progressos, progredir, adiantar-se: Um aluno que faz progressos de dia para dia. ${ }^{110}$

A ideia de progresso era dinâmica, trazia consigo a de mudança ascendente para a perfeição. A conexão com a palavra civilização era salientada, pois o progresso seria o descolamento crescente da civilização, algo que iria para uma condição melhor, proporcionando a felicidade do homem. Assim, a palavra já possuía uma conotação positiva, que levaria a sua aceitação, porque promoveria a felicidade da humanidade.

\footnotetext{
${ }^{109}$ Azevedo afirma que na Europa até a segunda metade do século XIX a ideia de civilização se sobrepôs à de progresso, como se esta estivesse contida na primeira. Após esse período ocorreu uma troca, embora a relação entre ambas tenha se mantido. Neste sentido, as exposições industriais ilustrariam essa inversão, pois elas traduziam esse culto ao progresso material. AZEVEDO, André Nunes de. Da Monarquia à República: um estudo dos conceitos de civilização e progresso na cidade do Rio de Janeiro entre 1868 e 1906. Tese (Doutorado em História) - Pontifícia Universidade Católica do Rio de Janeiro, Rio de Janeiro, 2003, p. 23.

${ }^{110}$ AULETE, C. Diccionario contemporaneo..., p. 1415. Grifos do original.
} 
Quando se referiu a progresso como adiantamento, o exemplo fornecido pelo dicionário foi com relação à ciência. De certa maneira isto estava vinculado com a concepção de civilização, que sublinhava o desenvolvimento nas ciências como condição para tal. Esses destaques fornecidos à ciência evidenciavam a força que ela possuía na sociedade de fins do Oitocentos. Acerca de seu papel como propulsora da civilização, Azevedo sustenta que "A civilização brasileira, por sua vez, encontraria a sua 'atualização histórica' na promoção da ciência, algo que possibilitaria ao Brasil aproximar-se do 'progresso da civilização' dos principais países europeus". ${ }^{111}$

Outra palavra vinculada a progresso e civilização era desenvolvimento. Aulete a definiu, em 1881, como “Aumento, crescimento, propagação, adiantamento, progresso: O desenvolvimento do comércio, da instrução. "Cultura intelectual, civilização". ${ }^{112}$ Tanto civilização como progresso foram apresentados como possíveis sinônimos; corroborando a relação entre os vocábulos.

Mas como eram definidos aqueles que não eram civilizados? No Diccionario contemporaneo da lingua portugueza, em 1881, bárbaro significava "rude, grosseiro, sem civilização; selvagem [opõe-se a civilizado e culto]. || Cruel, brutal, atroz. || Estilo bárbaro, não polido, incorreto". ${ }^{113}$ A mesma oposição a civilizado foi encontrada em 1889. ${ }^{114} \mathrm{O}$ bárbaro seria, então, o não civilizado. A definição de civilização marcava a ideia do processo pelo qual passava uma sociedade de um ponto ao outro, e também o resultado final desse processo. O estado inicial era antagônico ao final - civilização - e pode ser caracterizado como "natureza, selvageria, barbárie". ${ }^{115}$ Mas quando se justificava os argumentos em nome da civilização, não significava dizer que o Brasil encontrava-se em estado de barbárie, e sim que ainda não havia conseguido atingir a civilização, isto é, estava em um estágio intermediário entre a civilização e a barbárie.

O idealizador das Conferências Populares da Glória, Manoel Francisco Correia, ao salientar a importância da instrução da sociedade sinalizou para o estágio civilizacional em que se encontrava o Brasil:

A instrução há de afugentar as trevas que obscurecem a inteligência de grande número de brasileiros que vivem no interior de nossas

\footnotetext{
${ }^{111}$ AZEVEDO, A. N. de. Da Monarquia à República..., p. 90.

${ }^{112}$ AULETE, C. Diccionario contemporaneo..., p. 500. Grifo do original.

113 AULETE, C. Diccionario contemporaneo..., p. 203.

${ }^{114}$ SILVA, A, de M. Diccionario da lingua portugueza..., p. 319.

115 STAROBINSKI, J. A palavra “civilização”..., 16.
} 
províncias, libertando-os do império de preconceitos que podem perturbar a marcha ascendente do Brasil na escala da civilização. ${ }^{116}$

Somente com a instrução da população o país poderia ascender na "escala da civilização", portanto, instituir conferências públicas era uma maneira de contribuir para isso, já que a função principal delas seria instruir as pessoas. Para o conselheiro havia uma gradação civilizacional, na qual o Brasil necessitava subir vários degraus. Neste mesmo discurso, ele argumentou que a instrução traria benefícios ao país, ajudando-o a seguir o caminho correto para subir na escala de civilização: diminuir os crimes, manter a união física do país, fazer prosperar a indústria e o comércio ${ }^{117}$ apareciam como quesitos fundamentais para que um país crescesse e se tornasse mais civilizado.

Cabe aqui desenvolver a análise do conceito de instrução para melhor compreender seus significados. De acordo com Aulete, instruir era o mesmo que ensinar, que significava: "Instruir sobre; dar preleções sobre o que os outros ignoram ou sabem mal. || Dar conhecimentos (a alguém) sobre as regras e preceitos que constituem alguma ciência ou arte". ${ }^{118} \mathrm{O}$ ato de proferir preleções era também o de ensinar, sendo que naquele contexto os termos preleção e conferência eram utilizados de modos indistintos. ${ }^{119}$ Ensinar significava instruir alguém na ciência ou na arte, temas abordados nos cursos e conferências.

Outro vocábulo relacionado a instruir e ensinar era educar. O Diccionario contemporaneo da lingua portugueza assim o definiu:

instruir, doutrinar (as crianças); formar a inteligência, o coração e o espírito de; robustecer (os organismos) com o auxílio dos meios fornecidos pela arte: Educando na moral e na virtude, seus princípios foram os do homem honrado. (Garrett.) ॥ instruir-se, cultivar o espírito, adquirir os dotes intelectuais e físicos necessários: Educou-se na douta Alemanha primeiro a sós com os livros e depois entre os sábios... (R. da Silva.) ${ }^{120}$

\footnotetext{
${ }^{116}$ CORREIA, Manoel Francisco. Inauguração das Conferencias Populares em Nitheroy. Conferencias Populares. Rio de Janeiro: Typ. Imp. e Const. De J. Villeneuve. n. 2, fev. 1876, p. 25.

${ }^{117}$ CORREIA, M. F. Inauguração das Conferencias Populares em Nitheroy...

${ }^{118}$ AULETE, C. Diccionario contemporaneo..., p. 624.

${ }^{119}$ CARULA, K. A tribuna da ciência..., p. 31-36.

${ }^{120}$ AULETE, C. Diccionario contemporaneo..., p. 569. Grifo do original.
} 
Educar apareceu como sendo o mesmo que instruir, que por sua vez tinha o mesmo significado que ensinar. Portanto, instruir, educar e ensinar seriam sinônimos. Ao elaborar a inteligência, o coração e a alma a instrução promoveria o bem do indivíduo. Esse mesmo sentido era encontrado no dicionário de Antonio de Moraes Silva. Então, promover conferências era uma maneira de educar as pessoas, torná-las melhores intelectual e espiritualmente, o que, por sua vez, ajudaria no processo civilizacional, pois o desenvolvimento intelectual era um dos requisitos para este.

Segundo Starobinski, "Em comparação com a perfeição do polido, o bárbaro é uma espécie de criança, a criança é uma espécie de bárbaro". ${ }^{121}$ Pelo argumento do autor, é possível pensar que canalizar a preocupação para a educação infantil, seria uma maneira de polir esta criança e, assim, retirá-la do estado de barbárie, transformando-a em um ser civilizado. Chartier afirma que as traduções e adaptações da obra de Erasmo para as línguas vernáculas contribuíram para que o conceito de civilidade fosse incorporado como fundamental na educação das crianças; lembrando que civilidade muitas vezes foi considerada como sinônimo de polimento na sociedade. Muitos foram os "manuais" que ensinavam as normas corretas de conduta de civilidade aos pequenos, a fim de retirá-los da barbárie. ${ }^{122}$

Uma leitura que pode ser feita é a relacionada à grande atenção dada à educação das crianças. Algumas conferências e cursos foram realizados no intuito de educar a mãe, para que esta fizesse o mesmo com sua prole, e outros foram feitos tencionando discutir a importância da educação da criança, no sentido de que isto faria progredir o país. A importância de civilizar a criança estava relacionada com o princípio pregado pelos adeptos de que a ontogenia recapitulava a filogenia: a criança se comportaria como um homem menos evoluído, os primatas ou representantes das sociedades menos civilizadas (negros, asiáticos, etc.). ${ }^{123}$

A importância direcionada à educação não estava somente vinculada à criança. As conferências e os cursos tinham um projeto educativo, que era educar a população na ciência. Acerca da notabilidade da instrução, ao inaugurar as conferências públicas na cidade de Niterói, Manoel Francisco Correia frisou: "Deveis refletir, senhores, neste juízo acerca dos benefícios da instrução, que é em verdade o mais poderoso motor do

\footnotetext{
${ }^{121}$ STAROBINSKI, J. A palavra "civilização"..., p. 28. Grifos do original.

${ }^{122}$ CHARTIER, R. Distinção e divulgação...

${ }^{123}$ GOULD, Stephen Jay. A falsa medida do homem. Tradução de Valter Lellis Siqueira. $2^{\mathrm{a}}$ ed. São Paulo: Martins Fontes, 1999.
} 
progresso dos povos, e o mais firme sustentáculo das bases morais sobre que repousa o Estado." 124

Para o orador, a propagação da instrução era essencial, seria ela a força motriz que faria o país progredir. No caso das Conferências Populares da Glória, além do próprio evento ser educativo, ao propiciar a propagação de diversas áreas do conhecimento, várias preleções tiveram a questão da educação como temática.

Era necessário, portanto, polir os bárbaros a fim de torná-los civilizados. No caso brasileiro, não bastava isso. De acordo com a leitura liberal, precisava-se também abolir a escravidão e aumentar a indústria. A elite brasileira era bárbara porque estava imersa no mundo de outras raças, que não a branca; portanto, era necessário um esforço para que a mesma fosse melhorada. Para Maria Helena Pereira Toledo Machado, "Tomadas pela natureza selvagem, suas próprias elites encontram-se contaminadas pela barbárie do espírito tacanho, pelo atraso dos hábitos, pelo egoísmo desenfreado, pela falta de horizontes". ${ }^{25}$

Essa crença na superioridade da cultura branca europeia, de maneira oposta à existente no Brasil, marcada pela miscigenação, assemelhava-se aos ideais imperialistas britânicos. No caso brasileiro, os pensadores nacionais achavam que a supressão dos valores culturais existentes para a inserção dos europeus levaria o país a se tornar mais próximo do ideal de civilização desejado. Mary Louise Pratt assevera que civilizar para as elites da América hispânica era o mesmo que europeizar as populações nativas. ${ }^{126}$ Tal afirmação pode ser estendida para o caso brasileiro. Às elites cabia a tarefa de civilizar a nação e, assim, manter sua hegemonia no poder. Igualar-se ao capitalismo moderno europeu, industrializando o país por exemplo. Civilizar, nesta concepção, era o mesmo que europeizar o Brasil.

Starobinski afirma que apesar da acepção plural de civilização há “[...] algumas implicações que fazem dele um imperativo unitário, e que atribuem um sentido único à "marcha" do gênero humano inteiro". ${ }^{127}$ Haveria um processo único de civilização que seria válido para qualquer nação, independente de sua cultura, como um modelo préestabelecido a ser seguido.

\footnotetext{
${ }^{124}$ CORREIA, Manoel Francisco. Inauguração das Conferencias Populares em Nitheroy..., p. 19.

${ }^{125}$ MACHADO, Maria Helena Pereira Toledo. A natureza, o selvagem e o progresso: os projetos nacionais dos intelectuais e dos burocratas do Segundo Reinado. In: ___. Brasil a vapor: raça, ciência e viagem no século XIX. Tese (Livre Docência) - Faculdade de Filosofia Letras e Ciências Humanas, Universidade de São Paulo, São Paulo, 2005, p. 106.

${ }^{126}$ PRATT, Mary Louise. Os olhos do império: relatos de viagem e transculturação. Tradução Jézio Hernani Bonfim Gutierre. Bauru, SP: Edusc, 1999, Parte 2.

${ }^{127}$ STAROBINSKI, J. A palavra "civilização"..., p. 18.
} 
A leitura dos discursos proferidos nos cursos e conferências públicos mostra que o modelo de civilização seguido pelo Brasil era o europeu, com destaque para o modelo francês. Com relação ao forte papel exercido pela França, Starobinski sustenta que,

A linguagem pós-revolucionária consagrava-se a identificar os valores sagrados da Revolução como os da civilização e, em conseqüência, consagrava-se igualmente a reivindicar para a França, país da Revolução, o privilégio de ser a vanguarda (ou o farol) da civilização. $^{128}$

O autor sustenta que no decorrer do século XIX essa vocação francesa foi extremamente recorrente e vangloriada; sendo Victor Hugo um dos que mais usou a pena para ostentar e corroborar o papel da França como expressão máxima da civilização.

$\mathrm{Na}$ busca de seguir os ditames dos países civilizados, segundo o historiador Azevedo, o modelo de desenvolvimento de ciência adotado no Brasil foi o francês. De acordo com o pesquisador, o sistema franco proporcionava uma imagem de nação universalizante e neutra, o que estaria de acordo com os interesses da monarquia brasileira. $^{129}$

Ao inaugurar as conferências públicas em Niterói, em 1874, o então diretor das Conferências da Glória, Manoel Francisco Correia, para demonstrar a importância desses tipos de eventos, elogiou as congêneres francesas e inglesas, indicando que o modelo a ser seguido não era exclusivamente o francês. Com relação às da França, salientou que os proeminentes homens daquele país consideravam útil ocupar seu tempo proferindo conferências ao povo. A respeito da Inglaterra, destacou que lá a aristocracia se empenhava em generalizar os eventos. Para ele, realizar preleções públicas seria um "meio incessante de despertar o espírito". ${ }^{130}$ Despertar aqui aparece no sentido de desenvolver, então, as conferências seriam uma maneira de promover o progresso e a civilização.

Ladislau Netto abriu o primeiro número da revista Archivos do Museu Nacional homenageando os antigos diretores do Museu: “[...] homenagem lhes seja tributada nas

\footnotetext{
${ }^{128}$ STAROBINSKI, J. A palavra “civilização”..., p. 35.

${ }^{129}$ AZEVEDO, A. N. de. Da Monarquia à República...

${ }^{130}$ CORREIA, Manoel Francisco. Inauguração das Conferencias Populares em Nitheroy..., p. 17. Grifos do original.
} 
primeiras páginas dos anais com que o Museu Nacional, em sua nova e auspiciosa constituição, se prepara a vincular-se d'ora por diante aos grêmios científicos e aos congressos da civilização."131

Com a reforma de 1876, instituída pelo decreto 6116 daquele ano, o Museu se igualaria às outras instituições congêneres do mundo civilizado, ou seja, assemelhar-seia aos museus europeus. O Museu Nacional, levando o nome do Brasil, poderia vincular-se de modo efetivo às associações científicas internacionais. Regina Cândida Ellero Gualtieri assevera que a revista, na perspectiva de Ladislau Netto, seria a vitrine da produção do Museu não só dentro, mas fora do país. O diretor almejava contribuir "na construção de uma nova imagem do país que rompesse com a idéia de barbárie cultural que costumava transmitir e permitisse colocar o Brasil na marcha civilizatória da humanidade". 132

Além do tributo feito aos seus predecessores, o diretor da instituição felicitou o investimento do governo, uma vez que o Museu encontrava-se esquecido há mais de meio século. O descaso para com a instituição já havia sido sublinhado em 1870, quando, em seu relatório, o ministro da Agricultura destacou: "O apreço em que os povos civilizados têm os Museus contrasta sensivelmente com o quase abandono em tem estado o único, por assim dizer, que possui o Império". ${ }^{133}$ Para chegar ao nível dos países civilizados, o Brasil, neste caso o governo, deveria empenhar maiores investimentos financeiros no Museu, se assim o fizesse o país estaria mais próximo à civilização. Com tal apoio ele poderia cumprir a sua "missão civilizadora", qual seja, promover o desenvolvimento da ciência no país. ${ }^{134}$ Por meio da reestruturação de 1876 , "deixou o Museu de ser somente o repositório de muitas riquezas para se constituir também agente ativo da civilização" já podendo concorrer "para o progresso das ciências". ${ }^{135}$ Aqui aparecem imbricados os conceitos de civilização e progresso, este

\footnotetext{
${ }^{131}$ NETTO, Ladislau. Advertencia. Archivos do Museu Nacional. Rio de Janeiro: Imprensa Industrial. v. $1,1876$.

${ }^{132}$ GUALTIERI, Regina Cândida Ellero. O evolucionismo na produção científica do Museu Nacional do Rio de Janeiro (1876-1915). In: DOMINGUES, Heloisa Maria Bertol e SÁ, Magali Romero. In: DOMINGUES, Heloisa Maria Bertol, SÁ, Magali Romero, GLICK, Thomas (Orgs.). A recepção do darwinismo no Brasil. Rio de Janeiro: Editora da Fiocruz, 2003, p. 54.

133 BRASIL. Ministério da Agricultura, Commercio e Obras Publicas. Relatorio do anno de 1869 apresentado á Assembléa Geral Legislativa na $2^{\underline{a}}$ Sessão da $14^{\underline{a}}$ Legislatura. Rio de Janeiro, 1870, pelo ministro Diogo Velho Cavalcanti de Albuquerque, p. 88.

${ }^{134}$ BRASIL. Ministério da Agricultura, Commercio e Obras Publicas. Relatorio do anno de 1869...

135 BRASIL. Ministério da Agricultura, Commercio e Obras Publicas. Relatorio do anno de 1876 apresentado á Assembléa Geral Legislativa na $1^{\underline{a}}$ Sessão da $16^{\underline{a}}$ Legislatura. Rio de Janeiro, 1877, pelo ministro José Coelho de Almeida, p. 79
} 
como desenvolvimento das ciências que levaria a nação a adquirir um dos requisitos indispensáveis à civilização.

Com relação à oposição entre o civilizado e o bárbaro, Starobinski salienta que alguns escritores já haviam feito tal julgamento, muitas vezes atribuindo vantagem ao último, o exemplo clássico desta reflexão é Jean-Jacques Rousseau (1712-1778) e sua análise sobre o bom selvagem. Contudo, para os letrados brasileiros a vantagem, na maioria das vezes, estava do lado do civilizado, o que pode ser observado no modo como os índios foram retratados. Uma parcela sugeria, inclusive, a execução dos índios como maneira de civilizar o país. Outros, entretanto, optaram por sua inclusão na sociedade, civilizando-o. De uma maneira ou de outra, a cultura indígena era desvalorizada e deveria desaparecer.

Para que os valores europeus pudessem ser inseridos na sociedade, a elite nacional deparava-se com dois problemas: o índio e o negro. Com relação ao primeiro, como já foi dito, alguns sugeriam a inserção do indígena na sociedade, por meio de um processo civilizador, mais uma vez se assemelhando à missão civilizadora proposta pelo imperialismo inglês, que invadia e dominava outros povos e culturas com o argumento de civilizar os mesmos. No Brasil, Couto de Magalhães foi um dos que defendeu, fazendo uso de uma abordagem evolucionista e progressista, a possibilidade de se civilizar o índio. ${ }^{136}$ Para Magalhães, a civilização dos índios deveria ocorrer de modo pacífico. Favorável da mestiçagem indígena, ele caminhava na contramão das ideias de branqueamento via imigração, propostas na segunda metade do século XIX no Brasil. ${ }^{137}$

Maria Helena Machado destaca que o índio do qual se falava e se discutia nas propostas civilizacionais era o que estava longe dos centros urbanos, "congelado na paisagem tropical e luxuriante", nos distantes sertões. ${ }^{138}$ No caso daqueles que viviam no Rio de Janeiro, onde existiam poucos indígenas, era muito comum encontrar um posicionamento semelhante ao de Couto de Magalhães, uma vez que o "problema" estava, na realidade, a quilômetros de distância.

Para os que habitavam a Corte, a questão central era o elemento negro. Eram eles que estavam ali presentes, transitando no cotidiano dessas pessoas, tanto no ambiente privado quanto no público. Para o município neutro, o censo de 1872 delineou, segundo o critério raça, o seguinte perfil populacional: 151.799 brancos,

\footnotetext{
${ }^{136}$ MACHADO, M. H. P. T. Brasil a vapor..., p. 150.

${ }^{137}$ MACHADO, M. H. P. T. Brasil a vapor..., p. 151.

${ }^{138}$ MACHADO, M. H. P. T. Brasil a vapor..., p. 94.
} 
44.845 pardos, 28.466 pretos e 923 caboclos (índios). ${ }^{139}$ As cifras mostram o quanto o problema real não era o índio e sim o negro, este era o bárbaro que estava ao lado. Mas como civilizar o negro, sendo que vários ainda eram escravos? Como pensar na possibilidade de civilizar um sujeito que era propriedade de outrem? Nesse momento, as questões civilizacionais esbarravam numa delicada questão, a escravidão. Mesmo com relação aos que não eram cativos, como seria possível tornar os negros próximos ou iguais aos brancos, uma vez que civilizar era o mesmo que europeizar e branquear a sociedade? Uma solução para tal dilema foi não abordar o assunto. Assim como fizeram os sujeitos que proferiram conferências públicas neste período. A ausência de uma discussão acerca do negro sugere o quão tortuosa era a questão para essa elite letrada branca, que optou simplesmente por não tocar no assunto. Machado sublinha que o homem negro também foi deixado de lado nas discussões do Instituto Histórico e Geográfico Brasileiro, que estava incumbido de construir a história nacional, via uma concepção progressista de análise. ${ }^{140}$

Após a Lei do Ventre Livre, de 1871, algumas discussões se tornaram cada vez mais constantes, por exemplo, acerca da proximidade do término da escravidão, a melhor mão de obra a ser utilizada após a abolição, o incentivo à imigração europeia. ${ }^{141}$ Portanto, é extremamente difícil imaginar que o elemento negro não fosse um ponto que inquietasse a mente desses pensadores que desejavam o progresso do país via branqueamento da população, de modo a assemelhar o Brasil à Europa. Alguns intelectuais brasileiros debatiam e se opunham às propostas, por exemplo, de Louis Agassiz, este afirmava que a mestiçagem causava a degeneração. ${ }^{142} \mathrm{Na}$ perspectiva analítica dos brasileiros, que viviam em uma sociedade na qual havia uma imensa quantidade de mestiços, o miscigenado podia ser integrado, ainda que de modo autoritário. Uma solução encontrada foi efetuar o branqueamento via padrões europeizantes menos tolerantes. Não só via o incentivo da entrada de imigrantes brancos

\footnotetext{
${ }^{139}$ Ivana Stolze Lima destaca a inserção da categoria raça, indicando um modo de classificar a população fundamentado em um "suporte pretensamente mais rígido". LIMA, Ivana Stolze. Cores, marcas e falas: sentidos da mestiçagem no Império do Brasil. Rio de Janeiro: Arquivo Nacional, 2003, p. 121.

${ }^{140}$ MACHADO, M. H. P. T. Brasil a vapor..., p. 92.

${ }^{141}$ Conferir, entre outros: AZEVEDO, Celia Maria Marinho. Onda negra, medo branco: o negro no imaginário das elites século XIX. $2^{\text {a }}$ ed. São Paulo: Annablume, 2004. CHALHOUB, Sidney. Visões da liberdade: uma história das últimas décadas da escravidão na corte. São Paulo: Companhia das Letras, 1990. MACHADO, Maria Helena Pereira Toledo. O plano e o pânico: os movimentos sociais na década da abolição. Rio de Janeiro; São Paulo: UFRJ; Edusp, 1994.

${ }^{142}$ MACHADO, Maria Helena Pereira Toledo. A ciência norte-americana visita a Amazônia: entre o criacionismo cristão e o poligenismo "degeneracionista". Revista USP, São Paulo, n.75, p. 68-75, set./nov. 2007.
} 
no país, mas também estimulando a miscigenação, de modo a branquear o país. No sentido inverso de muitas teorias cientificistas que sustentavam a inferioridade do miscigenado, uma das opções foi valorizar a mestiçagem, mostrando que o mestiço seria superior ao negro progenitor.

Com relação ao vocábulo selvagem, o dicionário de Aulete o definiu como bárbaro, para o primeiro termo apresentou a seguinte acepção:

Que tem o que quer que seja de rude, de bárbaro (falando das qualidades morais). ॥ (Fig.) Grosseiro, rude, intratável, bruto; rústico; que vive em matos ou bosques; pessoa de costumes bárbaros; que teme o contato da gente civilizada. ${ }^{143}$

O selvagem, assim como o bárbaro, era o contrário do civilizado. Para selvagem o verbete sublinhou a grosseria e a rudeza, que seria a ausência de polidez, uma das características de quem era civilizado. Além dessas propriedades, ainda foi marcado o temor que o selvagem sentia ao entrar em contato com as pessoas civilizadas.

Louis Couty, em 1881, nos cursos públicos do Museu Nacional, apresentou uma série de conferências acerca do funcionamento do cérebro. Em sua $13^{\text {a }}$ preleção perpassou pela contraposição entre civilizado e selvagem:

[...] o Dr. Couty mostrou que o funcionamento do cérebro, aparentemente espontâneo, depende dos meios externos, clima, solo, alimentação, etc. Os selvagens que se ocupam exclusivamente de procurar sua alimentação, não têm tempo para educar-se. Os homens civilizados obtêm facilmente uma alimentação rica e irritante, que causa mesmo muitas vezes a loucura - o alcoolismo, etc. [...] é tão difícil fazer de um selvagem um homem civilizado, como transformar um cão de vigia em cão de caça. ${ }^{144}$

Assim como o significado do dicionário, para Couty o civilizado era o contrário do selvagem, sendo este o indígena e o primeiro o homem branco. Uma das características que atribuiu ao selvagem foi a de não educar-se, estando assim, por oposição, em concordância com a definição do dicionário para civilizado: "Instruído,

${ }^{143}$ AULETE, C. Diccionario contemporaneo..., p. 1624.
${ }^{144}$ Jornal do Commercio, 12/11/1881. 
esclarecido, que tem os sentimentos, ideias e costumes que caracterizam o estado de civilização: civil, cortês". ${ }^{145}$ Couty concebia a possibilidade de civilizar o selvagem, leia-se aqui substituir seus costumes e valores pelos do homem branco; entretanto, evidenciou que tal transformação seria extremamente difícil.

Ainda sobre a possibilidade de civilizar os bárbaros, merece destaque a análise de Manoel Francisco Correia. Ao discutir a importância da instrução para a sociedade, o conferencista citou e comentou trechos de Joseph Ernest Renan (1823-1892), se posicionando contra o escritor francês: "Não seria mais nobre missão civilizar a China sem escravizá-la?" ${ }^{\prime 146} \mathrm{O}$ orador explicitou que admitia a missão civilizadora de alguns países. Ao representar os chineses como bárbaros, apresentou como aceitável a invasão de países imperialistas na China, pois os invasores estariam lá para ajudar. Com relação à missão civilizadora promovida pelo imperialismo europeu, vale destacar que se tratava de um processo de longo alcance, uma maneira de tutelar por meio da civilização, que não pode ser confundida com filantropia. ${ }^{147} \mathrm{Na}$ fala do conselheiro Correia é possível observar um substrato racialista, quando ele representou os chineses como inferiores aos brancos europeus. Portanto, esta racialização estava surgindo e ao mesmo tempo sendo reinventada nas conferências.

O conselheiro também acreditava na incumbência civilizadora de determinada parcela da sociedade. Para Manoel Correia foi Deus que favoreceu essas classes que, por sua vez, tinham direitos e obrigações maiores.

[...] aqueles que têm a fortuna de distinguir-se na sociedade pelos mais elevados dotes do espírito e do coração, adquirindo vantajosa posição, não se mostram suficientemente gratos a essa mercê especial da Providência se deixam de cuidar com afinco no melhoramento das classes menos favorecidas. ${ }^{148}$

Um dos deveres seria, portanto, instruir as classes menos favorecidas. De acordo com Manoel Francisco Correia, a propagação da instrução era essencial, seria ela a força motriz que faria o país progredir. Na concepção do conselheiro, a desigualdade humana era natural - da mesma maneira que não existiam dois gêmeos idênticos, por

\footnotetext{
145 AULETE, C. Diccionario contemporaneo..., p. 337.

146 CORREIA, Manoel Francisco. Conferência de 21 de novembro. Conferencias Populares. Rio de Janeiro: Typ. Imp. e Const. de J. Villeneuve. n. 1, jan. 1876, p. 21.

${ }^{147}$ PRATT, M. L. Os olhos do império...

${ }^{148}$ CORREIA, Manoel Francisco. Inauguração das Conferencias Populares em Nitheroy..., p. 21.
} 
meio desta analogia, naturalizou a desigualdade, afirmando que havia uma diferença moral e intelectual entre as pessoas. Em sua concepção, existia uma aristocracia, estabelecida com a Constituição no Brasil, que teria a função de levar o conhecimento às classes menos privilegiadas. Para o idealizador das Conferências da Glória, todos seriam capazes de alcançar a civilização. As Conferências, na interpretação de Correia, exerciam também um papel civilizador, que seria o de levar o conhecimento científico à camada letrada da sociedade, para que esta o levasse aos outros estratos sociais.

Isto não significa, entretanto, que a audiência dos cursos e conferências fosse compreendida como bárbara. Havia sim a barbárie, porém circunscrita a determinadas parcelas da sociedade como, por exemplo, aos indígenas, aos negros, aos brancos pobres, às mulheres. Assim, embora o Brasil não fosse considerado um país bárbaro, ainda não era civilizado. Mas isso era algo que poderia ser resolvido por meio da civilização dos mesmos. A civilização era o patamar mais alto que um país poderia atingir, simbolizada nos países europeus, que serviam de modelo para o Brasil. O progresso, conceito imbricado com o de civilização, era compreendido como uma consequência de etapas ascendentes que promoveriam a elevação ao patamar de civilizado.

\section{Vulgarização da ciência}

No século XIX ocorreu uma especialização das áreas do conhecimento, que trouxe consigo a introdução de um campo semântico próprio. Neste contexto surgiu a figura do vulgarizador, que tinha o papel de traduzir essa linguagem técnica e específica para o público não científico. De acordo com Moema de Rezende Vergara, "o termo 'vulgarização científica' designava especificamente a ação de falar de ciência para os leigos", sendo a tradução um dos aspectos da vulgarização. ${ }^{149}$

Segundo Vergara, o termo vulgarização começou a circular na sociedade brasileira em torno dos anos de 1870. A autora argumenta que provavelmente o vocábulo tenha sido inserido por meio dos livros franceses, em especial pela obra Astronomia popular, de Camille Flammarion (1842-1925), vulgarizador francês muito conhecido no Brasil.

\footnotetext{
${ }^{149}$ VERGARA, M. de R. Ensaio sobre o termo "vulgarização científica" ..., p. 137.
} 
Em 1881, o dicionário de Caldas Aulete assim definiu vulgarizar:

tornar notório ou mui conhecido; propagar, vulgar, divulgar; pôr ao alcance, ao conhecimento de muitos ou de todos; popularizar: Vulgarizar a ciência. \| Tornar comum. \| Abandalhar. \| Traduzir em vulgar. \| Tornar-se vulgar, tornar-se mui conhecido; popularizar-se: Esta xácara é das que menos vulgarizaram. (Garrett.). ${ }^{150}$

Vulgarizar seria tornar algo extremamente conhecido e tinha como sinônimos propagar, divulgar e popularizar. Entretanto, no período que abrange este trabalho o termo mais utilizado era vulgarização. A acepção "traduzir em vulgar" não possui o caráter depreciativo que a palavra possui hoje, pois, de acordo com o mesmo dicionário, uma das significações de vulgar seria "divulgar, vulgarizar, fazer público, tornar conhecido pela palavra ou por escrito"; ${ }^{151}$ sendo, desta maneira, uma sinonímia de vulgarizar. Partindo dessas concepções, vulgarizar a ciência em fins do século XIX no Brasil seria torná-la pública, muito conhecida, colocando-a ao alcance de todos ou, ao menos, de uma grande parcela da população.

Cabe destacar, a especificação do verbete vulgar sobre o modo como se devia tornar público algo, oralmente ou por escrito. Na segunda metade do século, em especial na década de 1870, vários jornais foram criados no Rio de Janeiro tendo no título ou no subtítulo a palavra ciência, muitos deles adicionando artes e literatura, o que indica o apreço pelo tema nesse período. ${ }^{152}$ Ao apresentar notícias do cotidiano dedicavam seções específicas à vulgarização científica. Alguns tinham como meta principal vulgarizar a ciência, foi o caso de $O$ Vulgarizador, periódico ilustrado de caráter científico-literário que objetivava alcançar todas as inteligências, formando um pensamento verdadeiramente brasileiro. Seu editor era o português Augusto Emílio Zaluar e teve como alguns de seus colaboradores José de Alencar, Araripe Júnior,

\footnotetext{
${ }^{150}$ AULETE, C. Diccionario contemporaneo..., p. 1900.

${ }_{151}$ AULETE, C. Diccionario contemporaneo..., p. 1900.

152 Ao analisar o catálogo da Biblioteca Nacional, Ildeu de Castro Moreira e Luisa Massarani constatam que no decorrer do século XIX foram criados aproximadamente 7000 periódicos, e cerca de 300 estavam relacionados às ciências, possuíam "ciência" ou "científico" em seus títulos ou subtítulos, ou eram produzidos por instituições ou associações científicas. MOREIRA, I. de C.; MASSARANI, L. Aspectos históricos da divulgação científica no Brasil...
} 
Affonso Celso, Rangel S. Paio, Charles Hartt e Orville Derby, muitos dos quais proferiram conferências públicas no período aqui estudado. ${ }^{153}$

A Revista Brazileira foi outro periódico que se empenhou em promover a vulgarização científica, e da mesma forma contou com a participação de alguns conferencistas, por exemplo, João Baptista de Lacerda e Louis Couty, preletores dos cursos públicos do Museu Nacional. A terceira fase da revista (1879-1881), que interessa para essa pesquisa, teve Nicolau Midosi como coordenador e tinha o "homem culto" como leitor-alvo. ${ }^{154}$ Além de temas relacionados à ciência, possuía um forte caráter literário.

Em um artigo publicado na Revista Brazileira, acerca da importância e necessidade da implantação dos estudos experimentais no Brasil, Couty defendeu o desenvolvimento de uma ciência nacional, que seria a melhor maneira de sanar os problemas nacionais. Ciência nacional aqui seria o desenvolvimento de práticas científicas dentro do Brasil. Para ele, era essencial apresentar à sociedade em geral os avanços científicos, não só para se ter o apoio da mesma, mas também para ajudar o país. ${ }^{155} \mathrm{O}$ médico evidenciou os artigos da imprensa brasileira que expunham descobertas científicas europeias, mas frisou a necessidade desses meios de comunicação fazerem o mesmo com as brasileiras.

Os jornais destinados a um público específico também estavam preocupados com a vulgarização científica. A Mãi de Familia, ${ }^{156}$ dedicado ao público feminino, em 1880, tinha logo como primeira seção a "Palestra do médico", na qual o médico Carlos Costa (redator do periódico e que na década de 1870 realizou várias conferências públicas) enunciava assuntos científicos direcionados às mulheres; além desta havia também a seção "Revista dos Jornais científicos", que apresentava e comentava trechos de outros jornais, principalmente os relacionados a assuntos que consideravam ser de interesse feminino.

\footnotetext{
${ }^{153}$ VERGARA, Moema de Rezende. Ciência, cultura e público: periódicos científicos-literários no Rio de Janeiro oitocentista. In: Anais complementares do XXIV Simpósio de História. São Leopoldo, RS: Unisinos, 2007.

${ }^{154}$ VERGARA, Moema de Rezende. A Revista Brazileira: vulgarização científica e construção da identidade nacional na passagem da Monarquia para a República. Tese (Doutorado em História) Pontifícia Universidade Católica do Rio de Janeiro, Rio de Janeiro, 2003.

${ }^{155}$ COUTY, Louis. Os estudos experimentais no Brasil. Revista Brazileira. Rio de Janeiro: Escriptorio da Revista Brazileira. Tomo II, p. 215-239, $1^{\circ}$ de nov. 1879.

${ }^{156}$ Tinha como subtítulo: "Jornal científico, literário e ilustrado - Educação da infância, higiene da família".
} 
Publicações de caráter satírico não deixaram passar em branco essa ânsia em vulgarizar o conhecimento científico. Às vezes criticando esse processo e em outras compactuando com o mesmo. A Bibliotheca dos Bonds publicou vários pequenos artigos que, com linguagem simples e clara, discutiam assuntos relativos à ciência e à tecnologia. ${ }^{157}$ Locomotivas, telégrafo elétrico, história do vapor, luz das estrelas, eclipse, ar, sol, velocidade da luz foram alguns dos temas que estiveram presentes nas páginas da folha.

A revista Archivos do Museu Nacional tinha a incumbência de difundir um saber científico, e era considerada um meio de comunicação entre a comunidade científica e a sociedade. ${ }^{158} \mathrm{O}$ periódico foi inaugurado em 1876, quando o Museu estava sob a direção de Ladislau Netto. Para o diretor, os trabalhos realizados naquele espaço tinham que ser divulgados não só no Brasil, mas em outros países, e o lançamento do periódico ajudaria o país a se inserir no caminho da civilização. Esse papel atribuído aos Archivos pode ser observado no Relatório Ministerial referente ao ano de 1881:

Continua-se este estabelecimento a prestar à ciência valiosos subsídios, [...] como vulgarizador de conhecimentos úteis, já por meio de sua revista trimestral, já pelos cursos noturnos em que o pessoal docente torna públicos os resultados que realiza ou expõe os princípios das ciências que professa. ${ }^{159}$

Tanto os cursos públicos como a publicação eram concebidos como meios pelos quais o Museu vulgarizaria a ciência. Essa percepção era reforçada pela imprensa. O Jornal do Commercio, em 1880, noticiou que o Museu havia recebido da Biblioteca Nacional a obra Flora fluminense, do frei José Mariano Conceição Velloso, para que a mesma pudesse ser vulgarizada na revista da instituição. ${ }^{160}$ Entretanto, na prática a revista não se caracterizava por ser de vulgarização, mas sim de divulgação científica, em que se tencionava a difusão para os pares, neste caso principalmente os estrangeiros. $^{161}$

\footnotetext{
157 “Publicação diaria por uns litteratos desoccupados" era o subtítulo do periódico.

${ }^{158}$ GUALTIERI, R. C. E. O evolucionismo na produção científica do Museu Nacional...

159 BRASIL. Ministério da Agricultura, Commercio e Obras Publicas. Relatorio do anno de 1881 apresentado á Assembléa Geral Legislativa na $1^{\underline{a}}$ Sessão da $18^{\underline{a}}$ Legislatura. Rio de Janeiro, 1882, pelo ministro José Antonio Saraiva.

160 Jornal do Commercio, 15/08/1880.

161 VERGARA, M. de R. A Revista Brazileira...
} 
Mesmo a imprensa que não estava voltada especificamente para temas científicos oferecia espaço para expor temas relativos à ciência. O Jornal do Commercio, por exemplo, na seção "Gazetilha", trazia notícias relacionadas ao assunto, ao anunciar, resumir e comentar os cursos e conferências públicos que aconteciam; e ao informar as novas aquisições e as expedições científicas do Museu Nacional. A folha também editava artigos mais detalhados sobre inovações tecnológicas e teorias científicas.

Ao comentar a conferência feita pelo médico João Joaquim Pizarro no Museu Nacional, o Jornal do Commercio explicitou seu apreço com relação à existência de cursos e conferências públicos, enfatizando os benefícios que traziam aos países civilizados. Sobre a vulgarização da ciência, afirmou que o ganho era tanto para a ciência, que podia expor as "verdades demonstradas", quanto o povo, que com isso aumentaria seu "nível intelectual”, uma vez que o mesmo não podia “[...] se entregar a estudos profundos que demandam sólidos preparos". ${ }^{162}$ A função da vulgarização científica era explicitada como sendo, primeiramente, aumentar a intelectualidade do povo, fazendo-o progredir. Neste sentido, os espaços dedicados à vulgarização científica também seriam dotados de uma missão civilizadora, ao promoverem o aprimoramento da sociedade na ciência. O segundo ponto do papel desempenhado pela vulgarização da ciência era o de levar o conhecimento científico àquele que não se dedicava profissionalmente ao estudo das ciências. A essência da vulgarização da ciência estava em fazer o público crer que de fato a prática científica era importante para a sociedade, que a finalidade última da ciência era o bem comum; por exemplo, melhorando sua indústria e, com isso, ajudando o país a progredir. ${ }^{163}$

A vulgarização científica pressupõe a tradução, transformar o discurso científico, repleto de termos e conceitos complexos, em uma linguagem mais simples, acessível ao público leigo. ${ }^{164}$ No entanto, Vergara alerta que há um limite nesse processo de tradução, em vista da impossibilidade de se realizar a "transmissão integral" do conteúdo científico; assim, a vulgarização seria também uma atividade criadora. ${ }^{165} \mathrm{~A}$

\footnotetext{
162 Jornal do Commercio, 23/10/1880.

${ }^{163}$ VERGARA, M. de R. A Revista Brazileira...

164 Acerca da utilização dos textos de vulgarização científica como fonte histórica, Vergara salienta que eles possibilitam a compreensão mais ampla da sociedade e seus valores em si, uma vez que estão permeados de tantas outras coisas que, a princípio, o texto estritamente científico não está. VERGARA, M. de R. Ensaio sobre o termo "vulgarização científica"...,

${ }^{165}$ VERGARA, M. de R. Ensaio sobre o termo "vulgarização científica”..., p. 139. A questão da perda da totalidade do conteúdo científico é discutida quando se aborda a atual divulgação científica. O texto de divulgação, para alguns, é considerado como novo quando comparado ao científico original. Para uma
} 
pesquisadora defende que no Brasil do século XIX a vulgarização era um modo de propaganda, que servia para que o cientista conseguisse o apoio da sociedade em suas atividades científicas. Associar a ciência ao progresso era um mecanismo que facilitaria a aceitação do público leigo. Com isso, esses cientistas conseguiam prestígio social e apoio financeiro. $\mathrm{O}$ que fazia com que a vulgarização tivesse mais características de propaganda do que educacional. O próprio Couty, ao defender a vulgarização científica, via a mesma como um tipo de propaganda: "Quiseram meus amigos que eu começasse este trabalho declarando porque e como empreendemos realizar aqui a nova propaganda científica". 166

Com relação à maneira de se expressar em um discurso vulgarizador, o art. 33 do regimento interno do Museu Nacional já marcava o modo como isso deveria ocorrer. Segundo o regulamento, os cursos públicos deveriam ser ministrados "sob as formas mais claras e convincentes, evitando absolutamente quaisquer questões individuais". ${ }^{167}$ Os discursos deveriam apresentar uma linguagem mais clara, de fácil apreensão, o que caracterizava a vulgarização científica.

Para facilitar a compreensão, os preletores poderiam fazer uso de recursos pedagógicos. Em 1880, os cursos do Museu passaram a ser realizados em uma nova sala, no pavimento superior do prédio, onde havia "espaço suficiente à colocação de estampas murais, grandes cartas geológicas e outros objetos, podendo ser ampliados por meio de aparelhos de projeção a proporções convenientes ao ensino". ${ }^{168}$ Além de realizar alguns experimentos para ilustrar as suas falas, os oradores tinham à disposição esses outros materiais.

Entretanto, não eram todos os oradores daquela instituição que seguiam essa regra. Louis Couty, em artigo publicado na Revista Brazileira, explicitou seu posicionamento acerca do assunto: "Enfim, em lugar de reduzir por meio da vulgarização os problemas científicos a seus termos mais simples, não seria preferível

discussão a esse respeito conferir: SÁNCHEZ MORA, Ana María. A divulgação da ciência como literatura. Tradução Silvia Pérez Amato. Rio de Janeiro: Casa da Ciência - Centro Cultural de Ciência e Tecnologia da Universidade Federal do Rio de Janeiro: Editora UFRJ, 2003. MASSARANI, Luisa. A divulgação científica no Rio de Janeiro: alguns aspectos sobre a década de 20. Dissertação (Mestrado em Ciência da Informação) - Escola de Comunicação, Universidade Federal do Rio de Janeiro, Rio Janeiro, 1998.

${ }^{166}$ COUTY, L. Os estudos experimentais no Brasil..., p. 215.

${ }^{167}$ Regimento interno do Museu Nacional. 1879. Pasta 18, doc. 9A (SEMEAR).

168 BRASIL. Ministério da Agricultura, Commercio e Obras Publicas. Relatorio do anno de 1879 apresentado á Assembléa Geral Legislativa na $3^{\underline{a}}$ Sessão da $17^{\underline{a}}$ Legislatura. Rio de Janeiro, 1880, pelo ministro Manuel Buarque de Macedo. 
conservar-lhe a sua complexidade real?" "169 Apesar de enfatizar a necessidade de se vulgarizar o conhecimento científico, o médico francês sugeriu que a complexidade do saber não deveria ser minimizada, sinalizando que nesse processo de vulgarização da ciência havia uma perda da precisão. Para ele não era preciso simplificar o conteúdo porque o leitor do periódico, e possivelmente o público frequentador dos cursos do Museu, tinha cabedal intelectual para entender: "Os nossos artigos serão curtos, porque desejamos que sejam lidos; entretanto, não nos esquecendo de que escreveremos para homens instruídos, não procuraremos simplificar as questões e pô-las, conforme se diz, ao alcance de todos." 170

Embora advogasse a vulgarização científica, Couty não a via como de acesso a todos. Na Revista Brazileira, onde o artigo foi publicado, ele afirmou que não haveria simplificação dos preceitos científicos, pois o público visado era o dos "homens instruídos". ${ }^{171}$ Argumentou ainda que na Europa existiam vários meios de propaganda do conhecimento científico destinados "não já diretamente aos sábios, mas principalmente ao público ilustrado e culto". ${ }^{172} \mathrm{O}$ fisiologista francês explicitou a quem destinava suas palavras. É possível supor que ele partiu do mesmo princípio quando desenvolveu suas preleções nos cursos públicos do Museu.

Outro sujeito que proferiu conferências públicas e compactuava com a visão excludente de Couty foi o médico Joaquim José Teixeira:

Sei bem que nem todos os pensamentos são para o geral do povo; pois muitos se encontram tão elevados e tão metafísicos, que só os alcança inteligência cultivada. Mas é certo que um grande número deles pode ser facilmente compreendido; e eu não vejo razão para excluir o povo do conhecimento das verdades que eles encerram. Tudo quanto tende a formar o coração na família ou na cidade, deve merecer a atenção do governo, e das pessoas que se interessam pelo progresso moral do nosso povo. ${ }^{173}$

\footnotetext{
${ }^{169}$ COUTY, L. Os estudos experimentais no Brasil..., p. 237.

${ }^{170}$ COUTY, L. Os estudos experimentais no Brasil..., p. 238.

${ }^{171}$ Com relação à vulgarização científica para um público restrito, Ana María Sánchez Mora argumenta que ao escrever em língua vernácula, no italiano, Galileu realizou uma divulgação do conhecimento científico, uma vez que o conhecimento científico era escrito em latim. Todavia, essa não era para um público amplo, e sim para as "pessoas cultas" da sociedade. SÁNCHEZ MORA, A. M. A divulgação da ciência como literatura..., p. 16.

${ }^{172}$ COUTY, L. Os estudos experimentais no Brasil..., p. 236.

${ }^{173}$ TEIXEIRA, Joaquim José. Pensamentos. Conferencias Populares, Rio de Janeiro, n. 2, fev. 1876, p. 100.
} 
Para o médico, a vulgarização do conhecimento não era para todos, pois muitas vezes a complexidade era tão grande que apenas uma pequena parcela, os que possuem "inteligência cultivada", conseguiria compreendê-los. Teixeira não admitia a possibilidade de que após traduzir o saber, por meio da vulgarização, ele pudesse ser apreendido por um público mais amplo. Porém, os assuntos mais simples não só podiam como deveriam ser apresentados a todos. O conferencista também destacou a importância que carecia ser dada a temas que pudessem trazer benefícios às famílias ou à cidade; eles promoveriam o progresso do povo e, consequentemente, do país. Neste sentido, o progresso era resultante de forças que atuavam tanto no espaço público quanto no privado.

Sobre a compreensão da plateia em preleções públicas, o periódico $A$ Bibliotheca dos Bonds editou um artigo satirizando-a. O fictício Dr. Almondega teria sido convidado para se apresentar nas Conferências Populares da Glória, que sobre este evento ressaltou ser um local “[...] onde muito se aplaude e pouco se entende!". ${ }^{174}$ Segundo o autor, a vulgarização científica lá realizada era, de fato, pouco eficiente, quase não se compreendia o que era exposto. Mesmo a audiência letrada, que ia aos eventos, não conseguia absorver o conteúdo, a princípio já vulgarizado, em sua totalidade. $^{175}$

Em 1880, Joseph Auguste Aristide Fort, médico francês recém-chegado ao Brasil, proferiu na escola da Glória ${ }^{176}$ uma polêmica série de conferências sobre a febre amarela. ${ }^{177}$ Um leitor do Jornal do Commercio expressou a sua apreciação:

[...] se o orador dirigia-se a um auditório científico a sua conferência neste ponto não teve valor algum; as ideias emitidas foram tão elementares que não era permitido a ninguém ignorar; se ao contrário o orador se dirigia a um auditório popular, a sua preleção foi brilhante

\footnotetext{
${ }^{174}$ As conferencias populares. A Bibliotheca dos Bonds, Rio de Janeiro, n. 1, 1876, p. 18.

${ }^{175}$ VERGARA, M. de R. Ensaio sobre o termo "vulgarização científica"...

${ }^{176}$ Essas preleções não fizeram parte das Conferências Populares da Glória, somente foram realizadas no mesmo espaço.

${ }^{177}$ A referida celeuma girava em torno do médico brasileiro Maximiliano Marques de Carvalho, que reivindicava a autoria do método de prevenir a febre amarela exposto por Fort. Carvalho escreveu uma série de artigos no Jornal do Commercio, nos quais acusava Fort e apresentava as suas hipóteses a respeito do tema. O debate foi acentuado com o posicionamento de outros médicos, incluindo professores da Faculdade de Medicina do Rio de Janeiro, contrários às proposições defendidas por Fort. Mesmo não concordando com a proposta de análise de Carvalho, eles tampouco criam nas argumentações do médico francês.
} 
pela grandeza e limpidez com que apresentou fatos em si cheios de aridez. ${ }^{178}$

Aqui é possível notar como os homens letrados compreendiam a diferença entre um discurso científico e um de vulgarização científica. No caso de conferências destinadas a um público leigo, ou popular, o assunto deveria ser apresentado com "clareza e limpidez", ou seja, seria uma maneira de tornar mais palatáveis temas muitas vezes difíceis. Outro ponto que deve ser evidenciado é a simplificação do discurso científico, que, de acordo com o leitor, fora exposto de maneira bem elementar. A natureza do assunto e a grande quantidade de médicos presentes levaram o autor do artigo a crer que o público concebido por Fort era o médico, uma vez que assistiram à conferência "quase todo o corpo docente da faculdade de medicina, muitos médicos e estudantes da mesma faculdade". ${ }^{179}$ Entretanto, o modo como as ideias foram expressas parecia que era leigo. A segunda suposição é mais plausível, pois foram à referida preleção aproximadamente 300 pessoas, sendo muitas mulheres, além de representantes da imprensa, do governo, incluindo aí o próprio Imperador. ${ }^{180}$

O conhecimento científico era apresentado destacando suas possíveis aplicações na sociedade. ${ }^{181}$ Era, portanto, fundamental mostrar ao público não científico as novidades do campo da ciência. O caráter utilitário da ciência foi um traço marcante desde o século XVIII, que perdurou durante todo o século XIX. Maria Odila Leite da Silva Dias destaca a atração que a ciência despertava nos estudantes formados em direito em Portugal na virada para o Oitocentos. A maioria se formava no mínimo em um dos ramos da ciência, indicando "a tendência pragmática de suas mentalidades". ${ }^{182}$ No caso brasileiro, vale destacar os trabalhos científicos do patriarca da independência José Bonifácio, que valorizava os estudos que pudessem ter resultados úteis à

\footnotetext{
178 Jornal do Commercio, 25/07/1880.

179 Jornal do Commercio, 21/07/1880.

180 Jornal do Commercio, 21/07/1880.

${ }^{181}$ Russel Teresinha D. da Rosa e João Batista de S. Sobrinho, ao analisar frontispícios de publicações no século XIX verificam que nesse espaço da publicação algumas obras científicas esforçavam-se para explicitar sua relação com interesses técnicos e econômicos. Isto também pode ser uma maneira de categorizar o conhecimento científico como útil à sociedade. ROSA, Russel Teresinha D. da; SOBRINHO, João Batista de S. Publicações brasileiras e o desenvolvimento das ciências no século XIX. Episteme, Porto Alegre, v. 11, n. 23, p. 117-149, jan./jun. 2006.

${ }^{182}$ DIAS, Maria Odila Leite da Silva. Aspectos da ilustração no Brasil. Revista do Instituto Histórico e Geográfico Brasileiro, Rio de Janeiro, v. 278, jan.-mar. 1968, p. 107.
} 
sociedade. ${ }^{183}$ Maria Odila Dias também salienta como a crença na utilidade da ciência estava relacionada com o "despertar da preocupação com a realidade social brasileira", uma vez que desde fins do Setecentos os ilustrados, além de divulgar o conhecimento europeu, experimentavam e adaptavam o mesmo à realidade nacional. ${ }^{184}$

Acerca dessa utilidade, Vergara afirma que a ciência estava "comprometida com uma ampla difusão de suas descobertas; tanto para garantir o apoio do Estado, quanto para legitimar a prática científica na sociedade". ${ }^{185}$ A autora acrescenta que para o vulgarizador, expor a utilidade do conhecimento científico era uma maneira de facilitar a compreensão do público leigo e, ademais, conseguir o seu apoio. Mostrar a aplicabilidade da ciência também era um meio de ligar a prática científica ao progresso do país, fazendo parte, portanto, do ofício do cientista. Neste sentido, Couty ressaltou que os diversos meios de vulgarização científica foram responsáveis por despertar o gosto pelo saber científico e conhecimento de sua utilidade no Velho Mundo. ${ }^{186}$ Vergara sustenta que essa tendência ao utilitarismo da ciência era originária do Iluminismo, com os enciclopedistas, mas foi no século XIX que isso se tornou uma das principais características da atividade científica. ${ }^{187}$

A ligação Estado e serventia da ciência pode ser observada, no caso brasileiro, com o Museu Nacional, que estava vinculado ao Ministério da Agricultura e Obras Públicas, indicando que os conhecimentos ali produzidos deveriam ser de aplicações práticas para o país. Um exemplo de como se compreendia a ciência de modo utilitário, está na nota publicada pelo Jornal do Commercio quando da instalação do laboratório de fisiologia nessa instituição:

[...] grata notícia que acabamos de receber de que vai ser dotado o nosso museu com um laboratório de fisiologia experimental, de cuja direção se encarregará o Sr. Dr. Luiz Couty, e onde serão tratados certamente com grande proveito público os assuntos que mais se prendem aos interesses da economia rural do país. ${ }^{188}$

\footnotetext{
${ }^{183}$ Alex Gonçalves Varela analisa os projetos políticos e científicos de José Bonifácio, desenvolvendo a articulação entre ambos. VARELA, Alex Gonçalves. Atividades científicas na "Bela e Bárbara" capitania de São Paulo (1796-1823). São Paulo: Annablume, 2009, capítulo 3.

${ }^{184}$ DIAS, M. O. L. da S. Aspectos da ilustração no Brasil..., p. 133.

${ }^{185}$ VERGARA, M. de R. A Revista Brazileira ..., p. 13.

${ }^{186}$ COUTY, L. Os estudos experimentais no Brasil...

${ }^{187}$ VERGARA, M. de R. A Revista Brazileira...

${ }^{188}$ Jornal do Commercio, 17/01/1880.
} 
Havia a percepção de que a introdução do laboratório ajudaria a economia rural a desenvolver-se. Isto mostra a concepção de um emprego prático da ciência. Segundo Ana Carolina Vimieiro Gomes, o Museu Nacional foi pioneiro na inserção de estudos de fisiologia no país; foram lá desenvolvidas pesquisas sobre café, mate, álcool da canade-açúcar, assuntos ligados à agricultura brasileira; a fisiologia do cérebro; estudo de substâncias toxicas ou alimentares; ainda estavam previstos investigações sobre higiene, patologia e climatologia do Brasil. ${ }^{189}$ O laboratório era coordenado por Louis Couty e João Baptista Lacerada, sendo que alguns desses temas foram abordados por eles em suas preleções. Para Couty, o país precisava desenvolver pesquisas experimentais para poder progredir, e cabia ao público a fiscalização destes estudos. Porém, o público só poderia ter esse controle se tivesse habilitado para tal, o preparo viria por meio da vulgarização dos trabalhos científicos, com isso ele poderia "discutir e reconhecer os progressos" da ciência. ${ }^{190}$

Gomes argumenta que, ao propor a pesquisa de assuntos relacionados a questões brasileiras, realizada experimentalmente, a fisiologia se constituiu uma "disciplina exemplar". Além de ter fortalecido os ideais de ciência e civilização existentes, valorizando o empirismo defendido, por exemplo, no positivismo, corrente de pensamento com grande número de adeptos no Brasil; e desenvolvendo estudos em laboratório, como os que ocorriam em países europeus. ${ }^{191}$

Os cursos e conferências públicas, portanto, caracterizaram-se como espaços de vulgarização científica. Mas a vulgarização não era para todos e sim para uma pequena fração da população, a camada letrada da sociedade. Esta vulgarização, na verdade, se tratava de um projeto político que excluía a maior parte da população do Rio de Janeiro. Mesmo entre essa ínfima parcela, a efetivação da vulgarização nem sempre foi atingida. Alguns assuntos não eram de fato compreendidos em sua íntegra pela plateia que assistia a esses eventos. Uma possível explicação é que determinados oradores não se preocupavam em simplificar, traduzir, o conhecimento científico para o público leigo, muitas vezes com receio de perder a totalidade do conceito. A despeito disso, a

\footnotetext{
${ }^{189}$ A autora destaca que a fisiologia foi fundamental no processo de valorização da ciência experimental na medicina no século XIX, fornecendo a cientificidade almejada. GOMES, Ana Carolina Vimieiro. Um programa de "sciencia do Brazil": a inserção da fisiologia experimental na agenda científica brasileira em fins do século XIX (1880-1889). Tese (Doutorado em História) - Faculdade de Filosofia e Ciências Humanas, Universidade Federal de Minas Gerais, Belo Horizonte, 2009.

${ }^{190}$ COUTY, L. Os estudos experimentais no Brasil..., p. 235.

${ }^{191}$ COUTY, L. Os estudos experimentais no Brasil..., p. 66.
} 
vulgarização fazia parte da prática científica, sendo muito valorizada por mostrar a aplicação prática da ciência e por ajudar a promover a civilização do país.

O intento dos homes letrados que discursavam nos espaços públicos de vulgarização científica aqui analisados era difundir um conhecimento científico para seus pares, a fim de mostrar-lhes a necessidade de educar e civilizar aqueles que estariam impedindo o progresso da nação, os verdadeiros bárbaros - negros, índios, brancos pobres e mulheres. Dentre estes, apenas as mulheres, brancas e da elite, compareciam a tais eventos e mesmo assim, em pequena quantidade. Portanto, as conferências e cursos públicos apresentavam projetos modernos civilizadores, mas que não atuavam de forma prática na sociedade, civilizando diretamente os considerados bárbaros. 


\section{II - Concepções sobre o}

\section{darwinismo}

\section{O darwinismo nas conferências}

Em 1859, o naturalista inglês Charles Darwin publicou A origem das espécies, livro em que expôs sua teoria acerca da determinação da seleção natural sobre a evolução biológica. ${ }^{1}$ Para Ernst Mayr, embora Darwin se referisse a sua teoria no singular, o paradigma evolucionista por ele estabelecido estava fundamentado em cinco teorias independentes, quais sejam: "evolução propriamente dita, descendência comum, gradualismo, multiplicação de espécies e seleção natural." ${ }^{2}$ Vale sublinhar que muitos contemporâneos aceitavam algumas destas propostas e rejeitavam outras, confirmando, assim, a autonomia delimitada por Mayr. ${ }^{3}$

Regina Cândida Ellero Gualtieri afirma que dentre as proposições apresentadas por Darwin, as que foram assimiladas de maneiras diferentes foram "A idéia de seleção natural, a incorporação do ser humano no reino animal e a exclusão de um Criador agindo diretamente no processo de transformação orgânica”. À guisa de exemplo, dentre aqueles que receberam bem a teoria, Thomaz Huxley, "polemista e defensor de

\footnotetext{
${ }^{1} \mathrm{O}$ título original do livro é On the origin of species by means of natural selection.

${ }^{2}$ MAYR, Ernst. Biologia, ciência única: reflexões sobre a autonomia de uma disciplina científica. São Paulo: Companhia das Letras, 2005, p. 115. No correr do texto utilizarei a teoria no singular, mas sempre lembrando que ela era composta por tais proposições que poderiam ser compreendidas de maneira independente.

${ }^{3}$ A evolução afirmava que as espécies não eram constantes, sendo passíveis de sofrerem transformações. Já a descendência comum estava fundamentada na hipótese de que todos os organismos descenderiam de uma espécie ancestral. O gradualismo asseverava que as transformações ocorridas nas espécies ocorriam de maneira gradual, jamais em saltos. Para explicar a gigantesca diversidade biológica, Darwin, por meio da introdução da dimensão geográfica em sua análise, estabeleceu a teoria da multiplicação das espécies. A seleção natural, contrariando explicações sobrenaturais, abordava a maneira como ocorreria a mudança evolutiva, isto é, a remoção natural dos indivíduos menos aptos. MAYR, E. Biologia, ciência única..., p. 116-130.
} 
Darwin", (1825-1895) não apoiou a seleção natural; a inserção do homem no mundo natural não foi compartilhada pelo geólogo britânico Charles Lyell (1797-1875) e por Alfred Wallace (1823-1913); já Asa Gray (1810-1888), botânico norte-americano, não aceitou retirada de Deus no papel de criador. ${ }^{4}$

O vocábulo darwinismo, segundo Gualtieri, foi criado por Thomas Huxley, em 1864, para fazer referência às ideias do naturalista inglês. Em 1889, o termo foi reforçado com a publicação da obra Darwinismo, de Russel Wallace. Contudo, a autora afirma que nas décadas de 1870 e 1880 esta terminologia foi adotada não apenas pelos que compartilhavam de todas as assertivas de Darwin, mas também pelos que acolhiam apenas algumas, muitas vezes, mesclando-as com outras teorias, como com as de Ernst Haeckel (1834-1919) e de Herbert Spencer (1820-1903), mas nem por isso eram considerados antidarwinistas.

Diversas áreas do conhecimento interpretaram e ressignificaram as teorias de Darwin. Argumentos tidos como fundamentais, e muitas vezes de fato eram, na teoria darwinista passaram a fazer parte das análises em diferentes perspectivas. ${ }^{5} \mathrm{O}$ impacto da teoria foi grande, sua recepção gerou adesões e repulsas, marcadas por grande polêmica tanto no espaço científico quanto fora dele, ${ }^{6}$ a apropriação e ressignificação dos princípios darwinianos muitas vezes foram feitas no intuito de justificar questões de cunho social.

\footnotetext{
${ }^{4}$ GUALTIERI, Regina Cândida Ellero. Evolucionismo no Brasil: ciência e educação nos museus 18701915. São Paulo: Editora Livraria da Física, 2008, p. 20, 21.

${ }^{5}$ Uma discussão mais detalhada a este respeito, principalmente no que concerne à questão da raça, pode ser encontrada em: POLIAKOV, Léon. $O$ mito ariano. Tradução de Luiz João Gaio. São Paulo: Perspectiva, Editora da Universidade de São Paulo, 1974. TODOROV, Tzvetan. Nós e os outros: a reflexão francesa sobre a diversidade humana. Tradução de Sergio Goes de Paula. v. 1. Rio de Janeiro: Jorge Zahar, 1993.

${ }^{6}$ Com relação à recepção e ressignificação do darwinismo em várias partes do mundo e em espaços diversos, conferir, dentre outros: GLICK, Thomas F (Ed.). The comparative reception of Darwinism. Chicago: University of Chicago Press, 1988. GLICK, Thomas F., RUIZ GUTIÉRREZ, Rosaura; PUIGSAMPER, Miguel Ángel (Ed.). El darwinismo en España y Iberoamérica. México, DF: Universidad Autónoma de México; Madrid: Consejo Superior de Investigaciones Científicas, Ediciones Doce Calles, 1999. PUIG-SAMPER, Miguel Ángel; RUIZ GUTIÉRREZ, Rosaura; GALERA, Andrés (Ed.). Evolucionismo y cultura: darwinismo en Europa e Iberoamérica. México, DF: Junta de Extremadura, Universidad Nacional Autónoma de México, Ediciones Doce Calles, 2002. DOMINGUES, Heloisa Maria Bertol; SÁ, Magali Romero; PUIG-SAMPER, Miguel Ángel; RUIZ GUTIÉRREZ (Orgs.). Darwinismo meio ambiente e sociedade. São Paulo: Via Lettera; Rio de Janeiro: MAST, 2009. NUMBERS, Ronald L.; STENHOUSE, John (Ed.). Disseminating Darwinism: the role of place, race, religion, and gender. Cambridge: Cambridge University Press, 2001. RUIZ GUTIÉRREZ, Rosaura. Positivismo y evolución: introducción del darwinismo en México. México, DF: Limusa, 1991. MORENO, Roberto. La polémica del darwinismo en México: siglo XIX. México, DF: Universidad Autónoma de México, 1989. ARGUETA VILLAMAR, Arturo. El darwinismo en Iberoamérica: Bolivia y México. Madrid: Consejo Superior de Investigaciones Científicas, 2009. DOMINGUES, Heloisa Maria Bertol, SÁ, Magali Romero, GLICK, Thomas (Orgs.). A recepção do darwinismo no Brasil. Rio de Janeiro: Editora da Fiocruz, 2003. GUALTIERI, R. C. E. Evolucionismo no Brasil...
} 
Para o pesquisador Álvaro Girón Sierra, não é adequado estabelecer uma distinção rígida entre o darwinismo, enquanto ciência, e o darwinismo social, como uma ideologia. $^{7} \mathrm{O}$ autor frisa que nos anos de 1870 e 1880, não havia distinção entre o darwinismo (teoria científica) e sua aplicação no âmbito social e político, o darwinismo social. ${ }^{8}$ Considera infeliz a expressão darwinismo social, para ele, o darwinismo foi social desde o início, haja vista a pluralidade de leituras feita da teoria do naturalista inglês. O autor argumenta que, apesar de o darwinismo estar associado aos interesses da burguesia britânica, isto não impediu que grupos diversos apropriassem das ideias de Darwin para os fins mais diversos, sublinhando aqui aquelas feita pelos grupos de esquerda. ${ }^{9}$

Posicionamento divergente a este é o de Arturo Argueta Villamar, que diferencia o darwinismo do darwinismo social, este sendo considerado um termo equivocado. Para Argueta, utilizar o nome do naturalista inglês para se nomear a doutrina "darwinismo social" é um erro na medida em que as proposições que a fundamentam não se encontram na obra de Darwin, mas sim advindas das ideias de Herbert Spencer, que inclusive apresentou-as primeiramente. $\mathrm{O}$ autor, em sua abordagem, faz uso do conceito spencerismo social para compreender a utilização cientificista do darwinismo, e de darwinismo social para analisar como os termos da teoria de Darwin, elaborados para a esfera biológica, foram levados para o social. ${ }^{10}$

No presente trabalho, analiso como as proposições da teoria biológica de Darwin apareceram nos cursos e conferências públicos, observando quando e de que maneira elas foram apropriadas e ressignificadas para fins sociais. Entretanto, por não haver uma clara definição sobre o que era o darwinismo naquele momento, incluí aquelas ideias chamadas ou consideradas darwinistas que estavam impregnadas com outras teorias.

A década de 1870 no Brasil foi marcada por amplas discussões referentes a temas sociais, por exemplo, a organização do trabalho e a abolição da escravidão, com seus temas de raça, lugar social dos libertos, cidadania; bem como, as questões relativas à higiene, com propostas civilizatórias cientificistas e modernizadoras. O discurso cientificista que começou a ser produzido e difundido no Brasil neste período surgiu

\footnotetext{
${ }^{7}$ Uma perspectiva semelhante foi desenvolvida em: SADÍN, Máximo. Sobre una redundancia: el darwinismo social. Asclepio, v. LII, n. 2, p. 27-50, 2000.

${ }^{8}$ GIRÓN SIERRA, Álvaro. Darwinismo, darwinismo social e izquierda política (1859-1914). Reflexiones de carácter general. In: MIRANDA, Marisa; VALLEJO, Gustavo (Comp.). Darwinismo social y eugenesia en el mundo latino. Buenos Aires: Siglo XXI de Argentina Editores, 2005, p. 40.

${ }^{9}$ GIRÓN SIERRA, A. Darwinismo, darwinismo social...

${ }^{10}$ ARGUETA VILLAMAR, A. El darwinismo en Iberoamérica ..., p. 89.
} 
como um argumento novo para a compreensão destes problemas sociais. ${ }^{11}$ A utilização desses modelos para a interpretação da sociedade pode ser observada, na cidade do Rio de Janeiro, dentre outros, nos jornais, na Faculdade de Medicina, no Instituto Histórico e Geográfico Brasileiro, nas conferências e cursos públicos, etc., que focavam discussões embasadas nestes parâmetros científico/cientificistas. $\mathrm{O}$ darwinismo não fugiu a essa regra. ${ }^{12}$

Em 1877, Vicente Ferreira de Souza proferiu, perante numeroso auditório, na Escola de Santana, a seguinte preleção: "O homem diante da antropologia e da etnografia. Determinará a paleontologia com exatidão a existência do homem primitivo?" Nesta, tratou tanto da origem do homem quanto a da Terra:

Começou contestando as asserções do Mosaísmo a respeito da criação do mundo e do homem.

$$
[\ldots]
$$

Entrou desde logo em fundas considerações antropológicas, ocupou-se de distinguir os caracteres anatômicos dos antropoides e do homem: indicou as diferenças da mandíbula, dos dentes, das vértebras, dos ossos longos das mãos e dos pés de um e de outro, e concluiu pela falta de explicação clara pela qual o sistema de Lamarck e Darwin pudesse ser aceito. ${ }^{13}$

Ao explicitar seu posicionamento contrário ao Mosaísmo, o conjunto de leis e escritos atribuídos a Moisés, Vicente de Souza indicou que sua concepção acerca do

\footnotetext{
${ }^{11}$ Ao analisar a institucionalização das ciências geológicas no Brasil, Silvia Figueirôa enfatiza que a partir de 1870 houve uma maior valorização da ciência no Brasil - "mesclando, desta vez, cientificismo, evolucionismo e positivismo e, com isso, adquirindo perfil diferente do anterior." FIGUEIRÔA, Silvia. As ciências geológicas no Brasil: uma história social e institucional, 1875-1934. São Paulo: Hucitec, 1995 , p. 106.

${ }^{12}$ Merece destaque aqui as pesquisas desenvolvidas no Brasil pelo evolucionista alemão Fritz Müller (1821-1897), que tratou do darwinismo por meio de um viés estritamente biológico. Nelson Papavero sublinha a originalidade das ideias de Müller, que complementou a teoria de Darwin. Radicado no Brasil desde 1852, o naturalista germânico publicou, em 1864, o livro Für Darwin, obra na qual demonstrava o pensamento darwinista por meio de estudos embriológicos em crustáceos. PAPAVERO, Nelson. Fritz Müller e a comprovação da teoria de Darwin. In: DOMINGUES, H. M. B.; SÁ, M. R.; GLICK, T. (Orgs.). A recepção do darwinismo no Brasil..., p. 29-44. O texto de Müller repercutiu pouco no meio científico brasileiro, porém teve boa aceitação na Alemanha e na Inglaterra. Foi traduzido para o inglês por sugestão do próprio Darwin, que se tornou correspondente de Müller. Entre os anos de 1876 e 1891, o pesquisador alemão trabalhou como viajante naturalista do Museu Nacional, período em que publicou 17 artigos relacionados ao darwinismo na revista Archivos do Museu Nacional. DOMINGUES, Heloisa Maria Bertol; SÁ, Magali Romero. Controvérsias evolucionistas no Brasil do século XIX. In: DOMINGUES, H. M. B.; SÁ, M. R.; GLICK, T. (Orgs.). A recepção do darwinismo no Brasil..., p. $97-$ 124.

${ }^{13}$ Diario do Rio de Janeiro, 21/06/1877. Grifo do original.
} 
surgimento dos seres e das coisas não era pautada em explicações teológicas. A comparação entre o homem e o antropoide foi no intuito de distanciá-los, uma vez que eram comuns, após a teoria de Darwin, os esforços para mostrar que o homem não tinha parentesco com o grupo dos macacos. ${ }^{14}$ A suposta ancestralidade símia do homem gerou grande polêmica nas Conferências Populares da Glória, quando das preleções realizadas por Augusto Cezar de Miranda Azevedo, em 1875. ${ }^{15}$ Para o orador, as teorias de Lamarck e Darwin constituíam um único sistema interpretativo da natureza. ${ }^{16}$

Também em 1877, o professor de botânica da Escola Politécnica, José de Saldanha da Gama, apresentou naquela instituição uma conferência na qual pretendia discorrer sobre a teoria da evolução. Assistiram à preleção o Imperador, Visconde do Rio Branco, Visconde do Bom Retiro, Barão Homem de Mello, dentro outros professores da Politécnica.

Tratou S. Ex. da adaptação dos órgãos nas plantas, trazendo como exemplos a maneira como nos desertos se manifesta, conserva e propaga a vida vegetativa.

O ilustre professor admite a influência da Providência no desenvolvimento da vida, e mostrou como as plantas para viverem num certo meio se acham pré-munidas de certos órgãos em contradição com o que outros afirmam que por isso mesmo os vegetais têm certos e determinados órgãos, conservam-se em um meio em que os outros não encontram nenhuma condição de vida.

\footnotetext{
${ }^{14}$ A comparação entre o homem e o macaco era anterior a Darwin. Os primeiros a estabelecer uma relação estreita dos chimpanzés com os humanos foram os médicos holandeses Nycolas Tulp (1593-1674) e Jacobus Bondt (1592-1631), este introduziu o termo malaio orang (homem) hutan (selva ou bosque), orangotango, na literatura europeia. Em 1699, o medico inglês Edward Tyson (1650-1798), fundador da anatomia comparada, publicou Orang-Outang, sive Homo Sylvestris: or the Anatomy of the Pygmie compared with that of a Monkey, an Ape and a Man, na qual realizava tal comparação. Segundo Jorge Martínez-Contreras, esta obra introduziu, na tradição ocidental, a prova da existência de um animal tão próximo ao homem, que o conceito de gradação tomou um sentido diferente. MARTíNEZCONTRERAS, Jorge. Las primeras descripciones de antropoides en el siglo XVII y su importancia para filosofía de la evolución. In: ROSAS L., Alejandro (Ed.). Filosofía, darwinismo y evolución. Bogotá: Universidad Nacional de Colombia. Facultad de Ciencias Humanas, 2007, p. 213.

${ }^{15}$ A celeuma girou, fundamentalmente, em torno do jornal católico $O$ Apostolo, que se manifestou de modo hostil, explicitando sua oposição à teoria de Darwin. CARULA, Karoline. A tribuna da ciência: as Conferências Populares da Glória e as discussões do darwinismo na imprensa carioca (1873-1880). São Paulo: Annablume; Fapesp, 2009.

${ }^{16}$ Como ponto em comum, Darwin e Lamarck defendiam a ideia do gradualismo na evolução. Entretanto, para Lamarck a evolução era um processo finalista, não existia uma origem comum dos seres, as variações existentes eram todas adaptativas, a diversificação das espécies não era considerada, a adaptação dos seres ocorria de maneira imediata, a herança dos caracteres adquiridos compunha o núcleo duro da teoria, a seleção natural não fazia parte da análise, o acaso não participava da evolução e não existia a sobrevivência do mais forte. ARGUETA VILLAMAR, A. El darwinismo en Iberoamérica..., p. 92.
} 
S. S. terminando a conferência, que foi aplaudida, disse que para o desenvolvimento social eram precisas três coisas:

1. Crer em Deus.

2. Amar a ciência.

3. Amar a pátria nos altares da realeza. ${ }^{17}$

A adaptação, para Saldanha da Gama, era consequência de uma Providência divina, que determinava quais órgãos as plantas deveriam ter para se adaptarem ao meio. Não era a ação da natureza, a seleção natural de Darwin não fundamentava a sua interpretação dos fenômenos orgânicos. ${ }^{18}$ De acordo com Mayr, houve grande resistência à adoção da proposição da seleção natural principalmente entre os "que haviam sido formados na ideologia da teologia natural. Eram de todo incapazes de abandonar a idéia de um mundo projetado por Deus e de aceitar em seu lugar um processo mecânico." 19

Por fim, concluiu que o desenvolvimento da sociedade dependeria de Deus, da ciência e da manutenção da monarquia, indicando os pontos que considerava basilares para o progresso do país. As duas primeiras condições estariam articuladas, uma vez que suas explicações científicas eram fruto da ação de Deus. Defender a monarquia, inclusive perante o imperador, nesse momento era essencial para dar força ao regime, pois o movimento republicano crescia e as críticas ao regime político em vigor se tornavam cada vez mais contundentes. ${ }^{20}$

Na tribuna da Glória, em 1881, Julio Cesar Leal (1837-1897), advogado e romancista baiano, proferiu duas conferências intituladas "Materialismo e espiritualismo", sendo que em uma delas diferenciou o darwinismo do materialismo.

Apreciando a escola materialista contemporânea, desenvolveu as teorias mais importantes dessa escola e combateu-as [...].

Estudando Buchner e Hæckel, mostrou a diferença entre o darwinismo e o materialismo, e admirou-se da pretensão Hæckel, em

\footnotetext{
${ }^{17}$ Gazeta de Noticias, 28/10/1877.

${ }^{18}$ Segundo Mayr, era a teoria da seleção natural que "podia dar conta da aparente harmonia e adaptação do mundo orgânico. Tentava dar uma explicação natural, em lugar de uma explicação sobrenatural da teologia natural." MAYR, E. Biologia, ciência única..., p. 127.

${ }^{19}$ MAYR, E. Biologia, ciência única..., p. 128.

${ }^{20}$ FERNANDES, Maria Fernanda Lombardi. A esperança e o desencanto: Silva Jardim e a República. São Paulo: Humanitas, 2008.
} 
pedir, num congresso de sábios naturalistas alemães, que as doutrinas darwinistas fossem aceitas nas escolas dos sábios.

\section{$[\ldots]$}

Sustentando a existência desses seres invisíveis, que não são mais do que os próprios seres materiais desorganizados, conservando a sua própria autonomia ou existência na marcha infinita do progresso humano, que é duplo - moral e intelectual - concluiu, convidando os sábios a prosseguirem em seus estudos e a formarem uma cadeia de união científica, mostrando que todos eles, como o orador, aspiram à verdade e que essa - verdade - é Deus, termo de todas as nossas lucubrações. ${ }^{21}$

Não posso afirmar, pela análise do resumo da preleção, que Leal conhecia as ideias de Darwin, talvez o que sabia dela era por meio da obra de Haeckel. O orador não compactuava com o darwinismo, haja vista que considerou Haeckel pretencioso ao propor sua aceitação entre sábios alemães. Leal, um dos divulgadores do espiritismo no Brasil, desenvolveu sua conferência com vistas a combater o materialismo e a mostrar que a verdade estava em Deus. ${ }^{22}$ Cabe sublinhar que a importância que a proposição do naturalista inglês havia adquirido naquele momento, pois parte do discurso foi dedicado a sua análise e a mostrar que a teoria não era digna de toda notoriedade a ela fornecida.

O médico e professor do Colégio Pedro II, Feliciano Pinheiro de Bittencourt, grande combatente contra o darwinismo, em 1888, realizaria uma de suas conferências nas quais criticava a teoria de Darwin, o tema era a origem das espécies orgânicas. Porém, não pôde apresentá-la e, em seu lugar, Manuel Francisco Correia ocupou a tribuna da Glória versando sobre a mesma temática.

Mostrou a largos traços qual a importância capital da matéria, qual o grande alcance do curso que o Sr. Dr. Bittencourt iniciou no o ano passado, e vai continuar este ano.

Disse que a questão de saber-se se a humanidade descende de um tronco único ou de diversos é de máxima importância, pois uma vez resolvida faria uma verdadeira revolução no mundo científico.

\footnotetext{
${ }^{21}$ Jornal do Commercio, 21/03/1881.

${ }^{22}$ Julio Cesar Leal, em 1869, escreveu o livro $O$ espiritismo: meditações poéticas sobre o mundo invisível, acompanhadas de uma evocação. ARRIBAS, Célia da Graça. Afinal, espiritismo é religião? A doutrina espírita na formação da diversidade religiosa brasileira. Dissertação (Mestrado em Sociologia) Universidade de São Paulo, São Paulo, 2008, p. 50.
} 
Muitas teorias hoje aceitas teriam de ser modificadas ou rejeitadas, muitos princípios admitidos como verdadeiros teriam de ser substituídos. É muito nobre e digno o esforço dos sábios modernos, procurando investigar a natureza, estudando a ciência dos fósseis, buscando nela a revelação de segredos julgados impenetráveis pelas gerações passadas. ${ }^{23}$

Esta foi a única vez que o idealizador das Conferências Populares da Glória, o conselheiro Correia, perpassou pelo assunto da origem das espécies. A questão que estava em pauta era se a humanidade possuía uma origem única (monogenia), ou se existiram vários centros de criação (poligenia). De acordo com Léon Poliakov, a unidade do gênero humano já havia sido rejeitada desde antes do cristianismo; entretanto, fora no Iluminismo que os argumentos ganharam roupagem científica. ${ }^{24}$

Pela análise do resumo da preleção, não é possível inferir se Correia entrou ou não em detalhes maiores acerca da teoria de Darwin e nem se ele era partidário do monogenismo ou do poligenismo, creio que tenha ficado apenas em uma apresentação panorâmica da importância das pesquisas nessa área, uma vez que essa não era uma temática comumente abordada por ele. Não tenho como afirmar se o conselheiro era a favor ou não ao darwinismo. Enquanto coordenou as Conferências da Glória, foram realizadas preleções de favoráveis e contrários às ideias do naturalista inglês, posicionamento que estava em sintonia com o exposto por ele - a defesa da investigação na área.

O darwinismo, teoria de grande repercussão e impacto na sociedade ocidental, esteve presente nas conferências públicas promovidas na cidade do Rio de Janeiro nas décadas de 1870 e 1880. De forma direta, ou apenas perpassando pelo assunto, palavras de defesa e repreensão eram direcionadas às proposições do naturalista inglês, sendo que muitas vezes a sua compreensão era feita a partir de filtros de outros cientistas, ou seja, a obra de Darwin era analisada e (re)interpretada por meio do olhar de terceiros. ${ }^{25}$ Em consonância com o que era problematizado nos Estados Unidos e na Europa, local considerado como modelo de inspiração, a origem do homem e da Terra também era tema de reflexão dos homens de ciência aqui do Brasil.

\footnotetext{
${ }^{23}$ Jornal do Commercio, 08/05/1888.

${ }^{24}$ POLIAKOV, L. $O$ mito ariano..., p. 152.

${ }^{25}$ NUMBERS, R. L.; STENHOUSE, J. (Ed.). Disseminating Darwinism...
} 


\section{Feliciano Pinheiro de Bittencourt e a luta contra o darwinismo}

Feliciano Pinheiro de Bittencourt foi o orador que mais vezes se apresentou nas Conferências Populares da Glória no decorrer do período aqui estudado. Formado em medicina pela Faculdade do Rio de Janeiro, professor do Liceu de Artes e Ofícios e, após 1882, do Colégio Pedro II, sendo responsável neste último pela cadeira de história e corografia, Bittencourt abordou temas variados em suas preleções. Medicina, higiene, história, antropologia e evolucionismo foram alguns dos assuntos por ele apresentados. Em 1882 ele publicou um resumo dos assuntos que discorreu na tribuna da Glória na década anterior:

Apenas vos direi que fiz minha estreia nesta tribuna, tratando do espiritualismo, e do materialismo, mostrando a supremacia do primeiro sobre o segundo deplorável sistema, verdadeira aberração da inteligência humana. Depois ocupei-me com o positivismo, ou materialismo disfarçado, combatendo-o com todas as forças, e mostrando que o erro principal dos adeptos dessa doutrina consiste em quererem fazer de um simples método um sistema completo. [...] Em seguida tratei do darwinismo ou doutrina evolutiva, procurando mostrar que, no estado atual da ciência, é ainda coisa irrisória afirmarse que o homem descende do macaco aperfeiçoado. ${ }^{26}$

Contrário ao materialismo, Bittencourt muitas vezes criticou este modo de interpretação. Para ele, a natureza tinha que ser estudada considerando o papel fundamental de Deus. Julgava o método experimental importante, porém acreditava que não deveria ser estendido a tudo. ${ }^{27}$ Desta maneira, alguns fenômenos teriam explicações metafísicas, entretanto, nem por isso deixariam de estar inseridos no campo da ciência.

Com relação ao darwinismo, Bittencourt se referiu a ele como sendo a mesma coisa que "doutrina evolutiva", ou seja, de maneira generalizadora reportou-se à teoria de Darwin como apenas evolucionista. Após a publicação de A origem das espécies

\footnotetext{
${ }^{26}$ BITTENCOURT, Feliciano Pinheiro de. Conferencias efectuadas na escola da Gloria. Rio de Janeiro: Typographia e Lithographia a vapor, encadernação e Livraria Lombaerts \& C., 1882, p. 6. Grifos do original.

${ }^{27}$ Cabe evidenciar que este tipo de interpretação ocorreu em outros países. Na Bolívia, por exemplo, José de los Santos Taborga, professor de teologia e arcebispo de Sucre, empregou uma análise semelhante à de Bittencourt. Para o boliviano, o positivismo abusava na utilização do método experimental ao tentar aplicá-lo a todas as ciências. Taborga também se posicionou contrário ao materialismo evolucionista de Haeckel e de Spencer. ARGUETA VILLAMAR, A. El darwinismo en Iberoamérica..., p. 186-189.
} 
tornou-se relativamente comum mencionar o darwinismo, de modo mais amplo, como sinônimo de evolucionismo, mesmo quando não eram expostas proposições vinculadas às ideias do naturalista inglês.

A observação de Bittencourt sobre o homem descender de um "macaco aperfeiçoado" provavelmente estava relacionada com as preleções proferidas pelo médico Augusto Cezar de Miranda Azevedo, em 1875, também no espaço das Conferências Populares da Glória. Em uma destas apresentações, este orador afirmou que preferia descender de "um macaco aperfeiçoado antes do que de um Adão degenerado!....28 . As preleções de Azevedo sobre o tema tiveram grande repercussão na impressa, tal frase, por exemplo, provocou grande indignação do jornal católico $O$ Apostolo, seguida de polêmica. ${ }^{29}$ Para Bittencourt, que defendia uma interpretação mais teológica da natureza, a afirmação deve ter gerado profunda revolta.

Transcorrido pouco mais de um ano das conferências de Miranda Azevedo, Bittencourt apresentou e analisou, pela primeira vez, a temática do darwinismo na tribuna da Glória.

Discutiu de preferência dois pontos: a embriologia, e a questão importante dos fósseis humanos.

Não aceitou a unidade das diversas espécies animais, nem quanto aos seus caracteres físicos, e muito menos sob o ponto de vista moral.

Disse que os sectários das doutrinas de Carlos Darwin pretendem suscitar essa unidade, apelando para o embrião, para o óvulo, gérmen, ou princípio dos seres, mas que isso não se pode admitir, sendo que não há uma paridade absoluta, ou perfeita semelhança entre os óvulos dessas espécies animais.

Existe apenas para tal ou qual paridade, uns longes de semelhança, que de algum modo podem autorizar a afirmação dos adeptos da escola transformista. ${ }^{30}$

Na perspectiva de Bittencourt, os estudos embriológicos não comprovavam as assertivas de Darwin, porque não existiriam semelhanças significativas entre os

\footnotetext{
28 AZEVEDO, Augusto Cezar de Miranda. Darwinismo: seu passado, seu presente e seu futuro. Conferencias Populares, Rio de Janeiro: Typ. Imp. e Const. de J. Villeneuve \& C., n. 4, jan. 1876, p. 47.

${ }^{29}$ CARULA, K. A tribuna da ciência...

${ }^{30}$ Gazeta de Noticias, 09/11/1876. Grifos do original.
} 
embriões humanos e os de outras espécies animais. De acordo com Gualtieri, o passado evolutivo de um determinado grupo animal poderia ser conhecido pela análise embriológica de um representante atual, identificando-se características morfológicas dos tipos anteriores presentes no embrião. ${ }^{31}$

Dentre os darwinistas que defendiam o emprego da embriologia, encontrava-se Haeckel, que sustentava o recapitulacionismo. Para o evolucionista alemão, "o desenvolvimento embriológico das formas superiores poderia servir como guia para se deduzir de forma indireta a evolução da árvore da vida." Com isso, estabeleceu que a ontogenia recapitulava a filogenia, ou seja, todos os seres passariam por etapas sequenciais que equivaleriam às "formas adultas de seus antepassados". ${ }^{32}$

Gould afirma que a recapitulação foi uma das ideias científicas mais influentes do final do Oitocentos. Estudos de diversas áreas, como a embriologia, a morfologia comparada e a paleontologia, consideravam o conceito de recapitulação como importante chave interpretativa e, com isso, centravam suas pesquisas no intuito de "reconstruir linhagens evolutivas". A recapitulação forneceu preciosos argumentos para aqueles que pretendiam hierarquizar a humanidade, "os adultos dos grupos inferiores devem ser como as crianças dos grupos superiores, pois a criança representa um ancestral do adulto primitivo. ${ }^{33}$ Os grupos considerados inferiores eram comparados à crianças brancas do sexo masculino.

Pode ser que Bittencourt tenha lido Haeckel, ou apenas estivesse, mais uma vez, dialogando com Miranda Azevedo. Este, em uma conferência na Glória, apresentou ilustrações de embriões humanos e de cachorros, a fim de mostrar a similitude entre ambos e, com isso, expor provas empíricas da teoria darwinista. As ilustrações expostas haviam sido extraídas da obra de Haeckel. É possível que a imagem abaixo, presente na obra The history of creation do evolucionista alemão, tenha sido a apresentada por Miranda Azevedo:

\footnotetext{
${ }^{31}$ GUALTIERI, R. C. E. Evolucionismo no Brasil..., p. 25.

${ }^{32}$ GOULD, Stephen Jay. A falsa medida do homem. Tradução de Valter Lellis Siqueira. 2 ed. São Paulo: Martins Fontes, 1999, p. 112. Grifo do original.

${ }^{33}$ GOULD, S. J. A falsa medida do homem..., p. 112 e 113. Grifos do original.
} 


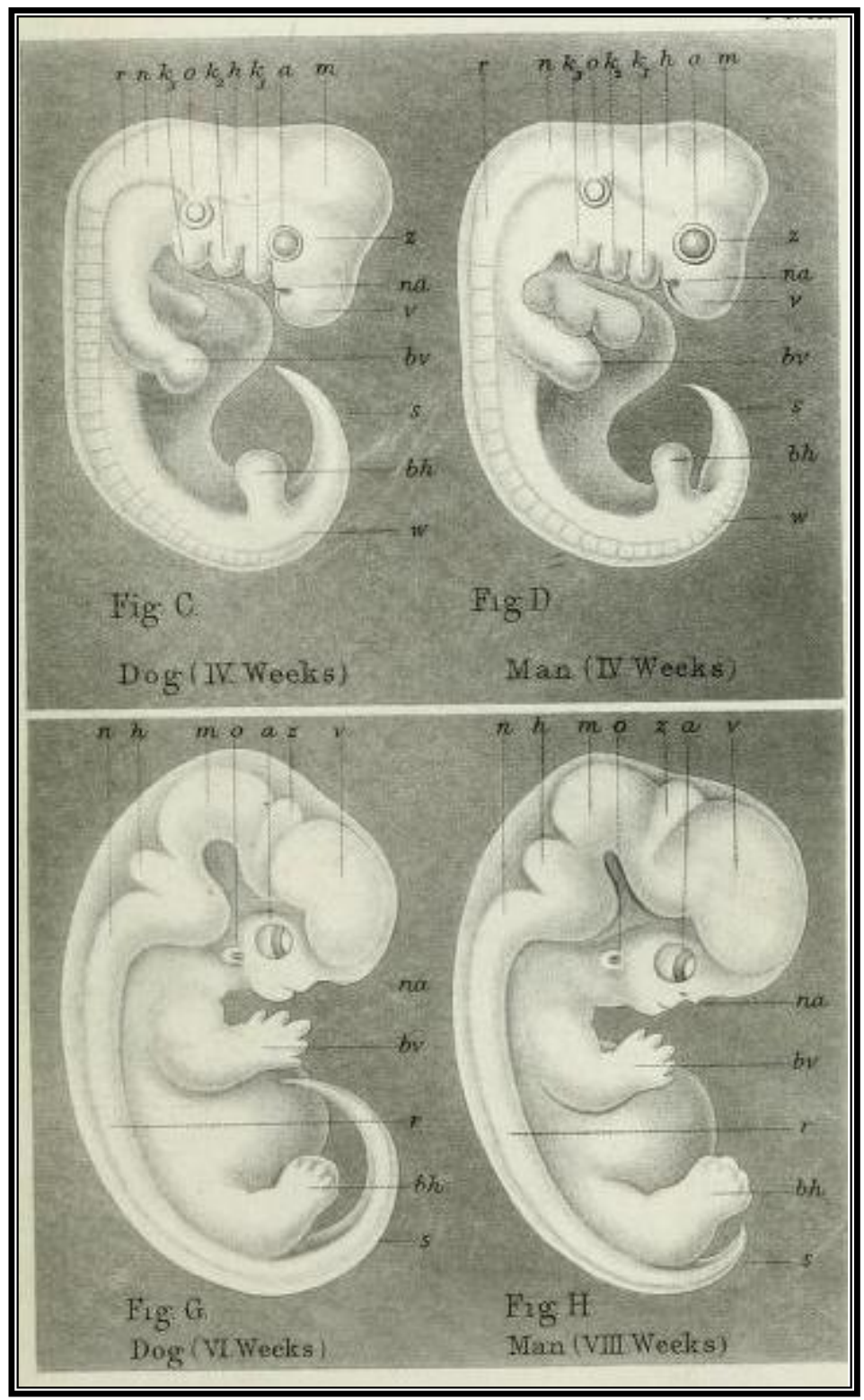

Imagem I - Ilustração de fetos presentes na obra The history of creation de Haeckel. ${ }^{34}$

Bittencourt também destacou seu posicionamento contrário à paridade das espécies. Adepto do poligenismo, na sua concepção as espécies eram diferentes porque haviam sido criadas separadamente. No caso do homem, por exemplo, este teria aparecido em diversos pontos da Terra e, por isso, os grupos variados tinham características físicas e morais diferentes.

Com relação aos fósseis humanos, outro ponto desenvolvido na conferência, Bittencourt afirmou que:

\footnotetext{
${ }^{34}$ HAECKEL, Ernst. The history of creation: or the development of the earth and its inhabitants by the action of natural causes. A popular exposition of the doctrine of evolution in general, and of that of Darwin, Goethe, and Lamarck in particular. v. I. London: Henry S. King \& Co., 1876, imagem entre as páginas 306 e 307.
} 
Falando dessas grandes escavações feitas em camadas terrestres pertencentes aos períodos terciário e quaternário, e em épocas e países diferentes, disse que nelas só tem sempre achado camadas de animais antediluvianos, em maior ou menor quantidade, mas que nunca se encontrou até hoje um só esqueleto humano perfeitamente reconhecido por seus caracteres próprios.

Há quem queira sustentar isso, mas sem o menor critério ou fundamento sólido.

Assim se por um lado não se pode negar que a existência dos animais fósseis antediluvianos é uma verdade científica, por outro lado não é muito menos verdade que o homem fóssil parece ser apenas uma engenhosa criação de certos naturalistas, que só quiseram por este meio celebrizar. ${ }^{35}$

Encontrar um fóssil humano poderia representar a comprovação da evolução do homem. Entretanto, a prova não existia, fato que mereceu críticas do conferencista. Para ele, os naturalistas que asseveravam ter descoberto esses fósseis estariam mentindo, teriam inventado tal falácia com o objetivo de se notabilizar perante o meio científico.

Onze anos após esta preleção, Bittencourt retomou a questão dos fósseis humanos na conferência "Origem das raças: o homem pré-histórico", também realizada na tribuna da Glória. No entanto, apresentou um posicionamento diferente:

A descoberta de fósseis humanos, feita pela primeira vez em 1823 por Amy Roué; os estudos de Boucher, de Perthes, em 1847; de Eduardo Lartet, em 1861, na gruta d'Aurignac; dos Drs. Blake e Wilson, na América do Norte; a descoberta de Lund, nas cavernas da Lagoa Santa, no Brasil, em 1844, e muitas outras, estabeleceram em base sólida a Paleontologia, que veio demonstrar que o homem viveu em meio da fauna quaternária, isto é, no período glacial ou mioceno; que foi contemporâneo do mamute, do mastodonte, do urso das cavernas, etc. E, acrescentou o orador, os sábios hoje vão já mais longe, recuando a existência do homem até o período terciário ou plioceno, firmando-se em dados positivos.

\footnotetext{
${ }^{35}$ Gazeta de Noticias, 09/11/1876. Grifos do original.
} 
Quanto à data do aparecimento do homem sobre a terra, nada se pode dizer de positivo, uma vez que é impossível a existência de qualquer documento que nos possa orientar.

Referiu-se o orador aos trabalhos do nosso ilustre compatriota Dr. Lacerda, citados com justo louvor no livro do Sr. Quatrefages intitulado: A espécie humana.

O Sr. Dr. Lacerda estudou perfeitamente os crânios da Lagoa Santa, bem como outros encontrados no Ceará, publicando a respeito importantes monografias, que muito honram a ciência brasileira perante o mundo civilizado. ${ }^{36}$

Nesta apresentação Bittencourt passou a admitir a existência de fósseis humanos, porém apenas os datados do período quaternário. $\mathrm{O}$ orador assegurou que os primeiros fósseis haviam sidos descobertos na década de 1820, citando em seguida outros que foram encontrados nos dois decênios seguintes. $\mathrm{O}$ que teria feito Bittencourt mudar de opinião da sua conferência de 1876 para esta de 1887, uma vez que todos os exemplos por ele citados já existiam quando de sua preleção anterior? Talvez ele não conhecesse esses trabalhos anteriormente. Porém, o mais provável é que, neste entremeio, além de ter tido contato com outros estudos, ele tenha assistido aos cursos públicos de antropologia do Museu Nacional ministrado por João Baptista de Lacerda, acompanhado os artigos da revista Archivos do Museu, ido à Exposição Antropológica Brasileira (1882), lido a revista decorrente da exposição e, com isso, tenha alterado a sua maneira de pensar.

O ponto fulcral estava em qual período geológico teriam vividos os primeiros representantes da espécie humana. Apesar de ressaltar que era difícil estabelecer a data correta do aparecimento do homem na Terra, Bittencourt assegurava que ele não existia até o período terciário, portanto, a sua presença seria mais recente, no quaternário.

A existência de um homem terciário, como precursor do humano, foi polêmica no correr do século XIX. De acordo com Francisco Pelayo-López, o prestígio do paleontólogo francês George Curvier (1769-1832), que negou a existência de fósseis humanos, serviu de obstáculo para a aceitação de trabalhos sobre o homem antediluviano. Entretanto, a partir das décadas de 1830 e 1840, a possibilidade da existência do homem terciário tornou-se foco de análises diversas. Neste período,

\footnotetext{
${ }^{36}$ Jornal do Commercio, 11/10/1887. Grifos do original.
} 
Jacques Boucher de Perthes (1788-1868) coletou material que utilizou na publicação de sua obra Antiquités celtiques el antédiluviennes, 1847-1864, na qual defendeu a existência do homem terciário. Todavia, ela não foi bem recebida entre os pares. ${ }^{37}$

Segundo Pelayo-López, foi na Academia Real de Ciências de Paris que se apresentaram os primeiros trabalhos sobre a presença humana na era terciária. Dentre os quais, o estudo de Louis-Alexis Bourgeois (1819-1878), datado de 1863 e influenciado pelas proposições de Boucher de Perthes, obteve grande repercussão na comunidade científica, seguido de polêmica que se estendeu até o início do século XX. A existência de sílex talhado do período terciário seria a prova de que o homem havia vivido neste período e feito tal artefato. A controvérsia, sobre o sílex ser ou não uma evidência, foi complexa, envolvendo tanto criacionistas quanto transformistas. ${ }^{38}$

Se não acompanhou a celeuma diretamente na fonte, certamente Bittencourt teve contato com o debate que se travava e, com isso, passou a aceitar a existência dos homens terciários e quaternários. A aceitação da existência desses fósseis como indícios de que o ser humano havia vivido naquele período, contudo, não significava que a partir de então Bittencourt tornara-se adepto do evolucionismo, continuava sendo poligenista.

Nesta mesma preleção, Feliciano de Bittencourt retomou a questão da existência de um ou mais centros de criação:

O orador desenvolveu estes pontos: descende o homem de um tronco primitivo único, ou de diferentes troncos? Devemos admitir a monogenia ou a poligenia? A unidade ou a pluralidade das espécies?

Qual a data do aparecimento do homem sobre a terra? qual a origem geográfica da espécie humana?

Quanto à primeira questão declarou-se o orador poligenista, isto é, pela pluralidade das espécies, apoiando-se sobretudo na teoria de Agassiz sobre os centros múltiplos de produção. Combateu a monogenia, apreciando as ideias de Quatrefages, principal sustentáculo dessa teoria, que hoje tende a ser abandonada. ${ }^{39}$

\footnotetext{
${ }^{37}$ PELAYO-LÓPEZ, Francisco. ¿"Hombre terciario" o precursor humano?: Sílex, transformismo y los orígenes de la humanidad. In: DOMINGUES, H. M. B.; SÁ, M. R.; PUIG-SAMPER, Miguel Ángel; RUIZ GUTIÉRREZ, R. (Orgs.). Darwinismo meio ambiente e sociedade..., p. 161-176.

${ }^{38}$ PELAYO-LÓPEZ, F. ¿"Hombre terciario" o precursor humano?...

${ }^{39}$ Jornal do Commercio, 11/10/1887. Grifos do original.
} 
Partidário do poligenismo, Bittencourt apoiava-se nas proposições de Agassiz para desenvolver suas ideias. Fora por influência de Samuel George Morton (17991851) que o naturalista suíço havia aderido ao poligenismo, na década de $1840 .{ }^{40} \mathrm{Nas}$ palavras do orador, o monogenismo era uma teoria que seria abandonada em breve, indicando que ela já estaria ultrapassada. Para apontar os problemas dessa concepção analítica, fundamentou-se nas proposições de Quatrefages, renomado defensor da abordagem.

De acordo com Jon Roberts, na interpretação de Agassiz, os registros fósseis também serviam para sustentar a proposta de um plano divino de criação. As evidências fósseis confirmavam as várias criações sucessivas da teoria do catastrofismo, na qual a Terra teria passado por várias catástrofes e, após cada uma delas, as espécies haviam sido recriadas pelas mãos de Deus. Agassiz afirmava que não havia provas de que uma espécie descenderia de outra, uma vez que não existiam fósseis de tipos intermediários, que apoiariam empiricamente as propostas evolucionistas. A propósito disso, ele já havia se manifestado contrário à hipótese da transmutação dois anos antes da publicação da obra de Darwin. ${ }^{41}$

Não posso afirmar que Bittencourt fosse partidário do catastrofismo, mas supostamente o conhecia, haja vista que dizia se fundamentar em Agassiz, prestigiado defensor da teoria. Porém, assim como o naturalista suíço, o conferencista brasileiro advogava em prol do essencial papel de Deus na criação. Segundo Agassiz, haveria um plano divino ao distribuir os organismos geograficamente por todo o planeta, colidindo de frente com as teorias que faziam uma interpretação materialista dos fenômenos naturais. Como Deus planejara todas as catástrofes, para Agassiz, cabia ao cientista “desvendar o plano divino por meio da observação científica da natureza. Destinado a esclarecer os desígnios divinos, o cientista deveria ler na 'bíblia da natureza' os caminhos traçados pela onisciência divina". ${ }^{2}$ Assim, "Agassiz não assume que a palavra de Deus estava fora de lugar no discurso científico", 43 e da mesma maneira o fazia Bittencourt.

\footnotetext{
${ }^{40}$ MACHADO, Maria Helena Pereira Toledo. A ciência norte-americana visita a Amazônia: entre o criacionismo cristão e o poligenismo "degeneracionista". Revista USP, São Paulo, n.75, set./nov. 2007, p. 74.

41 ROBERTS, Jon. Louis Agassiz: poligenismo, transmutação e a metodologia científica. Uma reavaliação. In: DOMINGUES, Heloisa Maria Bertol; SÁ, Magali Romero; PUIG-SAMPER, Miguel Ángel; RUIZ GUTIÉRREZ, R. (Orgs.). Darwinismo meio ambiente e sociedade..., p. 73-100.

${ }^{42}$ MACHADO, M. H. P. T. A ciência norte-americana visita a Amazônia..., p. 70.

${ }^{43}$ ROBERTS, J. Agassiz: poligenismo, transmutação e a metodologia científica..., p. 86.
} 
Na conferência seguinte, Feliciano Bittencourt deu continuidade ao tema, a preleção intitulava-se: “Origem das raças; o darwinismo; a América pré-histórica". Nesta o orador apresentou, de modo mais detalhado, seu posicionamento acerca da teoria de Darwin e como a compreendia.

Em seguida ocupou-se com o sistema darwinista ou transformismo, escola que reconhece como chefe o eminente sábio inglês Ch. Darwin, que escreveu uma obra monumental sobre a Origem das Espécies, pretendendo haver descoberto o segredo da gênese dos seres animais e vegetais.

Fez ver que esse sistema procura explicar a origem das espécies superiores por meio de transformações dos seres inferiores. É ininterrupta a cadeia dos seres animais e vegetais, havendo entre as espécies extremas muitos tipos intermediários.

Emitindo a sua opinião disse o orador que o sistema de Darwin se baseia em algumas leis e princípios incontestáveis, mas que não é possível, sem sofismo, chegar-se às conclusões a que chegou o sábio inglês. ${ }^{44}$

Novamente aqui aparece a associação, como conceitos sinônimos, entre darwinismo e evolucionismo de modo mais genérico, este referido como transformismo, indicando que qualquer outra corrente evolucionista era identificada como sendo darwinista, independente das diferenças interpretativas existentes.

Bittencourt apresentou a teoria de Darwin ligada à ideia de progresso, pois ela explicaria como as espécies inferiores haviam se transformado em superiores. Advertiu, também, que, nessa abordagem, entre esses dois extremos teriam existido tipos intermediários. A associação entre darwinismo e progresso foi recorrente. As mudanças ocorridas durante o processo evolutivo eram compreendidas como alterações de um sistema mais simples para um mais complexo, um movimento de avanço, de progresso. ${ }^{45}$ Entretanto, para Darwin, as modificações não produziam, necessariamente,

\footnotetext{
${ }^{44}$ Jornal do Commercio, 17/10/1887.

45 ARGUETA VILLAMAR, A. El darwinismo en Iberoamérica... MONTSERRAT, Marcelo. La mentalidad evolucionista en la Argentina: una ideología del progreso. In: GLICK, T. F., RUIZ GUTIÉRREZ, R.; PUIG-SAMPER, M. A. (Ed.). El darwinismo en España y Iberoamérica..., p. 16-46. RUSE, Michael. Evolución y progreso: crónica de los conceptos. In: WAGENSBERG, Jorge; AGUSTÍ, Jordi (Eds.). El progreso ¿Un concepto acabado o emergente? Traducción de Ambrosio García Leal. Barcelona: Tusquets Editores, 1998, p. 67-106.
} 
formações mais elaboradas. ${ }^{46}$ Conforme o naturalista inglês desenvolveu no quarto capítulo de A origem das espécies, dedicado à seleção natural, as transformações ocorriam no sentido de uma melhor adaptação das espécies às condições em que viviam em um determinado período, tal adequação poderia, inclusive, ocorrer no sentido de formar um sistema mais simples. ${ }^{47}$

O conferencista classificou o sistema do naturalista inglês como sofismático, já que ele estruturava sua abordagem dentro do protocolo da ciência, utilizando alguns princípios "incontestáveis", entretanto, para chegar as suas conclusões baseava-se em hipóteses não fundamentadas. Bittencourt falava sobre a inexistência de evidências que provassem as assertivas de Darwin, tais como, exemplares das espécies intermediárias.

Ao dar continuidade à explanação, Bittencourt enunciou:

Certamente são fatos inconcussos a luta pela existência, a seleção natural, a herança ou atavismo, a influência do meio etc. Mas tudo isso não nos pode explicar de modo claro e positivo o como das transformações específicas. Muitos dos supostos tipos intermediários, como o fazem darwinistas, que é ininterrupta a cadeia dos seres vivos.

Declarou positivamente que não se deve aceitar, por indemonstrada, a hipótese de Darwin, quando pretende que o homem não é mais do que um macaco aperfeiçoado!...

Para sustentar semelhante proposição Darwin argumentou com a morfologia dos seres, esquecendo as suas fundamentais diferenças anatômicas e fisiológicas. Este é o vício principal da sua doutrina, aliás muito sedutora. ${ }^{48}$

Bittencourt apresentou como evidências incontestáveis os seguintes pontos da teoria de Darwin: "luta pela existência, a seleção natural, a herança ou atavismo, a influência do meio". Embora não tenha entrado em detalhes como compreendia cada um desses pontos, é possível fazer algumas inferências. Herança e atavismo, por exemplo, foram expostos como sinônimos, desconsiderando assim o fato de o atavismo

\footnotetext{
${ }^{46}$ MAYR, E. Biologia, ciência única... GOULD, Stephen Jay. Darwin e os grandes enigmas da vida. Tradução de Maria Elizabeth Martinez. 2 ed. São Paulo: Martins Fontes, 2006. GOULD, Stephen Jay. Lance de dados: a idéia de evolução de Platão a Darwin. Tradução de Sergio Moraes Rego. Rio de Janeiro: Record, 2001. RUSE, M. Evolución y progreso...

${ }^{47}$ DARWIN, Charles. On the origin of species by means of natural selection, or the preservation of favoured races in the struggle for life. New York: D. Appleton and Company, 1864.

${ }^{48}$ Jornal do Commercio, 17/10/1887.
} 
estar relacionado à herança de características de ascendentes longínquos. Por meio da análise desta preleção, seria possível supor que Bittencourt estivesse de acordo com essas proposições do sistema de Darwin. Contudo, pela leitura do resumo da conferência seguinte, verifiquei que ele continuava a não concordar com a influência do meio. Ou talvez, e mais provável, ele apenas levantasse como fatos observáveis a existência desses pontos, mas não os considerava como agentes causadores, ou com força suficiente para provocarem transformações evolutivas.

A despeito de reconhecer esses princípios como verdadeiros, Bittencourt, novamente, sublinhou que o grande problema estava em torno da não existência de intermediários entre as espécies atuais e as passadas. Como o médico conferencista acreditava que a criação da Terra e do homem teriam sido trabalhos de Deus, que realizara tal feito com tamanha perfeição, era difícil conceber a ideia de que o produto desta obra tivesse que ser alterado. E o pior, que nos primórdios, o homem pudesse ter descendido de um macaco. Afinal, Deus não teria criado o homem a sua imagem e semelhança, como pregavam as escrituras sagradas? Mais uma vez, aqui foi retomado um ponto que esteve presente na polêmica provocada pelas preleções de Miranda Azevedo, em 1875, quando o jornal católico $O$ Apostolo questionou o parentesco humano com o macaco e a origem não divina da Terra e de seus habitantes. ${ }^{49}$

$\mathrm{Na}$ terceira conferência consecutiva sobre o mesmo tema, proferida perante numeroso auditório, Feliciano de Bittencourt

Discorreu largamente sobre as leis fundamentais do transformismo, explicando o alcance da luta pela existência, da seleção natural, e da lei da variedade das espécies.

Disse que as espécies transformam-se, variam quanto aos seus caracteres exteriores, mas que são sempre as mesmas quanto à estrutura íntima, quanto à essência. As condições múltiplas do meio não tem a força de mudarem completamente uma espécie animal ou vegetal, produzindo uma outra nova, diversa inteiramente da primeira.

Fez ver que se quisermos ser lógicos, tirando do darwinismo suas últimas e naturais conclusões, chegaremos ao materialismo absurdo, à negação da existência de Deus. ${ }^{50}$

\footnotetext{
${ }^{49}$ CARULA, K. A tribuna da ciência...

${ }^{50}$ Jornal do Commercio, 31/10/1887. Grifos do original.
} 
Nesta preleção, Bittencourt retomou algumas questões sobre o darwinismo discutidas na apresentação anterior. $\mathrm{Na}$ sua interpretação, as transformações sofridas pelas espécies seriam apenas superficiais, porque na "essência" continuavam as mesmas, ou seja, não ocorriam modificações. Desta maneira, o médico conferencista reafirmou seu posicionamento contrário ao evolucionismo, sendo ele adepto do poligenismo, não concebia a possibilidade de alterações no correr do tempo, uma vez que os seres teriam sido criados conforme um plano já preestabelecido pelo Criador. Neste sentido, ele mesmo enfatizou que a negação de Deus era um corolário da teoria de Darwin.

$\mathrm{Na}$ análise do darwinismo feita por Bittencourt, as mudanças evolutivas ocorridas seriam fruto da ação do meio. Contudo, para o orador, o ambiente não teria vigor para efetuar tais alterações. O ambiente foi tratado como uma força atuante na abordagem evolucionista de Darwin, que "sempre deixou um espaço para efeitos de uso e desuso e para uma influência direta ou ocasional do ambiente". ${ }^{51}$

As análises de Bittencourt, acerca da teoria darwinista, estavam fundamentadas nas assertivas do médico alemão e grande defensor do materialismo Ludwig Büchner ${ }^{52}$ (1824-1899), referenciado na fonte como Luiz Buchner. Büchner realizou seis conferências nas cidades de Frankfurt, Darmstadt e Worms, entre 1866 e 1868, publicando-as neste ano, sendo que no seguinte a obra seria traduzida para o francês. ${ }^{53} \mathrm{E}$ possível que Bittencourt tenha tido contato com as ideias do autor alemão por meio da tradução francesa, haja vista a grande circulação de edições francesas no Brasil. ${ }^{54}$ Isto indica que provavelmente o preletor brasileiro não fizera uma leitura direta da obra do naturalista inglês:

\footnotetext{
${ }^{51}$ MAYR, E. Biologia, ciência única... p. 128. Nesta perspectiva, Argueta Villamar afirma que: "No se puede afirmarse que la idea sobre el uso y desuso sea una de las nociones más importantes de la teoría evolucionista darwiniana, pero lo increíble es que se haya popularizado tanto, y sobre todo que en América Latina se haya difundido como uno de los elementos centrales de la teoría darwiniana, cuando es central en la teoría de Lamarck, pero relatico en la de Darwin." ARGUETA VILLAMAR, A. El darwinismo en Iberoamérica..., p. 75.

${ }^{52}$ Suas principais discussões sobre a filosofia materialista foram publicadas na obra Força e matéria, em 1855.

${ }^{53}$ BÜCHNER, Louis. Conférences sur la théorie darwinienne de la transmutation des espèces et de l'apparition du monde organique. Application de cette théorie à l'homme. Ses rapports avec la doctrine du progrès et avec la philosophie matérialiste du passé et du present. Traduit par Auguste Jacquot. Leipzig: Théodore Thomaz, Libraire-Éditeur; Paris: C. Reinwald, Libraire-Éditeur, 1869.

${ }^{54}$ FERREIRA, Tania Maria Bessone da Cruz. Palácios de destinos cruzados: bibliotecas, homens e livros no Rio de Janeiro, 1870-1920. Rio de Janeiro: Arquivo Nacional, 1999.
} 
Apoiou esta sua opinião nas conferências de Luiz Buchner sobre o darwinismo; ele diz que Charles Darwin não quis, ou não teve coragem de chegar às verdadeiras conclusões de sua doutrina, que são evidentemente materialistas.

Darwin admite quatro ou cinco tipos primitivos animais e vegetais, criados por Deus e de onde se originaram todos os seres orgânicos, que hoje povoam a superfície da terra.

Buchner diz que isto é absurdo, que tudo provém da matéria, pela ação única das forças físicas; para o sábio alemão a matéria é uma só, e não orgânica e inorgânica. Desta é que provém aquela pelo concurso das forças naturais.

$\mathrm{O}$ orador demonstrou com muitos argumentos que o materialismo de Buchner é grosseiro e inaceitável, pois pretende justificar o impossível, isto é, a ideia de que a matéria organizada provém da inorgânica; é uma deplorável confusão, que nada adianta, nada resolve. ${ }^{55}$

Defensor de uma visão de mundo teológica, Bittencourt não se furtou de mais uma vez acusar o naturalista inglês de materialista. ${ }^{56}$ Ao dizer que Darwin não teve coragem de se apresentar como materialista, o orador evidenciou que esse tipo de posicionamento poderia gerar críticas por levar à negação do papel criador de Deus. Entretanto, Bittencourt afirmou que para Darwin alguns seres primitivos haviam sido criados por Deus, indicando que na sua leitura o autor de A origem das espécies não chegava a rejeitar plenamente o Criador. Esses seres, por sua vez, teriam originado todos os outros.

Bittencourt contrapôs Darwin e Büchner, e, no seu julgamento, a abordagem deste último era mais reprovável que a do naturalista inglês. Isto porque o cientista alemão defendia calorosamente o materialismo, enquanto Darwin ainda acreditava na existência de seres criados por Deus. Assim, o ponto fulcral para ele era a negação da atuação divina, o que o tocava profundamente enquanto criacionista que era.

Haeckel também foi alvo das críticas de Bittencourt, ao asseverar que "as opiniões desse ilustre discípulo de Darwin são também demasiadamente ousadas e mistificáveis

\footnotetext{
55 Jornal do Commercio, 31/10/1887.

${ }^{56}$ De fato, após a publicação de A origem das espécies Darwin teve que trabalhar com a pecha de ateu. DESMOND, Adrian; MOORE, James. Darwin: a vida de um evolucionista atormentado. 5 ed. Tradução de Cynthia Azevedo. São Paulo: Geração Editorial, 2007.
} 
no terreno da experiência e da observação." ${ }^{57}$ Se referiu às proposições do evolucionista alemão como infundadas, uma vez que não poderiam ser comprovadas empiricamente. Desta maneira, para desqualificar o evolucionismo, o médico preletor fazia uso do discurso científico, no qual as teorias deveriam estar baseadas em observações e na experiência. As "ousadas e mistificáveis" afirmações de Haeckel poderiam ser as referentes à embriologia adotada pelo cientista, abordagem analítica já depreciada em conferências anteriores.

Ao dar continuidade à preleção, Bittencourt tratou da geração espontânea, afirmando que era "anticientífica, e nem merece as honras da discussão; e corroborou a sua asserção lendo trechos do livro moderno de Mathias Duval sobre o darwinismo." ${ }^{\text {, }}$ A hipótese da geração espontânea era, para Bittencourt, um absurdo não em função das recentes pesquisas desenvolvidas por Louis Pasteur (1822-1895), mas porque ele era um criacionista e não concebia outra forma de criação que não a divina. $O$ médico conferencista tinha conhecimento dos trabalhos de Pasteur, pois em 1885 proferiu uma conferência - "Doutrina microbiana em geral" - na qual discorreu, dentre outros, sobre os trabalhos de Domingos José Freire, acerca da febre amarela, e o de João Baptista de Lacerda, com relação ao beribéri. ${ }^{59}$

O orador estabeleceu uma relação entre a teoria da geração espontânea e o darwinismo, como para o naturalista inglês a explicação da origem dos seres acontecesse dessa forma. Esta conexão se apresentou de maneira contraditória à afirmativa anterior de Bittencourt, quando confirmou que para Darwin as espécies primitivas haviam sido criadas por Deus. Para tal, apoiou sua análise na interpretação do médico francês Mathias Duval (1844-1907), provavelmente a obra lida foi Le darwinisme, publicada em 1886, um ano antes da realização desta preleção e, por isso mesmo, tendo merecido o destaque de ser um "livro moderno". Isto mostra que Bittencourt estava a par do que era produzido de novo neste campo de investigação. Na extensa publicação, composta por 27 aulas ministradas na Escola de Antropologia entre 1883 e 1884, antes de tratar do darwinismo, Duval abordou a concepção de raça e

\footnotetext{
${ }^{57}$ Jornal do Commercio, 31/10/1887.

58 Jornal do Commercio, 31/10/1887.

59 Jornal do Commercio, 18/11/1885. Sobre Domingos Freire e sua luta contra febre amarela conferir: BENCHIMOL, Jaime Larry. Dos micróbios aos mosquitos: febre amarela e a revolução pasteuriana no Brasil. Rio de Janeiro: Editora Fiocruz / Editora UFRJ, 1999.
} 
espécie, o tratamento teórico de Agassiz, Cuvier, Lamarck, Geoffroy Saint-Hilaire, dentre outros. ${ }^{60}$

Com relação à geração espontânea, outros oradores abordaram o assunto. Em 1875, também nas Conferências Populares da Glória, o médico Galdino Emiliano das Neves enfocou especificamente o tema. Negou a hipótese da geração espontânea, considerada "improcedente por admitir efeitos sem causa, seres viventes criando-se a si mesmos, esquecendo-se que a matéria é inerte, e como tal incapaz de criar forças e muito menos de organizar-se." Para refutá-la, deteve-se nas experiências de Pasteur, conceituado "chefe da cruzada contra a geração espontânea". ${ }^{61}$

Assim como Neves, no ano de 1876, o quartanista de medicina Antonio Cerqueira Lima, em uma preleção proferida no Ateneu Acadêmico, desenvolveu uma análise sobre a geração espontânea. Rejeitou tal hipótese, apresentando dados de outros cientistas a fim de mostrar a inexistência dessa possibilidade. ${ }^{62}$

De volta à preleção de Bittencourt, para finalizá-la ele "tratou das opiniões do ilustre sábio Agassiz, exaradas em seu trabalho sobre as classificações, com as quais em parte concordou, como mais consentâneas com o seu modo de pensar sobre a questão da gênese primitiva do mundo orgânico." ${ }^{\text {,63 }} \mathrm{O}$ orador, apesar de não estar de acordo com todo o sistema de classificação de Agassiz, compartilhava com ele tanto o poligenismo como o criacionismo. ${ }^{64} \mathrm{E}$, por isso, era extremamente difícil para o médico brasileiro considerar o darwinismo como uma plausível chave explicativa da natureza.

Após dialogar de maneira mais explicita com a teoria de Darwin, Feliciano Bittencourt expôs uma série de 22 conferências que tinham como temática principal a origem do homem no continente americano, referenciadas como sendo um estudo da "América pré-histórica". Sobre os primeiros habitantes que povoaram esta região geográfica, ele concluiu que datavam do período quaternário. ${ }^{65} \mathrm{O}$ objetivo de tais preleções era "demonstrar que é uma única a origem do gentio de toda a América; que a raça é a mesma, dependendo as modalidades das condições de meio e outras”, e, por fim, que "o silvícola americano é autóctone". ${ }^{66}$ Assim, os discursos de Bittencourt

${ }^{60}$ DUVAL, Mathias. Le Darwinisme. Leçons profesées a l'École d'Anthropologie. Paris: Adrien Delahave et Émile Lecrosnier, 1886.

${ }^{61}$ O Globo, 24/10/1875.

${ }^{62}$ Jornal do Commercio, 10/07/1876.

${ }^{63}$ Jornal do Commercio, 31/10/1887.

${ }^{64}$ A respeito do posicionamento poligenista e criacionista de Agassiz conferir: MACHADO, M. P. T. A ciência norte-americana visita a Amazônia...

${ }^{65}$ Jornal do Commercio, 07/11/1887. Grifos do original.

${ }^{66}$ Jornal do Commercio, 04/07/1888. Grifos do original. 
visavam comprovar o poligenismo por meio do estudo do caso do homem americano. Partidário da crença na existência de vários centros de criação, o orador pretendia mostrar que um destes foi aqui na América, que, por sua vez, deu origem a todos os habitantes do continente. Centrou boa parte de suas apresentações em questões mais culturais daqueles que povoavam esse espaço antes da chegada do europeu, sobre os maias, astecas, toltecas e chichimecas enfatizou "sua religião, usos, costumes, agricultura, comércio e indústria." ${ }^{67}$ As exposições foram feitas no intuito de mostrar a semelhança entre os diversos povos, o que atestaria a mesma origem.

Fez ver que todos esses povos, que invadiram a América Central em meados do século $\mathrm{XV}$, pertenciam ao mesmo tronco, à raça Nahualt; sucessivamente uns dominaram os outros chegando a ter os vencedores certo grau de prosperidade e opulência, o que pode verificar pelos monumentos existentes no México, Guatemala, Honduras, Zucatan, e outros lugares, e lendo as narrativas dos conquistadores espanhóis de fins do século XV. ${ }^{68}$

Todos os assuntos abordados por Bittencourt foram baseados no poligenismo, do qual era "sectário confesso" ${ }^{69} \mathrm{O}$ orador provavelmente tratou desses mesmos temas em suas aulas de história e corografia que ministrava no Colégio Pedro II. Desta maneira, as Conferências Populares da Glória se tornaram um palanque excelente para que ele pudesse apresentar para um público mais amplo seu posicionamento acerca da teoria evolucionista de Darwin. Profundo admirador das ideias de Agassiz, assim como este, Bittencourt era criacionista e poligenista. E a crença em tais teorias era o que o impedia de aceitar o darwinismo. Neste combate, os pontos principais abordados por Bittencourt foram: a negação do Criador na origem da Terra e dos seus habitantes, e a evolução, pois para ele todos os seres foram planejados divinamente de um modo completo e pronto. Em menor escala, ele também desmereceu as proposições do naturalista inglês no tocante à suposta ancestralidade única entre o homem e o macaco. A questão maior em todas as suas preleções envolvia a luta entre o poligenismo e o monogenismo e entre o criacionismo e o evolucionismo. Cabe marcar, contudo, que todo esse combate ao darwinismo estava dentro da chave interpretativa da ciência, ou seja, em momento

\footnotetext{
${ }^{67}$ Jornal do Commercio, 02/08/1888.

${ }^{68}$ Jornal do Commercio, 02/08/1888.

${ }^{69}$ Jornal do Commercio, 14/08/1889.
} 
algum Bittencourt deixou de explicitar que suas argumentações também eram científicas.

\section{Miranda Azevedo e as aplicações do darwinismo}

Em 1875, o médico Augusto Cezar de Miranda Azevedo proferiu, nas Conferências Populares da Glória, sete conferências abordando a temática do darwinismo (Anexo 3). Suas apresentações tiveram grande repercussão na imprensa, com posicionamentos de adesão e recusa à teoria de Darwin. ${ }^{70} \mathrm{O}$ Jornal do Commercio e $O$ Globo noticiaram que se tratava da exposição de uma "teoria moderna de história natural", já conhecida na Europa e nos Estados Unidos ${ }^{71}$. Um ano antes, ele já havia tratado do tema em sua tese de doutorado, defendida na Faculdade de Medicina do Rio de Janeiro. O trabalho acadêmico compreendia uma dissertação sobre o beribéri, e três proposições referentes às seguintes seções da instituição: "seção cirúrgica - cadeira de medicina operatória", "seção médica - cadeira de higiene" e "seção acessória - cadeira de botânica e zoologia". Para esta última, apresentou a análise: "Do darwinismo - É aceitável o aperfeiçoamento cada vez mais completo das espécies até o homem?". ${ }^{72}$ A pesquisa realizada para o estudo fundamentou as suas preleções.

Nas suas apresentações públicas, Miranda Azevedo abordou o conceito de espécie, assinalando que:

da palavra espécie, e de sua interpretação decorrem as discussões e nasceu a linha divisória das duas escolas, a teológica e a darwinística. [...] os partidários da evolução e do darwinismo, sem se ocuparem com as distinções escolásticas do que é uma espécie boa ou má, estudam e consideram os indivíduos, e pouco se importam com essas convenções artificiais. ${ }^{73}$

\footnotetext{
${ }^{70}$ CARULA, K. A tribuna da ciência...

${ }^{71}$ Jornal do Commercio, 10/04/1875. O Globo, 10/04/1875.

72 AZEVEDO, Augusto Cezar de Miranda. Beriberi. Tese apresentada em 3 de novembro de 1874. Rio de Janeiro: Typographia Academica, 1875. A banca examinadora era composta por Torres Homem, João Silva, Joaquim Monteiro Caminhoá e L. Pientznauer. COLLICHIO, Therezinha Alves Pereira. Miranda Azevedo e o darwinismo no Brasil. Belo Horizonte: Itatiaia; São Paulo: Edusp, 1988, p. 24.

${ }^{73}$ AZEVEDO, A. C. de. Darwinismo. Seu passado, seu presente e seu futuro..., p. 57. Grifo do original
} 
Não apresentou uma definição clara do que compreendia como espécie, somente colocou em contraposição a significação teológica com a postulada pela teoria de Darwin. Miranda Azevedo apenas afirmou que na perspectiva darwinista não ocorriam juízos de valores, pretendendo, assim, evidenciar uma pretendida imparcialidade do conceito no tratamento científico.

Ainda no tocante à concepção do que era espécie:

Examinando as definições da espécie dadas por Linneo, Jussieu, Cuvier, Lamarck, Bonnet, Florena, Dugés, etc., [Miranda Azevedo] mostrou a dificuldade de bem precisar-se a significação desta palavra, sob o ponto de vista da escola dualística, portanto seguiria a opinião geral, e não se demoraria mais com essa questão. ${ }^{74}$

A dificuldade em precisar o conceito de espécio, entretanto, não foi uma especificidade do médico conferencista, ocorreu com outros homens de ciência do período. $^{75}$

Miranda Azevedo afirmava ter lido A origem das espécies e sugeriu que fez o mesmo com A Descendência do homem. No seu julgamento, a teoria da seleção fora plenamente desenvolvida por Darwin na primeira obra. ${ }^{76}$ Contudo, sua leitura do darwinismo esteve marcada por fundamentos postulados por outros evolucionistas, dentre os quais se destacava Haeckel. ${ }^{77}$ Muito do que apresentou sobre o paradigma de Darwin as Conferências Populares estava pautado na obra do evolucionista alemão: "De todos estes elementos expostos nasceu e ficou definitivamente fundado o darwinismo, como vos tenho dito, com Haeckel, é a coroação desse monumento admirável da escola evolucionista". 78

Utilizou os princípios postulados por Haeckel para definir o darwinismo em sua conferência:

\footnotetext{
74 Jornal do Commercio, 20/04/1875.

75 MAYR, E. Biologia, ciência única... Mayr assevera que ainda hoje tal definição é tema de controvérsias entre os cientistas.

${ }^{76}$ AZEVEDO, A. C. de M. Darwinismo. Seu passado, seu presente e seu futuro..., p. 55.

${ }^{77}$ CID, Maria Rosa Lopes. O aperfeiçoamento do homem por meio da seleção: Miranda Azevedo e a divulgação do darwinismo, no Brasil, na década de 1870. Dissertação (Mestrado em História das Ciências da Saúde) - Casa de Oswaldo Cruz, Fundação Oswaldo Cruz, 2004.

${ }^{78}$ AZEVEDO, A. C. de M. Darwinismo. Seu passado, seu presente e seu futuro..., p. 59.
} 
O darwinismo, como diz Haeckel, não é mais do que um fragmento, uma parte dessa lei geral da interpretação dos fatos universais; defini-lo-ei, portanto, assim: a teoria genealógica que sustenta que todos os organismos extintos, existentes, futuros, e vegetais ou animais derivam-se de um pequeno número de tipos antepassados, excessivamente simples e transformados por uma evolução ou metamorfose gradativa por meio da seleção natural.

As quatro leis fundamentais desta doutrina, excluindo as ideias das criações simultâneas adotadas por Curvier, que por tanto tempo reinaram na ciência, são o resumo e síntese dessa teoria que todos os dias encontra novas demonstrações a favor dos princípios que sustenta. Poder ser formulados do seguinte modo: 1a. luta pela existência, 2a. variabilidade das espécies, 3a. hereditariedade e 4a. seleção natural. ${ }^{79}$

Darwinismo era, portanto, uma teoria na qual as transformações evolutivas graduais ocorriam por meio da seleção natural. As quatro leis fundamentais do sistema de Darwin foram apresentadas e analisadas por Miranda Azevedo em várias de suas preleções. Cabe ressaltar que esses princípios também constavam na tese de doutorado do médico.

Além de Haeckel, outro evolucionista que embasou o modo de compreensão do darwinismo de Miranda Azevedo foi Lamarck: ${ }^{80}$

Senhores, repousemos um instante para contemplar Lamarck, esse talento admirável, esse sábio naturalista que deve ser considerado o verdadeiro fundador da teoria evolutiva.

\section{$[\ldots]$}

[...] Generalizando a soma de conhecimentos particulares, Lamarck traçou de uma maneira que surpreende, as mais ousadas proposições, hoje confirmadas pela ciência. Estabelecendo a descendência e evolução progressiva dos organismos, do mais simples para o mais complexo, reconheceu que só eram regulados pelas forças físico-químicas, da mesma maneira que os corpos inorgânicos. O homem considerado de acordo com sua doutrina ligava-se aos

${ }^{79}$ AZEVEDO, A. C. de M. Darwinismo. Seu passado, seu presente e seu futuro..., p. 43. Grifos do original.

${ }^{80}$ CID, M. R. L. O aperfeiçoamento do homem por meio da seleção... 
mamíferos superiores por intermédio dos quadrúmanos, e pela primeira vez, com coragem, sustentou a existência do homemmacaco...

É este, senhores, justamente um dos pontos, à primeira vista, mais delicado do darwinismo. Sei como ordinariamente é impensado esta proposição, que encontra quase sempre o riso impensado para criticá-la. Os adversários da doutrina evolutiva, e os levianos tomam superficialmente esta proposição destacada, e procurando provocar o riso e o ridículo, julgam ter alcançado a vitória. ${ }^{81}$

Miranda Azevedo atribuiu a Lamarck a fundação do evolucionismo, que seria um sistema de transformação de entidades mais simples em tipos mais complexos. Também creditou ao naturalista francês a afirmação da existência de um elo evolutivo entre o homem e o macaco. Entretanto, logo em seguida, Miranda Azevedo mostrou que tal ligação estava vinculada ao darwinismo, indicando que em sua concepção as teorias de Darwin e Lamarck não apareciam claramente diferenciadas. Salientou que a existência deste "homem-macaco" era um ponto suscetível às críticas dos adversários à teoria darwinista. De fato, a questão impulsionou a atenção dos opositores. Em decorrência das observações feitas pelo orador, o jornal $O$ Apostolo direcionou severos ataques ao darwinismo e a Miranda Azevedo no tocante à suposta origem símia do homem. ${ }^{82}$

A influência de Lamarck no tratamento de Miranda Azevedo sobre darwinismo se deu, principalmente, no peso atribuído à atuação do meio:

Passando em revista as condições que modificam os indivíduos as influências climatéricas, os hábitos, a nutrição como as causas principais geradoras desse transformismo. [...] Em seguida mostrou o poder modificador da nutrição, referindo as experiências feitas, com os óvulos das abelhas, de sorte que a ciência pode hoje transformar os germes das abelhas trabalhadoras em simples zangões e vice-versa. $\mathrm{O}$ hábito dá maior desenvolvimento a certos órgãos e atrofia outros e é por isso causa de numerosas variações. ${ }^{83}$

\footnotetext{
${ }^{81}$ AZEVEDO, A. C. de M. Darwinismo. Seu passado, seu presente e seu futuro..., p. 46.

${ }^{82}$ CARULA, K. A tribuna da ciência...

${ }^{83}$ Jornal do Commercio, 20/04/1875.
} 
O clima, a alimentação e outros hábitos foram apresentados como fatores que atuariam no processo de transformação evolutiva. Ou seja, Miranda Azevedo imputou principalmente ao meio o papel de agente causador das modificações. Tal interpretação se assemelhava muito à de Lamarck, muito embora Darwin não tivesse ignorado completamente a atuação do meio nas alterações. ${ }^{84} \mathrm{O}$ uso e desuso, também relacionado ao lamarckismo, foram considerados por Miranda Azevedo como atuantes nas mudanças evolutivas.

A luta pela existência foi discutida por Miranda Azevedo, que a classificou como "A primeira lei, aquela que por sua maior extensão talvez, e por sua inenterrompida execução nos desperta logo a inteligência é a luta pela existência, struggle for life como expressivamente chamou Darwin. ${ }^{" 85} \mathrm{O}$ orador assegurou que a luta pela existência era uma aplicação prática da lei do economista inglês Thomas Malthus (1766-1834), que era a "relação do crescimento das espécies em relação geométrica e a dos elementos em proporção aritmética; daí a necessidade fatal da luta para conservação própria", ${ }^{86}$

A luta pela existência regeria todos os organismos, incluindo aí o homem, considerado pelo conferencista como o "rei da criação": 87

As guerras que agitam a humanidade são consequências da luta pela existência em relação ao homem e têm as mesmas causas. Estas são, na frase de Schiller, a fome e o amor, que a ciência, em sua linguagem positiva, denomina instintos de conservação e reprodução. $\mathrm{Na}$ história pátria ainda vê esse fato nas lutas dos nossos indígenas entre si, e destes contra os europeus. ${ }^{88}$

\footnotetext{
${ }^{84}$ Conforme afiança Mayr: "Darwin não era um selecionista completo, porque sempre deixou espaço para efeitos de uso e desuso e para uma influência direta ocasional do meio." MAYR, E. Biologia, ciência única..., p. 128.

${ }^{85}$ AZEVEDO, A. C. de M. Darwinismo. Seu passado, seu presente e seu futuro..., p. 56.

${ }^{86}$ Jornal do Comercio, 21/04/1875. Segundo Julio Muñoz Rubio, na obra de Darwin encontram-se três tipos escassez: "la primera, que atraviesa el conjunto de la obra de Darwin, es la escasez clásica de recursos alimenticios, de espacio o de factores físico-químicos del ambiente, todas las cuales limitan y obstaculizan el crecimiento de la población; la segunda, común a todas las especies, especialmente animales, pero tratada con mayor precisión por Darwin en El Origen del Hombre es la escasez de individuos talentosos, con inventiva y espíritu guerrero, capaces de desplazar a otros menos dotados de esas cualidades en la lucha por la existencia; la tercera y última escasez, tratada por Darwin principalmente en La selección en relación al sexo, es aquella de individuos, especialmente del sexo femenino, atractivos y saludables, por quienes los machos puedan competir a fin de mejorar la raza o la especie.” MUÑOZ RUBIO, Julio. Una crítica a las raíces del concepto capitalista de escasez ( $T$. Malthus, D. Hume, A. Smith y C. Darwin). México, DF: Centro de Investigaciones Interdisciplinarias en Ciencias y Humanidades, Universidad Nacional Autónoma de México, 2005, p. 55.

${ }^{87}$ AZEVEDO, A. C. de M. Darwinismo. Seu passado, seu presente e seu futuro..., p. 57.

${ }^{88}$ Diario do Rio de Janeiro, 21/04/1875.
} 
Questões sociais seriam explicadas pelo princípio da luta pela existência. As guerras, por exemplo, teriam suas causas naturalizadas, uma vez que as disputas eram apresentadas como consequência de uma lei biológica que regeria todos os seres vivos. Desta maneira, Miranda Azevedo, utilizou conceitos biológicos como explicação para situações de cunho social, aproximando-se aqui com a abordagem de Haeckel.

Com relação à hereditariedade, o médico orador argumentou que:

As leis da adaptação, conservadora, progressiva $e$ cumulativa, de acordo com os fatos naturais, e auxiliadas pelo princípio da hereditariedade, explicam de maneira satisfatória as transformações estudadas pela doutrina evolutiva. As consequências da herança, que se tornam evidentes para todos, são verificadas constantemente pelos médicos no exame dos organismos doentes, e evidenciam a variedade da transmissão por esse meio, tanto das metamorfoses fisiológicas como das alterações teratológicas. Baseado no que tem exposto, o orador condenou o seguinte princípio: todo o organismo produz outro organismo igual, e, recapitulando tudo quanto tem dito, demonstrou que a verdade é a seguinte: todo o organismo produz um ser, que lhe é análogo. As aplicações práticas que a ciência e a indústria têm aproveitado são argumentos favoráveis para o darwinismo $^{89}$

Segundo Miranda Azevedo, a transmissão da adaptação, por meio da hereditariedade, garantiria o processo evolutivo. Ao assinalar que a adaptação era progressiva, o conferencista mostrou que, na sua concepção, ela se dava no sentido de uma situação mais simples para uma mais complexa, vinculando, desta maneira, o conceito de evolução ao de progresso, em acordo com o postulado por Haeckel. Como prova da importância das qualidades transmitidas para os descendentes, o médico citou o exemplo de moléstias que teriam tal origem. A perspectiva do orador era muito próxima à de Haeckel, tanto no papel atribuído à hereditariedade quanto na afirmação de que os descendentes são análogos aos progenitores. ${ }^{90}$

\footnotetext{
${ }^{89}$ Jornal do Commercio, 20/04/1875. Grifos do original.

${ }^{90}$ Segundo Rosaura Ruiz Gutiérrez: "Haeckel sostiene que hay dos tipos de fenómenos hereditarios: los caracteres legados, que son parte de la herencia conservadora y los caracteres adquiridos que integran la herencia progresiva. Esta distinción está fundada en la consideración de que los individuos pertenecientes a una especie vegetal o animal cualquiera, legan a su posteridad no sólo las propiedades que han heredado de sus antepasados, sino también las propiedades individuales que ellos han adquirido durante su vida.
} 
No tocante à origem do primeiro organismo vivo, Miranda Azevedo sublinhou:

Para falar de aparecimento do primeiro organismo na terra, estudou as condições do globo terrestre em sua origem, aceitando a doutrina geralmente aceita. No momento em que houve elementos para vida, apareceu o primeiro organismo por geração espontânea. [...] Atualmente, disse o orador, a ciência adquiriu fatos positivos que demonstram a geração espontânea, para os infusórios ou organismos inferiores, provenientes de infusões vegetais ou animais, e a membrana prolígera de Pouchet, primeiro elo dos fenômenos da heterogenia, pode ser verificada por todos. ${ }^{91}$

Na intepretação de Miranda Azevedo o primeiro organismo teria aparecido por meio da geração espontânea. Interessante evidenciar que, conforme anteriormente exposto, outros oradores, como Feliciano Pinheiro de Bittencourt, Galdino Emiliano das Neves e Antonio Cerqueira Lima, haviam se expressado contrários àquela hipótese. Os posicionamentos opostos destes conferencistas indicam que questionar a validade da geração espontânea era plausível, haja vista a existência de sectários da teoria, tal como Miranda Azevedo.

Para este médico, havia uma unidade entre os fenômenos físicos e sociais. Inclusive, Miranda Azevedo ao proferir sua primeira conferência sobre o darwinismo, destacou que difundia a teoria por estar certo que isto seria uma maneira de prestar um serviço à pátria. ${ }^{92}$ Desta maneira, os mesmos princípios que regiam a natureza também governavam a sociedade. ${ }^{93}$

Discorrendo sobre a unidade que se observa em todos os fenômenos, quer de ordem intelectual, quer do mundo físico, disse que a unificação dos povos e o ideal dos mais eminentes estadistas dos tempos modernos, a simplificação e a unidade das leis naturais é a

Las primeras son transmitidas en virtud de la herencia conservadora, sobre la cual el autor elaboró cinco leyes; la ley más general al respecto es la de herencia ininterrumpida. Consiste en que por lo general en la mayor parte de las especies animales y vegetales las generaciones se parecen, los padres son análogos lo mismo a los abuelos que a los hijos." RUIZ GUTIÉRREZ, R. Positivismo y evolución..., p. 236.

${ }^{91}$ Diario do Rio de Janeiro, 23/05/1875.

${ }_{92}^{92}$ CARULA, K. A tribuna da ciência..., p. 81-90.

${ }^{93}$ CID, M. R. L. O aperfeiçoamento do homem por meio da seleção... COLLICHIO, T. A. P. Miranda Azevedo e o darwinismo no Brasil... 
atual preocupação dos sábios que hoje honram a ciência e as letras com as duas investigações. ${ }^{94}$

Miranda Azevedo pretendia desenvolver "a doutrina darwinista até nas últimas instâncias", 95 ou seja, mostrar como a sociedade poderia ser compreendia pelo viés do paradigma evolucionista de Darwin. O preletor salientou que a unidade entre fenômenos físicos e sociais já era encontrada na obra de Agassiz, mas este atribuía "tudo ao Criador, por ser sectário das ideias dualistas e teleológicas", diferente do que ocorria com as interpretações darwinistas que não procuravam "causas sobrenaturais". 96 Assim, as explicações que ele forneceria, via darwinismo, seriam mais materialistas.

A aplicação social da teoria darwinista, segundo Miranda Azevedo, era o que o impulsionava a apresentá-la naquele espaço de vulgarização científica. Nas suas palavras: "É que no nosso viver prático, na nossa vida social, têm consequente e imediata aplicação como no estudo de todas as ciências naturais. " ${ }^{97}$ Os princípios de Darwin poderiam ser aplicados "à história da humanidade, em qualquer de suas manifestações, política, religiosa, literária, artística e social."98 Neste sentido, ele analisou os regimes políticos por meio de uma perspectiva evolucionista e progressista:

Passou a estudar ainda a verdade das suas leis na história da humanidade, analisando rapidamente as semelhanças e identidades observadas nas teogonias, instituições civis e políticas dos diversos povos, que apresentavam os mesmos hábitos e costumes em diferentes regiões sempre que se atender às condições de progresso e de condições em que vivem. Assim se observava nas formas de governo, a partir da teocracia, depois a monarquia despótica, a representativa e finalmente entre os povos mais civilizados, e que melhor compreendiam os seus direitos, a república federativa.

Em tradições e belas artes observa-se a mesma progressão, e igual fato era verdadeiro na linguística. ${ }^{99}$

\footnotetext{
${ }^{94}$ O Globo, 21/04/1875.

95 O Globo, 21/04/1875.

${ }^{96}$ Jornal do Comercio, 21/04/1875.

${ }^{97}$ AZEVEDO, A. C. de M. Darwinismo. Seu passado, seu presente e seu futuro..., p. 61.

${ }^{98}$ O Globo, 24/06/1875.

99 Jornal do Commercio, 24/06/1875.
} 
A história da humanidade, na análise do orador, era única. Todos os povos, independente de suas especificidades culturais, passariam pelos mesmos estágios. A existência de leis universais que orientavam as nações faria com que elas percorressem semelhante caminho, era inevitável e fatal, já estava determinado. Entretanto, Miranda Azevedo frisou que isso só acontecia quando os povos atendiam às "condições de progresso", logo, para conseguir caminhar na estrada da humanidade era necessário seguir a luz do progresso. Assim, para ele, todos estariam em condições de evoluir, bastavam entrar no eixo correto. Aqueles que não o fizessem, provavelmente, estariam na barbárie, ou ainda não teriam evoluído. De acordo com Gualtieri, "a lei biológica de Haeckel, transferida para o mundo social, previa que os povos, durante seu desenvolvimento, recapitulariam a história de outros povos já desenvolvidos". ${ }^{100}$

Os diversos regimes políticos foram apresentados como se estivessem engendrados dentro de um sistema que ia de uma situação mais simples para uma mais elaborada, melhor dizendo, de uma condição ruim para uma excelente. Para Miranda Azevedo, a posição última a ser alcançada era o regime republicano, uma vez que era partidário confesso desta forma de governo. Na plateia da conferência estava presente o Imperador, o que não intimidou Miranda Azevedo na defesa do republicanismo. De certo porque o monarca já conhecia o seu posicionamento político, haja vista que fora um dos signatários do Manifesto Republicano de $1870 .{ }^{101}$

Outra aplicação social do darwinismo, sugerida por Miranda Azevedo, estava relacionada com o recrutamento militar. Ao fazer uso das proposições de Haeckel, o médico conferencista argumentou que a convocação retirava os homens "sadios, fortes, vigorosos" da sociedade e os enviava para guerrear, enquanto os "fracos fisicamente" ficavam para procriar. ${ }^{102}$ Com esse sistema ocorreria a degeneração da humanidade, prejudicando a nação. Se fossem levados em consideração os princípios darwinistas, a sociedade sairia beneficiada com relação a este assunto. $\mathrm{Na}$ sua concepção, a teoria biológica de Darwin poderia ser utilizada em prol da sociedade. ${ }^{103}$

O emprego social das proposições darwinistas foi constantemente reiterado por Miranda Azevedo, que acreditava estar prestando um serviço à pátria e à sociedade ao

\footnotetext{
${ }^{100}$ GUALTIERI, Regina Cândida Ellero. O evolucionismo na produção científica do Museu Nacional do Rio de Janeiro (1876-1915). In: DOMINGUES, H. M. B.; SÁ, M. R.; GLICK, T. (Orgs.). A recepção do darwinismo no Brasil..., 2003, p.45.

${ }^{101}$ COLLICHIO, T. A. P. Miranda Azevedo e o darwinismo no Brasil...

${ }^{102}$ AZEVEDO, A. C. de M. Darwinismo. Seu passado, seu presente e seu futuro..., p. 60.

${ }^{103}$ CARULA, K. A tribuna da ciência...
} 
trazer a público a teoria de Darwin. ${ }^{104}$ Portanto, o darwinismo exposto pelo médico nas Conferências Populares da Glória era ressignificado, marcado pela presença de ideias de outros evolucionistas, como Haeckel e Lamarck. O paradigma biológico, todavia, foi utilizado para analisar questões sociais. Havia a frequente insistência, por parte de Miranda Azevedo, nas aplicações do darwinismo na sociedade, como meio de melhorála.

\section{O darwinismo no Museu Nacional}

O Museu Nacional foi um espaço privilegiado para discussões e ressignificações da teoria de Darwin. Local de desenvolvimento de pesquisa, os trabalhos que lá eram realizados dialogavam diretamente com a produção científica do mundo ocidental, em especial Europa e Estados Unidos. ${ }^{105}$ Com relação aos anos de 1876 a 1893, João Baptista de Lacerda, responsável pelo curso de antropologia, afirmou que este foi "o período mais fecundo, de maior atividade e de mais intenso brilho na história do Museu Nacional", tendo crescido muito a sua "reputação científica", não apenas dentro do país. Por esses motivos, a fase foi por ele considerada como "a idade de outro do Museu Nacional". 106

Segundo Gualtieri, o Museu foi uma das instituições pioneiras a divulgar as ideias evolucionistas. ${ }^{107}$ Ladislau Netto, então diretor, foi um dos pesquisadores que abraçou as ideias darwinistas. Além de seus trabalhos stricto sensu mais científicos, nas preleções do curso de botânica também apresentou a sua concepção a respeito do sistema interpretativo do naturalista inglês. Acerca das investigações do Museu Nacional sobre o evolucionismo, Netto ressaltou:

Ao Museu Nacional, tão eficazmente iniciado nos trabalhos transcendentes da experimentação, como nas mais elevadas cogitações da filosofia evolucionista, é de crer que venha a caber, em não muito

\footnotetext{
${ }^{104}$ CARULA, K. A tribuna da ciência...

105 GUALTIERI, R. C. E. Evolucionismo no Brasil... LOPES, Maria Margaret. O Brasil descobre a pesquisa científica: os museus e as ciências naturais no século XIX. São Paulo: Hucitec, 1997.

${ }^{106}$ LACERDA, João Baptista de. Fastos do Museu Nacional do Rio de Janeiro. Recordações historicas e scientificas fundadas em documentos authenticos e informações veridicas. Rio de Janeiro: Imprensa Nacional, 1905, p. 37.

${ }^{107}$ GUALTIERI, R. C. E. Evolucionismo no Brasil..., p. 45.
} 
remoto futuro, a gloriosa missão de quebrar o sigilo que prende e oculta o fecho destes assuntos. ${ }^{108}$

As expectativas de Ladislau Netto eram que o Museu, por desenvolver pesquisas científicas fundamentadas no evolucionismo, viesse a colaborar na comprovação das assertivas darwinistas. Neste sentido, ele estava se referindo às provas experimentais que atestariam a validade das proposições de Darwin, tanto reclamadas pelos críticos da teoria. Não só os diretores e subdiretores tinham trabalhos relacionados ao tema, mas também os naturalistas viajantes ${ }^{109}$, por exemplo, Fritz Müller ${ }^{110}$. Consoante Gualtieri, "investigar as características adaptativas dos organismos procurando elucidar o papel da seleção natural para seu surgimento era uma tarefa essencial para os que estavam interessados em compreender os processos evolutivos." "Caso as expectativas de Netto fossem alcançadas, não só os pesquisadores, mas, acima de tudo, o Museu se consagraria internacionalmente.

As plantas sarmentosas, trepadeiras com gavinhas, receberam de Ladislau Netto uma atenção especial, cujos resultados das análises foram apresentados nos cursos públicos. Este interesse estava relacionado com estudos feitos por Darwin, o movimento das plantas trepadeiras para buscar a luz nas regiões mais altas foi analisado pelo naturalista inglês pelo viés da adaptação e da seleção natural. ${ }^{112}$ Em uma de suas preleções, Netto assegurou que,

Para que estes vegetais [com caules sarmentosos] tornassem uma forma tão singular foi necessário que se exagerasse

\footnotetext{
${ }^{108}$ NETTO, Ladislau. Nota-prefacio ao estudo sobre os tembetás que possue o Museu Nacional. Revista da Exposição Anthropologica Brazileira, Rio de Janeiro, jul. 1882, p. 132.

${ }^{109}$ Cargo regulamentado no Capítulo I, artigo $5^{\circ}$, do decreto n. 6116, de 9 de fevereiro de 1876, este também estipulava (Capítulo II, Art. $4^{\circ}$ ) que os naturalistas seriam nomeados pelo diretor do Museu. Decreto n. 6116 de 9 de fevereiro de 1876. Disponível em:

<http://www6.senado.gov.br/legislacao/ListaPublicacoes.action?id=69806>. Acesso: 12 jan. 2010.

${ }^{110}$ Conforme asseverou Lacerda, "Darwin tinha-o [Müller] em grande estima, e considerava-o um valente colaborador da teoria transformista". LACERDA, J. B. Fastos do Museu Nacional..., p. 48. Sobre as pesquisas desenvolvidas por Müller, conferir: PAPAVERO, N. Fritz Müller e a comprovação da teoria de Darwin... WEST, David. Fritz Müller, o biólogo evolucionista pioneiro no Brasil. In: DOMINGUES, H. M. B.; SÁ, M. R.; PUIG-SAMPER, M. A.; RUIZ GUTIÉRREZ, R. (Orgs.). Darwinismo meio ambiente e sociedade..., p. 41-44.

${ }^{111}$ GUALTIERI, R. C. E. Evolucionismo no Brasil..., p. 39.

${ }^{112}$ Darwin "suspeitava que elas [plantas trepadeiras] fossem elos evolutivos entre as plantas que possuíam hastes e as que as que possuíam gavinhas. Elas serviriam ao seu propósito: mostrar que os ganchos eram hastes de folhas modificadas e que as gavinhas eram folhas ou talos de flor modificados drasticamente em forma de laços. As alterações auxiliavam a planta em sua luta esforçada e giratória pela existência." DESMOND, A.; MOORE, J. Darwin..., p. 542.
} 
extraordinariamente o desenvolvimento longitudinal do caule, do que foi decidido auxiliar o tecido do estofo medular, muito mais largo nestes do que em quaisquer outros vegetais.

Tratando dos caules chamados anormais, o professor apresentou-os como um caso de atavismo: - um primeiro grau de reversão ao tipo dicotiledônio normal, mas reversão que traz à lembrança as medidas coercivas empregadas às vezes indevidamente na ordem social contra abusos que, se deixam de existir, são substituídos por irregularidades mil vezes ainda mais desastrosas, com perfeita aplicação daquele dizer do povo, bem cabido em um curso dedicado ao mesmo povo, de sair assim pior a emenda que o soneto.

$\mathrm{O}$ professor, para justificar esses acertos, acrescentou que, sendo coisa eficiente da distensão longitudinal dos caules das trepadeiras a necessidade que elas têm de romper a espessa e alta ramagem dos matos virgens, a fim de receberem em suas folhas os raios solares, tanto menos crescem e, pois, tanto mais se aproximam do tipo dicotiledônio regular, quanto menos é o obstáculo que lhes intercepta a luz do sol. ${ }^{113}$

Netto buscou realizar um estudo semelhante ao de Darwin. Para o cientista brasileiro, os caules das sarmentosas haviam se estendido daquela maneira com o fim de buscar mais luz, assim, se adaptando melhor que as plantas que não fizeram o mesmo. Já, as que não possuíam tais tipos de caules alongados seriam resultado de manifestações atávicas.

O que vale salientar aqui é que as pesquisas desenvolvidas pelo diretor do Museu dialogavam de modo direto com o darwinismo e seus resultados eram apresentados ao público que comparecia para assistir aos cursos promovidos pela instituição. Esses espectadores, ao acompanharem um estudo de botânica, também entravam em contato com a perspectiva darwinista de análise.

Um ano antes desta conferência, Netto publicara um artigo sobre tais tipos de vegetais, na revista Archivos do Museu, que serviu de base para seu curso público, conforme é possível verificar pelo excerto abaixo. No texto científico, ele explicou como se deu o processo adaptativo das plantas sarmentosas.

${ }^{113}$ Diario do Rio de Janeiro, 01/10/1877. 
E efetivamente os sarmentosos são plantas que deviam ter tido primitivamente proporções iguais às dos mais vigorosos $\mathrm{e}$ desenvolvidos arbustos hoje conhecidos, e que habitando as florestas sombrias e compactas das primeiras idades da flora atual, onde não lhes era possível o gozo da luz direta do sol, distenderam-se por uma constante e aturada evolução de todos os tecidos do caule para o só crescimento longitudinal, até que dado lhes foi atingir a copa do arvoredo e expor com as deles suas folhas e vergônteas à elaboração da seiva de que são agentes imediatos os raios solares.

Força é confessar que não há, no reino vegetal, nem vitalidade mais notável, nem mais eloquente exemplificação da adaptação cumulativa; e acrescentarei que nenhum outro fato mais saliente que este, ou igual sequer a ele se nos depara, como prova da luta pela vida, entre as plantas. ${ }^{114}$

A extensão dos caules, com vias a favorecer a planta a atingir regiões mais altas com raios solares, foi apresentada por Netto como uma prova da adaptação e da luta pela existência, neste caso com o meio, que não permitia a chegada da luz. A influência do meio, muito associada a Lamarck, não foi negada por Darwin, que apenas não lhe forneceu o papel exclusivo. Destaca-se aqui, a busca das comprovações empíricas da teoria darwinista, embora estas não fossem o único impulsionador das investigações desenvolvidas pelo diretor do Museu.

No artigo, Netto tem Darwin como interlocutor, especialmente com relação ao trabalho publicado por este sobre as plantas trepadeiras. Em uma nota de rodapé, o diretor do Museu Nacional apresentou sua leitura da obra do naturalista inglês:

Carlos Darwin acredita terem sido primitivamente volúveis todas as plantas trepadeiras, sendo transformações desse tipo original as que possuem atualmente o só movimento revolutivo nos órgãos foliáceos e auxiliares mais ou menos modificados. Segundo os argumentos da doutrina evolutiva não há dificuldade em se admitir que assim fosse; mas baseando-se nas minhas observações in natura sobre tantas centenas de espécies de caules sarmentosos, força é confessar que se vejo, de acordo com a opinião do ilustre naturalista,

\footnotetext{
${ }^{114}$ NETTO, Ladislau. Estudos sobre a morphologia dos tecidos nos caules sarmentosos (continuação da pagina 30). Archivos do Museu Nacional, Rio de Janeiro, Imprensa industrial, vol. I, 1876, p. 133.
} 
nessa incompleta ou imperfeita volubilidade dos caules eretos, vestígios de sua franca espiralização, nada me faz recusar, antes mais prontamente aceitar a hipótese de que, por inaptidão orgânica ou por uma espécie de idiossincrasia, se tal expressão me é permitida, não se puderam de todo submeter estes caules à forma helicoidal dos outros, fazendo-o unicamente os órgãos de tais plantas que mais facilmente se puderam transformar em gavinhas e isso exageradamente, por uma lei compensadora e naturalíssima nos preceitos da evolução. ${ }^{115}$

Netto não concordava com todas as afirmações de Darwin sobre a evolução das trepadeiras. A divergência do pesquisador brasileiro estava fundamentada nas pesquisas que desenvolvia no Museu Nacional. A explicação do motivo pelo qual algumas plantas se enrolavam completamente em torno da base que lhes serviam de suporte e outras não o faziam eram diferentes para ambos. ${ }^{116}$ Isso mostra que, na busca de provas da teoria darwinista, que impulsionavam os estudos de Netto, poderiam existir pontos de discordância com as ideias de Darwin.

Evolução, luta pela existência e adaptação estavam dentre os pressupostos darwinistas aceitos por Netto. Neste sentido, a adaptação foi recorrentemente abordada de modo mais enfático. Nas preleções do curso de botânica realizado no ano de 1878, o pesquisador sublinhou esse ponto, considerado por ele como a proposição basilar do paradigma darwiniano:

Na menção das plantas que caracterizam determinadas estações, tentou explicar o como pela adaptação aos elementos cuja influência geral recebem, passaram, por transformações graduais até chegarem ao tipo que lhes era forçoso viver.

\section{$[\ldots]$}

O professor, desenvolvendo a tese que dá por primeira base das leis transformistas, a adaptação, fez sentir quanto neste particular é admirável o conjunto de circunstâncias de que se socorre a planta para

\footnotetext{
${ }^{115}$ NETTO, Ladislau. Estudos sobre a morphologia dos tecidos..., p. 134.

${ }^{116}$ De acordo com Gualtieri, a argumentação de Netto "não ficou muito clara, mas insistiu no fato de que, tendo se consagrado a examinar os movimentos desses caules, podia concluir que tais movimentos foram produzidos 'de apego aos objetos circunvizinhos'. Assim, essa perfeita adequação que imaginava ter percebido entre a 'necessidade do vegetal' e o tipo de movimento realizado, no caso a espiralização incompleta, parece tê-lo feito acreditar que tal adaptação só poderia ser a original, e não resultante de modificação de um outro tipo de variação, como era a interpretação de Darwin.” GUALTIERI, R. C. E. Evolucionismo no Brasil..., p. 46.
} 
a disseminação de suas sementes, ou tenha o auxílio dos ventos ou o não menos eficaz das águas pluviais e fluviais, ou ainda também o das correntes oceânicas, conforme a configuração das suas mesmas sementes se foi ajeitando a este ou àquele veículo de sua propagação. $^{117}$

Os diversos tipos de disseminação das sementes das plantas foram apresentados por Netto como adaptações feitas pelos vegetais com o intuito de sobreviverem. Novamente, ele evidenciou a influência do meio no processo adaptativo, as plantas recorreriam a diferentes tipos de meio de propagação das sementes em função do tipo de ambiente em que se encontravam.

$\mathrm{O}$ diretor do Museu assinalou que as transformações evolutivas ocorriam de maneira gradual, estando assim em sintonia com o que era sustentado por Darwin. Ao adotar o gradualismo como chave explicativa das alterações, o autor de $A$ origem das espécies entrou em choque com as elucidações essencialistas, que afirmavam que as novas espécies eram novas criações e, assim, as mudanças aconteciam em saltos. Na hipótese essencialista, as espécies novas já eram adaptadas e, portanto, só poderiam ter sido projetadas pelo Criador. ${ }^{118}$ De maneira oposta, Darwin sustentou a existência de modificações graduais das espécies no processo evolutivo. ${ }^{119}$

Ladislau Netto considerava a adaptação como a "primeira base das leis transformistas". ${ }^{120} \mathrm{O}$ conceito de adaptação para Netto estava muito marcado pela maneira que a espécie se adequava ao meio, numa abordagem quase lamarckista. No caso das trepadeiras, eram as plantas que buscavam luminosidade, mas também havia a adaptação às condições climáticas, conforme mostrou o cientista em uma preleção do curso de botânica de 1877:

Em seguida passou a descrever as plantas que caracterizam determinadas estações, e que pela adaptação aos elementos, cuja

\footnotetext{
${ }^{117}$ NETTO, Ladislau. Resumo do curso de botanica do Museu Nacional, em 1878. Archivos do Museu Nacional, Rio de Janeiro, Typographia do Imperial Instituto Artistico, vol. III, 1878, p. 186.

${ }^{118}$ MAYR, E. Biologia, ciência única..., p. 119.

${ }^{119}$ Darwin, no capítulo VII, apresentou os motivos pelos quais as transformações súbitas não poderiam ser consideradas. DARWIN, C. On the origin of species... Para Mayr, "a emergência geral do pensamento populacional em Darwin reforçou sua adesão ao gradualismo. Assim que se adota o conceito de que a evolução ocorre em populações e lentamente as transforma - e era disso que Darwin estava cada vez mais convicto -, é automaticamente forçoso adotar o gradualismo. É provável que gradualismo e pensamento populacional na origem fossem veios independentes no quadro convencional de Darwin, mas ao final eles reforçaram um ao outro de maneira poderosa". MAYR, E. Biologia, ciência única..., p. 121.

${ }^{120}$ NETTO, L. Resumo do curso de botanica do Museu Nacional, em 1878..., p. 186.
} 
influência recebem, passaram por uma evolução notável, sem a qual não poderiam existir, tais são: os mangues, os cactos, algumas plantas aquáticas, os vegetais sarmentosos e outros com cuja descrição deu por finda o professor esta preleção. ${ }^{121}$

A adaptação foi apresentada como primordial para o processo evolutivo. O modo como as plantas se comportavam nas estações do ano, para o diretor do Museu, era um indicativo de sua adequação ao meio e de sua evolução. O pesquisador fornecia um peso significativo para as adaptações ao meio, não dando ênfase a outros tipos de variações. Neste sentido, para Gualtieri, "Ladislau Netto se aproximava de Haeckel, para quem os fatores lamarckistas eram a força geradora da variação que, apesar de ser adaptativa para o indivíduo, passaria pelo teste da seleção natural, quando o organismo entrasse em competição com outras espécies." ${ }^{2122}$

De fato, o conceito de adaptação era importante no sistema darwiniano, pois os tipos mais bem adaptados teriam vantagens durante a seleção natural. ${ }^{123}$ As modificações graduais ocorriam no sentido de adaptar as espécies às condições impostas para sua sobrevivência em determinada situação. Entretanto, o peso fornecido por Netto era muito maior, principalmente no tocante à influência do meio nesta adaptação. Neste sentido, Heloisa Maria Bertol Domingues e Magali Romero Sá afirmam que o evolucionismo sustentado por Ladislau Netto apresentava "pontos convergentes com a teoria lamarckista, como 'herança progressiva' ou 'necessidade de se adaptar ao meio"". ${ }^{124} \mathrm{O}$ diretor do Museu, em suas preleções públicas, mostrava como esses paradigmas do darwinismo atuavam sobre os vegetais por meio de uma interpretação peculiar. Para tal, centrou suas análises em plantas que poderiam colaborar na comprovação empírica da teoria de Darwin, foi o caso, por exemplo, das sarmentosas, constantemente citadas pelo pesquisador:

Como assunto correlativo aos destes confrontos, seja-me dado acrescentar que pouquíssimos são os caules de estrutura anormal que

\footnotetext{
${ }^{121}$ Jornal do Commercio, 27/04/1877.

122 GUALTIERI, R. C. E. Evolucionismo no Brasil..., p. 49.

${ }^{123}$ De acordo com Argueta Villamar, "La selección natural fue propuesta por Darwin, principalmente, para dar cuenta de la organización adaptativa, o 'diseño', de los seres vivos; es un proceso que promueve o mantiene la adaptación. El cambio evolutivo a través del tiempo y la diversificación evolutiva (multiplicación de especies) no están directamente promovidos por la selección natural, pero a menudo resultan como co-producciones de ella." ARGUETA VILLAMAR, A. El darwinismo en Iberoamérica..., p. 72.

${ }^{124}$ DOMINGUES, H. M. B; SÁ, M. R. Controvérsias evolucionistas no Brasil..., p. 108.
} 
se mostram francamente volúveis, sendo que esses mesmos não pertencem à classe das anomalias constitutivas pelos corpos lenhosos independentes; fato este de si curioso e ainda mais para se considerar detidamente por parecer uma prova confirmativa da hipótese de C. Darwin acerca da precessão evolutiva dos sarmentosos volúveis sobre os outros. ${ }^{125}$

A adaptação darwiniana colidia diretamente com as explicações criacionistas, as quais afirmavam que a adaptação das espécies era resultado do papel criador de Deus, que teria projetado os tipos já adequados ao meio. Apesar de compartilhar com este paradigma de Darwin, Netto não excluía a atuação de um Criador, que estaria "dirigindo o processo evolutivo". ${ }^{126}$ Em seu curso de botânica de 1878, ele frisou que "Os vegetais armados deste modo pela natureza para a luta pela vida são os Alexandres e os Napoleões do mundo vegetativo; deu-lhes o Criador toda a energia dos conquistadores e

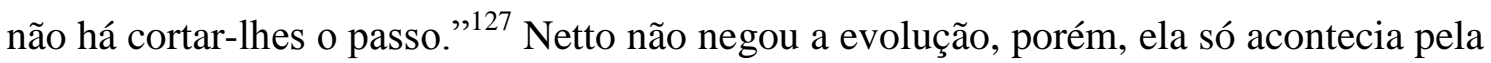
vontade divina. Havia um esforço, por parte do diretor do Museu em "não dissociar o pensamento evolucionista do religioso", ${ }^{2}$ ou seja, era perfeitamente possível conciliar essas duas vertentes e continuar dentro do protocolo da ciência.

A adaptação era tão essencial para Ladislau Netto, que até hábitos culturais eram interpretados por este viés. O uso do tembetá e a aplicação de adornos nasais pelos indígenas eram vistos pelo diretor do Museu como uma falta de evolução.

[...] muito comum é também conseguintemente a privação da sensação do beijo, que o uso daqueles adornos não permitiu, no decorrer de tantos séculos de adaptação, se desenvolvesse ou desabrochasse na evolução fisiológica dos povos que tinham os referidos adornos por costume. $^{129}$

Na sua interpretação, os lábios dos índios não tinham sido adaptados para a função do beijo. Desta maneira, ele estendeu um princípio da teoria biológica da

\footnotetext{
${ }^{125}$ NETTO, Ladislau. Estudos sobre a morphologia dos tecidos..., p. 136.

${ }^{126}$ GUALTIERI, R. C. E. Evolucionismo no Brasil..., p. 51.

${ }^{127}$ NETTO, L. Resumo do curso de botanica do Museu Nacional, em 1878..., p. 198.

${ }^{128}$ GUALTIERI, R. C. E. Evolucionismo no Brasil..., p. 50.

129 NETTO, Ladislau. Ponderações fisiológicas sobre o uso do tembetá. Revista da Exposição Anthropologica Brazileira, jul. 1882, p. 60. Mesma que NETTO, Ladislau. Apontamentos sobre os tembetás (adornos labiaes de pedra) da collecção archeologica do Museu Nacional. Archivos do Museu Nacional, Imprensa Industrial, vol. II, p. 105-164, 1877.
} 
evolução para a compreensão da cultura da sociedade indígena. $\mathrm{O}$ uso de adornos labiais, para Ladislau Netto, além de mania e "lacunas" na moral, indicava uma ausência de afeto entre aqueles que o utilizavam "a completa ausência do gozo do beijo, a ignorância e a privação da sua voluptuosa sensação de amor, ou da sua doce expressão de puríssimo afeto", ${ }^{130}$ imprimindo, assim, um juízo de valor.

Desta maneira, os espectadores dos cursos públicos tinham contato, por meio das preleções do diretor do Museu, com alguns princípios da teoria darwinista - adaptação, seleção natural e evolução - ao mesmo tempo em que esta lhes era apresentada como resultado da ação de Deus. Ele aliava evolução e criação a um mesmo sistema interpretativo.

Contudo, o uso dos princípios do paradigma evolucionista de Darwin por Ladislau Netto não se restringiu à esfera biológica. Em vários momentos, o pesquisador brasileiro fez analogias entre os preceitos científicos darwinianos e a sociedade, indicando que na sua perspectiva era possível analisar questões sociais por meio de um viés evolucionista darwinista. Em uma preleção realizada em 1885, ao tratar da flor e dos cruzamentos exogâmicos ou endogâmicos, Netto enunciou:

Não pense, entretanto, que nada tem que ver aí as leis da evolução. Na seleção da espécie influem os aperfeiçoamentos adquiridos pela exogamia, há sem dúvida nesta endogamia exclusiva, todas as vantagens da consanguinidade dos organismos mais perfeitos. Na mesma humanidade famílias há cuja organização, por perfeita, não repele, antes exige uniões consanguíneas. A transmissibilidade dos caracteres hereditários nesse caso é o veículo da seiva robusta e extrema dos antepassados - seiva nunca degenerada e ao contrário, melhorada às vezes.

Infelizmente são muito raros esses privilegiados da família humana. ${ }^{131}$

Por meio de uma interpretação evolucionista, Ladislau Netto defendeu os casamentos entre indivíduos de uma mesma família. Na sua concepção, entre os homens, os casamentos consanguíneos deviam ser estimulados, porque garantiriam a não degeneração da prole, aliás, favorecendo a melhoria da mesma. Com isso,

\footnotetext{
${ }^{130}$ NETTO, L. Ponderações fisiológicas sobre o uso do tembetá..., p. 60.

131 Jornal do Commercio, 19/10/1885.
} 
novamente, o diretor do Museu Nacional estendeu os conceitos biológicos para uma abordagem social.

Ainda no tocante às analogias entre o mundo vegetal e a vida humana, em 1877, em seu curso de botânica, Ladislau Netto tratou da emigração das plantas e animais:

As emigrações das plantas e dos animais em busca de novos climas, o que sem dúvida lhes é inspirado pela necessidade de encontrarem novos centros de vida, onde as espécies algumas vezes se modificam e melhoram, não podiam deixar de trazer à memória do orador as emigrações das espécies humanas, largo painel em que se desdobra a história da humanidade desde os tempos mais remotos, mas que impropriamente se chamaram fabulosos, até os nossos dias, em que todas as facilidades da civilização parecem convidar o homem a resolver o grande problema da unidade social. ${ }^{132}$

Para Netto, assim como ocorria com os vegetais, os homens se deslocavam à procura de melhores condições de vida. Desta maneira, as emigrações humanas poderiam ser tratadas como um tipo de luta pela sobrevivência, independente dos fatores que impulsionaram o êxodo.

Paralelos entre a esfera biológica e a social também foram feitas por Ladislau Netto em uma conferência proferida, em 1882, na Sociedade Científica Argentina, da qual era sócio correspondente. $\mathrm{O}$ cientista brasileiro estava na capital argentina para realizar uma investigação nos materiais sul-americanos antigos reunidos no Museu de Antropologia de Buenos Aires. Quando foi surpreendido por uma nota, em um jornal local, anunciando uma conferência sua sobre transformismo na referida agremiação científica. Netto disse que fora pego de surpresa, porque o tema escolhido não era exatamente ao que ele se dedicava naquele momento. ${ }^{133}$ No início da década de 1880 ele centrava seus estudos principalmente na arqueologia e na antropologia; no ano desta

\footnotetext{
${ }^{132}$ Gazeta de Noticias, 04/05/1877.

133 O diretor do Museu Nacional expôs esse mal-entendido em uma carta, direcionada ao botânico e médico francês Henri Ernest Baillon (1827-1895), que abriu o pequeno livro contendo a conferência publicada. NETTO, Ladislau. Aperçu sur la théorie de l'evolution. Conférence fait à Buenos-Ayres dans la séance solennelle, célébrée en son honneur par la Société Scientifique Argentine. Le 25 octobre 1882. Rio de Janeiro: Imprimerie du "Messader du Brésil", 1883. "Baillon, professor de história natural da Escola de Medicina de Paris, tinha sido, provavelmente, professor de Ladislau Netto", quando este esteve na França para aprimorar seus estudos em História Natural, entre os anos de 1864 e 1866. DOMINGUES, H. M. B; SÁ, M. R.. Controvérsias evolucionistas no Brasil..., p. 121.
} 
apresentação, 1882, coordenou a Exposição Antropológica Brasileira, realizada no Museu Nacional. Porém, não tendo como recusar, pronunciou o discurso.

Tal conferência foi assim noticiada pelo Jornal do Commercio:

[...] encontramos a sessão solene que, em honra ao hóspede brasileiro, celebrou a Sociedade Científica Argentina no vasto salão do Colyseum com a assistência de mais de mil pessoas, entre as quais contavam-se cerca de trezentas senhoras das mais distintas da capital. [...] Depois de algumas palavras do presidente para a apresentação do Sr. Dr. Ladisláo Netto, membro correspondente, que foi saudado pela assembleia, leu o professor Speggazini em belo trabalho sobre os costumes dos habitantes da Terra do Fogo. Em seguida, conforme o haviam anunciado os jornais do dia, o presidente declarou que, instado pela sociedade, ia ler um trabalho sobre a teoria evolutiva o hóspede brasileiro, que ocupou por mais de meia hora a atenção de todas as pessoas presentes, sendo saudado ao terminar a leitura, e acompanhado até a sua residência por todos os membros da sociedade que tinham comparecido. No dia seguinte a Nación publicou integralmente este discurso, que o general Mitre, redator principal daquele periódico, mandou imprimir em tipo de luxo e em brochura de 500 exemplares que com uma carta muito amável para o nosso compatriota, lhe ofereceu em nome dos amigos que o viajante brasileiro deixava em Buenos Aires. ${ }^{134}$

O periódico brasileiro destacou a grande assistência, bem como a presença feminina. É possível que o jornal que anunciara a conferência, sem o conhecimento de Ladislau Netto, tenha sido o La Nación, uma vez que publicou, no dia seguinte, o discurso na íntegra em uma edição de luxo. O Jornal do Commercio fez questão de ressaltar o prestígio que gozava o cientista brasileiro em terras portenhas.

Seis dias depois, o Jornal do Commercio reproduziu, na seção "Ciências", o discurso do diretor do Museu. Optei por analisar esta versão porque foi a que circulou na Corte. Ao compará-la com a que saiu no periódico da Sociedade Científica, ${ }^{135}$ constatei que eram muito parecidas, a diferença estava em algumas palavras mais

\footnotetext{
${ }^{134}$ Jornal do Commercio, 22/10/1882.

135 NETTO, Ladislao. Observaciones sobre la teoría de la evolución. Anales de la Sociedad Científica Argentina, Buenos Aires, Imprenta de Pablo E. Coni, tomo XIV, p. 147-158, seg. sem. 1882.
} 
rebuscadas que foram adicionadas ao texto em português, de certo consequência do domínio maior do idioma. Logo no início o orador assegurava que o evolucionismo não entrava em choque com a religião:

Conquistadora da razão, ela [teoria da evolução] oferece, no modo rápido pelo qual se assimila no seio da sociedade a mais eloquente prova da sua perfectibilidade, pois que em nenhum ramo dos conhecimentos humanos deixou porventura de insinuar-se, por imperceptível mas crescente adaptação, sem tentar, sequer, estabelecer conflitos na órbita da religião, nem desavir-se com as leis civis da sociedade, antes submetendo-as ao seu irresistível domínio. ${ }^{136}$

Netto deixava claro que, para ele, era possível manter em comunhão o evolucionismo com preceitos religiosos, indicando aqui a sua leitura peculiar da teoria biológica. Nesta mesma edição a folha publicou, na seção "Gazetilha", o seguinte comentário: "Transformista decidido, o Sr. Dr. Ladisláo Netto tem todavia a precaução de colocar a doutrina fora da órbita das religiões. Se o logrou, julguem-no por si mesmo os leitores. Não vemos aqui senão o lado científico." ${ }^{137}$ Isto indica como era delicada a exclusão de explicações religiosas para a criação dos seres. Tanto é, que o periódico se eximiu de fornecer qualquer julgamento. Ao assinalar que abordaria o assunto pelo "lado científico" pretendeu imprimir uma neutralidade ao que lá era exposto.

Na conferência, Ladislau Netto, dentre outros, tratou do que chamou de "seleção intelectual" humana:

[...] a parte mais importante desta ciência, qual é a seleção intelectual do gênero humano, ou o seu desenvolvimento psicológico a que mais acertadamente deveramos [sic] chamar de evolução social.

É claro que a inteligência humana se ampliou tão espantosamente, desde o homem habitante das cavernas até os dos nossos dias, que fora talvez preciso, para maior clareza do ensinamento do transformismo, preestabelecer e tornar bem patente uma subdivisão distinta para essa seleção psíquica, que foi a parte mais importante do aperfeiçoamento do indivíduo - homem; - esse mais complexo e mais adiantado na escala zoológica. E perdoai-me,

\footnotetext{
${ }^{136}$ Jornal do Commercio, 28/12/1882.

137 Jornal do Commercio, 28/12/1882.
} 
senhores, se vos pareço exagerado no que vos aqui exponho, mas deveis confessar que estudados detidamente os organismo na sua ascendência gradual, e bem apreciadas as faculdades superiores que logrou adquirir a raça indo-germânica - máxima expressão do aperfeiçoamento humano, - como que achamos maior diferença entre os mais cultos e mais belos tipos desta raça e os mais imperfeitos e bestiais representantes humanos, do que entre estes últimos e os gorilas e chipanzés. ${ }^{138}$

$\mathrm{Na}$ interpretação do diretor do Museu, a seleção intelectual ou psíquica do homem era o mesmo que evolução social, indicando que em seu tratamento analítico era possível aplicar os conceitos evolucionistas de Darwin à sociedade. Para Netto, o homem era o mais adiantado de todos os animais existentes e havia passado por um processo evolutivo no tocante à inteligência. A evolução aqui foi concebida como vinculada ao conceito de progresso, ou seja, as transformações teriam ocorrido num sentido de uma posição intelectualmente inferior para uma superior, desde os habitantes das cavernas até aqueles que viviam na contemporaneidade. Esta seleção intelectual teria sido fundamental na evolução humana, considerada por ele como a mais importante que qualquer outra categoria de seleção. Isto sugere que para Netto, a inteligência era uma das características essenciais que diferenciava o homem dos outros animais.

De acordo com Netto, havia uma escala hierárquica de inteligência segundo critérios de cunho racial, os indo-germânicos eram tidos como superiores, mais evoluídos, a "máxima expressão do aperfeiçoamento". Em oposição a estes estavam os "mais imperfeitos e bestiais representantes humanos", que, por sua vez, estariam mais próximos dos antropoides do que dos suprassumos da humanidade, os indo-germânicos. O padrão classificatório utilizado foi o linguístico. Embora Netto tenha utilizado o termo indo-germânico, certamente ele se referia ao tronco linguístico ariano, denominado naquela época de indo-europeu. As discussões e análises filológicas e linguísticas, desde o Iluminismo, giravam em torno de uma hierarquização das línguas e das civilizações, muitas com o intuito de estabelecer uma escala evolutiva fundamentada nesses critérios. Desta maneira, existia uma vinculação entre a origem da espécie humana e a da língua. Por meio de aproximações e analogias, estabeleceu-se o

${ }^{138}$ Jornal do Commercio, 28/12/1882. 
tronco linguístico indo-europeu, que passou a ser relacionado com a raça ariana. ${ }^{139}$ Netto não explicitou quem seriam as bestas não evoluídas, mas certamente estas não eram brancas.

Mais de uma vez, em seu discurso, o cientista confrontou o desenvolvimento e o modo de sobrevivência das plantas com os dos homens. Comparou a vida dos vegetais que habitavam as altas montanhas com a de proletários:

[...] é que aqueles pobres e rudes proletários são os descendentes de milhares de gerações como eles proletárias e como eles condenados a colonizar, de pais a filhos, aqueles ásperos cabeços de penedias. Mas tranquilizai-vos sobre a sorte destes heroicos montanheses! Eles não morrerão ao frio das irradiações noturnas, tão temerosa nos visos das serras; nem sucumbirão de frio aos rijos ventos das cordilheiras, porque se seus valentes antepassados e de muitos séculos atrás, aprenderam a lutar com os desabrimentos dos ardores do estio e com as inclemências dos regelos do inverno. ${ }^{140}$

Assim como as plantas que habitavam as regiões de difícil sobrevivência, os proletários estavam em tais condições porque a ancestralidade os condenou, ou seja, eles já nasciam fadados a viverem daquela maneira. Com isso, Ladislau Netto naturalizou os problemas sociais que os membros da classe proletária poderiam ter. Assinalou que não era necessário ter compaixão, pois tais proletários já haviam aprendido, com seus antepassados, a resistirem às adversidades que lhes eram impostas. A analogia também foi feita com os povos serranos:

Acabo de esboçar-vos, em cores verdadeiras, ainda que com traços incorretos, a luta que, pela existência, sustentam com os frios do inverno e com os ventos das montanhas, mal nutridos, raridispostos e sem nenhum conforto, os vegetais que são, na sua esfera e no seu mundo fitológico, a fiel imagem dos povos serranos, dos montanheses pobres que vivem em eterna peleja com a inditosa sorte de sua existência. $^{141}$

\footnotetext{
${ }^{139}$ POLIAKOV, L. O mito ariano...

140 Jornal do Commercio, 28/12/1882.

141 Jornal do Commercio, 28/12/1882.
} 
Os montanheses pobres, a despeito da desafortunada vida, conseguiam sobreviver. A luta pela existência ocorria contra as condições climáticas, sugerindo, mais uma vez, a preponderância dada ao meio por Ladislau Netto. Resistir àquelas situações mostrava que os habitantes serranos haviam tido êxito nesta luta.

O diretor do Museu Nacional assegurou que a luta pela existência não era um princípio que norteava apenas os vegetais, ele poderia ser estendido aos outros seres viventes:

Não imagineis, entretanto, que só eles lutam, que só eles sofrem. A struggle for life é o fatal atributo de tudo o que vive. [...]

E de fato, estas contendas e estas disputas [dos vegetais] não são como as dos míseros campônios, esforços feitos, nem contra os frios do inverno, nem contra os ventos da cordilheira, nem a fim de obter o parco alimento do solo estéril das montanhas. São como as das demandas que pleiteiam entre si as pessoas abastadas famílias aristocráticas e poderosas a quem não bastam os tesouros acumulados pelos antepassados, porque a sua aspiração há por fito a satisfação do seu orgulho e a exaltação da sua vaidade.

O high-life das florestas, como a fidalguia das grandes cortes europeias, vive a fazer os mais ingentes esforços e a empregar os maiores empenhos para receber o influxo direto do seu soberano, e para que os sorrisos e os olhares protetores e vivificantes da poderosa majestade se lhes poupem benignos, a cada instante, sobre a face.

O soberano que, por idealização, acabo de dar aqui às plantas florestais, é o Sol: e acreditai que esta imagem é a mais perfeita e natural figura da realidade. [...] longas horas de observação dediquei ao estudo deste fenômeno e asseguro-vos que nenhum outro, nem com mais eloquência, nem com maior precisão, fora capaz de pintar tão ao vivo as várias paixões, as inumeráveis pretensões e as não menos indescritíveis animosidades de uma corte. ${ }^{142}$

A luta pela existência dos vegetais, contra as adversidades climáticas e alimentícias, não poderia ser comparada com a dos camponeses, mas sim com a dos poderosos aristocratas. Assim, no entender de Ladislau Netto, os problemas enfrentados

${ }^{142}$ Jornal do Commercio, 28/12/1882. 
pelas camadas mais pobres, neste caso os "míseros campônios", eram menores ou até insignificantes quando confrontados com aqueles vivenciados pelos mais abastados da sociedade.

Netto se referiu à luta pela existência na vida cortesã. A aristocracia, para sobreviver e conseguir seus luxos, tinha que estar sempre próxima do soberano, mostrando-se presente e fazendo por merecer suas benesses. O cientista usou como exemplo as cortes europeias, mas de certo estava aludindo ao Brasil. Como o Museu Nacional era mantido pelo governo, contando com o apoio direto do Imperador, por motivos óbvios, ele não deveria explicitar essa alusão. Indispor-se com o poder imperial poderia gerar sérios problemas tanto para ele quanto para o Museu. É possível que o cientista tenha bajulado muito o soberano brasileiro para conseguir verbas e autorizações para a instituição e, em consequência disso, tenha utilizado daquela analogia para exprimir sua insatisfação por ter se sujeitado a tal situação.

Em outro momento, Ladislau Netto estabeleceu uma relação comparativa entre as plantas sarmentosas e os servos medievais:

Começarei dizendo-vos que uma série de observações e de experiências me fez ver como as plantas sarmentosas são vegetais arbustíveis condenados a viver ao pé das grandes gigantes das matas seculares, isto é: a morrer suplantados e amesquinhados, como os antigos servos da gleba, escravizados junto dos antemurais dos castelos dos senhores feudais da idade média. Muitos dos pobrezitos sucumbiram abafados pela densa folhagem dos poderosos vizinhos; alguns, porém, dentre eles resistiram e deixaram filhos, a quem transmitiram sucessivamente, e em progressão ascendente, a coragem, a robustez e, o que mais é, o espírito de vingança contra a prepotência dos déspotas. ${ }^{143}$

Cotejou a luta pela sobrevivência e a seleção dos mais aptos das plantas sarmentosas com a condição de vida dos servos de gleba. Estes não tinham como ascender socialmente, impedidos pelos senhores feudais. Netto referiu-se aos servos como escravizados, o que pode ter sido intencional. Mais uma vez, merece destaque aqui o fato de que o exemplo dado estava relacionado a uma realidade que não a do

${ }^{143}$ Jornal do Commercio, 28/12/1882. 
Brasil daquele momento. A sujeição vivida pelo servo medieval poderia ser comparada com a do escravo brasileiro daquele momento. Certamente, o pesquisador do Museu achou mais prudente citar exemplos de realidades distantes geográfica e historicamente, mesmo sabendo que as analogias com Brasil poderiam ser feitas por seus patrícios contemporâneos.

Com relação ao poligenismo, Ladislau Netto também compartilhava da crença nesta teoria, principalmente para explicar a origem do homem na América. Apesar de admitir que os poligenistas não tenham ofertado grande contribuição à antropologia. Destacou, inclusive, que sem que fosse sua intenção, forneceu argumentos contrários ao poligenismo.

Cabe-me contudo ponderar que das duas grandes classes em que se dividem os antropologistas, não creio ser a dos poligenistas a que maior e mais valioso quinhão tenha de respingar na messe que aí exponho às vistas dos dois grupos. Não sou suspeito nesta matéria em que até aqui me ei aliás mostrado mais inclinado ao autoctonismo americano; e embora o fosse, corre-me o dever de declarar que durante todo o tempo que empreguei no exame e na coordenação dos objetos aqui descritos e figurados, sempre me ative à mais escrupulosa reserva, evitando que de modo algum interviesse a menor sombra das minhas próprias prevenções. Lanço, porém, agora os olhos sobre a quota parte contributiva da minha tarefa no comum repositório em que assenta a etnologia do Novo Mundo e vejo que, mau grado meu, ou inesperadamente pelo menos, forneci talvez argumentos contrários à escola autóctone-poligenista americana a que eu quisera pertencer e a cuja frente vejo fulgir o vulto respeitável de Agassiz. Não é raro, porém, observar-se que onde maior força parecem ter os argumentos em favor de uma determinada ideia, encontra a ideia contrária as suas melhores armas defensivas e até agressivas. ${ }^{144}$

Segundo o diretor do Museu, o homem americano era autóctone, ou seja, teria tido um centro de criação na América que havia originado os habitantes desta parte do mundo. Ele conseguiu conciliar o evolucionismo, marcado por alguns princípios de

\footnotetext{
${ }^{144}$ NETTO, Ladislau. Investigações sobre a archeologia brazileira. Archivos do Museu Nacional, Rio de Janeiro, Typ. Economica de Machado \& C., v. VI, 1885, p. 259. Grifos meus
} 
matriz darwiniana, com o poligenismo. Entretanto, o cientista assinalava que eram necessárias mais evidências empíricas para determinar os "centros de criação" ou "estações de aparecimento" do homem na América. ${ }^{145}$ Assim, em seus cursos públicos, Ladislau Netto apresentou uma concepção muito peculiar do evolucionismo, baseado em alguns fundamentos darwinistas, como a luta pela sobrevivência e adaptação, esta muito pautada pela influência do meio, aliada ao poligenismo. Fez uso dessas ideias para analisar questões sociais, ampliando, desta maneira, paradigmas de uma teoria biológica para a interpretação da sociedade. Expôs também suas crenças nas múltiplas criações e no autoctonismo do homem americano.

Outro conferencista a tratar do darwinismo no Museu Nacional foi o médico João Joaquim Pizarro, em seu curso de zoologia. Com o talento da oratória, recebeu críticas de seu colega João Baptista de Lacerda com relação ao modo como apresentava as suas preleções: "Pizarro mostrou ser mais um bom conferente do que um professor técnico. Suas conferências visavam sempre assuntos genéricos que ele estendia com uma linguagem correntia, juntando-lhe o sal de uma anedota, uma pilheria ou uma alusão hilariante." ${ }^{146}$ Este modo mais extrovertido de apresentar os discursos também foi ressaltado pela Gazeta de Noticias, ao referir-se a Pizarro como "simpático orador". ${ }^{147}$ Apesar de Lacerda afirmar que, em suas conferências o responsável pelo curso de botânica apresentava o conteúdo de maneira genérica, esse mesmo jornal enfatizou que o preletor "mostrou-se, como sempre, profundo conhecedor da matéria que estuda", ${ }^{148}$ indicando que a apresentação fora feita de maneira pormenorizada. A apreciação da folha se mostrou destoante daquela manifestada por Lacerda.

Pizarro se dizia sectário do evolucionismo de Darwin e, segundo Lacerda:

Com seu radicalismo transformista exagerado ele escandalizou por mais de uma vez, o auditório feminino, frisando as linhas e os pontos de contato que existem entre o homem e o macaco. A impressão que isso produziu no ânimo de algumas damas presentes às conferências fê-las desertar do Museu, comprovando-se assim, ainda

\footnotetext{
${ }^{145}$ NETTO, L. Investigações sobre a archeologia brazileira..., p. 259.

${ }^{146}$ LACERDA, J. B. de. Fastos do Museu Nacional..., p. 60.

${ }^{147}$ Gazeta de Noticias, 04/05/1878.

${ }^{148}$ Gazeta de Noticias, 18/05/1877.
} 
uma vez a impossibilidade de reconciliar-se a ciência com a vaidade feminina e com os preconceitos humanos. ${ }^{149}$

Com relação às impressões femininas sobre o darwinismo, em 1875, quando Miranda Azevedo levou imagens de embriões humanos e de cachorros em sua conferência sobre darwinismo, o jornal $O$ Apostolo sinalizou para uma situação constrangedora que pode ter passado a Imperatriz ao ver as ilustrações, sugerindo que as mulheres sentiram-se incomodadas com a exposição. ${ }^{150} \mathrm{Na}$ mesma esteira de pensamento, Moema Vergara analisa a série de cinco artigos intitulados "O darwinismo: cartas a uma senhora”, publicanos em $O$ Vulgarizador entre 1877 e 1878, assinados por João Zeferino Rangel S. Paio, nos quais ele explicava o darwinismo a uma senhora, D. Julia. A autora aventa a hipótese que esta mulher "seria uma construção de Rangel S. Paio, talvez até decalcada das mulheres da Corte que frequentavam os cursos públicos do Museu Nacional ou as Conferências da Glória." "151 Segundo Paio, na primeira carta datada de novembro de 1877, fora uma conferência de Saldanha da Gama que o impulsionara a escrever os artigos. ${ }^{152}$ José de Saldanha da Gama efetuara em novembro daquele ano uma preleção na Escola da Glória (mas não integrante das Conferências Populares), intitulada "Leis gerais que presidem a vida das plantas". ${ }^{153}$ Porém, como argumenta Vergara, é possível que suas cartas estivessem relacionadas às outras preleções públicas que ocorriam naquele momento e também abordaram o darwinismo. ${ }^{154}$

Neste sentido, a audiência de uma preleção de Pizarro, 1877, foi comentada pelo jornal Gazeta de Noticias, que salientou o numeroso auditório, mas com pouca presença feminina. ${ }^{155}$ Evidenciar a pouca quantidade de mulheres pode ser um indício de que elas estavam evitando as apresentações do cientista do Museu, estando tal posicionamento em sintonia com o que fora afirmado por Lacerda.

\footnotetext{
${ }^{149}$ LACERDA, J. B. de. Fastos do Museu Nacional..., p. 60.

${ }^{150}$ CARULA, K. A tribuna da ciência..., p. 111.

151 VERGARA, Moema de Rezende. "Cartas a uma senhora": questões de gênero e a divulgação do darwinismo no Brasil. Estudos Feministas, Florianópolis, n. 15, v. 2, maio-ago. 2007, p. 385.

${ }^{152} O$ Vulgarizador, n. 13, 10/11/1877.

${ }^{153}$ Saldanha da Gama efetuou três preleções nas Conferências Populares, 1874, duas na Escola da Glória, 1877, e uma na Escola Politécnica, 1878, em todas versou sobre botânica. As conferências encontram-se listadas nos Anexos 3 e 4.

${ }^{154}$ VERGARA, M. R. de. "Cartas a uma senhora”...

${ }^{155}$ Gazeta de Noticias, 04/05/1877.
} 
O resumo desta mesma conferência foi apresentado no jornal Gazeta de Noticias, no folhetim "Digressões científicas", assinado por Varuna. Em tal preleção, Pizarro discorreu sobre o aparelho digestivo animal e declarou-se

[...] francamente partidário da doutrina de Darwin, como a única que até este momento explica os mais importantes fenômenos da vida na série animal.

Lamentou que os teimosos preconceitos de um mal entendido espírito religioso, embaraçassem a propagação de certas doutrinas científicas, [já ?] de certas verdades que a observação e a experiência puseram hoje fora de toda a dúvida, em detrimento das vantagens sociais que sem dúvida resultariam da generalização destas ideias.

Para Pizarro, o impedimento da franca propagação dos princípios darwinistas era consequência de uma preconceituosa visão religiosa. Esta atravancava a divulgação ampla da teoria de Darwin. Na intepretação do cientista existiria certo maquiavelismo religioso na rejeição.

Ao continuar a preleção,

Aceitando a teoria Darwiniana, o Sr. Dr. Pizarro mostrou-se franco, explícito, convencido [...]

O espaço de que dispomos não nos permite acompanhar o ilustre professor, ao menos nos tópicos do seu discurso que se tornaram mais salientes, assim como nas sensatas observações e comparações que fez entre as condições da vida de certos animais inferiores e as suas relações com as tendências de algumas castas ou grupos da família humana; mas para se fazer ideia do interesse que o Sr. Dr. Pizarro sabe despertar em seu auditório, basta dizer que depois de uma hora de preleção aqueles que tiveram a fortuna de ouvir retiraram-se agradavelmente impressionados. ${ }^{156}$

Por meio do pequeno comentário, é possível supor que Pizarro tenha expandido as explicações biológicas, uma vez que ele comparou a vida de alguns "animais inferiores" com a de determinadas "castas ou grupos da família humana". Ou seja, a

\footnotetext{
${ }^{156}$ Gazeta de Noticias, 04/05/1877.
} 
análise não ocorreu no sentido de incluir toda a humanidade no reino animal, mas apenas a parcela que pudesse ser relacionada com os animais inferiores.

O resumo da conferência seguinte também foi noticiado na mesma seção da Gazeta de Noticias. Nesta apresentação,

Adotando a doutrina evolucionista, como ponto de partida e base de seus estudos, o Sr. Dr. Pizarro não pretende fundar escola, mas entende ser obrigado a não recusar a verdade dos fatos e das observações dos naturalistas modernos, quando mesmo vão eles de encontro a preconceitos que só na ignorância ou em opiniões preconcebidas podem ter seu fundamento e origem. ${ }^{157}$

Na preleção, Pizarro expôs seu apreço pelo evolucionismo. Para o pesquisador, aqueles que criticavam esta teoria eram preconceituosos e ignorantes. Tais opiniões não atrapalhariam o seu objetivo, qual seja, apresentar os paradigmas evolucionistas, considerados como verdades absolutas.

Quando a ciência descobre novas verdades e estas penetram com mais ou menos resistência nos domínios das conquistas intelectuais, o espírito humano tem infalivelmente de mais cedo ou mais tarde quebrar o molde das ideias até então consagradas para vazá-las em outra forma mais ampla e mais adequada.

Cita o distinto professor a este respeito a comparação de um notável homem de ciência inglês a respeito das necessárias evoluções do progresso intelectual. ${ }^{158}$

O homem de ciência referenciado por Pizarro era Darwin. Fez uma analogia entre o desenvolvimento da teoria darwinista com o próprio processo evolucionista. $\mathrm{O}$ naturalista inglês teria realizado uma "evolução no progresso intelectual", o conceito de evolução, na interpretação do conferencista estava associado à ideia de progresso.

Para encerrar o artigo, o autor disse: "Terminaremos, finalmente, esta curta digressão, transcrevendo as palavras em que Haeckel consubstancia a doutrina de que o

\footnotetext{
${ }^{157}$ Gazeta de Noticias, 18/05/1877.

${ }^{158}$ Gazeta de Noticias, 18/05/1877.
} 
Sr. Dr. Pizarro se tem feito tão eloquente interprete". ${ }^{159}$ Não posso afirmar que o cientista do Museu tenha substanciado sua análise em Haeckel. Entretanto, é possível verificar que o sujeito que escreveu aquele folhetim associou as ideias apresentadas por Pizarro com as do evolucionista alemão.

No único artigo de Pizarro, publicado na revista Archivos do Museu Nacional, logo no início, ele perpassou pela teoria darwinista:

A doutrina do transformismo, tão habilmente sustentada pelo professor Darwin, já prevista e aceita por não pequeno número de naturalistas antigos, e há, pouco mais de meio século logicamente apresentada ao mundo científico por Lamarck, tem se constituído com o desenvolvimento à ela dado pelo naturalista inglês, o assunto das meditações e pesquisas dos sábios de nossos dias. Generalizada por alguns espíritos ousados tem-se procurado dar-lhe uma tal atitude que certo não comportam ainda os nossos conhecimentos atuais. Estabelecida depois de longo e afanoso trabalhar em objetos de pura observação e experiência, repetidas e multiplicadas pelo gênio indagador de notáveis colaboradores, parece achar esta teoria apoio no movimento intelectual, que ao nosso século tem imprimido os conhecimentos hodiernos. ${ }^{160}$

Pizarro não deixou claro se considerava como diferenciados o evolucionismo de Darwin e o postulado por Lamarck. Garantiu que fora o naturalista inglês quem colaborou de maneira significativa para que a teoria evolucionista se propagasse e se tornasse assunto de interesse entre os cientistas.

Com relação à propagação do paradigma darwiniano no Brasil, Pizarro exclamou:

O bom caminho e o progressivo desenvolvimento que começa a ter no Brasil o estudo das ciências naturais, graças à paternal solicitude do seu Imperante, pode-se dizer que é em boa parte devido ao impulso grandioso que ao movimento científico deste país deu o

\footnotetext{
${ }^{159}$ Gazeta de Noticias, 18/05/1877.

160 PIZARRO, João Joaquim. Nota descriptiva de um pequeno animal extremamente curioso e denominado Batrachychthis. Archivos do Museu Nacional, Rio de Janeiro, Imprensa Industrial, v. I, 1876, p. 31.
} 
gênio de Darwin com a publicação do seu trabalho sobre a Origem das espécies. Verdadeiro monumento da paciência e de gênio veio este livro despertar a atenção dos povos do continente sul-americano cujos filhos pareciam dormir o sono da indiferença sobre o mundo de preciosidades que entesouram as duas terras. ${ }^{161}$

A publicação de A origem das espécies, para Pizarro, teria impulsionado significativamente o desenvolvimento das ciências naturais no Brasil. Na tentativa de elevar o trabalho de Darwin, o pesquisador do Museu minimizou as pesquisas anteriores à referida obra do naturalista inglês.

Pizarro enalteceu a figura do Imperador como incentivador das práticas científicas no país. Da maneira como foi apresentado pelo cientista, pode-se dar a entender que o governante brasileiro era partidário do paradigma de Darwin, o que era justamente ao contrário. Domingues e Sá, ao analisarem a correspondência trocada entre D. Pedro II e Quatrefages, constataram que o monarca, até a sua morte, abraçou as propostas contrárias ao darwinismo sustentadas pelo naturalista francês. $\mathrm{O}$ apoio à teoria não se deu apenas em termos de adesão intelectual, Pedro II enviou, via Museu Nacional, "ossos e materiais indígenas para serem analisados". ${ }^{162}$

Neste artigo, Pizarro declarou admirar os trabalhos de Darwin e de Haeckel, o que sugere que sua interpretação da teoria do naturalista inglês poderia estar marcada por princípios haeckelianos, como, por exemplo, de uma aplicação social do darwinismo.

Pizarro, no texto da revista Archivos do Museu Nacional, analisou uma forma animal que poderia ser um tipo intermediário que ajudasse a comprovar experimentalmente as assertivas darwinianas, o que mostra o esforço de combater as críticas direcionadas à teoria de Darwin. Entretanto, conforme afirma Gualtieri, “observando-se as ilustrações que acompanham o artigo, não é difícil perceber que se trata de uma larva de anfíbio em processo de metamorfose." O trabalho foi posteriormente criticado por expor ao ridículo a publicação científica do Museu Nacional. $^{163}$

Assim, ao assistir os cursos públicos do Museu Nacional e as conferências públicas, a sociedade carioca que frequentava tais espaços teve contato com princípios

\footnotetext{
${ }^{161}$ PIZARRO, J. J. Nota descriptiva de um pequeno animal..., p. 31.

162 DOMINGUES, H. M. B.; SÁ, M. R. Controvérsias evolucionistas no Brasil..., p. 101.

${ }^{163}$ GUALTIERI, R. C. E. Evolucionismo no Brasil..., p. 57.
} 
da teoria de Darwin, apresentados por meio de leituras específicas e ressignificadas. Expor o darwinismo nestes locais era estratégico, uma vez que tais espaços caracterizaram-se por serem vulgarizadores da ciência. A discussão de teorias científicas modernas, como o darwinismo, era salutar na medida em que estas poderiam colaborar para a modernização do país, ajudando na promoção do progresso e da civilização.

Ao fazer um balanço de como o darwinismo foi tratado nas preleções, observo que houve maior aceitação que rejeição. Feliciano de Bittencourt foi o orador que mais se pronunciou avesso ao paradigma de Darwin, fora ele apenas outros poucos tangenciaram o assunto, mostrando-se contrários. Em todos eles, o ponto crucial para a recusa ao darwinismo era a exclusão do papel de Deus na criação. Questão que não foi problemática para Ladislau Netto, que conseguiu conciliar o evolucionismo darwinista com a ação de um Criador. A compreensão do sistema de Darwin era feita por meio de filtros. Preceitos de Lamarck e Haeckel apareciam imbricados ao darwinismo enunciado naqueles espaços públicos de vulgarização científica, tanto por quem defendia as ideias como por aqueles que lutavam contra. O lamarckismo esteve presente em Ladislau Netto, que enfatizou a influência do meio, e em Miranda Azevedo, que sublinhou a questão do uso e desuso. Já o haeckelismo marcou as preleções de Pizarro e Miranda Azevedo. O darwinismo discorrido nas apresentações do Museu era resultado das investigações desenvolvidas por aqueles pesquisadores, muitas das quais pretendiam encontrar provas empíricas que atestassem as proposições do paradigma de Darwin. Entretanto, o sistema do naturalista inglês não ficou restrito às interpretações do mundo biológico, foi estendido também para a esfera social, principalmente por Miranda Azevedo e Ladislau Netto, indicando, assim, uma apropriação e ressignificação dos princípios darwinista para analisar e justificar questões que atingiam a sociedade. 


\section{III - A raça em foco}

\section{Concepções sobre raça}

Temáticas relativas à raça estiveram presentes em várias falas dos conferencistas que se apresentaram nos espaços públicos de vulgarização científica aqui analisados. $\mathrm{O}$ termo raça, muitas vezes apresentado sem uma definição prévia, tinha significados diversos conforme quem expunha a preleção. Vale, entretanto, antes de analisar de que modo as questões referentes à raça apareceram nos discursos desses sujeitos, realizar uma breve reflexão sobre o tema.

Ao estudar a história do branqueamento, com ênfase no negro, o pesquisador Andreas Hofbauer evidencia a disputa existente entre os intelectuais acerca das mudanças semânticas do vocábulo raça ocorridas ao longo dos tempos, afirmando que, em seu surgimento, o termo não esteve relacionado a classificações humanas pautadas em diferenças de cor de pele, ou em outros "critérios fenotípicos". ${ }^{1}$ Hofbauer assegura que pertencer ou não ao mundo cristão era, no século XVI, o paradigma mais relevante; só posteriormente outros critérios, como a cor, ganharam relevo. Ser branco era, naquele momento, ser cristão, em oposição aos “pagãos, muçulmanos, judeus, etc.”. 2

Segundo Kabengele Munanga, nos séculos XVI e XVII as relações entre as classes sociais francesas passaram a sofrer atuação do conceito de raça; a nobreza, por se identificar com os francos, considerava-se de "sangue puro", em contraposição à

\footnotetext{
${ }^{1}$ HOFBAUER, Andreas. Uma história do branqueamento ou o negro em questão. São Paulo: Editora Unesp, 2006, p. 100. De acordo com Hofbauer, alguns estudiosos sustentam que o vocábulo raça teria origem no termo de ascendência latina ratio, cujo significado é "ordem, razão, modo, espécie". Outros, todavia, asseveram que o mesmo estaria vinculado à palavra árabe $r a$ 's, que significa "cabeça, chefe do clã" e, além de mostrar a ascendência de um indivíduo, "determinava seus papéis sociais". Foi na época da Reconquista que o termo passou a ser utilizado na Península Ibérica, inicialmente "nobres portugueses e espanhóis recorriam ao termo raça (raza) para - de forma semelhante ao uso árabe-beduíno - destacar sua origem, sua descendência”. HOFBAUER, A. Uma história do branqueamento..., p. 100.

${ }^{2}$ HOFBAUER, A. Uma história do branqueamento..., p. 88.
} 
plebe, identificada com os gauleses. ${ }^{3}$ Christian Delacampagne afirma que na França daquele período a palavra raça era empregada em "expressões como: 'raça boa', 'raça má', 'raça maldita', 'raça dos reis', 'nobre raça', 'raça de David', 4

Em sua concepção moderna, assevera Léon Poliakov, o termo raça data de 1684, quando o médico francês François Bernier (1625-1688), na obra Nouvelle division de la terre, par les diferentes espèces ou races d'hommes qui l'habitent, empregou-o para classificar a humanidade em "quatro ou cinco raças de homens", usando critérios como a "cor da pele e outros traços físicos" aliados a "dados geográficos e espaciais". 5

Foi durante o Iluminismo, entretanto, que as análises classificatórias começaram a se desenvolver mais extensamente. $\mathrm{O}$ conceito de raça nas ciências naturais esteve vinculado à necessidade de classificação das espécies, tanto vegetais quanto animais. Observar o mundo ao redor e separar seus integrantes em grupos com determinadas características comuns era fundamental para a melhor compreensão do todo. Nesta perspectiva, Carl von Linné (1707-1778), conhecido em português como Carlos Lineu, desenvolveu na obra Systema Naturae (1735) seu consagrado sistema taxonômico. Neste esquema o naturalista sueco integrou o homem ao reino animal, estabelecendo quatro variedades humanas. ${ }^{6}$

Sobre classificar a humanidade, Munanga destaca:

Os conceitos e as classificações servem de ferramentas para operacionalizar o pensamento. É neste sentido que o conceito de raça e a classificação da diversidade humana em raça teriam servido.

\footnotetext{
${ }^{3}$ MUNANGA, Kabengele. Uma abordagem conceitual das noções de raça, racismo, identidade e etnia. Palestra proferida no $3^{\circ}$ Seminário Nacional Relações Racial e Educação - PENESB-RJ, 05/11/03. Disponível em: 〈http://www.ufmg.br/inclusaosocial/?p=59>. Acesso: 08 dez. 2011. Uma discussão acerca da contenda francesa entre aqueles que se diziam descendentes de francos e os que tomavam para si a linhagem gaulesa pode ser encontrada em: POLIAKOV, Léon. $O$ mito ariano. Tradução de Luiz João Gaio. São Paulo: Perspectiva, Editora da Universidade de São Paulo, 1974, em especial o Capítulo 2 da Parte I - "França: A Querela das duas Raças".

${ }^{4}$ AZEVEDO, Célia Maria Marinho de. Para além das "relações raciais"; por uma história do racismo. In: Anti-racismo e seus paradoxos: reflexões sobre cota racial, raça e racismo. São Paulo: Annablume, 2004, p. 118.

${ }^{5}$ POLIAKOV, L. O mito ariano..., p. 118.

${ }^{6}$ Essa ordenação, afora a cor da pele, englobava atributos morais: "Europaeus albus: ... engenhoso, inventivo... branco, sangüíneo... É governado por leis. Americanus rubesceus: contente com sua sorte, amante da liberdade... moreno, irascível... É governado pelos costumes. Asiaticus luridus: ... orgulhoso, avaro... amarelado, melancólico... É governado pela opinião. After niger: ... astuto, preguiçoso, negligente... negro, fleumático... É governado pela vontade arbitrária de seus senhores." POLIAKOV, L. O mito ariano..., p. 137.
} 
Infelizmente, desembocaram numa operação de hierarquização que pavimentou o caminho do racismo. ${ }^{7}$

A racialização da humanidade iniciou-se em meados do Setecentos, ganhando extraordinária força no século seguinte. Tzvetan Todorov salienta a diferença entre o racismo e o racialismo, este relacionado "às doutrinas" e o primeiro ao “comportamento". Na avaliação de Todorov, o "racismo é um comportamento antigo e de extensão provavelmente universal; o racialismo é um movimento de idéias nascido na Europa ocidental". 8 Em sua interpretação, as doutrinas racialistas, para serem caracterizadas desta maneira, devem conter as seguintes proposições: "existência das raças", "continuidade entre o físico e o moral", "ação do grupo sobre o indivíduo", "hierarquia universal dos valores" e "política baseada no saber".

Ao analisar as formulações do racialismo, Todorov considera o conde de Buffon (1707-1788), e sua obra Histoire naturelle, générale et particulière (1749), como o mais importante expoente dentre os que desenvolveram teorias racialistas no século XVIII, principalmente devido à influência de suas ideias nas produções posteriores. Para o naturalista francês, a hierarquia humana fundamentava-se na sociabilidade e na racionalidade, que estariam presentes em maior ou em menor quantidade. Desta maneira, os homens poderiam ser classificados de acordo com o seu grau de civilização e polidez, em oposição à barbárie e à selvageria. Buffon estabeleceu também uma relação entre esses parâmetros e a cor da pele; com isso, o físico e o moral estariam vinculados. ${ }^{9}$ De acordo com Hofbauer, Buffon utilizou indiscriminadamente, quase como sinônimos, os "conceitos de espèce, race e variété". ${ }^{10}$

No século XIX, os discursos racialistas fizeram parte das abordagens de diversos pensadores das ciências naturais e sociais. Fosse pelo viés monogenista ou pelo poligenista, ${ }^{11}$ os trabalhos analisavam os meios natural e social, hierarquizavam a

\footnotetext{
${ }^{7}$ MUNANGA, K. Abordagem conceitual das noções de raça...

${ }^{8}$ TODOROV, Tzvetan. Nós e os outros: a reflexão francesa sobre a diversidade humana. Tradução de Sergio Goes de Paula. Rio de Janeiro: Jorge Zahar, 1993, p. 107.

${ }^{9}$ TODOROV, T. Nós e os outros...

${ }^{10}$ HOFBAUER, A. Uma história do branqueamento..., p. 107.

11 Stephen Jay Gould ressalta que tanto no monogenismo quanto no poligenismo as teorias de hierarquização racial se fizeram presentes. Para aqueles que acreditavam em uma origem única do homem, os monogenistas, toda a humanidade havia saído de Adão de Eva e as raças humanas se diferenciavam devido a uma degeneração da perfeição. As inferiores, portanto, seriam as mais degeneradas. Já para os poligenistas, teriam existido mais de um Adão e, com isso, as raças haviam se originado separadamente, motivo que justificava as diferenças entre elas. GOULD, Stephen Jay. A falsa medida do homem. Tradução de Valter Lellis Siqueira. 2 ed. São Paulo: Martins Fontes, 1999, p. 26. Sobre esta discussão, conferir também: POLIAKOV, L. O mito ariano...
} 
humanidade segundo critérios marcados pelo olhar europeu (ou simplesmente ocidental), branco e masculino. A existência de raças superiores e inferiores era comprovada por meio do discurso científico/cientificista, ${ }^{12}$ que vinha como portador da verdade inconteste.

A racialização da humanidade marcou muitas conferências públicas de vulgarização científica ocorridas no Rio de Janeiro nas décadas de 1870 e 1880. Ao refletirem acerca do local social dos habitantes do país, os oradores hierarquizaram a sociedade em termos raciais. A discussão sobre os lugares nos quais os indivíduos deveriam ser inseridos integrava projetos modernizadores da nação, que tencionavam o progresso e a civilização. Em suas falas, fazendo uso de um discurso científico/cientificista, aqueles preletores classificavam o ser humano segundo critérios variados, mas sempre colocando o homem branco no topo da hierarquia.

Em seu curso de fisiologia, desenvolvido no Museu Nacional em 1881, o médico fisiologista francês Louis Couty, pesquisador daquela instituição, em uma de suas preleções tratou do cérebro, suas generalidades fisiológicas e patológicas. A raça foi considerada como uma variável significativa para a compreensão das doenças que estivessem relacionadas com o cérebro. Comparou o desenvolvimento dessas moléstias no Brasil e na França, a fim de verificar se havia uma determinação climática no desenvolvimento das mesmas. Portanto, apesar de julgar a raça como critério importante e digna de ser estudada com mais afinco, não ignorava a atuação de outros fatores, inclusive os externos: ${ }^{13}$

No curso proceder-se-á por modo diverso. A princípio se estudarão os fenômenos simples como os movimentos, as paralisias ou sensações a fim de mostrar-se que cada uma pressupõe sinergia funcional de muitos aparelhos nervosos. Firmado este ponto se estudarão as variações de tal funcionalismo sensitivo e motor, devidas à idade, à espécie ou às raças - variações correspondentes com uma energia

\footnotetext{
${ }^{12}$ Todorov sinaliza para a ligação entre o cientificismo e o racialismo: "A doutrina racialista, como se viu, está ligada desde seu início ao estabelecimento das ciências, ou mais exatamente, ao cientificismo, quer dizer, a utilização da ciência para fundar uma ideologia". Acerca do cientificismo, o autor sustenta que o mesmo estava fundamentado em duas premissas, "o determinismo integral e a submissão da ética à ciência”. TODOROV, T. Nós e os outros..., p. 128 e 129.

${ }^{13}$ Couty, antes de vir para o Brasil, em 1878, já desenvolvia pesquisas fisiológicas sobre o cérebro em Paris. GOMES, Ana Carolina Vimieiro. Um programa de "sciencia do Brazil": a inserção da fisiologia experimental na agenda científica brasileira em fins do século XIX (1880-1889). Tese (Doutorado em História) - Faculdade de Filosofia e Ciências Humanas, Universidade Federal de Minas Gerais, Belo Horizonte, 2009.
} 
funcional mais íntima. Preceder-se-á em seguida ao estudo do sono, do coma, do sonambulismo, histeria cerebral, paralisia geral, loucura, e se tornarão palpáveis as relações íntimas de todos esses estudos complexos e o estado normal. ${ }^{14}$

Aqui, espécie e raça foram concebidas como conceitos diferentes, ambos apresentados como variáveis que poderiam atuar em uma determinada enfermidade. Entretanto, isso não significa que a distinção entre raça e espécie estivesse sempre presente nas argumentações de Couty. O fisiologista francês reportou-se, em outros momentos, à raça com o sentido de espécie.

Couty também empregou o termo raça para se referir à linhagem. A variedade humana era observada não apenas em parâmetros que privilegiavam as características físicas, mas também por meio do agrupamento da humanidade em termos de grupo de ascendência linguística:

E a vulgarização científica, assim compreendida, não dará o resultado de elevar ainda o nível, já tão alto, dos estudos neste país, e tornar mais forte a disciplina intelectual, que ordinariamente falta aos povos da raça latina em consequência da vivacidade de sua inteligência e de sua facilidade de compreensão? ${ }^{15}$

$\mathrm{Na}$ interpretação de Couty, faltava aos latinos a "disciplina intelectual", que poderia ser conseguida pelo conhecimento da ciência. Essa indisciplina latina seria consequência de uma suposta facilidade de compreensão que provocaria uma determinada preguiça em manter uma disciplina intelectual. Apesar da ausência de dificuldades de entendimento, a indolência tinha que ser superada. Difícil precisar se ele compreendia todos os povos latinos nessa observação. Assim, para o médico francês existiam subdivisões hierárquicas entre os considerados de raça branca. Os povos de língua latina, de certa maneira, foram apresentados como inferiores aos outros de outra origem, pois estariam marcados por esta indisciplina intelectual. ${ }^{16}$

\footnotetext{
${ }^{14}$ Jornal do Commercio, 30/07/1881.

${ }^{15}$ COUTY, Louis. Os estudos experimentaes no Brazil. Revista Brazileira, Rio de Janeiro: Escriptorio da Revista Brazileira, tomo II, p. 215-239, $1^{\circ}$ de nov., 1879, p. 237.

${ }^{16}$ Raça, nação e língua eram conceitos que se intercambiavam, sendo por vezes tratados como sinônimos. Linguistas e antropólogos, por exemplo, disputavam espaço na arena científica para provar quem melhor categorizava a humanidade. Neste sentido, Poliakov cita o exemplo do médico e antropólogo alemão Rudolf Virchow (1821-1902). Defensor da craniologia e de outros métodos de mensuração física,
} 
Apesar de Couty falar de modo genérico em países latinos, por meio da análise do texto em sua totalidade, é possível garantir que aqui ele fazia menção especificamente ao Brasil. Então, aqueles que deveriam receber o conhecimento científico eram os brancos da sociedade, desconsiderando, assim, o restante dos habitantes (índios, negros e mestiços). Faço tal afirmação porque o excerto acima foi extraído de um artigo publicado na Revista Brazileira, que tinha como público alvo a camada letrada da sociedade da Corte. Partindo dessa premissa, a população branca brasileira estaria situada numa posição inferior quando comparada a outros grupos também categorizados como brancos.

A hierarquização entre os considerados de raça branca foi recorrente em muitos trabalhos daqueles que se dedicaram à questão racial. Independente dos critérios utilizados para demarcá-las, os brancos sempre estavam no cume da hierarquia. Contudo, esse não era um grupo homogêneo, havia os superiores e os inferiores. ${ }^{17}$ Representantes e descendentes da Península Ibérica, por exemplo, eram brancos de segunda categoria.

A diversidade racial existente no Brasil e seu potencial enquanto laboratório de estudo antropológico despertou o interesse de Couty:

Atualmente que homens como Quatrefages, Broca, Bertillon, Martillet, tanto hão concorrido para os grandes progressos da antropologia, quanto interesse não haveria em estudar, por exemplo, não só os caracteres étnicos, craniológicos e outros das diferentes raças do Brasil, mas principalmente o cruzamento dessas raças, sua influência sobre o desenvolvimento orgânico ou intelectual, sobre a fecundidade do mestiço, etc.?! Conforme me dizia há poucos meses o Sr. Broca, que país se encontrará, a não ser o Brasil, onde esse estudo possa ser feito facilmente e em boas condições? ${ }^{18}$

Virchow criticava os linguistas, que "haviam primeiramente postulado raças 'puras', o que dificilmente era defensável do ponto de vista antropológico; eis que politizavam o debate, relacionando à mesma 'raça latina' arianos (tais como os celtas) e não-arianos (tais como os sardos e os iberos), e confundiam as raças, as nações e as línguas". POLIAKOV, L. O mito ariano..., p. 245.

${ }^{17}$ Em sua análise acerca da origem do mito ariano, Poliakov menciona o filosofo alemão Christoph Meiners (1747-1910), que desenvolveu pesquisas sobre antropologia em fins do século XVIII e início do XIX. Na análise de Meiners, existiam os homens de "raça clara e bela" e os de "raça escura e feia". Porém, mesmo entre os de pele clara havia os que apresentavam "traços inferiores"; este era o caso dos eslavos, que por estarem abaixo dos outros de tez alva poderiam ser tratados como servos pelos alemães. POLIAKOV, L. O mito ariano..., p. 156 e 157.

${ }^{18}$ COUTY, L. Os estudos experimentaes no Brasil..., p. 221. É provável que Couty mantivesse um diálogo científico com o médico e antropólogo francês Paul Broca (1824-1880), uma vez que ambos se 
Estudar as diferentes raças em si já era um tema de grande interesse para o fisiologista francês. Porém, analisar a miscigenação instigava-o ainda mais, despertava mais interesse, sobretudo pela possível influência da raça nas características intelectuais e orgânicas do híbrido resultante. O Brasil era visto por muitos estudiosos das raças como local privilegiado de investigação, haja vista a alta mestiçagem. Além de Paul Pierre Broca (1824-1882), acima citado por Couty, outros compartilhavam da mesma opinião.

A grande miscigenação existente no Brasil, a princípio, mostrava que a hipótese sobre ausência de fecundidade do mestiço pouco se sustentava. Contudo, pela análise dos dizeres de Couty, esse ainda era um tema de debate no meio científico. Armand de Quatrefages, eminente líder da escola antropológica francesa, estava entre aqueles que, em meados do século XIX, ainda defendia a suposta esterilidade dos mulatos. ${ }^{19}$ Quatrefages fundamentava seus argumentos no livro do médico britânico Edward Long (1734-1813), The history of Jamaica, obra ilustrada publicada em 1774. Para Long, os mulatos seriam inférteis assim como as mulas, frutos do cruzamento dos jumentos(as) com as éguas (cavalos). ${ }^{20}$

Segundo Couty, a compreensão da mestiçagem do Brasil só poderia ocorrer por meio de uma interpretação que considerasse as especificidades locais: "Não é menos evidente que a questão da transformação das raças humanas e do valor dos mestiços, ao menos quanto ao Brasil, não pode ser resolvida fora deste, das suas condições climatéricas, higiênicas e ainda sociológicas." ${ }^{21}$ Para essa análise ele não descartava as variáveis sociais. Provavelmente referia-se à questão da escravidão, pois muitos desses mestiços eram descendentes de negros cativos. Apesar de ainda intelectualmente

dedicavam ao estudo dos cérebros, dentro outros, Couty por meio de uma abordagem mais fisiológica e Broca por uma mais vinculada à craniometria.

${ }^{19}$ Sobre o conceito da palavra mulato, Hofbauer afirma que: "Em oposição a interpretações correntes que derivam de 'mulo' o conceito de mulato e insinuam uma analogia humana com o produto híbrido do cruzamento entre duas espécies de animais diferentes, [Jack D.] Forbes aponta uma raiz árabe da palavra. Ele sugere que teria ocorrido uma espécie de convergência 'semântico-funcional' entre duas palavras árabes [uma significava protetor ou protegido e a outra procriado, pessoa adotada] [...] A palavra 'muladi', 'malado' ou 'maladi' era de uso freqüente na língua portuguesa (e espanhola) no século X. [...] A tradução, também usual, de muwallad por 'descendente de um pai árabe e uma mãe estrangeira ou de um pai escravo e de uma mãe livre' aproxima ainda mais o conceito da semântica inicial arcaica de 'mestiço' e explica por que, no dicionário de H. Cardoso, de 1569, 'mulato' consta como sinônimo de mestiço. Ainda segundo Forbes, os conceitos de origem árabe devem ter sido 'sobrepostos' ('gradual overlapping of meaning) pela palavra de origem latina que expressa o 'produto híbrido' entre o cavalo (égua) e jumento(a). [...] De qualquer forma, demoraria ainda muito tempo até que o conceito de mulato fosse definido como produto do 'cruzamento' entre a 'raça branca' e a 'raça negra'." HOFBAUER, A. Uma história do branqueamento..., p. 90-92.

${ }^{20}$ POLIAKOV, L. $O$ mito ariano..., p. 155.

${ }^{21}$ COUTY, L. Os estudos experimentaes no Brasil..., p. 228. 
limitado, Couty considerava o mulato superior ao negro por ter "uma conformação cerebral e capacidade intelectual superiores". ${ }^{22}$ Com isso, é possível concluir que a hibridização era compreendida de maneira positiva pelo médico francês, porque ela poderia trazer melhoramentos raciais.

A relevância que Couty dava aos assuntos de cunho social pode ser atestada nas preleções do fisiologista:

Na sua terceira e última conferência [...] o Dr. Couty ocupouse da tuberculose pulmonar, infelizmente muito frequente em certas cidades do Brasil e na Europa, e procurou mostrar que essa moléstia de nutrição pode variar por causa do meio físico, do mesmo modo que as moléstias mentais e nervosas por causa das raças, da educação ou antes do meio sociológico. ${ }^{23}$

Para Couty, as doenças mentais e nervosas estariam relacionadas à raça e a questões sociais. Tais assuntos eram considerados tão relevantes que o médico publicou as obras A escravidão no Brasil (1881) e O Brasil em 1884; esboços sociológicos (1884). Celia Maria Marinho de Azevedo assegura que Couty estudou com afinco a sociedade brasileira, "como um cientista em seu laboratório". ${ }^{24}$ Observou, analisou, e desenvolveu sugestões para acabar com os males que acometiam o Brasil. De acordo com a autora, o médico francês exerceu papel essencial na fundamentação da imagem de um país sem preconceito racial.

Couty considerava o fim da escravidão primordial, já que ela era a causadora do atraso do país. Conforme afiança Azevedo, o francês colaborou para criação da imagem do negro vagabundo e preguiçoso. Na interpretação do fisiologista, os escravos eram bem tratados pelos senhores, tinham, inclusive, a oportunidade de trabalhar em seu roçado uma vez por semana. Mas, preguiçosos e satisfeitos com o cativeiro, não cultivavam a terra. Não obtinham a alforria porque não sabiam economizar o dinheiro que conseguiam, preferindo gastá-lo em "boas roupas, embebedando-se, comendo bem etc.”. ${ }^{25}$ E tal comportamento do negro era nato, pois o cérebro africano possuía uma capacidade insuficiente, conforme atestavam as pesquisas científicas. Segundo

\footnotetext{
${ }^{22}$ AZEVEDO, C. M. M. de. Onda negra, medo branco..., p. 68.

${ }^{23}$ Jornal do Commercio, 27/10/1882.

${ }^{24}$ AZEVEDO, C. M. M. de. Onda negra, medo branco..., p. 65.

${ }^{25}$ AZEVEDO, C. M. M. de. Onda negra, medo branco..., p. 67.
} 
Azevedo, apesar de combater a escravidão, Couty não advogava em prol da abolição imediata, uma vez que considerava o negro e o mulato incapazes de se adaptarem imediatamente ao trabalho assalariado. Defendia a imigração europeia como maneira de solucionar o problema do retardo social brasileiro. ${ }^{26}$

A citação abaixo elucida o modo como Couty relacionava questões biológicas e sociais.

O meio físico, biológico e social, a educação e a hereditariedade criam a forma e a rapidez da ação cerebral; os atos novos, os pensamentos e os juízos a que se não está habituado, são longos e penosos, enquanto que certos trabalhos cerebrais habituais, são feitos com rapidez e facilidade; e estes hábitos cerebrais ou cérebro-medulares receberam o nome de memória e de instintos.

Os atos funcionais criam para o cérebro, como para todos os órgãos, a forma dos atos, tanto normais como patológicos, e a loucura do negro da roça não se assemelha à do seu senhor nem a do homem muito instruído ou apaixonado à do homem ignorante ou pouco ativo.

$\mathrm{O}$ ato cerebral é porém sempre consecutivo a uma excitação vinda do exterior, ou a uma série de excitações, que se reúnem ou se repelem, daí as comparações, os juízos e muitos outros trabalhos cerebrais. Umas, relativas à necessidade de alimentação e de prazeres sexuais ou sensoriais, são os únicos motivos que influem nos homens inferiores e formam a base das alucinações delirantes, bem como de muitas teogonias religiosas, cujas recompensas e castigos são de ordem puramente física e sensitiva.

Outros motivos existem de ordem mais elevada.

Uns passionais ou emocionais correspondem às ideias adquiridas de riqueza, de beleza, de honra, de estima pública, etc., e formam a base dos delírios e manias de grandeza, de erotismo, de perseguição, etc. Outros enfim são motivos puramente intelectuais e correspondem, por exemplo, ao prazer do sábio que faz descobertas

\footnotetext{
${ }^{26}$ A repercussão e a influência das ideias de Couty sobre a imigração foram grandes, "Seria difícil determinar quem influenciou quem, mas o fato é que, um ano antes da morte do jovem médico francês no Rio de Janeiro, fundou-se em 17 de novembro de 1883, naquela mesma cidade, a Sociedade Central de Imigração (SCI), cujo intuito era justamente promover a imigração europeia nos moldes preconizados por ele em seus numerosos escritos e conferências." AZEVEDO, C. M. M. de. Onda negra, medo branco..., p. 71. Grifos do original.
} 
úteis, ao prazer do homem que salva seu semelhante ou do cidadão que defende seu país sem preocupar-se com a recompensa.

A importância recíproca destas três ordens de motivos crê a maneira de proceder de um indivíduo e, como pela educação se pode tornar predominantes estes ou aqueles móveis, cumpre desenvolver os móveis intelectuais que são os únicos que asseguram o desenvolvimento e a independência de cada individualidade.

Em resumo, podemos pois, reduzir à [sic] condições bastantes simples o funcionalismo intelectual: como todos os outros órgãos o cérebro é um simples aparelho de transformação dos excitantes exteriores, físicos ou sociológicos, e só a natureza íntima destes fenômenos é para nós tão obscura como a da afinidade química ao da gravidade. $^{27}$

$\mathrm{Na}$ concepção de Couty, variáveis biológicas e sociais exerciam papéis determinantes no funcionamento cerebral dos indivíduos. Com relação à loucura, patologia desse órgão, o médico francês assegurou que ela se manifestava de maneira diferente no cativo e no senhor. $O$ fato de o escravo ser negro era a principal explicação. ${ }^{28}$ Sendo o negro inferior ao homem branco, era natural que a loucura verificada fosse diferente, a conformação cerebral do negro já atestaria esse fenômeno dentro do protocolo da ciência. Portanto, a raça (meio biológico) era o fator que determinava a disparidade entre a doença no branco e no negro. A escravidão, que para alguns poderia ser considerada como agravante, era desconsiderada na análise de Couty, uma vez que os negros eram "Bem tratados, bem alimentados, curados nas doenças, conservados na velhice e assegurados contra o desemprego". ${ }^{29}$

A assimetria também poderia ser observada ao comparar a moléstia em um homem branco "instruído" e em um branco "ignorante". Neste caso, a instrução apresentava-se como a variável determinante, referida por ele como educação, motivo pelo qual defendia a vulgarização científica na sociedade. Sob esse prisma, tal tipo de problema, se não solucionado, poderia ao menos ser minimizado.

\footnotetext{
${ }^{27}$ Jornal do Commercio, 18/11/1881.

${ }^{28}$ Ainda sobre a inferioridade do negro, apregoada por Couty, Celia de Azevedo afirma que "O tema da inferioridade racial completa-se assim com a idéia de que o negro não se relaciona socialmente, não tinha família, era um desgraçado por natureza, cujos sentimentos oscilavam da indiferença e apatia à mais cruel violência.” AZEVEDO, C. M. M. de. Onda negra, medo branco..., p. 68.

${ }^{29}$ AZEVEDO, C. M. M. de. Onda negra, medo branco..., p. 67.
} 
O funcionamento cerebral estaria, portanto, marcado pelas influências externas. Os homens inferiores respondiam exclusivamente aos instintos e às necessidades vitais, como a alimentação. Os agentes exteriores causavam as alienações nos seres incultos. A ausência de instrução determinava que esses sujeitos não tivessem capacidade cognitiva e, assim, agissem apenas por instintos. Desta maneira, aqueles definidos como inferiores teriam uma proximidade maior com os animais.

Entretanto, na avaliação de Couty, para os considerados superiores existiam motivos de "ordem mais elevada", sua atividade cerebral não seria governada por respostas instintivas. As causas dos delírios nestes homens também eram de ordem superior, o sentimento e a emoção poderiam provocar tais tipos de doenças. Sentimento e emoção, qualidades estritamente vinculadas ao ser humano, bem distantes da aproximação ao mundo animal feita para os inferiores. Existiam os motivos intelectuais que atuavam no funcionamento do cérebro, todos relacionados com atitudes nobres - a satisfação de realizar uma pesquisa útil, o contentamento em salvar um semelhante, o orgulho de lutar por seu país em uma guerra. De certo, para o médico francês, os homens inferiores não seriam capazes dessas atitudes.

Outro conferencista que se dedicou às temáticas relativas à raça foi o médico Joaquim Baptista de Lacerda Filho. Como subdiretor, e posteriormente diretor, da seção de antropologia, zoologia geral e aplicada, anatomia comparada e paleontologia animal, Lacerda ficou responsável pelo curso público de antropologia do Museu Nacional. Suas pesquisas antropológicas ${ }^{30}$ estiveram centradas principalmente no estudo dos indígenas brasileiros. Em um artigo, de 1876, publicado em conjunto com Rodrigues Peixoto, ambos se declaram poligenistas.

Seja-nos, pois, lícito declarar que a respeito de tais questões não temos opinião formada, e quando no círculo das hipóteses prováveis houvéssemos de aceitar alguma, seríamos poligenistas com Agassiz. É possível que a América fosse um dos centros da criação e que mais tarde povos emigrados da Ásia ou de outros pontos do globo,

\footnotetext{
${ }^{30}$ Além de pesquisas antropológicas, Lacerda se dedicou aos estudos fisiológicos, trabalhou com Couty no laboratório de fisiologia experimental do Museu, onde desenvolveu várias investigações sobre a ação fisiológica do veneno curare, utilizado pelos índios da América do Sul. Alguns resultados foram publicados na revista Archivos do Museu Nacional. Para uma maior discussão sobre o laboratório conferir: GOMES, A. C. V. Um programa de "sciencia do Brazil”...
} 
mais próximos, viessem fundir-se com a raça primitiva, produzindo a raça atual. ${ }^{31}$

Lacerda e Peixoto afirmavam, sem forte convicção, se alinharem ao posicionamento de Louis Agassiz com relação ao poligenismo. Não posso precisar se, assim como o naturalista suíço, Lacerda e Peixoto eram criacionistas e partidários da teoria da degeneração. ${ }^{32}$ Para os pesquisadores do Museu, a América seria um dos centros de criação, seus povos originários, a "raça primitiva", teriam se miscigenado com os outros que haviam emigrado da Ásia para cá. ${ }^{33} \mathrm{O}$ conceito de raça estava relacionado aos habitantes de uma determinada região geográfica, no caso os da América. Assim, os índios seriam uma raça específica. Diferentemente da relação entre primitivo e selvagem, ao contrapor a "raça primitiva" com a "raça atual", eles não estavam trabalhando com o par selvagem/civilizado, o índio da atualidade ainda era considerado um selvagem. ${ }^{34}$

O médico Nicolau Joaquim Moreira foi outro preletor que tratou de questões referentes à raça nas conferências do Museu Nacional. Subdiretor da seção de botânica geral e aplicada, e paleontologia vegetal, seus cursos eram anunciados pela imprensa como sendo de agricultura. Entretanto, ele perpassou por questões relativas às raças humanas, principalmente quando tratou da imigração, como mostrarei adiante.

\footnotetext{
${ }^{31}$ LACERDA FILHO, João Baptista e PEIXOTO, Rodrigues. Contribuições para o estudo antropológico das raças indígenas do Brasil. Archivos do Museu Nacional, Rio de Janeiro, v. 1, 1876, p. 75.

${ }^{32}$ Adepto do poligenismo, Agassiz sustentava a degenerescência humana pelo cruzamento das raças. De acordo com Maria Helena Machado, o naturalista suíço se baseava na crença de que "as raças cruzadas, em vez de carregarem as melhores características de seus ascendentes, levavam a que traços atávicos viessem à superfície, expondo os descendentes de uniões mistas a todos os riscos de uma progressiva degenerescência.". MACHADO, Maria Helena Pereira Toledo. Os tupis e a turânia: hipóteses sobre a origem do homem e da civilização nas Américas na segunda metade do século XIX e primeiras décadas do XX. In: Brasil a vapor: raça, ciência e viagem no século XIX. Tese (Livre Docência) - Faculdade de Filosofia Letras e Ciências Humanas, Universidade de São Paulo, São Paulo, 2005, p. 63.

${ }^{33} \mathrm{Na}$ segunda metade do século XIX, a origem do homem na América foi tema análises de alguns intelectuais brasileiros, dentre outros, Gonçalves Dias, Varnhagen, Couto de Magalhães e Câmara Cascudo. Para uma discussão acerca do posicionamento destes, conferir: MACHADO, M. H. P. T. Os tupis e a turânia...

${ }^{34}$ Ao participar do Congresso Universal das Raças, realizado em Londres no ano de 1911, Lacerda, enviado como representante do Brasil, apresentou algumas considerações um pouco divergentes das que pregou nas décadas de 1870 e 1880. Segundo Lilia Moritz Schwarcz, o pesquisador do Museu chegou a oito conclusões sobre questões relativas à raça, dentre elas: "(1) homens brancos e negros formam duas raças, e não espécies; (2) o mestiço é um tipo étnico variável e pode retornar a uma ou outra raça que o produziu; [...] (4) se o mestiço é inferior ao negro em força física, rivaliza com o branco em sua capacidade intelectual." Contudo, era outro momento, centro minha análise apenas em suas ideias expostas nos cursos públicos do Museu Nacional do século XIX. SCHWARCZ. Lilia Moritz. Previsões são sempre traiçoeiras: João Baptista de Lacerda e seu Brasil branco. História, Ciências, Saúde Manguinhos, Rio de Janeiro, v.18, n.1, jan.-mar. 2011, p. 231.
} 
Para refletir sobre o mundo natural, Moreira pensava em termos de categorias, agrupamentos que levavam em consideração a presença ou ausência de características comuns: "Quando, pois, se quer raciocinar sobre a homogeneidade do tipo em um grupo de animais deve-se ter em vista os termos vagos de semelhança e de dissemelhança". ${ }^{35}$ Tinha como base as análises do médico neurologista francês Duchenne de Boulogne (1806-1875) para categorizar a humanidade em raças:

Duchenne (de Boulogne) o demonstrou de uma maneira peremptória. A homogeneidade de raça não pode se entender senão a similitude dos caracteres típicos, do que é infalivelmente hereditário entre os indivíduos do mesmo tronco. O resto, como a conformação do corpo, a aptidão, o pelo etc., é acessório para o característico e experimenta todas as influências do meio em que os animais se acham. $^{36}$

Para classificar a humanidade em raças, Moreira levava em consideração apenas as similitudes transmitidas hereditariamente. Fatores externos eram desacreditados por ele, bem como as conformações corpóreas. As mensurações físicas, muito em voga naquele período, atraíam a atenção de muitos cientistas, tudo se media a fim de melhor conhecer e classificar as raças humanas. Na contramão desta corrente, Moreira tributava apenas à hereditariedade o papel definidor das raças. Variáveis como a dolicocefalia e a braquicefalia, utilizadas como parâmetros classificatórios, para ele nada diziam a respeito da raça. ${ }^{37}$

Um crânio alongado, (dolicocéfalo) quer a cabeça aumente ou diminua de volume, será sempre alongado, isto é, que o seu diâmetro longitudinal cresce ou diminui na mesma proporção do diâmetro

\footnotetext{
${ }^{35}$ MOREIRA, Nicolau. Zootechnia. O que é raça. O Auxiliador da Industria Nacional. Rio de Janeiro: Industria Nacional, n. 10, p. 428-430, out. 1869, p. 429.

${ }^{36}$ MOREIRA, N. Zootechnia. O que é raça..., p. 429.

${ }^{37}$ Sobre esses parâmetros, Stephen Jay Gould ressalta: "Além do próprio tamanho do cérebro, as duas medidas craniométricas mais veneráveis - e também as mais manipuladas - foram, sem dúvida, a do ângulo facial (a projeção anterior do rosto e da mandíbula: quanto mais pronunciada melhor) e a do índice craniano. Este nunca fora muito empregado, se bem que fosse fácil de medir. Era obtido através do cálculo da proporção entre a largura e o comprimento máximos do crânio. Os crânios relativamente longos (média de 0,75 ou menos) eram chamados de dolicocéfalos; os crânios relativamente curtos (acima de 0,8), braquicéfalos." GOULD, S. J. A falsa medida do homem..., p. 93. Segundo Poliakov, o índice cefálico, ou craniano, foi introduzido por volta de 1845 pelo anatomista sueco Anders Retzius (17961860). Os classificados como dolicocéfalos, "tais como os escandinavos, os alemães, os ingleses e os franceses", eram considerados superiores aos braquicéfalos, "tais como os lapões, os fineses ou finoeslavos e os bretões". POLIAKOV, L. O mito ariano..., p. 251.
} 
transverso. Do mesmo modo a respeito do crânio curto, (braquicéfalo), para a face considerada isoladamente ou em relação com o crânio. ${ }^{38}$

Portanto, em sua concepção, uma raça era constituída por um grupo de indivíduos portadores de determinadas características semelhantes que eram transmitidas para os descendentes.

A raça não é portanto senão a série de gerações em um tipo determinado, e os naturalistas que acreditam na variabilidade limitada do tipo dizem que ela representa uma série de indivíduos distintos por caracteres tornados constantes, quando deveriam dizer naturalmente constantes. ${ }^{39}$

Silvio Cezar de Souza Lima sustenta que para Nicolau Moreira a ideia de fixidez das espécies era um conceito chave. ${ }^{40} \mathrm{O}$ cientista considerava as "raças humanas" como espécies diferentes. O posicionamento de Moreira indica que era seguidor das proposições defendidas por Agassiz, que influenciaram muitos homens de ciência brasileiros: "Socorra-nos, finalmente a autorizada palavra do Sr. Agassiz, quando na Universidade de Cambridge discorrera sobre o assunto que nos ocupa." ${ }^{41}$

O pesquisador do Museu Nacional, todavia, não especificou quais eram as características que considerava para classificar a humanidade em raças. Apenas afirmou que "cada raça verdadeira é composta de indivíduos homogêneos por seus caracteres típicos, os quais têm por atributo especial reproduzir-se com uma fixidade inabalável". ${ }^{4}$ O fato é que Moreira a classificou de modo hierarquizante, situando o branco no topo e os outros abaixo.

Assim como Agassiz, Moreira considerava a mestiçagem degenerativa, porque o híbrido resultante seria inferior aos progenitores: acreditava que o produto do

\footnotetext{
${ }^{38}$ MOREIRA, N. Zootechnia. O que é raça..., p. 429.

${ }^{39}$ MOREIRA, N. Zootechnia. O que é raça..., p. 430.

${ }^{40}$ LIMA, Silvio Cezar de Souza. Determinismo biológico e imigração chinesa em Nicolau Moreira (1870-1890). Dissertação (Mestrado em História das Ciências da Saúde) - Casa de Oswaldo Cruz, Fundação Oswaldo Cruz, Rio de Janeiro, 2005, p. 56-57.

${ }^{41}$ MOREIRA, Nicolau Joaquim. Questão ethnica-antropologica. O cruzamento das raças acarreta a degradação intelectual e moral do producto hybrido resultante? Resumo da memoria apresentada á Academia Imperial de Medicina e relatorio. Rio de Janeiro: Typographia Progresso, 1869, p. 25.

${ }^{42}$ MOREIRA, N. Zootechnia. O que é raça..., p. 428.
} 
cruzamento do branco e do negro era de fecundidade reduzida, compartilhando, desta maneira, com a opinião de cientistas como Quatrefages. ${ }^{43}$

Eu não vos falo, Senhores, dos mestiços provenientes da raça branca e da preta, e que se nos fosse permitido incluirmos na classe da paragenesia, criada por Broca, e caracterizada por indivíduos fecundos entre si, mas cujos descendentes diretos apresentam uma fecundidade limitada senão são retemperados por algum dos sangues primitivos, podendo neste caso verificar-se o fato conhecido em antropologia por - atavismo. $^{44}$

Era favorável à imigração com o objetivo de branquear o país. O cruzamento entre imigrantes europeus e a população branca local não era visto como mistura de raças (uma vez que todos pertenciam à categoria dos brancos), mas, sim, como uma mistura de povos.

As alianças entre povos da mesma raça são essencialmente benéficas.

Um povo, que pudesse cruzar-se numerosas vezes seguindo todas as regras de uma verdadeira seleção reunindo uma grande soma de boas qualidades e fundindo-as em sua constituição e em seu caráter, engrandecer-se-ia. ${ }^{45}$

Aqui o conceito de raça não se confundia com o de nação. Porém, em outros momentos esses termos apareceram como sinônimos. Principalmente quando defendia a vinda de imigrantes anglo-saxões para o Brasil, que minimizariam os problemas advindos do elemento lusitano. Assim sendo, para Moreira, na categoria brancos também havia subdivisões hierárquicas.

\footnotetext{
${ }^{43}$ MOREIRA, N. J. Questão ethnica-antropologica... Este artigo foi produzido como uma análise de Moreira sobre uma memória enviada por João Batista Ulhesperger ao concurso de memórias da Academia de Medicina, entre 1868 e 1869. O tema do trabalho era um estudo do cruzamento das raças. Os acadêmicos consideraram a relatório de Moreira superior ao texto entregue para a disputa. De acordo com Lima: "O Dr. Moreira apresentou o relatório para a apreciação da Academia oferecendo uma menção honrosa para o autor da memória. A Academia aprovou seu relatório por unanimidade, o que nos faz crer que as idéias propostas pelo acadêmico em seu relatório seriam então as que melhor respondiam à questão, tanto do seu ponto de vista, quanto de seus pares". LIMA, S. C. de S. Determinismo biológico e imigração..., p. 49.

${ }^{44}$ MOREIRA, N. J. Questão ethnica-antropologica..., p. 14.

${ }^{45}$ MOREIRA, N. J. Questão ethnica-antropologica..., p. 10.
} 
A despeito de sua opinião acerca da inferioridade dos negros, Nicolau Moreira era contrário à escravidão, o que não era de se estranhar, visto que isto não era um comportamento excepcional na época. Na década de 1880, ele proferiu discursos nas conferências abolicionistas chegando, inclusive, a ocupar os cargos de vice-presidente da Sociedade Emancipadora e de secretário honorário da Sociedade Brasileira contra a Escravidão. $^{46}$

Pelo acima exposto, observa-se que as temáticas relativas à raça marcaram as preleções públicas realizadas no Rio de Janeiro de fins do século XIX. Embora os textos analisados não sejam transcrições dos discursos expostos, certamente esses temas em algum momento perpassaram os discursos proferidos nas tribunas, pois os oradores apresentavam assuntos relativos às pesquisas que desenvolviam. $\mathrm{O}$ espaço dos cursos públicos do Museu Nacional foi privilegiado para a exposição de questões referentes à raça, já que lá tais tipos de estudos eram realizados. A concepção de raça defendida pelos pesquisadores não era única, cada um possuía um critério para a classificação, de acordo com a teoria científica que considerasse mais adequada. Os discursos eram pautados em um vocabulário científico/cientificista. Contudo, é possível constatar que conceber a humanidade divida em raças hierarquizadas era uma constante e que, nessa categorização, consideravam a raça branca como superior às outras, e esta, da mesma maneira, estava hierarquicamente subdividida. A miscigenação também foi um tema que preocupou esses homens de ciência que expunham publicamente seus conhecimentos. Enquanto para Couty ela poderia ser benéfica, Moreira condenava-a por degenerar as raças originais. Isto mostra que também neste quesito não havia unanimidade.

\section{Os índios nas conferências}

A classificação da humanidade em raças esteve presente em muitas das pesquisas científicas desenvolvidas no século XIX. As abordagens racialistas frequentemente consideravam os povos originários da América como uma raça específica. Desde o século XVI os habitantes do Novo Mundo já eram foco de análises em termos raciais, mas com acepção diferente, no sentido de um povo. Porém, foi no

\footnotetext{
${ }^{46}$ LIMA, S. C. de S. Determinismo biológico e imigração..., p. 53 e 62.
} 
Oitocentos que tais abordagens estiveram pautadas em um forte discurso cientificista, em especial com o desenvolvimento da antropologia física. ${ }^{47}$

A questão da construção da nação brasileira durante o Império foi marcada pelos debates em torno da identidade nacional que se buscava forjar. Qual a face que deveria ter a recente nação? Pretendia-se um país moderno, que estivesse no rumo da inspiradora e desejada civilização nos moldes europeus. Os homens letrados refletiam sobre essa questão em diversos espaços de sociabilidade. Nas suas análises e projeções futuras, se deparavam com dois elementos considerados como problemas para a configuração do povo brasileiro - o índio e o negro.

Acerca das discussões sobre os indígenas, Manuela Carneiro da Cunha assegura que até meados do século XIX elas giravam em torno de dois grandes eixos, civilizá-los ou exterminá-los. De acordo com a autora, os critérios de análise até esse momento estavam muito pautados no pensamento setecentista e foram de caráter mais filosóficos do que biológicos. Com o desenvolvimento das teorias evolucionistas, entretanto, o local ocupado pelos índios na história da espécie humana tornou-se ponto fulcral. Principalmente no último quartel do século XIX, os índios, assim como outros povos não ocidentais, passaram a ser consagrados “como 'primitivos', testemunhos de uma era pela qual já teríamos passado: fósseis, de certa forma, milagrosamente preservados nas matas e que, mantidos em puerilidade prolongada". ${ }^{48}$

Em consonância com esse pensamento, desenvolveram-se estudos no Museu Nacional. Alguns dos resultados dessas pesquisas foram apresentados nos cursos públicos. As preleções dedicadas à antropologia estavam entre as que mais abordaram o tema do índio, mas não foi apenas lá que a temática foi exposta.

Em 1875, um ano antes de terem iniciado os cursos públicos de maneira sistematizada e regulamentada, José Vieira Couto de Magalhães (1837-1898) proferiu uma preleção na qual elucubrou sobre a origem do homem na América. Adjunto da $4^{\text {a }}$

\footnotetext{
${ }^{47}$ As reflexões sobre a origem dos habitantes no Novo Mundo, de fato, pairavam na mente dos pensadores desde a chegada do homem europeu à América, quando da época dos "descobrimentos". Novas genealogias apareceram para dar conta daqueles indivíduos que foram encontrados do outro lado do Atlântico. Seriam eles também descendentes de Adão? Segundo Poliakov, para explicar a ancestralidade dos índios, os jesuítas optaram por ligá-la a Jafé, inserindo-os no mito de Noé. POLIAKOV, L. O mito ariano..., p. 112-114. Em 1768, o abade Cornielle de Pauw publicou Recherches philosophiques sur les Américains, ou Mémoires intéressants pour servir à l'histoire de l'espèce humaine, obra na qual descreveu os americanos como bárbaros, degenerados e fadados à extinção. Para uma análise pormenorizada sobre de Pauw e sua interpretação, ver: GERBI, Antonello. O novo mundo: história de uma polêmica: 1750-1900. Tradução de Bernardo Joffily. São Paulo: Companhia das Letras, 1996, capítulo 3.

${ }^{48}$ CARNEIRO DA CUNHA, Manuela. Política indigenista no século XIX. In: dos índios no Brasil. São Paulo: Companhia das Letras, 1992, p. 135. (Org.). História
} 
seção do Museu (numismática, artes liberais, arqueologia, usos e costumes das nações antigas e modernas), em substituição ao barão de Santo Angelo, diretor da respectiva seção, Couto de Magalhães discursou perante o Imperador e um concorrido auditório.

O ilustrado professor escolhendo para esta sua primeira lição a história da raça aborígene, sua civilização, suas crenças, seus hábitos e trabalhos industriais, descreveu a largos traços as migrações das várias tribos brasileiras que no seu dizer desceram pelo vale do Amazonas, prosseguiram para o Sul e daí se dirigiram pelo vale do Prata acima, onde apresentaram a sua última fase filológica aos povos que conquistaram esta parte da América. ${ }^{49}$

Para Couto de Magalhães, os indígenas que ocupavam o território nacional eram originários de um único grupo, que havia penetrado no país pelo Amazonas e de lá se espalhando para outras regiões, atingindo, então, o sul do Brasil. As mudanças ocorridas desde a chegada ao Amazonas até o contato com os europeus estariam marcadas por alterações linguísticas. $\mathrm{Na}$ interpretação de Magalhães os índios eram considerados uma raça específica e não havia um centro de criação aqui. Para o intelectual, o americano, fruto das três raças, era mais forte, o que indicava seu posicionamento favorável à miscigenação. ${ }^{50}$

Ainda sobre a preleção de Couto de Magalhães,

Encarando os nossos indígenas pelo lado intelectual descreveu-lhes as aptidões para as artes e especialmente para a música, que cultivavam com ardor; pelo lado físico disse que são os únicos homens capazes de resistir às intempéries a que se acham expostos os nossos pescadores, pastores e tropeiros; considerando-os preciosos pelo lado das suas várias indústrias extrativas, de que reverte em favor do país um imenso [?]. ${ }^{51}$

Pelo viés intelectual, o modo como abordou os índios foi positivo, mostrando suas qualidades, principalmente no tocante às habilidades musicais. Ao tratar das aptidões físicas não as valorizou, mas também não as desprezou, as descreveu como

\footnotetext{
${ }^{49}$ Diario do Rio de Janeiro, 26/07/1875.

${ }^{50}$ MACHADO, M. H. P. T. Os tupis e a turânia...

${ }^{51}$ Diario do Rio de Janeiro, 26/07/1875.
} 
iguais às de outros homens. Magalhães não fez uma comparação racial com relação ao físico, confrontou o índio com outros homens que exerciam atividades que requeriam certa resistência, "pescadores, pastores e tropeiros". Não foi à toa que fez tal comparação. Em suas propostas pregava a necessidade de se utilizar o trabalho indígena para o bem do país, sugerindo que os índios fossem empregados na pecuária, onde melhor se adaptariam. ${ }^{52}$

Não encontrei em nenhuma fonte analisada o discurso completo proferido por Couto de Magalhães. As únicas referências a sua preleção foram esta notícia do Diario do Rio de Janeiro e uma nota de anúncio no Jornal do Commercio. Com base nesse material, é possível inferir que a imagem do indígena transmitida pelo orador foi positiva. Provavelmente os índios analisados na conferência eram de origem tupi. Levanto a hipótese porque o tupi, desde o período colonial, adentrando pelo século XIX com o indianismo, foi descrito como o índio bom, dócil e civilizável. ${ }^{53}$ Consoante Maria Helena Machado, Couto de Magalhães colaborou sobremaneira na construção dessa imagem idílica em torno do tupi na segunda metade do Oitocentos, com destaque ao livro O Selvagem. Escrita especialmente por ocasião da Exposição da Filadélfia (1876), a pedido de D. Pedro II, marcada pelo emprego de assertivas evolucionistas e monogenistas, a obra "realiza plenamente o mito do tupi, como raça brasileira, superior em suas qualidades, perfectível em seu devir e base positiva para a mestiçagem". ${ }^{54}$

"Científico e romântico", assim John Monteiro define Couto de Magalhães, que em suas abordagens mesclava as teorias científicas modernas sobre "raça e evolução" juntamente com "um olhar específico para os fatores históricos e climáticos na condução de um processo de aperfeiçoamento humano". 55 Para explicar a degeneração indígena, por exemplo, ele utilizava argumentos políticos e históricos, em contraposição aos biológicos. Com relação aos paradigmas científicos empregados por Couto de Magalhães, merece destaque o evolucionismo. Segundo Maria Helena Machado,

Partindo de uma abordagem evolucionista e monogenista-católica e acompanhando a voga do nativismo indianista dos românticos, Couto dedicou a maior parte de seus esforços intelectuais na construção do

\footnotetext{
${ }^{52}$ MONTEIRO, John Manuel. Entre o gabinete e o sertão: projetos civilizatórios, inclusão e exclusão dos índios no Brasil Imperial. In: ___ . Tupis, tapuias e historiadores: estudos de história indígena e do indigenismo. Tese (Livre Docência) - Universidade Estadual de Campinas, Campinas, SP, 2001, p. 153. ${ }^{53}$ CARNEIRO DA CUNHA, M. Política indigenista no século XIX...

${ }^{54}$ MACHADO, M. H. P. T. Brasil a vapor..., p. 150.

${ }^{55}$ MONTEIRO, J. M. Entre o gabinete e o sertão..., p. 153.
} 
índio bom e perfectível, célula-máter de toda a constituição da nacionalidade brasileira. ${ }^{56}$

É plausível supor, portanto, que a conferência proferida por Couto de Magalhães no Museu Nacional estivesse fundamentada nas premissas teóricas científicas do evolucionismo e do monogenismo, bem como na construção da imagem positiva do índio e da miscigenação.

O diretor do Museu, Ladislau Netto, era responsável pelo curso de botânica. No entanto, tinha interesse por questões relativas à origem dos povos. ${ }^{57}$ Então, não é inverossímil admitir que ele tenha passado por temáticas relativas à raça. Ao discutir, em um artigo da Revista da Exposição Anthropologica Brazileira, as deformações ósseas provocadas pelos indígenas, Netto apresentou-as como consequência da falta de noção acerca do belo dos índios:

É que o sentimento do belo absoluto, como o do justo, tal qual o concebemos e definimos, não poderia ser o apanágio natural da inteligência inculta, senão o atributo moral adquirido, a pouco e pouco ampliado, e finalmente aperfeiçoado pelas numerosas gerações que se lhe adaptaram na rápida evolução psíquica da civilização; sentimento na verdade tão esplendidamente desenvolvido na idade áurea da Grécia, que ainda hoje se lhe não equipará o de que se jactam os países mais adiantados da Europa ocidental.

A cabeça deprimida, havida por tipo de suma beleza e de perfeição estética entre tantas nações da América, tal como o foi entre os habitantes pré-históricos da Europa, muitos dos quais caracterizados pela mesma platicefalia artificial dos Cambebas americanos, é uma prova de quanto, na sua gradual desenvolução de individuação moral, haviam-se afastado desses americanos ou dos europeus pré-históricos, colocados no mesmo horizonte antropológico, os povos indo-europeus ribeirinhos parte oriental do Mediterrâneo. ${ }^{58}$

\footnotetext{
${ }^{56}$ MACHADO, M. H. P. T. Brasil a vapor..., p. 148.

${ }^{57}$ GUALTIERI, Regina Cândida Ellero. Evolucionismo no Brasil: ciência e educação nos museus 18701915. São Paulo: Editora Livraria da Física, 2008.

58 NETTO, Ladislau. As deformações da face e do crâneo entre os povos americanos. Revista da Exposição Anthropologica Brazileira, p. 17-18, jul. 1882, p. 17. Este artigo é composto de excertos do seguinte trabalho: NETTO, Ladislau. Apontamentos sobre os tembetás (adornos labiaes de pedra) da collecção archeologica do Museu Nacional. Archivos do Museu Nacional, vol. II, p. 105-164, 1877. Acerca da Revista da Exposição Anthropologica Brazileira, John Monteiro afirma que "compilada por
} 
Sua afirmação teve como parâmetro estético o europeu, especificamente o grego, que desde o século XVIII representava o máximo da beleza. ${ }^{59}$ É possível perceber que para Netto, a ausência de gosto dos indígenas era resultado deles serem pouco evoluídos. Haveria, assim, um processo evolutivo natural do gosto estético. O mesmo raciocínio vale para o senso de justiça, conforme o diretor do Museu afirma: "o sentimento do belo absoluto, como o do justo, tal qual o concebemos e definimos, não poderia ser o apanágio natural da inteligência inculta". Ao assegurar que os índios não possuíam senso estético e de justiça, Netto os apresentou como inferiores aos brancos, uma vez que tais atributos, considerados como qualidades positivas, estavam ausentes no primeiro grupo.

O diretor do Museu comparou os tipos das deformações cranianas dos indígenas com as feitas pelos "habitantes pré-históricos da Europa". O índio seria equivalente a um branco primitivo, indicando que para Netto a ontogenia recapitulava a filogenia. Para provar sua tese, comparou os crânios de indígenas americanos com os dos povos mediterrâneos, na realidade, "com as cabeças das mais lindas estátuas da Grécia". Então, Netto levantou a seguinte questão: “qual destes dois tipos poder-se-á em rigor conceder a palma da supremacia? Anteriormente, já expendi o que, a meu ver, devia ser o belo absoluto, o verdadeiro belo." Concluiu que, "do ponto de vista etnológico" o belo dependia do povo que o apreciava. Neste ponto, em oposição à depreciação anteriormente feita, Ladislau Netto relativizou o conceito de beleza. ${ }^{60} \mathrm{O}$ que se depreende é que em sua opinião pessoal (não como cientista) o belo era um conceito absoluto, todavia, a análise fundamentada na ciência mostrava que a concepção do belo era ditada pelos paradigmas da seleção sexual, o que, na sua perspectiva, relativizava o conceito. Isto porque cada grupo agiria de determinada maneira, acentuando os pontos que eram considerados bonitos tendo como base a admiração existente em todos os homens pelos

\footnotetext{
Mello de Morais Filho para o evento, apresentava um cardápio realmente diversificado, dosando ponderações históricas, etnográficas, lingüísticas e - o prato principal, do ponto de vista do Museu Nacional - antropológicas, que, na época, diziam respeito às características físicas e morais das raças humanas." MONTEIRO, John Manuel. As "raças" indígenas no pensamento brasileiro do Império. In: MAIO, Marco Chor; SANTOS, Ricardo Ventura (Orgs.). Raça, ciência e sociedade. Rio de Janeiro: Editora Fiocruz / CCBB, 1996, p. 15.

${ }^{59}$ Para uma discussão sobre o estabelecimento do perfil grego como modelo de beleza da humanidade conferir: BIDMAN, David. Ape to Apollo: aesthetics and the idea of race in eighteenth century. Ithaca NY: Cornell University Press, 2002.

${ }^{60}$ NETTO, Ladislau. As deformações da face..., p. 17.
} 
[...] traços característicos que mais particularmente distinguem os seus antepassados, ou antes os seus conterrâneos, como já notou Humboldt, e que por uma lei radical de simpatia e afinidade nacional não somente admiram e veneram sobremodo esses caracteres [considerados belos], senão que vão ao ponto de exagerá-los por toda sorte de artifício, ao qual força é acrescentar o artifício da seleção sexual, porque natural é que tanto mais facilmente se requestem belezas típicas dessa plástica relativa, quanto maior número de atributos se houveres, reunido em um mesmo indivíduo. ${ }^{61}$

Portanto, para o diretor do Museu Nacional, a deformação óssea do crânio, feita pelos indígenas, seria um desses tipos de exagero. Os índios buscavam imitar a conformação craniana dos seus antigos chefes, que estaria ilustrada em monumentos e esculturas. Pode-se, então, inferir que havia certa tensão entre o sujeito/indivíduo e o cientista em Ladislau Netto. Enquanto homem de ciência ele acreditava no paradigma científico, no qual o belo era relativo. Já pessoalmente, considerava o conceito como absoluto e com o branco europeu representando o parâmetro de beleza ideal. ${ }^{62}$ Nesse jogo de forças, Netto mostrou que a ciência prevalecia.

Muitas das discussões sobre a "raça indígena" no Museu Nacional foram feitas por João Baptista de Lacerda Filho. Por ser o responsável pelo curso de antropologia, ele foi o orador que mais abordou a temática. Em 1876, com a reforma implementada naquele ano, a antropologia passou a integrar a primeira seção do Museu. ${ }^{63}$ No período que abarca essa pesquisa, 1870-1889, os estudos antropológicos desenvolvidos na instituição centravam-se principalmente na antropologia física, estando em consonância com o que ocorria na Europa e nos Estados Unidos. De acordo com Adriana Keuller, no final do Oitocentos “a questão do 'outro' trazia à Antropologia uma temática mais abrangente: nação, cidadania e raça estavam em pauta na discussão." ${ }^{64}$ Em torno dessas temáticas giravam as preleções ofertadas por Lacerda no seu curso de antropologia ministrado no Museu, suas conferências possuíam uma análise essencialmente baseada

\footnotetext{
${ }^{61}$ NETTO, Ladislau. As deformações da face..., p. 17.

${ }^{62}$ BIDMAN, D. Ape to Apollo...

${ }^{63}$ Segundo Adriana Keuller, a primeira vez que o termo antropologia apareceu no Brasil foi na revista o IHGB de 1856, em um artigo que apresentava instruções para a comissão científica que iria explorar o Ceará. Entretanto, a autora afirma que, nesse momento, a antropologia aqui desenvolvida ainda não era a mesma da realizada por Paul Broca. KEULLER, Adriana Tavares do Amaral Martins. Os estudos físicos de antropologia no Museu Nacional do Rio de Janeiro: cientistas, objetos, idéias e instrumentos (18761939). Tese (Doutorado em História Social) - Universidade de São Paulo, São Paulo, 2008.

${ }^{64}$ KEULLER, A. T. do A. M. Os estudos físicos de antropologia..., p. 63.
} 
na antropologia física. Segundo Keuller, este foi o primeiro curso de antropologia do Brasil.

Sobre os interesses do Museu Nacional pela antropologia, merece destaque a Exposição Antropológica Brasileira de 1882, organizada por Ladislau Netto. Para efetivar o evento, comunicados foram enviados aos presidentes das províncias solicitando a colaboração por meio do envio de materiais; com isso, o Museu recebeu doações de artefatos oriundos de diversas partes do país. ${ }^{65}$ Muitos dos resultados das investigações realizadas por João Baptista de Lacerda foram publicados na revista decorrente da Exposição. Além de objetos, alguns "exemplares" de botocudos foram levados para serem expostos.

Para Lacerda, a "antropologia não é uma ciência meramente especulativa, mas que ela é suscetível de ter aplicações práticas e úteis." ${ }^{\text {66 }}$ Desta maneira, os estudos antropológicos eram fundamentais, principalmente pelos empregos práticos que poderiam ter. É provável que Lacerda tenha partido dessa premissa ao apresentar suas conferências antropológicas, exposições públicas das pesquisas por ele desenvolvidas na instituição.

Os botocudos despertavam grande interesse por parte de Lacerda. O Museu possuía seis crânios desse grupo indígena em sua coleção. Com base no estudo de tal material, Lacerda colaborou na construção da imagem do índio botocudo como o mais inferior de todos os outros existentes naquele momento. Ele corroborou, desta maneira, a representação da oposição entre os tupis e os tapuias, estes aqui figurados como botocudos. Os índios históricos, civilizáveis e mortos contra aqueles viventes, selvagens ao extremo, quase impossível de se tornarem civilizados. ${ }^{67}$ Aqui está sua ótica acerca dos botocudos:

[...] O tronco é fornido e o tórax tem um notável desenvolvimento em largura, e é achatado, em vez de convexo, na face anterior. O tronco é também mais alongado do que costuma ser na raça caucásica. As

\footnotetext{
${ }^{65}$ Em ofício enviado ao governo imperial, a fim solicitar autorização para a realização do evento, Ladislau Netto explicitou a necessidade de se conhecer o homem americano em seus aspectos antropológicos, físico e moral, estes seriam estudados por meio da medição de suas ossadas, por seus artefatos e pela sua língua. KEULLER, A. T. do A. M. Os estudos físicos de antropologia..., p. 101.

${ }^{66}$ LACERDA, João Baptista de. A força muscular e a delicadeza dos sentidos de nossos indigenas. Revista da Exposição Anthropologica Brazileira, Rio de Janeiro, jul. 1882, p. 7.

${ }^{67}$ MONTEIRO, John Manuel. As "raças" indígenas no pensamento brasileiro do Império. In: MAIO, Marco Chor; SANTOS, Ricardo Ventura (Orgs.). Raça, ciência e sociedade. Rio de Janeiro: Editora Fiocruz / CCBB, 1996, p. 15-22.
} 
pernas são delgadas, as mãos e os pés relativamente pequenos e delicados.

Nas mulheres os seios são caídos, devido isso a uma notável inclinação para baixo do tórax. A cintura não é estreita como na raça caucásica, antes, ao contrário, ela é grossa e cheia. O abdômen é desenvolvido e proeminente, a cicatriz umbilical descendo muito mais abaixo do que na raça caucásica. Nas mulheres as pernas não são raramente arqueadas e a região glútea ampla.

$$
[\ldots]
$$

O lábio inferior apresenta-se quase sempre perfurado e distendido por uma rodela de madeira. Os lobos das orelhas são igualmente providos desse ornato, o que dá à fisionomia desses indivíduos um aspecto dos mais repulsivos. ${ }^{68}$

Todas as descrições foram feitas tendo como parâmetro de comparação a raça caucásica. Ao afirmar que o crânio do botocudo era achatado "em vez de convexo", Lacerda assegurou que o mesmo era considerado desviante, já que o correto seria apresentar a conformação convexa. Há aqui uma representação negativa do botocudo. De certa maneira, portanto, o destaque dado aos tamanhos das mãos e dos pés serviu para confirmar a inferioridade com relação ao branco, que supostamente apresentaria esses membros maiores.

As mulheres indígenas também foram descritas por Lacerda, em termos estéticos, como inferiores às brancas. Feias, elas teriam barriga sobressalente, ausência de cintura, seios caídos, até seus umbigos estariam nos locais incorretos. Particularmente neste período, a cintura fina era muito apreciada nos padrões de beleza brancos, mulheres usavam espartilhos apertadíssimos para conseguir a desejada "cintura de pilão", chegando às vezes a desmaiar por falta de ar.

Essas observações foram feitas por Lacerda quando já tivera seu contato pessoal com os botocudos, que provavelmente ocorreu em 1882, na ocasião da Exposição Antropológica. Porém, essa importante experiência só serviu para comprovar as descrições feitas por Charles Hartt, seu colega no Museu Nacional, conforme destacou em artigo publicado no ano de 1876:

\footnotetext{
${ }^{68}$ LACERDA, João Baptista de. Botocudos. Revista da Exposição Anthropologica Brazileira, Rio de Janeiro, jul. 1882, p. 2.
} 
Diz o professor Hartt que, em geral, as mulheres têm o abdômen muito volumoso, as mamas balofas e pendentes, e não raras têm as pernas arqueadas. A face é um tanto chata, os ossos do rosto geralmente muito salientes, a boca sempre muito grande e os lábios muito espessos. ${ }^{69}$

Ainda com relação à estética, a utilização de adereços de madeira nos lábios e nos lóbulos das orelhas fornecia aos botocudos um aspecto "repulsivo". 70 Tais índios não foram só representados como inferiores, mas também como os mais abjetos de todos. As ornamentações corporais despertavam grande interesse daqueles pesquisadores que se dedicavam aos estudos antropológicos no Brasil. Ladislau Netto, em artigo publicado na Revista da Exposição Anthropologica Brazileira, analisou o uso de ornatos no corpo, mais especificamente sobre o tembetá. Nas páginas da Revista, foram expostas ilustrações dos botocudos presentes na Exposição Antropológica. A imagem abaixo foi publicada logo acima do artigo "A força muscular e a delicadeza dos sentidos de nossos indígenas" de Lacerda, no qual também aborda, dentre outros grupos, os botocudos:

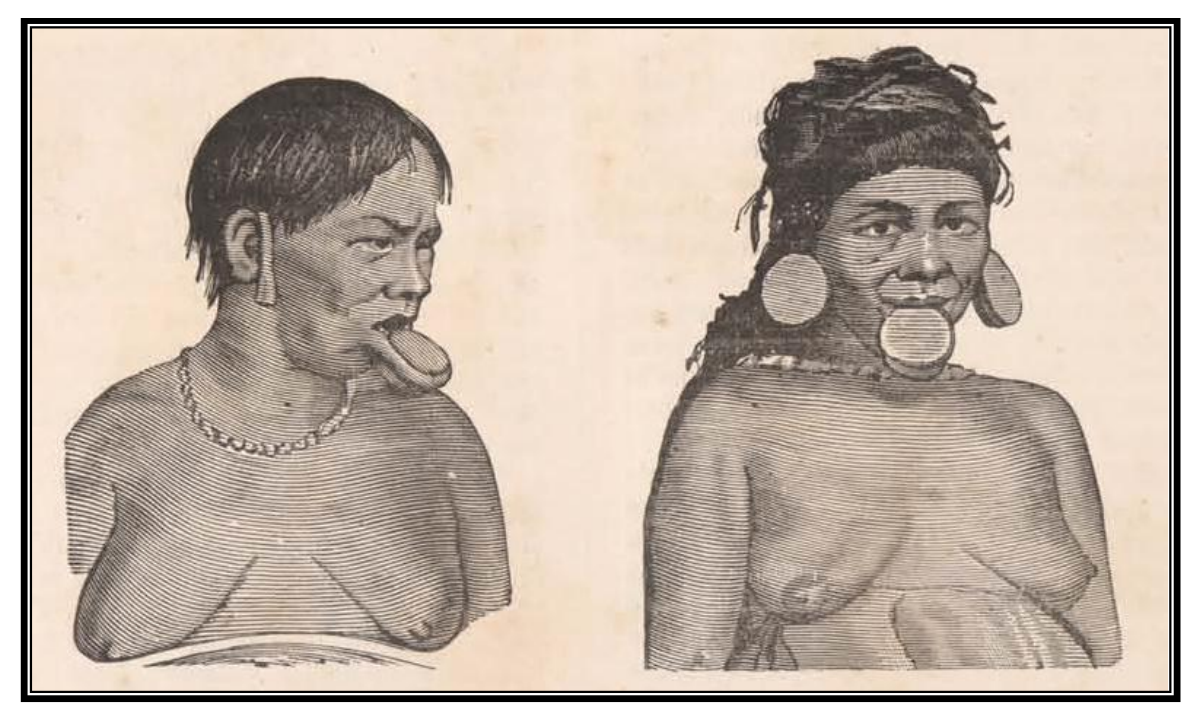

Imagem I - Botocudos da Exposição Antropológica. ${ }^{71}$

A julgar pelas observações manifestadas por esses dois cientistas do Museu Nacional, sobre o uso de adornos corporais pelos botocudos, é plausível supor que tais

\footnotetext{
${ }^{69}$ LACERDA FILHO, J. B. e PEIXOTO, R. Contribuições para o estudo antropológico..., p. 50.

${ }^{70}$ LACERDA, J. B. de. Botocudos..., p. 2.

${ }^{71}$ Revista da Exposição Anthropologica Brazileira, p. 6.
} 
ilustrações fossem apresentadas nos cursos públicos promovidos pela instituição. Faço essa afirmação porque a imprensa frequentemente destacava que os preletores utilizavam imagens para ilustrar suas conferências.

Outros aspectos dos botocudos foram examinados por Lacerda:

Sob o ponto de vista moral e intelectual são os Botocudos a expressão de uma raça humana no seu maior grau de inferioridade. Alguns conservam ainda o horrível costume de antropofagia e com grande dificuldade chegam a adaptar-se ao meio civilizado.

Também eles estão prestes a extinguir-se como raça, sendo provável que em meio século não se possa encontrar mais o tipo puro. $^{72}$

A inferioridade desses índios não se restringia ao físico, com relação à moral e ao intelecto Lacerda os apresentou como os mais inferiores da humanidade. Essa classificação estava substanciada pelo fato de alguns botocudos praticarem a antropofagia, hábito que dificultaria o processo civilizatório. Porém, isso não representava um problema, não era necessário grande empenho em civilizar os botocudos, visto que eles estavam fadados a desaparecer. Tal desaparecimento ocorreria por meio da hibridização. Aqui Lacerda considerou o botocudo como um "tipo puro", ou seja, uma raça pura. Neste ponto, o cientista ou mudou de opinião ou contradisse a hipótese levantada por ele e por Rodrigues Peixoto, em artigo publicado na revista Archivos do Museu, de 1876, no qual afirmavam que as raças indígenas existentes eram fruto de miscigenações das raças primitivas da América. ${ }^{73}$

Lacerda ressaltava que era recorrente, principalmente entre os viajantes que estiveram no Brasil, afirmar a existência de uma grande força muscular entre os indígenas. Entretanto, com base em pesquisas experimentais, ele havia comprovado que a assertiva não era real. O cientista fez seu estudo utilizando o dinamômetro de Mathieu $^{74}$ para medir a força muscular, confrontando índios adultos (três Xerentes e

\footnotetext{
${ }^{72}$ LACERDA, J. B. de. Botocudos..., p. 2.

${ }^{73}$ LACERDA FILHO, J. B. e PEIXOTO, R. Contribuições para o estudo antropológico...

74 A Casa Mathieu, de Paris, confeccionava vários tipos de instrumentos de medição. Muitos dos idealizados por Paul Broca foram produzidos pela Casa. O Museu Nacional importou de Paris uma variedade de aparelhos de mensuração, indicando a "influência dos estudos de Broca" na instituição brasileira, que se dava também "pela assimilação dos protocolos metodológicos". SÁ, Guilherme José da Silva; SANTOS, Ricardo Ventura; RODRIGUES-CARVALHO, Claudia; SILVA, Elizabeth Christina. Crânios, corpos e medidas: a constituição do acervo de instrumentos antropométricos do Setor de
} 
dois Botocudos) com "indivíduos civilizados da raça branca, de musculatura medíocre, e que jamais se tinham entregado a trabalhos braçais". ${ }^{75}$ A comparação foi feita com brancos de características medíocres a fim de provar que, mesmo perante a um branco fraco, os indígenas eram inferiores. A experiência, feita repedidas vezes, "não podia deixar dúvida de que a força muscular do braço do indígena era inferior à do homem branco civilizado. Entretanto, fato curioso, aqueles tinham os braços mais musculosos do que estes." 76 Destacou, então, que era um paradoxo de difícil solução, sendo necessário ainda muitos estudos experimentais. Assim, mesmo não tendo provas empíricas suficientes para fazer tal afirmação, Lacerda descreveu os índios como mais fracos que os brancos, no intuito de salientar ainda mais a inferioridade indígena apregoada por ele.

Ao descrever crânios encontrados num sambaqui em Santa Catarina, expostos na Exposição Antropológica, Lacerda frisou que os mesmos se destacavam "pelo aspecto singularmente feroz e bestial". 77 Interessante imaginar como é possível verificar ferocidade e bestialidade apenas observando um crânio, visto que são qualidades vinculadas a expressões faciais. A imagem abaixo estava inserida antes do início do artigo de Lacerda, no qual ele atribuiu tais características aos crânios: ${ }^{.78}$

Antropologia Biológica do Museu Nacional no fim do século XIX - início do século XX. In: MAIO, Marcos Chor; SANTOS, Ricardo Ventura. Raça como questão: história, ciência e identidades no Brasil. Rio de Janeiro: Editora Fiocruz, 2010, p. 117.

${ }^{75}$ LACERDA, J. B. de. A força muscular e a delicadeza dos sentidos de nossos indigenas...

${ }^{76}$ LACERDA, J. B. de. A força muscular e a delicadeza dos sentidos de nossos indigenas...

77 LACERDA, João Baptista de. A morfologia craneana dos homens dos sambaquis. Revista da Exposição Anthropologica Brazileira, Rio de Janeiro, jul. 1882, p. 22.

${ }^{78}$ O príncipe alemão Maximiliano de Wied-Neuwied, que esteve no Brasil entre 1815 e 1817 , teve contato com os índios botocudos e, em seu diário de viagem, questionou o modo como os botocudos eram representados por outros viajantes e pelos colonos. Na sua intepretação, muito influenciada pelo contato que teve com o jovem índio botocudo que o acompanhou, Guak, tal povo indígena era passível de ser civilizado, bastava que o processo ocorresse corretamente, para isso apresentou diversas sugestões. COSTA, Christina Rostworowski. O Príncipe Maximiliano de Wied-Neuwied e sua Viagem ao Brasil (1815-1817). Dissertação (Mestrado em História Social) - Universidade de São Paulo, São Paulo, 2008. 


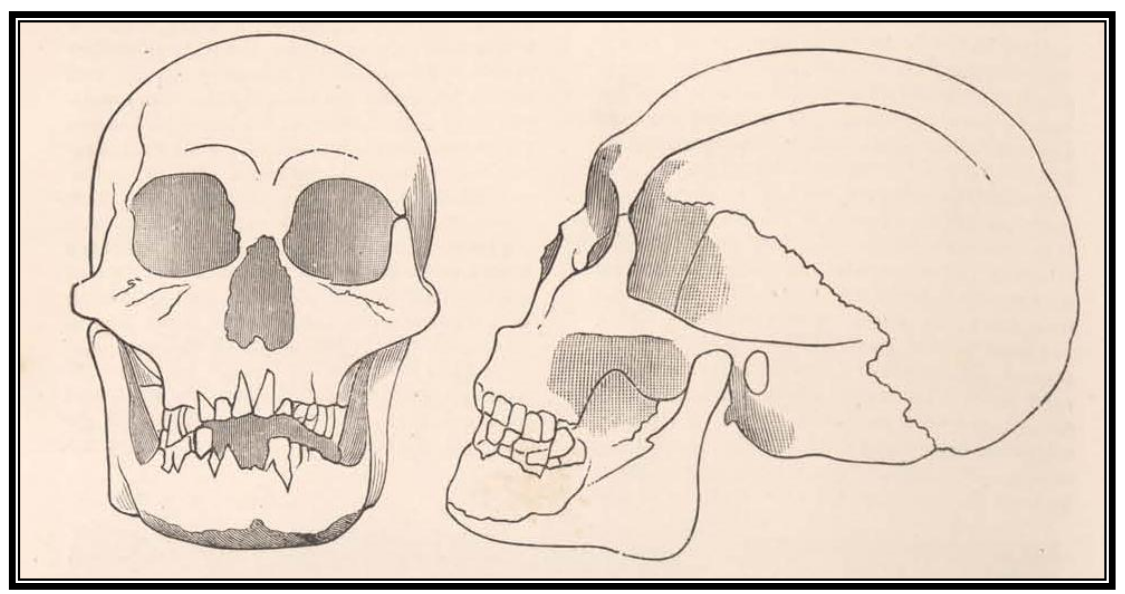

Imagem II - Crânios dos sambaquis. ${ }^{79}$

Enfim, o que precisa ser salientado aqui é a necessidade constante em qualificar negativamente o indígena. Com base em investigações craniométricas, Lacerda afirmou:

Posto que não tenhamos podido tomar a capacidade exata dessas cabeças, em virtude do estado de deterioração dos ossos do crânio, basta a simples inspeção da cavidade e das formas exteriores do crânio para se julgar o desenvolvimento cerebral do indivíduo.

Eles tinham um cérebro frontal rudimentário com um cérebro occipital mui desenvolvido, isto é, neles a mais nobre porção do órgão pensante atingia às proporções diminutas, que caracterizam os antigos crânios humanos ou as mais inferiores raças atuais.

O Botocudo, cuja morfologia craniofacial parece, nos tipos mais acentuados dessa raça, uma cópia do crânio humano do sambaqui, ocupa todavia um grau mais elevado na escala do desenvolvimento cerebral. Ora, o Botocudo é atualmente uma das raças indígenas mais brutalizadas do Brasil. ${ }^{80}$

Mesmo não realizando, de modo criterioso, as medições necessárias, Lacerda com uma "simples inspeção", conseguiu analisar os crânios do sambaqui e concluir que pertenciam a uma raça inferior às então existentes. Sua conclusão decorreu do pequeno tamanho da parte inferoposterior do crânio, onde estaria localizada a "parte mais nobre" do cérebro. Lacerda estava em sintonia com as pesquisas craniométricas que relacionavam o tamanho do crânio com a capacidade cerebral do indivíduo. Segundo o

\footnotetext{
${ }^{79}$ Revista da Exposição Anthropologica Brazileira, p. 22.

${ }^{80}$ LACERDA, J. B. de. A morfologia craneana dos homens dos sambaquis..., p. 23.
} 
pesquisador do Museu, a conformação craniológica do homem do sambaqui era muito próxima à dos botocudos. Esta proximidade forneceria mais argumentos para a propalada inferioridade dos botocudos, que seriam mais semelhantes aos habitantes dos sambaquis do que com as outras raças viventes.

Lacerda argumentou, em seguida, que o homem do sambaqui era um representante humano do tempo pré-histórico. Com o objetivo de corroborar sua assertiva, ele destacou que a arte produzida por aqueles indivíduos era "imperfeita e embrionária". A expressão artística, desta maneira, se tornava um parâmetro para qualificar e hierarquizar a humanidade. Com base nessas observações, o cientista concluiu que o "grau extremo de inferioridade em que encontramos o homem relativamente moderno do Brasil, faz-nos pensar que o desenvolvimento cerebral humano teve na Europa uma evolução mais rápida do que na América.” Em uma escala classificatória, Lacerda apresentou o indígena americano como inferior ao europeu. Para ele, o "homem quaternário do Cro-Magnon", o primitivo europeu, seria civilizado quando comparado ao representante do sambaqui, o que poderia ser comprovado pela observação admirável "arte de Magdalena". 81

Ainda em sua cruzada contra os botocudos, Lacerda sublinhou que:

Pela sua pequena capacidade craniana os Botocudos devem ser colocados a par dos Neo-Caledônios e dos Australianos, isto é, entre as raças mais notáveis pelo seu grau de inferioridade intelectual. As suas aptidões são, com efeito, muito limitadas e difícil é fazê-los entrar no caminho da civilização. ${ }^{82}$

Como representantes máximos da inferioridade racial, os botocudos só se aproximariam a outras raças também consideradas inferiores, como, por exemplo, os australianos. $^{83}$ Mais uma vez, o pesquisador do Museu ressaltou ser muito difícil conseguir civilizar os botocudos.

\footnotetext{
${ }^{81}$ LACERDA, J. B. de. A morfologia craneana dos homens dos sambaquis..., p. 23.

${ }^{82}$ LACERDA FILHO, J. B. e PEIXOTO, R. Contribuições para o estudo antropológico..., p. 71 e 72.

${ }^{83}$ Sobre a dita inferioridade dos australianos, o poligenista Louis-Antoine Desmoulins (1796-1828) utilizou-os para exemplificar a dificuldade em educar e aperfeiçoar as "raças selvagens". POLIAKOV, L. O mito ariano..., p. 203. Para Buffon, os australianos eram os que estariam mais próximos dos brutos. Já, o pensador francês Joseph Ernst Renan (1823-1892) considerava que a raça inferior era composta pelos nativos australianos, os negros africanos e os indígenas da América. TODOROV, T. Nós e os outros..., p. 116 e 122.
} 
Ao confrontar o crânio encontrado no sítio arqueológico da Lagoa Santa com o de um botocudo, Lacerda constatou, por meio do índice cefálico e do índice nasal, que ambos eram muito semelhantes. Com isso, concluiu que "no decurso de muitos séculos a raça dos Botocudos não tem subido um só grau na escala da intelectualidade". ${ }^{84}$ Desta vez, o pesquisador utilizou dados antropométricos para sustentar a inferioridade botocuda.

Outro crânio estudado por Lacerda foi o de Maracá (Guiana Brasileira). Após uma "simples inspeção", sem fazer uso de mensurações, o cientista inferiu que este se distinguia consideravelmente dos crânios dos botocudos, já que os de Maracá possuíam "contornos suaves" e "linhas mais regulares e corretas". Pode-se depreender que, na interpretação de Lacerda, os botocudos apresentavam uma conformação craniana incorreta, desviante da normalidade. Segundo o cientista, por apresentar essa suavidade de linhas, os crânios de Maracá não teriam o mesmo "aspecto feroz e brutal" que os botocudos. Então, ressaltou que tais expressões estéticas não tinham valor antropológico. Mesmo sabendo que essa observação não poderia ser considerada dentro do protocolo da ciência, o pesquisador não deixou de evidenciá-la, provavelmente com o intuito de reforçar a inferioridade dos botocudos. ${ }^{85}$

Nesse sentido, as comparações com relação ao índice cefálico, entre os indígenas de Maracá e os botocudos, foram inevitáveis.

O que parece, à primeira vista, fora de dúvida, é que os Botocudos e os indígenas de Maracá (Guiana brasileira) constituem dois tipos diferentes. Se pelo seu índice cefálico devem ser eles incluídos, como os Botocudos, na classe dos dolicocéfalos, essa identidade de classe não pode por si só estabelecer uma identidade de tipo, quando concorrem notáveis diferenças em outra ordem de caracteres. Sem querer desde já emitir uma proposição absoluta, porque os elementos que temos à mão não são ainda assaz numerosos, todavia quase chegamos a afirmar que a verdadeira braquicefalia não tem representantes nas raças aborígenes do Brasil. O futuro provará até que ponto é verdadeira esta presunção. ${ }^{86}$

\footnotetext{
${ }^{84}$ LACERDA FILHO, J. B. e PEIXOTO, R. Contribuições para o estudo..., p. 73.

${ }^{85}$ LACERDA, João Baptista de. Craneos de Maracá Guyana Brasileira. Contribuições para o estudo anthropologico das raças indigenas do Brasil. Archivos do Museu Nacional, Rio de Janeiro, vol. IV, p. 3545, 1881, p. 38.

${ }^{86}$ LACERDA, J. B. de. Craneos de Maracá..., p. 43.
} 
Lacerda não possuía dúvidas com relação às diferenças entre os dois grupos indígenas. Entretanto, ao aferir o índice cefálico dos índios de Maracá verificou que eram dolicocéfalos, assim como os botocudos. A constatação poderia ser suficiente para classificá-los como um grupo inferior, porém, teve seu grau de importância minimizado pelo cientista. Isso porque, ele queria provar, ou simplesmente já partiu do pressuposto, que os índios de Maracá não eram semelhantes aos botocudos, considerados os mais inferiores de todos. Como aquele crânio com linhas tão suaves poderia ser semelhante ao dos botocudos? Para resolver tal questão, Lacerda argumentou que ainda possuía poucos dados para inferir algo mais contundente. Cabe aqui salientar que, com muito menos, ele afirmava a inferioridade dos botocudos. Outro ponto a ser destacado é que em momento algum, ele evidenciou que os crânios dolicocéfalos eram típicos de povos nórdicos, talvez porque isso minimizaria a inferioridade do botocudo que ele tanto defendia. ${ }^{87}$ Lacerda levantou a hipótese da inexistência de crânios braquicéfalos entre os índios brasileiros. Logo em seguida informou que Couty, que estava no Paraná, havia comunicado, por carta, ter descoberto alguns crânios indígenas braquicéfalos. Tal evidência ratificaria a inferioridade do indígena do Brasil.

A dentição dos crânios indígenas também foi objeto de investigação de Lacerda. Com base na análise dentária, ele chegou a conclusões sobre características pertencentes não apenas aos indígenas brasileiros, mas a "quase todas as raças da América". Acerca da coloração dos dentes, observou que era "branca-amarelada" e opaca, contrastando com o "brilho vítreo da camada adamantina da raça caucásica". Ao descrever os dentes indígenas, o cientista os apresentou com traços inferiores. Apesar disso, elogiou a ausência de cárie nos "dentes nas raças indígenas" brasileiras. ${ }^{88}$ Comparando os dentes dos índios da Bolívia com os do Brasil, verificou a existência de semelhanças entre ambos e, com base nisso, assegurou que seria possível terem tido a mesma origem. Esse seria mais um dado para confirmar sua hipótese de uma origem única para povos americanos.

E, ao assumir a conformação dentária como indicativo da inferioridade racial indígena, afirmava:

\footnotetext{
${ }^{87}$ A seleção arbitrária de dados, que seriam convenientes de serem considerados como provas científicas, não foi exclusividade de Lacerda. Gould alerta para o caso de Broca, que "não falsifica dados numéricos: limita-se a selecioná-los à sua maneira para que justifiquem as conclusões desejadas" GOULD, S. J. A falsa medida do homem..., p. 80.

88 LACERDA, João Baptista de. Sobre a conformação dos dentes II. Revista da Exposição Anthropologica Brazileira, Rio de Janeiro, jul. 1882, p. 82.
} 
Encarando agora a questão [dos dentes dos indígenas serem naturalmente desgastados desde a infância] sobre um outro ponto de vista, somos levados a considerar a conformação geral dos dentes nas raças indígenas da América como um caráter da inferioridade étnica.

Percorrendo-se toda a coleção de Morton e a nossa, que existe no Museu Nacional, descobre-se logo à primeira vista um certo cunho de animalidade impresso na dentadura dos crânios americanos. ${ }^{89}$

Apesar de sublinhar que não desconsiderava o desgaste dentário provocado pela alimentação, para Lacerda o observado nos dentes analisados era indicativo da “inferioridade étnica” dos índios brasileiros. Em 1877, o antropólogo norte-americano Lewis Henry Morgan (1818-1881) empregou o termo étnico no sentido de estágios civilizatórios, que seriam três: selvageria, barbárie e civilização, cada um apresentando subdivisões. É possível que Lacerda tenha utilizado a conceito "étnico" nesta mesma acepção - estágios civilizatórios - numa visão evolutiva da sociedade. ${ }^{90} \mathrm{O}$ cientista do Museu aproximou os índios aos animais, desta maneira, distanciando-os ainda mais do homem branco. Tal comparação foi recorrente nos textos de Lacerda, por mais de uma vez advogou a existência de traços animalescos nos crânios indígenas. Ao término, ele concluiu que o estudo mostrava o "caráter distintivo das raças da América", indicando a "unidade do tipo étnico" dos habitantes originais do Novo Mundo. ${ }^{91}$

Pela citação acima, é possível depreender que Lacerda conhecia as pesquisas do médico e cientista norte-americano Samuel George Morton, que em sua carreira reuniu uma coleção com mais de mil crânios. Defensor do poligenismo, Morton tinha como intuito demonstrar que as características físicas do cérebro, com destaque particular ao tamanho, poderiam estabelecer uma hierarquia racial. ${ }^{92}$ Nessa pesquisa, o cientista dedicou especial atenção aos crânios dos indígenas da América. Em 1839, na obra ilustrada Crania Americana, o médico apresentou os resultados de suas pesquisas sobre os indígenas americanos. Por meio da craniometria, pelos padrões científicos da época,

\footnotetext{
89 LACERDA, João Baptista de. Sobre a conformação dos dentes III. Revista da Exposição Anthropologica Brazileira, Rio de Janeiro, jul. 1882, p. 91.

${ }^{90}$ MORGAN, Lewis H. Ancient society or researches in the lines of human progress from savagery, through barbarism to civilization. New York: Henry Holt and Company, 1877.

${ }^{91}$ LACERDA, J. B. de. Sobre a conformação dos dentes III..., p. 92.

${ }^{92}$ GOULD, S. J. A falsa medida do homem..., p. 40.
} 
Morton comprovou empiricamente a inferioridade intelectual do índio. ${ }^{93}$ A influência do cientista norte-americano nos estudos e interpretações de Lacerda deve ter sido significativa, tanto com relação à importância de se mensurar crânios quanto na sustentação da inferioridade indígena.

Ao comparar a audição e a visão dos indígenas com as dos brancos, Lacerda assegurou que nos primeiros elas possuíam "uma força de penetração maior”. Objetos e sons distantes seriam identificados pelos indígenas com maior facilidade. Contudo, segundo o pesquisador do Museu, os índios não observavam os pequenos detalhes quando próximos, denotando "a inferioridade do sentido visual do selvagem". Este problema explicaria a dificuldade dos indígenas em reproduzir melodias simples repetidas várias vezes, revelaria também porque seus cantos eram "de uma monotonia fatigante". Porém, isso não era uma característica da raça e sim "uma consequência natural e necessária das suas condições de vida". O mesmo ocorreria com as artes plásticas, as representações indígenas seriam "informes e grotescas". ${ }^{94}$ Portanto, neste caso, para Lacerda, a inferioridade não era natural, mas sim social.

O pesquisador ainda comparou a produção artística indígena com a dos antigos habitantes europeus: estes reproduziam formas animais "com mais exação e fidelidade" que os índios brasileiros da ilha de Marajó. ${ }^{95}$ Apesar da superioridade do homem primitivo branco em relação ao indígena brasileiro, o cientista afirmou que o índio fazia mais representações da forma humana do que a "arte relativamente adiantada dos trogloditas". ${ }^{96}$ Todavia, isso ainda não colocava os indígenas do Brasil em uma situação melhor, uma vez que a arte produzida pelos antigos índios brasileiros foi confrontada com a dos povos pré-colombianos do México e do Peru:

Os antigos mexicanos deixaram esculpidas nos seus monumentos formas particulares, que são hoje muito conhecidas e admiradas. O mesmo se deu com as mais antigas raças do Peru. Se os inábeis construtores dos sambaquis, dessas obras grosseiras, sem formas regulares e prefixas, houvessem querido com elas perpetuar algum importante acontecimento ou materializar um pensamento qualquer,

\footnotetext{
93 MORTON, Samuel George. Crania Americana; or, a comparative view of the skulls of various aboriginal nations of North and South America. An essay on the varieties of the human species. Philadelphia: J. Dobson; London: Simpkin, Marshall \& Co., 1839.

${ }^{94}$ LACERDA, J. B. de. A força muscular e a delicadeza dos sentidos de nossos indígenas..., p. 7.

${ }^{95}$ LACERDA, J. B. de. A força muscular e a delicadeza dos sentidos de nossos indígenas..., p. 7.

${ }^{96}$ LACERDA, J. B. de. A força muscular e a delicadeza dos sentidos de nossos indígenas..., p. 7.
} 
tal pensamento ter-se-ia certamente fundido em outros moldes talhados com uniformidade e um certo cunho artístico.

As manifestações da atividade cerebral humana, sob o ponto de vista da arte ou da indústria, há, é verdade, uma infinita gradação que ascende desde o mais ínfimo representante da espécie até o mais portentoso produto dela. Desde o Austrálio e o Tasmâni, quase nivelados ao bruto até o artístico cérebro de Miguel Angelo ou de Raphael, que inúmeras modalidades, que gradações infinitas pra a concepção de beleza e da regularidade das formas! O homem dos sambaquis não possuía certamente como os Astecas e os Peruanos, um cérebro afeiçoado às produções artísticas; sua inferioridade cerebral estava mesmo colocada a um nível tão baixo que não lhe permitia pensar em erguer monumentos, cuja existência pressupõe um grau de civilização. $^{97}$

Quando comparado aos indígenas peruanos e mexicanos, os do Brasil foram representados por Lacerda como inferiores, visto que seus resquícios arqueológicos não eram tão elaborados, mas sim apenas "obras grosseiras". Na interpretação do cientista, as expressões artísticas poderiam ser utilizadas para medir a "atividade cerebral" de determinado povo. Portanto, pode-se constatar que todos os povos da América haviam tido a mesma origem, porém, alguns eram superiores, especialmente aqueles que se localizavam no México e no Peru. Entre os índios brasileiros também existia uma gradação. Os botocudos, por exemplo, eram os mais inferiores de todos (isso já pensando nos índios contemporâneos de Lacerda). Para o pesquisador do Museu,

[As] raças aborígenes desta parte do novo mundo não deixaram sequer vestígios apagados de uma civilização incipiente; elas atravessaram os séculos, pela maior parte, na mais profunda barbárie e prolongaram até hoje essa longa e tenebrosa fase de sua vida primitiva. ${ }^{98}$

Segundo Lacerda, o estado atual do indígena nacional não poderia nem ser considerado como uma decadência, haja vista a inexistência de monumentos que

\footnotetext{
${ }^{97}$ LACERDA, João Baptista de. Os homens dos sambaquis (contribuição para a anthropologia brazileira). Archivos do Museu Nacional, Rio de Janeiro, vol. VI, 1885, p. 179 e 180.

${ }^{98}$ LACERDA, J. B. de. Os homens dos sambaquis..., p. 182.
} 
comprovassem o contrário. Os índios atuais estariam, então, "no mesmo nível de civilização, ou para melhor dizer de profunda barbárie" que os seus antecessores. ${ }^{99}$

O uso do índio como mão de obra também foi foco de sua reflexão. Neste tema, Lacerda expressou o seguinte posicionamento:

Poder-se-ia antes admitir que o músculo indígena fatiga-se mais depressa que o músculo da raça civilizada. Ao menos esta interpretação estaria de acordo com o fato reconhecido da inaptidão dos nossos selvagens para os trabalhos penosos. Trazidos para o meio civilizado, eles continuam a revelar a mesma inaptidão. A consequência importante desse fato seria - que o nosso indígena, mesmo civilizado, não poderia produzir a mesma quantidade de trabalho útil, no mesmo tempo, que os indivíduos de outra raça, especialmente da raça negra.

Reduzido o problema fisiológico a estes termos, fácil é compreender-se o seu alcance no aproveitamento das forças indígenas do país para os árduos trabalhos da lavoura. $\mathrm{O}$ índico não poderia substituir o negro como instrumento de trabalho; a sua produção seria descontínua, necessitando intervalos maiores de repouso.

Eis aí como de um problema antropológico deduz-se um problema econômico e industrial, o que mais uma vez demonstra que a antropologia não é uma ciência meramente especulativa, mas que ela é suscetível de ter aplicações práticas e úteis. ${ }^{100}$

Em um momento em que a questão da substituição da mão de obra escrava negra era discutida em vários espaços sociais, era marcante o posicionamento de Lacerda, que, ao concordar com outros tantos cientistas, mostrava-se contrário à utilização do trabalho indígena. Para ele, os índios seriam comprovadamente inaptos ao trabalho porque seus músculos cansavam-se facilmente. Ao comparar o trabalhado produzido por um índio com o de um negro, concluía que o segundo seria muito mais produtivo, ou seja, em uma escala de produtividade o índio seria inferior ao negro. E isso não era uma questão de falta de civilização, mas sim uma inaptidão inata.

Por fim, Lacerda enfatizou a aplicação prática da ciência na sociedade, porque seria possível, com base em estudos antropológicos, deduzir soluções para questões de

${ }^{99}$ LACERDA, J. B. de. Os homens dos sambaquis..., p. 182.

${ }^{100}$ LACERDA, J. B. de. A força muscular e a delicadeza dos sentidos..., p. 7. Grifo do original. 
cunho "econômico e industrial". Mais uma vez destaco que este, possivelmente, foi um dos princípios norteadores de suas preleções públicas no Museu Nacional.

Com relação à catequese dos botocudos, ressaltou:

Alguns, de índole bravia e indomáveis, têm resistido a todos os meios de catequese, e fugido diante da civilização internam-se cada vez mais no coração das florestas; outros, mais dóceis e mais acessíveis, vão se deixando conduzir ao grêmio da religião cristã e abandonando, pouco a pouco, os hábitos e costumes da vida selvagem. São estes últimos que formam os diversos aldeamentos que se encontram no norte da província de Minas, onde eles obedecem à voz de um chefe ou de um missionário. São eles geralmente indolentes, pouco amigos do trabalho, de um caráter excessivamente desconfiados, vingativos, e sustentam-se, uns com os produtos de caça, outros com os produtos de pesca. $^{101}$

A catequese dos botocudos, para Lacerda, era vista como um dos meios para civilizá-los, pois uma vez catequisados abandonariam a "vida selvagem". Porém, ela só seria produtiva nos índios "mais dóceis". Quanto aos mais arredios, a tentativa de catequização seria inútil: eles acabariam fugindo, o que não era de estranhar, visto que sempre foram descritos como os mais indomáveis de todos. Lacerda, contudo, era descrente sobre o real ganho com a civilização dos indígenas, porque mesmo aqueles índios que já estavam vivendo em aldeamentos, catequisados e obedecendo ao missionário responsável, continuavam "indolentes", "desconfiados" e "vingativos". Portanto, muito provavelmente Lacerda concebia a civilização dos botocudos como praticamente impossível, haja vista que seus supostos desvios morais continuariam intactos.

A temática indígena não esteve presente apenas no Museu Nacional. O tema também foi abordado na tribuna das Conferências Populares da Glória. O médico Feliciano Pinheiro de Bittencourt, por exemplo, tratou do assunto em várias oportunidades na década de 1880. Discursou sobre os indígenas brasileiros sublinhando aspectos variados, como a sua origem e seus hábitos culturais e sociais. Centrou também a atenção nos indígenas da América como um todo, com ênfase nos maias,

${ }^{101}$ LACERDA FILHO, J. B. e PEIXOTO, R. Contribuições para o estudo antropológico..., p. 49. 
astecas e incas. O resumo de sua primeira preleção sobre o tema, em 1883, foi assim noticiado pelo Jornal do Commercio:

Entrando na matéria da conferência [Feliciano Bittencourt] discutiu a origem primitiva do gentio do Brasil; os cruzamentos que se fizeram com a raça pura; as suas migrações pelo nosso território, mostrando que nada se sabe até hoje de positivo e real a respeito, fundando-se tudo em meras hipóteses, ou probabilidades, que não são de certo a verdade histórica. Dos cruzamentos resultaram as duas famílias de Tupis ou Guaranis, e Tapuias que dominavam o litoral e o interior do país quando os Portugueses chegaram às nossas plagas.

Mostrou detidamente qual a alimentação dos gentios, como a preparavam; quais os seus instrumentos de caça, de pesca, de música, de guerra, etc.; qual o gênero de agricultura a que se entregavam, como se tratavam em suas moléstias, como faziam o enterramento dos mortos, etc.

Falou das tabas ou aldeias, dos casamentos entre os gentios, do [?] dado aos prisioneiros e aos doentes de moléstias crônicas, prendendo sempre por mais de uma hora a atenção do numeroso auditório, que o aplaudiu ao descer da tribuna. ${ }^{102}$

Apesar de afirmar que a explicação das origens dos grupos indígenas brasileiros ainda era pautada em hipótese, segundo Feliciano de Bittencourt, existiu uma raça indígena pura, e dela originaram as duas grandes famílias existentes, qual seja, os tupis e os tapuias. ${ }^{103}$ Assim, na abordagem do conferencista, os indígenas existentes desde o período colonial seriam mestiços originários de uma raça pura. Cada agrupamento indígena, este feito em termos linguísticos, era considerado como uma raça específica. Em seguida, se deteve na descrição de alguns aspectos culturais e sociais dos mesmos.

Com relação à origem da tal "raça pura", em uma conferência de 1888, Bittencourt asseverou:

\footnotetext{
102 Jornal do Commercio, 15/05/1883. Grifos do original.

${ }^{103}$ Com relação à origem dos grupos indígenas brasileiros, havia também aqueles que defendiam uma ascendência asiática para os mesmos. Tal posicionamento foi acatado, por exemplo, por Gonçalves Dias (1823-1864), para este, "os tupis formavam uma raça invasora superior que, vinda do norte, havia conquistado os grupos tapuias de origem mongol e tomado suas mulheres. $\mathrm{O}$ resultado teria sido a decadência dos tupis mais civilizados, devido à sua integração de uma população mais bárbara e atrasada." Já Francisco Adolfo de Varnhagen (1816-1878) propunha que "os tupis eram um povo invasor, vindo do norte, aparentado originalmente aos egípcios e fenícios." MACHADO, M. H. P. T. Os tupis e a turânia..., p. 174-175.
} 
O fim principal do conferente tem sido demonstrar que é uma única a origem do gentil de toda a América; que a raça é a mesma, dependendo as modalidades das condições de meio e outras.

Outrossim que o selvícola americano é autóctone, isto é, não veio da Ásia, ou de qualquer outro ponto do globo. ${ }^{104}$

Cinco anos após considerar as teorias sobre a origem dos homens na América como apenas hipotéticas, Bittencourt passou a discutir a questão de maneira mais contundente. Por meio de uma interpretação poligenista, assegurou que todos os indígenas do Novo Mundo eram autóctones, tiveram a mesma origem, "constituindo uma grande raça - a vermelha ou cor de cobre". ${ }^{105}$ A cor da pele, desta maneira, era o parâmetro utilizado pelo médico conferencista para classificar a humanidade, esta também determinaria as características morais do indivíduo.

Como se definia um "sectário confesso" do poligenismo, afirmou que um dos centros de criação fora na América, sustentando que havia acumulado provas diversas para fundamentar as assertivas expostas em suas preleções. ${ }^{106}$ Evidências provavelmente coletadas em suas leituras, uma vez que não encontrei registro de pesquisas empíricas feitas por Bittencourt. Alguns trabalhos publicados na Revista do Instituto Histórico e Geográfico Brasileiro foram por ele referenciados como excelentes para o estudo acerca da "origem dos selvagens no Brasil". ${ }^{107}$

Outra temática sobre a qual Bittencourt versou foi a catequese indígena:
Ocupou-se por último com o importante assunto da catequese $e$ civilização dos índios, mostrando os grandes defeitos do sistema que tem sido empregado até agora, e apontando os meios que supõe mais próprios para colher-se resultado positivo de serviço tão necessário e urgente. $^{108}$

Para o preletor, catequizar o índio era primordial: a catequese colaboraria para civilizá-lo. Por este motivo, efetivar tal empreitada era fundamental para o progresso do

\footnotetext{
${ }^{104}$ Jornal do Commercio, 04/07/1888. Grifos do original.

105 Jornal do Commercio, 28/08/1888.

106 Jornal do Commercio, 14/08/1889.

107 Jornal do Commercio, 24/09/1889. Feliciano de Bittencourt citou os seguintes autores, que publicaram artigos sobre o tema na revista do Instituto: Varnhagen, Gonçalves Dias, Accioli de Cerqueira e Silva, Candido Mendes, Joaquim Norberto e engenheiro Tocantins.

108 Jornal do Commercio, 12/11/1882. Grifos do original.
} 
Brasil. De acordo com Bittencourt, para a boa imagem nacional, o selvagem precisava ser civilizado, o contrário denotaria um país atrasado. Entretanto, esta opinião não era unânime. Existiam aqueles que viam o extermínio indígena como a melhor solução. Para Varnhagen, por exemplo, não havia necessidade de civilizar o índio, porque eles já estavam em um processo de degeneração que levaria à inevitável extinção. Esta posição obteve relativa força nas discussões realizadas no Instituto Histórico e Geográfico Brasileiro, instituição da qual Bittencourt era membro. ${ }^{109}$

Bittencourt ressaltou os problemas na maneira como se dava a catequização, que não tornava frutífera a proposta original: catequizar para civilizar. Com relação à ausência de eficácia da catequização, Couto de Magalhães, por exemplo, afirmava que era ela que levava à degradação indígena, pois introduzia hábitos degradantes aos povos, preguiça, vícios, embriaguez. ${ }^{110}$ No correr do século XIX, eram comuns as críticas ao modo como era realizada o sistema, havia discordância se seriam mais adequados os religiosos brasileiros ou estrangeiros. Optou-se, por fim, pela utilização, na maioria dos aldeamentos, de capuchinos italianos. ${ }^{111}$

$\mathrm{Na}$ concepção de Bittencourt, o conhecimento da língua do indígena (nem que fosse por meio de intérpretes) e dos seus "usos e costumes" eram essenciais para que a catequese se realizasse na prática. Para exemplificar tal necessidade, ele citou os jesuítas que aprenderam o tupi para catequizar os índios do litoral em períodos anteriores. Somente assim seria possível, para o orador, obter "resultados positivos neste importante ramo do serviço público". ${ }^{112}$ Conforme sustenta Kaori Kodama, desde meados do século XIX a catequização e a civilização dos índios eram consideradas "um ramo do 'serviço público' integrado à pasta ministerial do Império.",113

Diferentemente de João Baptista de Lacerda, Bittencourt era favorável ao emprego do índio como mão de obra: "Respondeu o orador [Feliciano Bittencourt] às objeções dos que pensam que os índios não servem para o trabalho, lembrando que não há melhores para as indústrias extrativa e pastoril." ${ }^{114}$ Bittencourt sabia que sua afirmação estava na contramão de alguns paradigmas científicos que defendiam a

\footnotetext{
109 Varnhagen foi radical, chegando a propor o retorno das bandeiras particulares, com o intuito de capturar indígenas. MONTEIRO, J. Entre o gabinete e o sertão..., p. 147 e 148.

${ }^{110}$ MONTEIRO, J. Entre o gabinete e o sertão..., p. 152 e 153.

${ }^{111}$ MONTEIRO, J. Entre o gabinete e o sertão... KODAMA, Kaori. Os índios no Império do Brasil: a etnografia do IHGB entre as décadas de 1840 e 1860. Rio de Janeiro: Editora Fiocruz; São Paulo: Edusp, 2009.

112 Jornal do Commercio, 26/11/1883.

113 KODAMA, K. Os índios no Império do Brasil..., p. 244.

${ }^{114}$ Jornal do Commercio, 26/11/1883.
} 
inaptidão dos índios para o trabalho. Mas ele não estava só. Couto de Magalhães também compactuava com esse posicionamento. A diferença é que Magalhães indicou apenas a pecuária como atividade para o indígena, além desta, Bittencourt assegurava que eles poderiam também dedicar-se às atividades extrativistas. ${ }^{115}$ Assim, para Feliciano Bittencourt era necessário catequizar o índio, a fins de civilizá-lo. Tal programa era uma questão de Estado, pois isso iria colaborar tanto na imagem de um Brasil civilizado, quanto no emprego do indígena como mão de obra.

Por meio dessa análise é possível observar que todos os oradores, que trataram da temática indígena nos cursos e conferências, partiam do princípio que o índio era uma raça específica da humanidade. O único a apresentar uma representação mais positiva do índio foi Couto de Magalhães, os demais conferencistas classificaram os indígenas com inferiores em uma escala racial. João Baptista de Lacerda, por exemplo, fundamentava essa hierarquização nos estudos craniológicos, enquanto Feliciano Pinheiro de Bittencourt destacava a cor da pele. Com relação à utilização da mão de obra indígena, Lacerda era contrário ao uso, devido à inferioridade nata dos indígenas, já Magalhães e Bittencourt advogavam a favor, principalmente se o trabalho fosse relacionado à pecuária. Questões estéticas estiveram presentes nas análises de Ladislau Netto e de Lacerda, ambos destacando a ausência de beleza dos índios. Enfim, as abordagens, que o público espectador das preleções teve contato, eram múltiplas e marcavam a necessidade que aqueles cientistas tinham de estudar e classificar o índio enquanto uma raça humana.

\section{Os "esquecidos" negros}

Assim como os indígenas, a população negra foi foco de pesquisas científicas racializadas, as quais naturalizavam a classificação dos negros como inferiores aos brancos. A inferioridade do negro era comprovada por diversos métodos, que iam das medidas do crânio até o grau de "civilização" de suas sociedades. Essa inferioridade, inclusive, precisava apenas ser demonstrada, porque já se partia do princípio de sua

\footnotetext{
${ }^{115}$ Outro intelectual a defender o emprego da mão de obra indígena foi o Frei Serafim de Gorízia (18291918), em seus escritos feitos próximos à abolição, contrariando o que era sustentado por muitas teorias científicas. MONTEIRO, J. Entre o gabinete e o sertão..., p. 162.
} 
existência. ${ }^{116}$ Segundo Poliakov, já no século XVIII, Linné acentuava o abismo existente entre os brancos e os negros, ao comparar o europeu com o hotentote enfatizou que seria difícil convencer alguém de que ambos tiveram a mesma origem. ${ }^{117}$

As conferências e cursos públicos trataram de temáticas científicas variadas, e as relativas à raça se fizeram presentes e marcantes. Entretanto, nos inflamados discursos que abordavam a questão da raça, o elemento negro não mereceu destaque. Conforme apresentei no capítulo 1, ele era o "outro" que estava ao lado, diante dos olhos, e, devido à existência da escravidão na sociedade, que muito fundamentava as relações sociais, econômicas e culturais, optou-se por não abordar detidamente nem a temática da escravidão e nem aprofundar discussões raciais em torno do negro. ${ }^{118}$ É provável que o fator determinante para tal ausência tenha sido a escravidão e a rede interesses que envolvia muitos dos oradores e do público.

Todavia, ao ler os artigos publicados pelo diretor do Museu Nacional, Ladislau Netto, verifiquei que, por vezes, ele tocou em temáticas raciais que envolviam o negro. Neste sentido, penso que seja provável supor que em suas conferências Netto tenha tangenciado o assunto. Apesar de ser o responsável pelos cursos de botânica, em alguns momentos ele se afastava rapidamente de sua temática, dando exemplos fora da área ou comentando outros temas. Por esse motivo, considero relevante analisar seu posicionamento acerca dos negros, para compreender, um pouco melhor, quais poderiam ter sido os conteúdos dos seus discursos sobre os mesmos.

$\mathrm{Na}$ concepção de Ladislau Netto, as manifestações atávicas eram fundamentais para a compreensão da miscigenação das raças. Entretanto, ressaltou que ainda era necessária a produção de uma obra que analisasse o atavismo no "vasto crisol da humanidade, chamado "América"'. Com relação ao prognatismo, projeção para frente do maxilar inferior, ele salientou que era "um dos característicos mais notáveis da raça africana”, e muitas vezes passível de ser observado em indivíduos que já não possuíam nenhum outro tipo de característica óssea típica dos negros. Ainda sobre o atavismo, outro exemplo dado pelo diretor do Museu foi a coloração de determinadas partes do corpo, como da a "cavidade bucal". 119

\footnotetext{
${ }^{116}$ Gould destaca que os dados empíricos eram trabalhados de modo a comprovar a inferioridade da qual se partia como princípio norteador. GOULD. S. J. A falsa medida do homem...

${ }^{117}$ POLIAKOV, L. O mito ariano..., p. 137.

${ }^{118}$ Exceção feita às conferências abolicionistas, que não são meu foco de análise, e daquelas que discutiam a substituição da mão de obra cativa.

${ }^{119}$ NETTO, Ladislau. Do atavismo. Revista da Exposição Anthropologica Brazileira, Rio de Janeiro, jul. 1882 , p. 4. Este texto era parte do seguinte artigo, anteriormente publicado: NETTO, Ladislau.
} 
Alguns traços atávicos, segundo Netto, poderiam despontar em determinada fase da vida e depois desaparecer:

É pela época da puberdade que em geral mais claro se manifestam os sintomas atávicos nas pessoas mestiças, muitas vezes já de cor perfeitamente branca, e tendo o sangue africano em adiantadíssima diminuição nas veias.

Neste caso toda a constituição do indivíduo sofre notável alteração; além da pigmentação pronunciada nas regiões a que acima me referi, e que se estende aos mamelões e aos órgãos reprodutores de ambos os sexos, nota-se o desenvolvimento dos lábios e das narinas, de par como retraimento do mento, o aparecimento do cheiro acre e nauseabundo da transpiração axilar, denominado catinga, o encrespamento do cabelo, o colorido mais vigoroso de toda a pele, e quase sempre uma tal ou qual diminuição do próprio ângulo facial.

A todas estas modificações acresce a pronunciada indolência, apatia excessiva e profunda abstração, ou antes uma inação intelectual que lembra muito particularmente a estúpida inaptidão do negro. A esse abatimento, entretanto, antepõe-se um quer que seja de lúbrico, e um como desabrochar pujante de bruta sensualidade, a que só podem contrapor eficiente dique os liames da mais vigorosa educação moral.

Felizmente, este que eu chamarei estado mórbido, tem efêmera duração [...]

Assim é que em muitos indivíduos que, manifestaram entre os quatorze e dezesseis anos quase todos estes indícios de atavismo, vemo-los desaparecerem depois de vinte anos, inclusive o próprio encrespamento e aspereza do cabelo, na maior parte dos casos tão tenaz e tão rebelde característico da origem africana. ${ }^{120}$

De acordo com Ladislau Netto, a puberdade era a fase na qual as características negras poderiam aparecer no mestiço, mesmo naquele que fosse totalmente branco. Os traços atávicos eram depreciativos, descritos de modo a inferiorizar o negro. Sobre o "cheiro acre e nauseabundo", o cientista associou-o à herança negra. Havia uma metáfora, de procedência portuguesa, que dizia que os negros exalavam um cheiro 
semelhante ao bodum, a catinga, dos caritos não castrados. Por este motivo, segundo Ivana Stolze Lima, os mulatos eram designados como bodes e cabras. É possível que ao relacionar o cheiro ao negro, Netto tenha se pautado nessa apreensão. ${ }^{121}$

$\mathrm{Na}$ argumentação do diretor do Museu, além de alterações físicas, também seriam observadas mudanças de comportamento que estariam associadas à ascendência negra do indivíduo. A pessoa com tal origem passaria a apresentar comportamento insolente, apático e inércia intelectual que, na sua interpretação, lembravam a "estúpida inaptidão do negro". Esta era, portanto, a visão do cientista sobre o negro. Netto assegurou que uma sensualidade aflorada também se faria presente, e ela só poderia ser minimizada por meio do forte olhar educador. Desta maneira, o negro foi representado como o portador de uma apatia e sensualidades natas. Entretanto, a fim de tranquilizar aqueles que pudessem se sentir desesperados por trazerem consigo as marcas da procedência racial, Ladislau sublinhou que "felizmente" este "estado mórbido" despareceria. Características típicas da fase da puberdade, e consideradas como desviantes da normalidade (quase uma patologia), foram interpretadas pelo pesquisador como manifestações atávicas, decorrentes da origem negra.

Com relação às manifestações atávicas oriundas de uma mestiçagem com índios, Netto argumentou:

$\mathrm{O}$ atavismo nas pessoas de origem indígena é de caráter muito mais fixo, e portanto menos sujeito a esta influição da puberdade, denunciando-se, por assim dizer, desde o berço.

Acresce-se que, em tais indivíduos, manifesta-se caracterizando-lhes o atavismo, não a fera animal dos primeiros, mas quase sempre uma tal ou qual perfectibilidade de caráter moral e um desenvolvimento intelectual, que vem garantindo desde a mais tenra infância do jovem indivíduo o homem laborioso e honesto, que há de daí dar para o arrimo da família, para o benefício da pátria e para o bem geral da humanidade.

Este atavismo é o que me parece perfeitamente caracterizado em um dos atuais e melhores empregados do Museu Nacional, o Sr. João da Motta Teixeira, pelo lado paterno, radicado nas mais distintas famílias de Minas Gerais, porém descendente por sua avó materna do

${ }^{121}$ LIMA, Ivana Stolze. Cores, marcas e falas: sentidos da mestiçagem no Império do Brasil. Rio de Janeiro: Arquivo Nacional, 2003, p. 89. 
famoso chefe aborígene denominado Tebiriça, cujo nome acha-se enlaçado às primeiras lutas da invasão portuguesa no Brasil. ${ }^{122}$

$\mathrm{Na}$ análise de Netto, o atavismo indígena não seria externado em determinada fase da vida da pessoa, ela já nasceria com os traços atávicos visíveis, que a acompanhariam por toda a existência. Essas características seriam positivas para o país e para a humanidade como um todo. Assim, o cientista se mostrou favorável à miscigenação. Ao citar o exemplo do funcionário do Museu, Netto evidenciou que o antepassado indígena era um "famoso chefe aborígene", provavelmente tupi, uma vez que estava relacionado com as primeiras lutas com os portugueses. Será que o pesquisador teria o mesmo posicionamento caso fosse um índio tapuia? Talvez ele tenha feito tal observação apenas porque tivesse laços de amizade e estima com o referido empregado.

As características positivas, expostas pelo diretor do Museu, daqueles com ascendência indígena, entretanto, não os colocava como superiores aos que possuíam origem negra. Os traços atávicos negativos relacionados aos negros se manifestariam apenas em uma fase da vida do indivíduo e depois sumiriam. No correr de sua vida, esse sujeito ainda apresentaria de maneira mais evidente as qualidades que herdou do componente branco:

A estas observações acrescentarei uma reflexão a que poderão dar talvez um grande desenvolvimento os antropologistas que houverem de ocupar de tal matéria, e é que, em relação aos mestiços oriundos da raça branca com a preta, mostram-se eles ordinariamente mais inteligentes que os mestiços resultantes da junção do sangue branco ao sangue americano, ainda que menos refletidos, menos metódicos, no que produzem, em se me é permitido dizê-lo, menos equânimes. Notei até por vezes que nas famílias mestiças da primeira categoria, em que os caracteres africanos denunciam-se em manifestação atávica, num certo indivíduo, mais do que em seus irmãos ou primos, dá-se o interessante fenômeno de ser aquele indivíduo o mais inteligente representante da família, ou de se concentrar na sua individualidade qualquer aptidão artística, imaginação mais ardente, uma sequer, mais viva e mais pronta

\footnotetext{
${ }^{122}$ NETTO, L. Do atavismo..., p. 5.
} 
percepção. Feliz e providencial compensação para a vítima do atavismo, que mais o é dos despeitos de seus próprios pais e irmãos, cujas pretensões mais ou menos infundadas a uma brancura, às vezes duvidosa, foram por aquele natural fenômeno inteiramente burladas. ${ }^{123}$

Para Netto, o produto do cruzamento do branco com o negro era superior ao do branco com o índio. Desta maneira, ele procedeu a uma hierarquização racial, na qual o índio era o mais inferior. Talvez tenha feito tal observação porque os traços atávicos naquele de origem negra fossem passageiros. O diretor do Museu argumentou que, em uma mesma família de mestiços de brancos e negros, o indivíduo que apresentasse manifestações atávicas negras seria o mais inteligente quando comparado aos outros parentes. A inteligência pronunciada seria uma espécie de conforto para "vítima do atavismo". Outra espécie de consolo seria a aptidão para as artes, mais saliente naqueles com traços atávicos. ${ }^{124}$ Cabe destacar que essa superioridade seria apenas com relação aos outros membros da família, não significa que este mestiço fosse superior aos brancos em geral.

Por meio da análise do posicionamento de Ladislau Netto acerca da hibridização, é possível inferir que ele era favorável ao cruzamento como meio de melhorar a raça indígena e negra. $\mathrm{O}$ cientista não emitiu nenhuma opinião, nas fontes consultadas, se a mestiçagem traria a degeneração da raça branca.

Ladislau Netto atribuiu aos casamentos consanguíneos o papel de principais causadores dos casos de atavismo. Recomendou que João Baptista de Lacerda, por ser o responsável pela área de antropologia do Museu Nacional, se dedicasse atentamente a este assunto, considerado de suma importância. Por fim, com relação às características da população brasileira e suas relações com as raças, o cientista argumentou:

[...] Depende ainda de definitiva solução o reconhecer-se à qual das duas raças, à preta e à vermelha, devemos nós maior cópia dos hábitos hoje inveterados na população brasileira e mais particularmente na do norte do Império. Porque que muita da cor local de tais hábitos nos tenha sido transmitida pelos autóctones, força é confessar que a maior

\footnotetext{
${ }^{123}$ NETTO, L. Do atavismo..., p. 5.

${ }^{124}$ A habilidade artística dos mestiços de negros e brancos também foi evidenciada na literatura. Por exemplo, no romance $O$ Mulato, 1881, de Aluísio Azevedo, dois personagens destacaram a destreza musical dos mulatos, um deles afirmou que esses mestiços pertenciam à raça mais talentosa do Brasil. CARULA, Karoline. A tribuna da ciência: as Conferências Populares da Glória e as discussões do darwinismo na imprensa carioca. São Paulo: Annablume, 2009, p. 157.
} 
das práticas dos nossos sertanejos é puramente africana e em abono é verdade, confesso que, se muitas delas, se quase todas, direi, são com efeito deploráveis, alguns infelizmente adaptaram-se às necessidades do nosso povo, atalhando-lhes os efeitos dissipando-as inteiramente.

Está neste caso, cuido eu, o uso dos sacos de couro, muito mais perfeitos, que as bruacas e empregados pelos sertanejos do norte para o transporte de líquidos [...].

Este uso foi-lhes transmitido pelos africanos do sul, onde a manufatura do couro aplicada ao vasilhame é a indústria mais desenvolvida daquelas povoações barbarescas. ${ }^{125}$

Por meio dessa passagem é possível verificar que a classificação racial utilizada por Ladislau Netto estava pautada na cor da pele. Segundo Netto, os hábitos da população brasileira, vista aqui como mestiça, estariam muito mais marcados pela herança africana. A despeito da maioria dos costumes serem considerados como "deploráveis", Netto apresentou alguns muito úteis. Como exemplo, mencionou a confecção de sacos de couro para o transporte de líquidos que teria origem na África. Merece ser destacado que ele se referiu aos africanos como "povoações barbarescas", explicitando, desta maneira, sua apreciação acerca dos mesmos.

Ao escrever sobre quais raças seriam as responsáveis pelos costumes ruins arraigados da população nacional, o diretor do Museu não considerou o elemento branco. É provável que não tenha sido um mero "esquecimento", mas sim que considerasse a cultura branca como a padrão, a correta e normal, e as outras, a negra e a indígena, seriam como pinceladas sobre uma matriz já estabelecida.

Em outro artigo publicado na Revista da Exposição Anthropologica Brazileira, o pesquisador desenvolveu uma análise acerca da prática africana de efetuar um corte nos dentes incisivos superiores:

Um costume africano, que suponho ter sido empregado por imitação de certa conformação natural entre remotos antepassados, como tantos outros hábitos dos povos primitivos, é o corte dos dentes incisivos superiores, não separados regularmente um dos outros, como é de crer os houvessem os referidos antepassados, e com ainda os apresentam os modernos africanos por vício orgânico hereditário e

\footnotetext{
${ }^{125}$ NETTO, L. Do atavismo..., p. 5.
} 
característico da sua raça essencialmente prognata, mas dando-se-lhes com o habitual exagero desses usos imitativos a forma pontiaguda dos dentes dos peixes. Este mau e estúpido costume foi transmitido ao Brasil, de envolta com tantíssimos outros de igual desmérito, pelos escravos africanos, que por mais de três séculos nos ensombram os horizontes do Oriente, donde só deveria porvir, com os raios do sol desponte, a luz civilizadora da culta Europa; e se em nossas províncias meridionais mui raros exemplos apresentam-se-nos de tão bárbara prática, outro tanto não me é dado dizer a respeito das províncias setentrionais, e especialmente do sertão inteiro daquela parte do Império aonde o corte dos dentes é o principal adorno dos dois sexos. $^{126}$

Para Ladislau Netto, o costume estético era na realidade um vício hereditário. Na sua argumentação, o fato dos africanos serem prognatas fazia com eles tivessem esse vício, ou seja, naturalizou aquele hábito “estúpido". Em momento algum encarou aquilo como uma prática cultural. Ao dizer que os africanos "ensombraram os horizontes", o cientista deu margem para duas interpretações: por serem negros, impediram que a população brasileira fosse branca, e a outra é que eles trouxeram costumes primitivos, ruins, não civilizados, diferentes do que poderiam proporcionar os europeus. Talvez, para o diretor do Museu, as duas fossem verdadeiras.

Mais uma vez, Ladislau Netto discorreu sobre os valores estéticos, porém agora com relação aos negros:

Ninguém ignora que as mulheres da África Meridional são aos olhos dos homens de seu país tanto mais elegantes e graciosas, ou, porque sejamos mais rigorosos no sentido de nossa frase, tanto mais lascivas e tentadoras, quanto mais esteatopigas se manifestem, e que sendo naturalmente essas as que mais reproduzem, porque mais depressa se casam, a ampliação adiposa com que aprouve a natureza de lhes entufar as nádegas não desaparece de uma a outra geração, mas ao contrário mantém-se perfeitamente, e até certo ponto, em virtude das leis da hereditariedade e da transmissão progressiva que

\footnotetext{
${ }^{126}$ NETTO, Ladislau. O corte artificial dos dentes. Revista da Exposição Anthropologica Brazileira, Rio de Janeiro, jul. 1882, p. 46.
} 
dessas leis emana, vai-se em algumas tribos lentamente desenvolvendo. ${ }^{127}$

$\mathrm{Na}$ análise do diretor do Museu, as mulheres dessa região africana seriam atraentes para os seus pares por serem "lascivas e tentadoras". Toda essa extrema sensualidade seria consequência de suas nádegas avantajadas. Segundo o cientista, eram tais mulheres as que mais se reproduziam, porque se casavam mais rapidamente, já que eram preferidas dentre as outras. Essa característica seria transmitida hereditariamente.

É possível que Ladislau Netto estivesse se referindo às mulheres hotentotes, apesar de não ter feito nenhuma citação direta. No início do século XIX ficou conhecido o caso da Vênus Hotentote. Vivente numa região da atual África do Sul, Saartjie Baartman era uma mulher negra, de baixa estatura (cerca de 1,35 metros de altura), como outros do grupo ao qual pertencia, e portadora de esteatopigia, nádegas com grande acúmulo de gordura. Saartjie ("pequena Sara” em africânder ${ }^{128}$ ) foi levada para a Inglaterra, em 1810, para ser apresentada em exposições públicas do tipo "circo dos horrores". Além de seu tamanho, a esteatopigia era o que despertava o interesse do público que ia assistir a tais espetáculos. Em 1814, foi transportada para a França, para fazer o mesmo tipo de apresentação. Entretanto, após um tempo, ela foi levada para o Museu de História Natural de Paris, para servir de corpo de análise. O interesse dos cientistas estava na esteatopigia e na genitália de Saartjie. ${ }^{129}$ É aceitável supor que Ladislau Netto, por ser um cientista que estava a par do que era produzido na Europa, conhecesse o caso da Vênus Hotentote e que pretendia compreender a esteatopigia por meio dos paradigmas da hereditariedade.

Apesar de serem poucos os registros sobre os negros feitos por Ladislau Netto, quando comparados a sua produção acerca dos índios, pode-se observar que ao abordálos ele também empregou uma argumentação racialista, fundamentada em uma linguagem científica/cientificista. Os negros foram classificados como inferiores aos brancos, por serem "bárbaros" e "estúpidos", por exemplo. O diretor do Museu, todavia,

\footnotetext{
${ }^{127}$ NETTO, Ladislau. As deformações da face e do crâneo entre os povos americanos. Revista da Exposição Anthropologica Brazileira, Rio de Janeiro, jul. 1882, p. 17.

${ }^{128}$ GOULD, Stephen Jay. A Vênus hotentote. In: ___ O sorriso do flamingo: reflexões sobre história natural. Tradução de Luís Carlos Borges. São Paulo: Martins Fontes, 1990, p. 272.

${ }^{129} \mathrm{O}$ interesse pela genitália era devido ao chamado sinus pudores (cortina do pudor), típico das mulheres daquele grupo, que possuíam os lábios inferiores alongados. GOULD, S. J. A Vênus hotentote... Sobre este tema conferir também: CITELI, Maria Teresa. As desmedidas da Vênus negra: gênero e raça na história da ciência. Novos Estudos CEBRAP, n. 61, p. 163-175, nov. 2011. STROTHER, S. Z. Display of the Body Hottentot. In: LINDFORS, Bernth (Ed.). Africans on stage: studies in ethnological show business. Bloomington: Indiana University Press, 1999, p. 1-61.
} 
era favorável à mestiçagem, que traria benefícios aos negros, principalmente no correr das gerações. Portanto, se em alguma conferência o cientista abordou, ou perpassou pela questão, essa foi a representação do negro exposta para o público presente.

\section{A imigração e os chins}

Na segunda metade do século XIX, a abolição era vista como uma certeza próxima. As discussões giravam em torno de qual seria a mão de obra mais adequada para substituir o trabalho escravo, uma das sugestões era o uso de braços estrangeiros. Peter Eisenberg, ao analisar o Congresso Agrícola de 1878, realizado na Corte, afirma que a "opinião geral era a de que a mão-de-obra que faltava à grande lavoura não podia ser recrutada dentro do país, a alternativa lógica era de trazê-la de fora."130 A opção pela vinda de imigrantes já estava presente em algumas propostas do início do século, mas apenas em vozes pontuais. ${ }^{131}$ No entanto, foi com a lei Eusébio de Queirós, de 1850, que esta proposta começou a se tornar uma tônica.

Celia Azevedo afirma que parte dos intelectuais brasileiros optou pelo imigrantismo por considerar os negros e os mestiços como racialmente inferiores, "incapazes de interiorizar sentimentos civilizados sem antes que as virtudes étnicas dos trabalhadores brancos os impregnassem". ${ }^{132}$ Os imigrantes desejados eram os europeus, pois além de serem brancos, colaborariam com o progresso da nação. ${ }^{133}$

As primeiras práticas imigrantistas em maior escala aconteceram na Província de São Paulo, na década de 1840. Entretanto, até o final dos anos 1860 a imigração ainda era parca, principalmente devido aos relatos que chegavam à Europa sobre as péssimas

\footnotetext{
${ }^{130}$ EISENBERG, Peter L. A mentalidade dos fazendeiros no Congresso Agrícola de 1878. In: LAPA, José Roberto do Amaral. Modos de produção e realidade brasileira. Petrópolis, RJ: Vozes, 1980, p. 186. O Congresso foi realizado em junho daquele ano, foram convocados pelo Ministro dos Negócios de Agricultura, Comércio e Obras Públicas fazendeiros das seguintes províncias: Rio de Janeiro, São Paulo, Minas Gerais e Espírito Santo.

${ }^{131}$ Em 1818, D. João VI assinou o tratado de Nova Friburgo, cidade que seria fundada, um ano depois, por imigrantes suíços. De acordo com Giralda Seyferth, a "questão racial está implícita no Decreto Real que autorizou o estabelecimento dos imigrantes suíços na região serrana do Rio de Janeiro aludindo à civilização". SEYFERTH, Giralda. Colonização, imigração e a questão racial no Brasil. Revista USP, São Paulo, n. 53, março/maio 2002, p. 118.

${ }_{132}$ AZEVEDO, C. M. M. de. Onda negra, medo branco..., p. 53.

${ }^{133} \mathrm{Na}$ década de 1860, o alagoano Aureliano Cândido de Tavares Bastos (1839-1875) comparou "o atraso da província da Bahia, onde vivia uma maioria de negros 'grosseiros', ignorantes e incapazes para o trabalho, com o grande desenvolvimento do Rio Grande do Sul, com seus núcleos de colonos europeus, efervescentes em matéria de trabalho, progresso e civilização." AZEVEDO, C. M. M. de. Onda negra, medo branco..., p. 53.
} 
condições de vida e de trabalho dos imigrantes no Brasil, bem como sua conflituosa relação com os fazendeiros locais, desestimulando sobremaneira aqueles que pretendessem atravessar o Atlântico. Perante tal situação, o médico Luiz Pereira Barreto (1840-1923), em uma série de artigos publicados no jornal A Província de São Paulo em 1880, propôs a implementação de políticas que assegurassem condições propícias para a imigração branca europeia. Para Pereira Barreto, os negros, sendo uma raça inferior, haviam determinado a evolução ruim dos brancos brasileiros, por esse motivo era essencial que viessem brancos civilizados para cá. ${ }^{134}$ Muitos intelectuais compartilhavam essa linha de pensamento, fazendo uso de teorias científicas que determinavam a inferioridade racial dos negros, fundamentavam seus discursos na defesa da vinda de trabalhadores imigrantes brancos. É nesse contexto que, segundo Azevedo, começam a aparecer os primeiros traços da tese do branqueamento. Para que tal projeto se concretizasse, era necessário injetar mais brancos na sociedade brasileira, e isto seria possível via imigração europeia.

Dentro dessa perspectiva, em 1886, o médico Nuno de Andrade realizou duas preleções consecutivas, nas Conferências Populares da Glória, que tratavam da imigração e da aclimatamento dos europeus nos países quentes. A aclimatação destes imigrantes foi abordada em algumas teses de medicina na década de 1870, indicando a preocupação dos jovens médicos em encontrar um meio de melhor aclimatar os recémchegados ao país. ${ }^{135}$ A questão da aclimatação estava muito ligada às doenças que assolavam a cidade do Rio de Janeiro, em especial à febre amarela, que acometia uma quantidade significativa de imigrantes europeus. Conforme argumenta Sidney Chalhoub:

o que estava ocorrendo na década de 1870 era que a febre amarela, com os infalíveis estragos que provocava entre os imigrantes recentes, passou a ser percebida como um empecilho à idéia dos cafeicultores

\footnotetext{
${ }^{134}$ AZEVEDO, C. M. M. de. Onda negra, medo branco..., p. 52-59.

135 À guisa de exemplo, na Faculdade de Medicina do Rio de Janeiro foram defendidas as seguintes teses com vinculadas à aclimatação: Henrique Hermeto Carneiro, Da acclimatação nos paizes quentes em geral e especialmente no Brazil debaixo do ponto de vista da colonisação, 1870; Antonio José de Castro Junior, Acclimatamento das raças em geral e em particular sob o ponto de vista da colonização em relação ao Brasil, 1870; Domingos Jose Nogueira Jaguaribe Filho, Do acclimatamento das raças sob o ponto de vista da colonisação em relação ao Brazil, 1874.
} 
de "suavizar" - por assim dizer - a transição do trabalho escravo para o trabalho "livre" por meio da imigração européia. ${ }^{136}$

Em sua conferência, Andrade alertou que o aclimatamento dos europeus nos países quentes estava vinculado às questões de saúde pública. Então,

Examinando, especialmente em relação ao Rio de Janeiro, as condições de aclimatamento, declarou o orador que o principal obstáculo que encontravam os imigrantes era a febre amarela, que entre nós alojou-se, e que concorria com elevada cifra para o aumento da mortalidade média anual de nossa cidade. Prevendo a objeção de que, para as províncias onde a febre não se manifesta, a imigração escasseia também, disse que é fato de observação que os imigrantes espontâneos procurarão de preferência as capitais e que daí se dirigem para o interior, por virtude da lei de expansão lenta que rege o pequeno aclimatamento. ${ }^{137}$

O imigrante almejado pelo médico era o branco europeu, porém, para conseguir a vinda desse grupo era necessário garantir as condições de higiene locais. Com relação ao aclimatamento, Nuno de Andrade não estava tão preocupado com a ação do clima quente sobre os europeus, mas sim com a febre amarela, que acometia muito mais os brancos e, por conseguinte, uma parcela significativa dos imigrantes que chegavam principalmente ao Rio de Janeiro. ${ }^{138}$ Os surtos de febre amarela que assolavam a cidade e a repercussão da alta taxa de letalidade da doença poderiam espantar os almejados imigrantes brancos e, assim, se não findasse, ao menos retardaria o sonho do branqueamento da sociedade.

Todavia, desde as primeiras discussões sobre o incentivo da imigração branca europeia, outras possibilidades foram debatidas, uma vez que era preciso pensar em opções para a falta de mão de obra. Uma das alternativas defendidas por alguns foi trazer imigrantes chineses.

Em 1814, chegaram ao Brasil os primeiros imigrantes chineses. Oriundos da colônia portuguesa de Macau, eles vieram como colonos e agricultores para o cultivo de

\footnotetext{
${ }^{136}$ CHALHOUB, Sidney. Cidade febril: cortiços e epidemias na Corte imperial. São Paulo: Companhia das Letras, 1996, p. 89.

${ }_{137}$ Jornal do Commercio, 08/04/1876.

${ }^{138}$ CHALHOUB, S. Cidade febril...
} 
chá no Rio de Janeiro. D. João VI pretendia explorar economicamente a lavoura do chá utilizando técnicas advindas da China, para isso, escolheu o Jardim Botânico, a Ilha do Governador e a Fazenda Imperial como locais de plantio. Contudo, a empreitada fracassou devido ao desinteresse e à falta de experiência desses trabalhadores, às inadequadas condições do solo e do clima, o chá produzido era de qualidade inferior à do mercado, e aos maltratos, que fizeram com que muitos chineses fugissem. ${ }^{139}$

Antes de 1850 foram poucos aqueles que cogitaram a possibilidade do emprego de braços chineses na lavoura. Segundo Jeffrey Lesser, no final de 1854, o governo brasileiro determinou que seus representantes em Londres trouxessem para cá seis mil imigrantes da China. Entretanto, poucos chineses foram trazidos e o contrato firmado serviu para inflar o debate sobre a utilização de tal mão de obra. Ainda de acordo com o autor, existiam menos de mil chineses no Brasil entre as décadas de 1850 e $1860 .{ }^{140}$

O incentivo à imigração asiática, contudo, passou a ocupar certo espaço na pauta de discussão na segunda metade do Oitocentos, e desta vez de maneira bem mais acalorada, com contundentes posicionamentos contra e a favor. No Congresso Agrícola de 1878, por exemplo, as discussões acerca da possibilidade de incentivo para a imigração asiática foram marcadas por uma divisão de opiniões. ${ }^{141}$ Havia um ponto de convergência para os fazendeiros que lá se reuniam: a urgência de braços para lavoura. Entretanto, as soluções apontadas eram heterogêneas. Aqueles proprietários queriam garantir a sua produção agrícola lucrativa, isso era o essencial. Ou seja, debates acerca da mão de obra a ser empregada com o fim da escravidão estavam na ordem do dia.

Em diferentes espaços, nos anos de 1870 e 1880, a elite analisou e discutiu muitas possibilidades para a questão da mão de obra, imigração subsidiada, espontânea, de europeus, de chineses, de africanos, uso do índio, do trabalhador nacional, manutenção da escravidão, etc. A imigração chinesa, no conjunto disso, foi muito minoritária, mas esteve presente nas conferências e cursos públicos. Em 1877, no teatro Fênix Dramática, Rodrigo Octavio de Oliveira Menezes (1839-1882) expôs duas preleções sobre a imigração e a colonização. Liberal, formado em direito pela Faculdade de São Paulo e membro do conselho diretor do Instituo da Ordem dos Advogados do

\footnotetext{
${ }^{139}$ DEZEM, Rogério. Matizes do "amarelo”: a gênese dos discursos sobre os orientais no Brasil (18781908). São Paulo: Associação Editorial Humanitas, 2005.

${ }^{140}$ LESSER, Jeffrey. A negociação da identidade nacional: imigrantes, minorias e a luta pela etnicidade no Brasil. Tradução de Patricia de Queiroz Carvalho Zimbres. São Paulo: Editora Unesp, 2001, p. 42, 45.

${ }^{141}$ EISENBERG, P. A mentalidade dos fazendeiros..., p. 189.
} 
Brasil, ${ }^{142}$ o conferencista era contrário à entrada de imigrantes asiáticos no Brasil. A apresentação de Rodrigo Octavio foi assim noticiada pelo jornal $O$ Globo:

$\mathrm{O}$ orador mostrou todos os males que àquela importante necessidade pública [a colonização] tem sempre feito a intervenção oficial. Historia os acontecimentos últimos, relativos à colonização e imigração na província de Santa Catarina, mostrando como se atira fora o dinheiro dos contribuintes, e combate a introdução dos coolies.

\section{$[\ldots]$}

Por último devemos pedir licença ao orador, cujo talento somos os primeiros a reconhecer, para discordar da sua opinião, nas considerações econômicas que fez em relação à imigração e colonização dos asiáticos. ${ }^{143}$

O orador e o autor da notícia tinham posicionamentos contrários com relação à imigração asiática. Para o periódico, Rodrigo Octavio atribuía um peso demasiadamente grande à parcela de culpa creditada ao governo com relação aos projetos imigratórios já ocorridos. O conferencista, ao que tudo indica, era contrário à política imigratória subvencionada pelo Estado, na qual o governo subsidiava a vinda dos imigrantes pagando suas passagens e organizando núcleos coloniais.

Acerca da imigração ocorrida em Santa Catarina, criticada pelo orador, vale ressaltar que foi lá um dos primeiros núcleos coloniais, constituído entre os anos de 1824 e 1829. De acordo com Seyferth, a escolha por imigrantes alemães, naquele momento, não esteve relacionada com premissas raciais, e sim com a associação do alemão como agricultor eficaz. Posteriormente, proliferaram censuras contra a imigração germânica, argumentavam que, apesar de estarem no "topo da hierarquização por nacionalidade", os alemães ficavam fechados dentro de seus núcleos, não assimilavam a cultura local, além da patente diferença religiosa. ${ }^{144}$ As críticas de Rodrigo Octavio devem ter sido feitas neste sentido.

Sobre os termos coolies e chins, estes eram os modos como os letrados brasileiros se referiam aos imigrantes chineses. Em 1877, Pedro Gordilho de Mendonça Paes Leme, contrário à imigração chinesa, já havia destacado a importância de se

\footnotetext{
${ }^{142}$ No ano seguinte, Rodrigo Octavio tornar-se-ia presidente da Província do Paraná, ficando no cargo entre 23 de março de 1878 a 31 de março de 1879.

${ }^{143} O$ Globo, 04 e 05/06/1877. Grifo do original.

${ }^{144}$ SEYFERTH, G. Colonização, imigração e a questão racial..., p. 122.
} 
diferenciar os chins dos coolies. Isso mostra que para muitos, independente de serem favoráveis ou não a vinda desses imigrantes, não havia distinção entre ambos os trabalhadores. ${ }^{145}$ De acordo com Rogério Dezem, na obra Trabalhadores asiáticos, de 1879, Salvador de Menezes Drummond Furtado de Mendonça $(1841-1913)^{146}$ definiu

como chim aquele que emigrava espontaneamente sob a garantia de tratados entre autoridades governamentais, ou seja, o trabalhador chinês contratado mediante acordos reconhecidos oficialmente. O kuli ou coolie, termo de origem hindustânica que significa "carregadores de fardos", aplicado originalmente a trabalhadores indianos, seria aquele que emigrava "apanhado violentamente e metido a bordo pelo agente recrutador". ${ }^{147}$

Contudo, na documentação aqui analisada, não encontrei esse critério na utilização dos vocábulos, que, na maioria das vezes, apareciam como sinônimos. Segundo Giralda Seyferth, empregavam-se ambas as palavras, chins e coolies, para se referir aos chineses, mas a última era mais utilizada. ${ }^{148}$

Cabe destacar que a segunda conferência de Rodrigo Octavio foi realizada no mesmo dia em que, no teatro de S. Pedro, o republicano e também bacharel em direito, Carlos Augusto de Carvalho (1851-1905) efetuava nesse local sua primeira preleção sobre a mesma temática, intitulada "Convém ao Brasil a grande naturalização de estrangeiros?". Ao todo, discursou três vezes sobre o assunto. No ano anterior, 1876, nas Conferências Populares da Glória, Augusto de Carvalho havia apresentado a seguinte preleção: "Meios gerais de atrair a imigração para o Brasil”. ${ }^{149}$ Isso indica como a imigração estava na pauta das discussões, haja vista que era uma das opções para solucionar o problema da falta de mão de obra que afligia os fazendeiros naquele momento. Em 1874, Augusto Carvalho publicara, em Portugal, o livro Estudo sobre a colonização e emigração para o Brasil, no qual discutia os problemas da introdução em larga escala de grupos com língua e culturas muitos distintas das do Brasil, referindo-se

\footnotetext{
${ }^{145}$ DEZEM, R. Matizes do "amarelo"..., p. 78.

${ }^{146}$ Salvador Mendonça formou-se em direito pela Faculdade de São Paulo, jornalista e romancista, foi um dos fundadores do movimento republicano no Brasil, sendo um dos autores do Manifesto Republicano de 1870 .

${ }^{147}$ DEZEM, R. Matizes do “amarelo"..., p. 79.

${ }^{148}$ SEYFERTH, G. Colonização, imigração e a questão racial..., p. 124.

${ }^{149}$ Augusto de Carvalho seria nomeado presidente da Província do Paraná alguns anos depois, ficando no cargo entre 6 de março de 1882 a 26 de maio de 1883. Foi chefe de polícia do Paraná durante a administração de Rodrigo Octavio.
} 
aqui especialmente aos alemães. ${ }^{150}$ Argumentação semelhante à de Rodrigo Octavio. Talvez, essa ideia também tenha sido defendida nas preleções públicas.

Apesar de a imigração chinesa não ter se efetivado e de ser apenas uma sugestão, dentre outras tantas mais centrais, para a substituição de braços na lavoura, analisarei as propostas defendidas pelo médico Nicolau Joaquim Moreira nos cursos públicos de agricultura. Para este cientista, a questão da imigração chinesa era um importante tema de discussão e, neste sentido, tratou da mesma em suas apresentações públicas. Nos cursos do Museu Nacional, Moreira expôs muito do que discutia em outros espaços de sociabilidade que frequentava, tais como a Academia Imperial de Medicina e a Sociedade Auxiliadora da Indústria Nacional.

A Sociedade Auxiliadora nas três últimas décadas imperiais esteve envolvida nas discussões sobre a abolição da escravidão. Como meio de solucionar a ausência de braços na lavoura com o advento da abolição, o grêmio propunha a utilização de maquinário agrícola e o emprego de "métodos científicos" para a melhoria da produção. $^{151}$ Nicolau Moreira, membro da Comissão de Química Industrial da Sociedade Auxiliadora, em consonância com esses valores, também fez uso do espaço dos cursos do Museu Nacional para defender tais propostas, que aplicadas ajudariam a diminuir o número de escravos na agricultura. Na interpretação de Moreira, o conhecimento científico promoveria a melhora da qualidade da lavoura, e com isso, a produtividade aumentaria. Para tal, era necessário desenvolver um ensino profissional agrícola que levasse a instrução científica aos lavradores. ${ }^{152}$ Em uma preleção de 1877 ele desenvolveu o seguinte raciocínio:

Aplicando estes princípios racionais a [sic] lavoura do país, conclui o distinto professor, que, infelizmente os nossos proprietários agrícolas, na maior parte, estão longe de conhecer as vantagens que lhes resultaria desta inteligente direção de seus estabelecimentos rurais, em cuja máxima parte nem ao menos existe uma escrituração regular, ignorando por conseguinte o lavrador não somente a soma do capital empregado na sua indústria como também as vantagens que

\footnotetext{
${ }^{150}$ SEYFERTH, G. Colonização, imigração e a questão racial...

${ }^{151}$ DOMINGUES, Heloisa Maria Bertol. A Sociedade Auxiliadora da Indústria Nacional e as ciências naturais no Brasil Império. In: DANTES, Maria Amélia M. (Org.). Espaços da ciência no Brasil: 18001930. Rio de Janeiro: Editora Fiocruz, 2001, p. 94.

${ }^{152}$ A defesa de Moreira com relação ao ensino agrícola lhe rendeu, em 1883, um convite do ministro da agricultura para que ele organizasse um projeto, em nível nacional, para a criação de escolas de agricultura. LIMA, S. C. de S. Determinismo biológico e imigração..., p. 69.
} 
aufere dela podem razoavelmente satisfazer o empate do capital empregado em seu ramo de produção.

Não é só a escassez de capitais, diz o Sr. Dr. Nicolau Moreira, como especialmente a falta de conhecimentos profissionais que acusam a inferioridade de nossos produtos e finalmente o seu depreciamento nos grandes mercados.

\section{$[\ldots]$}

Querem eles [senhores de terras] obter capitais a todo o custo para comprar mais escravos, e comprarem estes para conseguirem maior soma de produção, afim [sic] [de] emprenharem-se de novo nessas perigosas transações financeiras.

Nasce daqui um círculo vicioso em que se debatem. Em lugar de máquinas, que dispensam os braços e aperfeiçoam o trabalho, ampliam e alargam os elementos do trabalho cativo. Em vez de aumentarem com capitais próprios o desenvolvimento de sua indústria, vão procurá-los com altos prêmios nas mãos dos intermediários e nas arcas dos banqueiros. ${ }^{153}$

A utilização de máquinas agrícolas e a aplicação de conhecimentos científicos no plantio, na análise do pesquisador do Museu, aumentariam os lucros porque proporcionariam uma produção de melhor qualidade e diminuiriam os gastos com a compra de escravos. Lembrando aqui que Nicolau Moreira estava inserido na luta abolicionista, então, para convencer os senhores escravocratas dos prejuízos da utilização de mão de obra cativa, ele não fez uso de argumentos humanitários, mas sim econômicos. Provavelmente por saber que estes seriam mais bem aceitos, e talvez até melhor compreendidos, pela camada senhorial. É possível também que para Moreira esse fosse o real motivo de ser contrário à escravidão, uma vez que creditava a ela o atraso do país.

Era comum a reclamação, principalmente entre os que defendiam a continuidade da escravidão ou a necessidade de um tempo maior até a definitiva abolição, da falta de braços na lavoura. ${ }^{154}$ Nicolau Moreira refutava tal argumento:

${ }^{153}$ Gazeta de Noticias, 25/05/1877.

154 AZEVEDO, C. M. M de. Onda negra, medo branco... Tal queixa foi constante no correr do século XIX. Jaime Rodrigues, ao analisar as discussões em torno do fim do tráfico transatlântico de escravos, assevera que este era um argumento muito utilizado por aqueles que eram contrários à proibição deste comércio. RODRIGUES, Jaime. O fim do tráfico transatlântico de escravos para o Brasil. In: 
Surpreende ouvir constantemente proclamar-se como causa do descalabro de nossa lavoura a insuficiência de braços, quando realmente não existe tal deficiência, como se comprova quer com escritos de autoridades competentes no assunto, com as observações dos fatos, quer estudando as leis de economia rural, relativamente ao desenvolvimento da extensão da lavoura e da quantidade de produtos.

É hábito de todos os países escravagistas e daqueles em que não existe a organização do trabalho, o gritarem por falta de braços; entretanto são esses mesmos países que mais depropositadamente empregam os braços que possuem. ${ }^{155}$

Alguns argumentavam que a escravidão não poderia acabar porque isso provocaria um colapso na economia do país, especialmente devido à agricultura. Para esses sujeitos, com a abolição, eles ficariam sem mão de obra para trabalhar em seus cultivos. O emprego do ex-escravo como trabalhador assalariado era defendido por pouquíssimos, bem como a utilização dos livres e dos indígenas. ${ }^{156}$ Neste sentido, era ampla a defesa da vinda de imigrantes, preferencialmente europeus, como a única solução.

Com relação ao emprego da população livre como mão de obra, era recorrente a afirmação de que essa camada não se adaptaria, ou simplesmente era "preguiçosa". $\mathrm{Na}$ contramão dessas ideias, Nicolau Moreira afirmava que "Os brasileiros não são geralmente indolentes; e, se eles fogem do trabalho, sobretudo rural, é pela presença do escravo que avilta a indústria e pela insignificante cotação de um labor apreciado muito abaixo do colono estrangeiro. $" 157 \mathrm{Na}$ interpretação do pesquisador do Museu, as condições existentes é que afugentavam os nacionais de se dedicarem ao trabalho agrícola. Eisenberg assevera que os fazendeiros, presentes no Congresso Agrícola, favoráveis à utilização "do trabalhador livre nacional afirmaram que este vivia na ociosidade, estando desempregado ou subempregado, e por isso podia ser melhor

GRINBERG, Keila; SALLES, Ricardo (Orgs.). O Brasil Imperial, volume II: 1831-1870. Rio de Janeiro: Civilização Brasileira, 2009, p. 297-337.

${ }^{155}$ MOREIRA, Nicolau Joaquim. Agricultura. $2^{\text {a }}$ Preleção de Dr. Nicolau Moreira Museu Nacional. $O$ Auxiliador da Industria Nacional, Rio de Janeiro: Typographia de Eduardo \& Henrique Laemmert, v. XLVII, n. 6, jun. 1879, p.123.

${ }^{156}$ Dentre aqueles que eram a favor da utilização do ex-escravo como mão de obra remunerada, Célia Azevedo destaca os positivistas Miguel Lemos (1854-1917) e Raimundo Teixeira Mendes (1855-1927), que pregavam a transformação do liberto em assalariado sem a necessidade de um período de trabalho compulsório. Já André Rebouças (1838-1898) propunha a utilização de imigrantes, libertos e nacionais pobres como mão de obra. AZEVEDO, C. M. M. de. Onda negra, medo branco..., p. 81.

${ }^{157}$ MOREIRA, N. J. Agricultura. 2a . Preleção..., p. 126. 
aproveitado pela grande lavoura." 158 Posicionamento semelhante ao sustentado por Moreira, que não só era a favor da utilização de braços nacionais na lavoura, como também do emprego dos libertos:

Não me persuado também que a nossa escravatura, mais bem tratada do que a das colônias, ao raiar o sol de sua liberdade, desampare o trabalho e se entregue à vagabundagem, e muito principalmente se aproveitando as lições da experiência procurarmos retê-la por meio de oportunas concessões. ${ }^{159}$

Ao defender que após a liberdade os ex-cativos trabalhariam satisfatoriamente na lavoura, Moreira estava em dissonância com aqueles que argumentavam que o liberto se entregaria à vagabundagem. Para ele, como o escravo era bem tratado, era natural que após ser liberto não tivesse problema algum em trabalhar para o seu ex-senhor.

Mesmo considerando essas possibilidades de utilização de mão de obra, Moreira não se furtou a defender a imigração europeia branca, que, acima de tudo, promoveria um melhoramento racial para o país. Porém, ela não deveria ser encarada como a única alternativa para a questão e nem ser dispendiosa para o Estado, neste sentido, alinhandose à posição de Rodrigo Octavio. Então, Moreira assim apresentou o assunto em sua conferência:

O problema da emigração e colonização é complexo, porque ele se relaciona não só com as condições do país para onde se dirige o êxodo como também com as circunstâncias excepcionais donde saem os emigrantes, e como, em vez de se examinar o problema em todas as suas partes, limitamo-nos a encará-lo debaixo de um único ponto de vista - o suprimento de braços à grande propriedade - não se tem até hoje obtido uma solução favorável aos interesses do país, e apenas concorrido para esgoto dos cofres públicos, o enriquecimento de alguns indivíduos e o descrédito do país. ${ }^{160}$

\footnotetext{
${ }^{158}$ EISENBERG, P. A mentalidade dos fazendeiros..., p. 180.

159 MOREIRA, Nicoláo Joaquim. Questão. Convirá ao Brasil a importação de colonos Chins? 20. Discurso pronunciado na sessão da Sociedade Auxiliadora da Industria Nacional em 17 de Novembro de 1870. Discutindo-se o parecer da secção de colonisação e estatistica. Rio de Janeiro: Typographia Universal de Laemmert, 1870, p. 43.

${ }^{160}$ MOREIRA, N. J. Agricultura. 2a . Preleção..., p. 122.
} 
O último quesito provavelmente era decorrente do ocorrido nas colônias alemãs do sul, nas quais os imigrantes permaneceram cerrados nos valores e hábitos culturais de seu país de origem. Ao ressaltar que as condições de origem do imigrante deveriam ser consideradas, Nicolau Moreira certamente estava analisando a questão por meio de uma ótica higienista. Ele era médico e membro da Academia Imperial de Medicina, onde a imigração era debatida e compreendida pelo viés higienista. ${ }^{161}$ Para o cientista do Museu, o imigrante ideal era o saudável, racialmente favorável ao Brasil e que estivesse disposto a se aculturar, ou seja, predisposto a adotar a nova nação como pátria.

[...] como as questões de imigração e colonização implicam com o estudo das influências telúricas e climatéricas, modificações por cruzamentos, transmissões hereditárias, etc., compreende-se sem esforço a necessidade de invocar para a resolução de tais problemas a ciência médica, única autoridade competente nestas matérias e, tanto assim é, senhores, que neste momento discute a Academia Imperial de Medicina - quais as raças cuja imigração convém favorecer no Brasil debaixo do ponto de vista médico e antropológico e qual deve ser a sua distribuição nos variados climas brasileiros. ${ }^{162}$

Portanto, nas discussões acerca da imigração, quem daria a palavra final era o médico, que por meio de uma abordagem higienista, analisaria todas as variáveis e daria o parecer sobre qual seria a melhor raça para trazer para o Brasil. Os debates em torno da imigração aconteciam em várias esferas da sociedade, no entanto, para Moreira, somente as proposições pautadas no discurso médico científico poderiam ser acatadas como corretas e verdadeiras.

Para Nicolau Moreira, o clima tropical não era impedimento para o imigrante europeu, cabia aos médicos determinar em qual região brasileira ele melhor se adaptaria. Contra aqueles que colocavam como empecilho o clima tropical para a vinda de imigrantes europeus, o cientista do Museu era enfático:

\footnotetext{
${ }^{161}$ Magali Engel destaca o papel fundamental da Academia Imperial de Medicina e da Faculdade de Medicina do Rio de Janeiro na construção do projeto normatizador que a medicina implementava naquele momento. ENGEL, Magali. Meretrizes e doutores: saber médico e prostituição no Rio de Janeiro (18401890). São Paulo: Brasiliense, 2004, p. 51.

${ }^{162}$ MOREIRA, N. J. Questão. Convirá ao Brasil a importação..., p. 9.
} 
Dizem: o colono europeu não pode prestar os serviços que reclamamos, porque o Brasil por sua posição geográfica, acha-se influenciado por uma excessiva temperatura.

Entretanto foi o europeu quem descobriu o Brasil, e roteou o seu solo nele domiciliando-se, e não o africano, o índio ou o chinês. ${ }^{163}$

Ao tratar da questão do aclimatamento do imigrante europeu, Moreira acabou hierarquizando os povos, colocando o branco europeu acima do africano, do índio e do chinês, uma vez que ele desbravou e cultivou a terra. Interessante que ele rebaixou o índio, que já vivia aqui e estava acostumado às altas temperaturas, porque ele não havia lavrado a terra. Isso indica que o fundamental não era a adaptação climática em si, mas sim lidar com a terra de acordo com o sistema ocidental, no caso, europeu.

Na concepção de Moreira, o governo deveria "dispensar sua influência moral" aos imigrantes, garantindo as "condições de estabilidade no solo brasileiro", que seriam a doação de terras, "liberdade de ensino, de associação, de consciência etc., e grande naturalização". ${ }^{164}$ Com relação a essas "condições" deve-se destacar a liberdade religiosa, que trazia a reboque a institucionalização do casamento civil e a construção de cemitérios laicos. Muitos dos imigrantes europeus desejados eram protestantes, leiam-se aqui os alemães, o que lhes causava vários impedimentos e transtornos locais devido ao catolicismo oficial. ${ }^{165}$ Neste sentido, Moreira afirmava que os europeus preferiam se dirigir para os Estados Unidos porque lá encontrariam a liberdade inexistente no Brasil. $^{166}$

O imigrante almejado por Nicolau Moreira era o europeu que viesse para o Brasil voluntariamente. Entretanto, isso só aconteceria quando houvesse "liberdade de culto, igualdade de direitos civis, garantias municipais e políticas, extinção da escravatura e nobilitação do trabalho pelo emprego do operário livre". ${ }^{167}$ Além dos

163 MOREIRA, Nicolau. Questão chinesa. Preleção no Museu Nacional em 1879. O Auxiliador da Industria Nacional, Rio de Janeiro: Typographia de Eduardo \& Henrique Laemmert, v. XLVIII, n. 1, abril 1880, p. 79.

${ }^{164}$ MOREIRA, N. J. Agricultura. 2a . Preleção..., p.123.

165 De acordo com Seyferth, "a perspectiva do isolamento dos alemães em colônias homogêneas, com liberdade religiosa para os protestantes, enunciada, inclusive, por algumas lideranças emergentes nos meios teuto-brasileiros, resultou numa reação nacionalista de setores contrários à imigração alemã e preocupados com a formação católica e latina do país." SEYFERTH, G. Colonização, imigração e a questão racial..., p. 127.

${ }^{166}$ MOREIRA, N. J. Questão chinesa. Preleção no Museu..., p. 79.

167 MOREIRA, Nicoláo Joaquim. Relatorio sobre a immigração nos Estados-Unidos da América. Apresentado ao Ex. Sr. Ministro da Agricultura, Commercio e Obras Publicas pelo Dr. Nicoláo Joaquim Moreira. Rio de Janeiro: Typographia Nacional, 1877, p. 26. 
direitos civis e religiosos, o cientista argumentava que era necessária uma mudança de mentalidade, que só viria com a abolição. A modificação se daria na medida em que, com o fim da escravidão, implantar-se-ia o trabalho assalariado, que, a partir de então, deveria ser valorizado pela população. $\mathrm{O}$ enaltecimento do operário estimularia $\mathrm{O}$ imigrante estrangeiro a vir espontaneamente para o Brasil. Ou seja, na sua interpretação, a existência da escravidão impedia que a sociedade valorizasse o trabalho.

$\mathrm{Na}$ abordagem de Nicolau Moreira, a antropologia fornecia um arcabouço teórico importantíssimo para a análise da questão da imigração, conforme ressaltou em uma conferência proferida no Museu Nacional:

A emigração e a colonização são sujeitas às leis naturais, que as constituem uma ciência de aplicação, e se faz necessário para que a emigração seja proveitosa que o emigrante possua a maior soma possível de qualidades físicas, intelectuais e morais; se o segundo ato da emigração a - colonização - tem por caráter principal a fixação do imigrante no solo que escolhera para por em atividade as suas faculdades, e da fixação do imigrante no solo nasce a indeclinável necessidade do cruzamento dos indivíduos estrangeiros com os nacionais, e finalmente, se o cruzamento das raças, sem a seleção deteriora o produto, limita a progênie, altera as faculdades físicas e intelectuais, como não pedir a antropologia e a etnologia os preceitos, ou regras as verdadeiras bases de uma valiosa emigração? ${ }^{168}$

O papel da antropologia seria, portanto, estipular se a entrada de um determinado imigrante seria racialmente favorável ao país. As qualidades físicas que Nicolau Moreira se referiu estavam relacionadas à cor da pele do imigrante, que deveria ser branca para colaborar no embranquecimento da nação. Os atributos "intelectuais e morais" também deveriam ser aqueles vinculados aos brancos, haja vista que Moreira era terminantemente contrário à vinda de imigrantes chineses e nunca sequer mencionou a possibilidade da entrada de negros.

No tocante à "valiosa emigração", o cientista estava de certo pensando naquela que não seria tão valiosa assim, no caso a imigração chinesa. Em resposta àqueles que

\footnotetext{
${ }^{168}$ MOREIRA, Nicoláo Joaquim. Imigração (Extracto de uma conferencia feita pelo Dr. Nicoláo Moreira no Museu Nacional em 1883). O Auxiliador da Industria Nacional, Rio de Janeiro: Typographia Universal de Laemmert, v. LIX, n. 1, jan. 1891, p. 2
} 
defendiam a entrada de imigrantes da China, ele levantou sua voz na Sociedade Auxiliadora, na Academia de Medicina e nos cursos públicos do Museu Nacional. Era comum, no discurso dos adeptos da imigração chinesa destacar que se tratava de um povo que tinha facilidade para a agricultura, aceitava trabalhar mediante baixos salários e não possuía a predisposição de se fixar no país, logo voltaria para o seu local de origem, garantindo a não miscigenação. ${ }^{169}$

Acerca da imigração chinesa, em outra conferência proferida no Museu, Nicolau Moreira salientou que o assunto dessa mão de obra já havia sido demasiadamente tratado. De fato, na década de 1870 os debates em torno da imigração chinesa foram intensos. No Congresso Agrícola, realizado em julho de 1878, para analisar possíveis soluções para os problemas que enfrentava a lavoura cafeeira, duas questões nortearam os as discussões: o crédito agrícola e a escassez de braços. Foram travadas disputas entre os contrários e os favoráveis à vinda de imigrantes chins. A celeuma adentrou no ano seguinte, na chamada "Questão Chinesa", iniciada na Província de São Paulo, quando o deputado Ulhôa Cintra apresentou seu projeto, na Assembleia, acerca da introdução do trabalhador chinês na lavoura. As ideias propostas se propagaram ao serem colocadas em pauta na Câmara dos Deputados. Nos debates parlamentares, Joaquim Nabuco, que já havia se posicionado contrário à introdução dos chins durante o Congresso Agrícola, acusou o conselheiro João Lins Vieira Cansanção de Sinimbu (1810-1906), então ministro da Agricultura e Obras Públicas, de querer "mongolizar" o Brasil, isto indica que a problemática estava pautada em proposições de cunho racial. ${ }^{170}$

Porém, apesar de considerar esgotada a discussão, um mês após o Congresso, Nicolau Moreira reiterava que era contrário à colonização asiática porque: " $1^{\circ}$, que era impossível reenviar os coolies depois de terminados seus contratos; $2^{\circ}$, que o meio de transição entre trabalho escravo e o trabalho livre era o mais desmoralizador possível, pois o chim é inferior ao escravo."171 É possível constatar que na hierarquização estipulada por Moreira os chineses estariam classificados como inferiores aos negros, não posso afirmar se racialmente ou apenas em termos de produção do trabalho, provavelmente até em ambos os aspectos.

\footnotetext{
${ }^{169}$ LIMA, S. C. de S. Determinismo biológico e imigração... DEZEM, R. Matizes do “amarelo”... ${ }^{170}$ DEZEM, R. Matizes do "amarelo"...

171 MOREIRA, Nicolau Joaquim. Agricultura. Curso publico no Museu Nacional. Preleção do Dr. Nicolau Moreira, em 14 de agosto de 1878. O Auxiliador da Industria Nacional, Rio de Janeiro, n. 10, out. 1878 , p. 228.
} 
Aqui Moreira estava dialogando diretamente com os argumentos daqueles que defendiam a entrada de imigrantes chineses no Brasil. Para estes, tal mão de obra seria utilizada como transitória, isto é, só seriam empregados esses imigrantes até que chegassem os europeus e, então, os chins seriam enviados de volta para a China. No Congresso Agrícola de 1878, este posicionamento foi proposto pelo governo e por uma comissão de agricultores de São Paulo. ${ }^{172}$ Outro argumento, utilizado pelos que advogavam a favor da imigração asiática no Congresso, era que os chins não se enraizavam no país e, por isso, não despertariam um problema racial em termos de miscigenação. ${ }^{173}$ Os que defendiam a imigração chinesa estavam, na prática, pensando em termos econômicos, uma vez que os esses asiáticos trabalhariam por uma remuneração muito inferior àquela paga aos europeus.

Moreira assegurava que seria difícil o reenvio do chinês, destacando que na Califórnia eles não conseguiram tal feito, conforme havia observado em sua viagem. $\mathrm{O}$ cientista do Museu fora enviado pelo governo para participar da comissão brasileira na Exposição da Filadélfia, em 1876, quando também lhe foi solicitado a elaboração de um relatório acerca das políticas imigratórias nos Estados Unidos. Neste país, assim como em Cuba e no Caribe, ${ }^{174}$ ocorreram debates sobre a imigração chin, com a presença de discursos racialmente contrários ao chinês, mas nem por isso esses locais deixaram de utilizá-los como mão de obra. No Brasil ela não se efetivou não pela ação do discurso racialista, mas sim pela distância que aumentava os custos do transporte quando comparada a esses outros locais. Aos fazendeiros interessava substituir os escravos por uma mão de obra barata. Sobre a imigração nos Estados Unidos, Moreira afirmou:

Em S. Francisco da Califórnia, senhores, existem para mais de 15,000 chins, em geral estúpidos e empregando-se muitos deles na importação de moças para a vida devassa e dissoluta. O pequeno número de mulheres chinesas que se transporta para a Califórnia

\footnotetext{
${ }^{172}$ De acordo com Eisenberg, vários fazendeiros do Vale do Paraíba apoiaram a opção da imigração chinesa, e a oposição à utilização desta mão de obra partiu de representantes de quase todas as regiões presentes no Congresso. EISENBERG, P. A mentalidade dos fazendeiros..., p. 191.

${ }^{173}$ DEZEM, R. Matizes do "amarelo"...

${ }^{174}$ Em Cuba, a discussão sobre a viabilidade da imigração chinesa também se fez presente. Com a incorporação de imigrantes chineses no final da década de 1840 , eles se tornaram foco das análises em diversos trabalhos, alguns classificavam o chin como superior ao negro, tanto na inteligência como em outras qualidades. Entretanto, ambos eram considerados como inferiores aos brancos, considerados superiores na inteligência e na civilização, motivos pelos quais se passou a estimular a vinda de imigrantes brancos para a ilha. NARANJO OROVIO, Consuelo; GARCÍA GONZÁLEZ, Armando. Racismo e inmigración en Cuba en el siglo XIX. Madrid: Doce Calles; Fundación de Investigaciones Marxistas, 1996.
} 
entregou-se à prostituição. Até 1851 eram poucas as Madalenas, d'ai por diante, porém, enlevadas pelos lucros, aumentaram extraordinariamente por meio da emigração clandestina. Também é a parte da população mais indecente e cínica que habita S. Francisco. ${ }^{175}$

Classificou os chineses como "estúpidos", “indecentes" e cínicos, além de incitadores da prostituição. Os adjetivos empregados eram depreciativos e sinalizavam para a inferioridade dos asiáticos. As poucas mulheres que emigravam, de acordo com o pesquisador do Museu, tornavam-se prostitutas, inclusive, muitas entravam no país clandestinamente apenas por saberem que ganhariam dinheiro com esta atividade. Desta maneira, concluía que se o Brasil trouxesse imigrantes chins o nível de prostituição aumentaria. ${ }^{176}$ A estratégia de Moreira aqui era despertar o medo, colaborando para uma repulsa à imigração chinesa.

Para aqueles que asseguravam que os chineses não se miscigenariam com a população brasileira, Nicolau Moreira respondia que dentre os chins há "algumas centenas de homens para o pequeno de mulheres, é bem claro que estes indivíduos virão contrair aliança entre nós com grave prejuízo de nossa geração futura." ${ }^{177}$ Este era um dos argumentos utilizados por quem era contrário à imigração chinesa. Assim, o pesquisador evidenciou que a questão racial era primordial para considerar a entrada de asiáticos no país, haja vista que eram uma raça inferior e, com isso, trariam prejuízos à nação.

Um dos pontos apresentados pelo pesquisador do Museu para desacreditar a vinda de imigrantes chineses era que ocorreria a substituição da escravidão negra pela asiática: "não se trata da substituição de trabalho escravo pelo trabalho livre e inteligente e sim da transformação de uma escravatura africana com todos os seus defeitos por uma outra mongólica com todos os seus vícios". ${ }^{178}$ Como os chins aceitavam trabalhar por salários muito baixos, na prática, acabariam sendo um outro tipo de escravos.

\footnotetext{
${ }^{175}$ MOREIRA, N. J. Questão. Convirá ao Brasil a importação..., p. 30.

${ }^{176}$ Em Cuba, também se destacavam os "vícios" dos chineses como fatores determinantes para desqualificá-los enquanto imigrantes. $\mathrm{O}$ alcoolismo, o consumo do ópio, a prostituição, a sodomia, dentre outros, eram evidenciados como tendências inerentes à raça. Trabalhos analisavam o índice de crimes cometidos por negros, chineses e mestiços a fim de estabelecer relações com base raciais. NARANJO OROVIO, Consuelo; PUIG-SAMPER, Miguel Ángel. "Delincuencia y racismo en Cuba: Israel Castellanos versus Fernando Ortiz". In: HUERTAS, Rafael; ORTIZ, Carmen (Ed.). Ciencia y fascismo. Madrid: Doce Calles, 1998, p. 11-23.

${ }_{177}$ MOREIRA, N. J. Agricultura. Curso publico no Museu Nacional..., p. 228.

${ }^{178}$ MOREIRA, N. J. Questão. Convirá ao Brasil a importação..., p. 4.
} 
A fim de provar os danos causados pela miscigenação chinesa, Nicolau Moreira citou a Rússia como exemplo:

Os estudos sobre a raça mongólica datam de longo tempo. [...] muitos autores querem mesmo que o atraso que se nota na civilização de parte do povo russiano, seja devido ao seu entrelaçamento com a raça mongólica, em geral servil, traiçoeira, cruel e tenaz em seus costumes a ponto de não admitir perfeição ulterior. ${ }^{179}$

Em sua interpretação, o atraso russo era consequência da mestiçagem que lá ocorreu com os chineses. Nicolau Moreira novamente utilizou a estratégia de criar temor para defender suas ideias, afinal, se o Brasil viabilizasse a entrada em massa de imigrantes chineses estaria fadado ao fracasso. Em um momento que fervorosos discursos e projetos eram feitos em prol do progresso e da civilização, fazer esse tipo de ameaça era providencial. Afinal de contas, a última coisa que a camada letrada brasileira queria era o atraso do país. Portanto, Moreira foi muito perspicaz ao fazer uso de um argumento que sabia que tocaria profundamente tanto aqueles que eram pró como os que eram contra à imigração chinesa. Ainda na esteira do desenvolvimento, Moreira ressaltou que a China era uma "petrificação colossal, nas palavras do Sr. Carné, não nos oferece nem pelo lado moral nem pelo lado científico e industrial essa maravilhosa perspectiva". ${ }^{180}$ Ou seja, como seria possível confiar em trabalhadores cujo país de origem era o exemplo do retardo.

Para Nicolau Moreira, os chineses eram "imorais" e possuíam "costumes inveterados", sendo a religião a única força que poderia lutar contra tais atributos. Interessante ressaltar que esse tipo de problema não existia com os imigrantes alemães, pois não eram "imorais", além de serem cristãos. Entretanto, o cientista do Museu alegou que os chineses, assim como os indianos, eram uma das raças mais "difíceis de converter-se ao cristianismo":

[...] raça caída na ignorância e na abjeção, são os mais incapazes de dar a razão das crenças que professam e que o único sentimento elevado que se encontra nos chineses é o respeito à memória daqueles

\footnotetext{
${ }^{179}$ MOREIRA, N. J. Questão. Convirá ao Brasil a importação..., p. 11.

${ }^{180}$ MOREIRA, N. J. Questão. Convirá ao Brasil a importação..., p. 24. Grifos do original.
} 
que já não existem, isto porém de modo que se torna prejudicial à saúde pública. ${ }^{181}$

O discurso higienista se fez presente aí. Segundo Moreira, o fato de não serem cristãos, de dificilmente se converterem ao cristianismo, e, acima de tudo, de venerarem a memória de seus entes mortos eram motivos para os chineses serem considerados prejudiciais à saúde pública.

Além de moralmente, os chineses também foram representados como fisicamente inferiores:

A fisiologia nos mostra a influencia da alimentação em relação ao vigor do corpo e estado de saúde individual. Não é possível que um indiático que se nutre com tâmaras, e um chim que absorve por dia quantidades enormes de arroz apresente o vigor de musculatura e essa imunidade de que goza o europeu que se alimenta de carne indo mesmo alguns autores ao ponto de admitirem com Virey que o europeu que vive de trigo, alimento substancial e azotado e fruto de uma cultura aperfeiçoada, não se curva tanto ao despotismo de um senhor como o asiático que se nutre de arroz, alimento proteico, único resultado possível de uma sociedade retrógrada ou estacionária. ${ }^{182}$

A defesa da vinda de imigrantes chineses para o Brasil só se sustentava porque eles trabalhariam nas lavouras, principalmente de café, que estavam carentes de braços. Contudo, para Moreira, isso não seria rentável porque a produção chinesa seria muito inferior, uma vez que eram fracos e franzinos, devido a seu tipo de alimentação. O hábito alimentar dos chineses seria consequência da incapacidade em produzir outro tipo de alimento de "cultura aperfeiçoada". Isto é, já que o país era atrasado ele não conseguiria cultivar nada mais elaborado. Ao desenvolver tal argumento, o cientista hierarquizou os povos, classificando os indianos e chineses como inferiores aos europeus, denotando aqui um tratamento racialista da questão.

$\mathrm{Na}$ interpretação de Nicolau Moreira, ele

${ }^{181}$ MOREIRA, N. J. Questão. Convirá ao Brasil a importação..., p. 19.

${ }^{182}$ MOREIRA, N. J. Questão. Convirá ao Brasil a importação..., p. 27. Com relação à observação de Moreira fundamentada em Julien-Joseph Virey (1775-1846), conferir: VIREY, Julien-Joseph. Natural history of the negro race. Charleston: D. J. Dowling, 1837, p. 106 e 151. 
[...] encarava os povos sem distinção de raça, nacionalidade, religião e cor, como única família de irmãos, mas que não podia deixar de reconhecer que algumas nações, por seu isolamento e pela opressão e despotismo de seus chefes, foram decaindo de mais em mais até tocarem a barbária ou o embrutecimento. ${ }^{183}$

O cientista e conferencista do Museu desejava passar a imagem que todos os homens eram iguais, porém alguns foram decaindo ao longo do tempo. Apesar de não se referir à degeneração, era este princípio que estava por de trás de sua fala. A China era uma nação degenerada, e, pelo visto, para ele não havia reversibilidade do processo, estava fadada à barbárie. Ela não era naturalmente inferior, mas se tornou devido aos seus líderes locais e ao seu isolamento, ou seja, se o país não estivesse tão isolado teria tido maior contato com o mundo ocidental que, por sua vez, teria contribuído para evitar a degradação.

Ainda no intuito de demonstrar a inferioridade chinesa, Moreira afirmou:

Ora, eu não neguei em tempo algum a sobriedade do chim, que em minha opinião toca à nojenta avareza [...]

Também sempre reconheci a paciência e a docilidade do chim sob a influência do policial e do bambu, sendo estas qualidades de que eles se revestem em tal grau, que me obrigam a colocá-los abaixo do escravo africano ou crioulo. ${ }^{184}$

A sobriedade e paciência orientais, apresentadas pelos defensores da imigração chinesa como positiva, eram desprezadas por Moreira. Para ele, essas qualidades seriam apenas dissimulações, que só seriam visíveis por meio de pressão. Concluiu, portanto, que o chinês era inferior ao africano, porque estes não tinham tais atributos. Demonstrar a inferioridade racial chinesa foi uma de suas bandeiras na Academia Imperial de Medicina, na Sociedade Auxiliadora da Indústria Nacional e nos cursos públicos do Museu Nacional.

A imigração chinesa, principalmente nas falas de Nicolau Moreira, e a imigração de forma mais ampla estiverem presentes nas preleções públicas do último quartel do século XIX. A proximidade do término da escravidão fez com que aqueles intelectuais

\footnotetext{
${ }^{183}$ MOREIRA, N. J. Questão. Convirá ao Brasil a importação..., p. 25.

${ }^{184}$ MOREIRA, N. J. Questão chinesa. Preleção no Museu..., p. 81.
} 
debatessem sobre alternativas para a mão de obra cativa. O imigrantismo, para muitos, apareceu como a melhor solução para a falta de braços na lavoura. $\mathrm{O}$ imigrante branco europeu era o mais desejado, pois além de resolver o problema da mão de obra, embranqueceria o país. A questão do embranquecimento foi fulcral no discurso de Nicolau Moreira, que lutou veementemente contra os que defendiam a vinda de imigrantes chineses para o Brasil. Mesmo sendo minoritários, no bojo de todas as propostas para a substituição de braços na lavoura, os debates sobre os chins eram cruciais para Moreira. A discussão para ele girava em torno de questões raciais.

Os discursos racialistas, baseados em vocabulário científico/cientificista, marcaram profundamente as tribunas públicas aqui estudadas. Os cursos e conferências eram espaços nos quais a temática da raça era debatida e construída. As discussões acerca dos lugares sociais aconteciam em diversas esferas da sociedade, uma vez que estavam inseridas em questões mais amplas de projetos modernizadores para a nação. No vasto debate que se estabeleceu, os preletores entraram com uma postura pedagógica, indicando quais seriam os caminhos corretos para branquear o país, para tratar a escravidão, para civilizar ou não o indígena, e o vocabulário por eles utilizado foi o da raça. E se não saíram vitoriosos em suas propostas, conseguiram estabelecer um discurso racial que influenciou as décadas seguintes.

A inferioridade racial do índio, do negro e do chinês era cientificamente constatada, ou simplesmente comprovada. Brancos, índios, negros, chineses eram tratados como raças diferentes, por meio de diferentes critérios de definição - cor da pele, nação, grupo étnico. Em todas as interpretações o branco era representado como superior. Esses grupos eram apenas temas de debates, pois os discursos expostos eram direcionados para uma audiência composta por uma elite letrada. Fazendo uso das palavras de Todorov, lá estavam "nós" (homens, cientistas, brancos, letrados) analisando, classificando e hierarquizando os “outros" (índios, negros e chineses). ${ }^{185}$

${ }^{185}$ TODOROV, T. Nós e os outros... 


\section{IV - Conferências... um}

\section{espaço de e para mulheres}

\section{As mulheres nas conferências}

A participação feminina nos espaços das conferências deve ser analisada de modo amplo e integrando as três maneiras em que as mulheres estiveram presentes como oradoras, plateia e tema das preleções. ${ }^{1}$ Com relação à primeira categoria, no recorte temporal aqui pesquisado, apenas duas mulheres subiram às tribunas para discursar.

Nas conferências “Avulsas”, a escritora russa Lydia Pasckoff, ${ }^{2}$ em 1877, discursou sobre a posição feminina no século XIX. A preleção transcorreu no Teatro de S. Pedro, mediante um público composto por muitos homens e mulheres no salão e poucas pessoas nos camarotes, contando com a presença do Imperador. ${ }^{3}$ Contudo, não foi bem recebida por parte da imprensa, que condenou a leitura do discurso feita pela condessa russa. Para o Diario do Rio de Janeiro: "Sobre o que lá se passou ocorre-nos, porém, uma dúvida, e é logo sobre o título do espetáculo que se nos deu com a entrada

\footnotetext{
${ }^{1}$ Ao trabalhar com a história das mulheres me alinho ao posicionamento defendido por Maria Odila Leite da Silva Dias. A autora utiliza a abordagem que prima por historicizar os conceitos que se procura analisar, "não somente as categorias das relações de gênero, como também os conceitos de reprodução, família, público, particular, cidadania, sociabilidades", ultrapassando, dessa maneira, as definições estanques e os valores culturais considerados como próprios de uma natureza feminina. Esta perspectiva fundamenta-se em demarcar "o lugar, a posição relativa do grupo social ou mulheres a serem estudadas no conjunto de uma certa sociedade". Para a pesquisadora, a integração da história conceitual com a história social é muito profícua para o estudo das mulheres, porque as considera como sujeitos e agentes da história. DIAS, Maria Odila Leite da Silva. Teoria e método dos estudos feministas: perspectiva histórica e hermenêutica do cotidiano. In: COSTA, Albertina de Oliveira; BRUSCHINI, Cristina (Orgs.). Uma questão de gênero. Rio de Janeiro: Rosa dos Tempos; São Paulo: Fundação Carlos Chagas, 1992, p. $41,44$.

${ }^{2}$ Não encontrei, nas fontes consultadas, referências sobre qual idioma foi utilizado pela oradora.

${ }^{3}$ Gazeta de Noticias, 05/11/1877.
} 
paga. É que em nossa língua aquilo não se chama conferência, mas uma leitura". ${ }^{4}$ Mesmo sabendo de antemão que a preleção era paga, pois era beneficente, em favor das vítimas da seca do Rio Grande do Norte, o periódico não se furtou a utilizar esse ponto como um adicional negativo. Referir-se à apresentação como "espetáculo" conferiu-lhe um caráter depreciativo com ares de chacota.

A Gazeta de Noticias também comentou o fato de ela ter feito a leitura e não pronunciado conforme fora anunciado, ${ }^{5}$ porém, sua crítica foi bem menos árdua, ressaltou apenas que o efeito seria maior se a preletora tivesse se atido ao programa. $\mathrm{Na}$ avaliação do Diario do Rio de Janeiro, a condessa Pasckoff

limitou-se a ler uma produção, que não nos pareceu distinguir-se, nem pelo alto conceito, nem pelo primoso estilo, nem por deduções filosóficas, a que se prestaria o assunto, sobretudo na parte que dizia respeito ao Estado da mulher na civilização moderna e em seu futuro. ${ }^{6}$

Afirmou também que a expectativa do público foi grande, e que o tema era relevante, contudo, merecia ser mais bem abordado. Apesar de depreciar o modo como o conteúdo da conferência foi desenvolvido, o Diario não o apresentou. Já o resumo da preleção foi editado na Gazeta de Noticias. Com relação ao teor, a oradora expôs a situação da mulher em várias partes do mundo. Sustentou que na Ásia e no Oriente as mulheres eram reprimidas e viviam em uma posição muito precária, se na Turquia o homem era visto como um ídolo, na Síria era temido como um senhor. Segundo o jornal, citando literalmente trecho da fala da oradora: "Não vi em parte alguma o respeito filial elevado a tal ponto de elevação." Por esta comentário, é possível supor que as afirmações feitas por Pasckoff tenham sido fruto das observações feitas em suas viagens. A oradora tratou, em seguida, da situação das mulheres nos seguintes locais: Alemanha, França, Itália, Inglaterra, Portugal, Espanha, Rússia e Brasil. ${ }^{7}$

Porém, a conferencista dispensou maior atenção à situação da mulher na Rússia, sobre a qual tinha maiores informações a respeito, uma vez que era seu país natal. De acordo com a escritora russa, a situação feminina lá mudava conforme a classe, relatou que entre os mercantes o marido "é temido, é um autocrata". Já entre a pequena

\footnotetext{
${ }^{4}$ Diario do Rio de Janeiro, 05/11/1877. Grifo do original.

${ }^{5}$ Gazeta de Noticias, 05/11/1877.

${ }^{6}$ Diario do Rio de Janeiro, 05/11/1877. Grifos do original.

${ }^{7}$ Gazeta de Noticias, 05/11/1877.
} 
nobreza a mulher era mais feliz, a despeito disso, censurou as mesmas por levarem a independência além do necessário - estudavam medicina, direito e outras ciências em demasia. Portanto, em sua concepção, as mulheres deveriam aprofundar-se nos estudos só até o limite necessário para bem cuidar dos filhos. Ela desaprovou, da mesma maneira, as mulheres da aristocracia, que apesar de "inteligentes e brilhantes" eram educadas para a vida dos salões. Valorizar a instrução apenas para serem boas mães e condenar a educação só para a vida social eram posicionamentos compartilhados por alguns brasileiros. ${ }^{8}$

Por meio da análise do conteúdo exposto na conferência é possível inferir algumas hipóteses sobre os motivos que levaram o Diario do Rio de Janeiro a ser incisivo em suas críticas. Lydia Pasckoff em vários momentos classificou os maridos como autoritários e temidos pelas mulheres, representadas como vítimas da situação. Talvez essa opinião da escritora russa tenha provocado a cólera de algum redator da folha, que se sentiu ofendido. Outra suposição é que a leitura da preleção tenha sido considerada uma falta de respeito para com a plateia, mais que isso, com o país, visto que ela estava ali como representante de outra nação.

Ser a primeira mulher a se apresentar nas conferências públicas e, ainda por cima, estrangeira deve ter criado uma grande expectativa naqueles que foram assisti-la. Como ela era? Como se vestia? Como se comportava? Como era sua oratória? Como procederia a primeira mulher a ocupar aquele espaço fundamentalmente masculino? Devem ter sido algumas das perguntas que povoaram a mente dos frequentadores de tais tipos de eventos. Soma-se a tudo isso o fato de sua preleção ter sido cancelada por motivo de enfermidade da oradora, o que certamente aumentou ainda mais a ansiedade pela espera da próxima oportunidade. Não encontrei sobre nenhuma outra conferência referência ao tipo físico do orador, nem a sua vestimenta. Porém, ao apresentar o resumo e comentar a exposição de Pasckoff, a Gazeta de Noticias evidenciou esses aspectos:

Mme. Pasckoff é de estatura mediana, compleição elegante, olhos expressivos, nariz aquilino, clara, cabelos louros. O seu traje era um pouco fantástico, vestido escuro, de longa cauda, afogado, mal se

\footnotetext{
${ }^{8}$ TURACK, Cynthia Fevereiro. Mulheres-mãe: memória e construção de sentidos no discurso do periódico A Mãi de Familia (1879-1888). Dissertação (Mestrado em Memória Social) - Centro de Ciências Humanas e Sociais, Universidade Federal do Estado do Rio de Janeiro, Rio de Janeiro, 2008.
} 
vendo o pescoço, envolvido de um colar de ouro. Comprido véu branco caia-lhe de um boné que cobria o penteado.

A posição da preletora era natural, sem afetação, e a leitura em voz fluente agradável, conquanto não bastante alta para o teatro de S. Pedro. ${ }^{9}$

Descrição física acurada foi feita para aqueles que não puderam comparecer à apresentação pudessem ter a dimensão de como se apresentara a oradora. Detalhes de seu figurino foram relatados a fim que se conseguisse imaginar como ela estava trajada. Resta saber o que seria um traje "um pouco fantástico". Talvez extravagante, ou simplesmente diferente do usual das brasileiras da elite? O jornal expôs o modo como a escritora russa se comportou ao fazer sua explanação. Nenhum pormenor poderia ser deixado de lado, qualquer minúcia era bem-vinda e interessante, afinal era "o outro", "o diferente", que estava lá ocupando um espaço que até então não lhe cabia. Assim, mesmo tendo sido aceita como oradora, o tratamento a ela dispensado fora diferente.

Nos 16 anos aqui analisados, nas Conferências Populares da Glória somente uma mulher discursou. Em 1888, Maria da Glória Loureiro de Andrade, diretora do Externato Andrade, apresentou a preleção "A mestra e a escola entre nós". ${ }^{10}$

Inicialmente a preletora expôs o método de Friedrich Frœbel, ${ }^{11}$ em seguida abordou o papel da educadora, ou jardineira, e a sua influência sobre o caráter e o espírito das crianças. Ressaltou que o fato destas serem os futuros cidadãos mostrava o quão importante era a função da educadora e o seu preparo, pois é “do educador, e do método por ele seguido, que depende o destino de um país, porque o mestre é que forma o caráter das gerações que hão de dirigir esse país". ${ }^{12}$ A educação infantil não era apenas importante pelos benefícios que proporcionaria à criança, mas pelo que poderia

\footnotetext{
${ }^{9}$ Gazeta de Noticias, 05/11/1877.

${ }^{10}$ Jornal do Commercio, 28/04/1888. Maria da Glória Loureiro de Andrade graduou-se em Nova Iorque, na academia de Kraus-Bœlte (dirigida pelos professores John Kraus e Miss Maria Kraus-Bœlte), e era discípula do educador alemão Friedrich Frœbel (1782-1852).

${ }^{11} \mathrm{O}$ suíço Friedrich Frœbel, pastor protestante, defendia que a educação da infância deveria ocorrer logo nos primeiros anos de vida. O pensamento de Rousseau fundamentava suas concepções pedagógicas, "expressas na valorização do homem, da natureza e do trabalho manual e físico como forma de elevar o espírito". Instituições comuns nos Estados Unidos e na Alemanha, nos jardins de infância eram matriculadas crianças entre 2 e 6 anos de idade, e a aprendizagem ocorria com o auxílio de jogos e brincadeiras, partindo do simples para o complexo. Alessandra Frota Martinez sustenta que no Brasil, com o intuito de educar e instruir a população, os dirigentes imperiais reinterpretaram os "fundamentos religiosos e a preocupação de Frœbel com a educação integral do homem como indivíduo e súdito do Estado, integrados na sociedade pela fé e pela moral". MARTINEZ, Alessandra Frota. Educar e instruir: a instrução popular na corte imperial - 1879-1889. Dissertação (Mestrado em História) - Universidade Federal Fluminense, Rio de Janeiro, 1997, p. 57, 58.

${ }^{12}$ Jornal do Commercio, 30/04/1888.
} 
propiciar à nação - melhores cidadãos e gestores. Para a diretora do Externato Andrade, "Não basta também que a mestra seja instruída; é preciso que saiba ensinar, que conheça a arte do ensino". ${ }^{13}$ Defendeu também as escolas mistas, afirmando que os preconceitos com relação a elas eram infundados. Por fim, a oradora convocou as mães de família para fazerem parte desta cruzada em prol da educação. Diferente do ocorrido com a conferência de Pasckoff, nenhum comentário sobre a vestimenta, o porte físico e a oratória de Maria de Andrade foi publicada na imprensa, talvez por ser ela uma mulher já conhecida da sociedade da Corte.

Portanto, excetuando os cursos públicos do Museu Nacional, nos quais só os diretores da instituição prelecionavam, apenas duas conferências foram proferidas por mulheres, uma quantidade ínfima quando comparada às 972 mapeadas. Isso indica que aqueles espaços ainda eram concebidos como masculinos. Por serem locais em que se apresentavam pessoas vistas como detentoras de um determinado saber, pode-se inferir que, no julgamento daqueles que selecionavam os oradores, as mulheres não possuíam saberes considerados dignos de serem compartilhados publicamente.

As mulheres também participaram das conferências como espectadoras, conforme analisei no primeiro capítulo. Segundo Maria Margaret Lopes, a participação feminina em tais encontros estava em concordância com "a mentalidade cientificista então moderna que incentivava a participação das mulheres nesse tipo de reuniões científicas, mas ainda não lhes permitia ingresso nos cursos regulares das faculdades do país". ${ }^{14}$ Cientes da importância desses espaços, os oradores muitas vez direcionaram seus discursos ao público feminino. Todavia, com relação à proporção de mulheres presentes, elas ainda compunham a minoria da plateia. Em uma preleção de 1873, nas Conferências Populares da Gloria, compareceram pouco mais de 200 pessoas, das quais cerca de 50 eram mulheres. ${ }^{15}$ Já quando da inauguração do novo prédio da escola da freguesia da Glória, onde se realizavam tais conferências, das três salas abertas destinadas para o evento, "uma delas ficou repleta só de mulheres", ${ }^{16}$ ou seja, um terço de audiência feminina. Esta presença um pouco maior talvez estivesse atrelada ao fato de ser a preleção de estreia naquele edifício.

\footnotetext{
${ }^{13}$ Jornal do Commercio, 30/04/1888.

${ }^{14}$ LOPES, Maria Margaret. O Brasil descobre a pesquisa científica: os museus e as ciências naturais no século XIX. São Paulo: Hucitec, 1997, p. 146.

${ }^{15}$ Diario do Rio de Janeiro, 08/12/1873.

${ }^{16}$ O Globo, 01/06/1875.
} 
A mulher foi tema de algumas conferências, tais como, a importância da educação feminina; as mulheres célebres e como desempenhavam os papéis de filha, mãe e esposa; a mãe de família; a mulher e o amor. Em 1874, Thomaz Alves Junior (1830-1895), bacharel em direito e professor da Escola Militar, realizou uma conferência sobre Madame Staël, na qual enfatizou a importância que a escritora francesa teve na política e na literatura de fins do século XVIII e início do XIX. ${ }^{17}$

Algumas preleções foram direcionadas ao público feminino, visando instruir as mulheres principalmente em como deveriam agir para serem boas mães, embora a porcentagem de mulheres presente fosse pequena. Eram apresentações que tinham como assunto central a higiene e a medicina. Merecem destaque as que abordavam as moléstias e a higiene infantis, proferidas em sua maioria pelos médicos Carlos Arthur Moncorvo de Figueiredo e Carlos Antonio de Paula Costa, sendo que este se apresentou tanto nas conferências "Avulsas" quanto nas Populares da Glória.

Por meio desta análise, pude verificar que o comparecimento como espectadoras, embora pequeno, foi sempre estimulado, uma vez que para modernizar o país, dentro da concepção moderna burguesa, a mulher deveria ser instruída para melhor desempenhar seu papel na sociedade. Por esse motivo, muitas preleções abordaram temas direcionados a elas. Entretanto, sua participação enquanto oradora não foi incentivada, haja vista que apenas duas mulheres discursaram no período de 1870 a 1889 . Talvez por não serem consideradas suficientemente aptas a expor conhecimentos ao público ou por não deterem o saber considerado necessário para ser divulgado.

\section{Carlos Costa e A Mãi de Familia}

Entre 1877 e 1879, Carlos Antonio de Paula Costa ministrou o curso de higiene popular na Escola de Botafogo e na Escola Noturna da Lagoa. No ano de 1887, ele proferiu 40\% das preleções realizadas nas Conferências Populares da Glória, nas quais abordou a higiene da infância. O médico era o fundador e o redator-principal do jornal $A$ Mãi de Familia. Nesta publicação, Costa publicou vários artigos nos quais abordou assuntos que também tratou em suas exposições públicas direcionadas ao público feminino. Por esse motivo, utilizo o período como fonte principal para compreender as

\footnotetext{
${ }^{17}$ Jornal do Commercio, 15/09/1874.
} 
ideias apresentadas pelo médico, uma vez que ele usou as plataformas das conferências para veicular as ideias que apareciam em A Mãi de Familia. Dentre as quais, merecem destaque o aburguesamento da família, o sanitarismo, a maternidade como papel fundamental da mulher na sociedade, a educação feminina, a escravidão e a abolição. Cabe, então, apresentar de modo mais detalhado a publicação.

Foi a partir da seção "Cartas às Senhoras Brasileiras", publicada na Gazeta de Noticias, em 1877, que Carlos Costa concebeu a ideia de produzir A Mãi de Familia. Na referida seção seu objetivo era tratar de questões relativas à higiene infantil. ${ }^{18}$ No mesmo ano em que atuou como colaborador da Gazeta de Noticias, o médico ofereceu várias conferências na cidade. ${ }^{19}$ Muito do que apresentou oralmente estava presente em seus artigos. Carlos Costa se inspirou no jornal francês La Jeune-Mère, editado pelo também médico André Théodore Brochard (1810-1882), para projetar A Mãi de Familia:

A nova publicação que oferecemos às mães de família brasileiras tem fim idêntico ao do jornal do Dr. Brochard que tanta aceitação tem tido em França.

[...] preenche importante lacuna na educação da mulher. Ensinará, em cada número, às mães jovens, a higiene da primeira idade. Sob diversos títulos achar-se-ão ordenados os conselhos ditados pela experiência e pela ciência, em relação aos cuidados de que se devem rodear as crianças: habitação, alimentação, vestuário, etc.

Cada número conterá uma PALESTRA DO MÉDICO, artigos sobre educação, receitas, novelas, conselhos sobre higiene, etc. ${ }^{20}$

A finalidade da publicação nacional era a mesma da congênere europeia: educar a mulher para que fosse uma boa mãe de família. Cynthia Fevereiro Turack argumenta que a influência também se deu em termos discursivos, "muitos dos sentidos organizados e veiculados no jornal francês acerca das mulheres e da maternidade foram (re)produzidos ou adaptados para sociedade carioca". ${ }^{21}$

\footnotetext{
${ }^{18}$ A Mãi de Familia, ano 6, n. 5, 15/03/1884, p. 33.

${ }^{19}$ A Mãi de Familia, ano 1, n. 1, jan. 1879, p. 7.

${ }^{20}$ A Mãi de Familia, ano 1, n. 9, maio 1879. Grifos do original.

${ }^{21}$ TURACK, C. F. Mulheres-mãe..., p. 55.
} 
Diferentemente dos demais jornais voltados para mulheres, geralmente de curta duração, A Mãi de Familia teve boa aceitação, circulando entre 1879 e $1888 .^{22}$ Era vendido não apenas no Rio de Janeiro, mas também em outras províncias, como em São Paulo e em Minas Gerais. ${ }^{23}$ Consoante as palavras de Carlos Costa, A Mãi de Familia não se restringiu aos "centros civilizados", entenda-se a Corte, mas atingiu também os "remotos lugares" do país. ${ }^{24}$

No último número de 1888 foi publicado um aviso às leitoras: "Completamos com este número dez anos de existência. [...] Não obstante, ainda ousamos esperar, e o ano de 1889 , ou iluminará as nossas vitórias ou nos deteremos na nossa propaganda". ${ }^{25}$ De fato, a partir de 1889 o periódico parou de ser impresso. Por meio da observação acima é possível supor que os editores e o redator já pretendiam encerrar a publicação, ou supunham que isto pudesse ocorrer. Não encontrei, entretanto, nas fontes, nada que indicasse o motivo do término.

Jornal ilustrado, publicado quinzenalmente, composto por oito páginas, A Mãi de Familia tinha paginação ininterrupta entre janeiro e dezembro de cada ano. No primeiro número de 1879 passou a utilizar o subtítulo: "Jornal Científico, Literário e Ilustrado Educação da Infância, Higiene da Família". No ano seguinte, também apenas na primeira edição, expôs o mesmo subtítulo, porém com a ordem invertida. Após 1883, houve outra mudança no subtítulo, que passou a constar em todos os números: "Jornal Científico-Literário - Educação da Infância, Higiene da Família - Modas para crianças".

Dentre os colaboradores estavam: José Ricardo Pires de Almeida, João Pizarro Gabizo, Emilio Maia, Mello de Oliveira, Remedios Monteiro, Langgard, Felix Ferreira, Dantas Júnior, Ribeiro Mendonça. ${ }^{26}$ Em seu décimo ano passou a vir impressos na página de abertura das edições os nomes dos que participavam da folha: "Fundador e Redator principal: Dr. Carlos Costa" e logo abaixo: "Redatores: Drs. Pires de Almeida, Alfredo Piragibe, Brito e Silva, Silva Araujo e Pires Farinha". ${ }^{27}$ A colaboração feminina se deu por meio da impressão de alguns poemas assinados por mulheres, e na série de

\footnotetext{
${ }^{22}$ TURACK, C. F.. Mulheres-mãe...

${ }^{23}$ CAMARA, Sonia. O jornal "Mãe de Família" como estratégia de intervenção medicina, higiene e educação na fabricação da infância e da família no Brasil dos finais do século XIX. Actas do VII Congresso Luso-Brasileiro de História da Educação: Cultura Escolar Migrações e Cidadania. Porto: Faculdade de Psicologia e Ciências da Educação (Universidade do Porto), 2008.

${ }^{24}$ A Mãi de Familia, ano 2, n. 24, dez. 1880, p. 186.

${ }^{25}$ A Mãi de Familia, ano 10, n. 24, 31/12/1888, p. 185.

${ }^{26}$ A Mãi de Familia, ano 8, n. 7, 15/04/1886, p. 49.

${ }^{27}$ A Mãi de Familia, ano 10, n. 1, 15/01/1888, p. 1.
} 
quatro artigos escritos por Maria de Montalchez, intitulados "Conselhos às Mães". Quando da publicação do segundo texto desta senhora, Carlos Costa escreveu duas notas de rodapé informando que sua opinião era diferente da sugerida pela autora. ${ }^{28}$ Assim, embora cedesse espaço à fala feminina, a palavra do médico, com a chancela da ciência, ainda vinha para dizer se a mulher estava correta ou não.

Com relação às ilustrações, elas estiveram presentes até 1882. Além da imagem de abertura (mãe com um bebê no colo escutando outra criança a ler), A Mãi de Familia apresentava pequenas gravuras ao término de cada artigo e algumas maiores que ocupavam uma página inteira. As pequenas imagens não tinham relação direta com o tema apresentado nos textos e repetiam-se em várias edições. A partir de 1883, somente a da abertura continuou a ser publicada, como uma espécie de marca do jornal.

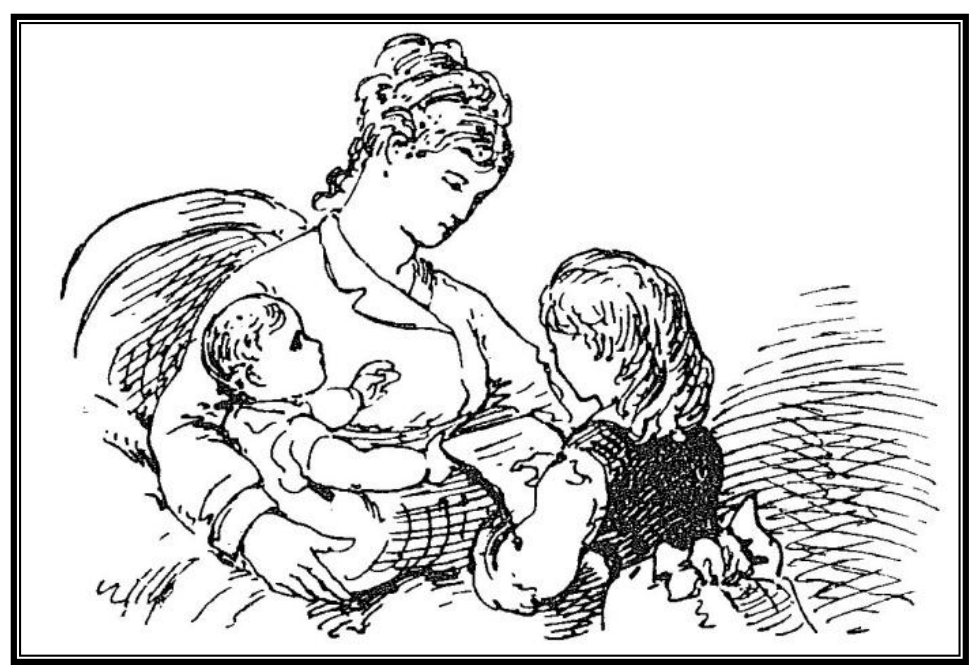

Imagem I - Ilustração que se tornou a marca de A Mãi de Familia.

A mãe é representada exercendo suas funções esperadas e adequadas segundo os parâmetros higienistas, pois cuida de seus filhos física e moralmente. Fisicamente, ela está segurando o bebê ao invés de deixar este tipo de cuidado à criadagem, zelando para que nada de ruim acontecesse com ele. Moralmente porque ela está preocupada com a educação de sua filha. Não é coincidência que seja uma menina ao invés de um menino, já que foi recorrente no periódico a insistência na importância de a mãe educar convenientemente sua filha.

A imagem abaixo também exibe uma mãe cuidadosa que vela o sono de seu bebê. Pelas vestimentas e decoração do quarto percebe-se que simbolizava uma mulher

\footnotetext{
${ }^{28}$ A Mãi de Familia, ano 2, n. 5, jan. 1880, p. 37.
} 
da elite da sociedade, ${ }^{29}$ que compunha o público leitor de A Mãi de Familia. Esta ilustração foi impressa mais de uma vez, tanto no meio de artigos quanto em folha separada de descrição do periódico.

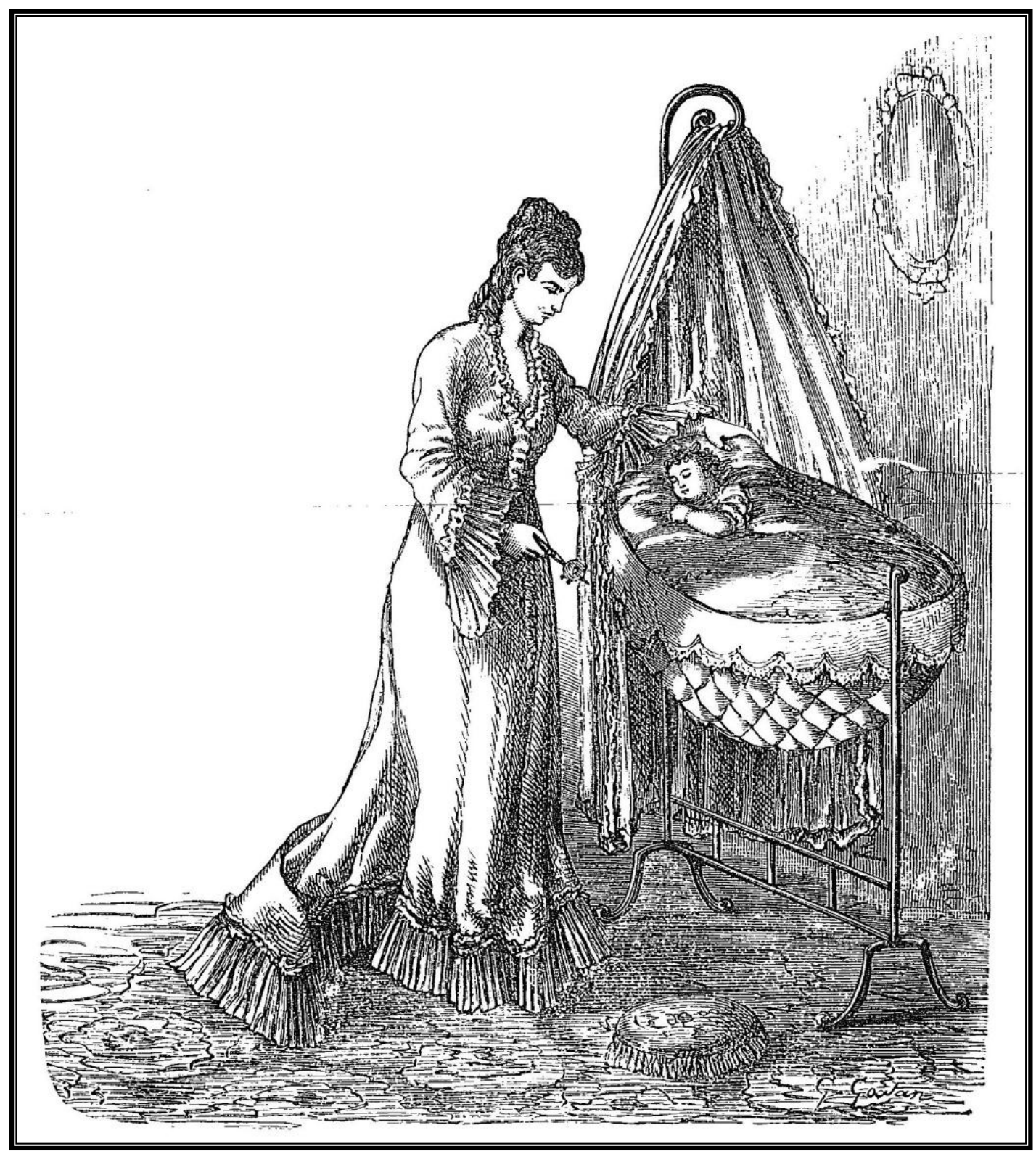

Imagem II - Mãe cuidando de seu filho.

29 Vestimentas femininas semelhantes foram publicadas em outros periódicos ilustrados também destinados às mulheres, principalmente nas seções que se refiram à moda. MALTA, Marize. Fundo, detalhe e satisfação visual: decoração doméstica em A Estação. In: KNAUSS, Paulo (et. al.) (Orgs.). Revistas ilustradas: modos de ler e ver no Segundo Reinado. Rio de Janeiro: Mauad X: Faperj, 2011, p. 91-104. 
Turack assevera que $A$ Mãi de Familia possuía o mesmo padrão gráfico do periódico francês La Jeune Mère, chegando o jornal brasileiro a ter uma gravura idêntica à da folha francesa (criança apresentada na imagem seguinte). ${ }^{30}$

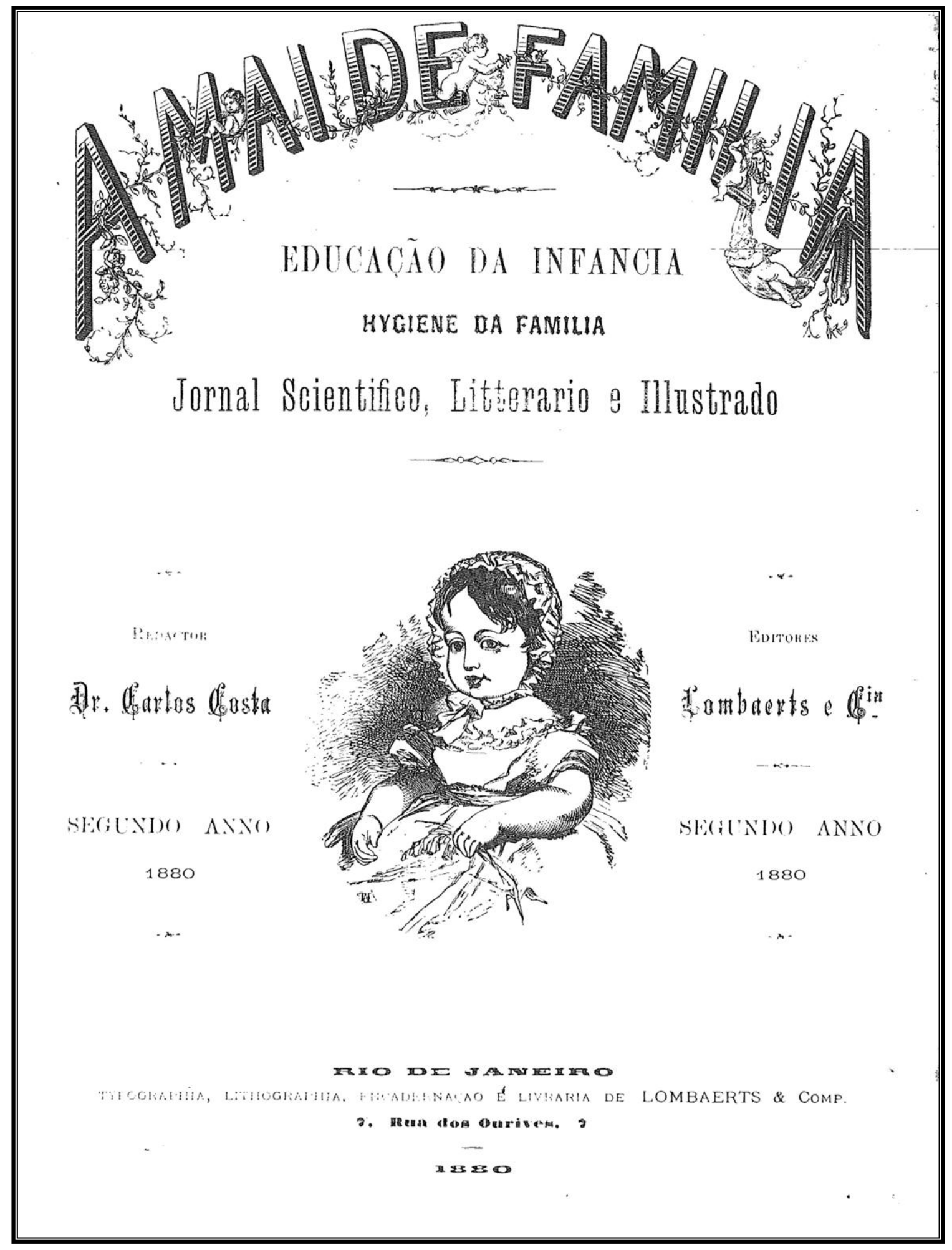

Imagem III - Capa do primeiro número de 1880 com imagem igual à de La Jeune Mère.

\footnotetext{
${ }^{30}$ TURACK, C. F. Mulheres-mães..., p. 56.
} 
A publicação contava com um anexo, no qual estavam impressos os figurinos coloridos que tinham sua explicação detalhada no corpo do jornal. Havia a possibilidade de comprar o periódico sem os figurinos, saindo mais barato. $\mathrm{O}$ valor da assinatura com o figurino para a Corte era de $9 \$ 000$ e para as províncias $10 \$ 000$. Já sem o figurino os preços caiam, sendo, respectivamente, $6 \$ 000$ e 7\$000. A partir de 1884 não estava mais disponibilizada a assinatura sem o figurino; entretanto, era possível a compra de exemplares avulsos por 500 rs.

A Mãi de Familia era editada por Lombaerts \& Companhia. No número de lançamento, Carlos Costa explicitou sua alegria em ter encontrado apoio nos proprietários da tipografia Lombaerts, ${ }^{31}$ que compactuavam com ele sobre a necessidade de ajudar a infância do país, considerada como "alvo de nossas esperanças para o engrandecimento de nossa Pátria". ${ }^{32}$ Para tal, instruir a mãe, a fim de que ela bem educasse seus filhos, era fundamental para a melhoria do país, isto dentro de um amplo projeto modernizador da nação.

Com relação às seções, até 1882 essas foram as que estiveram mais presentes: "Palestra do Médico", "Moléstia das Crianças", "Farmácia Doméstica", "Variedade", "Máximas e Pensamentos", "Revista dos Jornais Científicos". Excetuando a primeira, as outras não foram editadas em todos os números. Sem possuir uma seção nomeada para tal, pequenas poesias com temas diversos eram publicadas, contando com a colaboração de Arthur de Azevedo, Lopes Cardoso, Fontoura Xavier. No final das edições era dedicado um espaço às propagandas, porém não possuía um nome específico.

Dentre os exemplares disponíveis, o primeiro a apresentar anúncios foi o da primeira quinzena de março de 1879. Foram anunciados objetos para ajudar na dentição, consultórios médicos, farmácia, caneta contra tremor, e a farinha láctea da Nestlé, embora os artigos do periódico criticassem o aleitamento artificial. ${ }^{33}$ Dos consultórios médicos divulgados, estavam os de Carlos Costa e Pires de Almeida, que escreviam para o jornal. $^{34}$

\footnotetext{
${ }^{31}$ A tipografia Lombaerts \& Companhia, localizada à Rua do Ouvidor, n. 7, editava poucos livros e confeccionava muitas impressões por encomenda, trabalhava principalmente com jornais e revistas importados. Teve como proprietários o belga Jean Baptiste Lombaerts (1821-1875) e seu filho Henri Gustave Lombaerts (1845-1897). HALLEWELL, Laurence. O livro no Brasil: sua história. Tradução de Maria da Penha Vilalobos, Lólio Lourenço de Oliveira e Geraldo Gerson de Souza. 2 ed. São Paulo: Edusp, 2005, p. 229.

${ }^{32}$ A Mãi de Familia, ano 1, n. 1, jan. 1879, p. 7.

${ }^{33}$ A Mãi de Familia, ano 1, n. 11, jun. 1879, p. 89.

${ }^{34}$ A Mãi de Familia, ano 5, n. 6, mar. 1883, p. 48.
} 


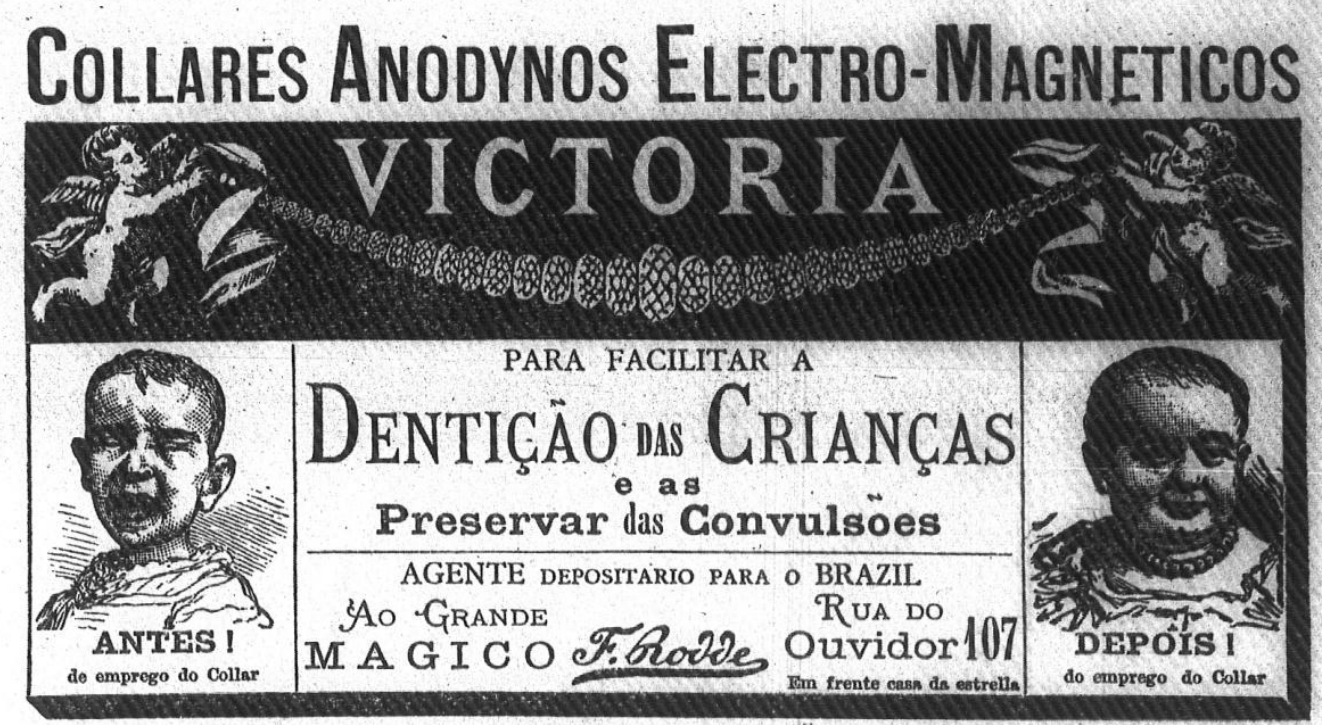

\section{DR CARI ${ }^{\circ} O S$ GOSTA}

Medieo especialista das molestias dias crianẹs

RESIDENCIA RUA DE SANTO AMARO 29

Consultorio, Rua Primeiro de Março n. 101; das 12 ás 3 da tarde e das 6 ás 8 da noite.

\section{Dr. C. Bettamio} MEDICO

FSPREALTSTA DAS HOLISTHAS DO LARYNGE E OUVIDOS

Residencia. rua Victor Meirelles, Engenho Novo Consultorio, rua do Visconde de Inhatima 29, da 1 ás 3 da tarde

\section{PXXARMAGCA}

DE

\section{Salvador de eAlmeida}

Pharmaceutico chimico pela Escola de Medicina do Rio de Janeiro, ex-pharmacentico no hospital geral da. Misericordia, ex-pensionista por concurso na pharmacia central do Hospital Militar da Côrte

\section{RUA do EVARISTO da VEIGA 18}

antiga rua dos Barbonos

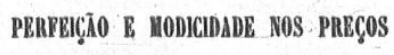

Especialidade de plantas e productos naturaes do Brasil, como oleos, gommas feculas, resinas e balsamos medicinaes.

\section{G A N E A Electrica Contra o T R M O R

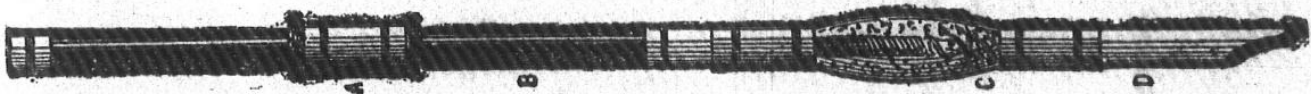

Combate et cura os espasmos nervosos da mâo tâo frequente nos escrivâo Ao Grande MAGICO Thoo2 Res Rua do Ouvidor, 107

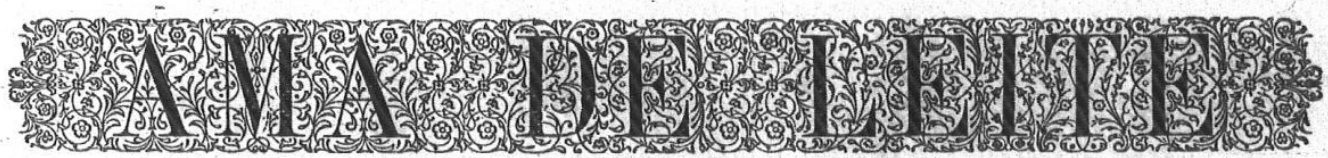

A farinha lactea e o leite condensado de Nestlé, premiados na exposição de Paris, inutilisam hoje em dia todas as amas de leite alugadas.

Um folheto sobre a nutricão das criancas de peito acompanha cada lata deste excellente alimento

Vende-se em casa de Filippone, á rua do Ouvidor n. 93.

N. B. - Todas as minhas latas expedidas para o Brazil têm o rotulo em portuguez

Imagem IV - Página de anúncios de A Mãi de Familia. 
Outros espaços da publicação também eram utilizados para propagandas. Após indicar o endereço da Livraria Lombaerts, onde poderiam ser feitas as assinaturas, foi mencionado que as correspondências deveriam ser direcionadas ao redator, Carlos Costa, que também recebia "consultas por escrito do interior e províncias". ${ }^{55}$ No conteúdo de alguns artigos aparecia a publicidade de maneira indireta, uma vez que eram citados objetos de marcas específicas com a referência aos locais em que eram vendidos. Ao discutir sobre a cama correta para o recém-nascido, o redator do jornal recomendou a de fundo de arame tecido, por estar dentro dos parâmetros higiênicos, indicando o nome do fabricante e seu endereço. ${ }^{36}$

Em termos de vulgarização da ciência, a proposta da seção "Moléstias das crianças" era muito semelhante à das conferências públicas realizadas pela cidade. Aqui Costa ressaltou que dirigia seus textos às "pessoas estranhas à ciência" e, por isso, não deveria expô-los da mesma maneira como faria para médicos ou estudantes de medicina. ${ }^{37} \mathrm{O}$ fundamental era apresentar brevemente os sintomas das moléstias, para que a mãe tivesse conhecimento da gravidade das mesmas e, assim, pudesse prestar os socorros necessários até a chegada do médico. Assim, ele não excluiu a presença do médico na cura, mas colocou a mãe como sua auxiliar imediata neste processo. É possível inferir que, de certa maneira, Carlos Costa valorizava o papel da mulher, uma vez que sua ajuda seria primordial nos primeiros momentos.

Em "Máximas e Pensamentos" reproduziam-se frases que refletiam os ideais propagados por A Mãi de Familia; algumas eram anônimas, outras assinadas por reconhecidos escritores e pensadores como Séneca, Michelet, Rousseau, Balzac, Victor Hugo, Locke e Goethe.

A grande arte da educação das crianças consiste em que elas considerem sempre divertimento e prazer o cumprimento de seus deveres.

Locke $^{38}$

De amor a mulher ama um dia, de Maternidade toda a vida...

Michelet

\footnotetext{
${ }^{35}$ A Mãi de Familia, ano 3, n. 19, out. 1881, p. 152.

${ }^{36}$ A Mãi de Familia, ano 1, n. 7, abr. 1879, p. 50.

${ }^{37}$ A Mãi de Familia, ano 3, n. 3, fev. 1881, p. 18.

${ }^{38}$ A Mãi de Familia, ano 1, n. 11, jun. 1879, p. 88.
} 
A Mãe de Família

Haverá no mundo um espetáculo mais tocante, mais sublime, e mais respeitável, que o de uma mãe rodeada de seus filhos, cuidando dos trabalhos domésticos, procurando dar uma vida feliz e tranquila a seu marido, e governando cuidadosamente a sua casa?

J. J. Rousseau

Amor de Mãe!

Oh! amor de mãe! amor que nunca esquece! Pão delicioso que um Deus distribui e multiplica, mesa sempre pronta no paterno lar! em que todos têm o seu quinhão, recebendo partes iguais...

V. Hugo ${ }^{39}$

Dar à luz uma criança, nada é: mas amamentá-la é dar-lhe a vida a cada momento.

H. de Balzac

Os homens superiores são todos os filhos de sua mãe; reproduzem suas impressões morais bem como as suas feições.

Michelet ${ }^{40}$

É muitas vezes com perigo de vida e quase sempre a expensas de sua saúde que a mãe recusa criar seus filho.

[anônima]

Numerosos exemplos provam que uma mulher fraca e delicada fortifica o seu temperamento aleitando.

[anônima $]^{41}$

A valorização do trabalho, da honestidade, da leitura, da educação; a higiene; o amor materno; e a família foram temas presentes em tais máximas. É possível que estas tenham sido extraídas de La Jeune-Mère, jornal que servia de inspiração para A Mãi de Familia. Em 1881, a seção passou a se chamar "Citações", depois "Mosaico" e, por fim, "Máximas Higiênicas".

Traduções de excertos de publicações estrangeiras eram publicadas na seção "Revista dos Jornais Científicos" de A Mãi de Familia. Segundo Carlos Costa, eram transcritos textos de assuntos que ocupariam a mãe de família, ${ }^{42}$ leia-se aqui, temas que ele queria, e estava se esforçando para que fossem apreciados por esse público. Como

\footnotetext{
${ }^{39}$ A Mãi de Familia, ano 2, n. 8, abr. 1880, p. 62. Grifos do original.

${ }^{40}$ A Mãi de Familia, ano 1, n. 13, jul. 1881, p. 103. Grifos do original.

${ }^{41}$ A Mãi de Familia, ano 3, n. 18, set. 1881, p. 141.

${ }^{42}$ A Mãi de Familia, ano 2, n. 4, fev. 1881, p. 31.
} 
exemplos das temáticas expostas, é possível citar a vacina na América, o fumo, os saltos altos, a patinação, o uso do óleo de rícino. Os fragmentos eram extraídos de jornais científicos e de vulgarização, em sua maioria franceses, dentre eles, La Jeune-Mère, Annales d'Hygiène et de Médicine, Lyon Medical, Journal d'Hygiène, Moniteur Therapeutique.

Em 1883, A Mãi de Familia sofreu mudanças. A diagramação passou a ser feita em colunas contínuas, assim, ao acabar um artigo o seguinte continuava na mesma coluna. Antes disso, ao término havia uma ilustração ou um traço horizontal, e abaixo deste iniciava o outro artigo. A formatação das seções também mudou, tornaram-se mais sistematizada. Elas passaram a ser apresentadas sempre na mesma sequência: "Palestra do Médico"; "Medicina" (farmácia, moléstias, o que fazer enquanto o médico não chega); "Higiene" (ar, alimentação, banhos, casamento), "Educação", "Recreio" (pequenas peças teatrais); "Modas"; e "Folhetins Instrutivos", que começava na segunda página e continuava por mais duas ou três. Eventualmente, outras eram inseridas entre elas, como, por exemplo, "Conhecimentos Úteis", "Economia Doméstica", "Bibliografia" (lançamentos de livros), "Petisqueiras" (receitas). Os anúncios continuaram a ser impressos na última página.

No ano seguinte, na página inicial de cada número, começou a ser destacada a periodicidade quinzenal da publicação, a folha sairia nos dias 15 e 30 dos meses, sendo que a partir de então todos os números mostraram a data da publicação. No editorial de abertura deste sexto ano (1884), os editores relembraram e demarcaram o objetivo de $A$ Mãi de Familia, evidenciando-o na primeira página: o "jornal destina-se a representar na família o papel de médico, de mestre e de costureira”. No caso da função de médico, o periódico se dispunha a apresentar quais os cuidados que as mães deveriam ter com relação às moléstias típicas da infância, e, em casos mais sérios, como deveriam agir até a chegada do médico. Enquanto mestre, era expor o que de "mais notável e prático" estabeleciam os educadores modernos e antigos. E, por fim, oferecer moldes para a costura de roupas infantis, a fim de que a mãe pudesse confeccioná-las e assim economizar nos gastos domésticos. ${ }^{43}$ A Mãi de Familia possuía, portanto, um caráter doutrinário, determinando quais conhecimentos as mulheres deveriam ter e como deveriam agir. A publicação pretendia, de fato, estabelecer um novo padrão de

\footnotetext{
${ }^{43}$ A Mãi de Familia, ano 6, n. 1, 15/01/1884, p. 1.
} 
comportamento feminino, por meio de um aburguesamento da mulher e da família, com vias a uma mudança mais ampla da sociedade.

Ainda com relação às divisões internas do jornal, antes da implantação dos folhetins, em 1884, pequenas histórias com mensagens moralizantes foram impressas na seção "Variedade". Da mesma maneira que em um folhetim, a trama desenrolava-se no decorrer de vários números. Posteriormente a seção "Folhetins Instrutivos" passou a ser publicada, indicando que o caráter pedagógico/educativo esteve presente da mesma. Só publicavam-se romances considerados úteis para educar a mulher, por apresentarem orientações de como deveriam se comportar, principalmente enquanto mães, e os conhecimentos que tinham que possuir. Um exemplo foi o folhetim "A hereditariedade na família", que abordou a questão da hereditariedade, em especial com relação às doenças transmissíveis. ${ }^{44}$ A seção "Recreio" oferecia às leitoras pequenas peças teatrais, algumas escritas pelos editores do jornal, sempre de caráter moralizador. Segundo Sônia Camara, essas peças seriam representadas pelas alunas das escolas femininas da Corte:

A idéia formalizou-se a partir da prática de algumas diretoras de encenarem nos colégios, por ocasião dos festejos de final de ano, textos teatrais. O Jornal atuou sobre esta prática, demonstrando a necessidade de uma orientação apropriada e educativa para as meninas, onde fossem enfocadas as virtudes, a modéstia, a piedade e a brandura de gênio como esteios fecundos de formação das novas gerações. $^{45}$

Assim, os princípios defendidos em A Mãi de Familia eram estendidos a uma parcela maior da sociedade, por meio dessas peças teatrais. As estudantes, que porventura não tivessem contato direto com o jornal, poderiam ter acesso aos valores por ele pregados ao encenarem as histórias que lá eram publicadas.

Os assinantes podiam enviar cartas com dúvidas a respeito de assuntos relativos à higiene, moléstias, entre outros assuntos. Em vários momentos o redator reclamou que gostaria de receber algum retorno das leitoras do periódico, a fim de saber se os conselhos emitidos haviam sido úteis nos cuidados com os filhos. Carlos Costa ressaltava que a opinião das mães era sempre "digna de consideração dos homens de ciência”, e que o espaço da publicação estava aberto para que elas expusessem suas

\footnotetext{
${ }^{44}$ A Mãi de Familia, ano 7, n. 15, 15/08/1885, p. 115.

${ }^{45}$ CAMARA, S. O jornal "Mãe de Família"..., p. 9.
} 
opiniões e indagações. ${ }^{46}$ Valorizar as opiniões das mães não significava que aqueles homens de ciências iriam acatar as proposições maternas, mas sim que ajudariam a repensar sobre quais os erros que elas poderiam estar cometendo ao tratar de sua prole.

Uma seção que dediquei atenção pormenorizada foi a "Palestra do Médico", que teve maior periodicidade. Escrita por Carlos Costa, o próprio título já alude às conferências ocorridas na cidade, muitas das quais ele foi preletor.

As preleções públicas mereceram a atenção de A Mãi de Familia. Ao tratar da importância da educação, Costa elogiou a iniciativa particular que criou os "cursos gratuitos, verdadeiramente democráticos, onde o pobre e o rico se confundem para receberem o alimento do espírito". ${ }^{47}$ Entretanto, não encontrei, nas fontes consultadas, nenhum outro espaço em que tenha ocorrido essa mistura de pobres e ricos entre os espectadores. A maioria das conferências tinha como público as camadas mais abastadas da sociedade, sendo que apenas as realizadas nas escolas noturnas traziam uma audiência diferenciada, com pessoas menos favorecidas. Talvez, neste espaço, a plateia fosse mais heterogênea.

O jornal também anunciou e comentou algumas das conferências públicas, como as proferidas por Moncorvo Figueiredo, na Policlínica Geral, e as de Carlos Costa, nas Conferências Populares da Glória. Com relação a estas, a publicação destacou que o médico havia sido convidado pelo senador Correia, idealizador e organizador do evento, e que falaria "com toda franqueza e sem ornatos de retórica", dando a entender que objetivava atingir um público mais amplo. ${ }^{48}$ Ressaltou que o redator do jornal aguardava no auditório uma quantidade significativa de leitoras de A Mãi de Familia. Logo, é possível perceber que Carlos Costa utilizava a tribuna daqueles eventos para propalar as ideias que defendia no periódico.

Ao apresentar a programação das preleções que Costa daria nas Conferências da Glória, o anuncio comprovou que a temática era a mesma que a apresentada em $A$ Mãi de Familia. Na primeira conferência o médico exporia o planejamento das próximas; na segunda os cuidados necessários às crianças ao nascerem (banho, vestuário, leito, cordão umbilical); na terceira, a amamentação (tema que também abordaria nas preleções seguintes). ${ }^{49}$

\footnotetext{
${ }^{46}$ A Mãi de Familia, ano 2, n. 12, jul. 1880, p. 89.

${ }^{47}$ A Mãi de Familia, ano 1, n. 24, dez. 1879, p. 187. Grifos do original.

${ }^{48}$ A Mãi de Familia, ano 9, n. 8, 30/04/1887, p. 58.

${ }^{49}$ A Mãi de Familia, ano 9, n. 10, 31/05/1887, p. 78.
} 
Foram poucas as edições em que Carlos Costa não escreveu a seção "Palestra do Médico”. Após a ausência da seção nos dois primeiros números de 1883, o médico desculpou-se com as leitoras por não tê-la redigido. $\mathrm{O}$ motivo apontado para o afastamento temporário foi devido "aos interesses dos amigos editores e a ocupação muito sérias de nossa parte". ${ }^{50}$ Embora não tenha entrado em detalhes, é possível que tivesse ocorrido algum desentendimento entre o redator e os editores sobre os rumos que a publicação deveria tomar. Todavia, a desavença não acabou com a parceria. Vale marcar que foi justamente neste ano que a folha sofreu mudanças com relação a sua formatação.

A "Palestra do Médico", nas primeiras edições de 1884, não foi assinada pelo redator-principal, e sim pelo médico Pires Almeida. Carlos Costa, então, publicou um artigo justificando a sua ausência.

Pela primeira vez, depois de cinco anos, deixaste de ver o meu humilde nome nos primeiros números deste ano. [...]

Felizmente para os que realmente ouviam ou liam o rabugento, estou aqui firme no meu posto... Aos outros direi somente que... leiam ou ouçam ler... ${ }^{51}$

Agradeceu, por fim, a Pires de Almeida por manter a seção de acordo com a filosofia do jornal.

Entretanto, nos últimos números de 1884 e durante todo o ano de 1885 , ela não foi publicada, regressando apenas em 1886. No artigo de retorno, Carlos Costa pediu desculpas e informou que o afastamento fora causado por "Atribulações diversas". Afirmou que voltava por ter consciência da necessidade de cooperar "na grande obra de regeneração física e moral da sociedade Brasileira", sendo que o jornal contribuía para o bem da nação, que até então era degenerada física e moralmente. ${ }^{52}$

Acerca da proposta de A Mãi de Familia, no seu lançamento, Carlos Costa ressaltou: “dirigiremos as seguintes palavras, que já tendo sido ditas em outro lugar [...] Povo e governos estão intimamente convencidos que do desenvolvimento da instrução depende a grandeza desta terra e a iniciativa particular". ${ }^{53}$ Desta maneira, o que seria

\footnotetext{
${ }^{50}$ A Mãi de Familia, ano 5, n. 3, fev. 1883, p. 17.

${ }^{51}$ A Mãi de Familia, ano 6, n. 4, 29/02/1884, p. 26. Grifo do original.

${ }^{52}$ A Mãi de Familia, ano 8, n. 7, 15/04/1886, p. 49.

${ }^{53}$ A Mãi de Familia, ano 1, n. 1, jan. 1879, p.1.
} 
noticiado pelo jornal fazia parte de um movimento modernizador maior da sociedade, tanto as ideias, quanto a importância da instrução da mulher como meio de promover o progresso do país. A missão de aconselhar só poderia estar a cargo dos médicos, já que lhes fora incumbido "o elevado encargo de cuidar da saúde pública". ${ }^{54}$ Instruir as mães para que elas garantissem o desenvolvimento físico das crianças era encarado como uma questão de saúde pública.

Para o redator, "O higienista é desta maneira tão necessário como o pedagogo para o desenvolvimento da instrução pública, e todo o seu esforço deverá ser empregado em difundir os sãos princípios da higiene". ${ }^{55}$ Nesta concepção, o higienista assumiria na sociedade não só o papel de médico, pensado aqui como aquele que cura as doenças, mas o de educador. Ampliava-se a importância dispensada ao profissional, estendendo assim o seu poder de influência sobre outros setores, ${ }^{56}$ sua função era a de incutir determinados valores por meio da educação, marcada por um vocabulário científico/cientificista. A ação estaria, portanto, respaldada no discurso médico científico que, supostamente, forneceria a credibilidade necessária para que tais preceitos fossem aceitos. Digo supostamente porque, no período em questão, a medicina oficial disputava espaço com outros métodos de cura, sabendo-se que muitos procuravam curadores para tratar de seus males. ${ }^{57}$

Ao enfatizar "os sãos princípios da higiene", duas leituras podem ser feitas. A primeira seria "são" como saudáveis, assim, os temas desenvolvidos estariam pautados em um discurso visto com correto, em oposição ao que não era saudável, isto é, o desviante da normalidade, o incorreto. "São" também poderia significar verdadeiro, então, as proposições apresentadas seriam verdades absolutas que, por isso, deveriam ser aceitas. Em qualquer das interpretações, havia uma valoração positiva, fazendo com que os "princípios da higiene" fossem considerados como indispensáveis e fundamentais para o bom desenvolvimento da sociedade. Cabe marcar que as duas podem ter ocorrido simultaneamente.

\footnotetext{
${ }^{54}$ A Mãi de Familia, ano 1, n. 1, jan. 1879, p.1.

${ }^{55}$ A Mãi de Familia, ano 1, n. 1, jan. 1879, p. 2.

${ }^{56} \mathrm{O}$ século XIX foi marcado pela medicalização da sociedade, processo no qual a "medicina em tudo intervém e começa a não ter mais fronteiras [...] é a descoberta de que, com o objetivo de realizar uma sociedade sadia, a medicina social esteve, desde a sua constituição, ligada ao projeto de transformação deo desviante - sejam quais forem as especificidades que ele apresente - em um ser normatizado". MACHADO, Roberto; LOUREIRO, Angela; LUZ, Rogerio; MURICY, Katia. Danação da norma: a medicina social e constituição da psiquiatria no Brasil. Rio de Janeiro: Edições Graal, 1978, p. 156.

${ }^{57}$ SAMPAIO, Gabriela do Reis. Nas trincheiras da cura: as diferentes medicinas no Rio de Janeiro. Campinas, SP: Editora da Unicamp, CECULT, IFCH, 2001.
} 
Segundo o redator do periódico, os médicos deveriam ser “incansáveis em empregar todos os meios para que sejam vulgarizados todos os conselhos que tiverem por fim mostrar os males que nos cercam para que eles sejam prevenidos antes de remediados". 58 Foi, provavelmente, partindo desse preceito que Carlos Costa proferiu várias conferências nas décadas de 1870 e 1880. Todas tendo o mesmo objetivo do jornal: instruir as mães a cuidar de seus filhos dentro dos ditames da higiene.

A maternidade, na concepção do redator, era a "única" e "sublime" missão confiada às mulheres. $\mathrm{O}$ encargo, entretanto, não era satisfatoriamente cumprido, algumas "por vaidade, outras por pobreza e finalmente muitas por desculpada ignorância", isso porque "lhes faltam conhecimento especiais que antes de tudo lhes deveriam ensinar". Para solucionar o problema que afetaria não só o ambiente privado (a família), mas também o púbico (o progresso do país), Carlos Costa proferiu conferências públicas e fundou A Mãi de Familia, “onde se procurará ensinar tudo quanto se liga à Educação física da criança, mostrar, baseados na experimentação e na prática de todos os homens de ciência". ${ }^{59}$ A educação da mulher era importante para bem criar seu filho, com vias a fazer o país progredir. De acordo com a filosofia do periódico: “A proteção da Infância e A Educação da Família, [eram] bases para o progresso e felicidade de nossa pátria". 60

Carlos Costa sustentava que o país só iria progredir se houvesse uma "completa reforma na direção, moral, intelectual e física da [mulher] brasileira”. Para desenvolver o Brasil era fundamental que se educasse primeiramente a mãe, pois ao educar a sua prole ela promoveria a formação do cidadão que faria o país progredir. ${ }^{61}$ Ele vulgarizava a medicina para as mães abastadas da sociedade - as que assistiam às preleções e as leitoras do jornal - que, por sua vez, deveriam educar as menos favorecidas. Assim, ele seguia a mesma linha de raciocínio do idealizador das Conferências Populares da Glória, Manoel Francisco Correia.

$\mathrm{Na}$ interpretação de Carlos Costa, a educação salvaria o país da degeneração social e moral em que caminhava. Somente quando as mulheres se colocassem "à frente de uma cruzada regeneradora", quando elas atuassem de maneira "patriótica" e se engajassem na educação, principalmente de suas filhas (as futuras mães de família), o

\footnotetext{
${ }^{58}$ A Mãi de Familia, ano 1, n. 1, jan. 1879, p. 2.

${ }^{59}$ A Mãi de Familia, ano 1, n. 1, jan. 1879, p. 2. Grifos do original.

${ }^{60}$ A Mãi de Familia, ano 1, n. 24, dez. 1979, p. 185.

${ }^{61}$ A Mãi de Familia, ano 2, n. 12, jun. 1880, p. 90.
} 
país poderia ser salvo. Ele sublinhou que a educação da menina deveria ser realizada por sua mãe e não por "mãos mercenárias" ou pelos "anti-higiênicos internatos". 62

Vários fatores, segundo o médico, faziam as mães errarem na educação de suas filhas, umas eram muito moças (novas) e incentivavam-nas a ter uma vida social excessiva; outras eram muito velhas e não mais acompanhavam as jovens, deixando-as desprotegidas; algumas eram ignorantes e, fazendo uso dos antigos sistemas de educação, enclausuram suas filhas em casa, obrigando-as a exageradas práticas religiosas; e, por fim, havia as "pobres infelizes", que não sabiam ler e deixavam suas filhas ao "acaso da sorte". 63

Apesar de propalar a necessidade da instrução feminina, o redator não considerava adequado às mulheres um aprofundamento maior do aprendizado. Ao anunciar o recebimento das "tabuadas", organizadas pela professora D. Guilhermina de Azambuja Neves, Carlos Costa enfatizou que não aconselhava às mulheres o estudo das matemáticas superiores, porque elas só precisavam conhecer as quatro operações, a fim de que, como donas de casa, não fossem enganadas pelos comerciantes. ${ }^{64}$

O médico defendeu a necessidade das mulheres se educarem nas ciências (no caso biologia), para que com esse conhecimento fossem mães higienicamente corretas. A aquisição desse saber tinha a função de melhorar a maternidade.

Perguntei: Porque haverá mais interesse em ensinar às meninas os nomes dos astros, a sua rotação, etc., e não os nomes dos órgãos do corpo humano, o seu mecanismo e funções?

Sabendo-se como funciona normalmente o estômago, mais facilmente se compreenderá qualquer alteração e com isto há mais que lucrar uma senhora, uma mãe de família, do que saber as constelações do firmamento, as fases da lua, a passagem dos cometas! $!^{65}$

A despeito de considerar a maternidade como único papel social que a mulher deveria exercer, Carlos Costa não deixou de parabenizar a Dra. Maria Generoso Estrella, brasileira que estudou medicina nos Estados Unidos. Porém, mesmo elogiandoa, frisou que a médica havia abandonado "os prazeres efêmeros da vida, tornou opaco o

\footnotetext{
${ }^{62}$ A Mãi de Familia, ano 2, n. 13, jul. 1880, p. 97.

${ }^{63}$ A Mãi de Familia, ano 2, n. 14, jul. 1880, p. 106.

${ }^{64}$ A Mãi de Familia, ano 3, n. 3, fev. 1881, p. 21.

${ }^{65}$ A Mãi de Familia, ano 4, n. 1, jan. 1882, p. 2.
} 
espelho onde se refletiam os seus encantos femininos". Isto é, ele sugeriu que ela abdicara de ser mulher ao escolher a profissão. ${ }^{66}$

Enfim, A Mãi de Familia tinha o papel de colaborar na educação da mulher, no intento de que ela melhor desempenhasse sua maternidade nos moldes burgueses europeus, já que para a modernização da nação também era necessária uma atuação direta na família. Os artigos que lá eram publicados reforçavam a importância da mulher no lar, sendo este seu locus por natureza. ${ }^{67}$ Contudo, o raio de ação da educação feminina estendia-se além do espaço privado, estaria também no plano da esfera pública, pois a mãe bem instruída poderia bem educar seu filho, que se tornaria um bom cidadão e, desta maneira, contribuiria para o progresso e civilização do país. Embora seu público leitor fosse composto pela elite da Corte, esperava-se que esta levasse o conhecimento adquirido às mães menos favorecidas da sociedade. Ao propor vulgarizar conhecimentos higienistas, A Mãi de Familia se inseria no rol de publicações que tinham como fim vulgarizar a ciência. A peculiaridade desta folha era que a vulgarização estaria direcionada ao público feminino, compreendido como as mães de família.

\section{Mães desnaturadas}

Já nos primeiros números Carlos Costa delineou um tema que permearia todas as edições seguintes: as mulheres que não exerciam adequadamente o papel de mães. Era recorrente descrevê-las como negligentes ao desempenhar o único e natural papel que podiam ter, a maternidade. Para provar que suas atitudes eram erradas, o redator de $A$ Mãi de Familia utilizava, por meio do discurso médico normatizador, argumentos advindos da ciência.

O redator criticava as mães que reclamavam das crianças que estariam interferindo em sua vida social, impedindo-as de sair de casa. Agindo desta maneira, seriam pecadoras e não cumpriam a sublime tarefa que lhes havia sido confiada. Elas não aleitavam sua prole e não as educavam, entregavam esses afazeres a outras mulheres que neste período, via de regra, eram escravas. Suas críticas acentuavam-se

\footnotetext{
${ }^{66}$ A Mãi de Familia, ano 4, n. 23, dez. 1882, p. 178.

${ }^{67}$ BADINTER, Elisabeth. Um amor conquistado: o mito do amor materno. Tradução de Waltensir Dutra. Rio de Janeiro: Nova Fronteira, 1985.
} 
sobre as mulheres que habitavam os centros urbanos, onde tal atitude era mais difundida.

Um artigo de 1879, assinado por uma pessoa que se identificou como "Uma Mãe" que vivia fora da Corte, expunha a opinião da leitora acerca das mulheres desta cidade.

[...] vamos provar neste humilde artigo, ainda mais humilde pelo obscuro nome de sua autora, uma das razões que obrigam-na a conservar o incógnito. Devo porém prevenir as leitoras que é ele escrito por uma mãe de família, cujo berço natal não foi esta cidade. No interior, quando querem dizer que uma moça é muito bem educada, acrescentam a frase: foi educada na Corte. Se as mães provincianas soubessem qual a educação que aqui se dá às moças, preferirão vê-las completamente ignorantes, à conterem tão profundas saudades suas, durante alguns anos, e depois julgando verem-nas um modelo de prendas e virtudes; encontrarem nelas umas bonecas da moda, cheias de defeitos, e absolutamente inúteis dentro de uma casa.

Mas quem é o culpado desta tão defeituosa educação.

São as mães fluminenses. ${ }^{68}$

A autora lançou várias críticas às mães do Rio de Janeiro que, em sua interpretação, não sabiam educar corretamente suas filhas, estando apenas preocupadas com os passeios e eventos sociais. Ela sugeriu que tais mulheres fizessem seus próprios vestidos, ensinando o mesmo as suas filhas. Além de economizarem o dinheiro do marido, isso as deixaria ocupadas e, assim, não iriam a tantos passeios, bailes e teatros. O discurso da leitora se harmonizava ao defendido pelo jornal, em especial por Carlos Costa, inclusive utilizando argumentos idênticos. Por isso, é possível que o texto não tenha sido escrito por uma leitora, mas sim pelo próprio redator do jornal, a fim de mostrar que suas ideias também eram aceitas pelas mulheres.

Em A Mãi de Familia a vida doméstica era valorizada em oposição à vida mundana, a reclusão ao ambiente do lar era vista como benéfica, pois a mulher estaria se dedicando integralmente às tarefas que naturalmente lhe cabiam. Aquelas que devotavam seu tempo às atividades que só a elas interessavam e não trariam benefícios aos filhos e à família estariam abstendo-se da função materna higienicamente correta.

\footnotetext{
${ }^{68}$ A Mãi de Familia, ano 1, n. 24, dez. 1879, p. 190.
} 
Essa atitude fazia com que essas mulheres fossem execradas pela folha, que apresentava os males físicos e morais decorrentes desse comportamento.

O descaso materno prejudicava as crianças, que poderiam até adoecer. Para o médico, já era de se esperar que as crianças em lares pobres sucumbissem mais facilmente às moléstias. Contudo, o que realmente provocava maiores repreensões eram as crianças de famílias abastadas que adoeciam porque as mães deixavam a cargo das criadas a criação dos filhos. Novamente Carlos Costa censurou a atitude, descrevendo as criadas como descuidadas e displicentes.

A fala era constantemente enfática, e mostrava inclusive, que em muitos casos, a consequência do desleixo materno poderia ser fatal. Pretendia-se, por meio de um discurso que provocava pânico, deixar as mães alertas para o problema. Ao abordar as infecções de garganta, Carlos Costa enfatizou: "As anginas ulcerosas e gangrenosas, são gravíssimas, sendo raras as crianças que escapam". ${ }^{69}$ A escolha dos brinquedos das crianças também deveria ser feita de maneira consciente, aproveitando "o que nos ensina a ciência". De acordo com o redator, a química mostrava que alguns corantes utilizados na confecção dos brinquedos eram "extremamente venenosos". Então, a mãe, zelosa e conhecedora deste saber científico, não deveria deixar seus filhos tomarem contato com aqueles objetos, uma vez que poderiam colocá-los na boca, o que poderia provocar "até a morte" do infante. ${ }^{70}$

A fim de enfatizar a necessidade de sempre se recorrer a um médico, o redator, dando maior dramaticidade ao seu argumento, afirmou que alguns erros cometidos pelas mães poderiam colocar em risco a vida das crianças. Não descartava a possibilidade de equívocos médicos, porém sublinhava que eles eram maiores com os "profanos".71 Chamar os não médicos de profanos situava os esculápios numa esfera sublime, sagrada, quase como representantes divinos, sendo, desta maneira, considerados como infalíveis e corretos por sua natureza sacra.

Em contraposição, a boa mãe era a que relegava a vida mundana para se dedicar exclusivamente à criação dos filhos, seguindo, para isso, os conselhos ditados pela ciência médica higiênica. A defesa do enclausuramento materno norteou a obra Emilio de Rousseau, em 1762. ${ }^{72}$ Elisabeth Badinter afirma que no ideal feminino sustentado pelo iluminista francês, o sacrifício e a reclusão serviriam para salvar a mãe, como uma

\footnotetext{
${ }^{69}$ A Mãi de Familia, ano 3, n. 3, fev. 1881, p. 19. Grifos do original.

${ }^{70}$ A Mãi de Familia, n. 7, abr. 1879, p. 52. Grifos do original.

${ }^{71}$ A Mãi de Familia, ano 1, n. 1, jan. 1879, p. 6. Grifo do original.

${ }^{72}$ BADINTER, E. Um amor conquistado...
} 
religiosa em seu claustro. ${ }^{73}$ Não posso afirmar que Carlos Costa tenha lido este livro, mas certamente teve contato com suas ideias por meio do jornal La Jeune-Mère, onde eram publicados trechos de Rousseau. ${ }^{74}$ Vale relembrar, que algumas máximas do iluminista francês também foram impressas em A Mãi de Familia.

A moda era outro hábito que as mulheres teriam que abdicar, para de fato serem mães exemplares. $\mathrm{O}$ uso do colete era apontado como deformador das mamas, impedindo a secreção do leite. De acordo com o médico, a utilização do espartilho durante a gravidez e a amamentação provocaria o corrimento anormal de leite na lactante. Essas mulheres "não tiveram certos cuidados higiênicos", por preferirem a vida das festas, bailes e teatros. ${ }^{75}$

A vida na cidade, apesar de civilizada, era recorrentemente criticada. Um dos danos que o ritmo citadino poderia acarretar era a precoce menarca. Isso ocorreria devido ao modo de viver das moças nos centros urbanos, que era mais agitado: "Nas cidades a menstruação se faz geralmente mais cedo do que no campo, em razão da vida pouco regular, das excitações de toda a sorte porque passa o sistema nervoso das moças. " ${ }^{, 76}$ Fabíola Rohden, ao analisar teses médicas do século XIX, verificou que era recorrente relacionar a chegada prematura da primeira menstruação com a "voluptuosidade característica dos romances, pinturas, bailes, teatros e da mistura contínua entre os sexos que identifica as cidades populosas”, já as moças que viviam no campo tinham seu ritmo ditado pela natureza. ${ }^{77}$

Outro fator que levaria à antecipação da menarca seria a hereditariedade. De acordo com Carlos Costa, havia "famílias em que as meninas se tornam mulheres muito cedo e vice-versa". ${ }^{78}$ Por meio desta observação é possível notar o peso que o médico dava à questão da hereditariedade. Entretanto, ele destacou que fatores externos, como a educação, poderiam ser determinantes, sendo, então, possível se evitar esse adiantamento. Por conseguinte, o contrário deveria ser feito caso a primeira menstruação demorasse a vir, a menina deveria ser estimulada para resolver este problema.

\footnotetext{
${ }^{73}$ BADINTER, E. Um amor conquistado...

${ }^{74}$ TURACK, C. F. Mulheres-mãe...

${ }^{75}$ A Mãi de Familia, ano 1, n. 17, set. 1879, p. 131.

${ }^{76}$ A Mãi de Familia, ano 2, n. 21, nov. 1880, p. 161. Grifo do original.

${ }^{77}$ ROHDEN, Fabíola. Uma ciência da diferença: sexo e gênero na medicina da mulher. Rio de Janeiro: Editora Fiocruz, 2001, p. 127.

${ }^{78}$ A Mãi de Familia, ano 2, n. 21, nov. 1880, p. 161. Grifos do original.
} 
Discussões sobre a puberdade e a menstruação eram importantes porque a partir delas a menina se tornava mulher, ou seja, apta para ser mãe. Muitas teses de medicina foram produzidas sobre o momento em que o corpo da menina passava por transformações, diferindo a partir de então dos meninos. Contudo, nada foi dito acerca dos meninos, que só passavam por mudanças cerebrais, exceto para aqueles casos considerados desviantes da normalidade, como o onanismo e o homossexualismo. ${ }^{79}$

Apesar de a menarca ser o momento em que a menina entra para o mundo fértil, Carlos Costa não aconselhava que a mulher se tornasse mãe muito cedo, por não possuir maturidade suficiente. Esta opinião era compartilhada por vários médicos, sendo tema recorrente nas teses das faculdades de medicina do Brasil. ${ }^{80}$ Ao analisar teses médicas que abordavam a mulher, Ana Paula Vosne Martins verificou que a maioria delas, além da justificativa científica, ressaltava que estudavam a mulher por ser um tema com "desdobramento sociais importantes devido ao papel desta como reprodutora e educadora dos filhos e futuros cidadãos". ${ }^{81}$ Justificativa semelhante à de Carlos Costa ao escrever seus artigos na Mãi de Familia e ao proferir suas conferências públicas.

Já a menopausa não recebeu igual atenção dos médicos. Martins sustenta que o desinteresse se deve ao fato dos médicos se preocuparem apenas pelo período em que a mulher exercia a sua função reprodutiva, podendo, a partir do término desta, ser comparada a um homem. ${ }^{82}$ A primeira menção feita em A Mãi de Familia ocorreu em 1881:

Chama-se menopausa a cessação da menstruação. A época deste fenômeno natural, fisiológico constitui sem dúvida uma idade crítica para a mulher. Com muitos autores diremos que é a ocasião em que mulher cessa de viver, ou melhor, que é a época em que mulher deixa de ser mulher.

\footnotetext{
${ }^{79}$ MARTINS, Ana Paula Vosne. Visões do feminino: a medicina da mulher nos séculos XIX e XX. Rio de Janeiro: Editora Fiocruz, 2004. Os casos desviantes femininos também foram alvos dos médicos. Magali Engel destaca que as análises sobre a prostituição e a prostituta, que representava a sexualidade doente, o par oposto da esposa/mãe, que era a sexualidade sadia. ENGEL, Magali. Meretrizes e doutores: saber médico e prostituição no Rio de Janeiro (1840-1890). São Paulo: Brasiliense, 2004, p. 78.

${ }^{80}$ Martins assevera que Adam Raciborski foi um dos autores mais citados nas teses médicas brasileiras. Professor da Faculdade de Medicina de Paris, Raciborski escreveu, em 1868, um famoso tratado sobre a menstruação em que se apresentava contrário aos casamentos precoces. Com relação à menarca, o médico, embora não tenha estipulado uma idade fixa, ressaltou que vários fatores influenciavam, como "o clima, a temperatura média, a posição social e a raça”. MARTINS, A. P. V. Visões do feminino..., p. 164. ${ }^{81}$ MARTINS, A. P. V. Visões do feminino..., p. 155.

${ }^{82}$ Raciborski sugeria que as mulheres nessa fase se dedicassem a obras de caridade e beneficentes, a fim de empregarem o tempo disponível. MARTINS, A. P. V. Visões do feminino..., p. 168.
} 
Compreendendo que o principal papel da mulher no mundo é o da fecundação, desde que ela atinja a idade, em que a concepção não é mais possível, deixa ela de ser útil, começa a morrer, bem entendido para o fisiologista.

Ouço desde já os protestos que farão as santas avozinhas, essas verdadeiras segundas mães, ou mães duas vezes. Mas não me refiro ao moral das mulheres, não!... Bem sei que mulher mesmo na mais avançada idade é sempre a mesma carinhosa companheira do homem. Se ela não desperta mais esse sentimento indizível que chamamos amor, procura outro mais doce e mais respeitoso, se é possível dizer. ${ }^{83}$

A mulher só era considerada "plenamente mulher" enquanto durasse seu período de fertilidade, enquanto pudesse ser mãe ainda teria utilidade. Carlos Costa, já supondo as críticas que poderia receber, tentou escusar-se indicando qualidades que a mulher passava a ter com a idade mais avançada. Todavia, as suas características mais sublimes, estas ela só possuía durante a sua vida fértil. Segundo Martins, nas teses de medicina a menopausa era descrita como um período de "tranqüilidade e sabedoria". ${ }^{84}$ A descrição se aproxima à do redator do jornal, na qual ressaltou que apesar de não ter os mesmos atrativos físicos capazes de despertar o desejo, referenciado como amor, a mulher provocava outro sentimento "mais doce e mais respeitoso", ou seja, algo mais tranquilo.

Embora tenha dedicado alguma atenção ao período da menopausa, o tema não mereceu tanto destaque, análise, muito menos recorrência em várias edições. Tratava-se do momento em que a mulher não poderia mais exercer a maternidade, finalidade essencial de sua vida. Portanto, era como uma morte simbólica inevitável e, por isso, não carecia de extensas e profundas reflexões.

Não seguir os conselhos estipulados pela medicina higiênica e não consultar os doutores preferencialmente eram outros motivos para desqualificar as mães. Carlos Costa recriminou as muitas mulheres "inteligentes e bem educadas" que procuravam os conselhos das comadres e dos curandeiros. ${ }^{85}$ Chamá-las dessa maneira pode ter sido um artifício de retórica, uma vez que ele tinha consciência a quem se destinava a publicação - à parca elite letrada da sociedade. Mesmo culpando-as por buscarem tais métodos de

\footnotetext{
${ }^{83}$ A Mãi de Familia, ano 3, n. 11, jun. 1881, p. 81. Grifos do original.

${ }^{84}$ MARTINS, A. P. V. Visões do feminino..., p. 168.

${ }^{85}$ A Mãi de Familia, ano 1, n. 1, jan. 1879, p. 7.
} 
cura, ele não podia simplesmente achincalhá-las, pois isso poderia gerar um repúdio ao jornal e aos discursos por ele proferidos. O uso dos adjetivos também serviria para mostrar que não eram apenas as mulheres pobres que recorriam aos charlatães, mas as que vinham de famílias mais abastadas.

Charlatães eram como os médicos pejorativamente designavam todos os outros que se dedicavam a curar as pessoas:

\begin{abstract}
Assim, curandeiros, espíritas, sangradores, parteiras, ervateiros, farmacêuticos que produziam remédios e não revelavam suas fórmulas, enfim, qualquer diferente era igualmente um perverso charlatão, que agia sempre de má-fé, enganando as pessoas para enriquecer chegando a matá-las. ${ }^{86}$
\end{abstract}

No intuito de provocar temor na população, para desqualificá-los, seus erros eram apontados. Gabriela dos Reis Sampaio afirma que na década de 1880 foi intensificada a perseguição aos curandeiros e acentuadas as discussões acerca da necessidade de se criar uma legislação para a prática da medicina (que só seria instituída na República). Os periódicos da época frequentemente divulgavam artigos mostrando os erros cometidos, bem como denunciando aqueles que estavam praticando a cura ilegal. Era usual as notícias a respeito virem com a seguinte chamada: "Curandeiros" ou "Exercício ilegal da medicina". 87

Naquele momento havia uma disputa pelo legítimo direito de cura, que na visão da categoria médica caberia a si. Entretanto, junto aos próprios esculápios existiam divergências entre o que seria a prática de medicina legalmente adequada. Por exemplo, a homeopatia era exercida por muitos médicos e recriminada por outros. Para os alopatas era complicado qualificar os homeopatas de charlatães, porque eram adversários que também faziam uso do discurso científico para sustentar seus argumentos. Além desta contenda, os próprios médicos denunciavam erros cometidos por outros colegas de profissão. Publicavam as acusações e as defesas na imprensa, os envolvidos não dispensavam os detalhes, sendo os desaforos também expostos. Cirurgias mal sucedidas, procedimentos inadequados e mesmo acusações de provocar a morte de pacientes eram discutidos publicamente. ${ }^{88}$

\footnotetext{
${ }^{86}$ SAMPAIO, G. dos R. Nas trincheiras da cura..., p. 53.

${ }^{87}$ SAMPAIO, G. dos R. Nas trincheiras da cura...

${ }^{88}$ SAMPAIO, G. dos R. Nas trincheiras da cura...
} 
Carlos Costa, inserido nessa luta pela defesa da medicina científica como prática legítima de cura, usou o espaço do jornal, e provavelmente das conferências, para advogar em favor da medicina como única atividade de cura. $\mathrm{O}$ redator de $A$ Mãi de Familia evidenciou os perigos que os curandeiros poderiam causar para a sociedade. Em sua visão, os que procuravam os charlatães seriam ignorantes e possuíam devoção cega. Vale destacar que representantes das várias parcelas da sociedade buscavam a ajuda desses curandeiros.

É igualmente sabido que para os lados de Niterói existe um caboclo, que afronta todas as leis de nossas corporações sanitárias, e a torto e a direito, receita para uma infinidade de beócios e fanáticos que lá vão, a despeito de todos os incômodos e sacrifícios buscar ilusório alívio a seus sofrimentos.

Também se encontra, em diferentes épocas aqui, nas barbas da polícia, outros índios que trazem sacos às costas, contendo quanta bugiganga inventam, com que iludem aos papalvos, vendendo-as como substâncias de propriedades miraculosas.

Para os lados da freguesia da Lagoa tivemos muitas ocasiões de pedir o auxílio da polícia, contra estes charlatães ambulantes, que poderão ou já terão sido causa de muitas desgraças. O mesmo já fizemos na cidade. Mas a impunidade para ele e para muitos outros de outra espécie que existem até no seio das famílias é sabida e já que o castigo tarda a vir dos poderes competentes, sois vós mães de família, que deveis infligi-lo, desprezando os pedantes e os conselhos até das comadres mexeriqueiras e procurando as sempre prudentes admoestações dos homens de ciência.

Quantas vezes não tereis ouvido com os corações angustiados, em presença dos sofrimentos de vossos filhinhos, as extravagantes receitas de um sem número de beatas curandeiras?! [...]

Será preciso lembrar essas tolas expressões: seu filho, minha senhora, tem com certeza quebranto, a senhora deve mandá-lo benzer?! Etc., etc. Estes preconceitos impróprios de uma época que se diz de progresso e de adiantamento, são na maior parte das vezes, causas de agravação dos sofrimentos, que terminam pela 
incurabilidade de moléstias que discretamente medicadas teriam melhor resultado. ${ }^{89}$

A referida corporação sanitária era a Junta Central de Higiene Pública. Órgão formado por médicos, vinculado à política higienista do Império, a Junta foi instituída para melhorar as condições sanitárias da cidade do Rio de Janeiro e de outras regiões do país, centralizando as determinações acerca da saúde pública. Orientava as autoridades nas medidas que deveriam ser tomadas em situações de epidemia, regulamentava e fiscalizava o mercado de medicamentos. A Junta servia para assegurar o monopólio terapêutico dos médicos. ${ }^{90}$ Algo que na prática não foi alcançado, como mostra o caso do citado curandeiro de Niterói, que afrontava as determinações da Junta justamente por vender substâncias curativas que não haviam sido autorizadas, referidas como "bugiganga" - palavra que foi diferenciada no texto a fim de ridicularizar o remédio prescrito.

É possível que o supracitado caboclo de Niterói seja o mesmo que, durante vários meses de 1888, viria a ocupar as páginas das gazetas da Corte. Lanço essa hipótese porque além de ambos serem da mesma cidade, tratavam seus pacientes com muitas ervas, modo de cura considerado semelhante ao utilizado pelos índios, sendo por isso chamados de caboclos. O curandeiro de Niterói, que recebeu inúmeras e severas críticas na imprensa no decorrer de 1888, era Eduardo David Reys, conhecido como Marius. Segundo Sampaio, os métodos utilizados por ele "eram comparados aos de antigos 'curandeiros-caboclos', famosos por seu conhecimento de plantas medicinais". 91 Marius, extremamente procurado, atendia a pessoas de diversas camadas da sociedade, inclusive aquelas mais abastados, que iam atrás de suas milagrosas curas.

A dificuldade em punir os charlatães foi ressaltada pelo redator do jornal, ao sublinhar que muitas vezes eles agiam sob o olhar da polícia. Essa impunidade pode justamente ter sido consequência do público diversificado que atendiam, o qual incluía pessoas ilustres da sociedade, por exemplo, contando com a presença de autoridades e políticos, com cabedal para ajudar os curandeiros a exercerem suas terapias livremente.

\footnotetext{
${ }^{89}$ A Mãi de Familia, ano 1, n. 1, jan. 1879, p. 6. Grifos do original.

${ }^{90}$ A Junta de Higiene Pública foi criada em 1850, mas só teve suas atribuições detalhadamente descritas no regulamento que passaria a valer no ano seguinte, quando o órgão passou a se chamar Junta Central de Higiene Pública. Para cumprir com suas atribuições, contava com seus delegados, autoridades judiciárias e policiais, além dos fiscais da Câmara Municipal. PIMENTA, Tânia Salgado. Os exercícios das artes de curar no Rio de Janeiro (1828-1855). Tese (Doutorado em História) - Universidade Estadual de Campinas, Campinas, 2003. Em 1881, a Junta foi substituída pela Inspetoria Geral de Higiene Pública.

${ }^{91}$ SAMPAIO, G. dos R. Nas trincheiras da cura..., p. 23.
} 
O comparecimento dessas pessoas poderia dar maior credibilidade ao curandeiro, contribuindo para atrair mais clientes. A existência de tantos outros curadores pela cidade indica que eles tinham público suficiente para isso, ou seja, uma clientela formada por sujeitos que não confiavam plenamente nos métodos e procedimentos utilizados pela medicina científica, ou que não obtiveram êxito ao buscar esse sistema de cura.

Carlos Costa, ao chamar os clientes do curandeiro de "beócios e fanáticos" e "papalvos", classificou os que iam buscar tal tipo de ajuda como ignorantes, que possuíam fé cega. Portanto, não eram pessoas esclarecidas que seguiam ditames da medicina científica. O médico gostaria que suas leitoras, as quais provavelmente procuravam os métodos terapêuticos, se instruíssem na ciência e buscassem apenas ajuda na medicina para curar seus males. Para o médico, cabia às mães afastar os charlatães do seio familiar. Elas deveriam procurar "sempre as prudentes admoestações dos homens da ciência". Destacar a palavra "sempre" servia para enfatizar que, em hipótese alguma, elas deixassem de procurar o médico científico, mesmo se os métodos e procedimentos utilizados pela medicina oficial não parecessem extremamente confiáveis. A palavra máxima, única e verdadeira só poderia ser dada pelos homens da ciência, neste caso, os médicos.

Carlos Costa também alertava para o perigo das "comadres mexeriqueis", as "beatas curandeiras", que da mesma maneira deviam ser evitadas pelas mães de família realmente zelosas. Elas indicavam rezas para sanar males físicos, para doenças que poderiam ser curadas por meio de medicamentos.

Os curandeiros, além de tratarem de problemas do corpo também medicavam os da alma, sendo que muitas vezes as causas dos primeiros eram consideradas como provenientes de questões espirituais. ${ }^{92}$ Todas as recomendações de Carlos Costa poderiam estar fundamentadas no fato de muitas mulheres procurarem curandeiros para solucionar seus problemas físicos e espirituais. Eles, frequentemente, eram considerados por seus pacientes como feiticeiros e milagreiros. Para vários curandeiros a prática de cura não estava dissociada das atividades de magia.

Ao escrever daquela maneira, o redator de $A$ Mãi de Familia podia estar se referindo ao caso do renomado curandeiro Juca Rosa, que fora preso e condenado por estelionato em 1871. A prisão e o julgamento de Rosa tiveram ampla repercussão na

\footnotetext{
92 SAMPAIO, Gabriela dos Reis. Juca Rosa: um pai-de-santo na Corte imperial. Rio de Janeiro: Arquivo Nacional, 2009.
} 
imprensa. Apesar de ter sido acusado pelo referido crime, o processo se desenrolou indicando que a questão fundamental eram suas práticas de cura e o modo como as desenvolvia, envolvendo inclusive prostituição. ${ }^{93}$ Discutia-se seu envolvimento sexual e espiritual com as muitas mulheres que iam procurá-lo (as quais compunham a maioria de seus pacientes). Interessante ressaltar o alto preço que pagavam pela consulta, chegando a ser equivalente ao de uma com um médico diplomado. ${ }^{94}$ Portanto, não eram questões econômicas que levavam as mulheres a buscar o auxílio desses curadores, mas sim a crença de poder sarar seus males, fossem eles físicos ou espirituais. Isto, de certo, causava ainda mais preocupação em Carlos Costa, pois ele teria que ser muito mais contundente ao incutir na mente daquelas mulheres que procurar um médico era a melhor solução.

Costa incentivou a presença do médico ou de uma "parteira digna deste nome" (legalmente habilitada) durante os partos, repudiando a presença das "comadres", consideradas prejudiciais. ${ }^{95}$ Tânia Pimenta argumenta que as parteiras, embora também desqualificadas, eram encaradas pelos médicos de maneira diferente que os curandeiros (que representavam a concorrência). Elas eram criticadas por não chamarem os médicos em partos difíceis e por receitarem remédios, ultrapassando os limites de suas atividades. As parteiras legalmente reconhecidas deveriam ser subalternas ao médico, apenas prestando-lhe ajuda, o que não ocorria no cotidiano da cidade. ${ }^{96} \mathrm{Na}$ prática, elas desempenhavam outras atividades além de partejar, muitas das quais teoricamente caberia apenas aos médicos. Ao analisar artigos e anúncios publicados na imprensa das cidades de São Paulo e Rio de Janeiro, entre 1830 e 1930, Maria Lucia Mott detectou seis grandes grupos de atividades desenvolvidas pelas parteiras:

\footnotetext{
${ }^{93}$ O Código Criminal do Império não enquadrava como crime o culto de outras religiões que não a católica, desde que fosse limitado ao espaço privado sem nada no exterior que denotasse um templo. Entretanto, a lei protegia apenas os cultos dos não-católicos europeus, os de matriz africana ficavam numa "espécie de limbo jurídico", eram muitas vezes considerados superstições ou feitiçarias - que também não eram criminalizadas pelo Código. Então, utilizavam-se outros meios para deter criminalmente os feiticeiros. Ao analisar o caso de Domingos Sodré, feiticeiro africano vivente na Bahia da segunda metade do século XIX, João José Reis afirmou que muitos eram presos porque os cultos perturbavam o sossego público, mas este não fora o caso de Sodré, que "Teria, então, que ser investigado e punido por outro delito, e o foi por suspeita de receptação de objetos roubados, ou estelionato, que era crime em geral imputado aos pais-de-santo quando as autoridades daquele Brasil decidiam tirá-los de circulação.” REIS, João José. Domingos Sodré, um sacerdote africano: escravidão, liberdade e candomblé na Bahia do século XIX. São Paulo: Companhia das letras, 2008, p. 142 e 144.

${ }^{94}$ SAMPAIO, G. dos R. Juca Rosa...

${ }^{95}$ A Mãi de Familia, ano 3, n. 6, mar. 1881, p. 41. Grifos do original.

${ }^{96}$ PIMENTA, T. S. Os exercícios das artes de curar...
} 
1. voltadas para a saúde da mãe e do recém-nascido (gravidez, parto, puerpério, tratamento do umbigo); 2. em torno da vida sexual e reprodutiva das mulheres (contracepção, aborto, infertilidade, reconstituição de virgindade); 3. tratamento ginecológico ("doenças de senhoras"); 4. alojamento e tratamento de parturientes e doentes; 5 . comerciais (aluguel de amas-de-leite); e 6. De "redistribuição" de recém-nascidos, atividade nem sempre dentro da legalidade. ${ }^{97}$

Segundo Mott, no século XIX, o parto era um acontecimento vivido entre mulheres - parentes, vizinhas e amigas. A presença masculina era rara: apenas em caso de partos complicados chamava-se o médico. "Comadre" era como as mulheres se referiam às parteiras, de acordo com a autora, "palavra que demonstra afetividade e respeito, evidência do vínculo entre quem assiste e quem é assistida". ${ }^{98}$

Com a chegada da família real no Brasil, as parteiras locais passaram a ter concorrência das profissionais diplomadas, principalmente estrangeiras. Com a fundação da Faculdade de Medicina, os médicos começaram a normatizar a arte de partejar, estipulando regras e condutas a serem tomadas. Em 1832 foi criado o curso de partos na instituição, entretanto, poucas mulheres se matricularam durante todo o período imperial. As parteiras diplomadas divulgavam seus serviços em folhetos distribuídos nas ruas e em anúncios de jornal. ${ }^{99}$ Cabe ressaltar que entre as próprias parteiras havia disputa, as diplomadas muitas vezes denunciavam aquelas que atuavam sem possuir a qualificação legalmente exigida. ${ }^{100}$

Poucas mulheres recorriam aos médicos na hora do parto. Ao ensinar os primeiros procedimentos a serem tomados durante a parturição, Carlos Costa destacou que as mulheres mais pobres poderiam ir ao Hospital da Santa Casa. A utilização da instituição hospitalar só serviria em última instância, no caso de uma mulher muito pobre, embora ele afirmasse que lá a parturiente contaria com "hábeis médicos e professores". 101

Desde 1847 havia uma enfermaria de partos para atender às mulheres carentes na Santa Casa. Todavia, conforme afirma Martins, os provedores e as irmãs de caridade

\footnotetext{
${ }^{97}$ MOTT, Maria Lucia. Parteiras: o outro lado da profissão. Gênero, Niterói, RJ, v. 6, n. 1, p. 117-140, 2 sem. 2005, p. 126.

${ }^{98}$ MOTT, M. L. Parteiras: o outro lado da profissão..., p. 119.

${ }^{99}$ MOTT, M. L. Parteiras: o outro lado da profissão...

100 PIMENTA, T. S. Os exercícios das artes de curar... MOTT, M. L. Parteiras: o outro lado da profissão...

${ }^{101}$ A Mãi de Familia, ano 3, n. 6, mar. 1881, p. 42.
} 
impuseram impedimentos aos alunos de medicina para terem aulas práticas no local, principalmente no tocante à moralidade. A entrada de homens nas áreas femininas era vista como um problema que afetava os princípios morais da época. Outro motivo, apontado pela pesquisadora, estava no temor das irmãs de que o estabelecimento estimulasse a maternidade fora do matrimônio. A Reforma Sabóia, de 1882, que reestruturou o ensino de medicina no Brasil, ampliou a grade de disciplinas clínicas que os estudantes deveriam cursar, dentre as quais estavam a de obstetrícia e ginecologia. As aulas práticas, entretanto, não começaram imediatamente na Santa Casa devido às instalações precárias. Martins assevera que a exposição aos alunos de medicina e as condições péssimas colaboraram para que as mulheres optassem por não dar à luz no hospital, ficando a instituição como alternativa apenas para as desvalidas. ${ }^{102}$

Para ser uma boa mãe e conseguir cumprir seus deveres estabelecidos pela natureza, a mulher deveria seguir os preceitos da higiene. Segundo Carlos Costa, o higienista exerceria na sociedade um papel semelhante ao do pedagogo: "O higienista é desta maneira tão necessário como o pedagogo para o desenvolvimento da instrução pública." ${ }^{\prime 103}$ A mãe era representada como a principal aliada do médico no processo de implantação de uma maternidade higiênica. Muitas vezes ele sinalizou para o fato de que tudo que poderia acontecer de ruim à criança era culpa da mãe, que não utilizava os preceitos da higiene médica moderna. Portanto, ao mesmo tempo em que valorizava a mulher, como a responsável pela educação das crianças, aquela que agiria nos primeiros socorros até a chegada do médico, Carlos Costa representava-a como a desprovida de conhecimentos, a displicente e irresponsável.

De acordo com o médico, era necessário criar uma lei que obrigasse a população a "cuidar da própria saúde". ${ }^{104}$ A lei provavelmente seria formulada pelos higienistas, que a instituiria seguindo os preceitos da medicina higiênica. A proposta de Carlos Costa indica como já se pensava em exercer medidas coercitivas legais sobre os corpos, as mulheres seriam coagidas legalmente a agir de determinada maneira com relação a sua saúde e ao trato com seus filhos.

Ainda com relação às políticas higienistas, destacou que, por "uma manifesta desconfiança das nossas Instituições sanitárias oficiais”, foi criada, na escola municipal de S. José, por iniciativa particular a "Associação do Saneamento da Capital do

\footnotetext{
${ }^{102}$ MARTINS, A. P. Vosne. Visões do feminino...

${ }^{103}$ A Mãi de Familia, ano 1, n. 1, jan. 1879, p. 2.

${ }^{104}$ A Mãi de Familia, ano 2, n. 1, jan. 1880, p. 2.
} 
Império". ${ }^{105} \mathrm{O}$ fato de a Associação ser uma iniciativa particular mostra como a sociedade civil atuou em vários pontos na educação higiênica, promovendo conferências, criando associações dedicadas à área da saúde. Cabe sublinhar que algumas sessões da agremiação ocorreram em uma sala cedida pela Escola Politécnica. Contudo, sua atuação durou pouco tempo. É possível, com isso, verificar como a população não confiava na medicina, mesmo quando esta tentava se firmar como oficial.

Também o casamento estaria sob o olhar e supervisão do médico, que daria ou não o aval para a realização do mesmo. ${ }^{106}$ Neste sentido, a proposta de Carlos Costa estaria dentro do que posteriormente se chamou de eugenia. $\mathrm{O}$ vocábulo eugenia foi cunhado, em 1883, pelo britânico Francis Galton (1822-1911) para designar a ciência que se preocupava com o aperfeiçoamento da humanidade por meio das leis da hereditariedade. ${ }^{107}$ Para além do aspecto científico, a eugenia também se caracterizou por ser um movimento social, com projetos que estimulavam a reprodução dos indivíduos considerados adequados e desestimulavam a dos inadequados. ${ }^{108} \mathrm{O}$ controle reprodutivo da população foi centro de interesse dos eugenistas, sendo que a boa condição física e mental dos futuros genitores era considerada de suma importância. ${ }^{109}$ Para tal, debateram-se estratégias políticas de controle sobre o casamento, e propostas foram levadas para discussão no Congresso Nacional a fim de que se tornassem lei, o que não ocorreu. ${ }^{110}$

Carlos Costa não pode ser considerado eugenista, uma vez que este movimento se estruturou apenas no início do século XX e caracterizou-se pela implantação de

\footnotetext{
${ }^{105}$ A Mãi de Familia, ano 2, n. 1, jan. 1880, p. 2.

${ }^{106}$ Conforme afirma Jurandir Freire Costa, "No casamento idealmente concebido pela higiene o casal olhava o futuro e não o passado. Seu compromisso era com os filhos e não com os pais. A escolha do cônjuge estava manietada a esta proposição. O cuidado com a prole converteu-se, por esta via, no grande paradigma da união conjugal." COSTA, Jurandir Freire. Ordem médica e norma familiar. 5 ed. Rio de Janeiro: Edições Graal, 2004, p. 219.

107 Além de criar o termo eugenia, Francis Galton, segundo Stephen Jay Gould, foi o "pioneiro da moderna estatística [...] A quantificação era o deus de Galton, e à sua direita estava a firme convicção de que quase tudo que podia medir tinha um caráter hereditário. Acreditava que até mesmo os comportamentos mais inseridos no contexto social possuíam fortes componentes inatos". GOULD, Stephen Jay. A falsa medida do homem. Tradução de Valter Lellis Siqueira. 2 ed. São Paulo: Martins Fontes, 1999, p. 67 e 68.

${ }^{108}$ STEPAN, Nancy Leys. A hora da eugenia: raça, gênero e nação na América Latina. Rio de Janeiro: Editora Fiocruz, 2005.

${ }^{109}$ MASIERO, André Luís. A psicologia racial no Brasil (1918-1929). Estudos de Psicologia, Natal, v. 10, n. 2, p. 199-206, 2005.

${ }^{110}$ CASTAÑEDA, Luzia Aurelia. Eugenia e casamento. História, Ciências, Saúde - Manguinhos, Rio de Janeiro, v. 10, n. 3, p. 901-930, 2003.
} 
políticas sociais. Entretanto, suas proposições se enquadravam ao que seria posteriormente sustentado por muitos eugenistas:

A jovem mulher sente em breve a necessidade de amar. Eis o momento em que a mãe e o médico precisam ligar-se para que a consequência dessa atração inevitável dos dois sexos não tenha funestas consequências tantas vezes lamentadas.

\section{$[\ldots]$}

[Antigamente] A voz do médico era ouvida como uma sentença irrevogável e o casamento não se fazia ou quando fosse já tarde para evitar a ligação de duas almas que já se entendiam, então não lhes cabendo assim mais a responsabilidade, tinham de assistir ao triste espetáculo de uma gravidez horrível, de sofrimentos e de partos dificílimos e perigosos, que acarretariam a morte da mãe ou da criança. ${ }^{111}$

A mãe da jovem moça era a responsável por pedir auxílio ao médico, que determinaria se o casamento era possível ou não. A palavra final seria do médico, mas a responsabilidade para tal seria da mãe.

Carlos Costa evidenciou seu posicionamento contrário aos matrimônios consanguíneos, apoiando seus argumentos em De Maistre: "Nas nações degeneradas que se esqueceram, até permitir o casamento entre irmãos, essas uniões produziram monstros."112 A degeneração era o motivo pelo qual o médico se opunha a tais uniões. ${ }^{113}$ Segundo ele, esses tipos de núpcias teriam como frutos crianças monstruosas ou com doenças graves.

É provável que ele tenha feito tal observação porque era comum entre a elite o matrimônio entre membros da mesma família a fim de preservar a fortuna dentro de um

\footnotetext{
${ }^{111}$ A Mãi de Familia, ano 3, n. 1, jan. 1881, p. 2. Grifos do original.

${ }_{112}$ A Mãi de Familia, ano 3, n. 4, fev. 1881, p. 25.

${ }^{113}$ Marisa Romero assevera que, em 1857, o médico inglês Benedict-Augustin Morel definiu degenerado como aquele que se desviava do tipo primitivo ideal, estando alocados na categoria loucos, doentes, viciosos, criminosos. ROMERO, Mariza. Medicalização da saúde e exclusão social. Bauru, SP: Edusc, 2002, p. 108. Segundo Mário Eduardo Costa Pereira, "Morel indica diferentes causas para a degenerescência que incluem o abuso do álcool, alimentação deficiente, meio social miserável, imoralidade dos costumes, conduta sexual desregrada, doenças da infância e a própria herança de uma carga de degenerescência (em outros termos, a degenerescência poderia ser herdada ou adquirida)." PEREIRA, Mário Eduardo Costa. Morel e a questão da degenerescência. Revista Latinoamericana de Psicopatologia Fundamental, São Paulo, v. 11, n. 3, p. 490-496, 2008, p. 493.
} 
mesmo núcleo familiar. ${ }^{114}$ Sendo seu público leitor composto por integrantes dessa camada social, enfatizou: "Sei muito bem que vou levantar novas reclamações, inúmeros protestos por parte das interessantes priminhas, que desde a meninice não pensam senão no feliz dia que as unirá para sempre a seu querido priminho...". ${ }^{115}$

A histeria, moléstia que aparecia com destaque por acometer especialmente as mulheres, era para o redator motivo para se evitar o casamento. Dentre as várias características atribuídas pelos médicos às histéricas estava o desejo sexual acentuado, levando comumente à masturbação e ao enfraquecimento dos órgãos genitais. Por este motivo, muitos médicos recomendavam o casamento como prevenção e cura da enfermidade. No entanto, não havia consenso com relação ao tratamento, o matrimônio aconselhado por alguns não era recomendado por outros, que às vezes chegavam a prescrever a reclusão da doente. ${ }^{116}$ Carlos Costa era contrário ao casamento como solução, um dos motivos para seu posicionamento escorava-se na hereditariedade. Disse ele: "Os autores que têm o modo de pensar diverso, entretanto admitem a hereditariedade nessa moléstia". Embora não de modo explícito, Carlos Costa compartilhava da ideia: "Não seria esse um motivo bastante para que se procurasse impedir que os filhos oriundos de uma mulher histérica viessem a sofrer dessa impertinente moléstia?". Acrescentou que o mesmo ocorreria com a epilepsia e com as doenças mentais. ${ }^{117}$ Novamente era delineado um pensamento eugênico na fala do redator de A Mãi de Familia.

De acordo com Rohden, alguns médicos asseguravam que a causa da histeria estava no cérebro, desta maneira, poderia manifestar-se tanto em homens quanto em mulheres, embora nelas fosse mais recorrente, por serem "naturalmente mais predispostas". Enquanto outros sustentavam que origem estava no útero, o que corroborava a ideia de ser esta uma doença feminina. A autora afirma que no final do século XIX o tratamento dispensado à histeria destacava os prejuízos que poderiam sofrer a sociedade e a família em razão dos ataques histéricos das mulheres. ${ }^{118}$

No prognóstico de muitos médicos, problemas menstruais, na gravidez, puerperais e relativos à menopausa poderiam levar à histeria. Fatores externos como as

\footnotetext{
114 Outra estratégia utilizada para manter a fortuna era a união com outras famílias de mesmo status econômico. FREIRE, Jonis. Escravidão e família escrava na Zona da Mata Mineira. Tese (Doutorado em História) - Universidade Estadual de Campinas, Campinas, 2009.

${ }^{115}$ A Mãi de Familia, ano 3, n. 4, fev. 1881, p. 25.

${ }^{116}$ A Mãi de Familia, ano 3, n. 4, fev. 1881, p. 25.

${ }_{117}^{11}$ A Mãi de Familia, ano 3, n. 3, fev. 1881, p. 18. Grifo do original.

${ }^{118}$ ROHDEN, F. Uma ciência da diferença..., p. 154.
} 
influências do meio e da educação também eram considerados como causadores de histeria. Rohden salienta que no "Rio de Janeiro em particular, o modo de vida, os bailes, os teatros e tudo quanto deles se aproximava constituíam uma esplêndida escola de educação histérica". ${ }^{119} \mathrm{O}$ mesmo estilo de vida que Carlos Costa tanto condenava em seus inúmeros artigos publicados em A Mãi de Familia.

Com o objetivo de instruir as mães da sociedade da Corte nos preceitos da medicina higiênica, Carlos Costa recorreu à estratégia de apontá-las como desnaturadas. Seus hábitos sociais foram alvos de severas críticas, que classificavam as frequentadoras bailes, teatros, passeios como egoístas e ignorantes, uma vez que agiam dessa maneira devido ao fato de não conhecerem os males físicos e morais que tais hábitos poderiam trazer, tanto à mãe quanto à prole. Para tal, o médico lançou mão de argumentos fundamentados em uma linguagem científica/cientificista. As mães, a quem as palavras do jornal estavam direcionadas, eram as da elite do Rio de Janeiro, que iam com assiduidade a tais locais. Já as mães das camadas menos abastadas tinham que sair às ruas para trabalhar. A falta de interesse materno com a educação das filhas também foi apontada como preocupante. Cabia às dedicadas mães garantir a educação de suas filhas, com vistas a criar mais uma boa e cuidadosa mãe de família. E, na concepção de Carlos Costa, cabia a ele, por meio de seus artigos em A Mãi de Familia e de suas conferências, instruir aquela mulher para assegurar que ela se tornasse a mãe perfeita. Este aburguesamento da mulher inseria-se em um projeto de modernização da sociedade, que pretendia elevar o Brasil à nação civilizada.

\section{Aleitamento materno e escravidão}

A defesa do aleitamento materno foi um assunto prioritário em $A$ Mãi de Familia. Essa persistência indica a importância que o tema havia adquirido na sociedade de fins do século XIX. Maria Elizabeth Ribeiro Carneiro assegura que as saúdes da mulher e da criança, bem como a questão da amamentação, passaram a ser

\footnotetext{
${ }^{119}$ ROHDEN, F. Uma ciência da diferença..., p. 156.
} 
tratados como "assuntos de Estado", no sentido de que suas remodelações poderiam contribuir positivamente na imagem do país enquanto civilizado. ${ }^{120}$

Entregar o filho para ser amamentado por outra era apontado como um erro gravíssimo. $\mathrm{Na}$ interpretação de Carlos Costa, as mulheres eram displicentes ao cumprirem o único papel que lhes cabia, a maternidade. O médico sustentava que era necessário ensinar a mulher a ser mãe - "não será verdadeiramente mãe a mulher que não aleitar seu filho". ${ }^{121}$ Ele afirmava que às mães brasileiras não faltava amor a sua prole, mas que não tinham conhecimento do modo adequado de exercer a maternidade. Os ilustrados em ciência deveriam levar esse saber, para que elas desempenhassem satisfatoriamente sua função social.

Para Carlos Costa, as mulheres que recusavam amamentar seus filhos o fariam devido "a negligência, o egoísmo, a indolência, a servil submissão às etiquetas sociais, a vaidade e o luxo". ${ }^{122}$ Condenava também aquelas que saiam com seus filhos, para gozar a vida em sociedade (teatros, passeios, bailes, etc.), sem se preocupar com a saúde dos pequenos; elas esqueciam as obrigações maternas (que seriam sagradas porque haviam recebido de Deus) preferindo os "prazeres mundanos". ${ }^{123}$ Diferente da falta de instrução, aqui seriam os desvios de uma determinada conduta moral que fariam com que essas mulheres não exercessem a maternidade em sua plenitude. Entretanto, tudo poderia ser diferente se elas seguissem os "conselhos dos homens de ciência", neste caso os médicos. ${ }^{124}$

Para dar maior credibilidade a suas palavras, o redator de A Mãi de Famila sublinhou falar em nome da ciência, disse ele: "declaro com a autoridade dos homens encanecidos na ciência e na observação que o leite é o único real alimento das crianças". ${ }^{125} \mathrm{Na}$ sua perspectiva, pertencer à categoria de homem da ciência lhe fornecia a autoridade necessária para que suas palavras fossem dignas de confiança, podendo ser consideradas como verdades.

Se a mulher havia alimentado o filho com o seu sangue durante nove meses, nada mais correto que, após o nascimento, continuasse a fazê-lo por meio do leite. Para sustentar seu argumento, Carlos Costa citou os animais na natureza que alimentam seus

\footnotetext{
${ }^{120}$ CARNEIRO, Maria Elizabeth Ribeiro. Procura-se uma "preta, com muito bom leite, prendada $e$ carinhosa": uma cartografia das amas-de-leite na sociedade carioca (1850-1888). Tese (Doutorado em História) - Instituto de Ciências Humanas, Universidade de Brasília, Brasília, 2006, p. 40.

${ }^{121}$ A Mãi de Familia, ano 1, n. 8, abr. 1879, p. 58. Grifos do original.

${ }^{122}$ A Mãi de Familia, ano 1, n. 9, abr. 1879, p. 65

${ }^{123}$ A Mãi de Familia, ano 1, n. 8, abr. 1879, p. 64

${ }^{124}$ A Mãi de Familia, ano 1, n. 9, jan. 1879, p. 65.

${ }^{125}$ A Mãi de Familia, ano1, n. 8, abr. 1879, p. 58. Grifos do original.
} 
filhotes sem que ninguém tivesse lhes dado esse conselho. Foram publicados vários artigos no jornal que destacavam o amor materno, ou instinto maternal, em animais (cobras, aves, insetos, cetáceos) a fim de mostrar que era natural a existência de tal sentimento. Questionou, então, por que o mesmo não acontecia com a mulher, uma vez que ela possuía inteligência, diferente dos outros animais. ${ }^{126}$ Por meio destes exemplos é possível inferir que o homem estava incluso no mundo animal, sendo que o diferencial humano era a presença de inteligência.

Segundo o médico, a alimentação do bebê poderia ocorrer das seguintes maneiras: "devemos apresentar três hipóteses, em relação ao aleitamento: $1^{\circ}$. Ou a mãe amamenta seu filho; $2^{\circ}$. Ou é feito o aleitamento artificial", sendo sempre a amamentação materna a higienicamente mais adequada. ${ }^{127} \mathrm{~A}$ terceira hipótese, que não foi publicada no jornal, provavelmente era a utilização da ama de leite. É possível que, por um erro de editoração, ela não tenha sido impressa, uma vez que esse método foi discutido outras vezes no jornal.

Era comum nas teses de medicina o aleitamento vir dividido em quatro tipos: materno, artificial, o misto feminino e o mercenário. O artificial, segundo Silvana Sofia Machado Koutsoukos só deveria ser utilizado quando a mãe não pudesse amamentar por algum motivo físico e não encontrasse uma ama de leite que satisfizesse os preceitos higiênicos. Este alimento era composto pelo leite animal ou por produtos industrializados destinados à alimentação infantil. O misto seria aquele em que mãe, em virtude de não produzir leite o suficiente ou ter o "leite fraco" dividia a amamentação com uma ama. ${ }^{128}$

O aleitamento "mercenário" referia-se àquele em que as mulheres amamentavam a criança mediante um pagamento previamente estipulado. Se fosse uma ama de leite escrava este valor iria para o seu proprietário. De acordo com Maria Carneiro, o vocábulo mercenário era

usado pelo discurso da medicina para distingui-lo do aleitamento materno e do artificial, o termo, habitualmente usado para designar soldados "mercenários" que trabalham por dinheiro e "sem amor à

\footnotetext{
${ }^{126}$ A Mãi de Familia, ano1, n. 8, abr. 1879, p. 58.

${ }^{127}$ A Mãi de Familia, n. 8, jan. 1879, p. 59.

${ }^{128}$ KOUTSOUKOS, Sandra Sofia Machado. Negros no estudo do fotógrafo: Brasil, segunda metade do século XIX. Campinas, SP: Editora da Unicamp, 2010.
} 
pátria", sugere que se tratava de um serviço "estrangeiro", venal e interesseiro, ou realizado pelo dinheiro. ${ }^{129}$

A autora aventa que a implicação negativa da palavra tenha sido importada dos textos da Europa, onde as mulheres que vendiam seu leite pensavam, antes de qualquer coisa, no lucro que obteriam. Diferente do que ocorria aqui, pois a maioria das amas de leite eram escravas e não optaram por vender seu leite e muito menos ficavam com o lucro.

$\mathrm{Na}$ análise do médico, juntamente com "muitos ilustres especialistas", o melhor leite para substituir o da mulher era o de vaca. ${ }^{130}$ Chamar seus colegas de "ilustres" fornecia ao seu argumento uma confiabilidade maior. Acrescentou que a melhor maneira de oferecê-lo à criança era por meio da mamadeira.

Por ser um leite fácil de encontrar e de ter uma composição próxima ao humano, Carlos Costa indicava o leite de vaca para alimentar as crianças que não eram amamentadas por mulheres. Era necessário, entretanto, tomar alguns cuidados para ministrá-lo. Recomendou que fosse misturada água, na proporção de dois terços do leite para um de água, uma vez que o leite do animal teria mais manteiga e caseína que o da mulher. Indicou também adicionar bicarbonato de sódio (cinco centigramas por mamadeira). Essa mistura faria com que o leite de vaca se tornasse menos irritante ao estômago dos pequenos. Desaconselhou a fervura do leite, sugerindo apenas amorná-lo em banho-maria. ${ }^{131}$

Embora tenha referenciado outros colegas que compartilhavam com ele a mesma opinião sobre o leite animal mais adequado, não havia consenso entre os médicos neste assunto. Maria Elizabeth Carneiro, ao analisar teses produzidas pela Faculdade de Medicina do Rio de Janeiro, constatou que era recorrente comparar outras formas de aleitamento com o materno. A autora afirma que essa produção acadêmica estava sintonizada com as pesquisas francesas acerca do aleitamento artificial e misto.

Em sua tese de 1869, o médico Murillo Mendes Vianna recomendava, caso a mãe não pudesse amamentar, o leite de cabra ou de ovelha, por serem animais mais dóceis e não por suas qualidades nutricionais. Em outra tese do mesmo ano, José Ribeiro dos Santos Zamith afirmou que o melhor era o da jumenta, por se aproximar ao

\footnotetext{
${ }^{129}$ CARNEIRO, M. E. R. Procura-se uma “preta..., p. 45. Grifos do original.

${ }^{130}$ A Mãi de Familia, ano 1, n. 13, jul. 1879, p. 97.

${ }^{131}$ A Mãi de Familia, ano 1, n. 13, jul. 1879, p. 97, 98.
} 
da mulher, mas era pouco utilizado devido à dificuldade de encontrá-lo. ${ }^{132}$ Apesar das divergências entre os médicos com relação ao melhor leite animal a ser utilizado, todos concordavam que o melhor alimento para o bebê era o leite materno.

Com relação ao leite de cabra, alguns médicos indicavam que a ingestão fosse feita diretamente no animal por se tratar de um animal mais dócil. De acordo com Koutsoukos, recomendavam que "a cabra fosse bem alimentada, que não vivesse o tempo todo presa, não tivesse chifres e que, no início do processo de alimentação (por que apenas no início?), fosse constantemente vigiada". ${ }^{133}$

Os jornais, além de anunciarem o serviço das amas de leite, também publicavam a venda de cabras e de alimentos artificiais para a alimentação do bebê, como a farinha láctea da Nestlé e o leite condensado, este deveria ser diluído para ser oferecido. Esses produtos passaram a ser anunciados a partir da década de 1870, todavia, só foram mais utilizados nas primeiras décadas do século XX. ${ }^{134}$ No recorte temporal dessa pesquisa, o aleitamento feito por meio de ama de leite continuou sendo o mais comum. Embora Carlos Costa defendesse veementemente o aleitamento materno, foi publicado no periódico um anúncio dos produtos utilizados no aleitamento artificial:

Ama de Leite

A farinha láctea e o leite condensado de Nestlé, premiados na exposição de Paris, inutilizam hoje em dia todas as amas de leite alugadas.

Um folheto sobre a nutrição das crianças de peito acompanha cada lata deste excelente alimento.

Vende-se em casa de Filippone, à rua do Ouvidor n. 93.

N.B. - Todas as minhas latas expedidas para o Brasil têm o rótulo em português. ${ }^{135}$

Interessante que a chamada do anúncio era "Ama de Leite", talvez para atrair mais atenção da leitora, a publicidade afirmava que os produtos Nestlé serviam para tornar desnecessárias as amas de leite. A propaganda divergia do que era pregado pelo

\footnotetext{
${ }^{132}$ CARNEIRO, M. E. R. Procura-se uma “preta..., p. 247 e 248.

${ }^{133}$ KOUTSOUKOS, S. S. M. Negros no estudo do fotógrafo..., p. 161.

${ }^{134}$ Uma discussão acerca da alimentação infantil nesse período pode ser encontrada em: FREIRE, Maria Martha de Luna. Mulheres, mães e médicos: discurso maternalista no Brasil. Rio de Janeiro: Editora FGV, 2009. PEREIRA, Júnia Sales. História, ciência e infância: narrativas profissionais no processo de singularização da pediatria como especialidade. Brasília: CAPES; Belo Horizonte: Argvmentvm, 2008.

${ }^{135}$ A Mãi de Familia, ano 1, n. 5, mar. 1879, p. 41.
} 
redator da folha, que propagava o aleitamento humano era preferível ao artificial. A nota final dá a entender que circulavam produtos da marca vindos de países europeus onde não se falava o português.

O médico higienista asseverava que a alta taxa de mortalidade infantil era resultado da má alimentação. ${ }^{136}$ Outra maneira de coagir a mãe a amamentar seu próprio filho era produzindo nela um sentimento de perda e culpa. ${ }^{137}$ Por exemplo, o primeiro sorriso da criança iria para quem lhe amamentava. Para a mãe, perder essa experiência seria o "castigo, justo e merecidamente infligido pela natureza" para tal desleixo. ${ }^{138}$ Eram comuns ameaças feitas pelos médicos, estes ressaltavam que os seios e outros órgãos inflamariam em consequência do acúmulo de líquido, e que o filho apenas teria afeto por aquela que o amamentou. ${ }^{139}$

Da mesma maneira que para a maioria dos médicos, na concepção de Carlos Costa, o leite transmitiria às crianças características morais da nutriz. Uma maneira de garantir esses traços era a própria mãe aleitar sua prole. Havia também o receio da transmissão de doenças físicas da ama para a criança. Neste sentido, Machado destaca o caso da escrava Benedicta/Ovídia, que, em 1879, fora dispensada das funções de ama de leite por possuir uma mancha no pescoço, esta levantou suspeitas de que a cativa poderia passar alguma doença para o bebê que amamentava. ${ }^{140}$

No caso do Brasil, o redator de A Mãi de família destacou que o problema das mulheres não amamentarem era mais grave:

Quanto às crianças são indescritíveis as vantagens do aleitamento natural, em relação ao físico ou moral.

Quanto ao físico, tudo depende da qualidade do leite, sua abundância e método na sua administração.

Quanto ao moral, é fato, de cuja exatidão estou convencido, que as crianças adquirem o gênio, o caráter das mães ou das amas, desde

\footnotetext{
${ }^{136}$ A Mãi de Familia, ano 1, n. 8, abr. 1879, p. 59.

${ }^{137}$ De acordo com Costa, "A culpabilização da mulher foi uma faceta importante em sua relação com a higiene. É provável que a mulher de elite estivesse tendo, pela primeira vez, conhecimento de que não sabia cuidar dos filhos. Até então, nada podia certifica-la de que 'amor de mãe' fosse sinônimo de amamentação". COSTA, J. F. Ordem médica e norma familiar... p. 258.

${ }^{138}$ A Mãi de Familia, ano 1, n. 17, jan. 1879, p. 133.

${ }^{139}$ KOUTSOUKOS, S. S. M. Negros no estudo do fotógrafo...

140 MACHADO, Maria Helena Pereira Toledo. Corpo, gênero e identidade no limiar da abolição: a história de Benedicta Maria Albina da Ilha ou Ovídia, escrava (Sudeste, 1880). Afro-Ásia, Salvador, n. 42, p. 157-193, 2010.
} 
os primeiros tempos da vida. Desde essa idade convém ser educado o homem, que é tão fácil em adquirir tudo quanto é mau.

É o que se dá com as amas, sobretudo aqui em nosso país, onde para tudo somos fáceis.

Entregam com toda a liberdade as crianças às amas, negras africanas, estúpidas, cheias de vícios, sem carinhos, etc., o que faz que as crianças facilmente adquiram esses vícios, tornam-se impertinente, etc., etc. ${ }^{141}$

$\mathrm{O}$ aleitamento materno traria uma dupla vantagem, primeiro a qualidade do leite da mãe era sempre melhor que qualquer outro e, principalmente, com ele garantia-se a qualidade moral do filho, dado que esta seria transmitida pelo seu leite.

Carlos Costa censurou aquelas que entregavam seus filhos às amas de leite, neste caso as negras, fossem elas escravas ou libertas (uma vez que não especificou a condição jurídica). Havia nas suas palavras uma forte conotação baseada em termos raciais, já que ele parte do princípio que são mulheres sem inteligência, repletas de vícios e desprovidas de carinho. Características estas consideradas inerentes, que poderiam passar por meio do leite para os filhos das mulheres brancas, que contrairiam os mesmos vícios se tornando insolentes.

Aqui está um ponto recorrente do discurso médico da época, a valorização do aleitamento materno em oposição ao efetuado por escravas. Incentivar esse tipo de alimentação colocava o Brasil no rol dos países considerados civilizados, nos quais os médicos também sustentavam, com base em discursos científicos, a amamentação materna. Entretanto, em terras brasileiras havia a peculiaridade de a maioria das amas de leite ser escrava, alugadas ou pertencentes à própria família. Isto proporcionava aos médicos nacionais um argumento a mais. $\mathrm{O}$ aleitamento materno garantia que as crianças brancas não fossem amamentadas por mulheres consideradas racialmente inferiores, haja vista a crença de que o leite transmitiria qualidades morais aos bebês. A possibilidade de infectar moralmente os infantes, deturpando seu caráter, mostra outro perigo que os cativos representavam para as famílias brancas no imaginário desses homens de ciência.

O medo do escravo doméstico, que estava ali ao lado no convívio privado e cotidiano, percorreu todo o século XIX. O escravo que escutava as conversas dos seus

\footnotetext{
${ }^{141}$ A Mãi de Familia, ano 1, n. 9, jan. 1879, p. 67.
} 
senhores e as reproduziam na rua, em especial o que vivia na cidade e tinha maior mobilidade e, por conseguinte, mais contato com outras pessoas. Sandra Lauderdale Graham assevera que as vidas dos pobres "pertenciam ao mundo da rua". ${ }^{142}$ Havia uma apropriação dos espaços públicos por essa camada da população, eram locais de sociabilidade onde encontravam e teciam relações de amizade e afeto, se divertiam, jogavam, etc. Os perigos que esses escravos que transitavam pelas ruas causavam às famílias muitas vezes foram apresentados na literatura.

Na peça teatral $O$ demônio familiar, José de Alencar, em 1857, narrou a história do moleque Pedro, escravo que manipulava seu senhor. $O$ menino, com intuito alcoviteiro, criou grande intriga e confusão. O senhor, assim como o cativo, era representado como vítima da escravidão, pois tinha o inimigo em casa, que inventava e espalhava situações de foro íntimo e familiar para espaços públicos.

Existia também o medo de ser envenenado pelo escravo. João José Reis destaca o uso pelos escravos de ervas, na maioria das vezes prescritas por pais de santo, para "amansar senhor", com o fim de diminuir a crueldade dos senhores, e para promover a liberdade. Segundo o autor, era recorrente, na documentação policial baiana, casos de envenenamento de senhores provocados por escravos. ${ }^{143}$ Maria Helena Machado encontrou material semelhante no interior de São Paulo. Em 1854, Ricardo Gumbleton Daunt, um senhor escravocrata da região de Campinas, denunciou, em oficio enviado à Assembleia Provincial, "a existência de frequentes crimes envolvendo feitiçaria e envenenamento". 144

Ademais, existia o medo com relação às amas e criadas que conviviam no espaço interno da casa, tendo contato principalmente com as mulheres e crianças da família. O perigo que representavam para a educação, principalmente das filhas dos senhores, por contarem histórias escabrosas e fantásticas que alimentavam a crendice em superstições e criaturas de outro mundo, fazendo com que as moçoilas se distanciassem da desejada mulher burguesa moderna que tinha o conhecimento da ciência para melhor desempenhar suas atividades. ${ }^{145}$ As amas de leite podiam ir aos

\footnotetext{
${ }^{142}$ GRAHAM, Sandra Lauderdale. Proteção e obediência: criadas e seus patrões no Rio de Janeiro, 18601910. São Paulo: Companhia das Letras, 1992, p. 77.

${ }^{143}$ REIS, J. J. Domingos Sodré...

${ }^{144}$ MACHADO, Maria Helena Pereira Toledo. O plano e o pânico: os movimentos sociais na década da abolição. $2^{\text {a }}$ ed. São Paulo: Edusp, 2010, p. 102.

${ }^{145}$ Neste sentido, o romance $O$ mulato, de Aluísio Azevedo, serve para exemplificar como esse tema também era abordado pela literatura. Na obra são feitas críticas com relação à formação das mulheres, que não recebiam conhecimentos científicos. CARULA, Karoline. A tribuna da ciência: as Conferências
} 
locais onde eram vendidos talismãs e objetos místicos e religiosos e comprar amuletos para si e para as crianças que amamentavam, ${ }^{146}$ levando essas crenças à casa dos senhores para quem trabalhavam.

Esse tipo de medo também foi retratado na literatura, dentre outros, por Joaquim Manoel de Macedo em As vítimas-algozes, de 1869, romance de cunho abolicionista composto por três novelas que narravam os perigos que os escravos poderiam proporcionar às famílias brancas. De vítimas do sistema escravista, e em decorrência deste, os cativos passavam a carrascos, traindo seus senhores. Em todas as histórias os escravos foram descritos como dissimulados fazendo-se de submissos para os seus senhores, mas cometendo atos de desobediência para conseguir seus desejos. Na trama "Lucinda a mucama", uma das três novelas que compõem o romance, foi narrada a história da referida cativa, evidenciando como pernicioso seu convívio com a filha do senhor, uma vez que Lucinda fora descrita como moralmente desviante do padrão normativo branco. $^{147}$

Ainda com relação às mucamas, amas e criadas, Carlos Costa alertou para os possíveis acidentes que as crianças poderiam sofrer quando deixadas sob os cuidados de tais mulheres. O médico ressaltou que no caso das famílias abastadas eles ocorriam porque as mães deixavam seus filhos aos cuidados das amas, não cumprindo plenamente sua função de mãe. A fim de provar suas assertivas, em 1879, foi publicada no jornal uma listagem com os acidentes sofridos por crianças no primeiro semestre daquele ano. Foram apresentados 32 acidentes sucedidos com crianças entre 8 meses e 15 anos, sendo quatro deles fatais. Além desses dados, a tabela dava a conhecer os nomes dos infantes, as freguesias onde moravam, as datas dos ocorridos, os tipos de acidentes e suas consequências. Não foi especificado qual era a fonte daqueles dados. ${ }^{148}$

Para o médico, as criadas eram displicentes e não teriam esmero ao cumprir tal função, estavam mais preocupadas em fazer fofoca da vida de seus senhores e conversar futilidades do que em cuidar do rebento alheio:

Populares da Glória e as discussões do darwinismo na imprensa carioca (1873-1880). São Paulo: Annablume; Fapesp, 2009.

${ }^{146}$ GRAHAM, S. L. Proteção e obediência...

147 AMARAL, Sharyse. Emancipacionismo e as representações do escravo na obra literária de Joaquim Manoel de Macedo. Afro-Ásia, Salvador, n. 35, p. 199-336, 2007. Segundo Robert W. Slenes, ao analisar o referido romance e depoimentos de viajantes europeus que estiveram no Brasil: "o racismo, os preconceitos culturais e a ideologia do trabalho da época predispunham os viajantes europeus e os brasileiros 'homens de bem' a verem os negros, que aparentemente não seguiam suas regras na vida íntima, como desregrados." SLENES, Robert W. Na senzala uma flor: esperanças e recordações na formação da família escrava - Brasil, Sudeste, século XIX. Rio de Janeiro: Nova Fronteira, 1999, p. 141.

${ }^{148}$ A Mã̃i de Familia, ano 1, n. 13, jul. 1879, p. 103. 
[...] não haverá quem não tenha tido ocasião de ver uma criancinha caminhar só pela rua, enquanto a criada ou pajem entretem-se com a parceira a dar e receber notícias do que se passa no interior de nossas famílias.

Outras vezes contra a moral e a higiene vê-se uma menina interessante e bem vestidinha no colo de algum beberrão de venda, enquanto a aia conversa com o vendelhão ou o caixeiro. ${ }^{149}$

A criada era acusada de abandonar a criança e aproveitar aquele ponto de encontro para entreter-se, chegando a deixá-la até mesmo com indivíduos alcoolizados. De acordo com Graham, as vendas e tavernas estavam entre os locais mais frequentados pelas camadas menos abastadas da sociedade. As tavernas eram espaços destacados de sociabilidade, nos quais as pessoas iam para conversar, beber, além de comprar alimentos e mercadorias variadas. Para mostrar a importância desses locais na vida da população mais pobre, a autora cita o caso da venda de um português onde uma jovem negra deixava sua lata de água para sair com o seu amado soldado. ${ }^{150}$ No exemplo publicado por Carlos Costa, não era a lata de água e sim a criança que era deixada aos cuidados de outrem. Para provocar indignação e dramaticidade maiores ele descreveu o sujeito como um "beberrão".

O problema principal das amas de leites dava-se quando a nutriz era escrava, considerada "mulher de mau gênio, pouco paciente e pouco jeitosa". Devido a esses problemas, segundo Carlos Costa, a mãe não deveria nunca deixar a criança a sós com a ama. O autor assegurou ainda ter visto "amas que criam filhos de importantes e abastadas famílias nas tavernas, nos cortiços e até nas cocheiras!...”. ${ }^{151}$ Assim, a escrava representava o perigo para a família, não apenas pelo seu leite, por meio do qual passaria suas negativas características morais às crianças, mas também porque colocaria suas vidas em risco ao levá-las em locais considerados de pouca segurança e não higiênicos.

Ao apresentar os acidentes acontecidos com crianças na cidade do Rio de Janeiro entre janeiro e junho de 1879 , o médico afirmou que muitas crianças estavam apenas acompanhadas de criadas, que por serem descuidadas e desleixadas, não perceberam o perigo que acabou ocasionando o acidente, muitas vezes fatal. Para resolver tal

\footnotetext{
${ }^{149}$ A Mãi de Familia, ano 1, n. 8, abr. 1879, p. 62. Grifos do original.

${ }^{150}$ GRAHAM, S. L. Proteção e obediência..., p. 78.

${ }^{151}$ A Mãi de Familia, ano 1, n. 11, jun. 1879, p. 82. Grifos do original.
} 
problema, sustentava que as mães não deveriam deixar "um só instante" de vigiar seus filhos. $^{152}$

A responsabilidade era sempre materna, e apenas por descaso esta entregava as crianças aos cuidados de outra pessoa. A educação infantil não devia ser relegada às descuidosas mucamas, portadoras de costumes pouco louváveis, as mães que assim agiam eram irresponsáveis, por depositarem a confiança nesses "cancros sociais". 153 Terminologia comum àqueles abolicionistas que consideravam que os males da sociedade brasileira eram decorrentes da escravidão.

A ameaça que as amas representavam para as meninas pode ser observada na seção "Palestra do Médico" de Carlos Costa:

se a menina for amamentada por uma pessoa estranha e distante da vigilância materna, desde os primeiros tempos, receberá a influência da ama, talvez mesmo tomará o caráter desta, não conhecendo as mais puras e santas carícias, e a saúde sofrendo, na maior parte das vezes, tornar-se-á mais tarde uma mulher pouco útil. ${ }^{154}$

No correr do texto, ele não deixou claro o que poderia acontecer com essa mulher, que a tornaria "pouco útil". Talvez, uma consequência seria ela deixar de ter carinho pelos outros, uma vez que fora amamentada por uma ama também desprovida de afeto. A ausência do sentimento transformaria a mulher em uma inútil, porque não possuiria um dos atributos necessários para desempenhar adequadamente seu papel de mãe. Outra hipótese é que o leite da ama não seria tão nutritivo quanto o materno e, portanto, faria com que a menina crescesse com uma saúde debilitada, eventualmente não conseguindo engravidar, ou seja, seria "pouco útil” por não poder desempenhar a principal função feminina, a maternidade. É possível que tenha sido por esses motivos que ele tenha destacado em itálico a palavra mulher, para assinalar que se ela não exercesse a maternidade, ou não a executasse segundo os preceitos higiênicos, não poderia ser realmente chamada de mulher. Interessante que até àquele momento a maioria esmagadora das mulheres que eram leitoras de seu jornal provavelmente, quando bebês, haviam sido amamentadas por amas, então, se levada à risca a afirmação

\footnotetext{
${ }^{152}$ A Mãi de Familia, ano 1, n. 13, jul. 1879, p. 102. Grifos do original. ${ }^{153}$ A Mãi de Familia, ano 2, n. 13, jul. 1880, p. 98.

${ }^{154}$ A Mãi de Familia, ano 2, n. 24, dez. 1880, p. 186. Grifos do original.
} 
de Costa, todas as suas leitoras também teriam sido acometidas pelos problemas por ele descritos.

Outra temática desenvolvida em A Mãi de Familia, na seção "Moléstia das Crianças", foi o onanismo, um assunto que deveria deter a atenção da boa mãe de família. Carlos Costa definiu o onanismo como a sensação agradável provocada pelo atrito nos órgãos sexuais. Afirmou que a sensação iniciava-se já nos primeiros meses de vida. Por este motivo, alertou às mães com relação à "perversidade das amas ou das criadas, que o provocam [sensação de prazer] para aquietar as crianças, porque elas sabem que isto lhes causa prazer". Aconselhou, então, que a mãe tivesse uma vigilância intensa. Mais uma vez descreveu a ama como aquela que levava o mal à família, pois "nenhuma ama ou criada lhes deve merecer completa confiança". ${ }^{155}$ Recomendou que a mãe observasse a criança na idade de 10 para 12 anos em diante, porque nesta época o hábito ficava intenso, provocando a perda da saúde. O tratamento do onanismo também era de responsabilidade da mãe, que deveria fiscalizar rigorosamente as amas e criadas, já que tal vício era iniciado por elas. Salientou ainda que as mães "com todo o jeito poderão aconselhar as [criadas] que não forem mal intencionadas e que façam as coisas por ignorância, lhes mostrando os perigos que sem querer fazem correr as crianças". 156 Novamente as amas representavam o perigo dentro de casa.

Ao avaliar como a prática do onanismo foi transformada em doença em fins do século XVIII e no decorrer do XIX, Rohden afirma que a "campanha contra a masturbação seria mais um dos elementos relacionados à ascensão da burguesia, que precisava se diferenciar da nobreza degenerada e da imprevidência operária, cuja sexualidade também seria desordenada". ${ }^{157}$ Assim, a preocupação de Carlos Costa em garantir a ausência de tal "hábito" estava inserida em uma esfera de valores burgueses que se pretendia impor à elite da sociedade do Rio de Janeiro e, de modo mais amplo à do Brasil, considerando o referencial de valores que a Corte representava para o resto do país.

A fim de fortalecer seus argumentos contra as amas de leite, o jornal apresentou na seção "Revista dos Jornais Científicos" uma notícia sobre amas que se embriagavam. Era uma nota do jornal francês Lyon Medical, que relatava o caso de um recém-nascido que apresentava convulsões, e as mesmas se findaram quando foi descoberto que a ama

\footnotetext{
${ }^{155}$ A Mãi de Familia, ano 8, n. 17, 15/09/1886, p. 131.

${ }^{156}$ A Mãi de Familia, ano 8, n. 19, 15/10/1886, p. 147. Grifos do original.

${ }^{157}$ ROHDEN, F. Uma ciência da diferença..., p. 115.
} 
utilizava álcool. Após não mais ingerir o vinho a criança melhorou. ${ }^{158} \mathrm{O}$ excerto servia para alertar às mães brasileiras que o mesmo poderia acontecer aqui, que os maus hábitos da nutriz colocavam em risco a saúde dos alimentados por ela.

Era recorrente afirmar que as amas não tinham afeto por aqueles que nutriam. ${ }^{159}$ Isso ocorreria devido ao fato de terem, quando com sorte, que dividir o alimento de seu filho com outro bebê; e na maior parte das vezes por não terem mais o seu rebento por perto. Afastar o filho da escrava foi uma estratégia muito utilizada pelos senhores para alugá-las a um preço mais alto. Os pequenos cativos frequentemente eram levados para a Roda dos Expostos da Santa Casa de Misericórdia, onde o futuro era incerto e a morte uma probabilidade alta, já que a taxa de mortalidade das crianças lá abandonadas era grande. As crianças renegadas eram automaticamente consideradas livres. Havia o receio, por parte das irmãs de caridade, que uma escrava fujona deixasse o filho objetivando um futuro melhor para ele ou que um proprietário viesse posteriormente buscar o escravinho entregue à roda. ${ }^{160}$

Além da falta de carinho das amas escravas, as teses de medicina apontavam outros fatores para desqualificar a salubridade do seu leite, a própria escravidão prejudicaria a qualidade do leite, visto que elas sofriam maus tratos físicos e morais decorrentes do sistema; a precária condição do cativeiro, que favorecia o aparecimento de muitas doenças; os fatores hereditários, que poderiam ser transmitidos aos bebês provocando problemas terríveis. ${ }^{161}$

Apesar de considerar a amamentação materna como fundamental e execrar as realizadas pelas amas de leite, Costa era a favor da criação de uma lei que obrigasse as escravas que eram alugadas como amas de leite a passarem por um "rigoroso exame". ${ }^{162}$ Defender a criação da referida lei indica que o médico tinha consciência de que este recurso de alimentação era muito utilizado na sociedade brasileira e ainda o seria por algum tempo. Tal posição seria, então, uma tentativa de minimizar os problemas decorrentes desse tipo de aleitamento.

\footnotetext{
${ }^{158}$ A Mãi de Familia, ano 3, n. 15, ago. 1881, p. 116.

159 A questão do afeto dos senhores pelas amas, das amas pelos senhores e das amas para as crianças por elas aleitadas é discutida por Koutsoukos ao analisar as fotografias de amas negras e crianças brancas que foram por elas amamentadas. KOUTSOUKOS, S. S. M. Negros no estúdio do fotógrafo...

${ }^{160}$ CARNEIRO, M. E. R. "Procura-se uma preta... Para uma discussão pormenorizada acerca das crianças abandonadas na roda dos expostos, conferir: VENÂNCIO, Renato Pinto. Famílias abandonadas: assistência à crina de camadas populares no Rio de Janeiro e em Salvador - séculos XVIII e XIX. Campinas, SP: Papirus, 1999.

${ }^{161}$ CARNEIRO, M. E. R. "Procura-se uma preta..

${ }^{162}$ A Mãi de Familia, ano 3, n. 9, mai. 1881, p. 67.
} 
Contudo, nem todas as amas necessitariam passar por exames, uma vez que apenas as cativas eram objeto de suspeita. $\mathrm{O}$ grande problema desse tipo de aleitamento não era a mãe deixar de amamentar seu filho, mas, sim, entregá-lo para uma escrava o fazer. Caso o contrário, o médico recomendaria que qualquer ama passasse pela avaliação, independente de seu status jurídico. Muito provavelmente Costa desejasse que tal tipo de exame se estendesse também às libertas e que o ponto central fosse o aleitamento feito por negras, haja vista o modo como o médico já havia se referido a elas: "negras africanas, estúpidas, cheias de vícios, sem carinhos, etc."163, o que evidencia a presença da questão racial em sua interpretação. Outro motivo para ser considerado é que o exame também poderia valer para as forras, que tendo passado pela escravidão vivenciaram todos os males decorrentes do sistema e estariam nas mesmas condições físicas e morais daquelas que ainda sofriam com o cativeiro.

Já existiam médicos que examinavam amas para atestar a qualidade do leite. Entretanto, era facultativo levar a nutriz para ser avaliada e esse recurso foi pouquíssimo utilizado, demonstrando que, talvez, as mulheres não julgassem necessário o exame. $\mathrm{O}$ redator de $A$ Mãi de Familia enalteceu a iniciativa privada que colocou à disposição consultórios para os referidos exames, como o que era gerenciado pelos médicos Silva Araujo e Moncorvo de Figueiredo (destaco que ambos proferiram conferências sobre moléstias infantis, destinadas principalmente ao público feminino).

Moncorvo de Figueiredo, em 1876, redigiu um projeto que previa a obrigatoriedade da inspeção de todas as amas de leite (livres ou escravas). Contudo, assim como os anteriores, este não foi levado a cabo por falta de apoio das autoridades. O projeto regulamentava um sistema de controle e fiscalização, além de estabelecer condições institucionais para o seu funcionamento, por meio da criação de um escritório central na Corte, anexo à Junta Central de Higiene, e de outros nas províncias. O serviço ajudaria tanto as mães das classes abastadas, porque garantiria a qualidade do leite que amamentaria seus filhos, e as das camadas médias e pobres, ao servir de intermediário gratuito entre elas e as amas de leite. De acordo com Maria Carneiro, "era uma proposta objetiva e política de encaminhar aquele debate no âmbito da administração pública", com objetivo de controlar e assim promover um governo higiênico. ${ }^{164}$

Dez anos após a confecção do projeto de Moncorvo de Figueiredo, Carlos Costa ainda lamentava que a criação de um instituto específico para o exame das amas de leite

\footnotetext{
${ }^{163}$ A Mãi de Familia, ano 1, n. 9, jan. 1879, p. 67.

${ }^{164}$ CARNEIRO, M. E. R. "Procura-se uma preta..., p. 172.
} 
tivesse sido deixada de lado pelo Ministério do Império. Recordava, todavia, que existiam locais para efetuar o exame das amas de leite. Tendo em vista a pouca procura para a realização dos exames, sugeriu que a Inspetoria de Higiene proibisse o anúncio de amas sem que as mesmas estivessem munidas do certificado de qualidade. ${ }^{165}$ Com isso, é possível inferir que, na interpretação de Carlos Costa, eram necessárias políticas públicas que garantissem as propostas higiênicas por ele sustentadas. Para que suas ideias fossem colocadas em práticas, além da mudança de mentalidade das mães brasileiras, era preciso o apoio governamental para a execução das mesmas. ${ }^{166}$

Ainda na esteira do aleitamento feito por ama de leite cativa, entre o final de 1879 e o início de 1880 foi publicado em A Mãi de Familia o conto "A mãe escrava", assinado por Solrac. É provável que tenha sido escrito pelo próprio redator, pois Solrac é um anagrama de Carlos e as ideias apresentadas eram as mesmas por ele defendidas. A história publicada em oito partes narrava as desventuras de uma ama de leite. ${ }^{167}$ Clara era escrava e fora alugada para ser ama de leite em uma casa onde, para seu espanto, além de amamentar a filha da senhora, teria uma criança negra para amamentar. Ela não sabia quem era a mãe daquela enjeitada e se questionou a respeito. Lembrou de sua filha, que imaginava ter morrido após ter sido arrebatada pelos seus senhores, a despeito de suas súplicas para deixá-la ao seu lado.

Enquanto amamentava a magra criança negra, foi chamada pelos senhores e "prontamente à ordem dos brancos" foi apresentada à robusta filha da senhora, que deveria ser amamentada de 2 em 2 horas, enquanto que a outra de 3 em 3, sendo que nos intervalos deveria ser dado leite de vaca à mesma. ${ }^{168}$ Esse sistema de revezamento, favorecendo o bebê branco, era comum quando a escrava ainda tinha seu rebento por perto, tendo também que amamentá-lo. ${ }^{169}$

\footnotetext{
${ }^{165}$ A Mãi de Familia, ano 8, n. 9, 15/05/1886, p. 69.

${ }^{166}$ Com relação à monitoração do serviço de amas de leite, Machado afirma que as "crescentes tentativas de controle do serviço doméstico - sobretudo quando se referia à amamentação - acabaram por florescer o desenvolvimento deste tipo de negócio [casas de aluguel de escravos e livres], o qual, em princípio ou hipoteticamente, garantia as condições higiênicas e morais das amas e criadas que iriam se infiltrar no dia-a-dia das famílias." MACHADO, M. H. P. T. Corpo, gênero e identidade..., p. 170.

${ }^{167}$ Porém, só comecei a acompanhá-la a partir do quarto episódio, pois não encontrei a série completa do jornal, estando ausentes os números nos quais o conto começou. A trama aqui narrada refere-se à que foi impressa entre janeiro e maio de 1880.

${ }^{168}$ A Mãi de Familia, ano 2, n. 1, jan. 1880, p. 7. Grifos do original.

${ }^{169}$ Este revezamento de alimentação, à guisa de exemplo, bem como todos os dramas e tristezas que provocavam na mãe que via seu filho receber menos alimento materno, conforme mostra Machado, fez parte da vivência da ama de leite escrava Ambrosina, que tinha seu filho e uma criança branca para nutrir (ambos chamados Beneditos). Ambrosina foi acusada de ter provocado a morte, por sufocamento, do menino da família senhorial. MACHADO, Maria Helena Pereira Toledo. Entre dois Beneditos: histórias de amas de leite no ocaso da escravidão. In: GOMES, Flávio dos Santos; CÔRTES, Giovana Xavier da
} 
A senhora questionou o motivo pelo qual Clara ficara tão comovida ao amamentar a pequena negra. A cativa narrou o ocorrido e, então, a Sra. C. prometeu verificar que fim havia levado sua pequenina filha. Clara perguntou-lhe sobre a origem da menininha negra, e a senhora respondeu que ela era uma enjeitada que o caridoso Sr. C. havia recolhido.

Ao saber desta conversa, o Sr. C. perguntou à proprietária de Clara quando seu bebê fora enviado à roda. Após investigar, concluiu que a escrava e a criança que estavam em sua casa eram mãe e filha. Clara não ficou sabendo da descoberta porque a "Sra. C. entretanto quis guardar o silêncio em relação à Clara para que a amamentação de sua filha nada sofresse". ${ }^{170}$ No início da narrativa, o senhor é descrito como uma pessoa extremamente boa e generosa, considerado obcecado em realizar bondades. Entretanto, aqui aparece o medo que o escravo poderia representar à família, mesmo sendo considerado extremamente bondoso, o Sr. C. concordou com a sua esposa, afastando a pequenina da mãe escrava. A sua bondade estava estruturada dentro da lógica paternalista, na qual a proteção senhorial estava vinculada à obediência escrava. Com receio que este sistema se rompesse, ele não revelou a descoberta.

Clara, nas semanas seguintes, continuou a amamentar as duas crianças mostrando a sua "boa índole e bem tratada como era, muito lucrou na nutrição". Mais uma vez o esquema paternalista era mantido, ela recebia alimento e, em contrapartida, se comportava bem. Porém, em determinado momento a Sra. C. deixou escapar algo insinuando a verdade. Clara não compreendeu porque os seus amos, que eram tão bons, não haviam contado tudo. E isto "fez nascer em seu espírito fraco, ideias até extravagantes". ${ }^{171}$ A sua "boa índole" desapareceu quando a verdade veio à tona e ela descobriu que estava sendo enganada pelos senhores. A escravidão corrompera aquela alma originalmente boa.

Após tal descoberta, a ama tratou com mais zelo a criança que suspeitava ser sua filha. Mesmo não tendo a certeza, deixou de atender prontamente a criança branca. Mas Clara agia dessa maneira por seguir seu "coração de mãe infeliz", não era má por natureza, o instinto materno a comandava, fazendo-a preterir a filha do senhor em favor da sua. ${ }^{172}$

Conceição; FARIAS, Juliana Barreto (Orgs.). Mulheres Negras no Brasil escravista e do pósemancipação. São Paulo: Summus Editorial, 2012 (no prelo).

${ }^{170}$ A Mãi de Familia, ano 2, n. 3, fev. 1880, p. 23.

${ }^{171}$ A Mãi de Familia, ano 2, n. 3, fev. 1880, p. 23.

${ }^{172}$ A Mãi de Familia, ano 2, n. 3, fev. 1880, p. 23. 
Ao perceber que Clara dedicava mais atenção a sua suposta filha, Sra. C., sem o conhecimento de seu marido, enviou a criancinha negra para a casa de uma parenta, tomando o cuidado de alugar uma escrava para amamentá-la ou para efetuar o aleitamento artificial.

Quando Clara soube que a criança não estava mais lá, sem saber a real razão do fato, ficou desolada e como “a voz impotente da maternidade lhe gritava n'alma e esta embora sufocada, desde o nascer, pela injustiça dos usurpadores da liberdade, sacudiu os grilhões e pela primeira vez em sua vida revoltou-se". ${ }^{173}$ A cativa, que até aquele momento suportava o jugo do cativeiro em silêncio, pela primeira vez foi contra a opressão. A retirada de sua filha, pela segunda vez, foi mais forte. Mais uma vez era a escravidão que desvirtuava e pervertia a pessoa.

Ao tomar conhecimento do ocorrido o Sr. C. condenou a atitude de sua esposa, planejando buscar a menininha de volta. Mas a Sra. C. mostrou-se imutável, retrucando: "Negros são sempre negros, respondeu a Sra. C., não duvido que ela estime seu filho; mas também agora são exagerações; porque talvez espere algum benefício...". ${ }^{174}$ Para a senhora, aquela atitude de Clara era condicionada ao fato de ela ser negra e, não ao sofrimento que sentia. Mesmo contrariado, o Sr. C. acatou as exigências de sua esposa e não foi buscar a criança. O Sr. C. foi sempre descrito como uma pessoa muito bondosa, as atitudes contrárias a sua natural bondade foram tomadas por influência de sua esposa. As atitudes da Sr. C. corroboram a hipótese de que Carlos Costa era o autor do romance, pois em 1884 ele publicaria uma série de artigos nos quais denunciava as mulheres brasileiras como escravocratas.

O Sr. C. passou a observar Clara, que durante um tempo voltou a se comportar como anteriormente. Porém, certa noite, a viu pegando um líquido de um frasco e colocando umas gotas do mesmo em um copo. Ao ir para o piso superior desistiu e jogou fora o conteúdo do copo. A escrava saiu de casa e na rua encontrou com um negro, conversaram e saíram andando. Sr. C., que seguia a cativa, voltou para a casa e avisou a polícia sobre o ocorrido.

Pouco tempo depois, o Sr. C. recebeu um pedido das autoridades policiais e foi atendê-lo. Foi até a Cidade Nova, onde um soldado havia encontrado, em uma miserável casa, os cadáveres de Clara e de uma criança. O subdelegado já estava lá, pois havia sido chamado devido a um caso de suicídio. O Sr. C. relatou todo o ocorrido,

\footnotetext{
${ }^{173}$ A Mãi de Familia, ano 2, n. 6, mar. 1880, p. 47.

${ }^{174}$ A Mãi de Familia, ano 2, n. 6, mar. 1880, p. 47.
} 
informando que iria providenciar o enterro de ambos e pagar a proprietária da escrava. Mas questionou sobre quem seria aquele negro.

O negro que acompanhou Clara foi quem esclareceu tudo. A escrava havia decidido fugir com sua filha, mas não sabia onde ela se encontrava. Foi então que ouviu as outras negras da cozinha comentarem sobre "um preto que adivinhava, um feiticeiro, uma espécie de Juca Rosa”, famoso feiticeiro preso na década de 1870, como já foi dito. Ela viu naquele homem a possibilidade de conhecer o paradeiro de sua filhinha, foi procurá-lo para buscar auxílio, mas "O que se passou, bem podem avaliar todos os que conhecem a malvadez estúpida e a credulidade fanática dos africanos". ${ }^{175}$ Suponho que o autor do conto não estivesse se referindo apenas aos africanos, mas aos negros em geral, visto que não eram só africanos que buscavam tal tipo de ajuda. Aliás, muitos brancos também faziam o mesmo. Porém, a crítica era direcionada aos negros, descritos como portadores de uma "malvadez estúpida" inata, esta aliada à grande fé que possuíam eram extremamente danosas. Classificar os negros como naturalmente cruéis coloca-os como inferiores àqueles que não o eram, no caso aos brancos, indicando uma racialização da sociedade.

O feiticeiro, alcunhado pelo autor como "Pai Quibombo", ${ }^{176}$ havia aconselhado Clara a embriagar o bebê do Sr. C., para que não quisesse mamar à noite e, assim, ela pudesse concretizar o plano de capturar sua filha. O grande culpado pelo triste desenrolar da história teria sido o feiticeiro que persuadiu Clara, que apesar de moralmente boa tinha o "espírito fraco" e seguiu os seus conselhos:

O preto Africano ousadamente e com todos os artifícios soube iludir a pessoa que guardava a filha de Clara, e na noite da fuga desta lha entregou.

\footnotetext{
${ }^{175}$ A Mãi de Familia, ano 2, n. 10, jan. 1880, p. 79.

176 "Pai Quibombo" era o modo como a imprensa se referia ao feiticeiro Juca Rosa. De acordo com Sampaio, "Termos próximos a estes são referidos por Nei Lopes em seu Dicionário banto: quimbombo, por exemplo, é 'pai de santo'; o termo seria relativo a quimbanda, 'linha ritual da umbanda que trabalha principalmente com exus', que no Brasil seria 'linha de práticas também maléficas'. Outra possibilidade para o termo quimbanda seria 'sacerdote de cultos de origem banta', ou 'sacerdote e médico ritual, correspondente ao kikongo nganga'. Já quimbanba significa 'entre fantástico', e quimbango, 'feiticeiro'. Todos podem ser variações do termo que tanto aparece nos jornais do século XIX, 'Pai Quibombo'. Na consulta a outros dicionários, 'quimbombo' significa exatamente pai-de-santo, dirigente de terreiro, iniciado-chefe; deriva do quimbundo 'kimbamba'. Já 'cambondo', 'cambono' ou 'cambone', com origem no quimbundo 'kambundu', aparece em vários dicionários de cultos afro-brasileiros, ora significando auxiliar de pai-de-santo, ora tocador de atabaque, mas sempre ligado ao candomblé de Angola-Congo e outros cultos de influência banto." SAMPAIO, G. dos R. Juca Rosa..., p. 197.
} 
Como se recordam as leitoras, Clara ao sair da casa de seus amos, patenteara ao princípio, alucinada como mostrava estar, desejos criminosos sobre a criança que amamentava. O seu coração naturalmente bom arredou-a desse infame propósito.

Mas todas as cenas que tinham se passado desde o seu parto, as lutas que tinha tido o seu espírito fraco abateram-lhe finalmente o moral e um médico-legista não erraria se considerasse Clara louca na noite em que saiu da casa do Sr. C.

Assim é que apenas o feiticeiro lhe entregou a filha, precipitouse sobre ela e estrangulou-a com suas mãos ingerindo imediatamente depois todo o conteúdo de um frasco que consigo trouxera.

O que podemos acrescentar a esta história de todos os dias?

É que a nuvem negra que empana o brilho do sol de nossa Pátria só poderá dissipar-se com o sopro benéfico da Emancipação dos escravos!

$$
\text { FIM }^{177}
$$

O líquido que Clara ingeriu era o mesmo que pretendia dar ao bebê do Sr. C., mas que neste provavelmente não provocaria a morte por ser ministrado em pequena quantidade. Era comum os feiticeiros e curandeiros prescreverem substâncias, compostas por diferentes ervas, para os mais diversos fins. ${ }^{178}$

Clara, desesperada, preferiu a morte a se separar novamente de sua filha, ambas acabaram mortas em decorrência da escravidão. Por ser escrava, teve sua filha retirada de seu lado duas vezes. Apesar de não ser má, Clara era moralmente frágil, e estes acontecimentos, acrescido o forte instinto maternal (considerado natural em toda mulher), transformaram aquela pobre alma. Ela deixou de se comportar amavelmente e cometeu atos de loucura - fugiu, matou a sua filha e depois a si mesma. ${ }^{179}$

\footnotetext{
${ }_{177}$ A Mãi de Familia, ano 2, n. 10, maio 1880, p. 79. Grifos do original.

178 Com relação às "ervas para amansar senhor provavelmente, então, faziam parte de um complexo medicinal que não se restringiam a um ou dois tipos e que produziam efeitos variados". REIS, J. J. Domingos Sodré..., p. 153.

${ }^{179}$ Não era raro o caso de escravas que, em atitude extrema, matavam seus filhos e depois se suicidavam, ou pelo menos tentavam, quando se viam na possibilidade de serem separadas desses entes queridos. Hebe Maria Mattos cita o caso da cativa Justina, que matou seus três filhos, dois naturais e um de criação (separado da mãe natural que havia sido vendida). A autora destaca que embora não tenha passado por situações de grande "violência, tortura e humilhação", ao perceber que poderia ser vendida, deixando para trás seus filhos, Justina preferiu a morte de todos à dor da separação. MATTOS, Hebe Maria. Das cores
} 
Koutsoukos compara a mudança de comportamento de Clara com o caso real da escrava Joaquina, que, em 1803, foi vendida na condição de que seria libertada após três anos. O casal que a comprou já havia alugado-a como ama de leite para o primeiro filho e queria que ela prestasse o mesmo serviço para o seu segundo filho, uma vez que tinha se mostrado muito amável. Entretanto, quando descobriu que teria sua liberdade em breve, Joaquina começou a ser "desobediente" e "petulante". Tanto no caso fictício de Clara, quanto no verídico de Joaquina, o que estava em questão era a fragilidade do afeto da ama. ${ }^{180}$

O conto de cunho abolicionista afirmava que a história era corriqueira e que todos os dramas vivenciados poderiam deixar de existir com o fim da escravidão. Nele estão apresentados os perigos que os escravos domésticos representavam para as famílias brancas, os problemas de entregar as crianças para serem amamentadas por amas de leite, o paternalismo senhorial, a corrupção da moral provocada pela escravidão, os perigos que os feiticeiros negros significavam para a sociedade, a hierarquização racial da sociedade, a histeria feminina. Pontos que foram tratados por Carlos Costa em seus diversos artigos, principalmente na seção "Palestra do Médico", e que provavelmente estiveram presentes em suas conferências públicas.

A Mãi de Familia era um jornal de caráter abolicionista. Logo no primeiro ano de publicação, Carlos Costa destacou que esperava contar em breve com a colaboração de José do Patrocínio, o que sugeria uma possível simpatia com a causa da abolição. A hipótese pode ser corroborada pelo fato de o médico também ter escrito na Gazeta de Noticias quando Patrocínio era colaborador da folha. ${ }^{181}$

Em 1884, na seção "Educação", Carlos Costa publicou uma série de artigos intitulados "As senhoras brasileiras são escravocratas". Inicialmente, o médico ressaltou que a abolição da escravidão era uma "magna questão [que] preocupa hoje todos os espíritos em nosso país", e lembrou que o jornal já havia abordado o assunto em 1879, quando publicou o pequeno romance "A Mãe Escrava". Sublinhou o papel preponderante que a mulher tinha a fim de acabar com a utilização do elemento servil. Citou, como exemplo, o caso da Condessa do Rio-Novo, que havia alforriado muitos cativos. $^{182}$

do silêncio: os significados da liberdade no Sudeste escravista, Brasil Século XIX. Rio de Janeiro: Nova Fronteira, 1998, p.112.

${ }^{180}$ KOUTSOUKOS. S. S. M. Negros no estúdio do fotógrafo..., p. 181-184.

${ }^{181}$ A Mãi de Familia, ano 1, n. 8, abr. 1879, p. 57.

${ }^{182}$ A Mãi de Familia, ano 6, n. 5, 15/03/1884, p. 37. 
O redator afirmou que as senhoras não educavam e sim tratavam as escravas como "animal de estimação", quando estas eram crianças. ${ }^{183}$ Davam-lhes não apenas cafunés, mas também castigos físicos. Isto até que a cativa tivesse entre 8 e 13 anos. Após esta faixa etária, o tratamento mudava devido às alterações físicas sofridas pela escrava. O médico criticou as senhoras que não educavam suas cativas e depois pediam pudor às mesmas. Ou seja, ele considerava as escravas despudoradas, mas não naturalmente e sim como consequência da ausência de educação.

A esses entes [escravas] que não quiseram educar nem física, nem moral, nem intelectualmente, completamente materializadas, pretendem inspirar um pudor, que entretanto não têm as pobres coitadas o direito de guardar, desde que o capricho de qualquer sensualista, o queiram comprar. ${ }^{184}$

As senhoras não ofereciam nenhum tipo de educação às escravas, por isto elas não possuíam nenhum tipo de pudor. Contudo, mesmo que tivessem sido educadas, de nada valeria, pois quem quisesse poderia comprar seu pudor devido à condição cativa a que estavam submetidas.

Para exemplificar o modo como as senhoras agiam com relação à escravidão, mencionou o caso de uma escrava cuja filha recorreu à justiça para solicitar a sua alforria. A filha da dita escrava havia sido libertada e conseguira a quantia de 200\$000. Deu este dinheiro a sua mãe, que estava com cerca de 50 anos, para que ela pudesse comprar sua liberdade. Foi, então, a cativa até a sua senhora e, argumentando estar doente, pediu para que a senhora concedesse a carta e alforria por tal valor. A senhora indignada negou, replicando que não a daria “por menos de um conto de réis". Porém, a filha da escrava entrou na justiça para requerer a liberdade de sua mãe. ${ }^{185}$ Carlos Costa, por ser o médico da família da senhora, foi convidado a ser o perito da proprietária. Ao examinar a cativa constatou que a mesma estava realmente doente, com "dilatação da aorta", e que seria uma "pechincha obter os $200 \$ 000 "$ ". A senhora ficou indignada com

\footnotetext{
${ }^{183}$ A Mãi de Familia, ano 6, n. 5, 15/03/1884, p. 38. Grifos do original.

${ }^{184}$ A Mãi de Familia, ano 6, n. 5, 15/03/1884, p. 38.

${ }^{185}$ Sidney Chalhoub verificou que embora o pecúlio escravo não fosse legalmente reconhecido (era um direito costumeiro), nas décadas de 1850 e 1860, muitos cativos recorreram à justiça para obrigar os senhores a alforriá-los mediante a apresentação de seu valor venal. Com a Lei do Ventre Livre, de setembro de 1871, o pecúlio se tornou legal e as ações de liberdade passaram a ser legisladas. CHALHOUB, Sidney. Visões da liberdade: uma história das últimas décadas da escravidão na corte. São Paulo: Companhia das Letras, 1990.
} 
o fato de ele ter considerado justa a quantia. O médico perito da escrava concordou com o referido valor e a pobre mulher foi libertada. Devido ao seu parecer, Carlos Costa não foi mais chamado para ser o médico da família. ${ }^{186}$

Não era extraordinária uma situação como essa, em que o médico era afastado ou repreendido por não concordar com a proposta senhorial, desta maneira, beneficiando o escravo. Os médicos eram chamados quando os escravos pretendiam provar doença, problema físico ou idade avançada a fim de diminuir seu valor. Nas ocasiões em que o laudo era oposto ao esperado os curadores reclamavam, chegando a contestar a legitimidade e a acusar o médico de imparcial. ${ }^{187}$

Ainda nas denúncias contra as senhoras escravistas, o redator ressaltou que as "senhoras idosas e jovens" ensinavam às crianças o modo como tratar com os escravos e também a valorização da escravidão. De acordo com Carlos Costa, as crianças aprendiam a considerar o escravo como qualquer outra criação que possuíam, e só depois com a educação percebiam como foram criminosas. Entretanto, afirmou que existiam mulheres que "seja por vaidade, ou por ostentação, ou por coquetterie" já estavam atuando na causa "civilizadora", fazendo doações às festas abolicionistas. Em momento algum ele descreveu as mulheres como conscientes dos males da escravidão. Se agiam contrárias ao sistema não era por princípios. Congratulou, por fim, a criação da "sociedade abolicionista infantil", que transformaria os "futuros cidadãos" em "paladinos" da "ideia abolicionista". ${ }^{188}$

Após condenar a escravidão durante todos seus anos de existência, os colaboradores de A Mãi de Familia comemoraram a emancipação em 1888. Na abertura da primeira edição após a o 13 de maio, Carlos Costa e os redatores apresentaram uma nota referente à abolição, enfatizando estarem "orgulhosos" por não fazerem parte de um país onde exista a escravidão. Condizente com toda a crítica que haviam feito ao sistema escravista, destacaram: "Nós, que também deste lugar, trabalhávamos pela grande ideia, congratulamo-nos com o mundo Livre, pela última conquista que lhe restava". 189

Para Carlos Costa, a escravidão era o cancro da sociedade, a causa de inúmeros males. Com relação às amas de leite, por exemplo, a questão central estava no fato de

\footnotetext{
${ }^{186}$ A Mãi de Familia, ano 6, n. 6, 31/03/1884, p. 46. Grifos do original.

${ }^{187}$ XAVIER, Regina Célia Lima. A conquista da liberdade. Libertos em Campinas na segunda metade do século XIX. Campinas, SP: Área de Publicações CMU/UNICAMP, 1996, p. 53.

${ }^{188}$ A Mãi de Familia, ano 6, n. 9, 15/05/1884, p. 69. Grifos do original.

${ }^{189}$ A Mãi de Familia, ano 10, n. 9, 15/05/1888, p. 65.
} 
muitas delas serem cativas, e por isso não produziam leite de qualidade porque a maioria tinha seus próprios filhos levados para longe. Todavia, com o fim da escravidão não existiriam tais problemas.

Com a transcrição da lição do professor Budin, publicada no número passado, procuramos robustecer a vossa confiança nos conselhos tantas vezes ditados deste lugar, e nos exime de maiores minudências acerca do aleitamento materno e a respeito da escolha da ama; mas, seguindo as sentenças traçadas no $\mathrm{n}^{\circ} 6$ (31 de Março de 1888), devemos dizer alguma coisa ainda em relação a terceira sentença, isto é, que só na falta absoluta e irremediável do leite materno poderá ser utilizado o leite de outra mulher, de uma ama.

As regras gerais estabelecidas por todos os higienistas, e que tão sabiamente foram apresentadas pelo professor Budin, atualmente, em nosso país, algumas considerações devemos acrescentar.

Bem sabeis, minhas senhoras, quantas lutas, quantos sofrimentos experimentaram as senhoras brasileiras, durante o longo e desgraçado período da escravidão no Brasil, quando eram obrigadas a recorrer às pobres mães escravas para servirem de amas! Sabeis que estas mulheres iam muitas vezes, como verdadeiras vítimas para o sacrifício, sendo forçadas por bárbaros senhores a enjeitarem seus filhos $[\ldots]$

Pois bem, agora, graças a [sic] gloriosa lei de 13 de Maio, não há mais mães escravas; todas as mulheres são iguais; de sorte que não haverá mais distinção entre as amas de leite livres e escravas. Elas poderão atualmente servirem como amas, por sua livre vontade e é natural supor-se que farão a amamentação de bom coração, podendo levar consigo seus filhos. ${ }^{190}$

Com a abolição, Carlos Costa reforçou seu posicionamento contrário ao regime. Solidarizou-se com os sofrimentos das mães escravas, que eram obrigadas a enjeitar seus filhos e servirem de amas de leite. A partir do momento em que essas mulheres se tornaram livres, elas poderiam trabalhar como amas por livre escolha, e isso faria com que o leite produzido fosse de melhor qualidade, porque não seriam obrigadas a abandonar seus filhos. Ao igualar todas as amas de leite, independente de serem brancas

\footnotetext{
${ }^{190}$ A Mãi de Familia, ano 10, n. 12, 30/06/1888, p. 89. Grifos do original.
} 
ou negras, Carlos Costa não utilizou o discurso baseado em conceitos raciais que havia lançado mão alguns anos antes durante a vigência do sistema escravista.

Todavia, o médico continuava a sustentar que o melhor alimento ainda era o leite materno, e que o aleitamento feito por uma ama só deveria ocorrer em última hipótese. Mesmo livres essas amas ainda despertavam perigo, "as amas sendo livres terão outras exigências, poderão facilmente abandonar a casa ou contrair ligações que podem ser prejudiciais às crianças. Convém pois que saibas dirigir, por assim dizer a educação dessas mulheres". 191

As amas continuavam representando perigo para aqueles que requeriam seus serviços. Não mais por não possuírem leite de qualidade, mas por não terem uma vida regrada dentro da moral estabelecida pelos preceitos da higiene. Se antes eram os males advindos da escravidão que poderiam fluir através do leite e contaminar os bebês, agora era o próprio comportamento que denotava uma moral não muito sólida. Uma maneira de minimizar esses transtornos era a contratante conduzir e orientar a educação da ama, garantindo que ela estivesse satisfeita em seu trabalho e, assim, amamentasse adequadamente a criança. O projeto modernizador brasileiro, portanto, era baseado na questão da superação da escravidão e no lugar do liberto na sociedade.

Enfim, para Carlos Costa a mãe deveria amamentar seu próprio filho, porque entregá-lo para ser alimentado por uma ama de leite era extremamente perigoso, especialmente se a maior parte delas fosse escrava. A instituição da escravidão havia corrompido essas mulheres, que não aleitavam adequadamente segundo os parâmetros higiênicos. O seu leite era ruim, pois elas tiveram seus filhos levados, na maioria das vezes à roda, e ficaram dominadas por tristeza e rancor que acabaram prejudicando a qualidade do leite. Além do perigo moral, as crianças poderiam adquirir características da nutriz, tornando-se impertinentes, dentre outros. A construção da crítica às amas de leite estava fundamentada na escravidão. Acabar com o hábito de amamentar os bebês com amas era também se distanciar do regime de escravidão, tornando a imagem do país mais higiênica e condizente com os valores burgueses então em voga.

Defender o aleitamento materno era uma maneira de forjar uma mudança na ordem familiar, que a partir de então estaria fundamentada em uma sociedade burguesa liberal. A nova família deveria abandonar o uso das amas de leite, escravas em sua maioria. Desta maneira, afastando também o próprio escravismo. Aqueles que tinham

${ }^{191}$ A Mãi de Familia, ano 10, n. 12, 30/06/1888, p. 89. Grifos do original. 
seus filhos amamentados pelo seio materno estariam alinhados às propostas de modernização do país, por meio de um ambiente familiar higiênico longe da escravidão. O passado colonial e a escravidão eram a barbárie. Para distanciar-se desse modelo de sociedade, um projeto moderno devia ser instaurado, no qual estava inclusa a reformulação da ordem familiar.

Carlos Costa, nos seus artigos publicados em A Mãi de Familia e muito provavelmente nas conferências públicas que apresentou, valorizava o papel da mulher como educadora, mas que precisava ser instruída nos termos da ciência. Sua atuação na sociedade era importante, pois era ela que iria cuidar dos filhos e do lar. Porém, ao mesmo tempo ele a depreciava, pois representava a mulher como fútil, escravista, responsável pelo descaso como com as crianças.

Para conseguir o aburguesamento da família, era indispensável instruir a mulher na ciência. Ela precisava do conhecimento científico para bem executar suas tarefas domésticas, amamentar sua prole sem fazer uso de ama de leite, educar e cuidar pessoalmente dos filhos. Assim, ela se tornaria a perfeita mãe de família e rainha do lar. No intuito de promover tal instrução, Carlos Costa, ao expor conhecimentos científicos que julgava necessários às mulheres, apresentou sua argumentação fundamentada no higienismo, manifestou seu posicionamento contrário à escravidão e analisou a sociedade por um viés racialista. A ascensão de um tipo de ideologia burguesa tinha na ciência a sua aliada, por meio de uma linguagem científica; isto como parte de um amplo projeto disciplinarizante, por exemplo, de formação da família. Portanto, as mulheres, e também os homens, que liam o jornal e/ou iam as suas preleções tiveram contato com toda essa ampla temática de assuntos, que estavam presentes no cotidiano daquelas pessoas no final do século XIX.

Para concluir, uma questão que merece ser levantada é acerca da prática, recepção e compreensão da sociedade sobre esses temas vinculados ao aburguesamento da mãe de família expostos nas conferências públicas. Se as preleções sobre puericultura e amamentação eram assistidas majoritariamente por homens, para quem de fato aqueles médicos falavam? Seriam discursos sobre a inferioridade feminina, necessidade de tutela masculina sobre as mulheres, ou as conferências estavam de fato voltadas para a educação prática das mães? Difícil responder a tais perguntas, são questionamentos que devem ser considerados, porém ficarão para uma outra história... 


\section{Considerações finais}

Os projetos modernizadores do Império foram norteados pelos princípios de civilizar e educar a sociedade, visando inserir o país no caminho do progresso. Neste sentido, as preleções públicas realizadas na capital imperial não fugiram à regra. A análise das conferências e cursos mostrou a existência de um discurso científico/cientificista que serviu de argumento para projetos mais amplos de modernização da nação, nomeadamente, o emprego do darwinismo na sociedade, a hierarquização racial da população e a elaboração de uma mãe de família burguesa.

Nos três espaços públicos aqui analisados - Conferências Populares da Glória, cursos públicos do Museu Nacional e conferências "Avulsas" - foram abordados temas relativos às ciências. Tanto preletores quanto público eram compostos pela elite letrada da sociedade, sendo que a plateia contava com uma pequena parcela de mulheres. Desta maneira, as conferências e cursos públicos se caracterizaram por serem espaços de sociabilidade letrada e científica, bem como de vulgarização científica.

Lá, os homens letrados que discursavam tencionavam difundir um conhecimento científico para seus pares, alertando-lhes para a necessidade de se civilizar e educar os bárbaros da sociedade, quais sejam, negros, índios, brancos pobres e mulheres. Em suas interpretações, somente após retirar essa parcela da população da barbárie, o país poderia progredir e tornar-se civilizado. A ciência, portanto, aparecia com o papel de controle social, pois os argumentos empregados por aqueles sujeitos pautavam-se em um vocabulário científico/cientificista. Entretanto, embora as conferências e os cursos apresentassem modernos projetos civilizadores, eles não operavam de forma prática na sociedade, uma vez que não civilizaram os considerados bárbaros de maneira direta.

Uma das temáticas desenvolvidas nesses eventos foi 0 darwinismo. Compreendido com uma teoria moderna, ele recebeu manifestações de apoio e repreensão por parte dos conferencistas, sendo que a aceitação foi maior. A acepção do 
paradigma de Darwin era feita por filtros, tanto pelos favoráveis quanto pelos contrários à teoria, princípios de Haeckel e de Lamarck eram mesclados ao darwinismo exposto.

Dentre os detratores, o médico Feliciano Pinheiro de Bittencourt foi quem mais se empenhou na luta contra o darwinismo na tribuna da Glória. A problemática essencial do darwinismo, para ele, era a retirada da atuação de Deus na criação. Suas críticas, entretanto, também eram feitas dentro do protocolo da ciência, girando em torno da disputa entre o monogenismo e o poligenismo, do qual era sectário, e entre o evolucionismo e o criacionismo.

Com relação à defesa do darwinismo, o médico Augusto Cesar de Miranda Azevedo foi um dos que se dedicou à causa nas Conferências Populares da Glória. Ele acreditava prestar um serviço à pátria e à sociedade ao publicizar o sistema de Darwin. Para este orador, era possível empregar socialmente as proposições darwinistas. Imbuído em preceitos de Haeckel e Lamarck, o darwinismo foi apropriado e ressignificado pelo médico, e o paradigma biológico foi utilizado para a compreensão de questões sociais. Na sua concepção, a aplicação social do darwinismo seria um meio de melhorar a sociedade.

Nos cursos públicos do Museu Nacional, as ideias do naturalista inglês foram defendidas por Ladislau Netto e João Joaquim Pizarro. O darwinismo apresentado era fruto das pesquisas desenvolvidas pelos cientistas da instituição, que buscavam encontrar evidencias empíricas que confirmassem as assertivas de Darwin. A plateia que assistiu às preleções de Netto teve contato com as proposições darwinistas de adaptação, seleção natural e evolução, enunciadas como produto da ação divina. Em suma, Netto conseguiu harmonizar evolucionismo e criacionismo. Assim como Miranda Azevedo, ele fez uso de princípios do darwinismo para compreender e explicar questões da sociedade.

$\mathrm{Na}$ esteira de modernizar a nação, a reflexão acerca do local social dos habitantes do país era de suma importância. Para tal, o discurso científico/cientificista serviu de sustentáculo para que alguns preletores observassem e interpretassem a população em termos de raça. A hierarquia racial estabelecida justificaria os lugares sociais nos quais os indivíduos deveriam ser introduzidos na sociedade. Esses discursos que racializavam a humanidade marcaram as conferências e os cursos públicos. A concepção de raça apresentada pelos oradores era plural. Contudo, todas as hierarquizações raciais inseriam o branco no ápice da escala. Índios e negros, por meio de abordagens múltiplas, foram categorizados como inferiores. 
A imigração, em especial a chinesa, também foi tratada por uma ótica racializada. Neste sentido, Nicolau Moreira foi o conferencista mais engajado contra a entrada dos chins. Fez uso de argumentos embasados em uma linguagem científico/cientificista, para determinar se a introdução de um determinado imigrante seria racialmente favorável ao Brasil. As discussões sobre a imigração se davam em várias esferas da sociedade, todavia, para Moreira apenas as proposições fundamentadas no discurso médico científico deveriam ser consideradas como corretas e verdadeiras.

Nos debates enunciados nos cursos e conferências, a postura dos oradores era pedagógica, sinalizavam para a maneira adequada de branquear a nação, tratar a escravidão e civilizar o indígena. Para isto, valiam-se da linguagem da raça. A despeito de não terem triunfado em seus projetos, os preletores estabeleceram um discurso racial que se fez presente nas décadas posteriores.

Para a construção de um país moderno era essencial uma atuação na esfera privada, na família. Com este intuito, conferências foram proferidas e direcionadas especificamente ao público feminino, era preciso educar a mulher na ciência a fim de que ela se tornasse uma boa mãe de família, nos moldes burgueses europeus. Assim, ela poderia executar adequadamente as funções domésticas e maternas. Desta maneira, as conferências proferidas para o público feminino buscavam instruir as mulheres para que fossem boas mães, e tinham como tema principal a higiene e a medicina. Nesta perspectiva, foram destacados Carlos Costa, preletor de tais tipo de preleção, e o jornal do qual era redator-principal, A Mãi de Familia. Nas páginas da publicação e em suas falas nas conferências, Costa evidenciava sua preocupação com a educação feminina. A importância desta educação situava-se em garantir que as mães, seguindo os preceitos ditados pela medicina higiênica, criassem adequadamente seus filhos: os futuros cidadãos do país.

A defesa do aleitamento materno, presente nos discursos de Costa, também fazia parte do aburguesamento da maternidade. Aqui, a discussão atrelava-se com a escravidão. A nova família burguesa deveria abrir mão das amas de leite, muitas das quais escravas. Esta atitude, de certo modo, distanciava o núcleo familiar do próprio escravismo. As famílias que alimentassem seus filhos com o leite materno estariam em sintonia com as propostas modernizadoras da nação, em um ambiente higiênico, afastado da escravidão. Contudo, embora as preleções fossem dedicadas às mulheres, elas compunham a minoria da audiência daquelas preleções. 
Por fim, a análise das Conferências Populares da Glória, dos cursos públicos do Museu Nacional e das preleções "Avulsas" mostra como o discurso científico/cientificista serviu de base para projetos modernizadores da sociedade, que objetivavam estabelecer o progresso e a civilização da nação. A aplicação social do darwinismo, as análises racializadas sobre os locais sociais dos habitantes do país o aburguesamento da mãe de família foram alguns desses projetos. As discussões, entretanto, ficavam restritas àqueles espaços de sociabilidade científica e letrada, não chegaram a se concretizar de modo mais prático na sociedade. 


\section{Arquivos pesquisados}

Academia Nacional de Medicina

Arquivo Digital: Center for Research Libraries - University of Chicago. Disponível em:

$<$ http://crl.edu/brazil/almanak>

Arquivo Digital: Internet Archive. Disponível em: 〈http://archive.org/index.php>

Arquivo Digital: Senado Federal. Disponível em: <http://www.senado.gov.br/sf/>

Arquivo Edgard Leuenroth (AEL)

Biblioteca Digital do Museu Nacional. Disponível em:

<http://www.obrasraras.museunacional.ufrj.br/index.html>

Biblioteca do Museu Nacional

Biblioteca Nacional

Instituto Histórico e Geográfico Brasileiro (IHGB)

Seção de Memória e Arquivo do Museu Nacional (SEMEAR)

\section{Fontes}

\section{Periódicos}

Almanak Administrativo, Mercantil e Industrial da Corte e do Rio de Janeiro (1877)

Archivos do Museu Nacional (1876-1885)

O Auxiliador da Industria Nacional (out. 1869, out. 1871, out. 1878, jun. 1879, abr. 1880, jan. 1891)

Bibliotheca dos Bonds (1876)

Conferencias Populares (1876)

Diario do Rio de Janeiro (1873-1878)

Gazeta de Noticias (1875-1880)

O Globo (1874-1878)

Jornal do Commercio (1870-1889)

A Mãi de Familia (1879-1888)

Revista Brazileira (1879-1881)

Revista da Exposição Anthropologica Brazileira (1882)

O Vulgarizador (1877-1878) 


\section{Publicações Científicas}

AGASSIZ, Elizabeth Cary; AGASSIZ, Louis. Viagem ao Brasil 1865-1867. Tradução de Edgar Süssekind de Mendonça. Brasília: Senado Federal, Conselho Editoria, 2000.

AZEVEDO, Augusto Cezar de Miranda. Beriberi. Tese apresentada em 3 de novembro de 1874. Rio de Janeiro: Typographia Academica, 1875.

BITTENCOURT, Feliciano Pinheiro de. Conferencias efectuadas na escola da Gloria. Rio de Janeiro: Typographia e Lithographia a vapor, encadernação e Livraria Lombaerts \& C., 1882.

BÜCHNER, Louis. Conférences sur la théorie darwinienne de la transmutation des espèces et de l'apparition du monde organique. Application de cette théorie à l'homme. Ses rapports avec la doctrine du progrès et avec la philosophie matérialiste du passé et $d u$ present. Traduit par Auguste Jacquot. Leipzig: Théodore Thomaz, Libraire-Éditeur; Paris: C. Reinwald, Libraire-Éditeur, 1869.

COUTY, Louis. O Brasil em 1884: esboços sociológicos. Tradução de Ligia Vassalo. Rio de Janeiro: Fundação Casa de Rui Barbosa; Brasília: Senado Federal, 1984.

DARWIN, Charles. On the origin of species by means of natural selection, or the preservation of favoured races in the struggle for life. New York: D. Appleton and Company, 1864.

DUVAL, Mathias. Le Darwinisme. Leçons profesées a l'École d'Anthropologie. Paris: Adrien Delahave et Émile Lecrosnier, 1886.

HAECKEL, Ernst. The history of creation: or the development of the earth and its inhabitants by the action of natural causes. A popular exposition of the doctrine of evolution in general, and of that of Darwin, Goethe, and Lamarck in particular. Volume I. London: Henry S. King \& Co., 1876.

LACERDA, João Baptista de. Fastos do Museu Nacional do Rio de Janeiro. Recordações historicas e scientificas fundadas em documentos authenticos e informações veridicas. Rio de Janeiro: Imprensa Nacional, 1905.

MOREIRA, Nicoláo Joaquim. Questão. Convirá ao Brasil a importação de colonos Chins? 2o. Discurso pronunciado na sesão da Sociedade Auxiliadora da Industria Nacional em 17 de Novembro de 1870. Discutindo-se o parecer da secção de colonisação e estatistica. Rio de Janeiro: Typographia Universal de Laemmert, 1870.

Questão ethnica-antropologica. O cruzamento das raças acarreta a degradação intelectual e moral do producto hybrido resultante? Resumo da memoria apresentada á Academia Imperial de Medicina e relatorio. Rio de Janeiro: Typographia Progresso, 1869.

Relatorio sobre a immigração nos Estados-Unidos da América. Apresentado ao Ex. Sr. Ministro da Agricultura, Commercio e Obras Publicas pelo Dr. Nicoláo Joaquim Moreira. Rio de Janeiro: Typographia Nacional, 1877. 
MORGAN, Lewis H. Ancient society or researches in the lines of human progress from savagery, through barbarism to civilization. New York: Henry Holt and Company, 1877.

MORTON, Samuel George. Crania Americana; or, a comparative view of the skulls of various aboriginal nations of North and South America. An essay on the varieties of the human species. Philadelphia: J. Dobson; London: Simpkin, Marshall \& Co., 1839.

NETTO, Ladislau. Aperçu sur la théorie de l'evolution. Conférence fait à Buenos-Ayres dans la séance solennelle, célébrée en son honneur par la Société Scientifique Argentine. Le 25 octobre 1882. Rio de Janeiro: Imprimerie du "Messader du Brésill", 1883.

Observaciones sobre la teoría de la evolución. Anales de la Sociedad Científica Argentina, Buenos Aires, Imprenta de Pablo E. Coni, tomo XIV, p. 147-158, seg. sem. 1882.

\section{Documentação do Museu Nacional}

Pasta 16, Doc. 35, 15/03/1877.

Pasta 16, Doc. 36, 16/03/1877.

Pasta 16, Doc. 39, 20/03/1877.

Pasta 16, Doc. 47, 31/03/1877.

Pasta 17, Doc. 29, 30/03/1878.

Registro de Atas do Conselho Administrativo do Museu Nacional. Livro n. 3. 18761885.

Registro de Atas do Conselho Administrativo do Museu Nacional. 1885-1893.

Registro da Correspondência Oficial do Museu Nacional. Livro $7^{\circ}$ 1881-1885.

Registro da Correspondência Oficial do Museu Nacional. Livro $6^{\circ}$ 1875-1881.

Registro da Correspondência Oficial do Museu Nacional. Livro $8^{\circ}$ 1885-1890.

Regimento interno do Museu Nacional. 1879. Pasta 18, doc. 9A.

\section{Relatórios Ministeriais}

BRASIL. Ministério da Agricultura, Commercio e Obras Publicas. (1869 e 1876-1889). Rio de Janeiro.

\section{Legislação}

BRASIL. Decreto n. 6116 de 9 de fevereiro de 1876. Reorganiza o Museu Nacional.

BRASIL. Decreto n. 9942, de 25 de abril de 1888. Reorganiza o Museu Nacional. 
BRASIL. Regulamento n. 123 de 3 de fevereiro de 1842. Dá ao Museu Nacional uma organisação accommodada á melhor classificação e conservação dos objectos.

\section{Obras de referência}

AULETE, Caldas. Diccionario contemporaneo da lingua portugueza. Lisboa: Imprensa Nacional, 1881.

BLAKE, Augusto Victorino Alves Sacramento. Diccionario bibliográfico brasileiro. Rio de Janeiro: Typographia Nacional, 1893.

SILVA, Antonio de Moraes. Diccionario da lingua portugueza. 8. ed. Rio de Janeiro: Empreza Litteraria Fluminense, 1889. 


\section{Bibliografia}

ALONSO, Angela. Idéias em movimento: a geração de 1870 na crise do Brasil-Império. São Paulo: Paz e Terra, 2002. Joaquim Nabuco. São Paulo: Companhia da Letras, 2007.

AMARAL, Sharyse. Emancipacionismo e as representações do escravo na obra literária de Joaquim Manoel de Macedo. Afro-Ásia, Salvador, n. 35, p. 199-336, 2007.

ARGUETA VILLAMAR, Arturo. El darwinismo en Iberoamérica: Bolívia y México. Madrid: Consejo Superior de Invetigaciones Científicas, Cararata, 2009.

ARRIBAS, Célia da Graça. Afinal, espiritismo é religião? A doutrina espírita na formação da diversidade religiosa brasileira. Dissertação (Mestrado em Sociologia) Universidade de São Paulo, São Paulo, 2008.

AZEVEDO, André Nunes de. Da Monarquia à República: um estudo dos conceitos de civilização e progresso na cidade do Rio de Janeiro entre 1868 e 1906. Tese (Doutorado em História) - Pontifícia Universidade Católica do Rio de Janeiro, Rio de Janeiro, 2003.

AZEVEDO, Celia Marinho de. Onda negra, medo branco: o negro no imaginário das elites século XIX. 2. ed. São Paulo: Annablume, 2004.

Para além das "relações raciais"; por uma história do racismo. In: . Antiracismo e seus paradoxos: reflexões sobre cota racial, raça e racismo. São Paulo: Annablume, 2004, p. 107-126.

A recusa da "raça": anti-racismo e cidadania no Brasil dos anos 1830. Horizontes Antropológicos, Porto Alegre, ano 11, n. 24, p. 297-320, jul./dez. 2005.

BADINTER, Elisabeth. Um amor conquistado: o mito do amor materno. Tradução de Waltensir Dutra. Rio de Janeiro: Nova Fronteira, 1985.

BASTOS, Maria Helena Camara. Conferências populares da freguesia da Glória (18731890). In: Anais do II Congresso Brasileiro de História da Educação: História e Memória da Educação brasileira. Natal: Núcleo de arte e cultura da UFRN, 2002.

BENCHIMOL, Jaime Larry. Dos micróbios aos mosquitos: febre amarela e a revolução pasteuriana no Brasil. Rio de Janeiro: Editora Fiocruz / Editora UFRJ, 1999.

Pereira Passos: um Haussmann tropical: A renovação urbana da cidade do Rio de Janeiro no início do século XX. Rio de Janeiro: Secretaria Municipal de Cultura, Turismo e Esportes, Departamento Geral de Documentação e Informação Cultural, Divisão de Editoração, 1992.

BENJAMIN, Walter. Charles Baudelaire um lírico no auge do capitalismo. Obras escolhidas. Volume III. Tradução de José Carlos Martins Barbosa e Hemerson Alves Baptista. São Paulo: Brasiliense, 1989. 
BERMAN, Marshall. Tudo que sólido se desmancha no ar: a aventura da modernidade. Tradução de Carlos Felipe Moisés e Ana Maria L. Ioriatti. São Paulo: Companhia das Letras, 1986.

BIDMAN, David. Ape to Apollo: aesthetics and the idea of race in eighteenth century. Ithaca NY: Cornell University Press, 2002.

BOURDIEU, Pierre. Capital simbólico. In: O senso prático. Tradução de Maria Ferreira. Petrópolis, RJ: Vozes, 2009, p. 187-202.

O capital social - notas provisórias. Tradução de Denice Barbara Catani e Afrânio Mendes Catani. In: NOGUEIRA, Maria Alice; CATANI, Afrânio (Orgs.). Escritos de educação. Petrópolis, RJ: Vozes, 1998, p. 65-71.

. Espaço social e génese das "classes". In: O poder simbólico. Tradução de Fernando Tomaz. 8. ed. Rio de Janeiro: Bertrand Brasil, 2008, p. 133-161.

. Os três estados do capital simbólico. Tradução de Magali de Castro. In: NOGUEIRA, Maria CATANI, Afrânio (Orgs.). Escritos de educação. Petrópolis, RJ: Vozes, 1998, p. 71-79.

CAMARA, Sonia. O jornal "Mãe de Família" como estratégia de intervenção medicina, higiene e educação na fabricação da infância e da família no Brasil dos finais do século XIX. Actas do VII Congresso Luso-Brasileiro de História da Educação: Cultura Escolar Migrações e Cidadania. Porto: Faculdade de Psicologia e Ciências da Educação (Universidade do Porto), 2008.

CANGUILHEM, Georges. Études d'histoire et de philosophie des sciences. Paris: Librairie Philosophique J. Vrin, 1975.

CARDOSO, Luciene P. Carris. Novos horizontes para o saber geográfico: a Sociedade de Geografia do Rio de Janeiro (1883-1909). Revista da SBHC, Rio de Janeiro, v. 3, n. 1, p. 80-96, jan./jun. 2005.

CARNEIRO, Maria Elizabeth Ribeiro. Procura-se uma "preta, com muito bom leite, prendada e carinhosa": uma cartografia das amas-de-leite na sociedade carioca (18501888). Tese (Doutorado em História) - Instituto de Ciências Humanas, Universidade de Brasília, Brasília, 2006.

CARNEIRO DA CUNHA, Manuela. Política Indigenista no Século XIX. In: (Org.). História dos índios no Brasil. São Paulo: Companhia das Letras, 1992, p. 133154.

CARULA, Karoline. A tribuna da ciência: as Conferências Populares da Glória e as discussões do darwinismo na imprensa carioca (1873-1880). São Paulo: Annablume; Fapesp, 2009.

CARVALHO, José Murilo. As conferências radicais do Rio de Janeiro: novo espaço de debate. In: (Org.). Nação e cidadania no Império: novos horizontes. Rio de Janeiro: Civilização Brasileira, 2007, p. 17-42. 
CASTAÑEDA, Luzia Aurelia. Eugenia e casamento. História, Ciências, Saúde Manguinhos, Rio de Janeiro, v. 10, n. 3, p. 901-930, 2003.

CHALHOUB, Sidney. Cidade febril: cortiços e epidemias na Corte imperial. São Paulo: Companhia das Letras, 1996.

-Visões da liberdade: uma história das ultimas décadas da escravidão na corte. São Paulo: Companhia das Letras, 1990.

CHARTIER, Roger. Distinção e divulgação: a civilidade e seus livros. In:

Leituras e leitores na França do Antigo Regime. Tradução de Álvaro Lorencini. São Paulo: Editora Unesp, 2004, p. 45-89.

História intelectual e história das mentalidades: uma dupla reavaliação. In: A história cultural: entre práticas e representações. Tradução de Maria Manuela Galhardo. $2^{\text {a }}$ ed. Lisboa: Diefel, 2002, p. 29-67.

CID, Maria Rosa Lopes. O aperfeiçoamento do homem por meio da seleção: Miranda Azevedo e a divulgação do darwinismo, no Brasil, na década de 1870. Dissertação (Mestrado em História das Ciências da Saúde) - Casa de Oswaldo Cruz, Fundação Oswaldo Cruz, 2004.

CITELI, Maria Teresa. As desmedidas da Vênus negra: gênero e raça na história da ciência. Novos Estudos CEBRAP, n. 61, p. 163-175, nov. 2011.

COLLICHIO, Therezinha Alves Pereira. Miranda Azevedo e o darwinismo no Brasil. Belo Horizonte: Itatiaia; São Paulo: Edusp, 1988.

COMPAGNON, Antoine. O leitor. In: O demônio da teoria: literatura e senso comum. Tradução de Cleonice Paes Barreto Mourão e Consuelo Fortes Santiago. Belo Horizonte: Editora UFMG, 2006, p.139-164.

COSTA, Ana Luiza Jesus da. À luz das lamparinas. As escolas noturnas para trabalhadores no Município da Corte (1860-1889). Dissertação (Mestrado em Educação) - Faculdade de Educação, Universidade do Estado do Rio de Janeiro, Rio de Janeiro, 2007.

COSTA, Christina Rostworowski. O Príncipe Maximiliano de Wied-Neuwied e sua Viagem ao Brasil (1815-1817). Dissertação (Mestrado em História Social) Universidade de São Paulo, São Paulo, 2008.

COSTA, Jurandir Freire. Ordem médica e norma familiar. 5 ed. Rio de Janeiro: Edições Graal, 2004.

DARNTON, Robert. O beijo de Lamourette: mídia, cultura e revolução. Tradução de Denise Bottmann. São Paulo: Companhia das Letras, 2010.

Os best-sellers proibidos da França Revolucionária. Tradução de Hildegard Feist. São Paulo: Companhia das Letras, 1998.

DESMOND, Adrian; MOORE, James. Darwin: a vida de um evolucionista atormentado. 5 ed. Tradução de Cynthia Azevedo. São Paulo: Geração Editorial, 2007. 
DEZEM, Rogério. Matizes do "amarelo": a gênese dos discursos sobre os orientais no Brasil (1878-1908). São Paulo: Associação Editorial Humanitas, 2005.

DHOMBRES, Jean. Livros: dando nova forma à ciência. In: DARNTON, Robert; ROCHE, Daniel (Orgs). Revolução impressa: a imprensa na França, 1775-1800. Tradução de Marcos Maffei Jordan. São Paulo: Editora da Universidade de São Paulo, 1996, p. 239-285.

DIAS, Maria Odila Leite da Silva. Aspectos da ilustração do Brasil. Revista do Instituto Histórico e Geográfico Brasileiro, Rio de Janeiro, v. 278, p. 105-170, jan.-mar. 1968.

Hermenêutica do cotidiano na historiografia contemporânea. Projeto História, São Paulo, São Paulo, n. 17, p. 223-258, nov. 1998.

Teoria e método dos estudos feministas: perspectiva histórica e hermenêutica do cotidiano. In: COSTA, Albertina de Oliveira; BRUSCHINI, Cristina (Orgs.). Uma questão de gênero. Rio de Janeiro: Rosa dos Tempos; São Paulo: Fundação Carlos Chagas, 1992, p. 39-53.

Dicionário Histórico-Biográfico das Ciências da Saúde no Brasil (1832-1930).

Disponível em: <http://www.dichistoriasaude.coc.fiocruz.br>.

DOMINGUES, Heloisa Maria Bertol. A Sociedade Auxiliadora da Indústria Nacional e as ciências naturais no Brasil Império. In: DANTES, Maria Amélia M. (Org.). Espaços da ciência no Brasil: 1800-1930. Rio de Janeiro: Editora Fiocruz, 2001, p. 83-110.

DOMINGUES, Heloisa Maria Bertol, SÁ, Magali Romero, GLICK, Thomas (Orgs.). A recepção do darwinismo no Brasil. Rio de Janeiro: Editora da Fiocruz, 2003.

DOMINGUES, Heloisa Maria Bertol; SÁ, Magali Romero; PUIG-SAMPER, Miguel Ángel; RUIZ GUTIÉRREZ (Orgs.). Darwinismo meio ambiente e sociedade. São Paulo: Via Lettera; Rio de Janeiro: MAST, 2009.

EISENBERG, Peter L. A mentalidade dos fazendeiros no Congresso Agrícola de 1878. In: LAPA, José Roberto do Amaral. Modos de produção e realidade brasileira. Petrópolis, RJ: Vozes, 1980, p. 167-194.

ELIAS, Norbert. O processo civilizador. Tradução de Ruy Jungmann. Rio de Janeiro: Jorge Zahar. 1994. $2 \mathrm{v}$.

ENGEL, Magali. Meretrizes e doutores: saber médico e prostituição no Rio de Janeiro (1840-1890). São Paulo: Brasiliense, 2004.

FALCON, Francisco José Calazans. História das idéias. In: CARDOSO, Ciro Flamarion; VAINFAS, Ronaldo (Orgs.). Domínios da História: ensaios de teoria e metodologia. Rio de Janeiro: Editora Campos, 1997, p. 91-126.

FERNANDES, Maria Fernanda Lombardi. A esperança e o desencanto: Silva Jardim e a República. São Paulo: Humanitas, 2008. 
FERREIRA, Jonatas; HAMLIN, Cynthia. Mulheres, negros e outros monstros: um ensaio sobre corpos não civilizados. Revista Estudos Feministas, Florianópolis, v. 18, n. 3, p. 811-836, set./dez. 2010.

FERREIRA, Tania Maria Bessone da Cruz. Palácios de destinos cruzados: bibliotecas, homens e livros no Rio de Janeiro, 1870-1920. Rio de Janeiro: Arquivo Nacional, 1999.

FIGUEIRÔA, Silvia. As ciências geológicas no Brasil: uma história social institucional, 1875-1934. São Paulo: Hucitec, 1997.

FONSECA, Maria Rachel Fróes da. As "Conferências Populares da Glória": a divulgação do saber científico. História, ciências, saúde - Manguinhos, Rio de Janeiro, Casa de Oswaldo Cruz / Fiocruz, v. 2, n. 3, p. 135-166, nov. 1995/fev. 1996.

FRANCHETTI, Paulo. O primo Basílio e a batalha do realismo no Brasil. In: BERRINI, Beatriz (Org.). Eça \& Machado. Conferências e textos das mesas redondas do Simpósio Internacional Eça \& Machado - setembro de 2003. São Paulo: EDUC, Fapesp, Fundação Gulbenkian, 2005, p. 89-113.

FREIRE, Jonis. Escravidão e família escrava na Zona da Mata Mineira. Tese (Doutorado em História) - Universidade Estadual de Campinas, Campinas, 2009.

FREIRE, Maria Martha de Luna. Mulheres, mães e médicos: discurso maternalista no Brasil. Rio de Janeiro: Editora FGV, 2009.

FREITAS, Marcus Vinícius de. Charles Frederick Hartt, um naturalista no império de Pedro II. Belo Horizonte: Editora UFMG, 2002.

GERBI, Antonello. O novo mundo: história de uma polêmica: 1750-1900. Tradução de Bernardo Joffily. São Paulo: Companhia das Letras, 1996.

GIRÓN SIERRA, Álvaro. Darwinismo, darwinismo social e izquierda política (18591914). Reflexiones de carácter general. In: MIRANDA, Marisa; VALLEJO, Gustavo (Comp.). Darwinismo social y eugenesia en el mundo latino. Buenos Aires: Siglo XXI de Argentina Editores, 2005, p. 23-58.

GLICK, Thomas $\mathrm{F}$ (Ed.). The comparative reception of Darwinism. Chicago: University of Chicago Press, 1988.

GLICK, Thomas F., RUIZ GUTIÉRREZ, Rosaura; PUIG-SAMPER, Miguel Ángel (Ed.). El darwinismo en España y Iberoamérica. México, DF: Universidad Autónoma de México; Madrid: Consejo Superior de Investigaciones Científicas, Ediciones Doce Calles, 1999.

GOMES, Ana Carolina Vimieiro. Um programa de "sciencia do Brazil": a inserção da fisiologia experimental na agenda científica brasileira em fins do século XIX (18801889). Tese (Doutorado em História) - Faculdade de Filosofia e Ciências Humanas, Universidade Federal de Minas Gerais, Belo Horizonte, 2009.

GONDRA, José Gonçalves. Artes de civilizar: medicina, higiene e educação escolar na Corte imperial. Rio de Janeiro: EdUERJ, 2004. 
GONDRA, José Gonçalves; SHUELER, Alessandra. Educação, poder e sociedade no Império brasileiro. São Paulo: Cortez, 2008.

GOULD, Stephen Jay. Darwin e os grandes enigmas da vida. Tradução de Maria Elizabeth Martinez. 2 ed. São Paulo: Martins Fontes, 2006.

A falsa medida do homem. Tradução de Valter Lellis Siqueira. 2 ed. São Paulo: Martins Fontes, 1999.

Lance de dados: a idéia de evolução de Platão a Darwin. Tradução de Sergio Moraes Rego. Rio de Janeiro: Record, 2001.

A Vênus hotentote. In: O sorriso do flamingo: reflexões sobre história

natural. Tradução de Luís Carlos Borges. São Paulo: Martins Fontes, 1990, p. 271-283.

GRAHAM, Sandra Lauderdale. Proteção e obediência: criadas e seus patrões no Rio de Janeiro, 1860-1910. São Paulo: Companhia das Letras, 1992.

GUALTIERI, Regina Cândida Ellero. O evolucionismo na produção científica do Museu Nacional do Rio de Janeiro (1876-1915). In: DOMINGUES, Heloisa Maria Bertol e SÁ, Magali Romero. In: DOMINGUES, Heloisa Maria Bertol, SÁ, Magali Romero, GLICK, Thomas (Orgs.). A recepção do darwinismo no Brasil. Rio de Janeiro: Editora da Fiocruz, 2003, 45-96.

Evolucionismo no Brasil: ciência e educação nos museus 1870-1915. São Paulo: Editora Livraria da Física, 2008.

HABERMAS, Jürgen. Mudança estrutural da esfera pública. Rio de Janeiro: Tempo Brasileiro, 1984.

HALLEWELL, Laurence. O livro no Brasil: sua história. Tradução de Maria da Penha Vilalobos, Lólio Lourenço de Oliveira e Geraldo Gerson de Souza. 2 ed. São Paulo: Edusp, 2005.

HAROCHE, Claudine. Da palavra ao gesto. Tradução de Ana Montoia e Jacy Seixas. Campinas, SP: Papirus, 1998.

HOFBAUER, Andreas. Uma história do branqueamento ou o negro em questão. São Paulo: Editora Unesp, 2006.

KEULLER, Adriana Tavares do Amaral Martins. Os estudos físicos de antropologia no Museu Nacional do Rio de Janeiro: cientistas, objetos, idéias e instrumentos (18761939). Tese (Doutorado em História Social) - Universidade de São Paulo, São Paulo, 2008.

KODAMA, Kaori. Os índios no Império do Brasil: a etnografia do IHGB entre as décadas de 1840 e 1860. Rio de Janeiro: Editora Fiocruz; São Paulo: Edusp, 2009.

KOSELLECK, Reinhart. Futuro passado. Para uma semântica de los tiempos históricos. Barcelona: Ediciones Paidós Ibérica, 1993. 
KOUTSOUKOS, Sandra Sofia Machado. Negros no estudo do fotógrafo: Brasil, segunda metade do século XIX. Campinas, SP: Editora da Unicamp, 2010.

LESSER, Jeffrey. A negociação da identidade nacional: imigrantes, minorias e a luta pela etnicidade no Brasil. Tradução de Patricia de Queiroz Carvalho Zimbres. São Paulo: Editora Unesp, 2001.

LIMA, Ivana Stolze. Cores, marcas e falas: sentidos da mestiçagem no Império do Brasil. Rio de Janeiro: Arquivo Nacional, 2003.

LIMA, Luiz Costa. Da existência precária: o sistema intelectual no Brasil. In:

Dispersa demanda: ensaios sobre literatura e teoria. Rio de Janeiro: Francisco Alves, 1981, p. 3-29.

LIMA, Silvio Cezar de Souza. Determinismo biológico e imigração chinesa em Nicolau Moreira (1870-1890). Dissertação (Mestrado em História das Ciências da Saúde) Casa de Oswaldo Cruz, Fundação Oswaldo Cruz, Rio de Janeiro, 2005.

LOPES, Maria Margaret. O Brasil descobre a pesquisa científica: os museus e as ciências naturais no século XIX. São Paulo: Hucitec, 1997.

MACHADO, Maria Helena Pereira Toledo. Brasil a vapor: raça, ciência e viagem no século XIX. Tese (Livre Docência) - Faculdade de Filosofia Letras e Ciências Humanas, Universidade de São Paulo, São Paulo, 2005.

A ciência norte-americana visita a Amazônia: entre o criacionismo cristão e o poligenismo “degeneracionista”. Revista USP, São Paulo, n.75, p. 68-75, set./nov. 2007.

Corpo, gênero e identidade no limiar da abolição: a história de Benedicta Maria Albina da Ilha ou Ovídia, escrava (Sudeste, 1880). Afro-Ásia, Salvador, n. 42, p. 157$193,2010$.

Entre dois Beneditos: histórias de amas de leite no ocaso da escravidão. In: GOMES, Flávio dos Santos; CÔRTES, Giovana Xavier da Conceição; FARIAS, Juliana Barreto (Orgs.). Mulheres Negras no Brasil escravista e do pós-emancipação. São Paulo: Summus Editorial, 2012 (no prelo).

Introdução: o adão norte-americano no éden amazônico. In: (Org.). $O$ Brasil no olhar de William James: cartas, diários e desenhos, 1865-1866. São Paulo: Editora da Universidade de São Paulo, 2010.

O plano e o pânico: os movimentos sociais na década da abolição. $2^{\mathrm{a}}$ ed. São Paulo: Edusp, 2010.

MACHADO, Roberto; LOUREIRO, Angela; LUZ, Rogerio; MURICY, Katia. Danação da norma: a medicina social e constituição da psiquiatria no Brasil. Rio de Janeiro: Edições Graal, 1978.

MAIO, Marcos Chor. Raça, doença e saúde pública no Brasil: um debate sobre o pensamento higienista do século XIX. In: MAIO, Marcos Chor; SANTOS, Ricardo 
Ventura. Raça como questão: história, ciência e identidades no Brasil. Rio de Janeiro: Editora Fiocruz, 2010, p. 51-82.

MALTA, Marize. Fundo, detalhe e satisfação visual: decoração doméstica em $A$ Estação. In: KNAUSS, Paulo (et. al.) (Orgs.). Revistas ilustradas: modos de ler e ver no Segundo Reinado. Rio de Janeiro: Mauad X: Faperj, 2011, p. 91-104.

MARINHO, Pedro Eduardo Mesquita de Monteiro. De politécnicos a engenheiros: a engenharia entre a sociedade civil e a sociedade política no Brasil oitocentista. In: ALMEIDA, Marta de, VERGARA, Moema de Rezende. Ciência, história $e$ historiografia. São Paulo: Via Lettera; Rio de Janeiro: MAST, 2008, p. 13-24.

MARTINEZ, Alessandra Frota. Educar e instruir: a instrução popular na corte imperial - 1879-1889. Dissertação (Mestrado em História) - Universidade Federal Fluminense, Rio de Janeiro, 1997.

MARTÍNEZ-CONTRERAS, Jorge. Las primeras descripciones de antropoides en el siglo XVII y su importancia para filosofía de la evolución. In: ROSAS L., Alejandro (Ed.). Filosofía, darwinismo y evolución. Bogotá: Universidad Nacional de Colombia. Facultad de Ciencias Humanas, 2007, p. 181-217.

MARTINS, Ana Paula Vosne. Visões do feminino: a medicina da mulher nos séculos XIX e XX. Rio de Janeiro: Editora Fiocruz, 2004.

MASIERO, André Luís. A psicologia racial no Brasil (1918-1929). Estudos de Psicologia, Natal, v. 10, n. 2, p. 199-206, 2005.

MASSARANI, Luisa. A divulgação científica no Rio de Janeiro: alguns aspectos sobre a década de 20. Dissertação (Mestrado em Ciência da Informação) - Escola de Comunicação, Universidade Federal do Rio de Janeiro, Rio de Janeiro, 1998.

MASSARANI, Luisa; MOREIRA, Ildeu de Castro. Popularisation of Science: historical perspectives and permanente dilemas. Quark, n. 32, p. 75-79, april-june 2004.

MATTOS, Hebe Maria. Das cores do silêncio: os significados da liberdade no Sudeste escravista, Brasil Século XIX. Rio de Janeiro: Nova Fronteira, 1998.

MAYR, Ernst. Biologia, ciência única: reflexões sobre a autonomia de uma disciplina científica. São Paulo: Companhia das Letras, 2005.

MCKITTERICK, David. A biblioteca como interação: a leitura e a linguagem da bibliografia. In: BARATIN, Marc; JACOB, Christian (Orgs.). O poder das bibliotecas: a memória dos livros no Ocidente. Tradução de Marcela Mortara. Rio de Janeiro: Editora UFRJ, 2000, p. 94-107.

MONTEIRO, John Manuel. As "raças" indígenas no pensamento brasileiro do Império. In: MAIO, Marco Chor; SANTOS, Ricardo Ventura (Orgs.). Raça, ciência e sociedade. Rio de Janeiro: Editora Fiocruz / CCBB, 1996, p. 15-22.

Entre o gabinete e o sertão: projetos civilizatórios, inclusão e exclusão dos índios no Brasil Imperial. In: Tupis, tapuias e historiadores: estudos de história 
indígena e do indigenismo. Tese (Livre Docência) - Universidade Estadual de Campinas, Campinas, SP, 2001, p.129-169.

MONTSERRAT, Marcelo. La mentalidad evolucionista en la Argentina: una ideología del progreso. In: GLICK, Thomas F., RUIZ GUTIÉRREZ, Rosaura; PUIG-SAMPER, Miguel Ángel (Ed.). El darwinismo en España y Iberoamérica. México, DF: Universidad Autónoma de México; Madrid: Consejo Superior de Investigaciones Científicas, Ediciones Doce Calles, 1999, p. 16-46.

MOREIRA, Ildeu de Castro; MASSARANI, Luisa. Aspectos históricos da divulgação científica no Brasil. In: MOREIRA, Ildeu de Castro; MASSARANI, Luisa; BRITO, Maria de Fátima (Orgs.). Ciência e público: caminhos da divulgação científica no Brasil. Rio de Janeiro: Casa da Ciência, 2002, p. 43-64.

MOREL, Marco. As transformações do espaço público: imprensa, atores políticos e sociabilidades na Corte Imperial, 1820-1840. São Paulo: Hucitec, 2005.

MORENO, Roberto. La polémica del darwinismo en México: siglo XIX. México, DF: Universidad Autónoma de México, 1989.

MOTT, Maria Lucia. Parteiras: o outro lado da profissão. Gênero, Niterói, RJ, v. 6, n. 11, p. 117-140, 2 sem. 2005.

MUNANGA, Kabengele. Uma abordagem conceitual das noções de raça, racismo, identidade e etnia. Palestra proferida no $3^{\circ}$ Seminário Nacional Relações Racial e Educação - PENESB-RJ, 05/11/03. Disponível em: <http://www.ufmg.br/inclusaosocial/?p=59>. Acesso: 08 dez. 2011.

MUÑOZ RUBIO, Julio. Una crítica a las raíces del concepto capitalista de escasez ( $T$. Malthus, D. Hume, A. Smith y C. Darwin). México, DF: Centro de Investigaciones Interdisciplinarias en Ciencias y Humanidades, Universidad Nacional Autónoma de México, 2005.

NARANJO OROVIO, Consuelo; GARCÍA GONZÁLEZ, Armando. Racismo $e$ inmigración en Cuba en el siglo XIX. Madrid: Doce Calles; Fundación de Investigaciones Marxistas, 1996.

NARANJO OROVIO, Consuelo; PUIG-SAMPER, Miguel Ángel. "Delincuencia y racismo en Cuba: Israel Castellanos versus Fernando Ortiz". In: HUERTAS, Rafael; ORTIZ, Carmen (ed.). Ciencia y fascismo. Madrid: Doce Calles, 1998, p. 11-23.

NASCIMENTO. Kelly Cristina. Entre a mulher ideal e a mulher moderna: representações femininas na imprensa mineira - 1873-1932. Dissertação (Mestrado em História) - Faculdade de Filosofia e Ciências Humanas, Universidade Federal de Minas Gerais, Belo Horizonte, 2006.

NUMBERS, Ronald L.; STENHOUSE, John (Ed.). Disseminating Darwinism: the role of place, race, religion, and gender. Cambridge: Cambridge University Press, 2001.

PAPAVERO, Nelson. Fritz Müller e a comprovação da teoria de Darwin. In: DOMINGUES, Heloisa Maria Bertol, SÁ, Magali Romero, GLICK, Thomas (Orgs.). A recepção do darwinismo no Brasil. Rio de Janeiro: Editora da Fiocruz, 2003, p. 29-44. 
PELAYO-LÓPEZ, Francisco. ¿"Hombre terciario” o precursor humano?: Sílex, transformismo y los orígenes de la humanidad. In: DOMINGUES, Heloisa Maria Bertol; SÁ, Magali Romero; PUIG-SAMPER, Miguel Ángel; RUIZ GUTIÉRREZ Rosaura (Orgs.). Darwinismo meio ambiente e sociedade. São Paulo: Via Lettera; Rio de Janeiro: MAST, 2009, p. 161-176.

PEREIRA, Júnia Sales. História, ciência e infância: narrativas profissionais no processo de singularização da pediatria como especialidade. Brasília: CAPES; Belo Horizonte: Argvmentvum, 2008.

PEREIRA, Mário Eduardo Costa. Morel e a questão da degenerescência. Revista Latinoamericana de Psicopatologia Fundamental, São Paulo, v. 11, n. 3, p. 490-496, 2008.

PESAVENTO, Sandra Jathay. Exposições universais: espetáculos da modernidade do século XIX. São Paulo: Hucitec, 1997.

PIMENTA, Tânia Salgado. Os exercícios das artes de curar no Rio de Janeiro (18281955). Tese (Doutorado em História) - Universidade Estadual de Campinas, Campinas, 2003.

POLIAKOV, Léon. $O$ mito ariano. Tradução de Luiz João Gaio. São Paulo: Perspectiva, Editora da Universidade de São Paulo, 1974.

PRATT, Mary Louise. Os olhos do império: relatos de viagem e transculturação. Tradução de Jézio Hernani Bonfim Guitierre. Bauru, SP: Edusc, 1999.

PUIG-SAMPER, Miguel Ángel; RUIZ GUTIÉRREZ, Rosaura; GALERA, Andrés (Ed.). Evolucionismo y cultura: darwinismo en Europa e Iberoamérica. México, DF: Junta de Extremadura, Universidad Nacional Autónoma de México, Ediciones Doce Calles, 2002.

RAMOS, Jair de Souza; MAIO, Marcos Chor. Entre a riqueza natural, a pobreza humana e os imperativos da civilização, inventa-se a investigação do povo brasileiro. In: MAIO, Marcos Chor; SANTOS, Ricardo Ventura. Raça como questão: história, ciência e identidades no Brasil. Rio de Janeiro: Editora Fiocruz, 2010, p. 25-50.

REIS, João José. Domingos Sodré, um sacerdote africano: escravidão, liberdade e candomblé na Bahia do século XIX. São Paulo: Companhia das letras, 2008.

ROBERTS, Jon. Louis Agassiz: poligenismo, transmutação e a metodologia científica. Uma reavaliação. In: DOMINGUES, Heloisa Maria Bertol; SÁ, Magali Romero; PUIGSAMPER, Miguel Ángel; RUIZ GUTIÉRREZ, Rosaura (Orgs.). Darwinismo meio ambiente e sociedade. São Paulo: Via Lettera; Rio de Janeiro: MAST, 2009, p. 73-100.

RODRIGUES, Jaime. O fim do tráfico transatlântico de escravos para o Brasil. In: GRINBERG, Keila; SALLES, Ricardo (Orgs.). O Brasil Imperial, volume II: 18311870. Rio de Janeiro: Civilização Brasileira, 2009, p. 297-337.

ROHDEN, Fabíola. Uma ciência da diferença: sexo e gênero na medicina da mulher. Rio de Janeiro: Editora Fiocruz, 2001. 
ROMERO, Mariza. Medicalização da saúde e exclusão social. Bauru, SP: Edusc, 2002.

ROSA, Russel Teresinha D. da; SOBRINHO, João Batista de S. Publicações brasileiras e o desenvolvimento das ciências no século XIX. Episteme, Porto Alegre, v. 11, n. 23, p. 117-149, jan./jun. 2006.

RUIZ GUTIÉRREZ, Rosaura. Positivismo y evolución: introducción del darwinismo en México. México, DF: Limusa, 1991.

RUSE, Michael. Evolución y progreso: crónica de los conceptos. In: WAGENSBERG, Jorge; AGUSTÍ, Jordi (Eds.). El progreso ¿Un concepto acabado o emergente? Traducción de Ambrosio García Leal. Barcelona: Tusquets Editores, 1998, p. 67-106.

SÁ, Guilherme José da Silva; SANTOS, Ricardo Ventura; RODRIGUESCARVALHO, Claudia; SILVA, Elizabeth Christina. Crânios, corpos e medidas: a constituição do acervo de instrumentos antropométricos do Setor de Antropologia Biológica do Museu Nacional no fim do século XIX - início do século XX. In: MAIO, Marcos Chor; SANTOS, Ricardo Ventura (Orgs.). Raça como questão: história, ciência e identidades no Brasil. Rio de Janeiro: Editora Fiocruz, 2010, p. 109-127.

SÁ, Magali Romero; DOMINGUES, Maria Bertol Domingues. O Museu Nacional e o ensino das ciências naturais no Brasil no século XIX. Revista da SBHC, n. 15, p. 79-88, 1996.

SADÍN, Máximo. Sobre una redundancia: el darwinismo social. Asclepio, v. LII, n. 2, p. 27-50, 2000.

SAMPAIO, Gabriela dos Reis. Juca Rosa: um pai-de-santo na Corte imperial. Rio de Janeiro: Arquivo Nacional, 2009.

Nas trincheiras da cura: as diferentes medicinas no Rio de Janeiro. Campinas, SP: Editora da Unicamp, CECULT, IFCH, 2001.

SÁNCHEZ MORA, Ana María. A divulgação da ciência como literatura. Tradução de Silvia Pérez Amato. Rio de Janeiro: Casa da Ciência - Centro Cultural de Ciência e Tecnologia da Universidade Federal do Rio de Janeiro: Editora UFRJ, 2003.

SANTOS, Gislene Aparecida dos. A invenção do "ser negro": um percurso das idéias que naturalizaram a inferioridade dos negros. São Paulo: Educ/Fapesp; Rio de Janeiro: 2005.

SANTOS, Ricardo Ventura. Mestiçagem, degeneração e a viabilidade de uma nação: debates em antropologia física no Brasil (1870-1930). In: MAIO, Marcos Chor; SANTOS, Ricardo Ventura. Raça como questão: história, ciência e identidades no Brasil. Rio de Janeiro: Editora Fiocruz, 2010, p. 83-109.

SCHWARCZ. Lilia Moritz. Previsões são sempre traiçoeiras: João Baptista de Lacerda e seu Brasil branco. História, Ciências, Saúde - Manguinhos, Rio de Janeiro, v.18, n.1, p. 225-242, jan.-mar. 2011. 
SCOTT, Joan. História das mulheres. In: BURKE, Peter (Org.). A escrita da história: novas perspectivas. Tradução de Magda Lopes. São Paulo: Editora Unesp, 1992, p. 6395.

Prefácio a Gender and politics of history. Tradução de Mariza Corrêa. Cadernos Pagu, Campinas, SP, vol. 3, p. 11-27, 1994.

SEYFERTH, Giralda. Colonização, imigração e a questão racial no Brasil. Revista USP, São Paulo, n. 53, p. 117-149, março/maio 2002.

Construindo a nação: hierarquias raciais e o papel do racismo na política de imigração e colonização. In: MAIO, Marco Chor; SANTOS, Ricardo Ventura (Orgs.). Raça, ciência e sociedade. Rio de Janeiro: Editora Fiocruz / CCBB, 1996, p. 41-58.

SILVEIRA, Renato da. Os selvagens e a massa: papel do racismo científico na montagem da hegemonia ocidental. Afro-Ásia, n. 23, p. 87-144, 1999.

SLENES, Robert W. Na senzala uma flor: esperanças e recordações na formação da família escrava - Brasil, Sudeste, século XIX. Rio de Janeiro: Nova Fronteira, 1999.

STAROBINSKI, Jean. A palavra "civilização". In: . As máscaras da civilização: ensaios. Tradução de Maria Lúcia Machado. São Paulo: Companhia das Letras, 2001. p. $11-56$.

STEPAN, Nancy Leys. A hora da eugenia: raça, gênero e nação na América Latina. Rio de Janeiro: Editora Fiocruz, 2005.

STROTHER, S. Z. Display of the Body Hottentot. In: LINDFORS, Bernth (Ed.). Africans on stage: studies in ethnological show business. Bloomington: Indiana University Press, 1999, p. 1-61.

TILLY, Louise A. Gênero, história das mulheres e história social. Tradução de Ricardo Augusto Ferreira. Cadernos Pagu, Campinas, SP, vol. 3, p. 29-62, 1994.

TODOROV, Tzvetan. Nós e os outros: a reflexão francesa sobre a diversidade humana. Tradução de Sergio Goes de Paula. v. 1. Rio de Janeiro: Jorge Zahar, 1993.

TURACK, Cynthia Fevereiro. Mulheres-mãe: memória e construção de sentidos no discurso do periódico A Mãi de Familia (1879-1888). Dissertação (Mestrado em Memória Social) - Centro de Ciências Humanas e Sociais, Universidade Federal do Estado do Rio de Janeiro, Rio de Janeiro, 2008.

VARELA, Alex Gonçalves. Atividades científicas na "Bela e Bárbara" capitania de São Paulo (1796-1823). São Paulo: Annablume, 2009.

VARIKAS, Eleni. Gênero, experiência e subjetividade: a propósito do desacordo TillyScott. Tradução de Ricardo Augusto Ferreira. Cadernos Pagu, Campinas, SP, vol. 3, p. 63-84, 1994.

VENÂNCIO, Renato Pinto. Famílias abandonadas: assistência à crina de camadas populares no Rio de Janeiro e em Salvador - séculos XVIII e XIX. Campinas, SP: Papirus, 1999. 
VERGARA, Moema de Rezende. "Cartas a uma senhora": questões de gênero e a divulgação do darwinismo no Brasil. Estudos Feministas, Florianópolis, n. 15, v. 2, p. 383-398. maio-ago. 2007.

Ciência, cultura e público: periódicos científicos-literários no Rio de Janeiro oitocentista. In: Anais complementares do XXIV Simpósio de História. São Leopoldo, RS: Unisinos, 2007.

Contexto e conceitos: história da ciência e "vulgarização científica" no Brasil do século XIX. Interciencia, vol. 33, n. 5, p. 324-330, may 2008.

Ensaio sobre o termo "vulgarização científica" no Brasil do século XIX. Revista

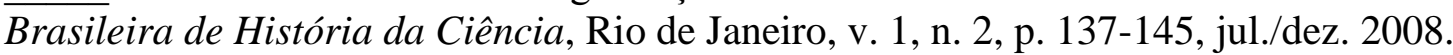

A Revista Brazileira: vulgarização científica e construção da identidade nacional na passagem da Monarquia para a República. Tese (Doutorado em História) - Pontifícia Universidade Católica do Rio de Janeiro, Rio de Janeiro, 2003.

WEST, David. Fritz Müller, o biólogo evolucionista pioneiro no Brasil. In: DOMINGUES, Heloisa Maria Bertol; SÁ, Magali Romero; PUIG-SAMPER, Miguel Ángel; RUIZ GUTIÉRREZ (Orgs.). Darwinismo meio ambiente e sociedade. São Paulo: Via Lettera; Rio de Janeiro: MAST, 2009, p. 41-44.

XAVIER, Regina Célia Lima. A conquista da liberdade. Libertos em Campinas na segunda metade do século XIX. Campinas, SP: Área de Publicações CMU/UNICAMP, 1996. 


\section{Anexos}

\section{Anexo 1 - Dados biográficos profissionais dos conferencistas até 1889}

\begin{tabular}{|c|c|c|c|c|}
\hline Conferencista & Formação & Local de Formação & Atuação Política & Ocupação Profissional \\
\hline $\begin{array}{l}\text { Affonso Celso de Assis } \\
\text { Figueiredo } \\
(\mathbf{1 8 3 7 - 1 9 1 2 )}\end{array}$ & Direito & $\begin{array}{l}\text { Faculdade de Direito de } \\
\text { São Paulo }\end{array}$ & $\begin{array}{l}\text { Foi oficial de gabinete dos presidentes Diogo de } \\
\text { Vasconcellos e Fernandes Torres. Para a província } \\
\text { de Minas Gerais foi - secretário da polícia, } \\
\text { inspetor da tesouraria província, procurador fiscal } \\
\text { da tesouraria geral, além de ter sido deputado } \\
\text { provincial. Representou a província mineira nas } \\
\text { seguintes legislaturas: } 12^{\mathrm{a}}, 13^{\mathrm{a}} \text { e } 17^{\mathrm{a}} \text {. Tornou-se } \\
\text { senador do Império em } 1879 ; \text { ministro e secretário } \\
\text { de estado dos negócios da marinha no gabinete de } \\
03 / 08 / 1866 \text {, ministro da fazenda no gabinete de } \\
05 / 01 / 1878 \text {. Conselheiro do Imperador. }\end{array}$ & Advocacia. \\
\hline $\begin{array}{l}\text { Antenor Augusto Ribeiro } \\
\text { Guimarães }\end{array}$ & Medicina & & & \\
\hline $\begin{array}{l}\text { Antonio Ferreira Vianna } \\
(1833-1903)\end{array}$ & Direito & $\begin{array}{l}\text { Faculdade de Direito de } \\
\text { São Paulo }\end{array}$ & $\begin{array}{l}\text { Atuou como promotor público da capital imperial. } \\
\text { Representou Corte na câmara temporária nas } \\
\text { legislaturas de } 1869 \text { a } 1877 \text { e na primeira realizada } \\
\text { por eleição direta. }\end{array}$ & $\begin{array}{l}\text { Diretor geral das aulas municipais, advogado } \\
\text { dos auditórios da Corte. }\end{array}$ \\
\hline $\begin{array}{l}\text { Antonio Herculano de } \\
\text { Souza Bandeira Filho }\end{array}$ & Direito & $\begin{array}{l}\text { Faculdade de Direito do } \\
\text { Recife }\end{array}$ & $\begin{array}{l}\text { Foi diretor da } 2^{\mathrm{a}} \text { seção da secretaria de estado dos } \\
\text { negócios de justiça. }\end{array}$ & $\begin{array}{l}\text { Professor de filosofia e direito natural público e } \\
\text { constitucional da escola normal. A cargo do } \\
\text { governo, foi à Europa para visitar os jardins de } \\
\text { infância e estudar as escolas normais. Ao } \\
\text { retornar ao Brasil, foi nomeado diretor da } \\
\text { instrução pública da Corte. }\end{array}$ \\
\hline $\begin{array}{l}\text { Antonio José Pereira da } \\
\text { Silva Araujo }\end{array}$ & Medicina & $\begin{array}{l}\text { Faculdade de Medicina } \\
\text { da Bahia }\end{array}$ & & $\begin{array}{l}\text { Professor de clínica de moléstias sifílicas e da } \\
\text { pele, e diretor do laboratório de microscopia da } \\
\text { Policlínica Geral do Rio de Janeiro. }\end{array}$ \\
\hline $\begin{array}{l}\text { Augusto Cezar de } \\
\text { Miranda Azevedo } \\
(\mathbf{1 8 5 1 - 1 9 0 7 )}\end{array}$ & Medicina & $\begin{array}{l}\text { Faculdade de Medicina } \\
\text { do Rio de Janeiro }\end{array}$ & & $\begin{array}{l}\text { Após clinicar na Corte, exerceu sua profissão } \\
\text { na província de São Paulo. }\end{array}$ \\
\hline
\end{tabular}




\begin{tabular}{|c|c|c|c|}
\hline $\begin{array}{l}\text { Carlos Antonio de Paula } \\
\text { Costa } \\
(1844-?)\end{array}$ & Medicina & $\begin{array}{l}\text { Faculdade de Medicina } \\
\text { do Rio de Janeiro }\end{array}$ & $\begin{array}{l}\text { Médico e bibliotecário da Faculdade de } \\
\text { Medicina. Em } 1876 \text { foi médico da Escola } \\
\text { Militar e de uma das enfermarias criadas pelo } \\
\text { governo para cuidar dos pacientes com febre } \\
\text { amarela. Foi um dos fundadores da Policlínica } \\
\text { do Rio de Janeiro. Redator do jornal A Mãi de } \\
\text { Familia }\end{array}$ \\
\hline $\begin{array}{l}\text { Carlos Arthur Moncorvo } \\
\text { de Figueiredo } \\
(\mathbf{1 8 4 6 - 1 9 0 1 )}\end{array}$ & Medicina & $\begin{array}{l}\text { Faculdade de Medicina } \\
\text { do Rio de Janeiro }\end{array}$ & $\begin{array}{l}\text { Professor de clínica das moléstias da infância } \\
\text { na Policlínica do Rio de Janeiro. }\end{array}$ \\
\hline $\begin{array}{l}\text { Carlos Luiz de Saules } \\
\text { Junior } \\
\text { (1824-1880) }\end{array}$ & Medicina & $\begin{array}{l}\text { Faculdade de Medicina } \\
\text { do Rio de Janeiro }\end{array}$ & $\begin{array}{l}\text { Médico do Hospital de Misericórdia e do } \\
\text { Internato do colégio Pedro II. Foi subdiretor da } \\
\text { seção de "Ciências físicas: mineralogia, } \\
\text { geologia e paleontologia geral", do Museu } \\
\text { Nacional, até a sua morte em } 1880 \text {. }\end{array}$ \\
\hline $\begin{array}{l}\text { Charles Frederick Hartt } \\
(1840-1878)\end{array}$ & Geologia & & $\begin{array}{l}\text { Chefiou a Comissão Geológica do Império. Foi } \\
\text { diretor da seção de "Ciências físicas: } \\
\text { mineralogia, geologia e paleontologia geral" } \\
\text { até } 1878 \text {, quando faleceu. }\end{array}$ \\
\hline $\begin{array}{l}\text { Feliciano Pinheiro de } \\
\text { Bittencourt } \\
\text { (1854-?) }\end{array}$ & Medicina & $\begin{array}{l}\text { Faculdade de Medicina } \\
\text { do Rio de Janeiro }\end{array}$ & $\begin{array}{l}\text { Lecionou várias disciplinas em colégios do Rio } \\
\text { de Janeiro, foi professor de história e } \\
\text { corografia do Pedro II. }\end{array}$ \\
\hline $\begin{array}{l}\text { Fernando Pires Ferreira } \\
(1843-?)\end{array}$ & Medicina & $\begin{array}{l}\text { Faculdade de Medicina } \\
\text { de Paris }\end{array}$ & \\
\hline $\begin{array}{l}\text { Francisco Ignacio de } \\
\text { Carvalho Rezende }\end{array}$ & Direito & $\begin{array}{ll}\text { Faculdade de Direito de } & \begin{array}{l}\text { Representou o Piauí no parlamento na } 16^{\mathrm{a}} \\
\text { legislatura. }\end{array}\end{array}$ & \\
\hline Francisco José de Freitas & Engenharia & & \\
\hline $\begin{array}{l}\text { Francisco Marques de } \\
\text { Araújo Góes } \\
\text { (1837-?) }\end{array}$ & Medicina & $\begin{array}{l}\text { Faculdade de Medicina } \\
\text { da Bahia }\end{array}$ & $\begin{array}{l}\text { Professor de história natural do colégio Pedro } \\
\text { II, adjunto à Inspetoria Geral de Higiene. }\end{array}$ \\
\hline $\begin{array}{l}\text { Francisco Ribeiro de } \\
\text { Mendonça }\end{array}$ & Medicina & $\begin{array}{l}\text { Faculdade de Medicina } \\
\text { do Rio de Janeiro }\end{array}$ & $\begin{array}{l}\text { Professor adjunto da cadeira de botânica e } \\
\text { zoologia da Faculdade de Medicina da Corte. }\end{array}$ \\
\hline Guilherme Belmonte & Medicina & & Professor de clínica oftalmológica da \\
\hline
\end{tabular}




\begin{tabular}{|c|c|c|c|c|}
\hline & & & & Faculdade de Medicina do Rio de Janeiro. \\
\hline Hilário Soares de Gouveia & Medicina & $\begin{array}{l}\text { Faculdade de Medicina } \\
\text { do Rio de Janeiro }\end{array}$ & & \\
\hline $\begin{array}{l}\text { João Baptista de Lacerda } \\
\text { Filho } \\
(1846-1915)\end{array}$ & Medicina & $\begin{array}{l}\text { Faculdade de Medicina } \\
\text { do Rio de Janeiro }\end{array}$ & & $\begin{array}{l}\text { Clinicou na Corte. Foi subdiretor da seção de } \\
\text { antropologia, zoologia e paleontologia do } \\
\text { Museu Nacional; e do Laboratório de } \\
\text { Fisiologia da mesma instituição. }\end{array}$ \\
\hline $\begin{array}{l}\text { João Braz da Silveira } \\
\text { Caldeira } \\
(1841-?)\end{array}$ & $\begin{array}{l}\text { Fez estudos } \\
\text { especiais de } \\
\text { linguística } \\
\text { em Paris e } \\
\text { em } \\
\text { Bruxelas }\end{array}$ & & & $\begin{array}{l}\text { Lecionou geografia no Liceu de Artes e Ofícios } \\
\text { do Rio de Janeiro. }\end{array}$ \\
\hline $\begin{array}{l}\text { João Joaquim Pizarro } \\
(1842-1906)\end{array}$ & Medicina & $\begin{array}{l}\text { Faculdade de Medicina } \\
\text { do Rio de Janeiro }\end{array}$ & & $\begin{array}{l}\text { Lente de botânica e zoologia da Faculdade de } \\
\text { Medicina do Rio de Janeiro, lente da Faculdade } \\
\text { Livre de Direito do Rio de Janeiro, diretor da } \\
\text { seção de antropologia, zoologia e paleontologia } \\
\text { do Museu Nacional, diretor do asilo de } \\
\text { meninos desvalidos. }\end{array}$ \\
\hline $\begin{array}{l}\text { João Manoel Pereira da } \\
\text { Silva } \\
(\mathbf{1 8 1 7 - 1 8 9 8 )}\end{array}$ & Direito & $\begin{array}{l}\text { Faculdade de Direito de } \\
\text { Paris }\end{array}$ & $\begin{array}{l}\text { Deputado provincial em várias legislaturas desde } \\
\text { 1840, deputado geral desde } 1843 \text {, sendo } \\
\text { apresentado na lista tríplice de senadores várias } \\
\text { vezes, foi escolhido em } 1888 \text {. Filiado ao Partido } \\
\text { Conservador. Foi advogado do conselho de estado. } \\
\text { Conselheiro do Imperador. }\end{array}$ & $\begin{array}{l}\text { Atuou como advogado até } 1850 \text {, dedicou-se } \\
\text { também ao jornalismo. }\end{array}$ \\
\hline João Paulo de Carvalho & Medicina & $\begin{array}{l}\text { Faculdade de Medicina } \\
\text { do Rio de Janeiro }\end{array}$ & & $\begin{array}{l}\text { Lente da cadeira de fisiologia prática e } \\
\text { experimental da Faculdade de Medicina da } \\
\text { Corte. }\end{array}$ \\
\hline $\begin{array}{l}\text { Joaquim José Teixeira } \\
(1811-1885)\end{array}$ & Direito & $\begin{array}{l}\text { Faculdade de Direito de } \\
\text { São Paulo }\end{array}$ & $\begin{array}{l}\text { Juiz municipal da província do Rio de Janeiro, foi } \\
\text { deputado provincial por diversas vezes, presidente } \\
\text { de Sergipe em } 1839 \text {, representante desta mesma } \\
\text { província nas legislaturas de } 1848 \text { a } 1851 \text {. }\end{array}$ & Exerceu advocacia na cidade do Rio de Janeiro. \\
\hline $\begin{array}{l}\text { Joaquim Monteiro } \\
\text { Caminhoá } \\
(\mathbf{1 8 3 6 - 1 8 9 6 )}\end{array}$ & Medicina & $\begin{array}{l}\text { Faculdade de Medicina } \\
\text { da Bahia }\end{array}$ & Conselheiro do Imperador. & $\begin{array}{l}\text { Foi opositor da seção de ciências acessórias na } \\
\text { Faculdade de Medicina do Rio de Janeiro, } \\
\text { sendo depois lente de história natural do }\end{array}$ \\
\hline
\end{tabular}




\begin{tabular}{|c|c|c|c|c|}
\hline & & & & colégio Pedro II. \\
\hline $\begin{array}{l}\text { José Cardoso de Moura } \\
\text { Brazil } \\
(\mathbf{1 8 4 9 - 1 9 2 8 )}\end{array}$ & Medicina & $\begin{array}{l}\text { Faculdade de Medicina } \\
\text { da Bahia }\end{array}$ & & $\begin{array}{l}\text { Professor de clínica das moléstias dos olhos da } \\
\text { Policlínica Geral do Brasil. }\end{array}$ \\
\hline José da Cunha Ferreira & Medicina & & & \\
\hline $\begin{array}{l}\text { José de Saldanha da Gama } \\
(1839-1905)\end{array}$ & $\begin{array}{l}\text { Ciências } \\
\text { físicas e } \\
\text { matemática }\end{array}$ & $\begin{array}{l}\text { Escola Politécnica do } \\
\text { Rio de Janeiro }\end{array}$ & Foi cônsul geral do Brasil na Bélgica. & Professor de botânica da Escola Politécnica. \\
\hline $\begin{array}{l}\text { José Martins da Cruz } \\
\text { Jobim } \\
(\mathbf{1 8 0 2 - 1 8 7 8 )}\end{array}$ & Medicina & Faculdade de Paris & & \\
\hline $\begin{array}{l}\text { Joseph Auguste Aristide } \\
\text { Fort }\end{array}$ & Medicina & & & \\
\hline $\begin{array}{l}\text { Ladislau de Souza Mello } \\
\text { Netto } \\
(\mathbf{1 8 3 8 - 1 8 9 4 )}\end{array}$ & Botânica & & & $\begin{array}{l}\text { Entre } 1864 \text { e } 164 \text {, esteve na França para } \\
\text { aperfeiçoar seus conhecimentos em história } \\
\text { natural, frequentou aulas na Sorbonne e no } \\
\text { Jardim das Plantas de Paris. Nomeado } \\
\text { subdiretor do Museu Nacional em } 1870 \text {, } \\
\text { assumindo o cargo de diretor em } 1876 \text {, ficou na } \\
\text { direção desta instituição até o fim do Império. }\end{array}$ \\
\hline $\begin{array}{l}\text { Louis Couty } \\
(1854-1884)\end{array}$ & Medicina & & & $\begin{array}{l}\text { Veio para o Brasil para trabalhar lecionar na } \\
\text { Escola Politécnica, onde trabalhou por pouco } \\
\text { tempo. Em seguida foi para o Museu Nacional, } \\
\text { onde atuou como diretor do laboratório de } \\
\text { fisiologia experimental. }\end{array}$ \\
\hline Luiz Corrêa de Azevedo & Medicina & $\begin{array}{l}\text { Faculdade de Medicina } \\
\text { do Rio de Janeiro }\end{array}$ & & \\
\hline $\begin{array}{l}\text { Luiz Joaquim Duque- } \\
\text { Estrada Teixeira } \\
(\mathbf{1 8 3 6}-1884)\end{array}$ & Direito & $\begin{array}{l}\text { Faculdade de Direito de } \\
\text { São Paulo }\end{array}$ & $\begin{array}{l}\text { Filiado ao Partido Conservador. Foi juiz de paz, } \\
\text { deputado geral. }\end{array}$ & Advocacia. \\
\hline Lydia Pasckoff & & & & Escritora russa. \\
\hline $\begin{array}{l}\text { Manoel Francisco Correia } \\
(1831-1905)\end{array}$ & Direito & $\begin{array}{l}\text { Faculdade de Direito de } \\
\text { São Paulo }\end{array}$ & $\begin{array}{l}\text { Foi } 2^{\circ} \text { oficial da secretaria da fazenda, após foi } 1^{\circ} \\
\text { oficial, sendo transferido, neste mesmo cargo, para } \\
\text { secretaria do Império e depois para a da Justiça. }\end{array}$ & \\
\hline
\end{tabular}


Foi secretário do governo na Corte, oficial de

gabinete de mais de um ministro, presidente de

província, conselheiro de Estado extraordinário,

deputado e senador pela província paranaense, e

ministro dos negócios estrangeiros no gabinete de

07/03/1871

\begin{tabular}{|c|c|c|c|c|}
\hline $\begin{array}{l}\text { Nicolau Joaquim Moreira } \\
(\mathbf{1 8 2 4 - 1 8 9 4 )}\end{array}$ & Medicina & $\begin{array}{l}\text { Faculdade de Medicina } \\
\text { do Rio de Janeiro }\end{array}$ & Conselheiro do Imperador. & $\begin{array}{l}\text { Cirurgião do hospital militar. Diretor da seção } \\
\text { de botânica e subdiretor do Museu Nacional. } \\
\text { Diretor do Jardim Botânico. }\end{array}$ \\
\hline $\begin{array}{l}\text { Nuno Ferreira de Andrade } \\
(1851-1922)\end{array}$ & Medicina & $\begin{array}{l}\text { Faculdade de Medicina } \\
\text { do Rio de Janeiro }\end{array}$ & Conselheiro do Imperador. & $\begin{array}{l}\text { Professor da Faculdade de Medicina da Corte, } \\
\text { inspetor geral da saúde dos portos. }\end{array}$ \\
\hline $\begin{array}{l}\text { Octaviano Hudson } \\
(1837-1886)\end{array}$ & & & & Tipógrafo da Tipografia Nacional. \\
\hline $\begin{array}{l}\text { Orville Adalbert Derby } \\
(1851-1915)\end{array}$ & Geologia & $\begin{array}{l}\text { Universidade de } \\
\text { Cornell }\end{array}$ & & $\begin{array}{l}\text { Foi assistente de Charles Hartt na Comissão } \\
\text { Geológica do Império. Foi diretor da seção de } \\
\text { "Ciências físicas: mineralogia, geologia e } \\
\text { paleontologia geral" do Museu Nacional, a } \\
\text { partir de } 1879 .\end{array}$ \\
\hline Vicente Ferreira de Souza & Medicina & $\begin{array}{l}\text { Faculdade de Medicina } \\
\text { da Bahia }\end{array}$ & & Lecionou latim no Colégio Pedro II. \\
\hline $\begin{array}{l}\text { Tristão de Alencar } \\
\text { Araripe Filho } \\
(1848-1911)\end{array}$ & Direito & $\begin{array}{l}\text { Faculdade de Direito do } \\
\text { Recife }\end{array}$ & $\begin{array}{l}\text { Foi secretário do governo da província de Santa } \\
\text { Catarina; juiz municipal no Ceará, deputado desta } \\
\text { província de } 1872 \text { a } 1875 \text {. Foi nomeado, em } 1886 \text {, } \\
\text { secretário de Estado dos Negócios do Império. }\end{array}$ & Até 1886 exerceu advocacia na Corte. \\
\hline
\end{tabular}


Anexo 2 - Oradores que se apresentaram nas Conferências Populares da Glória entre 1873 e 1889

\begin{tabular}{|c|c|c|c|c|c|c|c|c|c|c|c|c|c|c|c|c|c|c|}
\hline Orador & Total & 1873 & 1874 & 1875 & 1876 & 1877 & 1878 & 1879 & 1880 & 1881 & 1882 & 1883 & 1884 & 1885 & 1886 & 1887 & 1888 & 1889 \\
\hline Adolpho Pinheiro & 1 & & & & & & & & & & & & & 1 & & & & \\
\hline $\begin{array}{l}\text { Affonso Celso de Assis } \\
\text { Figueiredo }\end{array}$ & 1 & 1 & & & & & & & & & & & & & & & & \\
\hline $\begin{array}{l}\text { Affonso Celso de Assis } \\
\text { Figueiredo Junior }\end{array}$ & 3 & & & & 1 & & & & & 2 & & & & & & & & \\
\hline Aleixo dos Santos & 1 & & & & & & & & & & & & 1 & & & & & \\
\hline Alfredo da Silveira Bastos & 1 & & & & & & 1 & & & & & & & & & & & \\
\hline $\begin{array}{l}\text { Alfredo Menus Barreto de Barros } \\
\text { Falcão }\end{array}$ & 2 & & & & & & & & & & & & 2 & & & & & \\
\hline Amaro Cavalcanti & 3 & & & & & & & & & & & 2 & & & 1 & & & \\
\hline Amaro José da Silveira & 1 & & & & & & & & & & & 1 & & & & & & \\
\hline Antão de Vasconcellos & 4 & & & & & & & & & & & & & 1 & 2 & 1 & & \\
\hline $\begin{array}{l}\text { Antenor Augusto Ribeiro } \\
\text { Guimarães }\end{array}$ & 11 & & 7 & 4 & & & & & & & & & & & & & & \\
\hline $\begin{array}{l}\text { Antonio Ayndas Gonçalves de } \\
\text { Almeida }\end{array}$ & 1 & & & & & & & & & & & & 1 & & & & & \\
\hline Antonio Coelho Rodrigues & 7 & & & & & & & & & & 4 & 3 & & & & & & \\
\hline Antonio de Almeida Oliveira & 4 & & & & & & & & & 4 & & & & & & & & \\
\hline Antonio de Castro Lopes & 2 & & & & & & & & & 2 & & & & & & & & \\
\hline Antonio Ennes de Souza & 4 & & & & & & & & 2 & & & & 2 & & & & & \\
\hline Antonio Felício dos Santos & 1 & & & & 1 & & & & & & & & & & & & & \\
\hline Antonio Ferreira Vianna & 21 & & 19 & & & & 2 & & & & & & & & & & & \\
\hline $\begin{array}{l}\text { Antonio Herculano de Souza } \\
\text { Bandeira Filho }\end{array}$ & 3 & & & 3 & & & & & & & & & & & & & & \\
\hline Antonio José de Sampaio & 1 & & & & & & & & & & & & 1 & & & & & \\
\hline
\end{tabular}




\begin{tabular}{|c|c|c|c|c|c|c|c|c|c|c|c|c|c|c|c|c|c|c|}
\hline Orador & Total & 1873 & 1874 & 1875 & 1876 & 1877 & 1878 & 1879 & 1880 & 1881 & 1882 & 1883 & 1884 & 1885 & 1886 & 1887 & 1888 & 1889 \\
\hline $\begin{array}{l}\text { Antonio José Pereira da Silva } \\
\text { Araújo }\end{array}$ & 2 & & & 1 & & & & & 1 & & & & & & & & & \\
\hline Antonio Limoeiro & 3 & & & & 1 & & & & 1 & & 1 & & & & & & & \\
\hline Antonio Maria de Miranda Castro & 2 & & & & & & & & & & 2 & & & & & & & \\
\hline Antonio Zeferino Candido & 3 & & & & & & 1 & & & & 1 & & 1 & & & & & \\
\hline $\begin{array}{l}\text { Augusto Cezar de Miranda } \\
\text { Azevedo }\end{array}$ & 12 & & 1 & 7 & 4 & & & & & & & & & & & & & \\
\hline Aydano de Almeida & 1 & & & & & & & & & & & & 1 & & & & & \\
\hline Baldomero Carqueja Fuentes & 1 & & & & & & & & & 1 & & & & & & & & \\
\hline $\begin{array}{l}\text { Balthazar Bernardino Baptista } \\
\text { Pereira }\end{array}$ & 2 & & & & & & & & & & & & & 2 & & & & \\
\hline Benjamin Franklin Ramiz Galvão & 1 & & & & & & & & 1 & & & & & & & & & \\
\hline Bento Gonçalves Cruz & 1 & & & & 1 & & & & & & & & & & & & & \\
\hline Candido Gomes de Vasconcellos & 1 & & 1 & & & & & & & & & & & & & & & \\
\hline Carlos Antonio de Paula Costa & 10 & & & & & & & & & & & & & & & 10 & & \\
\hline Carlos Arthur Busch Varella & 4 & & 3 & & & & & & 1 & & & & & & & & & \\
\hline Carlos Augusto de Carvalho & 3 & & & & 1 & & & & & & & & 2 & & & & & \\
\hline Carlos Victor Boisson & 5 & & & 2 & & & 1 & & 2 & & & & & & & & & \\
\hline Castorino de Faria & 1 & & & & & & & & & & & & & & 1 & & & \\
\hline Charles Frederick Hartt & 1 & & 1 & & & & & & & & & & & & & & & \\
\hline Cincinato Americo Lopes & 1 & & & & & & & & & & & & 1 & & & & & \\
\hline Clément Jobert & 2 & & & & 2 & & & & & & & & & & & & & \\
\hline Constante Jardim & 2 & & & & & & & & & & & & 1 & & & & 1 & \\
\hline Cypriano de Sousa Freitas & 1 & & & & & & & & 1 & & & & & & & & & \\
\hline Domingos Carlos da Silva & 1 & & & & & & & & & & & & 1 & & & & & \\
\hline
\end{tabular}




\begin{tabular}{|c|c|c|c|c|c|c|c|c|c|c|c|c|c|c|c|c|c|c|}
\hline Orador & Total & 1873 & 1874 & 1875 & 1876 & 1877 & 1878 & 1879 & 1880 & 1881 & 1882 & 1883 & 1884 & 1885 & 1886 & 1887 & 1888 & 1889 \\
\hline $\begin{array}{l}\text { Domingos José Bernardino de } \\
\text { Almeida }\end{array}$ & 1 & & & & & & & & 1 & & & & & & & & & \\
\hline $\begin{array}{l}\text { Domingos José Nogueira } \\
\text { Jaguaribe Filho }\end{array}$ & 1 & & & & & & & & & & & & & & & 1 & & \\
\hline Eliseu de Sousa Martins & 1 & & & & & & & & 1 & & & & & & & & & \\
\hline Erico Marinho da Gama Coelho & 3 & & & & & & & & & & & & 3 & & & & & \\
\hline Eugenio Guimarães Rebello & 2 & & & & & & & & & & & & 2 & & & & & \\
\hline Feliciano Pinheiro de Bittencourt & 90 & & & & 3 & & 4 & 15 & 4 & 5 & 3 & 8 & 7 & 6 & 4 & 8 & 8 & 15 \\
\hline Felix Belly & 1 & & 1 & & & & & & & & & & & & & & & \\
\hline Francisco Antonio de Carvalho & 1 & & & & & 1 & & & & & & & & & & & & \\
\hline Francisco Carlton & 2 & & & & & & & & & 2 & & & & & & & & \\
\hline $\begin{array}{l}\text { Francisco Ignácio de Carvalho } \\
\text { Rezende }\end{array}$ & 3 & & & 2 & 1 & & & & & & & & & & & & & \\
\hline Francisco José de Freitas & 1 & & 1 & & & & & & & & & & & & & & & \\
\hline $\begin{array}{l}\text { Francisco Marques de Araújo } \\
\text { Góes }\end{array}$ & 6 & & & & & & 4 & & & & 1 & & & 1 & & & & \\
\hline $\begin{array}{l}\text { Francisco Praxedes de Andrade } \\
\text { Pertence }\end{array}$ & 3 & & & & & & & & 3 & & & & & & & & & \\
\hline Francisco Rebello de Carvalho & 3 & & & & & & & & & & 2 & & & & & & & 1 \\
\hline Francisco Ribeiro de Mendonça & 13 & & & & 8 & & 2 & 1 & & & & & 1 & 1 & & & & \\
\hline Francisco Travassos Valdez & 1 & & & & & & & & 1 & & & & & & & & & \\
\hline Frank Cowen & 1 & & & & & & & & & & & & 1 & & & & & \\
\hline Galdino Emiliano das Neves & 1 & & & 1 & & & & & & & & & & & & & & \\
\hline Gustave Aimard & 1 & & & & & & & 1 & & & & & & & & & & \\
\hline Gustavo José Alberto & 3 & & & 2 & & & & & & 1 & & & & & & & & \\
\hline Henrique Antão de Vasconcellos & 1 & & & & & & & & & & & & 1 & & & & & \\
\hline
\end{tabular}




\begin{tabular}{|c|c|c|c|c|c|c|c|c|c|c|c|c|c|c|c|c|c|c|}
\hline Orador & Total & 1873 & 1874 & 1875 & 1876 & 1877 & 1878 & 1879 & 1880 & 1881 & 1882 & 1883 & 1884 & 1885 & 1886 & 1887 & 1888 & 1889 \\
\hline Henrique de Toledo Dodeworth & 1 & & & & & & & & & & & 1 & & & & & & \\
\hline Herman Luiz Gade & 1 & & & & 1 & & & & & & & & & & & & & \\
\hline Hilário Soares de Gouvea & 1 & & & & & & & & 1 & & & & & & & & & \\
\hline Ignacio Joaquim da Fonseca & 3 & & & & & & & & & & 2 & 1 & & & & & & \\
\hline $\begin{array}{l}\text { João Baptista da Silva Gomes } \\
\text { Barata }\end{array}$ & 6 & & & 6 & & & & & & & & & & & & & & \\
\hline João Baptista Kossuth Vinelli & 1 & & & & & & & & 1 & & & & & & & & & \\
\hline João Barbosa Rodrigues & 1 & & & & & & & & 1 & & & & & & & & & \\
\hline $\begin{array}{l}\text { João Batista da Silva Gomes } \\
\text { Barata }\end{array}$ & 1 & & & & & & & & & & & & & & & & & \\
\hline João Braz da Silveira Caldeira & 12 & & & & & & 6 & 5 & 1 & & & & & & & & & \\
\hline João Cordeiro da Graça & 1 & & & & & & & & & & 1 & & & & & & & \\
\hline $\begin{array}{l}\text { João da Costa Lima e Castro } \\
\text { Filho }\end{array}$ & 1 & & & 1 & & & & & & & & & & & & & & \\
\hline $\begin{array}{l}\text { João dos Reis de Souza Dantas } \\
\text { Sobrinho }\end{array}$ & 1 & & & & & & 1 & & & & & & & & & & & \\
\hline João Kopke & 4 & & & & & & & & & & & & & & 4 & & & \\
\hline João Manoel Pereira da Silva & 47 & 2 & 8 & 6 & 9 & & 1 & 6 & 4 & 4 & & 5 & & 2 & & & & \\
\hline João Martins Teixeira & 1 & & & & & & & & 1 & & & & & & & & & \\
\hline João Paulo de Carvalho & 1 & & & & & & & & 1 & & & & & & & & & \\
\hline João Pizarro Gabizo & 3 & & & & 3 & & & & & & & & & & & & & \\
\hline $\begin{array}{l}\text { Joaquim José de Amorim } \\
\text { Carvalho }\end{array}$ & 2 & & 2 & & & & & & & & & & & & & & & \\
\hline Joaquim José de Menezes Vieira & 2 & & 1 & & & & & & & & & & & 1 & & & & \\
\hline Joaquim José Teixeira & 2 & & 2 & & & & & & & & & & & & & & & \\
\hline Joaquim Monteiro Caminhoá & 12 & & 2 & & 9 & & & & 1 & & & & & & & & & \\
\hline
\end{tabular}




\begin{tabular}{|c|c|c|c|c|c|c|c|c|c|c|c|c|c|c|c|c|c|c|}
\hline Orador & Total & 1873 & 1874 & 1875 & 1876 & 1877 & 1878 & 1879 & 1880 & 1881 & 1882 & 1883 & 1884 & 1885 & 1886 & 1887 & 1888 & 1889 \\
\hline Joaquim Murtinho & 3 & & & & & & & & & 3 & & & & & & & & \\
\hline Joaquim Nabuco & 3 & & 3 & & & & & & & & & & & & & & & \\
\hline John Landsman & 3 & & & & & & 2 & 1 & & & & & & & & & & \\
\hline Jorge Mirandola Filho & 1 & & & & & & & & & & & 1 & & & & & & \\
\hline José Agostinho dos Reis & 3 & & & & & & & & & 2 & & 1 & & & & & & \\
\hline José Antonio Fernandes Lima & 1 & & 1 & & & & & & & & & & & & & & & \\
\hline José Cardoso de Moura Brasil & 1 & & & & & & & & 1 & & & & & & & & & \\
\hline José Carlos de Carvalho & 2 & & & & & & & & & & & & 2 & & & & & \\
\hline José Carneiro Campos & 1 & & & & & & & & & & & 1 & & & & & & \\
\hline José da Cunha Ferreira & 3 & & & & 3 & & & & & & & & & & & & & \\
\hline José de Almeida Soares & 1 & & & & & & & 1 & & & & & & & & & & \\
\hline José de Oliveira Campos & 1 & & 1 & & & & & & & & & & & & & & & \\
\hline José de Souza Lima & 2 & & & & & & & & & & & & & & & & 2 & \\
\hline José Frederico de Freitas Junior & 1 & & & & & & & & & & 1 & & & & & & & \\
\hline José Hermann de Tautphoeus & 5 & & 3 & & & & 1 & 1 & & & & & & & & & & \\
\hline José Innocencio de Miranda & 3 & & & & & & & & & & & & & & & 3 & & \\
\hline José Liberato Barroso & 3 & & 3 & & & & & & & & & & & & & & & \\
\hline José Maria Velho da Silva & 9 & & & & & & 8 & 1 & & & & & & & & & & \\
\hline José Marques Guimarães & 1 & & & & & & & & & & & 1 & & & & & & \\
\hline José Martins da Cruz Jobim & 8 & & 1 & 2 & 5 & & & & & & & & & & & & & \\
\hline José Palmella & 1 & & 1 & & & & & & & & & & & & & & & \\
\hline José Pereira Rego Filho & 1 & & & & & & & & & & & 1 & & & & & & \\
\hline José Saldanha da Gama & 4 & & 3 & & & & & & 1 & & & & & & & & & \\
\hline José Thomaz da Porciúncula & 1 & & & & 1 & & & & & & & & & & & & & \\
\hline Joseph Auguste Aristide Fort & 14 & & & & & & & & 1 & 13 & & & & & & & & \\
\hline Julio Cesar de Moraes Carneiro & 2 & & & & & & & & & & & & & 2 & & & & \\
\hline
\end{tabular}




\begin{tabular}{|c|c|c|c|c|c|c|c|c|c|c|c|c|c|c|c|c|c|c|}
\hline Orador & Total & 1873 & 1874 & 1875 & 1876 & 1877 & 1878 & 1879 & 1880 & 1881 & 1882 & 1883 & 1884 & 1885 & 1886 & 1887 & 1888 & 1889 \\
\hline Julio Cesar Leal & 5 & & & & & & & & & 4 & & & & & 1 & & & \\
\hline Julio Cesar Ribeiro de Souza & 2 & & & & & & & & & 1 & & & & 1 & & & & \\
\hline Licino Chaves Barcellos & 5 & & & & & & & & & & 4 & 1 & & & & & & \\
\hline Louis Couty & 3 & & & & & & & & & & 3 & & & & & & & \\
\hline Luiz Alves de Oliveira Bello & 1 & & 1 & & & & & & & & & & & & & & & \\
\hline $\begin{array}{l}\text { Luiz Alves Leite de Oliveira } \\
\text { Bello }\end{array}$ & 1 & & 1 & & & & & & & & & & & & & & & \\
\hline Luiz Corrêa de Azevedo & 1 & & 1 & & & & & & & & & & & & & & & \\
\hline $\begin{array}{l}\text { Luiz de Albuquerque Araujo } \\
\text { Cavalcanti }\end{array}$ & 1 & & 1 & & & & & & & & & & & & & & & \\
\hline $\begin{array}{l}\text { Luiz de Almeida Araujo } \\
\text { Cavalcante }\end{array}$ & 1 & & 1 & & & & & & & & & & & & & & & \\
\hline Luiz Henrique Pereira de Campos & 6 & & & & & & & & & & & 1 & & 2 & 3 & & & \\
\hline $\begin{array}{l}\text { Luiz Joaquim Duque-Estrada } \\
\text { Teixeira }\end{array}$ & 11 & 3 & 3 & 1 & & & & & 4 & & & & & & & & & \\
\hline Luiz Maria Vidal & 1 & & & & 1 & & & & & & & & & & & & & \\
\hline Manoel Cyridião Buarque & 3 & & & & & & & & & & 2 & & 1 & & & & & \\
\hline Manoel Francisco Correia & 53 & 1 & 8 & 6 & 8 & & 6 & 6 & 6 & 5 & 2 & & & 1 & & 1 & 1 & 2 \\
\hline Manoel Francisco Correia Junior & 5 & & & 1 & & & 1 & & & & & & 1 & & 1 & & & 1 \\
\hline Manoel Hilário Pires Ferrão & 3 & & & 3 & & & & & & & & & & & & & & \\
\hline Manoel Jesuíno Ferreira & 2 & & 2 & & & & & & & & & & & & & & & \\
\hline Manoel Joaquim da Silva Filho & 1 & & & & & & & & & & & & & & & 1 & & \\
\hline Manoel Joaquim Fernandes Eiras & 3 & & & & & & & & 2 & & & 1 & & & & & & \\
\hline $\begin{array}{l}\text { Maria da Glória Loureiro de } \\
\text { Andrade }\end{array}$ & 1 & & & & & & & & & & & & & & & & 1 & \\
\hline Miguel Antonio da Silva & 2 & & & & 1 & & 1 & & & & & & & & & & & \\
\hline
\end{tabular}




\begin{tabular}{|c|c|c|c|c|c|c|c|c|c|c|c|c|c|c|c|c|c|c|}
\hline Orador & Total & 1873 & 1874 & 1875 & 1876 & 1877 & 1878 & 1879 & 1880 & 1881 & 1882 & 1883 & 1884 & 1885 & 1886 & 1887 & 1888 & 1889 \\
\hline Miguel de Pino & 2 & & & & & & & & & & 1 & & & & & 1 & & \\
\hline Misael Ferreira Penna & 1 & & 1 & & & & & & & & & & & & & & & \\
\hline Mucio Teixeira & 1 & & & & & & & & & & & & 1 & & & & & \\
\hline $\begin{array}{l}\text { Nicolau Rodrigues dos Santos } \\
\text { França Leite }\end{array}$ & 1 & & 1 & & & & & & & & & & & & & & & \\
\hline Nuno Ferreira de Andrade & 8 & & 1 & 2 & 3 & & 1 & & 1 & & & & & & & & & \\
\hline $\begin{array}{l}\text { Pedro de Alcântara Nabuco de } \\
\text { Araujo }\end{array}$ & 1 & & 1 & & & & & & & & & 1 & & & & & & \\
\hline Pedro Meirelles & 1 & & & & & & & & & & & & & & & & & \\
\hline Ramos de Queiroz & 1 & & & & & & & & & 1 & & & & & & & & \\
\hline Rodrigo Otávio & 1 & & & & 1 & & & & & & & & & & & & & \\
\hline Rozendo Moniz Barreto & 1 & & 1 & & & & & & & & & & & & & & & \\
\hline Soeiro Guarany & 2 & & 2 & & & & & & & & & & & & & & & \\
\hline Theophilo das Neves Leão & 7 & 2 & 5 & & & & & & & & & & & & & & & \\
\hline Thomaz Alves Junior & 1 & & 1 & & & & & & & & & & & & & & & \\
\hline Tristão de Alencar Araripe & 4 & & & & 2 & & 1 & & 1 & & & & & & & & & \\
\hline $\begin{array}{l}\text { Sujeito não identificado que já fez } \\
\text { uma conferência em } 1874\end{array}$ & 1 & & 1 & & & & & & & & & & 1 & & & & & \\
\hline Total & 145 & & & & & & & & & & & & & & & & & \\
\hline
\end{tabular}

Fontes: Jornal do Commercio (1873-1889), Gazeta de Noticias (1875-1880), Diario do Rio de Janeiro (1873-1878), O Globo (1874-1878), Conferencias Populares (1876). 


\section{Anexo 3 - Conferências Populares da Glória que abordaram assuntos relativos à ciência}

\begin{tabular}{|c|c|c|c|c|}
\hline N. & Data & Orador & Tema & Assunto \\
\hline \multicolumn{5}{|c|}{1874} \\
\hline 11 & 08/jan & Antenor Augusto Ribeiro Guimarães & Meios preventivos contra a invasão de moléstias pestilenciais ( $1^{\mathrm{a}}$ conf. do curso de higiene) & Higiene \\
\hline 13 & $15 / \mathrm{jan}$ & Antenor Augusto Ribeiro Guimarães & $\begin{array}{l}\text { Meios preventivos contra a invasão de moléstias perniciosas (cont.) } 2^{\mathrm{a}} \text { conf. do curso de } \\
\text { higiene }\end{array}$ & Higiene \\
\hline 15 & 22/jan & Antenor Augusto Ribeiro Guimarães & $\begin{array}{l}\text { Meios preventivos contra a invasão de moléstias perniciosas (cont.) } 3^{\text {a }} \text { conf. do curso de } \\
\text { higiene }\end{array}$ & Higiene \\
\hline 17 & 29/jan & Antenor Augusto Ribeiro Guimarães & $\begin{array}{l}\text { Meios preventivos contra a invasão de moléstias perniciosas (cont.) } 4^{\mathrm{a}} \text { conf. do curso de } \\
\text { higiene }\end{array}$ & Higiene \\
\hline 19 & $05 / f e v$ & Soeiro Guarany & Da utilidade e necessidade para as mães de família do estudo da puericultura & Higiene \\
\hline 21 & $12 / \mathrm{fev}$ & Theophilo das Neves Leão & A terra e o universo & Geologia \\
\hline 23 & $19 / \mathrm{fev}$ & Antenor Augusto Ribeiro Guimarães & $\begin{array}{l}\text { Medidas sanitárias e cautelas que devem tomar, na invasão de epidemias, a administração } \\
\text { pública e os particulares. } 5^{\text {a }} \text { Conf. do curso de higiene }\end{array}$ & Higiene \\
\hline 25 & $26 /$ fev & Soeiro Guarany & $\begin{array}{l}\text { Considerações preliminares sobre o casamento debaixo do ponto de vista moral, fisiológico e } \\
\text { higiênico. Cuidados que devem ser prodigalizados à mulher do sétimo mês da gestação em } \\
\text { diante, e os que devem dispensar aos recém-nascidos na amamentação materna. } 2^{\text {a }} \text { conf. do } \\
\text { curso de puericultura }\end{array}$ & Higiene \\
\hline 31 & 19/mar & Theophilo das Neves Leão & A terra e o universo (cont.). $4^{\mathrm{a}}$ conf. do curso de geografia & Geologia \\
\hline 41 & $30 / \mathrm{abr}$ & Antenor Augusto Ribeiro Guimarães & Lazaretos e quarentenas ( $6^{\text {a }}$ conf. do curso de higiene) & Higiene \\
\hline 48 & 28/mai & Antenor Augusto Ribeiro Guimarães & Lazaretos e quarentenas (cont.). $7^{\mathrm{a}}$ conf. do curso de higiene & Higiene \\
\hline 52 & 11/jun & Augusto Cezar de Miranda Azevedo & Necessidade e vantagens do estudo das ciências naturais & Ciências Naturais \\
\hline 63 & 19/jul & José Saldanha da Gama & Instinto dos vegetais & Botânica \\
\hline 71 & 16/ago & José Saldanha da Gama & Legendas das plantas & Botânica \\
\hline 92 & 25/out & José Martins da Cruz Jobim & Sobre a natureza e contagiosidade da febre amarela e meios de a reprimir & Higiene \\
\hline 94 & 01/nov & José Saldanha da Gama & O modo de viver das plantas & Botânica \\
\hline \multicolumn{5}{|c|}{1875} \\
\hline 108 & 10/jan & Carlos Victor Boisson & Métodos de ensino das matemáticas elementares, especialmente da geometria & Matemática \\
\hline 110 & 24/jan & Carlos Victor Boisson & Métodos de ensino das matemáticas elementares, especialmente da geometria (cont.) & Matemática \\
\hline
\end{tabular}




\begin{tabular}{|c|c|c|c|c|}
\hline 116 & 07/mar & Antenor Augusto Ribeiro Guimarães & Influência da medicina sobre a educação & Medicina \\
\hline 118 & $21 / \mathrm{mar}$ & Antenor Augusto Ribeiro Guimarães & Influência da medicina sobre a educação (cont.) & Medicina \\
\hline 120 & 04/abr & Antenor Augusto Ribeiro Guimarães & Aparelho locomotor, educação dos sentidos, voz e palavra & Medicina \\
\hline 121 & $11 / \mathrm{abr}$ & Augusto Cezar de Miranda Azevedo & O darwinismo, seu passado, seu presente, seu futuro & Evolucionismo \\
\hline 122 & $18 / \mathrm{abr}$ & Augusto Cezar de Miranda Azevedo & Idem & Evolucionismo \\
\hline 123 & $25 / a b r$ & Augusto Cezar de Miranda Azevedo & Estudo e demonstração das leis fundamentais do darwinismo & Evolucionismo \\
\hline 125 & 16/mai & Augusto Cezar de Miranda Azevedo & Os diversos meios de reprodução dos organismos & Evolucionismo \\
\hline 128 & 20/jun & Augusto Cezar de Miranda Azevedo & Os embriões & Evolucionismo \\
\hline 130 & 04/jul & José Martins da Cruz Jobim & $\begin{array}{l}\text { Da intervenção da medicina legal como uma necessidade indispensável para a boa } \\
\text { administração da justiça }\end{array}$ & Medicina \\
\hline 134 & 01/ago & José Martins da Cruz Jobim & As diversas espécies de Asfixia & Medicina \\
\hline 135 & 08/ago & Augusto Cezar de Miranda Azevedo & Sistema de Darwin (cont.) & Evolucionismo \\
\hline 136 & 13/ago & Antonio José Pereira da Silva Araújo & Importância do microscópio em medicina e consequências filosóficas que dela se deduzem. & Medicina \\
\hline 138 & 19/ago & Nuno Ferreira de Andrade & O filosofismo médico & Medicina \\
\hline 141 & $05 /$ set & Manoel Francisco Correia Junior & Os aeróstatos & Física \\
\hline 144 & $26 /$ set & Augusto Cezar de Miranda Azevedo & Aplicação da doutrina evolutiva ao homem & Evolucionismo \\
\hline 146 & $10 /$ out & Galdino Emiliano das Neves & Geração espontânea & Evolucionismo \\
\hline 147 & 17/out & Manoel Hilário Pires Ferrão & A Farmácia no Brasil sua utilidade e meios de desenvolvê-la & Farmácia \\
\hline 148 & 24/out & Manoel Hilário Pires Ferrão & Idem & Farmácia \\
\hline 153 & 05/dez & João Manoel Pereira da Silva & Desenvolvimento dos povos americanos falando especialmente acerca do Rio da Prata & Antropologia \\
\hline 155 & 19/dez & Nuno Ferreira de Andrade & Acomodação dos organismos aos meios ambientes, doutrina etnográfica da colonização & Antropologia \\
\hline \multicolumn{5}{|c|}{1876} \\
\hline 158 & 09/jan & Augusto Cezar de Miranda Azevedo & Águas minerais especialmente as do Brasil & Química \\
\hline 160 & 23/jan & Augusto Cezar de Miranda Azevedo & Águas minerais do Brasil & Química \\
\hline 163 & $13 / \mathrm{fev}$ & Augusto Cezar de Miranda Azevedo & Águas minerais de Baependy, Campanha, Contendas e Caldas. & Química \\
\hline 165 & $27 / \mathrm{fev}$ & João Pizarro Gabizo & A higiene das escolas & Higiene \\
\hline 166 & 05/mar & João Pizarro Gabizo & Idem & Higiene \\
\hline 168 & 19/mar & João Pizarro Gabizo & Higiene das escolas & Higiene \\
\hline 172 & 16/abr & Antonio Felício dos Santos & Da moda em relação com a higiene & Higiene \\
\hline 174 & $30 / a b r$ & Nuno Ferreira de Andrade & Os banhos & Química \\
\hline 175 & 07/mai & Augusto Cezar de Miranda Azevedo & A responsabilidade médica & Medicina \\
\hline
\end{tabular}




\begin{tabular}{|c|c|c|c|c|}
\hline 181 & $18 /$ jun & José Thomaz da Porciúncula & Organização e vida & Biologia \\
\hline 189 & 10/ago & Joaquim Monteiro Caminhoá & Curso de Botânica Popular ( $1^{\mathrm{a}}$ conf. do curso $)$ & Botânica \\
\hline 193 & 31/ago & Bento Gonçalves Cruz & Prolegômenos de biologia ( $2^{\mathrm{a}}$ conf. do curso de botânica popular) & Botânica \\
\hline 194 & $02 /$ set & Joaquim Monteiro Caminhoá & Curso de Botânica Popular II & Botânica \\
\hline 196 & 08/set & Joaquim Monteiro Caminhoá & $\begin{array}{l}\text { Curso de Botânica Popular III. Do microscópio e seu emprego no estudo da anatomia das } \\
\text { plantas, células, sua composição e modificações. }\end{array}$ & Botânica \\
\hline 198 & $14 /$ set & Joaquim Monteiro Caminhoá & $\begin{array}{l}\text { Curso de Botânica Popular IV. Combinação das células formando tecidos e órgãos. Raiz e } \\
\text { suas aplicações }\end{array}$ & Botânica \\
\hline 200 & $21 /$ set & Joaquim Monteiro Caminhoá & Curso de Botânica V. Das células, formando tecidos e órgãos & Botânica \\
\hline 202 & $28 /$ set & Joaquim Monteiro Caminhoá & Curso de Botânica Popular VI. Da raiz e do caule & Botânica \\
\hline 204 & out $/ 10$ & Joaquim Monteiro Caminhoá & Curso de Botânica Popular VII. Dos órgãos que são a transição entre a raiz e o caule & Botânica \\
\hline 206 & $14 /$ out & Francisco Ribeiro de Mendonça & Curso de Botânica Popular VIII. A folha & Botânica \\
\hline 208 & 19/out & Joaquim Monteiro Caminhoá & Curso de Botânica Popular IX.A folha & Botânica \\
\hline 209 & 22/out & Miguel Antonio da Silva & Física do globo & Física \\
\hline 210 & 27/out & Joaquim Monteiro Caminhoá & Curso de Botânica Popular X. A flor & Botânica \\
\hline 212 & 31/out & Francisco Ribeiro de Mendonça & Curso de Botânica Popular XI. Da flor em particular & Botânica \\
\hline 213 & 05/nov & Feliciano Pinheiro de Bittencourt & Darwinismo & Evolucionismo \\
\hline 214 & 09/nov & Francisco Ribeiro de Mendonça & Curso de Botânica Popular XII. A flor (cont.) & Botânica \\
\hline 216 & $16 /$ nov & Francisco Ribeiro de Mendonça & Curso de Botânica Popular XIII & Botânica \\
\hline 217 & $23 /$ nov & Francisco Ribeiro de Mendonça & Curso de Botânica Popular XIV. Os órgãos sexuais das flores & Botânica \\
\hline 219 & 29/nov & Francisco Ribeiro de Mendonça & Curso de Botânica Popular XV. A flor (cont.) & Botânica \\
\hline 222 & 14/dez & Francisco Ribeiro de Mendonça & Curso de Botânica Popular XVI. O fruto & Botânica \\
\hline 224 & $21 / \mathrm{dez}$ & Francisco Ribeiro de Mendonça & Curso de Botânica Popular XVII. Fecundação & Botânica \\
\hline 225 & $24 / \mathrm{dez}$ & José da Cunha Ferreira & Educação sob o ponto de vista higiênico & Higiene \\
\hline \multicolumn{5}{|c|}{1878} \\
\hline s.d. & $17 / \mathrm{mar}$ & Manoel Francisco Correia & A escola de humanidades do Instituto Farmacêutico do Rio de Janeiro & Farmácia \\
\hline 229 & $24 / \mathrm{mar}$ & Manoel Francisco Correia Junior & Nutrição dos vegetais & Botânica \\
\hline 234 & 28/abr & Francisco Ribeiro de Mendonça & $\begin{array}{l}\text { Influência dos meios sobre os seres orgânicos em geral e particularmente sobre o reino } \\
\text { vegetal }\end{array}$ & Botânica \\
\hline 238 & 26/mai & Francisco Marques de Araújo Góes & Origem da terra, sua idade e seus fins & Geologia \\
\hline 243 & 23/jun & Francisco Marques de Araújo Góes & O período glacial: suas causas e efeitos e sua provável extensão ao Brasil & Geologia \\
\hline
\end{tabular}




\begin{tabular}{|c|c|c|c|c|}
\hline 244 & 30/jun & Francisco Marques de Araújo Góes & Período glacial do globo; sua provável extensão ao Brasil & Geologia \\
\hline 246 & 14/jul & Nuno Ferreira de Andrade & Base física da vida & Biologia \\
\hline 247 & $21 /$ jul & Francisco Ribeiro de Mendonça & Primeiras experiências com o 'fonógrafo' no Brasil & Tecnologia \\
\hline 249 & 04/out & Francisco Marques de Araújo Góes & A circulação do sangue no reino animal & Medicina \\
\hline 254 & $08 /$ set & $\begin{array}{l}\text { João dos Reis de Souza Dantas } \\
\text { Sobrinho }\end{array}$ & Lutas pela existência: seu papel na evolução das espécies & Evolucionismo \\
\hline 265 & $24 /$ nov & Feliciano Pinheiro de Bittencourt & Influência higiênica dos climas & Higiene \\
\hline 267 & 08/dez & Feliciano Pinheiro de Bittencourt & Higiene das habitações & Higiene \\
\hline 270 & 29/dez & Feliciano Pinheiro de Bittencourt & Higiene das habitações & Higiene \\
\hline \multicolumn{5}{|c|}{1879} \\
\hline 271 & 05/jan & Feliciano Pinheiro de Bittencourt & Regime alimentar & Medicina \\
\hline 274 & $27 / \mathrm{abr}$ & Feliciano Pinheiro de Bittencourt & Regime alimentar: bebidas & Medicina \\
\hline 276 & 11/mai & Feliciano Pinheiro de Bittencourt & Falsificação de vinhos & Medicina \\
\hline 280 & 08/jun & Feliciano Pinheiro de Bittencourt & Bebidas aromáticas e ácidas, ação do álcool sobre o organismo & Medicina \\
\hline 283 & 29/jun & Feliciano Pinheiro de Bittencourt & O exercício e o movimento & Higiene \\
\hline 284 & 06/jul & Feliciano Pinheiro de Bittencourt & Ginástica, natação e equitação & Higiene \\
\hline 286 & 20/jul & Feliciano Pinheiro de Bittencourt & Das paixões, suas influências sobre os principais atos orgânicos & Medicina \\
\hline 287 & 27/jul & Feliciano Pinheiro de Bittencourt & Do sono fisiológico, seus efeitos sobre o organismo & Medicina \\
\hline 292 & 31/ago & Feliciano Pinheiro de Bittencourt & Magnetismo animal & Medicina \\
\hline 293 & $07 /$ set & Feliciano Pinheiro de Bittencourt & Dos excitantes sistema muscular, e especialmente do imã e da eletricidade & Física \\
\hline 295 & $21 /$ set & Feliciano Pinheiro de Bittencourt & Eletricidade médica ou aplicações terapêuticas desse agente. & Medicina \\
\hline 296 & 12/out & Francisco Ribeiro de Mendonça & Estudo tanto teórico como experimental do radiômetro & Medicina \\
\hline 297 & 19/out & Feliciano Pinheiro de Bittencourt & Eletricidade médica & Medicina \\
\hline 298 & 26/out & Feliciano Pinheiro de Bittencourt & Valor da teoria da assistologia de Beau, higiene das moléstias do coração & Higiene \\
\hline 303 & $23 /$ nov & Feliciano Pinheiro de Bittencourt & Será contagiosa a tuberculose pulmonar? Será inoculável? Experiências de Villemin & Medicina \\
\hline 305 & 07/dez & Feliciano Pinheiro de Bittencourt & Do uso e abuso do tabaco & Medicina \\
\hline \multicolumn{5}{|c|}{1880} \\
\hline 310 & $18 / a b r$ & Feliciano Pinheiro de Bittencourt & Será a hemoptise causa ou efeito da tuberculose pulmonar? & Medicina \\
\hline 316 & 06/jun & Feliciano Pinheiro de Bittencourt & $\begin{array}{l}\text { Higiene dos tuberculosos: vida agreste, climas, altitudes e latitudes, viagens do oceano, } \\
\text { exercício, alimentação, hidroterapia }\end{array}$ & Higiene \\
\hline 317 & 13/jun & Feliciano Pinheiro de Bittencourt & Influência dos climas, do exercício, da alimentação e da hidroterapia sobre as tuberculoses & Medicina \\
\hline
\end{tabular}




\begin{tabular}{|c|c|c|c|c|}
\hline 321 & $11 /$ jul & Feliciano Pinheiro de Bittencourt & Uso e abuso do tabaco & Medicina \\
\hline 326 & 01/ago & Joseph Auguste Aristide Fort & Sobre febre amarela & Medicina \\
\hline 327 & 08/ago & $\begin{array}{l}\text { Francisco Praxedes de Andrade } \\
\text { Pertence }\end{array}$ & Ensino superior & Medicina \\
\hline 328 & 12/ago & Nuno Ferreira de Andrade & Ensino superior. Faculdades de medicina & Medicina \\
\hline 329 & 15/ago & João Paulo de Carvalho & Ensino superior. Ciência prática e experimental. Laboratórios & Medicina \\
\hline 330 & 19/ago & Hilário Soares de Gouvea & Ensino superior. Organização do ensino médico na Alemanha & Medicina \\
\hline 331 & 22/ago & João Baptista Kossuth Vinelli & Ensino superior. Vícios de organização da faculdade de medicina & Medicina \\
\hline 332 & 26/ago & Cypriano de Sousa Freitas & Ensino superior. Fisiologia e patologia experimentais & Medicina \\
\hline 333 & 29/ago & João Martins Teixeira & Reforma do ensino superior & Medicina \\
\hline 334 & $02 /$ set & Benjamin Franklin Ramiz Galvão & As ciências físicas e naturais nas faculdades de medicina & Medicina \\
\hline 335 & $05 /$ set & Joaquim Monteiro Caminhoá & Meios práticos e econômicos para a reforma do ensino médico & Medicina \\
\hline 336 & $09 /$ set & Antonio José Pereira da Silva Araújo & Ensino superior, microscopia prática & Medicina \\
\hline 337 & $12 / \mathrm{set}$ & $\begin{array}{l}\text { Francisco Praxedes de Andrade } \\
\text { Pertence }\end{array}$ & O ensino superior & Medicina \\
\hline 338 & $16 /$ set & Manoel Joaquim Fernandes Eiras & O alienado perante a ciência médica, a sociedade, a família, a autoridade e a lei & Medicina \\
\hline 340 & $23 /$ set & Antonio Ennes de Souza & O mundo, o trabalho e a vida subterrânea & Geologia \\
\hline 342 & $30 /$ set & Antonio Ennes de Souza & O mundo, o trabalho e a vida subterrânea & Geologia \\
\hline 344 & 10/out & João Barbosa Rodrigues & O curare, seu uso, armas em que é usado e seu manejo & Medicina \\
\hline 345 & 17/out & Manoel Joaquim Fernandes Eiras & O alienado perante a ciência médica, a sociedade, a família, a autoridade e a lei & Medicina \\
\hline 355 & 25/dez & José Cardoso de Moura Brasil & Abuso do tabaco, cegueira dos fumantes & Medicina \\
\hline \multicolumn{5}{|c|}{1881} \\
\hline 377 & 12/jun & Joseph Auguste Aristide Fort & Fisiologia e higiene aplicadas à medicina usual e ao alcance de todos & Medicina \\
\hline 380 & 03/jul & Joseph Auguste Aristide Fort & Fisiologia e higiene aplicadas à medicina usual e ao alcance de todos & Medicina \\
\hline 381 & 10/jul & Joaquim Murtinho & Homeopatia. Regulamento da junta de higiene & Higiene \\
\hline 383 & 24/jul & Joseph Auguste Aristide Fort & Fisiologia e higiene aplicadas à medicina usual e ao alcance de todos & Medicina \\
\hline 384 & 31/jul & Feliciano Pinheiro de Bittencourt & Fisiologia do coração, influência deste órgão sobre os nossos sentimentos & Medicina \\
\hline 385 & 07/ago & Joseph Auguste Aristide Fort & Fisiologia e higiene aplicadas à medicina usual e ao alcance de todos & Medicina \\
\hline 386 & 14/ago & Joaquim Murtinho & A lei fundamental da homeopatia provada pela escola de medicina & Medicina \\
\hline 388 & 27/ago & Joseph Auguste Aristide Fort & Fisiologia e higiene aplicadas à medicina usual e ao alcance de todos & Medicina \\
\hline 390 & $11 / \mathrm{set}$ & Joseph Auguste Aristide Fort & Fisiologia e higiene aplicadas à medicina usual e ao alcance de todos & Medicina \\
\hline
\end{tabular}




\begin{tabular}{|c|c|c|c|c|}
\hline 391 & $18 /$ set & Joaquim Murtinho & A lei fundamental da homeopatia provada pelo Museu Nacional & Medicina \\
\hline 392 & $25 /$ set & Joseph Auguste Aristide Fort & Fisiologia e higiene aplicadas à medicina usual e ao alcance de todos & Medicina \\
\hline 393 & 02/out & Joseph Auguste Aristide Fort & Fisiologia e higiene aplicadas à medicina usual e ao alcance de todos & Medicina \\
\hline 394 & 09/out & Joseph Auguste Aristide Fort & Fisiologia e higiene aplicadas à medicina usual e ao alcance de todos & Medicina \\
\hline 395 & $15 /$ out & Joseph Auguste Aristide Fort & Fisiologia e higiene aplicadas à medicina usual e ao alcance de todos & Medicina \\
\hline 396 & 23/out & Joseph Auguste Aristide Fort & Fisiologia e higiene aplicadas à medicina usual e ao alcance de todos & Medicina \\
\hline 397 & 30/out & Joseph Auguste Aristide Fort & Fisiologia e higiene aplicadas à medicina usual e ao alcance de todos & Medicina \\
\hline 398 & 06/nov & Joseph Auguste Aristide Fort & Fisiologia e higiene aplicadas à medicina usual e ao alcance de todos & Medicina \\
\hline 399 & 13/nov & Feliciano Pinheiro de Bittencourt & Uso e abuso do tabaco & Medicina \\
\hline 400 & 20/nov & Feliciano Pinheiro de Bittencourt & Uso e abuso do tabaco - alcoolismo e nicotismo & Medicina \\
\hline 401 & $27 /$ nov & Antonio de Castro Lopes & Doses imponderáveis e sua eficácia & Medicina \\
\hline 402 & 04/dez & Feliciano Pinheiro de Bittencourt & $\begin{array}{l}\text { A nicotina abrevia a existência e é também causa da degenerescência física e moral das } \\
\text { sociedades modernas. Uso do tabaco nos exércitos }\end{array}$ & Medicina \\
\hline 405 & $25 / \mathrm{dez}$ & Feliciano Pinheiro de Bittencourt & Do nicotismo como causa da alienação mental & Medicina \\
\hline \multicolumn{5}{|c|}{1882} \\
\hline 412 & 09/jul & Licino Chaves Barcellos & Iluminação elétrica & Tecnologia \\
\hline 413 & 16/jul & Licino Chaves Barcellos & Iluminação elétrica (cont.) & Tecnologia \\
\hline 417 & 20/ago & Francisco Marques de Araújo Góes & $\begin{array}{l}\text { Os micróbios como fatores de moléstias, cultura dos micróbios. A tísica pulmonar como } \\
\text { moléstia parasitária }\end{array}$ & Medicina \\
\hline 419 & $03 /$ set & Feliciano Pinheiro de Bittencourt & $\begin{array}{l}\text { Do abuso do fumo como causa importante de cancros dos lábios, da língua do estômago, } \\
\text { moléstias do nariz, dos olhos e dos ouvidos, devidos à mesma causa }\end{array}$ & Medicina \\
\hline 423 & 01/out & Feliciano Pinheiro de Bittencourt & $\begin{array}{l}\text { Moléstias dos olhos devidas ao abuso do fumo. Maléfica influência do fumo sobre o sistema } \\
\text { nervoso }\end{array}$ & Medicina \\
\hline 424 & 08/out & Louis Couty & Comparação das moléstias cerebrais e medulares em França e no Brasil & Medicina \\
\hline 425 & $15 /$ out & Louis Couty & Comparação das moléstias cerebrais e medulares em França e no Brasil & Medicina \\
\hline 426 & 22/out & Louis Couty & Comparação das moléstias cerebrais e medulares em França e no Brasil & Medicina \\
\hline 427 & 29/out & Feliciano Pinheiro de Bittencourt & $\begin{array}{l}\text { O abuso do fumo é um dos mais poderosos obstáculos ao desenvolvimento físico e intelectual } \\
\text { das crianças. E também causa importante de certas afecções dos olhos }\end{array}$ & Medicina \\
\hline 432 & 03/dez & Licino Chaves Barcellos & A passagem de Vênus pelo disco do Sol & Astronomia \\
\hline \multicolumn{5}{|c|}{1883} \\
\hline 437 & 13/mai & Feliciano Pinheiro de Bittencourt & Indígenas do Brasil, sua língua, usos e costumes & Antropologia \\
\hline 440 & 03/jun & Feliciano Pinheiro de Bittencourt & Indígenas do Brasil, sua religião, forma de governo, guerras, matança dos prisioneiros & Antropologia \\
\hline
\end{tabular}




\begin{tabular}{|c|c|c|c|c|}
\hline 444 & 08/jul & Feliciano Pinheiro de Bittencourt & Indígenas do Brasil & Antropologia \\
\hline 445 & 15/jul & Pedro de Alcântara Nabuco de Araujo & Alienação mental & Medicina \\
\hline 446 & 22/jul & João Manoel Pereira da Silva & Ciências matemáticas nos séculos XV e XVI & Matemática \\
\hline 454 & $23 /$ set & Feliciano Pinheiro de Bittencourt & Indígenas do Brasil, seus ídolos, seus casamentos e suas festas & Antropologia \\
\hline 455 & $30 /$ set & Feliciano Pinheiro de Bittencourt & Indígenas do Brasil, seus ídolos, suas festas, seus casamentos e suas bebidas especiais & Antropologia \\
\hline 456 & 07/out & José Carneiro Campos & Origem parasitária das moléstias & Medicina \\
\hline 459 & 28/out & Feliciano Pinheiro de Bittencourt & Indígenas do Brasil, sua língua, usos e costumes & Antropologia \\
\hline 461 & $11 /$ nov & Feliciano Pinheiro de Bittencourt & Indígenas do Mato Grosso; meios mais adequados para a sua catequese e civilização & Antropologia \\
\hline 463 & $25 /$ nov & Feliciano Pinheiro de Bittencourt & Indígenas do Mato Grosso, seus usos e costumes & Antropologia \\
\hline \multicolumn{5}{|c|}{1884} \\
\hline 471 & 11/mai & $\begin{array}{l}\text { Alfredo Menus Barreto de Barros } \\
\text { Falcão }\end{array}$ & O alcoolismo & Medicina \\
\hline 478 & 06/jul & Feliciano Pinheiro de Bittencourt & Higiene da alma; moléstias imaginárias & Higiene \\
\hline 482 & 03/ago & Domingos Carlos da Silva & $\begin{array}{l}\text { Considerações históricas, econômicas, financeiras, administrativas e profiláticas sobre o } \\
\text { cholera-morbus epidêmico }\end{array}$ & Medicina \\
\hline 484 & 24/ago & Francisco Ribeiro de Mendonça & $\begin{array}{l}\text { Eletricidade aplicada à medicina, apresentando o orador o novo aparelho de sua invenção, } \\
\text { que fará funcionar }\end{array}$ & Medicina \\
\hline 490 & 19/out & Eugenio Guimarães Rebello & A higiene como principal fator da prosperidade dos Estados & Higiene \\
\hline 491 & 26/out & Antonio José de Sampaio & Influência da química no desenvolvimento industrial e agrícola & Química \\
\hline 492 & $02 /$ nov & Constante Jardim & $\begin{array}{l}\text { Higiene pública, águas públicas, circulação contínua, influência das obras do Corcovado } \\
\text { sobre as águas do rio Carioca, meios de purificação das mesmas }\end{array}$ & Higiene \\
\hline 493 & 09/nov & Eugenio Guimarães Rebello & $\begin{array}{l}\text { Importância da higiene, necessidade da polícia sanitária, medidas complementares da } \\
\text { organização do serviço sanitário no Brasil }\end{array}$ & Higiene \\
\hline 494 & 16/nov & Erico Marinho da Gama Coelho & Do ensino médico na Faculdade do Rio de Janeiro e seus embaraços & Medicina \\
\hline 495 & $23 /$ nov & Erico Marinho da Gama Coelho & $\begin{array}{l}\text { Das condições da atual instalação da cadeira de clínica de partos e dos embaraços que sofre o } \\
\text { ensino respectivo }\end{array}$ & Medicina \\
\hline 496 & $30 /$ nov & Erico Marinho da Gama Coelho & Da assistência de partos no estrangeiro e ensino respectivo & Medicina \\
\hline 497 & 07/dez & Feliciano Pinheiro de Bittencourt & Influência perniciosa do fumo sobre as crianças e sobre os operários das respectivas fábricas & Medicina \\
\hline 499 & $21 / \mathrm{dez}$ & Feliciano Pinheiro de Bittencourt & O tabaco e os micróbios, afecções da vista devidas ao abuso do fumo & Medicina \\
\hline 500 & 28/dez & Feliciano Pinheiro de Bittencourt & As moléstias dos olhos devidas ao abuso do fumo & Medicina \\
\hline \multicolumn{5}{|l|}{1885} \\
\hline 501 & 28/jun & Francisco Ribeiro de Mendonça & Vida dos vegetais parasitas & Botânica \\
\hline
\end{tabular}




\begin{tabular}{|c|c|c|c|c|}
\hline 502 & 05/jul & Feliciano Pinheiro de Bittencourt & Uso e abuso do fumo, fábricas onde é manipulado & Medicina \\
\hline 508 & 23/ago & Balthazar Bernardino Baptista Pereira & $\begin{array}{l}\text { Estudos meteorológicos, sua importância, necessidade do estabelecimento deste serviço no } \\
\text { Brasil }\end{array}$ & Meteorologia \\
\hline 510 & $06 /$ set & Adolpho Pinheiro & $\begin{array}{l}\text { Organizações dos diferentes serviços meteorológicos e o magnetismo do mundo, e sua atual } \\
\text { criação no Império }\end{array}$ & Meteorologia \\
\hline 511 & $13 /$ set & Feliciano Pinheiro de Bittencourt & $\begin{array}{l}\text { Será o fumo um antídoto dos micróbios? Ter-se-á descoberta o meio de neutralizar a } \\
\text { existência da nicotina contida nos cigarros e charutos }\end{array}$ & Medicina \\
\hline 512 & $20 /$ set & Francisco Marques de Araújo Góes & $\begin{array}{l}\text { Medidas higiênicas contra a febre amarela, o valor econômico das vidas arrebatadas por esta } \\
\text { moléstia no Rio de Janeiro }\end{array}$ & Medicina \\
\hline 513 & $27 /$ set & Feliciano Pinheiro de Bittencourt & Higiene das fábricas de fumo; influência do tabaco sobre o presente o futuro dos povos & Higiene \\
\hline 515 & 11/out & Balthazar Bernardino Baptista Pereira & Estabelecimento do serviço meteorológico no Brasil & Meteorologia \\
\hline 516 & $18 /$ out & Feliciano Pinheiro de Bittencourt & $\begin{array}{l}\text { O abuso do fumo e do álcool exerce notável influência sobre o presente e o futuro dos povos } \\
\text { modernos }\end{array}$ & Medicina \\
\hline 518 & $01 /$ nov & Feliciano Pinheiro de Bittencourt & Desenvolvimento paralelo do alcoolismo e do nicotismo; suas consequências desastrosas & Medicina \\
\hline 519 & $15 /$ nov & Feliciano Pinheiro de Bittencourt & Da doutrina microbiana em geral; seu alcance prático. Valor do fumo como parasita & Medicina \\
\hline \multicolumn{5}{|c|}{1886} \\
\hline 522 & 23/mai & Feliciano Pinheiro de Bittencourt & Progresso da ciência e da literatura da Alemanha moderna & Ciência \\
\hline 523 & 30/mai & Castorino de Faria & Sistema métrico & Matemática \\
\hline 524 & 06/jun & Feliciano Pinheiro de Bittencourt & Progresso da ciência e da literatura da Alemanha moderna & Ciência \\
\hline \multicolumn{5}{|c|}{1887} \\
\hline 539 & $15 /$ mai & Carlos Antonio de Paula Costa & Higiene da infância (curso popular de higiene) & Higiene \\
\hline 540 & $22 /$ mai & Carlos Antonio de Paula Costa & Higiene da infância (curso popular de higiene) & Higiene \\
\hline 541 & $29 /$ mai & Carlos Antonio de Paula Costa & Higiene da infância. Amamentação (curso popular de higiene) & Higiene \\
\hline 542 & 05/jun & Carlos Antonio de Paula Costa & Higiene da infância. Amamentação (curso popular de higiene) & Higiene \\
\hline 543 & $12 /$ jun & Carlos Antonio de Paula Costa & Higiene da infância; aleitamento artificial (curso popular de higiene) & Higiene \\
\hline 544 & 19/jun & Carlos Antonio de Paula Costa & Higiene da infância; alimentação, dentição (curso popular de higiene) & Higiene \\
\hline 545 & 26/jun & Carlos Antonio de Paula Costa & Higiene da infância; vacina (curso popular de higiene) & Higiene \\
\hline 546 & 03/jul & Carlos Antonio de Paula Costa & Higiene da infância; o desmamar, a dentição (curso popular de higiene) & Higiene \\
\hline 547 & 10/jul & Carlos Antonio de Paula Costa & Alimentação das crianças (curso popular de higiene) & Higiene \\
\hline 548 & 17/jul & Carlos Antonio de Paula Costa & Alimentação das crianças (curso popular de higiene) & Higiene \\
\hline 550 & $31 /$ jul & Feliciano Pinheiro de Bittencourt & Flora e fauna das regiões polares & Biologia \\
\hline 551 & 07/ago & Feliciano Pinheiro de Bittencourt & Flora e fauna das regiões polares & Biologia \\
\hline
\end{tabular}




\begin{tabular}{|c|c|c|c|c|}
\hline 552 & 14/ago & Feliciano Pinheiro de Bittencourt & Usos e costumes dos povos que habitam as regiões polares & Antropologia \\
\hline 560 & 09/out & Feliciano Pinheiro de Bittencourt & Origem das raças: o homem pré-histórico & Evolucionismo \\
\hline 561 & $16 /$ out & Feliciano Pinheiro de Bittencourt & Origem das espécies, hipóteses transformistas, o homem terciário & Evolucionismo \\
\hline 562 & $30 /$ out & Feliciano Pinheiro de Bittencourt & Origem das raças; o darwinismo; a América pré-histórica & Evolucionismo \\
\hline 563 & $06 /$ nov & Feliciano Pinheiro de Bittencourt & América pré-histórica & Antropologia \\
\hline \multicolumn{5}{|c|}{1888} \\
\hline 565 & 06/mai & Manoel Francisco Correia & Origem das espécies orgânicas & Antropologia \\
\hline 568 & 03/jun & Feliciano Pinheiro de Bittencourt & Raças americanas primitivas, sua religião, usos e costumes & Antropologia \\
\hline 569 & 17/jun & Constante Jardim & Higiene municipal & Higiene \\
\hline 570 & 01/jul & Feliciano Pinheiro de Bittencourt & Religião, usos e costumes das raças primitivas da América & Antropologia \\
\hline 571 & $22 /$ jul & Feliciano Pinheiro de Bittencourt & Religião, usos e costumes das raças primitivas da América & Antropologia \\
\hline 572 & 29/jul & Feliciano Pinheiro de Bittencourt & Povos da América Central, sua religião, usos e costumes & Antropologia \\
\hline 573 & 05/ago & Feliciano Pinheiro de Bittencourt & Os meteoritos em geral e o de Bedengó em particular & Química \\
\hline 574 & 19/ago & Feliciano Pinheiro de Bittencourt & Os meteoritos em geral e o de Bedengó em particular & Química \\
\hline 575 & 26/ago & Feliciano Pinheiro de Bittencourt & Aborígenes da América & Antropologia \\
\hline 576 & $04 /$ nov & Feliciano Pinheiro de Bittencourt & Aborígenes da América & Antropologia \\
\hline \multicolumn{5}{|c|}{1889} \\
\hline 577 & 26/mai & Feliciano Pinheiro de Bittencourt & América pré-histórica - os maias & Antropologia \\
\hline 578 & 02/jun & Feliciano Pinheiro de Bittencourt & América pré-histórica - os maias & Antropologia \\
\hline 579 & 16/jun & Feliciano Pinheiro de Bittencourt & Antiguidades da América Central & Antropologia \\
\hline 580 & 30/jun & Feliciano Pinheiro de Bittencourt & Antiguidades da América Central & Antropologia \\
\hline 581 & 14/jul & Feliciano Pinheiro de Bittencourt & América Meridional - Incas do Peru & Antropologia \\
\hline 582 & 21/jul & Feliciano Pinheiro de Bittencourt & Arqueologia das repúblicas do Pacífico & Antropologia \\
\hline 583 & 28/jul & Feliciano Pinheiro de Bittencourt & Antiguidades do Peru, e especialmente da cerâmica & Antropologia \\
\hline 584 & 11/ago & Feliciano Pinheiro de Bittencourt & Arqueologia das repúblicas do Pacífico & Antropologia \\
\hline 585 & $01 /$ set & Feliciano Pinheiro de Bittencourt & Arqueologia pré-histórica das repúblicas do Prata & Antropologia \\
\hline 586 & 08/set & Feliciano Pinheiro de Bittencourt & Arqueologia pré-histórica das repúblicas do Prata & Antropologia \\
\hline 587 & $15 /$ set & Feliciano Pinheiro de Bittencourt & República do Uruguai & Antropologia \\
\hline 588 & $22 /$ set & Feliciano Pinheiro de Bittencourt & Aborígenes do Brasil & Antropologia \\
\hline 590 & $27 /$ set & Feliciano Pinheiro de Bittencourt & Aborígenes do Brasil & Antropologia \\
\hline 591 & $04 /$ nov & Feliciano Pinheiro de Bittencourt & Aborígenes do Brasil & Antropologia \\
\hline
\end{tabular}




$591 \quad$ 10/nov $\quad$ Feliciano Pinheiro de Bittencourt $\quad$ Aborígenes do Brasil

Fontes: Jornal do Commercio (1873-1889), Gazeta de Noticias (1875-1880), Diario do Rio de Janeiro (1873-1878), O Globo (1874-1878), Conferencias Populares (1876). 


\section{Anexo 4 - Conferências Avulsas que abordaram assuntos relativos à ciência}

\begin{tabular}{|c|c|c|c|c|}
\hline Data & Local & Orador & Título & Tema \\
\hline \multicolumn{5}{|l|}{1874} \\
\hline $10 /$ mai & $\begin{array}{l}\text { Colégio Nossa Senhora da } \\
\text { Glória }\end{array}$ & Carlos Arthur Moncorvo de Figueiredo & Higiene da infância ( $2^{a}$ conf.) & Higiene \\
\hline 23/jun & Escritório - r. São Pedro, 54 & Pires Ferreira & Moléstias do aparelho lacrimal ( $4^{\mathrm{a}}$. conf.) & Medicina \\
\hline jun & & José Lourenço & $\begin{array}{l}\text { Diversas alterações apresentadas pelos olhos, nos diferentes } \\
\text { períodos da diabetes }\left(1^{\text {a }} \text {. conf.) }\right.\end{array}$ & Medicina \\
\hline \multicolumn{5}{|c|}{ - } \\
\hline 11/jan & $\begin{array}{l}\text { Palácio da Exposição } \\
\text { Nacional }\end{array}$ & Charles Frederick Hartt & Os recifes do Brasil & Geologia \\
\hline 07/jul & Ateneu Acadêmico & Antonio de Cerqueira Lima & Geração espontânea & Evolucionismo \\
\hline 28/jul & $\begin{array}{l}\text { Grande Oriente Unido do } \\
\text { Brasil }\end{array}$ & Augusto Cezar de Miranda Azevedo & Das mistificações religiosas perante o estudo das ciências naturais & Evolucionismo \\
\hline 04/set & Instituto Farmacêutico & Manoel Maria de Moraes e Valle & $\begin{array}{l}\text { Necessidade do ensino da farmácia em escolas especiais de } \\
\text { instrução profissional e suas vantagens para a saúde pública e } \\
\text { outras conveniências da sociedade }\end{array}$ & Farmácia \\
\hline \multicolumn{5}{|l|}{1877} \\
\hline 17/jun & $\begin{array}{l}\text { Escola de meninos da Praça } \\
\text { da Aclamação }\end{array}$ & Vicente de Souza & $\begin{array}{l}\text { O homem diante da antropologia e da etnografia. Determinará a } \\
\text { paleontologia com exatidão a existência do homem primitivo? }\end{array}$ & Antropologia \\
\hline 27/jun & Ateneu Acadêmico & Arthur Fernandes Campos da Paz & $\begin{array}{l}\text { Do ar atmosférico, sua razão de ser na economia geral do } \\
\text { universo. }\end{array}$ & Química \\
\hline 01/jul & Instituto Farmacêutico & Teixeira de Azevedo & $\begin{array}{l}\text { Divulgação da legislação farmacêutica de cada um dos países } \\
\text { mais adiantados da Europa. }\end{array}$ & Farmácia \\
\hline 08/jul & & Antonio de Cerqueira Lima & Geração espontânea & Evolucionismo \\
\hline 08/jul & Instituto Farmacêutico & Teixeira de Azevedo & $\begin{array}{l}\text { Divulgação da legislação farmacêutica de cada um dos países } \\
\text { mais adiantados da Europa. }\end{array}$ & Farmácia \\
\hline 15/jul & Escola da Glória & Joaquim Manoel Pereira da Silva & Origens dos povos e línguas modernas (tratando de Portugal) & Antropologia \\
\hline 22/jul & Escola da Glória & Carlos da Luz & $\begin{array}{l}\text { História das ciências físicas, a sua utilidade e a organização do ar } \\
\text { atmosférico. }\end{array}$ & Física \\
\hline
\end{tabular}




\begin{tabular}{|c|c|c|c|c|}
\hline 26/jul & Escola de Botafogo & Carlos Antonio de Paula Costa & Higiene Popular & Higiene \\
\hline 17/ago & Externato Aquino & Alfredo Alberto Leal da Cunha & $\begin{array}{l}\text { Inconveniência da habitação dos tuberculosos nos lugares } \\
\text { elevados }\end{array}$ & Medicina \\
\hline 19/ago & Escola da Glória & Theophilo das Neves Leão & Curso de geografia e astronomia & Astronomia \\
\hline 23/ago & & Carlos Antonio de Paula Costa & Questão da alimentação & Higiene \\
\hline 30/ago & Escola Noturna da Lagoa & Carlos Antonio de Paula Costa & $\begin{array}{l}\text { Considerações gerais sobre a função digestiva, sobre a definição } \\
\text { de alimentos de onde são extraídos, qual o seu modo de atuar na } \\
\text { economia }\end{array}$ & Higiene \\
\hline 01/set & Escola de S. Sebastião & Guilherme Belmonte & Higiene popular & Higiene \\
\hline $02 /$ set & Escola da Glória & Francisco Carlos da Luz & $\begin{array}{l}\text { História das ciências físicas, e suas multíplices e variadíssimas } \\
\text { aplicações às artes, mostrando o interesse e proveito de seus } \\
\text { estudos. }\end{array}$ & Física \\
\hline 06/set & & Carlos Antonio de Paula Costa & Da alimentação & Higiene \\
\hline $06 /$ set & Escola de S. Sebastião & Guilherme Belmonte & $\begin{array}{l}\text { Higiene da prenhez, quer em relação à mãe, quer em relação ao } \\
\text { feto (Curso de higiene popular) }\end{array}$ & Higiene \\
\hline 13/set & Escola de Botafogo & Carlos Antonio de Paula Costa & Questão da alimentação & Higiene \\
\hline set & Escola de S. Sebastião & Guilherme Belmonte & Curso de higiene popular & Higiene \\
\hline set & Escola de S. Sebastião & Guilherme Belmonte & Curso de higiene popular & Higiene \\
\hline 16/set & Escola da Glória & Theophilo das Neves Leão & Geografia e astronomia & Astronomia \\
\hline 20/set & Escola de Botafogo & Carlos Antonio de Paula Costa & Questão da alimentação & Higiene \\
\hline 30/set & Escola da Glória & José de Saldanha da Gama & Plantas aquáticas & Botânica \\
\hline 07/out & Escola da Glória & José de Saldanha da Gama & $\begin{array}{l}\text { Leis gerais que presidem a vida das plantas aquáticas, começando } \\
\text { pela dos mares e passando às dos rios, lagos brejos, etc. }\end{array}$ & Botânica \\
\hline 07/out & Escola da Glória & Carlos da Luz & Ciências físicas & Ciências físicas \\
\hline 11/out & Escola de S. José & Carlos da Luz & Curso elementar de ciências físicas & Física \\
\hline 10/out & & Carlos Antonio de Paula Costa & Questão da alimentação (curso de higiene popular) & Higiene \\
\hline \multirow[t]{2}{*}{ 12/out } & Escola de S. Sebastião & Guilherme Belmonte & Educação física da criança, tratando da alimentação & Higiene \\
\hline & Escola de Botafogo & Carlos Antonio de Paula Costa & Questão da higiene das bebidas, começando pelas águas & Higiene \\
\hline 07/nov & Escola de Botafogo & Carlos Antonio de Paula Costa & Questão das bebidas alcoólicas & Higiene \\
\hline 08/nov & Escola de S. José & Carlos da Luz & $\begin{array}{l}\text { Ciências físicas - história e aplicação das ciências ao progresso e } \\
\text { florescimento das nações }\end{array}$ & Física \\
\hline 08/nov & Escola de S. Sebastião & Guilherme Belmonte & Higiene popular & Higiene \\
\hline
\end{tabular}




\begin{tabular}{|c|c|c|c|c|}
\hline 21/nov & Escola de Botafogo & Carlos Antonio de Paula Costa & Questão das bebidas alcoólicas (19a e penúltima lição) & Higiene \\
\hline \multicolumn{5}{|l|}{1878} \\
\hline 31/jan & Escola Noturna da Lagoa & Carlos Antonio de Paula Costa & Curso de higiene popular & Higiene \\
\hline 18/mai & Instituto Farmacêutico & Moraes e Valle & Curso de química geral & Química \\
\hline 18/jul & Escola Politécnica & José Saldanha da Gama & A influência do parentesco consanguíneo nos vegetais & Botânica \\
\hline 04/out & Escola de Botafogo & Carlos Antonio de Paula Costa & Utilidade da vacinação e da revacinação & Higiene \\
\hline 28/nov & $\begin{array}{l}\text { Escola Industrial da } \\
\text { Sociedade Auxiliadora da } \\
\text { Indústria Nacional }\end{array}$ & Manoel de Mello Braga & Higiene das indústrias & Higiene \\
\hline 30/nov & $\begin{array}{l}\text { Escola Industrial da } \\
\text { Sociedade Auxiliadora da } \\
\text { Indústria Nacional }\end{array}$ & Camillo de Lellie[?] e Silva & Tecnologia elementar & Tecnologia \\
\hline \multicolumn{5}{|l|}{1879} \\
\hline 30/jan & Escola Noturna da Lagoa & Carlos Antonio de Paula Costa & Curso de higiene popular ( $1^{\mathrm{a}}$ conf. $)$ & Higiene \\
\hline 01/fev & Escola Noturna da Lagoa & Lyra da Silva & Higiene das indústrias & Higiene \\
\hline 13/fev & Escola de Botafogo & Carlos Antonio de Paula Costa & Higiene ( $2^{a}$ conf.) & Higiene \\
\hline 20/fev & Escola Noturna da Lagoa & & Higiene industrial ( $2^{\mathrm{a}}$ conf.) & Higiene \\
\hline 28/fev & Escola Noturna da Lagoa & Francisco Siqueira Dias Sobrinho & Higiene da alma ( $1^{\mathrm{a}}$ conf. $)$ & Higiene \\
\hline 28/mar & Escola Noturna da Lagoa & Siqueira Dias & Higiene d'alma & Higiene \\
\hline 18/abr & Escola Noturna da Lagoa & Carlos Antonio de Paula Costa & Higiene popular. ( $5^{\mathrm{a}}$. conf.) & Higiene \\
\hline \multicolumn{5}{|l|}{1880} \\
\hline 14/jul & Faculdade de Medicina & Joseph Auguste Aristide Fort & Curso livre de anatomia do sistema nervoso & Medicina \\
\hline 20/jul & Escola da Glória & Joseph Auguste Aristide Fort & $\begin{array}{l}\text { Circulação do sangue nos pulmões, a absorção [?] miasmas em } \\
\text { geral e especialmente o da febre amarela }\end{array}$ & Medicina \\
\hline \multicolumn{5}{|l|}{1881} \\
\hline 03/jun & Faculdade de Medicina & Joseph Auguste Aristide Fort & Curso de anatomia topográfica, aplicada à medicina e à cirurgia & Medicina \\
\hline 17/jun & Faculdade de Medicina & Joseph Auguste Aristide Fort & Curso de anatomia topográfica, aplicada à medicina e à cirurgia & Medicina \\
\hline \multirow[t]{2}{*}{ 05/ago } & Faculdade de Medicina & Joseph Auguste Aristide Fort & Curso de anatomia topográfica, aplicada à medicina e à cirurgia & Medicina \\
\hline & Faculdade de Medicina & Joaquim Monteiro Caminhoá & Curso de botânica & Botânica \\
\hline 23/out & Escola de S. José & Castro Lopes & Fundamento fisiológico da ciência médica & Medicina \\
\hline \multicolumn{5}{|l|}{1882} \\
\hline 24/ago & Colégio Aquino & Antonio José de Sampaio Junior & Química industrial & Química \\
\hline
\end{tabular}




\begin{tabular}{|c|c|c|c|c|}
\hline 02/set & Colégio Aquino & Theophilo das Neves Leão & Cosmografia & Astronomia \\
\hline $10 /$ nov & Colégio Aquino & Antonio José de Sampaio Junior & $\begin{array}{l}\text { O carvão, seus principais produtos, sua utilidade, tanto nos } \\
\text { misteres da vida como na indústria }\end{array}$ & Química \\
\hline $05 / \mathrm{dez}$ & Colégio Aquino & Theophilo das Neves Leão & A passagem de Vênus pelo disco do Sol & Astronomia \\
\hline \multicolumn{5}{|l|}{1883} \\
\hline 10/ago & Faculdade de Medicina & Olageo Bilac & $2^{\mathrm{a}}$ conferência acadêmica & Medicina \\
\hline 24/ago & Faculdade de Medicina & Medeiros Mallet & Darwinismo & Evolucionismo \\
\hline 31/ago & Faculdade de Medicina & Viriato Guimarães & Luta pela existência & Evolucionismo \\
\hline 07/out & Policlínica & Carlos Arthur Moncorvo de Figueiredo & Paralisia espinhal da infância & Medicina \\
\hline \multicolumn{5}{|l|}{1884} \\
\hline mai & & Carlos Arthur Moncorvo de Figueiredo & Curso de patologia e clínica da infância & Medicina \\
\hline 04/mai & Policlínica & Carlos Arthur Moncorvo de Figueiredo & Curso de patologia e clínica da infância & Medicina \\
\hline 11/mai & Policlínica & Carlos Arthur Moncorvo de Figueiredo & Curso de patologia e clínica da infância & Medicina \\
\hline 25/mai & Policlínica & Carlos Arthur Moncorvo de Figueiredo & Curso de patologia e clínica da infância & Medicina \\
\hline 01/jun & Policlínica & Carlos Arthur Moncorvo de Figueiredo & Curso de patologia e clínica da infância & Medicina \\
\hline 02/jun & Policlínica & Silva Araujo & Curso de moléstias da pele e sífilis & Medicina \\
\hline 08/jun & Policlínica & Carlos Arthur Moncorvo de Figueiredo & Curso de patologia e clínica da infância & Medicina \\
\hline 09/jun & Policlínica & Silva Araujo & Curso de moléstias da pele e sífilis ( $2^{\mathrm{a}}$ conf.) & Medicina \\
\hline 18/jun & Policlínica & João Paulo & Teoria parasitária e os micróbios & Medicina \\
\hline 19/jun & Policlínica & Silva Araujo & Curso de moléstias da pele e sífilis & Medicina \\
\hline 23/jun & Policlínica & Silva Araujo & Curso de moléstias da pele e sífilis ( $4^{\mathrm{a}}$ conf.) & Medicina \\
\hline 19/jun & Policlínica & Carlos Arthur Moncorvo de Figueiredo & Curso de patologia e clínica da infância & Higiene \\
\hline 26/jun & Policlínica & Carlos Arthur Moncorvo de Figueiredo & Curso de patologia e clínica da infância & Higiene \\
\hline 03/jul & Policlínica & Carlos Arthur Moncorvo de Figueiredo & Curso de patologia e clínica da infância & Higiene \\
\hline 07/jul & Policlínica & Silva Araujo & Curso de moléstias da pele e sífilis ( $6^{\mathrm{a}}$ conf.) & Medicina \\
\hline 10/jul & Policlínica & Carlos Arthur Moncorvo de Figueiredo & Curso de patologia e clínica da infância & Higiene \\
\hline 17/jul & Policlínica & Carlos Arthur Moncorvo de Figueiredo & Curso de patologia e clínica da infância & Higiene \\
\hline 20/jul & & Nerval de Gouvêa & Evolução orgânica & Evolucionismo \\
\hline 21/jul & Policlínica & Silva Araujo & Curso de moléstias da pele e sífilis ( $8^{\text {a }}$ conf.) & Medicina \\
\hline 24/jul & Policlínica & Carlos Arthur Moncorvo de Figueiredo & Curso de patologia e clínica da infância & Higiene \\
\hline 28/jul & Faculdade de Medicina & Torres Homem & Cholera-morbus & Medicina \\
\hline
\end{tabular}




\begin{tabular}{|c|c|c|c|c|}
\hline 31/jul & Policlínica & Carlos Arthur Moncorvo de Figueiredo & Curso de patologia e clínica da infância & Higiene \\
\hline 04/ago & Policlínica & Silva Araujo & Curso de moléstia da pele e sífilis ( $10^{\mathrm{a}}$ conf.) & Medicina \\
\hline 07/ago & Policlínica & Carlos Arthur Moncorvo de Figueiredo & Curso de patologia e clínica da infância & Higiene \\
\hline 08/ago & Faculdade de Medicina & Ribeiro Mendonça & Aplicações médicas da luz elétrica & Medicina \\
\hline 18/ago & Policlínica & Silva Araujo & Curso de moléstia da pele e sífilis ( $12^{\mathrm{a}}$ conf.) & Medicina \\
\hline 21/ago & Policlínica & Carlos Arthur Moncorvo de Figueiredo & Curso de patologia e clínica da infância & Higiene \\
\hline 28/ago & Policlínica & Carlos Arthur Moncorvo de Figueiredo & Curso de patologia e clínica da infância & Higiene \\
\hline 04/set & Policlínica & Carlos Arthur Moncorvo de Figueiredo & Curso de patologia e clínica da infância & Higiene \\
\hline 11/set & Policlínica & Carlos Arthur Moncorvo de Figueiredo & Curso de patologia e clínica da infância & Higiene \\
\hline 26/set & Policlínica & Carlos Arthur Moncorvo de Figueiredo & Curso de patologia e clínica da infância & Higiene \\
\hline 02/out & Policlínica & Carlos Arthur Moncorvo de Figueiredo & Curso de patologia e clínica da infância & Higiene \\
\hline 03/out & Policlínica & Silva Araujo & Curso de moléstias da pele e sífilis ( $16^{\mathrm{a}}$ conf.) & Medicina \\
\hline \multirow[t]{2}{*}{ 09/out } & Policlínica & Carlos Arthur Moncorvo de Figueiredo & Curso de patologia e clínica da infância & Higiene \\
\hline & Policlínica & Silva Araujo & Curso de moléstias da pele e sífilis ( $17^{\mathrm{a}}$ conf.) & Medicina \\
\hline \multirow[t]{2}{*}{ 16/out } & Policlínica & Carlos Arthur Moncorvo de Figueiredo & Curso de patologia e clínica da infância & Higiene \\
\hline & Policlínica & Silva Araujo & Curso de moléstias da pele e sífilis ( $18^{\mathrm{a}}$ conf.) & Medicina \\
\hline \multicolumn{5}{|c|}{, } \\
\hline 15/mai & Liceu de Artes e Ofícios & Silva Araujo & Curso de moléstias da pele e sífilis & Medicina \\
\hline 07/jun & Policlínica & Carlos Arthur Moncorvo de Figueiredo & Curso de patologia e clínica da infância & Higiene \\
\hline 13/jun & Policlínica & Carlos Arthur Moncorvo de Figueiredo & Curso de patologia e clínica da infância & Higiene \\
\hline 02/jul & Policlínica & Carlos Arthur Moncorvo de Figueiredo & Curso de patologia e clínica da infância & Higiene \\
\hline 05/jul & Policlínica & Carlos Arthur Moncorvo de Figueiredo & Curso de patologia e clínica da infância & Higiene \\
\hline 12/jul & Policlínica & Carlos Arthur Moncorvo de Figueiredo & Curso de patologia e clínica da infância & Higiene \\
\hline 17/jul & & Silva Araujo & Curso de moléstias da pele e sífilis ( $6^{\mathrm{a}}$ conf.) & Medicina \\
\hline 23/ago & Policlínica & Carlos Arthur Moncorvo de Figueiredo & Curso de patologia e clínica da infância & Higiene \\
\hline $06 /$ set & Policlínica & Carlos Arthur Moncorvo de Figueiredo & Curso de patologia e clínica da infância & Higiene \\
\hline 27/set & Policlínica & Carlos Arthur Moncorvo de Figueiredo & Curso de patologia e clínica da infância & Higiene \\
\hline \multicolumn{5}{|l|}{1886} \\
\hline 15/mai & Liceu de Artes e Ofícios & Silva Araujo & Curso de moléstias da pele e sífilis & Medicina \\
\hline 04/jun & Colégio Internacional & N. Chatrlan & Meteoros & Astronomia \\
\hline 27/jun & Policlínica & Carlos Arthur Moncorvo de Figueiredo & Curso de patologia e clínica da infância & Higiene \\
\hline
\end{tabular}




\begin{tabular}{|c|c|c|c|c|}
\hline $14 /$ jul & Liceu de Artes e Ofícios & Carlos Antonio de Paula Costa & Higiene da alimentação & Higiene \\
\hline 25/jul & Policlínica & Carlos Arthur Moncorvo de Figueiredo & Curso de patologia e clínica da infância & Higiene \\
\hline 15/ago & Policlínica & Carlos Arthur Moncorvo de Figueiredo & Curso de patologia e clínica da infância & Higiene \\
\hline 22/ago & Policlínica & Carlos Arthur Moncorvo de Figueiredo & Curso de patologia e clínica da infância & Higiene \\
\hline \multicolumn{5}{|l|}{1887} \\
\hline 31/jul & Liceu de Artes e Ofícios & Oliveira de Menezes & Eletricidade & Física \\
\hline 12/dez & Sociedade de Geografia & Frederico Corrêa da Camara & Ciclones & Geologia \\
\hline \multicolumn{5}{|l|}{1888} \\
\hline
\end{tabular}

Fontes: Jornal do Commercio (1873-1889), Gazeta de Noticias (1875-1880), Diario do Rio de Janeiro (1873-1878), O Globo (1874-1878). 